Arquiteturas vernáculas e processos contemporâneos de produção: Formação, experimentação e construção em um assentamento rural

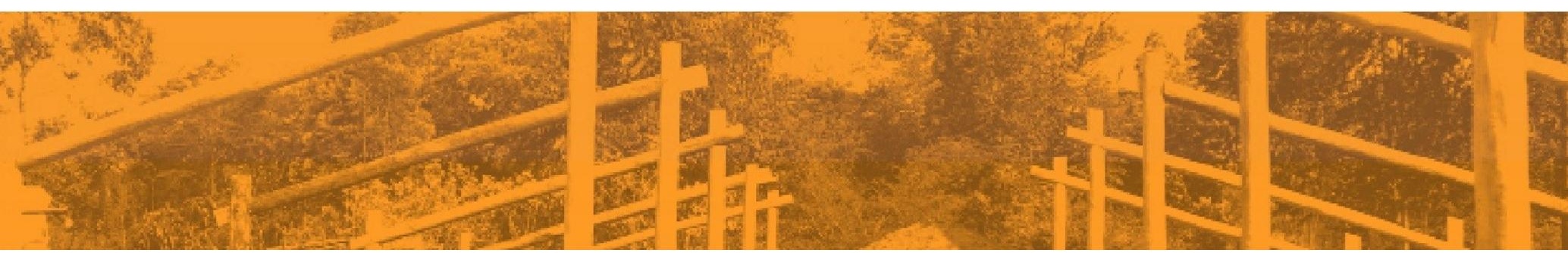

Thiago Lopes Ferreira

Tese de doutorado

Orientadoras: Profa. HDR Anne Coste (ENSAG)

e Profa. Dra. Akemi Ino (IAU/USP)

Grenoble, 2014 

Tese de doutorado realizada em cotutela entre a

Université de Grenoble / Ecole Nationale Supérieure d'Architecture de Grenoble (ENSAG) e a Universidade de São Paulo / Instituto de Arquitetura e Urbanismo (IAU/USP)

\section{Arquiteturas vernáculas e processos contemporâneos de produção: Formação, experimentação e construção em um assentamento rural}

\section{Thiago Lopes Ferreira}

Tese defendida publicamente na Ecole Nationale Supérieure

d'Architecture de Grenoble em 18 de dezembro de 2014, como requisito à obtenção do grau de doutor em Arquitetura.

Orientadoras:

Profa. HDR Anne Coste (ENSAG) e Profa. Dra. Akemi Ino (IAU/USP)

Comissão avaliadora:

Anne Coste

École Nationale Supérieure d'Architecture de Grenoble

Akemi Ino

Instituto de Arquitetura e Urbanismo de São Carlos

Philippe Potie

École Nationale Supérieure d'Architecture de Versailles

Silke Kapp

Escola de Arquitetura e Urbanismo de Minas Gerais

Alain Findeli

Université de Nîmes

Hubert Guillaud

École Nationale Supérieure d'Architecture de Grenoble 

Grupo de Pesquisa em Habitação e Sustentabilidade - HABIS

Instituto de Arquitetura e Urbanismo - USP

Avenida Trabalhador São-Carlense, 400

Centro CEP: 13566-590

São Carlos - SP - Brasil

Unité de recherche Architecture, Environnement \& Cultures Constructives

Laboratoire Cultures Constructives

École Nationale Supérieure d'Architecture de Grenoble

60 avenue de Constantine BP 2636

38036 Grenoble cedex 2 

AUTORIZO A REPRODUÇÃO E DIVULGAÇÃO TOTAL OU PARCIAL DESTE TRABALHO, POR QUALQUER MEIO CONVENCIONAL OU ELETRONICO, PARA FINS DE ESTUDO E PESQUISA, DESDE QUE CITADA A FONTE.

Contato: thi.lopes.ferreira@gmail.com

Ficha catalográfica preparada pelo Serviço de Biblioteca "Prof. Dr. Sergio Rodrigues Fontes" - EESC/USP

"Prof. Dr. Sergio Rodrigues Fontes" - EESC/USP
Ferreira, Thiago Lopes
Arquiteturas vernáculas e processos contemporâneos de
produção: Formação, experimentação e construço em um
assentamento rural / Thiago Lopes Ferreira; orientadoras
Anne Coste, Akemi Ino. -- Grenoble, 2014.
Tese (Doutorado - Programa de Pós-Graduação em
Arquitetura e Urbanismo e Área de concentração em
Arquitetura, Urbanismo e Tecnologia) -- Instituto de
Arquitetura e Urbanismo da Universidade de São Paulo,
realizada em cotutela coma Ecole Nationale Supérieure
d'Architecture de Grenoble da Université de Grenoble.
1. Arquitetura vernácula. 2. Canteiro-escola.
3. Habitação popular. 4. Formação. 5. Tecnologia social.
6. Assentamento rural. I. Título.


Em dose dupla

No momento em que escrevo estes agradecimentos, um duplo sentimento orienta o meu pensar, que busca nas palavras (nem sempre justas) sua forma de expressão. De um lado, uma explosão contagiante, ainda que em fogo baixo, indica a proximidade transitória para novos desafios. Do outro, a responsabilidade de preencher estas palavras com conteúdos que anunciem o real valor de seus significados.

Passaram-se quatro anos de intensas novidades duplamente vividas entre o equilíbrio (nem sempre equilibrado) dos lados norte e sul de meus trabalhos de pesquisa. Tempos em horários diferenciados, misturaram a França e o Brasil nesta dupla tese de doutorado. E duplamente me sinto gratificado e agradecido.

Às minhas duas orientadoras, Profa. Anne Coste e Profa. Akemi Ino, pela dupla confiança, duplo apoio e dupla parceria. Gratidão enorme por acreditarem em minhas utopias concretas e orientarem meus passos neste longo caminhar.

À Meire e ao Gilson, queridos amigos, duplamente responsáveis pela oportunidade de aproximar aquilo que escrevo daquilo que faço. Obrigado pela práxis e pela confiança.

Minha gratidão aos professores Maria Zanin e loshiaqui Shimbo por me apresentarem os caminhos até a Comunidade Nova São Carlos.

Às equipes de professores e pesquisadores dos laboratórios Culturas Construtivas e CRAterre, por instrumentalizarem meus conhecimentos e ampliarem meus horizontes. Se escrevo sobre este tema é graças ao tempo que passei em vossas companhias.

Aos professores e pesquisadores do grupo HABIS, por tornarem real o que antes era possibilidade. Suas trajetórias são referências que carrego, aprendo e respeito. Entendi com vocês a amplitude da extensão popular na realidade social. Gratidão profunda.

À todas e a todos que contribuíram com as atividades da Casa Suindara, organizando, realizando, acompanhando e apoiando. Parabenizo e agradeço. Em especial à Anaïs Guéguen Perrin e ao Gabriel Delduque, grupo embrionário neste processo.

À Escola Nacional Superior de Arquitetura de Grenoble (ENSAG) e ao Instituto de Arquitetura e Urbanismo / USP, pelo apoio e perseverança em estabelecer esta cotutela de dupla titulação e por todas as questões administrativas que me ajudaram a resolver. Gratidão pela insistência e disponibilidade na reta final de nosso convênio de cotutela. 
Igualmente à Escola de Engenharia de São Carlos por estabelecer a primeira convenção de dupla titulação.

Ao Ministério francês da Cultura e da Comunicação, que concedeu o apoio financeiro para o desenvolvimento deste trabalho de doutorado.

Ao LABEX/AE\&CC por também conceder o apoio financeiro para desenvolvimento deste trabalho de doutorado.

À família "Terreriste", por terem surgido em minha vida. Gratidão eterna por tudo o que me possibilitaram viver e aprender.

Aos meus amigos pessoais de perto e de longe. Parte do que sou foram vocês que construíram.

À minha família, pelo amor, apoio e formação, que me foram e são dados. Se alcancei e trilho o caminho que escolhi, foi por terem me ensinado a enxergar o mundo a partir de suas contradições. Aos que partiram, aos que estão chegando, e aos que aqui estão. Amor imenso. Em especial, à minha mãe e ao meu pai. Obrigado, sempre!

Agradecimento especial à Anaïs Guéguen Perrin. Companheira de todas as horas, em todo caminhar. Sonhos e práticas que se misturam. Vida compartilhada que tece e norteia cada escolha, em cada razão. Gratidão imensurável pelas intermináveis leituras, releituras, traduções, diálogos e paciências. Carinho e cumplicidade. Que venha a próxima etapa.

Às trabalhadoras e aos trabalhadores rurais deste país continental. À vocês dedico o que escrevo. À vocês dedico minha técnica. 

Esta tese possui como perspectiva de análise as manifestações contemporâneas de produção das arquiteturas vernáculas e culturas construtivas, dentro da complexa correlação de forças e interesses que formatam e determinam os fenômenos de produção capitalista das habitações populares.

Seu contorno analítico está delineado a partir de uma série de reflexões de ordem teórico-conceituais relacionadas com as análises de um canteiro habitacional dentro de um assentamento rural de reforma agrária. Este, assume a forma de um Canteiro-Escola e se projeta como palco de experimentações e vivências, onde se propõe como prática o exercício de conjugar pedagogia e produção no mesmo espaço. Os processos de formação e construção dos conhecimentos ocorrem de maneira complementar e simultânea às realizações práticas e ao desenvolvimento das tecnologias.

O canteiro se transforma, assim, em ferramenta para constituição de um espaço dialético de trabalho social, onde o experimentar produtivo está focado no desafio de conceber uma habitação a partir da geração local de tecnologias sociais, por meio do uso de materiais naturais e da reutilização de recursos descartados.

O trabalho teórico, apresentado nas primeiras partes da tese, define o quadro de sua práxis, que por sua vez, realimenta a reflexão sobre os processos de produção e desenvolvimento de novas formas de arquiteturas vernáculas, integradas aos seus territórios.

Título: Arquiteturas vernáculas e processos contemporâneos de produção: Formação, experimentação e construção em um assentamento rural

Palavras chaves: arquitetura vernácula, canteiro-escola, habitação popular, formação, tecnologia social, assentamento rural 
Cette thèse a comme perspective d'analyse les manifestations contemporaines de production des architectures vernaculaires et cultures constructives dans la corrélation complexe de forces et d'intérêts qui mettent en forme et déterminent les phénomènes de production capitaliste des habitations populaires.

Son contour analytique est délimité à partir d'une série de réflexions d'ordre théorico-conceptuelles mises en relation avec les analyses de terrain sur le chantier d'un habitat réalisé dans une communauté rurale de réforme agraire au Brésil. Ce chantier revêt la forme d'un chantier-école et se dessine comme la scène d'expérimentations et d'expériences de vie où est proposé comme pratique l'exercice de conjuguer pédagogie et production dans le même espace. Les processus de formation et de construction des connaissances ont lieu de manière complémentaire et simultanée aux pratiques constructives et au développement des technologies.

Ainsi, le chantier se transforme en outil de constitution d'un espace dialectique de travail social, où l'expérimenter productif se concentre sur le défi de concevoir une habitation à partir de la génération locale de technologies sociales, en employant des matériaux naturels et de récupération.

Le travail théorique, présenté dans les premières parties de la thèse, définit le cadre de sa praxis, qui alimente en retour la réflexion sur des processus de production et de développement de nouvelles formes d'architectures vernaculaires, intégrées à leurs territoires.

Titre: Architectures vernaculaires et processus de production contemporains : Formation, expérimentation et construction dans une communauté rurale au Brésil

Mots clés: architecture vernaculaire, chantier-école, habitation populaire, formation, technologie social, assentamentos ruraux 
This thesis takes as its analytical perspective the contemporary manifestations of vernacular architecture production and building cultures within the complex correlation of forces and interests that shape and determine the phenomena of capitalist production of popular housing.

The analytic framework is delineated from a series of reflections of theoretical and conceptual order, in relation to the analysis of a popular housing building site within an agrarian reform rural settlement in Brazil. This assumes the form of a field school in loco on the building site and is projected as a stage for experiments and experiences, where the proposal is to combine pedagogy and production in the same space. The processes of knowledge formation and construction occur simultaneously and complementarily to practical achievements and development of technologies.

This building site is thus transformed into a tool for the constitution of a dialectical space of social work, where the orientation of its productive experimenting is focused on the challenge of designing a house from the local generation of social technologies, through the use of natural materials and reuse of discarded resources.

A theoretical work, presented in the initial of the thesis, provides the framework for this fieldwork, which feeds back our reflection on processes of production and development of new vernacular architectures, integrated into their territories.

Title: Vernacular architecture and contemporary productions process: Formation, experimentation and construction in a Brazilian rural settlement

Keywords: vernacular architecture, design build program, popular housing, formation, social technologies, rural settlements 

As fotos referentes às atividades ocorridas na Comunidade Rural Nova São Carlos e contidas no Momento 4 desta tese possuem os seguintes créditos autorais:

Anaïs Guéguen Perrin: Fotos 47, 48, 50, 52, 53, 54, 55, 56, 59, 60, 62, 63, 64, 65, 66, 67, $73,74,75,76,77,78,79,80,81,84,86,90,91,92,94,95,96,97,98,99,100,102,103$, $104,106,108,113,114,115,117,120,122,123,124,125,131,134,136,140,141,142$, $143,144,147,148,149,153,156,160,161,162,163,164,165,167,171,172,173,174$, $175,176,177,178,179,180,181,182,184,186,187,189,190,191,192,193,215,217$, $220,224,226,228,232,233,234,235,236,237,238,243,245,246,248,249,250,252$, $254,256,258,259,262,263,264,265,266,267,268,269,271,272,273,274,275,277$, $278,279,280,281,282,283,284,285,287,288,290,291,292,293,294,299,302,304$, $314,315,317,318,321,322,323,324,331,332,334$

Angel Castañeda: Fotos: 213, 219, 251, 253, 255

Camila Garcia: Fotos 101, 107

Inna Mascarin: Fotos 70, 71, 72, 87, 88, 89, 105, 112, 116, 118, 119, 132, 133, 135, 154, $168,183,185,188,205,209,225,229,240$

Nicole de Souza: Fotos 191, 202, 203

Pedro Teixeira: Foto 121

Thiago Lopes Ferreira: Fotos 45, 46, 49, 51, 57, 58, 61, 68, 69, 82, 83, 85, 93, 109, 126, $127,128,129,130,137,138,139,145,146,150,151,152,155,157,158,159,166,169$, 170, 195, 196, 197, 198, 199, 200, 201, 204, 206, 207, 208, 210, 211, 212, 214, 216, 218, $221,222,223,227,230,231,239,241,242,244,247,257,260,261,270,276,286,289$, $295,296,297,298,300,301,303,305,306,307,308,309,310,311,312,313,316,319$, $320,325,326,327,328,329,330,333,335,336,337,338,339,340$ 
INTRODUÇÃO

Questionamentos e delimitações 25

Procedimentos metodológicos e arranjos textuais 29

Norte e sul através de uma perspectiva de pesquisa 34

O tempo e os instrumentos 40

MOMENTO 1 - CULTURAS CONSTRUTIVAS TRADICIONAIS 43

Inteligências e tradições $\quad 45$

Elementos e fenômenos $\quad 48$

Localização $\quad 55$

$\begin{array}{ll}\text { Recursos disponíveis } & 63\end{array}$

$\begin{array}{ll}\text { Sistemas construtivos } & 66\end{array}$

$\begin{array}{ll}\text { Sistemas de mediação e organização } & 72\end{array}$

$\begin{array}{ll}\text { Sistemas de representação } & 74\end{array}$

$\begin{array}{ll}\text { Sistemas de memorização } & 81\end{array}$

Sistemas de transmissão e difusão $\quad 83$

$\begin{array}{ll}\text { Período histórico } & 84\end{array}$

Ensaios e compreensões $1 \quad 87$

MOMENTO 2 - EM DIREÇÃO À HOMOGENEIZAÇÃO DO HABITAT?

$\begin{array}{ll}\text { Processos e reversos } & 93\end{array}$

$\begin{array}{ll}\text { Engrenagens produtivas } & 103\end{array}$

$\begin{array}{ll}\text { Ensaios e compreensões } 2 & 112\end{array}$

MOMENTO 3 - OUTROS PROCESSOS / NOVAS TECNOLOGIAS 117 

EXPERIMENTAÇÃO DIALÉTICA

O palco e seu quadro histórico

Oficina 1

Oficina 2

Oficina 3 

Quando adentramos pela primeira vez este lugar que hoje nos é familiar, não tínhamos ainda a clareza e a compreensão madura da trajetória que estávamos prestes a iniciar. Tateávamos algo que ainda não existia mas que já se anunciava a partir de uma primeira forma, contanto ainda embrionária e moldável, e assumia-se como fruto de um natural processo, obviamente evolutivo, daquilo que já datava de longas primaveras. Nos bastava o peso de nossas intuições e bagagens para legitimar nossas convicções e nos assegurar de que era o caminho mais acertado a seguir.

Encontrávamos face àqueles de quem hoje já não consigo mais recordar sem submetê-los à um cenário onde certos termos como cumplicidade, amizade, complementaridade, diálogo e compromisso celebram sua práxis, materializada em um processo por nós vivido e que neste trabalho de tese procuro expor, explicar, analisar, justificar e inclusive me servir, quem sabe como instrumento em busca de saltos outros, ainda incertos, mas já desejáveis e legitimados pela mesma intuição que nos assegurou quando deste primeiro encontro.

O processo ao qual faço alusão teve como embrião a busca pela produção de uma nova "experiência de lugar" a partir da materialidade da acumulação de todos os conteúdos influentes nesta realidade, e que a ensaiou sob as vistas de uma compreensão crítica e consciente do indivíduo enquanto indivíduo social, buscando reaproximar (como exercício) o Homo Faber e o Homo Sapiens, e resgatar inclusive o sentido estruturante da educação e de sua relação com o trabalho.

O território palco deste encontro é reconhecido aos olhos do Estado brasileiro como sendo um assentamento rural de reforma agrária* e, assim como nos tantos outros assentamentos rurais do Brasil, as famílias que ali se encontram estão sujeitas a condições particulares de vida e reprodução social, tema que tratarei mais adiante. Tais situações englobam, inclusive, o acesso à habitação, saneamento, eletricidade e demais benfeitorias que possam vir a ser construídas dentro do assentamento.

No tocante ao acesso ao habitat popular rural, este trabalho de tese se esforça por trilhar um caminho em que ao mesmo tempo que propõe o mergulho analítico em um caso específico - permitindo assim uma melhor compreensão de seus processos produtivos, lança uma série de reflexões pautadas por uma perspectiva histórica global, 
buscando evitar o direcionamento de nossa compreensão a estereótipos deterministas ou idealistas.

O desafio social de acessar uma habitação que reúna com certo grau de qualidade as condições básicas que assegurem de maneira satisfatória a vida e reprodução dos mais variados grupos sociais é transversal à própria existência humana. E, embora nos encontremos hoje ao final da primeira quinzena do século XXI, a maior parte da população mundial ainda busca estratégias pessoais, familiares e coletivas de acesso a tal habitação. Não bastasse o acúmulo das experiências construídas ao longo dos mais diversos períodos históricos, ainda nos saltam aos olhos as precárias condições habitacionais e de salubridade em que se encontram expostas bilhões de pessoas distribuídas nos mais variados contextos geográficos e políticos.

Portanto, numerosos são os exemplos de situações onde inteligências e conhecimentos construtivos souberam aproveitar-se das contingências existentes em suas realidades e tornar concretas soluções adequadas às suas necessidades e anseios. Tais referências materializadas inclusive nos mais variados exemplos de arquiteturas, em parte tradicionais, serão inseridas e tratadas nesta tese através das dimensões assumidas por termos como arquiteturas vernáculas e culturas construtivas. Entretanto, isso se fará dentro de uma perspectiva e abordagem atual.

Esta intenção revelará uma apreensão e ressignificação conceitual que inserirá estes termos dentro de uma leitura crítica da ordem capitalista de produção do habitat popular, tecida a partir do exercício prático de uma "experimentação produtiva" vivenciada dentro de um assentamento rural de reforma agrária no Brasil.

As análises traçadas nesta tese convergem para o processo de produção do habitat popular rural. A atenção voltada ao processo produtivo se explica em virtude da compreensão de ser no interior deste processo que residem as essências das possíveis transformações. É nele que se configuram os elementos capazes de questionar, assegurar ou romper com ordens estabelecidas. É ali o local onde a experimentação, análise e desenvolvimento dos conhecimentos são processados em sua totalidade e em sua síntese. Percebendo assim o processo, podemos compreender melhor a materialização das ideologias e a confecção das utopias. 
É neste horizonte que se revelarão as tensões, contradições, complementaridades, rupturas, continuidades, inovações e ressignificações no desafio de produzir o habitat popular como resultado de um processo social constante e dialético, reflexo da produção consciente do grupo que o produziu.

Os textos escritos na primeira pessoa do singular misturam-se e alternam-se com outros tantos na primeira pessoa do plural, pois o "eu" que aqui analisa e escreve é também resultado do "nós" que tornou possível e real a construção daquilo que se transformou no campo principal e objeto de análise desta tese. Assim, deixo como pista a estrutura textual escolhida visto que escrevo como pesquisador sobre algo em que também participei enquanto arquiteto, construtor, aprendiz, professor, militante, companheiro, observador, crítico, cúmplice, enfim, como mais um dentre tantos outros que por ali passaram e deixaram suas marcas, rastros, ideias e suor.

Entre Grenoble e São Carlos, meados de 2014.

\footnotetext{
* Trataremos de assentamentos rurais mais adiante no texto (principalmente no Momento 4). Entretanto, podemos compreender o termo em uma forma genérica. Segundo Bergamasco (1996), os assentamentos rurais podem ser definidos como sendo a "criação de novas unidades de produção agrícola, por meio de políticas governamentais, visando o reordenamento do uso da terra em benefício dos trabalhadores rurais sem terra (ou com pouca terra), envolvendo também a disponibilidade de condições adequadas ao uso da terra e, o incentivo à organização social e à vida comunitária".
} 
"Mas toda a crítica, mesmo radical, que não conduz a uma prática modificadora, é um exercício acadêmico de pouco interesse." (Sérgio Ferro) 


\section{Questionamentos e delimitações}

Esta tese possui como perspectiva de análise as manifestações contemporâneas de produção das arquiteturas vernáculas ${ }^{1}$ e culturas construtivas ${ }^{2}$ dentro da complexa correlação de forças e interesses que formatam e determinam os fenômenos de produção capitalista das habitações populares. Seu contorno analítico será delineado a partir de uma abordagem que dispõe em mútua relação uma série de reflexões de ordem teórico-conceituais com outras relativas às atividades práticas de um canteiro de obras pedagógico-experimental ${ }^{3}$, dentro de um assentamento rural de reforma agrária no interior do Estado de São Paulo.

Mais precisamente, tal perspectiva analítica se efetua por meio de uma série de diálogos reflexivos que permeiam e colocam face a face os momentos investigativos complementares da tese. O primeiro deles refere-se às análises acerca dos fenômenos de produção das culturas construtivas outrora presentes em certas sociedades tradicionais, com o intuito de evidenciar alguns processos e características particulares, expressas em suas formas de produzir e viver seus habitats. Em seguida, oriento as reflexões em direção das transformações ocorridas no seio de tais fenômenos de produção quando do estabelecimento de um novo modelo produtivo, global e de hegemonia inquestionável, baseado e legitimado, por sua vez, pela estrutura capitalista de sociedade.

A partir da relação entre esses dois primeiros ensaios analíticos, procuro enfatizar algumas pistas que nos forneçam subsídios reflexivos sobre o desenvolvimento de outros processos, que se apresentam como "resistências e contrapontos" ao modelo produtivo estabelecido, e que nos permitam avançar analiticamente em direção a um campo de

\footnotetext{
${ }^{1}$ As noções referentes às arquiteturas vernáculas serão tratadas no Momento 1 da tese. Ressalto aqui que trataremos de tais arquiteturas a partir de uma óptica similar à Carlos Lemos (1989), ou seja, analisando as arquiteturas vernáculas como sendo expressões culturais de um grupo social, transversais às sucessivas gerações e adaptadas às especificidades de um lugar particular.

${ }^{2}$ As noções referentes às culturas construtivas também serão tratadas ao longo do Momento 1 da tese. Todavia, vale explicitar que iniciaremos nossas análises assumindo que na dimensão que tal termo composto engloba, interagem uma pluralidade de sistemas constituídos por campos de conhecimentos e competências, associados a diferentes modos de memorização e transmissão, que tornam-se estruturantes no lento processo de produção material e imaterial dos laços estabelecidos por um grupo social particular com sua base territorial, o que proporciona, por sua vez, a constituição de um patrimônio cultural próprio ao grupo.

${ }^{3}$ Termo usado pelo autor para denotar o caráter primeiro e essencial do canteiro de obras em questão.
} 
produção, ainda embrionário, portanto promotor de novas culturas construtivas locais, agora contemporâneas.

No último momento de análise considero as condições e processos vividos dentro de um canteiro de obras que assume a forma de um "espaço de trabalho social" 4 e se projeta como palco de vivências e experimentações, onde se propõe como prática o exercício de conjugar pedagogia e produção no mesmo espaço de trabalho. Os processos de conscientização e produção dos conhecimentos ocorrem de maneira complementar e paralela às práticas construtivas e ao desenvolvimento das tecnologias.

A ideia norteadora deste experimentar produtivo está focada no desafio de conceber uma habitação a partir da geração local de tecnologias sociais ${ }^{5}$, compartilhando e utilizando as condições, recursos, conjunturas e formas existentes e criadas no lote, no canteiro e no próprio processo produtivo. Assim, o pensar, o projetar, o praticar e o desenvolver, vão buscar nas interfaces entre os materiais locais, capitais disponíveis, inteligências construtivas e forças/relações de trabalho social, o conjunto dos elementos norteadores destes processos de produção. Nestes termos, as tecnologias sociais se desenvolvem através dos constantes diálogos entre os conhecimentos científicos, os conhecimentos técnicos e os conhecimentos populares.

A construção de uma habitação popular dentro de um assentamento rural de reforma agrária se transforma em ferramenta para constituição de um espaço dialético de trabalho social onde pessoas, de diferentes classes sociais, com formações e nacionalidades diversas, compartilham o mesmo ambiente e participam de todas as atividades, cada um com seu perfil, competências e habilidades. Aprendendo, ensinando, praticando e desenvolvendo, todos realizam cada etapa da obra, passando pela preparação dos materiais, arrumação do canteiro, realização das atividades construtivas,

\footnotetext{
${ }^{4}$ Inspirado nas compreensões de Sérgio Ferro sobre o canteiro, o desenho, a arquitetura e o trabalho livre. Em busca daquilo que Ferro (2006) chamaria de trabalho coletivo autonomamente organizado, onde o sujeito coletivo adquire consciência de si como produtor do espaço. Um canteiro que possui como norte o exercício da prática em prol do trabalho livre, não alienado.

${ }^{5}$ No Momento 3 da tese trataremos conceitualmente das "tecnologias sociais". No entanto, vale ressaltar aqui a compreensão de Hermán Thomás (2009, p.27) que considera tais tecnologias como sendo "formas de criar, desenvolver, implementar e administrar tecnologias, orientadas para a resolução de problemas sociais e ambientais, gerando dinâmicas de inclusão social e de desenvolvimento sustentável, além de basear-se na demanda de uso intensivo do conhecimento disponível localmente."
} 
organização dos grupos de trabalho, gestão das ferramentas e equipamentos, limpeza dos espaços, dentre outros.

As reflexões construídas a partir desta perspectiva de análise buscam responder a uma questão principal: Sob quais circunstâncias canteiros habitacionais podem se configurar como espaços de trabalho social e formação crítica, potencializando processos locais de expressão e desenvolvimento de novas arquiteturas vernáculas?

Esta questão nos leva ao desafio de buscar algumas alternativas que nos orientem a outras possibilidades de produção social da habitação popular, que não a imposta pela lógica financeira e especulativa de produção da habitação enquanto mercadoria. E ademais, nos impulsiona a questionarmos e repensarmos sobre as manifestações evolutivas das arquiteturas vernáculas e os novos significados que este termo, assim como o termo culturas construtivas, adquirem no momento atual.

Sob esta óptica de leitura, encontramos um amplo horizonte analítico composto por um campo de reflexões cruzadas a partir dos momentos tratados na tese, das quais emergem uma série de questões, agora intermediárias, ao longo de nosso caminho analítico.

- Quais condições fundamentais tecem as relações entre o processo de produção de tecnologias sociais locais e o processo de desenvolvimento de novas culturas construtivas?

- Quais contribuições esta outra perspectiva analítica aporta aos exercícios de uma práxis transformadora dentro do processo de produção do habitat rural?

- Como a produção de tecnologias sociais locais pode fortalecer os mecanismos de desenvolvimento local em comunidades rurais?

As respostas a estas questões serão tratadas e ensaiadas ao longo da tese. Parto, para tanto, da hipótese de que os canteiros habitacionais que estimulam a produção de tecnologias sociais locais, de processos formadores e conscientizadores, e de organização coletiva e solidária do trabalho social, fortalecidos em suas potencialidades 
transformadoras, fomentam por sua vez, processos embrionários de produção e desenvolvimento de novas arquiteturas vernáculas.

Neste ponto, nossas análises adquirem uma dimensão que assume como objetivo contribuir tanto com as reflexões teórico-críticas relativas à produção das arquiteturas vernáculas e culturas construtivas - quando de suas inserções no momento histórico contemporâneo, quanto à uma dimensão prática de fortalecimento dos mecanismos de desenvolvimento local, dentro de comunidades rurais brasileiras, principalmente na produção de seus habitats - quando da criação e experimentação de novas práticas coletivas de trabalho, de novas formas de concepção dos projetos e de suas realizações, e de novos programas pedagógicos e de instrumentalização do aprendizado.

A experimentação prática aqui concebida, construída, vivida e analisada busca fomentar algumas reflexões acerca da constituição de um espaço de trabalho que estimule ações em prol da prática emancipatória do trabalhador - de sua consciência, de sua criatividade, de sua compreensão crítica enquanto sujeito histórico -, e de seu trabalho - no produto da materialização expressa de seu gesto ${ }^{6}$. A resistência às relações produtivas estabelecidas pela ordem capitalista de produção, o ensaio de superação da hierarquia da divisão social do trabalho e as ações com vistas a processos de "contraconsciência", assim como nomeou István Mészáros (2008)7, norteiam conceitualmente a organização do trabalho e as práticas em campo.

Os processos produtivos das tecnologias criadas no próprio canteiro de obras buscam o "fazer-se" de forma coletiva, solidária, consciente $^{8}$ e sustentável ${ }^{9}$, e experimentam interagir processos pedagógicos, com práticas dialógicas ${ }^{10} \mathrm{e}$

\footnotetext{
${ }^{6}$ Faço referência aqui a processos que orientem práticas em prol da desalienação e tomada de consciência. Essa orientação apoia-se nos conceitos de alienação em Marx $(1973,1977,1978)$, de esclarecimento em Adorno (1985), de catarse em Gramsci (2000), entre outros.

7 Mészáros $(2008$, p.56) entende a "contraconsciência" como processos de ação engendrados contra a modelagem de consciências no interesse do controle pelo capital. Desta forma, o desafio se coloca nas compreensões, estratégias e experimentações que são susceptíveis de serem alimentadas nas tentativas de superação da ordem estabelecida.

${ }^{8}$ No sentido de haver a compreensão crítica do produto criado, da função social do processo realizado, dos procedimentos técnicos escolhidos, assim como, do executor ser sujeito protagonista de suas ações, escolhas e gestos.

${ }^{9}$ Em suas relações sociais, políticas, econômicas, culturais e com a natureza local.

${ }^{10}$ Inspiradas nas ideias de Paulo Freire e seu conceito de "ações pedagógicas dialógicas". Práticas baseadas na construção de diálogos que revelem relações horizontais de trocas entre sujeitos. (FREIRE 1970, 1985)
} 
participativas $^{11}$, assumindo a produção como processo conscientizador e estimulador de novos conhecimentos. Isso, a partir do uso e do reuso de uma série de materiais e recursos disponíveis no local e nas proximidades do canteiro de obras.

\section{Procedimentos metodológicos e arranjos textuais}

A orientação das reflexões teórico-conceituais, da realização das atividades práticas, assim como, da formulação das análises oriundas das relações entre estas duas dimensões (teórica e prática), resulta de uma abordagem integrada de conhecimentos, mais precisamente nas esferas que abrangem a Arquitetura e Urbanismo, e que estabelecem laços de diálogo e ação com a Educação e a Sociologia. Tal abordagem é transversal às reflexões inseridas em temporalidades diversas e às análises abrangendo escalas espaciais que alternam-se entre o local (canteiro de obras), o regional (território geográfico) e o global (relações geopolíticas).

Com relação à orientação metodológica utilizada, adotei tipos diferenciados de procedimentos de pesquisa, na medida em que se mostravam mais adequados ao momento tratado. De maneira geral, optei prosseguir o caminho de uma abordagem metodológica qualitativa, assumindo leituras e coletas de dados de ordens mais subjetivas (embora suas objetividades também tenham sido exploradas), buscando estabelecer uma maior proximidade entre minhas posturas e atuações, e meu objeto de pesquisa, esforçando-me por compreendê-lo em sua totalidade, a partir da coleta de dados mais detalhada.

Neste desafio, a observação da realidade social torna-se estratégia de ação. $\mathrm{Na}$ compreensão de Leandro Konder (2007, p.08), a realidade dialética é tida como "o modo de pensarmos as contradições da realidade - o modo de compreendermos a realidade como essencialmente contraditória e em permanente transformação". Assim, ao interior

\footnotetext{
11 Inspiradas nas pesquisas praxiológicas de Ardoino (apud ANDALOUSSI, 2004, p.87) que "corresponde a uma implicação do pesquisador (no caso dos participantes) dentro de uma situação concreta e a sua participação ativa no desenvolvimento da ação." (Grifo adicionado pelo autor). Ainda no mesmo sentido, evocamos a pesquisa-ação integral de Morin (apud ANDALOUSSI, 2004, p.107) que as delineia dentro das condições que "almejem implicar os parceiros, transformar a realidade social com seu consentimento e sua participação ativa."
} 
de todas as coisas, lutam forças contrárias que movem-se, ora no sentido da afirmação, ora no sentido da negação. Esse movimento gera contradições e destas contradições advêm as mudanças. Neste sentido, a dialética ${ }^{12}$ vem alimentar o exercício de produzir uma síntese a partir do esforço de entender a realidade em sua totalidade, e torna-se método de análise e de ação sobre a realidade.

$\mathrm{Na}$ tentativa de facilitar a compreensão sobre os diferentes procedimentos de pesquisa utilizados, apresento a estrutura dos textos e arranjo dos capítulos (chamados "Momentos"), a partir de seus temas tratados e das estratégias e métodos de análise utilizados.

O Preâmbulo tem como objetivo inserir paulatinamente o universo tratado, seguido da Introdução, onde exponho a organização geral da tese a partir dos quatro itens adotados: i) Questionamentos e delimitações - trata da delimitação da tese a partir de sua problemática de análise, dos temas e questionamentos evocados, do objeto, da hipótese e dos objetivos da pesquisa, dentre outros; ii) Procedimentos metodológicos e arranjos textuais - trata da metodologia de pesquisa e dos métodos de ação utilizados, expostos a partir da organização dos Momentos da tese e de seus arranjos textuais; iii) Norte e sul através de uma perspectiva de pesquisa - trata da construção da perspectiva desta pesquisa, relatando o processo de produção vivido ao longo dos anos de doutorado; iv) O tempo e os instrumentos - relata brevemente meu percurso trilhado em torno dos temas tratados.

No Momento 1 (Culturas construtivas tradicionais), Proponho uma reflexão sobre as noções de arquiteturas vernáculas e culturas construtivas tradicionais, buscando elencar elementos que nos deem suporte para uma melhor compreensão de como certas sociedades produziram "tecnologias" em diferentes momentos da história social - sendo

\footnotetext{
${ }^{12}$ Partindo da dialética marxista que postula que as leis do pensamento correspondem às leis da realidade, sendo esta, assim, contraditória, possuindo em sua essência aquilo que Marx chama de "unidade de contrários", faço referência à dialética de Lefebvre como a "ciência que mostra como as contradiçães podem ser concretamente idênticas, como passam uma na outra, mostrando também porque a razão não deve tomar essas contradições como coisas mortas, petrificadas, mas como coisas vivas, móveis, lutando uma contra a outra e através de sua luta." (1979, p.192). E ainda à compreensão Lukásiana que permite à dialética de enxergar a realidade através dos processos e inter-relações que a compõe. Tais processos e inter-relações estariam sob a abrangência daquilo que Konder (2007, p.47) chamou de dimensão imediata (que nós percebemos imediatamente) e dimensão mediata (que vamos descobrindo, construindo ou reconstruindo aos poucos). Assim vamos construindo nossa percepção da realidade.
} 
estas legitimadas por fatores ligados mais à tradição cultural do que à razão técnica - e conseguiram reproduzi-las e transmiti-las ao longo do tempo, através de sucessivas gerações. Para tanto, divido o Momento nos três itens seguintes: i) Inteligências e tradições; ii) Elementos e fenômenos; iii) Ensaios e compreensões 1.

Apresento uma proposta de decomposição dos fenômenos de produção das culturas construtivas tradicionais, revelando seus elementos estruturantes e suas relações intrínsecas. Esta decomposição evidenciará indícios que nos auxiliarão na busca por respostas às diferentes questões, tais como: Do que trata a noção de culturas construtivas? Quais seriam sua natureza e seus elementos estruturais? Como as culturas construtivas são produzidas pelas sociedades e legitimadas pelo tempo?

Para a realização deste Momento, navego entre os métodos descritivos e analíticos: descrevendo, classificando, interpretando e analisando certos elementos e estudos de casos. Utilizo diferentes fontes bibliográficas que relacionam conceitos e noções através de algumas referências (casos) escolhidas, permitindo elaborar uma análise a partir da proposta de decomposição dos fenômenos de produção das culturas construtivas tradicionais.

No Momento 2 (Em direção à homogeneização do habitat?), continuo a utilizar métodos descritivos e analíticos de pesquisa. O universo de análise de certos autores, a partir de livros, artigos, teses, entre outros, auxilia nas reflexões e interpretações relativas, agora, às mutações do processo de produção baseado em tradições culturais para um novo processo assentado, por sua vez, na racionalização técnica dos sistemas produtivos, e suas consequências e desdobramentos. Assim, trataremos de certas condições intrínsecas ao modelo capitalista de produção habitacional. Este Momento está dividido nos dois itens: i) Processos e reversos; ii) Engrenagens produtivas; iii) Ensaios e compreensões 2 .

Procurarei evidenciar as engrenagens de uma racionalização técnica - legitimadora de um modelo ideológico de sociedade - que alimenta "rupturas" e mudanças nos sistemas de produção habitacional, em escala global, convencionando-os e tornando-os instrumentos de um modelo hegemônico, com tendências homogeneizantes. Sistema este, que aporta como consequência a desconfiguração e, frequentemente, a eliminação 
de antigas formas de produção habitacional, baseadas e legitimadas pela tradição cultural.

O Momento 3 (Outros processos / novas tecnologias) abrange uma série de experiências práticas e reflexões teórico-conceituais aqui evidenciadas com o intuito de enfatizar realizações concretas, a partir de ações e experimentações, que possuem como objetivo o desenvolvimento de novos ou outros processos produtivos, que buscam alternativas ao determinismo histórico do processo de produção industrial/capitalista. Consistem em projetos executados por diferentes grupos sociais: grupos de pesquisa, organizações da sociedade civil, movimentos sociais, entre outros. Trabalharei com o conceito de tecnologias sociais e com algumas experiências ligadas às Universidades, como o Canteiro-Experimental, o Canteiro-Escola (Brasil) e o Grands Ateliers de Villefontaine (Isle-d'Abeau, France). Tratarei ainda de alguns projetos realizados junto a assentamentos de reforma agrária no Brasil.

Este Momento está dividido nos três itens seguintes: i) Resistências e continuidades, ii) Contextos e territórios; iii) Tecnologias sociais e processos experimentais; iv) Outras relações entre educação e trabalho; v) Ensaios e compreensões 3.

Para seu desenvolvimento, assumo um procedimento mais exploratório a partir de uma pesquisa documental sobre estudos de casos que me instrumentalizem e me permitam estabelecer uma maior aproximação com o objeto fruto da análise realizada no Momento 4 deste trabalho.

Assim, os três primeiros Momentos estruturam o corpo teórico do trabalho e sua orientação metodológica de análise. Essa base reflexiva acompanhará a realização do Momento 4 e auxiliará na construção e conclusão do Momento 5.

O Momento 4 (Casa Suindara: produção e formação em uma experimentação dialética), refere-se à atividade prática de realização do canteiro de obras pedagógicoexperimental, dentro de um assentamento rural de reforma agrária, onde a construção de uma habitação popular tornou-se instrumento constituinte de um processo dialético em que a produção e a pedagogia interagem, complementam-se e desenvolvem um 
"espaço de trabalho social" diferenciado em sua prática existencial e em sua crítica reflexiva.

Este Momento está dividido nos itens seguintes: i) O palco e seu quadro histórico; ii) Sobre os métodos de ação; iii) Olhares em choque; iv) A Casa Suindara em suas primeiras práticas; v) Canteiro-Escola: por um espaço do trabalho livre; iv) Ensaios e compreensões 4. No primeiro e segundo item introduzo um quadro geral sobre a questão agrária no Brasil focalizando certos aspectos referentes ao habitat rural. Relato o processo vivido em nossa chegada ao assentamento e a construção de nossas relações com as famílias moradoras. Nos itens seguintes, trato das atividades práticas em torno do canteiro de construção desta habitação rural.

Nessa perspectiva, analiso o processo de produção, as variáveis que interferiram no desenrolar de nossas participações, refletindo sobre as limitações vividas, as potencialidades alcançadas, e analisando: a construção do projeto enquanto programa de formação e a apropriação deste pelos participantes envolvidos nos diferentes momentos; os processos de concepção dos projetos arquitetônicos; a preparação do canteiro; as experimentações construtivas; as formas de organização do trabalho social; os materiais de construção e as técnicas construtivas; as tecnologias criadas no canteiro; os equipamentos e instrumentos de trabalho; os métodos e dinâmicas utilizados nas atividades; os recursos naturais, sociais e econômicos disponíveis no local e região; as características culturais dos participantes; as relações sociais estabelecidas ao longo dos processos vividos; os resultados alcançados; assim como as expectativas e perspectivas vislumbradas.

Neste momento da tese me sirvo do método de pesquisa-ação. A minha atuação enquanto pesquisador se mistura com a do técnico, do arquiteto, do aprendiz, do professor, enfim, minha participação passa a ser interna ao próprio processo produtivo das atividades. E corresponde, dentro da situação concreta, a uma maior implicação e efetiva participação de minha parte no desenvolvimento das ações em questão.

Tal dimensão aumenta, sem dúvida, o grau de complexidade analítica, embora me permita construir uma análise mais rica, detalhada e apurada dos fenômenos estudados. Para tanto, procurei fontes distintas de evidências: documentos e registros escritos, 
fotografias, vídeos, entrevistas semi-estruturadas, conversas informais, comparecimento a reuniões, observação direta, observação participante, etc. Tudo isso como subsídio para expor, relatar, descrever, ilustrar, explorar, analisar, explicar e avaliar.

Enfim, o Momento 5 (Síntese Conclusiva), através do item: i) Ressignificações e novas fronteiras, sugere uma reaproximação e revisita à tese a partir da análise cruzada de seus diferentes Momentos constituintes, desenhando uma espécie de "teia" reflexiva através das linhas convergentes de nossa investigação. Teorias relevantes e observações empíricas afloram para o feixe conclusivo, onde o momento é o da síntese crítica e de sua leitura global construtiva. A realidade define o novo conceito ${ }^{13}$ e novas fronteiras são flexibilizadas, surgindo assim novas utopias ${ }^{14}$.

Os conteúdos trabalhados, embora delineados pelos Momentos evocados nesta apresentação, estão entrelaçados por uma rede analítica que espero apresentar com clareza.

\section{Norte e sul através de uma perspectiva de pesquisa}

A construção e realização desta tese em arquitetura é fruto de uma perspectiva de pesquisa que projetou-se nos laços tecidos por uma cooperação internacional entre dois diferentes grupos de pesquisa e viabilizou-se por meio de uma convenção de cotutela estabelecida entre a Universidade de Grenoble - UPMF / França e a Universidade de São Paulo - USP / Brasil. No hemisfério norte, a tese enquadrou-se dentro da Escola Nacional Superior de Arquitetura de Grenoble, na Unidade de pesquisa "Arquitetura, Meio Ambiente \& Culturas Construtivas" - AE\&CC, no seio do laboratório Culturas Construtivas ${ }^{15}$. Pelo lado sul, ela inseriu-se dentro do Programa de Pós-Graduação em

\footnotetext{
${ }^{13}$ Faço referência à Howard Becker $(2007$, p. 167) quando escreve ser a realidade a formadora dos conceitos. "De fato, os conceitos são generalizações empíricas que cabe testar e refinar com base nos resultados empíricos da pesquisa - isto é, no conhecimento do mundo."

${ }^{14}$ Refiro à noção de utopias concretas proposta por Ernst Bloch, onde o utópico se construirá no ultrapassar daquilo que hoje nos é apresentado, e evocadas por Alberto Magnaghi $(2003$, p.79) em "duas dimensões: no seu realismo crítico, fundamental na apreensão das problemáticas sociais, (...) e em sua relação com o futuro aberto, no que concerne precisamente o fazer acontecer coletivamente."

${ }^{15}$ O laboratório Culturas Construtivas faz parte da Unidade de Pesquisa "Arquitetura, Meio-ambiente \& Culturas Construtivas - AE\&CC", e situa-se na Escola Nacional Superior de Arquitetura de Grenoble -
} 
Arquitetura e Urbanismo do Instituto de Arquitetura e Urbanismo - IAU / USP São Carlos, no seio do grupo de pesquisa "Habitação e Sustentabilidade - HABIS"16.

Tendo sido iniciado em outubro de 2010, o percurso do doutorado previa no planejamento de seu projeto de pesquisa a realização de uma série de viagens entre a França e o Brasil com o intuito de aproveitar a oportunidade de participar da rotina dos dois laboratórios e assim, transitar pelos dois ambientes intercambiando investigações técnicas, informações bibliográficas e práticas de campo; visitando bibliotecas e centros de documentação; dialogando e trocando reflexões com professores e pesquisadores, entre outras práticas favorecidas pela efetivação concreta do quadro de cooperação institucional entre os dois países.

Num primeiro período, foi realizado um trabalho de leitura e reflexão a respeito dos quadros teóricos e das metodologias de pesquisa que eu propunha explorar. Tal ciclo foi realizado na França, durante o primeiro ano de doutorado, e já demonstrava em sua conclusão, as principais diretrizes e as bases teóricas com os quais eu começava a tecer alguns diálogos, questões e análises.

A ideia central era partir de uma reflexão acerca das noções de culturas construtivas tradicionais, inserindo-as dentro de uma óptica analítica de questionamento dos processos de produção capitalista do habitat popular rural. Estava interessado em compreender melhor como se constituíam os fenômenos gerais de produção das culturas construtivas tradicionais, com o intuito de captar com mais clareza as transformações ocorridas no seio de sua produção a partir do estabelecimento do modelo capitalista de sociedade, e assim esboçar contribuições para com certas correntes do conhecimento ${ }^{17}$ que se esforçam em pensar e praticar novos processos de produção habitacional, que se

\footnotetext{
ENSAG. Criado em 2002, abrange um campo de pesquisa que se interessa pelas dimensões e relações existentes entre as ações construtivas e os diversos sistemas culturais. São três os temas trabalhados pelo laboratório: Habitat, Materiais e Patrimônio. http://culturesconstructives-aecc.com/, visto em 14/02/2014). ${ }^{16}$ O Grupo de pesquisa em Habitação e Sustentabilidade - HABIS, foi criado em 1993 dentro do atual Instituto de Arquitetura e Urbanismo da Universidade de São Paulo - USP/São Carlos. Primeiramente pesquisando o uso da madeira nas construções, o HABIS foi pouco a pouco desenvolvendo pesquisas e trabalhos nos temas do habitat social, de sistemas construtivos sustentáveis, de processos construtivos participativos e dos empreendimentos solidários.

http://www.iau.usp.br/pesquisa/grupos/habis/habis.html. (Consultado em 14/02/2014)

17 Ligadas neste caso, principalmente, às áreas das ciências sociais humanas e aplicadas (arquitetura, sociologia, pedagogia, antropologia, geografia, entre outras).
} 
apresentam hoje como alternativas ao modelo estabelecido. Nesta percepção, o laboratório de pesquisa Culturas Construtivas me oferecia subsídios e condições para mergulhar e avançar nas compreensões teóricas e analíticas dos temas acima sugeridos.

Entretanto, minha intenção não era delimitar as análises à um campo estritamente teórico. Meu interesse maior sugeria a construção de uma ação concreta dentro de um território particular no Brasil, onde a dimensão teórica de minhas pesquisas pudessem encontrar seu complementar, posto hoje em oposição - sua dimensão prática. A minha práxis de pesquisa viria efetuar-se dentro de um assentamento rural de reforma agrária, a partir de um trabalho realizado em torno do tema do habitat rural.

Nesta perspectiva, o segundo ano de doutorado foi realizado no Brasil, no interior do grupo de pesquisa HABIS, local onde encontrei as condições necessárias para avançar as minhas pesquisas bibliográficas e os quadros teóricos de análise, revelando-se ao mesmo tempo, base efetiva de suporte, partida e regresso, que deu norte aos anseios e buscas pelo local onde eu pudesse estabelecer o elo entre o pensar e sua prática, naquele momento ainda desconhecida.

Este período foi o mais difícil vivido ao longo do trabalho de tese. Quando iniciei minhas pesquisas, na França, a partir de um projeto que vislumbrava realizar uma análise que articulasse um conjunto de reflexões teóricas com uma ação prática concreta dentro de uma comunidade rural no Brasil, tal comunidade ainda não existia no horizonte, e o tempo que paradoxalmente "avançava em regressão", colocava dia após dia minhas estratégias em questão. Assim, o continuar do caminho foi-se desenrolando, por um lado, a partir do acúmulo teórico das pesquisas, e por outro, pela incessante busca por possíveis inserções em contextos abertos à construção prática de atividades ligadas às questões do habitat rural.

Mediado por numerosos contatos, visitei uma série de comunidades rurais em regiões diversas do Brasil, fundamentalmente nos estados de Minas Gerais, Paraná e São Paulo. Estabeleci, ainda, contatos nos estados de Santa Catarina, Rio Grande do Sul e Rio de Janeiro. Todavia, as distâncias geográficas, os custos relativos e as possibilidades concretas deste trabalho inviabilizavam uma ação contínua. 
Algumas práticas chegaram a ser realizadas e, julgo que foram bem sucedidas, apesar de não terem prosseguido. Foi o caso de uma atividade realizada sobre o tema do Saneamento Ambiental, dentro do assentamento rural Ireno Alves, no estado do Paraná, em parceria com o Movimento dos Trabalhadores Rurais Sem Terra do Paraná (MST), o Centro de Desenvolvimento Sustentável e Capacitação em Agroecologia (CEAGRO), a Central das Associações Comunitárias do Assentamento Ireno Alves dos Santos (CACIA), o Sistema de Cooperações de Crédito Rural (CREHNOR), e o Atelier de Realização e Criação de Arquiteturas com terra (A.R.C.A. terra).

Este trabalho consistiu em uma oficina teórico-prática, executada em conjunto com a arquiteta Anaïs Guéguen Perrin ${ }^{18}$, e propunha dois momentos de atividades. $\mathrm{O}$ primeiro, uma atividade de sensibilização e prática dialógica a respeito do ciclo das águas em um lote familiar, da produção dos lixos e das doenças relacionadas, das ações de reaproveitamento e reciclagem dos materiais descartados, da importância e dos métodos existentes de tratamento das águas cinzas e negras, das condições gerais de saneamento ambiental existentes no assentamento em questão, entre outros temas relacionados. Esta primeira atividade foi realizada dentro de um quadro de participação coletiva, a partir de dinâmicas criadas sobre as questões citadas.
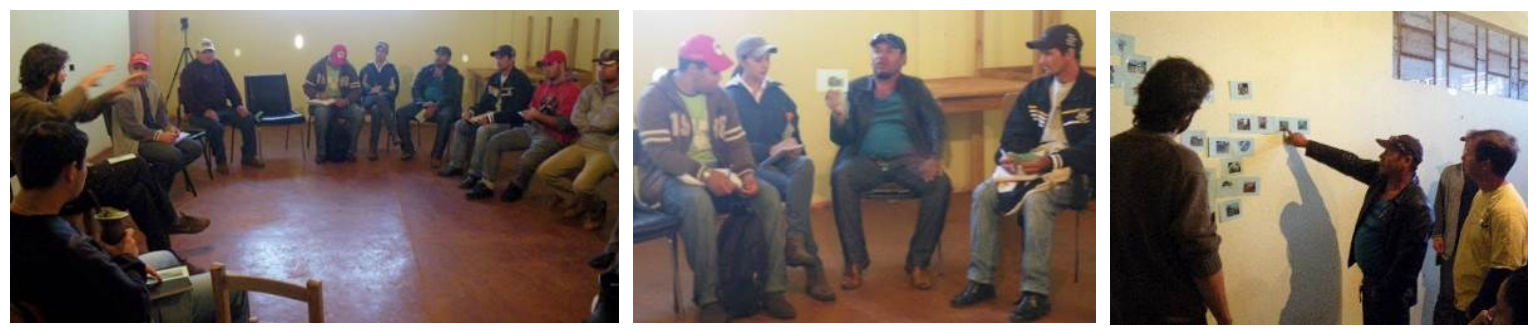

Foto 1 - Sequência de imagens acerca dos debates sobre Saneamento Ambiental - Assentamento Ireno Alves [Paraná], 2012. Foto: Anaïs Guéguen Perrin.
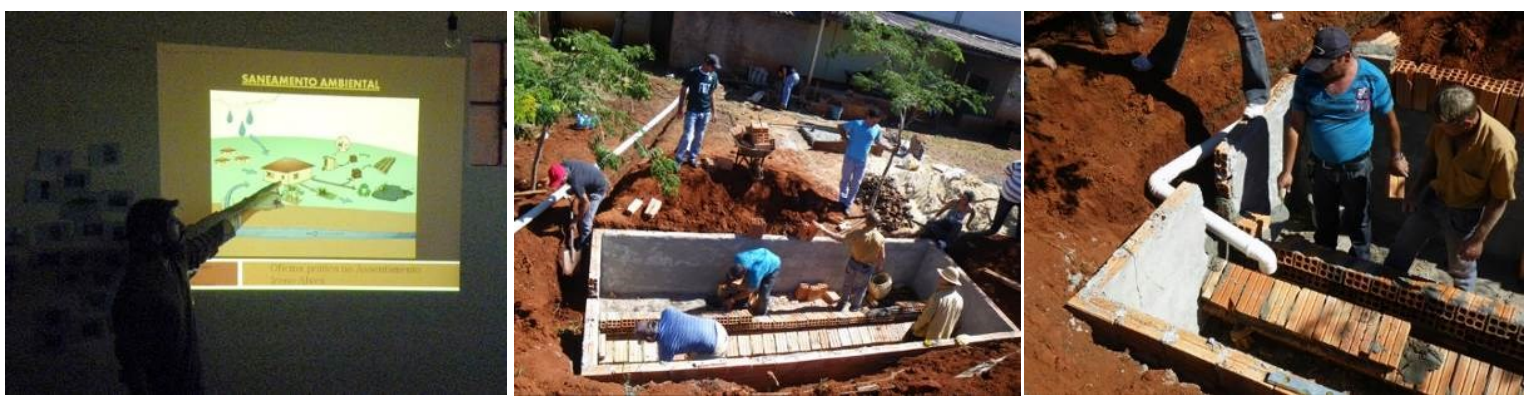

Foto 2 - Sequência de imagens acerca da apresentação e construção da fossa bioséptica - Assentamento Ireno Alves [Paraná], 2012. Foto: Anaïs Guéguen Perrin.

\footnotetext{
18 Arquiteta francesa, diplomada pela Escola Nacional Superior de Arquitetura da Bretanha/França e especialista em arquitetura de terra pelo laboratório CRAterre/França.
} 
No segundo momento, foi realizada a construção de uma fossa bioséptica de tratamento das águas negras (esgoto sanitário) ${ }^{19}$, na sede da Central das Associações Comunitárias do Assentamento Ireno Alves dos Santos (CACIA). Esta fossa consiste em um sistema que opera a partir de um primeiro tratamento dos sólidos em uma câmara predominantemente anaeróbica, seguido por uma camada de filtragem e por uma zona de raízes de plantas, onde bactérias e micro-organismos aeróbicos digerem a matéria orgânica restante. A água residual é absorvida pelas plantas e evapotranspirada ${ }^{20}$ através de suas folhas.

Esta atividade prática foi realizada dentro de um quadro onde o aprendizado e a capacitação técnica ocorreram no canteiro de obras, durante a construção da fossaprotótipo que hoje serve à Associação. Assim, diversos assentados, técnicos rurais e interessados aprenderam a construir a fossa durante a própria prática construtiva. Participantes inexperientes e pedreiros experientes vivenciaram um canteiro de formação onde os diálogos, as trocas de informações e as práticas construtivas foram as principais ferramentas desta experimentação que propiciou novas iniciativas de salubridade no assentamento.

Infelizmente, devido à longa distância entre o assentamento e a universidade onde realizo as pesquisas no Brasil - cerca de $800 \mathrm{~km}$ - não foi possível dar continuidade às atividades. Todavia, a partir desta experiência começamos a vislumbrar novas formas de materializar as atuações e contribuições junto às comunidades rurais. Tecíamos com mais nitidez as relações que poderiam ser articuladas entre os aspectos produtivos e construtivos, e as dimensões pedagógico-educativas.

Foi somente no início do terceiro ano de tese que tive a oportunidade de estabelecer laços sociais mais sólidos com as famílias de um assentamento rural vizinho à cidade de São Carlos. Tal proximidade foi primordial e decisiva no processo de

\footnotetext{
${ }^{19}$ Este método de tratamento das águas negras é conhecido, tem sido testado e praticado em diversas regiões do país, tendo inclusive ganhado prêmios por seu caráter de tecnologia social.

${ }^{20}$ Toda a água é absorvida e sai do sistema (fossa bioséptica) por evaporação ou transpiração das plantas que ficam na parte superior da fossa. Não há efluentes, e dessa forma diminuem-se as chances de poluição dos solos ou riscos de algum patógeno humano sair do sistema. A evapotranspiração é realizada principalmente pelas plantas de folhas largas como as bananeiras, as taiobas, etc. Além disso, tais plantas consomem os nutrientes presentes nos resíduos orgânicos, permitindo que a fossa não encha.
} 
reconhecimento e de construção social daquilo que viria a ser o objeto central de análise da tese.

A Comunidade Agrária Nova São Carlos é um assentamento rural de reforma agrária localizada dentro do município de São Carlos, estado de São Paulo. Formalmente reconhecida pelo Estado Brasileiro em 2009, a comunidade ocupa uma área de 1.158,5 hectares, onde 83 famílias vivem, convivem, resistem e traçam suas estratégias de reprodução familiar a partir das contingências dispostas em sua realidade social. Das articulações coletivas resultam o acesso, nem sempre concluído com sucesso, aos apoios, créditos e financiamentos públicos, referentes a algumas políticas públicas formatadas aos grupos sociais das chamadas famílias beneficiárias da reforma agrária.

Nossa entrada na comunidade ${ }^{21}$ se deu a partir da articulação feita por um casal de professores, dos quais um deles foi coordenador do laboratório HABIS, com uma família moradora da comunidade. Sem saber o que aconteceria a partir daquele momento, tais professores viabilizaram nosso primeiro encontro. Foram a "chave" que abriu a possibilidade de construção da relação social e de trabalho que relatarei, explicarei e analisarei, mais precisamente no Momento 4, e que assumiu a forma e conteúdo de uma atividade social pedagógico-experimental em torno das questões do habitat rural.

Esta atividade 22 opera em um campo de paradoxos, onde o desafio reside na constante busca por sua compreensão e apreensão consciente ${ }^{23}$. O simples e complexo,

\footnotetext{
${ }^{21}$ Usarei os termos comunidade e assentamento para tratar do mesmo local. Esta escolha se dá pelo fato da comunidade ser formalmente reconhecida como um assentamento rural, e também em razão do assentamento rural chamar-se Comunidade Agrária Nova São Carlos. Ademais, em lugar de buscar definir a comunidade por meio de uma conceituação elaborada a priori, prefiro pensar a noção de comunidade como categoria nativa, ou seja, a partir do sentido atribuído por quem vive, considerando-o como um ponto de vista. Embora nunca estejamos inteiramente seguros de que o que atribuímos ao outro, corresponde ao que ele atribui a si mesmo, buscamos nos aproximar desse entendimento e observar a realidade por eles construída, constituída de uma linguagem socialmente elaborada e internalizada pelos moradores. Dessa forma, eles se denominam simbolicamente, a partir de um discurso, sobre si mesmo, que opera como um discurso oficial. A respeito, ver NARAYAN (1997), WANDERLEY (1999), MOURA (1978), HEREDIA (1979), entre outros.

${ }^{22}$ A palavra assume para si um campo dimensional que abrange modos e sistemas operacionalizados em reflexões, ações, processos, experiências, vivências, experimentações, trocas, ganhos, perdas, entre outros.

${ }^{23}$ Nas reflexões acerca da busca pela verdadeira realidade, Paulo Freire $(1985$, p.43) cita Hegel dizendo: " $A$ verdadeira realidade é o devir", não é o ser nem o não ser, mas a tensão entre ambos - o processo histórico é o verdadeiro. E continua, "Assim, se propõe que o verdadeiro é uma busca e não um resultado, que o
} 
objetivo e subjetivo, ordem e desordem, teoria e prática, quantitativo e qualitativo, distanciamento e implicação, entre outros, compõem essa realidade dialética, e é a partir dela e dentro dela que estabelecemos nossas compreensões e construímos nossas próximas utopias. As antigas (utopias), agora realizando-se, materializam-se na dimensão de um curso universitário no seio de um lote familiar de produção agrícola, na forma de um Canteiro-Escola.

\section{O tempo e os instrumentos}

A minha relação com a realidade social dos acampamentos e assentamentos rurais remonta aos anos 2001 quando dos meus primeiros passos na construção do meu trabalho final de curso em Arquitetura e Urbanismo ${ }^{24}$.

No ano de 2006, trabalhei com as questões habitacionais em diversos assentamentos rurais distribuídos no estado do Rio de Janeiro ${ }^{25}$. Na época, o trabalho se fazia, em parte, junto às instituições financeiras do Estado pelo acesso a créditos destinados à habitação rural. O governo federal brasileiro, através do Ministério do Desenvolvimento Agrário (MDA) e do Instituto Nacional de Colonização e Reforma Agrária (INCRA), era o responsável por criar, executar, acompanhar e avaliar as políticas públicas referentes aos territórios dos assentamentos rurais de reforma agrária. Juntamente com o banco estatal Caixa Econômica Federal, o INCRA articulava seus programas de créditos financeiros relacionados às habitações rurais. Prática cada vez mais corrente que derrocou por, nos dias atuais, transferir ao banco a responsabilidade de financiamento dos programas habitacionais nos assentamentos rurais do Brasil ${ }^{26}$.

verdadeiro é um processo, que o conhecimento é um processo e, enquanto tal, temos de fazê-lo e alcança-lo através do diálogo, através de rupturas."

${ }^{24}$ Trabalho final apresentado em 2003, na Universidade Federal do Rio de Janeiro - UFRJ, para obtenção do título de arquiteto e urbanista. Nesta ocasião, apresentei um trabalho sobre a organização espacial de um acampamento rural do Movimento dos Trabalhadores Rurais Sem Terra (MST).

${ }^{25}$ Como associado da Cooperativa de Trabalho Social Estruturar e membro da equipe de assistência técnica que prestava serviços ao INCRA-RJ em assentamentos rurais do Movimento dos Trabalhadores Rurais Sem Terra MST-RJ.

${ }^{26}$ Atualmente o acesso aos créditos financeiros para a construção das casas nos assentamentos rurais se faz através do Programa Federal Minha Casa Minha Vida Rural. Programa criado pelo governo federal que através do banco Caixa Econômica Federal financia os materiais de construção (e ainda parte da mão de 
No ano anterior (2005), inicie o curso de mestrado em Ciências Sociais em Desenvolvimento, Agricultura e Sociedade, junto ao departamento de Desenvolvimento, Agricultura e Sociedade (CPDA), do Instituto de Ciências Humanas e Sociais da Universidade Federal Rural do Rio de Janeiro ${ }^{27}$. Minha dissertação intitulada: "Dos sonhos de uma casa à casa dos sonhos: moradia e qualidade de vida na Comunidade Terra Livre $^{\prime 28}$, buscou analisar as relações entre os trabalhadores rurais e o espaço no qual vivem e constroem parte de suas relações sociais: a casa, o lote, a comunidade rural. Como na época as famílias moradoras estavam no processo de discussão das novas casas a serem construídas, o trabalho teve como atividade prática a realização de um processo participativo de concepção de cada um dos novos projetos habitacionais ou de reforma e ampliação das moradias já existentes. Ao todo foram feitos 30 projetos habitacionais destinados às famílias moradoras na comunidade ${ }^{29}$.

Mais tarde, já no ano de 2008, tive a oportunidade de realizar o curso de especialização em arquitetura de terra - DSA Terre (Diploma de Especialização) no seio do laboratório CRAterre ${ }^{30}$, na Escola Nacional Superior de Arquitetura de Grenoble / França. Este curso, Cátedra da Unesco, me aportou como ferramenta um novo olhar sobre a matéria prima terra, sua transformação em material de construção e sua utilização na produção das arquiteturas e territórios. Ao final do curso, elaborei em

obra e assistência técnica) para as famílias assentadas. Discutiremos mais a respeito no Momento 4 do trabalho.

27 O Programa de Pós-Graduação de Ciências Sociais em Desenvolvimento, Agricultura e Sociedade (CPDA), foi criado em 1977 e está inserido dentro da Universidade Federal Rural do Rio de Janeiro (UFRRJ). Este centro de excelência em estudos agrários, propõe um programa interdisciplinar de ensino, pesquisa, extensão e intercâmbio em Ciências Sociais aplicadas ao conhecimento do mundo rural e áreas afins.

http://r1.ufrrj.br/cpda/. (Consultado em 14/02/2014)

${ }^{28}$ Dissertação de mestrado apresentada em 2007 para obtenção do título de mestre em Ciências Sociais em Desenvolvimento, Agricultura e Sociedade.

${ }^{29}$ Complementada por algumas avaliações técnicas (de materiais empregados, técnicas de construção, organização espacial interna, condições de habitabilidade, salubridade, qualidade das instalações sanitárias, ambiente construído, acesso à eletricidade e água potável, entre outros), o trabalho foi um primeiro exercício de análise que me permitiu melhor compreender as relações sociais e simbólicas existentes no habitat rural, através das representações, sentimentos e percepções que o trabalhador rural e sua família possuem do território onde vivem e constroem suas identidades e suas estratégias de organização e reprodução familiar.

30 O laboratório CRAterre faz parte da Unidade de Pesquisa "Arquitetura, Meio-ambiente \& Culturas Construtivas - AE\&CC", da Escola Nacional Superior de Arquitetura de Grenoble - ENSAG. Este centro de referência mundial sobre a arquitetura de terra foi criado em 1979, e abrange um campo de pesquisa que se interessa por três temas principais: Habitat, Materiais e Patrimônio.

http://craterre.org/. (Consultado em 14/02/2014) 
conjunto com a arquiteta Anaïs Guéguen Perrin o trabalho ${ }^{31}$ intitulado: "Canteiroformação e melhorias do habitat nos campos de refugiados Saharauis" 32 .

Este caminhar, brevemente resumido nestas linhas, consiste como parte do acúmulo que coloco à disposição deste novo trabalho, fornecendo a oportunidade de ampliar as reflexões globais e específicas que venho suscitando ao longo de meu percurso profissional, e aprofundar consideravelmente minhas experiências nesta área do conhecimento ligada à produção do habitat popular e do território rural.

Comecemos as análises.

31 Trabalho defendido em 2010 para obtenção do diploma de Especialização e Aprofundamento em Arquitetura de Terra - DSA Terre.

32 Este trabalho foi fruto de um projeto, no qual participamos, realizado pela parceria entre o laboratório CRAterre e a organização OXFAM/Solidariedade Bélgica, chamado "Melhoria do habitat e prevenção de catástrofes naturais nos campos de refugiados Saharauis", durante o ano de 2009 e 2010, dentro do campo de refugiados Saharauis, no sul da Argélia. Esse projeto consistiu em um processo de capacitação de trabalhadores durante a realização de algumas construções com técnicas construtivas em terra, especialmente abóbodas e cúpulas em adobes (blocos de terra crua). 


\section{MOMENTO 1}

\section{CULTURAS CONSTRUTIVAS TRADICIONAIS}

"(...) Cultura para nós, insisto, são todas as manifestações humanas, inclusive a cotidianidade, $e$ fundamentalmente na cotidianidade está a descoberta do diferente, que é essencial. Esta é uma concepção do essencial que é distinta do tradicional, que considera o essencial como o comum, os traços comuns. No entanto, para nós, e acredito que você concorda comigo, o essencial é o diferente, o que nos torna diferente." (Diálogo entre Paulo Freire e Antônio Faundez, 1985.) 


\section{Inteligências e tradições}

"Existe mais inteligência na concepção dos pilares da UNESCO desenhados por Nervi, na estrutura metálica do Grand Palais, em uma abóboda gótica, em uma estrutura em madeira de uma igreja norueguesa ou em um dos altos prédios de terra no Yémen?" (UNESCO, 1993, p.09)

A questão evocada servirá como ponto de partida para algumas reflexões acerca dos termos culturas construtivas e arquiteturas vernáculas. Meu interesse não está focado numa análise comparativa das referências citadas, na busca por uma resposta elucidadora ou conclusiva. O que cativa a reflexão reside nos diferentes processos produtivos estabelecidos e nas relações entre suas características e condições de existência. Neste sentido, me enveredo por caminhos internos às suas engrenagens de produção, com o intuito de refletir seus incisivos sistemas e mecanismos, explícitos e implícitos, de funcionamento.

O texto citado indica que cada uma das opções mencionadas apresenta, por estarem inseridas em diferentes momentos históricos, políticos e sociais, esquemas estruturantes diferenciados no interior do seu próprio sistema de produção. Isso foi e ainda é decisivo na produção dos conhecimentos e das tecnologias de uma determinada sociedade.

Assim, o texto expõe que a partir de uma série de mudanças estruturais ocorridas no interior da sociedade (ocidental), de maneira progressiva e sobretudo a partir do Renascimento, o pensamento passou a encontrar-se cada vez mais submisso à razão técnica, em detrimento à sua adequação ao complexo contexto de diversidade social e cultural, engajado no processo produtivo. E reivindica "(...) Uma démarche inventiva e pragmática onde o homem da arte e o homem do trabalho saibam conjugar seus talentos, recusando a submissão do gesto à uma função de simples executante e valorizando o saber-fazer do qual ele é portador." (UNESCO, ibid., p.09)

Embora eu trate da produção das tecnologias dentro do modelo capitalista de produção no segundo Momento da tese, cabem aqui algumas observações referentes a 
essa submissão do pensamento à razão técnica e alguns desdobramentos frutos da hegemonia deste modelo ideológico.

Em sua obra "Técnica e ciência como ideologia", Jurgen Habermas (1968) defende a ideia de que dentro do sistema capitalista, a cientificação da técnica em prol de uma busca inesgotável pela intensificação da produtividade, a partir da fragmentação do trabalho social, se torna legitimadora, dominando e redefinindo sistemas culturais inteiros, e desconstruindo antigas legitimações baseadas na tradição cultural.

"Com a investigação industrial de grande estilo, a ciência, a técnica e a revalorização do capital confluem num único sistema." (HABERMAS, p. 72)

E concorda com Marcuse com relação a leitura crítica de que "(...) a técnica se torna, no sistema capitalista, um projeto histórico-social, onde se projeta o que uma sociedade e os interesses nela dominantes pensam fazer com os homens e com as coisas." (HABERMAS, p.46)

Desta forma, a submissão do pensamento criador é legitimada por um projeto de sociedade onde a razão técnica é ideologia, se configura e se apresenta sobre a base de uma técnica relativamente desenvolvida, onde a organização do processo de produção é estruturada, entre outras coisas, pela divisão social do trabalho.

Este recorte paralelo ao texto justifica-se pelo fato de que os exemplos citados na questão inicial tiveram seus processos produtivos estabelecidos em períodos históricos, políticos e sociais distintos, dentro dos quais existiam projetos diferentes de sociedade. Alguns deles ocorreram dentro de um modo de produção pré-capitalista, contendo uma técnica pré-industrial, sendo assim estruturalmente diferentes dos exemplos que se desenvolveram dentro do modo de produção industrial capitalista. Com isso, tornam-se complexos os exercícios comparativos entre os altos prédios de terra no Yémen, edificados no século XVI, e as estruturas metálicas do Grand Palais na França, cuja construção foi concluída em 1900.

Procurando atrair a atenção para o caráter mais amplo dos processos de produção, o texto mencionado (UNESCO, op.cit., p.10) posiciona as referências como 
"verdadeiras expressões de conhecimentos científicos e técnicos, de saber-fazer dominados, centrados e perfeitamente situados dentro do contexto histórico de produção".

Assim, a questão é reformulada e expressa da seguinte maneira: "Existe mais inteligência no cálculo da curvatura dos pilares da UNESCO, ou na sequência meticulosa de gestos que segundo as regras validadas por gerações de construtores permitiram levantar uma abóboda e uma estrutura?" (UNESCO, ibid., p.09).

Este novo posicionamento mergulha a reflexão no cerne do processo produtivo, numa instância em que a produção cognitiva se retroalimenta com o saber-fazer das técnicas construtivas. Desta síntese e de sua adequação a um determinado contexto ambiental, cultural e político, nascem condições potenciais para que um grupo social crie suas estratégias de desenvolvimento e reprodução, das quais as culturas construtivas são um dos elementos, instrumentos e processos.

Ora, se o processo de racionalização da técnica implementa uma racionalidade própria que se apodera das esferas institucionais da sociedade e as transforma, legitimando assim uma nova forma de dominação política, devemos tentar compreender melhor como esta racionalização técnica desconfigura e muitas vezes elimina as antigas formas de legitimação, baseadas na tradição cultural, que agora se apresentam como o reverso desta racionalidade crescente.

Esta se torna, então, uma das reflexões deste trabalho: compreender melhor como se estruturavam os fenômenos de produção das culturas construtivas tradicionais, decompondo seus elementos estruturantes de produção e suas relações intrínsecas, para colocá-los face ao atual modelo de produção baseado na racionalidade técnica, apoiado pelo processo de produção industrializado e legitimado pelo modelo capitalista de sociedade. E assim, apontar algumas pistas sobre novos processos de produção, que se apresentam como processos de resistência a este modelo industrial/capitalista e propõem formas desalienantes e conscientes de produção de novas tecnologias.

Neste sentido, proponho uma reflexão sobre as noções de culturas construtivas, buscando elencar elementos que nos ofereçam subsídios e suporte a uma melhor 
compreensão de como certas sociedades conseguiram produzir tecnologias, em um momento específico, legitimadas por fatores ligados mais à tradição cultural do que à razão técnica, transmitindo-as e desenvolvendo-as ao longo do tempo.

De que trata a noção de culturas construtivas? Qual seria sua natureza e seus elementos constitutivos? Estas reflexões não passam por uma busca, que muitos diriam nostálgica, de retorno ao passado e aos modelos de produção inerentes às sociedades tradicionais, próprios a um determinado momento histórico. O interesse reside numa melhor compreensão de como certas tecnologias tradicionais, constituídas em adequação a determinados valores e condições particulares, foram legitimadas e reproduzidas ao longo de sucessivas gerações.

Evidenciar os fenômenos de produção das culturas construtivas tradicionais pode nos revelar pistas de como, para além dos processos produtivos capitalistas, pensar e produzir culturas construtivas contemporâneas.

\section{Elementos e fenômenos}

"A materialidade do espaço não se limita à construção material dos lugares. Ela inclui a presença ativa neles contida, que os relaciona entre si." (Svensson, 2001)

No exercício por uma melhor compreensão a respeito das relações construídas e constantemente dinamizadas entre as sociedades tradicionais e seus territórios, é necessário se debruçar sobre o conjunto de valores que atuaram como "regentes" e forneceram as informações, regras, conhecimentos e saberes que proporcionaram a materialização de suas produções arquitetônicas, garantindo coerência e funcionalidade aos usos, crenças dos grupos, interação equilibrada com a natureza e reprodução social ao longo do tempo.

De acordo com Norberg-Schulz, a arquitetura popular que exprime a vivência em seu conjunto e não separa o sentimento do pensamento, é tanto funcional quanto artística. “(...) é por essa razão que a arquitetura popular é capaz de aproximar do homem 
a paisagem habitada e de instalar esta última como paisagem "compreendida", onde a obra da natureza e as realizações do homem entram em ressonância." (NORBERGSCHULZ, 1997, p.227)

Neste sentido, as reflexões aqui expostas, para além das tipologias construtivas e descrições técnicas, orientam-se para a percepção das identidades culturais e dos modos de funcionamento práticos e simbólicos que nos expliquem sobre a produção das arquiteturas vernáculas e culturas construtivas tradicionais, seus usos sociais e suas paisagens habitadas.

Tais modos de funcionamento parecem depender de numerosos fatores. Entre eles: uma certa similaridade das condições sociais de existência do grupo, supondo assim uma proximidade cultural; uma relativa homogeneidade morfológica do território, o que contribui para o surgimento de uma tipologia construtiva comum; uma permanência de longo prazo, propiciando a inserção, adaptação e interação com o território, bem como um acúmulo técnico adaptado pelo aprimoramento dos processos produtivos; entre outros.

As construções populares são para Jean-Paul Loubes (2010) o testemunho do mundo físico que as circundam, revelando as culturas locais das sociedades que as produziram. São para ele, as responsáveis pela leitura antropológica da arquitetura, na medida em que materializam-se como os objetos onde estão inscritos tanto os homens quanto o território.

"O texto arquitetônico podia ser decifrado sob a luz das cosmogonias, dos sistemas de representação, mas também dos usos, dos modos de vida, da posição respectiva dos gêneros. Esta relação da forma arquitetônica com os valores e os usos foi fundamental pois forneceu as bases de uma teorização sobre a natureza do objeto arquitetônico considerado como uma fabricação cultural." (LOUBES, 2010, p.167)

Até o presente momento, utilizei os termos "arquiteturas vernáculas" e "culturas construtivas" para expressar processos pares e complementares, que muitas vezes 
apareceram juntos em um mesmo parágrafo como se fossem sinônimos ou com definições similares.

Habitualmente, o termo "arquiteturas vernáculas" vem designando as arquiteturas ligadas à um território, à um grupo étnico localizado. É importante salientar a existência de controvérsias quanto ao emprego do termo "arquiteturas vernáculas". Günter Weimer sugere o uso do termo "arquiteturas populares", distinguindo-as das "arquiteturas eruditas" e daquelas dos chamados "grupos excluídos". Ele questiona o uso do termo "vernáculo", lembrando que este, deriva do latim clássico vernaculus, e que significa relativo aos escravos nascidos na casa do senhor, e por extensão, quem é do lugar, da vida doméstica. Segundo ele, o termo estaria mal-empregado, “(...) visto que o equacionamento da arquitetura popular não poderia se reduzir a uma apreciação de suas qualidades plásticas, conquanto nessas manifestações as características funcionais e principalmente - construtivas são bem mais preponderantes." (WEIMER, 2005, p. XXXIX)

Embora concorde com certa inadequação do termo em seu sentido etimológico, estou convencido de que hoje o termo adquire novos significados, através de manifestações construtivas essencialmente ecológicas e adaptadas ao meio ambiente natural e construído, com forte caráter crítico e conscientizador, que procura se revelar e se afirmar entre as arestas do modelo socioeconômico estabelecido, reexperimentando formas alternativas de gestão e de trabalho.

Para Ivan Illich (2005, p.74), o termo vernáculo é um "termo técnico emprestado do direito romano, onde o encontramos desde as primeiras estipulações até o código de Théodose. Ele designa o inverso de uma mercadoria. Era vernáculo tudo o que era confeccionado, tecido, criado em casa e destinado não à venda mas ao uso doméstico."

Assumindo o uso do termo "arquitetura vernácula", reforço a compreensão que aporto a seu significado ao longo dos capítulos da tese. No meu entender, os termos "arquiteturas vernáculas" e "culturas construtivas tradicionais" são origem do mesmo processo produtivo, sendo as culturas construtivas a realização transversal às temporalidades do conjunto de arquiteturas vernáculas do mesmo grupo social em um território específico. 
As produções das arquiteturas vernáculas constituem parte do processo embrionário das culturas construtivas tradicionais. Estas, consolidam as inteligências construtivas criadas e as relações sociais estabelecidas nos processos produtivos das arquiteturas vernáculas, inscrevendo seus sistemas de memorização e transmissão nos cenários societários, dos sucessivos períodos históricos.

Quanto ao termo "culturas construtivas", seu interesse não passa pela construção conceitual dos termos "cultura" e "construção" de forma separada. Ele se orienta em torno da articulação dos dois termos, que adquire significado próprio com vasto conteúdo, inserido em processos dinâmicos, temporais e localizados, possibilitando reflexões a partir de diferentes campos de análises.

Isto se deve inclusive ao fato de que os dois termos empregados de maneira separada se tornam pouco operantes nas análises. Por um lado, a "cultura" é um conceito que consiste em um vasto domínio do conhecimento, cobrindo uma enorme gama de fenômenos humanos, sendo assim, extremamente geral e abstrato. Ela é uma construção social em constante dinamismo e transformação, que nos serve para ordenar, sistematizar, identificar, relacionar e representar as coisas e as pessoas. Neste sentido, necessitamos decompô-la em outros elementos menos abstratos para melhor analisá-la e compreendê-la. Por outro lado, o termo "construção" está inserido em uma cultura, constituindo-se como parte e componente desta. Dessa forma, é sob a luz da aproximação dos termos "cultura" e "construção" que as reflexões se realizam.

Em uma primeira leitura, o termo "culturas construtivas" tende nossa percepção ao seu caráter linguístico. De um lado, há o caráter produtivo das culturas. Culturas que produzem e constroem, remetendo aos processos de produção. Em outro sentido, há o caráter cultural da ação construtiva, onde características socioculturais de uma sociedade são "materializadas" em suas construções e arquiteturas.

O grupo de pesquisa "Culturas Construtivas" 33 , vem desde os anos 80 participando deste debate, entendendo que a ordem construtiva não deva se apresentar de forma

\footnotetext{
${ }^{33}$ Membro da Unidade de Pesquisa "Arquitetura, Meio ambiente \& Culturas Construtivas - AE\&CC", da Escola Nacional Superior de Arquitetura de Grenoble - França.
} 
antagônica aos valores culturais. Pelo contrário, o ato construtivo deve ser compreendido como um ato cultural. A partir desta ideia, o grupo propõe que:

“(...) a disciplina arquitetônica consiste justamente em rearticular constantemente a "ordem da construção", em perpétua evolução, com a "ordem cultural", buscando restituir a entidade da "experiência" edificadora." (CULTURES CONSTRUCTIVES, 2005, p.15)

Desta forma, as representações sociais se tornam os elementos norteadores a partir dos quais a arquitetura é experimentada e concebida dentro do seu processo de produção e a noção de "experiência" ganha uma posição central no debate.

"(...) o ato construtivo do ponto de vista cultural conduz ao questionamento sobre a natureza da "experiência" engajada, onde essa interroga sobre a organização social, a repartição das competências distribuídas, as instituições que se estruturam, assim como os tipos de saberes que se formalizam e se transmitem." (CULTURES CONSTRUCTIVES, ibid., p.15)

Assim sendo, o termo "culturas construtivas" adiciona à ação construtiva esta aproximação cultural onde "(...) as ferramentas, o saber-fazer, a estrutura do grupo social, a distribuição das tarefas, e ainda os rituais e a mitologia, constroem um sistema global onde seu equilíbrio definirá a cultura de uma sociedade ao mesmo tempo que sua eficácia operatória." (CULTURES CONSTRUCTIVES, ibid., p.14)

A trajetória das culturas construtivas ao longo do tempo aporta os acúmulos primorosos de seus processos (conceituais e de criação, de experimentação e expressão, de sistematização, representação e apropriação das técnicas, etc.), mobilizando, adaptando e reatualizando os modos e saberes construtivos tradicionais.

A arquitetura não pode ser compreendida como a soma de transformações operadas pelo homem em seu ambiente, pois sob esta lógica, nos escaparia o ponto crucial da interpretação dada por cada cultura ao produto construído, do seu uso e de sua significação em relação ao conjunto da sociedade. 
"Não se trata somente de uma interpretação a posteriori, mas de um feixe de atitudes arquitetônicas criadas por cada cultura particular como reserva de valor, parcialmente utilizadas para suas necessidades específicas de ordem socioeconômica. São estes valores que permitem a assimilação e as transformações dos tipos de construções $e$ dos materiais, sem necessariamente inferir em uma mudança do quadro social." (GUIDONI, 1994, p.06)

Assim, o termo "culturas construtivas" assume a responsabilidade de decifrar o imenso leque de criatividades arquitetônicas desenvolvidas pelas mais variadas civilizações ao longo dos diferentes períodos históricos. Neste desafio, destaco a importância de compreendê-las a partir de uma leitura que evidencia seu caráter identitário. Modos de vida, laços sociais, normas, regras, valores, etc., são exemplos de elementos em constante transformação, que por serem formadores de identidades, são parte da essência produtora das culturas construtivas.

Neste momento, torna-se necessário elencar alguns caminhos que ofereçam subsídios a uma melhor compreensão dos mecanismos gerais de produção das culturas construtivas. Sugiro, então, a "decomposição" de seu fenômeno de produção, com o intuito de facilitar nossa análise.

Em um primeiro momento, considero os elementos elencados pelo grupo de pesquisa Culturas Construtivas como "chaves" dentro deste processo de criação e estruturação das culturas construtivas. São eles: os materiais disponíveis; os processos construtivos; os sistemas de mediação e de representação; e os sistemas de memorização e transmissão de experiências ${ }^{34}$. A este grupo de elementos adiciono, com o mesmo grau de importância, os elementos relativos à localização e ao tempo, ou seja, o lugar e o período histórico em que as culturas construtivas são produzidas. Com a análise destes elementos, podemos perceber o grau de influência que determinados ambientes exerceram sobre certas sociedades, e como determinados contextos políticos e

\footnotetext{
${ }^{34}$ ÉQUIPE CULTURES CONSTRUCTIVES, 2005.
} 
econômicos influenciaram certas escolhas e diretrizes assumidas pelas diferentes sociedades.

A partir da figura seguinte, sugiro a decomposição do fenômeno de produção das culturas construtivas, revelando certos elementos que influenciam a constituição e o desenvolvimento das mesmas.

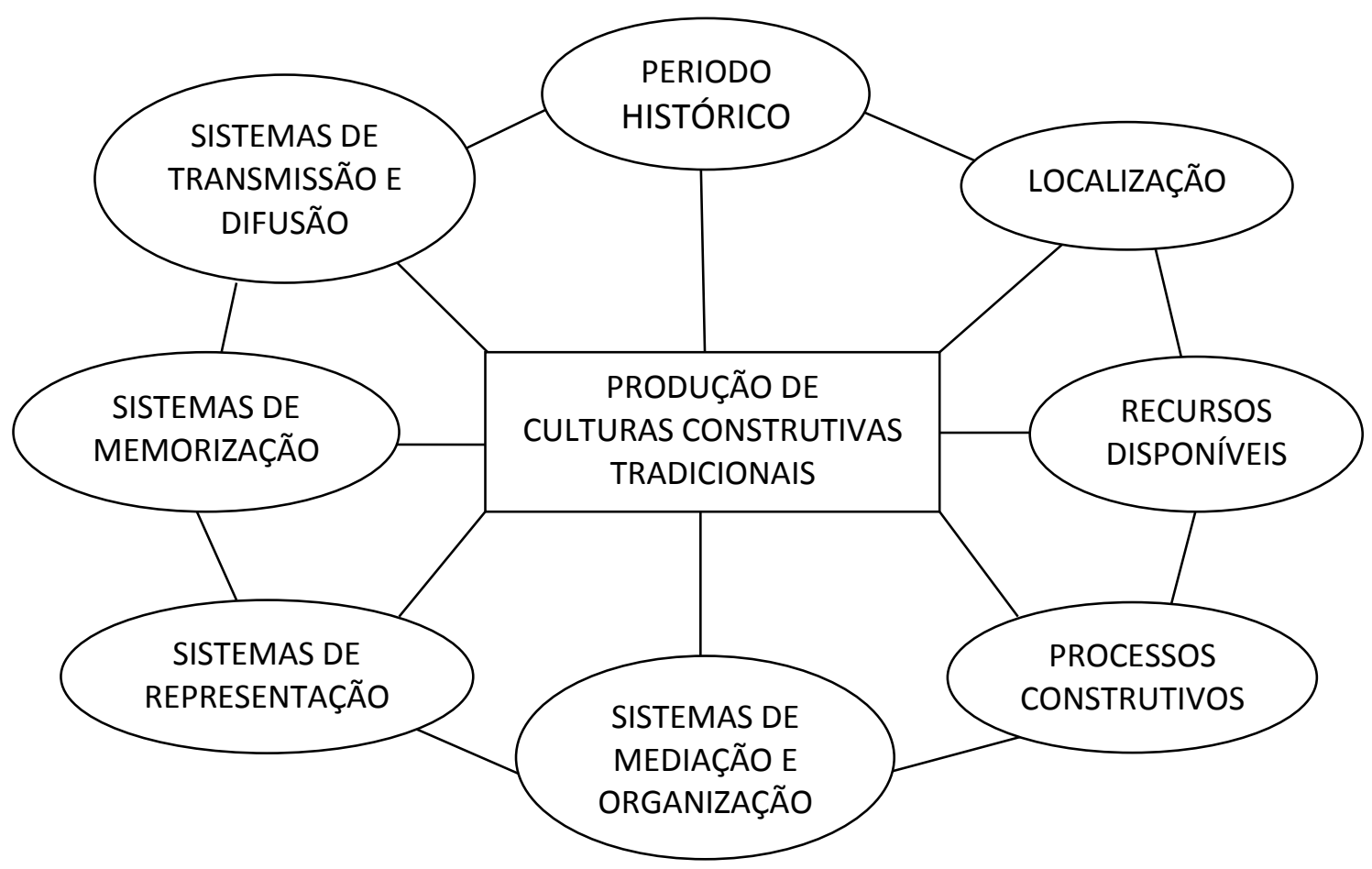

Figura 1- Decomposição do fenômeno de produção das culturas construtivas.

Esta decomposição constitui apenas uma possibilidade de leitura do fenômeno de produção. E como toda decomposição analítica, necessita ser amadurecida e desenvolvida criteriosamente. Os elementos sugeridos, entretanto, não se configuram e nem se realizam de maneira isolada ou separada. São, por essência, parte do mesmo processo produtivo e se retroalimentam na medida em que se estruturam em um ciclo de constante dinamismo transformador. Carregam processos internos e coletivos de experimentação e aprendizagem, de troca e complementaridade, de conscientização e elucidação, de produção e construção, de transmissão e reprodução, etc.

Assim, ao invés de mergulharmos nas engrenagens produtivas de uma cultura construtiva específica, proponho analisarmos as culturas construtivas através de seus 
fenômenos de produção. Uma série de referências serão evocadas com o intuito de dialogar com os elementos elencados acima.

\section{Localização}

"A escola positivista se esforça em demonstrar, se apoiando em mapas de distribuição mundial das formas de habitat, que a localização de tipos arquitetônicos se dá em função do clima, de recursos naturais, de materiais disponíveis, etc. Entretanto, toda análise mais aprofundada deve levar em consideração, entre outras coisas, as correntes culturais, as estruturas sociais e econômicas, o conjunto de ritos e de mitos, que, cada vez mais, conduzem a pensar que a influência do meio ambiente sobre a arquitetura se exerce menos positivamente que negativamente (impossibilidade de emprego de certos materiais, de certos tipos de formas, etc.). A arquitetura se desenvolveu e se diferenciou como instrumento da vida social, apesar das limitações impostas pelo meio ambiente, e não por causa delas; ela não pode, certamente, ignorar as características do entorno, mas tende, em geral, a minimizar a ação redutora." (GUIDONI, 1994, p.05)

Segundo Roque Laraia (1986), a ideia do determinismo ambiental já vem sendo refutada desde os anos 1920 do século passado, por diversos antropólogos, dentre eles Boas, Wissler e Kroeber. Isso se explica pela grande diversidade cultural localizada numa mesma região, ou em regiões distantes mas com contextos ambientais semelhantes, demonstrando assim, a existência de uma limitação da influência geográfica sobre os fatores culturais. O trabalho de Felix Keesing (1961, p.184) sobre os lapões e os esquimós que vivem na calota polar norte, sendo os primeiros no norte da Europa e os segundos no norte da América, ilustra bem esta ideia. Os dois grupos vivem em contextos físicos e climáticos similares, caracterizados por longos e rigorosos invernos, com fauna e flora semelhantes.

"Os esquimós constroem suas casas (iglus) cortando blocos de neve $e$ amontoando-os num formato de colmeia. Por dentro, a casa é forrada com 
peles de animais e com o auxílio do fogo conseguem manter o seu interior suficientemente quente. É possível, então, desvencilhar-se das pesadas roupas, enquanto no exterior da casa a temperatura situa-se muitos graus abaixo de zero grau centigrado. Quando deseja, o esquimó abandona a casa tendo que carregar apenas os seus pertences e vai construir um novo retiro. Os lapões, por sua vez, vivem em tendas de peles de rena. Quando desejam mudar os seus acampamentos, necessitam realizar um árduo trabalho que se inicia pelo desmonte, pela retirada do gelo que se acumulou sobre as peles, pela secagem das mesmas e o seu transporte para o novo sitio. Em compensação, os lapões são excelentes criadores de renas, enquanto tradicionalmente os esquimós limitam-se à caça desses mamíferos." (LARAIA, 1986, p. 22)

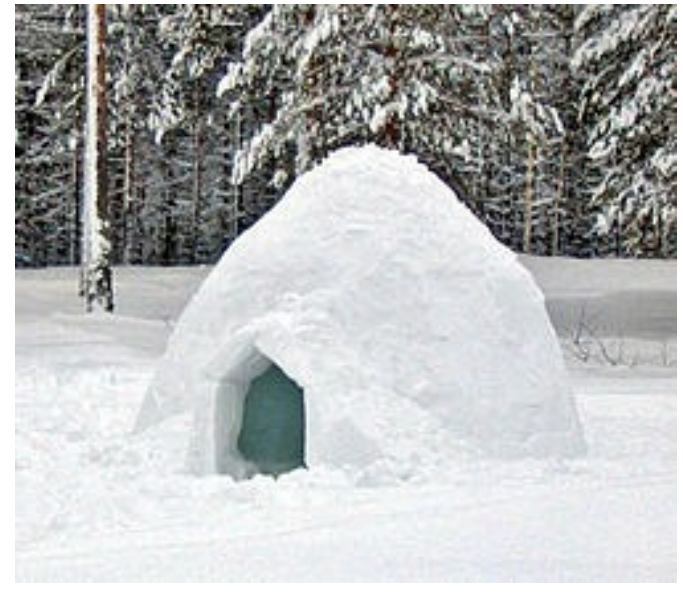

Foto 3 - Habitat típico dos esquimós (Iglu). ${ }^{35}$

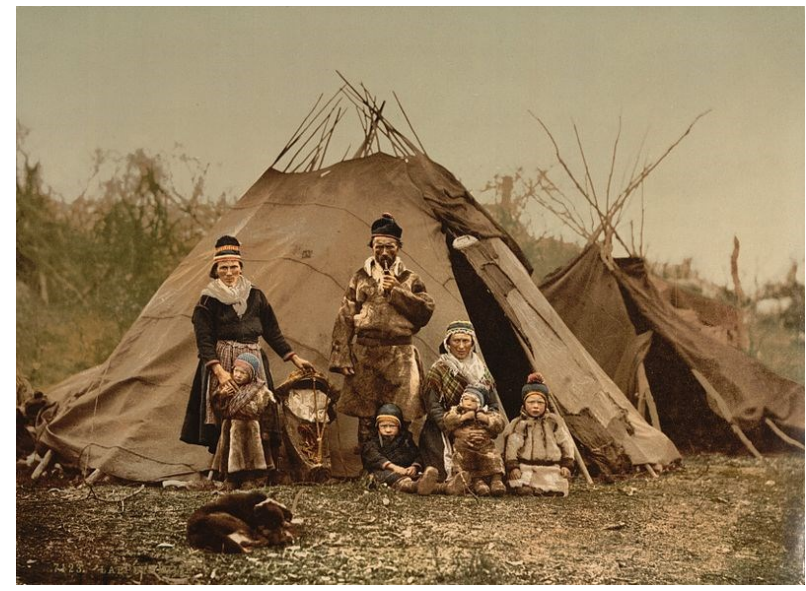

Foto 4 - Habitat típico dos lapões (tenda). ${ }^{36}$

Laraia não admite a ideia de um determinismo geográfico onde os grupos sociais se mostram puramente receptivos face à ação mecânica determinante e decisiva das forças naturais. Segundo ele:

"(...) a posição da moderna antropologia é que a cultura age seletivamente e não casualmente sobre seu meio ambiente, explorando determinadas

\footnotetext{
${ }^{35}$ Fonte: http://pt.wikipedia.org/wiki/Iglu. (Consultado em 27/02/2014). Foto: Alpo Hassinen.

${ }^{36}$ Font: http://pt.wikipedia.org/wiki/Lap\%C3\%B5es. (Consultado em 27/02/2014) Foto: Autor desconhecido
} 
possibilidades e limites ao desenvolvimento, para o qual as forças decisivas estão na própria cultura e na história da cultura." (LARAIA, ibid., p. 24)

Evidentemente, meu intuito não é orientar nossa reflexão a uma compreensão de neutralidade com relação às influências do meio ambiente sobre os mais diversos grupos sociais. Essas influências existem e são de enorme importância nas formulações das estratégias de ocupação do solo e reprodução social. Entretanto, não são determinantes. Determinantes são as "inteligências construtivas" 37 criadas e desenvolvidas por tais sociedades buscando aproveitar, em sua melhor condição, dos elementos e características dispostos pelo entorno natural, minimizando as dificuldades encontradas e reforçando as relações sociais e os aspectos culturais específicos. Inclusive, tais inteligências construtivas, uma vez desenvolvidas, memorizadas, transmitidas e reproduzidas, tornam-se parte do embrião das posteriores culturas construtivas, específicas aos territórios e às sociedades.

A influência que o meio ambiente exerce nas pessoas e grupos sociais produz efeitos diretos e/ou indiretos sobre os mesmos. Tais efeitos interagem com as organizações sociais estabelecidas, e assim, com suas estratégias e atividades produzidas, com suas condições e tempo de produção, com seus humores, emoções, etc. Esta relação entre o meio ambiente e o comportamento social constitui o eixo central de interesse da ciência conhecida como "Ecologia Humana"38.

No livro "Cultura, Arquitetura e Desenho" (2000), Amos Rapoport tece uma lista eventual de mecanismos de interação recíproca entre os indivíduos (e grupos sociais) e o meio ambiente no qual estão inseridos. Essa lista inclui:

\section{“(...) a fisiologia (a adaptação, o conforto em relação à temperatura, umidade, intensidade luminosa, barulho, etc.), a anatomia (o tamanho e a altura dos elementos, etc.), a percepção (a recepção sensorial de informações originárias do meio ambiente), a cognição (os processos}

\footnotetext{
37 As inteligências construtivas reúnem os saberes e saberes-fazer desenvolvidos (experimentação, sistematização, aprimoramentos, etc.) ao longo de um período de tempo, e os materializam a partir das mais diversas técnicas construtivas, produzindo respostas bem adaptadas aos múltiplos contextos de uma sociedade.

38 Para saber mais sobre o tema, ver autores como: Robert Park, Amos Hawley, Eugene Odum, Amos Rapoport, entre outros.
} 
mentais que intervém entre a percepção e os conhecimentos sobre o meio ambiente. A compreensão antropológica do termo "cognição" indica a maneira como o mundo é interpretado, classificado segundo domínios e esquemas, e nominados, ou seja, a maneira de funcionar no mundo), os sentidos (ligados aos aspectos antropológicos da cognição e relacionados a imagens, ideais, status, identidades, etc.), a afeição (emoções, sentimentos, humores, etc., provocados pelo meio ambiente, sua significação, etc.), a evolução (ela provoca as preferências e as escolhas que produzem vantagens dos desejos sobre as necessidades), a ação e o comportamento (é a resposta dada à cognição, ao sentido, ao afeto e à evolução) e o apoio (que pode ser fisiológico, anatômico, psicológico, social, cultural, afetivo, etc.)". (RAPOPORT, p.24)

Neste sentido, é justamente com intuito de minimizar as influências negativas do meio ambiente sobre os grupos sociais, que estes mesmos, ao escolherem um local para se instalarem, o fazem de maneira a potencializar as qualidades específicas encontradas no sistema escolhido: localização (qualidade do espaço, distância ao trabalho, etc.), vizinhança (características sociais dos grupos já estabelecidos no local, etc.), recursos disponíveis (água, materiais de construção, fontes de alimento, etc.), entre outros. E a partir destas condições, as sociedades se servem de seus conhecimentos, de seus instrumentos e ferramentas, de suas crenças, entre outros, para adaptar e preparar o território geográfico da melhor maneira possível para suas reproduções sociais.

A cidade de Djenné no Mali, fundada a mais de doze séculos, é um exemplo de cidade cuja localização foi estabelecida, baseada tanto na proximidade do acesso à água, quanto ao acesso às rotas comerciais existentes na época. Sua ocupação se deu em uma região de entroncamento entre as rotas comerciais que ligavam o sul da África do Oeste à Tombuctu, e da África do Norte em direção ao Ocidente e ao Oriente. Essa escolha acarretou inúmeras consequências, entre elas: o desenvolvimento progressivo do comércio e da troca de mercadorias no local, a migração massiva de diferentes grupos 
étnicos em direção a esta nova cidade, e o desenvolvimento de técnicas construtivas servindo-se dos materiais disponíveis localmente, no caso a terra e a madeira. ${ }^{39}$

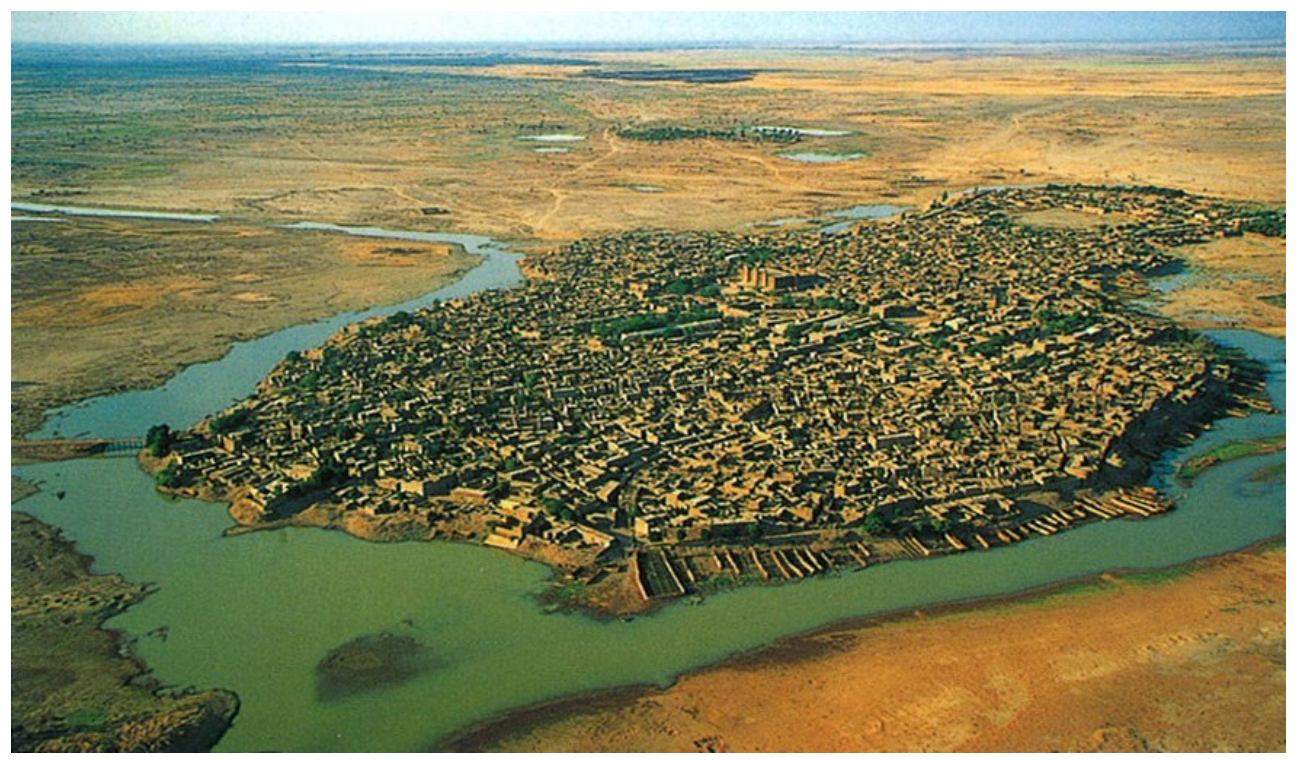

Figura 2 - Vista aérea da cidade de Djenné. ${ }^{40}$

Foram justamente as trocas materiais e culturais com o mundo árabe que permitiram a expansão do Islã na região e, por conseguinte, a evolução de novas técnicas construtivas inspiradas nas mesquitas e nas madrassas (escolas corânicas), resultando no nascimento do estilo árabe-sudanês, conhecido como arquitetura sudanesa. ${ }^{41}$

Inúmeros outros exemplos nos demonstram esta particular relação que se desenvolve entre os diferentes grupos sociais e os ambientes escolhidos por estes para se estabelecer. A cidade de Mari, na Síria, que teve seu apogeu no terceiro milênio antes de Cristo, foi construída próximo ao rio Eufrates e controlava as importantes trocas comerciais entre as montanhas de Taurus e a Babilônia. Um aspecto notável a se sublinhar é a compreensão apurada que seus fundadores possuíam sobre o uso das técnicas construtivas com terra.

"Eles conheciam perfeitamente bem suas propriedades térmicas e também sua sensibilidade à água, provenientes tanto do lençol freático quanto das chuvas. (...) Para assegurar a boa durabilidade, o nível da cidade foi

\footnotetext{
${ }^{39}$ YAMOUSSA, Fané e JOFFROY, Thierry, Villes Anciennes de Djenné, CRAterre-ENSAG, 2010.

${ }^{40}$ Fonte: CRAterre.

${ }^{41}$ YAMOUSSA, Fané e JOFFROY, Thierry, Villes Anciennes de Djenné, CRAterre-ENSAG, 2010, p.06.
} 
elevado de forma a afasta-la do lençol freático e seus espaços a céu aberto foram recobertos com materiais com boas características drenantes, como cascalhos e terras com cinzas." (BENDAKIR, 2008, p.11)

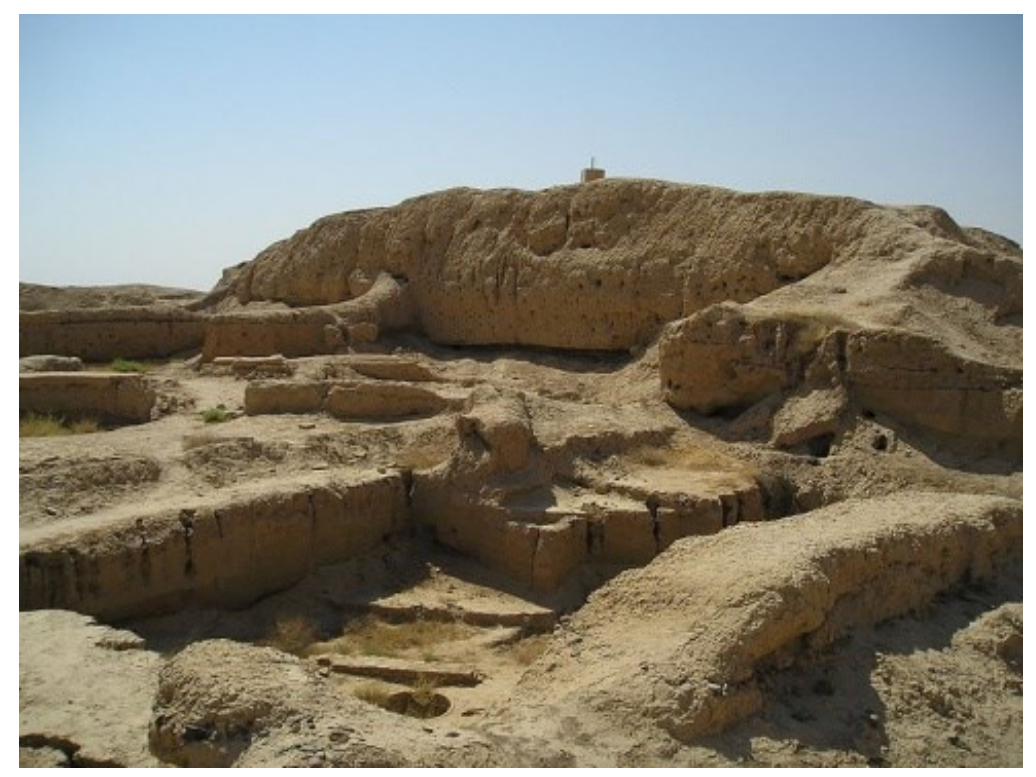

Foto 5 - Ruínas da antiga cidade de Mari, Síria. ${ }^{42}$

Outra característica surpreendente é a amplitude dos trabalhos realizados.

"Mari foi construída atrás de uma barragem de 1900 metros de diâmetro e o coração da cidade foi protegido por uma muralha de 1300 metros de diâmetro, espessa de mais de seis metros, com uma altura de pelo menos oito metros e ritmada por torres maciças." (BENDAKIR, ibid., p.11)

À imagem de Mari, as primeiras cidades do território que hoje compreende a Síria foram organizadas e equipadas objetivando permitir boas condições de vida às suas populações, face às condições climáticas particularmente difíceis da região. As estratégias e ações pelas quais optaram suas populações nos revelam uma civilização de grande poder e potencial que soube se adaptar e exercer certo domínio sobre as limitações condicionadas pelo meio ambiente natural. Demonstraram-nos uma consistente

\footnotetext{
42 Fonte: http://commons.wikimedia.org/wiki/File:MariZiggurat.jpg?uselang=es. (Consultado em 27/02/2014)
} 
sabedoria e engenhosidade com a utilização da matéria prima disponível em suas construções e uma organização social preventiva face aos riscos externos. ${ }^{43}$

"Há 5000 anos atrás, os construtores mesopotâmicos já utilizavam uma corda para medir, piquetes, prumos, desempenadeiras e colheres de pedreiro. Eles desenhavam a planta da casa no solo e traçavam os ângulos retos das habitações com a ajuda de uma corda com nós padronizada." (LAFFON, 2004, p. 53)

Outro exemplo que demonstra uma inter-relação equilibrada entre um determinado grupo social, uma cultura particular e uma região específica, diz respeito aos Batammaribas. Este grupo étnico, que vive na atual fronteira entre o Togo e o Benin, estabeleceu-se em um território de savana, cercado pelos maciços montanhosos do Atacora, e soube tanto adaptar-se ao meio ambiente natural quanto transformar a matéria prima disponível localmente em um conjunto de patrimônios arquitetônicos fascinantes, particularmente enriquecidos de elementos culturais que lhes são próprios. ${ }^{44}$

Eles desenvolveram uma cultura que relaciona elementos de ordem simbólica, religiosa, técnica e funcional, com os elementos naturais necessários à sua subsistência e ao equilíbrio com o entorno. Desta forma, a sociedade Batammariba confiou à sua ocupação territorial os elementos constituintes de sua unidade comunitária, baseados, sobretudo, em suas crenças, ritos e no respeito com o meio ambiente.

Não se conhece ao certo a origem deste grupo étnico. Especula-se que são originários da região do atual Burkina Faso, tendo migrado devido às sucessivas guerras e tentativas de colonização. O processo de ocupação territorial dos Batammaribas constitui-se em um verdadeiro reflexo de seus elementos místicos e é organizado a partir de diversos rituais realizados em torno de seus lugares sagrados, como por exemplo: o cemitério (onde os rituais se fazem ao lado da tumba do fundador do "clã"); a grande casa de iniciação dos jovens (onde residiu o ancestral fundador do "clã" e onde as

\footnotetext{
${ }^{43}$ BENDAKIR, Mahmoud, Architectures de terre en Syrie : une tradition de onze millénaires. Grenoble : Ed. CRAterre-ENSAG, 2008.

${ }^{44}$ Informações coletadas da exposição "Architecture et Paysage Betammaribe" do Ministério da Cultura, do Artesanato e do Turismo francês, realizada na embaixada da França no Benin e organizada pelo CRAterre/França.
} 
cerimônias oficiais se realizam) e o santuário da Serpente (lugar místico onde, segundo as crenças locais, habita a serpente subterrânea que deu origem aos ancestrais Batammaribas). ${ }^{45}$ Todos estes lugares estão intrinsecamente ligados aos processos de transformação das paisagens naturais, fundação das cidades locais e construção territorial em sua escala regional.

"A criação de uma nova cidade obedece ao mito da criação da primeira cidade por "Kuyé", o Deus criador, arquiteto do mundo que construiu a primeira "Takienta" para o homem e as divindades. O fundador da nova cidade se desloca de seu "clã" de base e constrói sua "Takienta", uma "Takienta-mãe" a partir do modelo original com todas as configurações iniciadas por Kuyé (torres, sótãos, terraços, etc.). (...) Ele estabelece um acordo prévio com "Butan ", a deusa da terra, esposa de "Kuyé », e mãe protetora dos humanos que governa a agricultura, as florestas, os animais, os cemitérios. (...) Ele levanta os santuários para os "Dibo », as forças naturais, com os quais a população deverá usar para compor seu território. (...) Finalmente, o fundador instala um centro de ritual composto pela casa grande de cerimônias, pelo altar da Serpente tutelar e pelo cemitério". (JOFFROY, DJANGUENANE, 2005, p. 15)

Esta paisagem territorial torna-se mais essencial do que a forma arquitetônica que reflete. Constitui-se como reflexo de um modo de vida específico, baseado em procedimentos e práticas cotidianas tradicionais e seculares, representativas de uma sociedade e das interações de suas crenças e outros elementos culturais com o meio ambiente natural. Suas casas, cercas, cemitérios, etc., são compostas também por seus ritos, cantos, danças e lutas, assim como pelas rochas, florestas, animais, campos, etc., constituindo-se e revelando-se como uma "paisagem viva".

\footnotetext{
45 UNESCO, Koutammakou - le pays des Batammariba: ceux qui façonnent la terre, Proposition d'inscription de biens sur la liste du patrimoine mondial, République du Togo, 2002.
} 

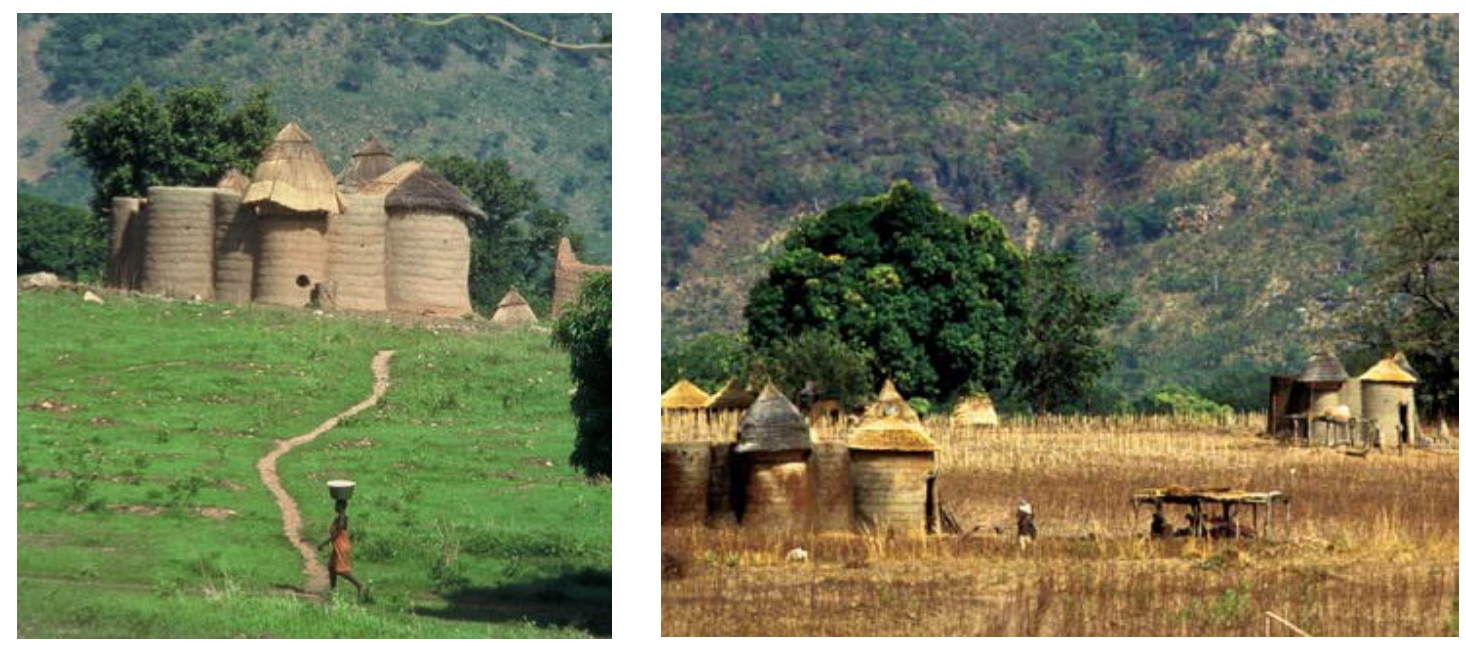

Fotos 6 e 7 - Paisagem Cultural Batammariba, Togo. ${ }^{46}$ e 47

Os territórios foram transformados, estruturados, organizados e embelezados a partir das representações e concepções que cada grupo social fez de seu lugar específico. A utilização do território demonstra um processo complexo que não pode ser reduzido a um comportamento físico ou à uma compreensão racional. Sua essência compreende todas as dimensões culturais.

\section{Recursos disponíveis}

"Apropriar-se das formas naturais testemunha o fato de que o humano faz parte integrante do universo. As casas religadas entre elas por suas formas e enraizadas na paisagem exprimem a consciência comum que possui o grupo em se aliar às árvores, às rochas, às areias, às asperezas, aos caminhos das águas, aos terrenos, em uma visão conjunta do universo, das paisagens e dos homens." (LAFFON, 2004, p. 21)

Mas como as diferentes sociedades se apropriam e utilizam os materiais localmente disponíveis no meio ambiente natural no momento de edificar seus habitats? Quais fenômenos criam resistências à utilização de uns tantos e integração aos modos de vida de outros tantos? Podemos observar que noções de higiene, beleza, conforto,

\footnotetext{
${ }^{46}$ Fonte: http://whc.unesco.org/fr/list/1140/gallery. (Consultado 27/02/2014)

${ }^{47}$ Fonte: Exposição "Architecture et Paysage Betammariba" do Ministério da Cultura, do Artesanato e do Turismo francês, realizada na embaixada da França no Benin e organizada pelo CRAterre/França.
} 
segurança, status, etc., rejeitam ou valorizam tais materiais através de seu uso intensivo ou de sua resistência em oposição. Mesmo os materiais de uso mais antigo, são inseridos ou excluídos dos processos produtivos por interesses diversos, por percepções simbólicas ou por falta de conhecimento técnico suficiente.

De origem mineral, vegetal ou animal, disponibilizados pela natureza e transformados pelas diversas culturas existentes, são as matérias-primas e os materiais, os interlocutores privilegiados dos sonhos e desejos daqueles que os compreendem e os manipulam. Tais materiais ocupam lugar de destaque nas decisões e estratégias de reprodução dos mais diversos grupos sociais. Tornam-se, assim, parte da história produtiva, desde a escolha judiciosa da matéria-prima adequada, passando pelas transformações experimentadas por séculos de repetição e desenvolvimento, até sua forma "produto final" em acordo com a finalidade concebida.

Com as terras erguem-se casas, igrejas, fortalezas, prédios de múltiplos andares, cúpulas, muros, enfim, cidades inteiras executadas a partir dos mais variados sistemas construtivos, desenvolvidos em função das características e propriedades das terras disponibilizadas e das inteligências construtivas de seus construtores. Dos bambus surgem pontes, estruturas leves e complexas, objetos decorativos em todas as escalas imaginadas. Das madeiras materializam-se estruturas, esquadrias, revestimentos, telhados, enfim, sejam fatiadas em lâminas ou roliças, construções dos mais diversos formatos aparecem a partir do uso deste nobre material. Das pedras, fundações são estruturadas, paredes são levantadas, aquedutos construídos, e de sua transformação novos materiais ganham forma e abrem novas possibilidades de uso. Dos vidros, o diálogo entre o interior e o exterior se afirma e a luz marca presença dentro dos espaços. Dos metais, os velhos limites se perdem no tempo, distâncias se reduzem e novas resistências mecânicas aparecem nos discursos técnicos. Além destes, tantos outros são os materiais, disponíveis ou transformados, cujos potenciais de utilização variam em função de suas qualidades específicas e dos conhecimentos de quem os manipulam.

Conhecimentos estes que são evocados conforme as criatividades e potencialidades adaptativas, a partir dos saberes e experiências acumuladas, que revelam múltiplos elementos e aspectos culturais, e que estão sob a influência das ordens 
estabelecidas pelas condições político-econômicas e sociais do momento histórico referente.

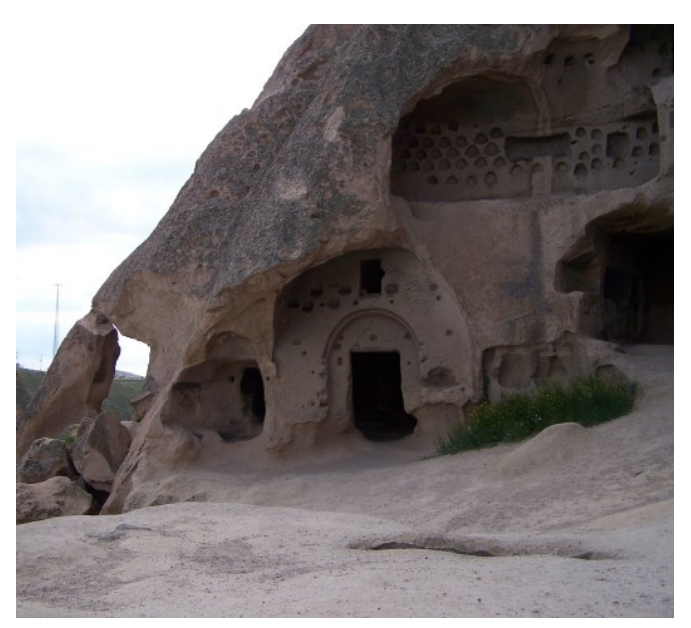

Foto 8 - Casas trogloditas de pedra da Capadócia. ${ }^{48}$

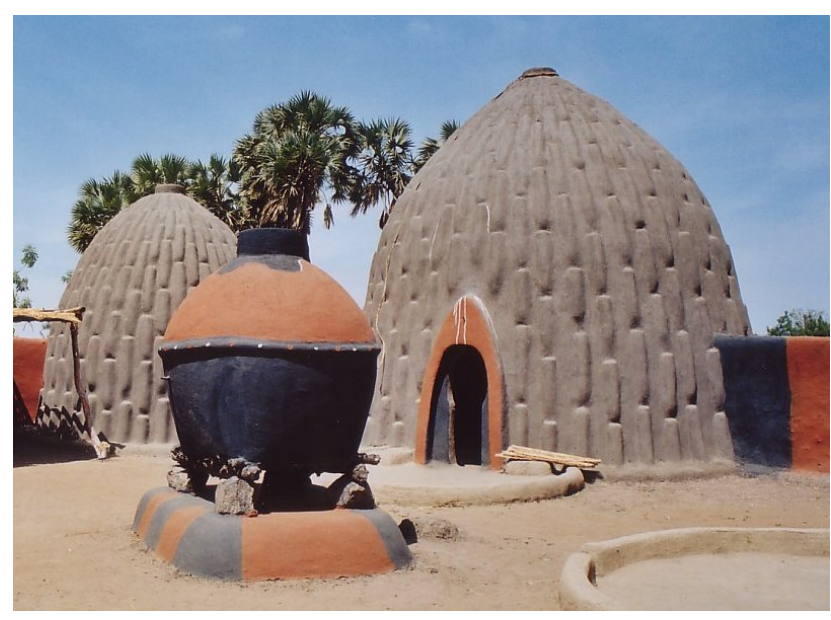

Foto 9 - Casas Obus em terra, no Camarões. ${ }^{49}$

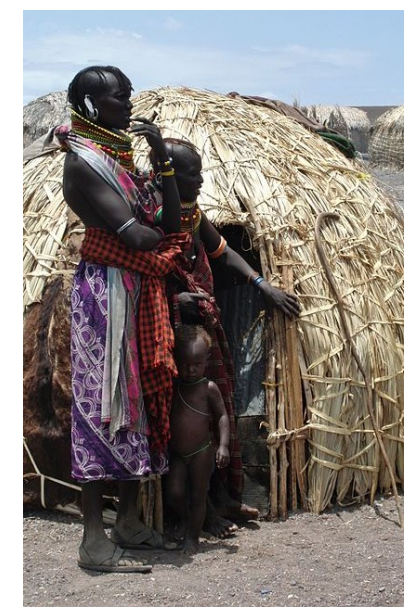

Foto 10 - Casas de palha no Lago Turkana, Quênia. ${ }^{50}$

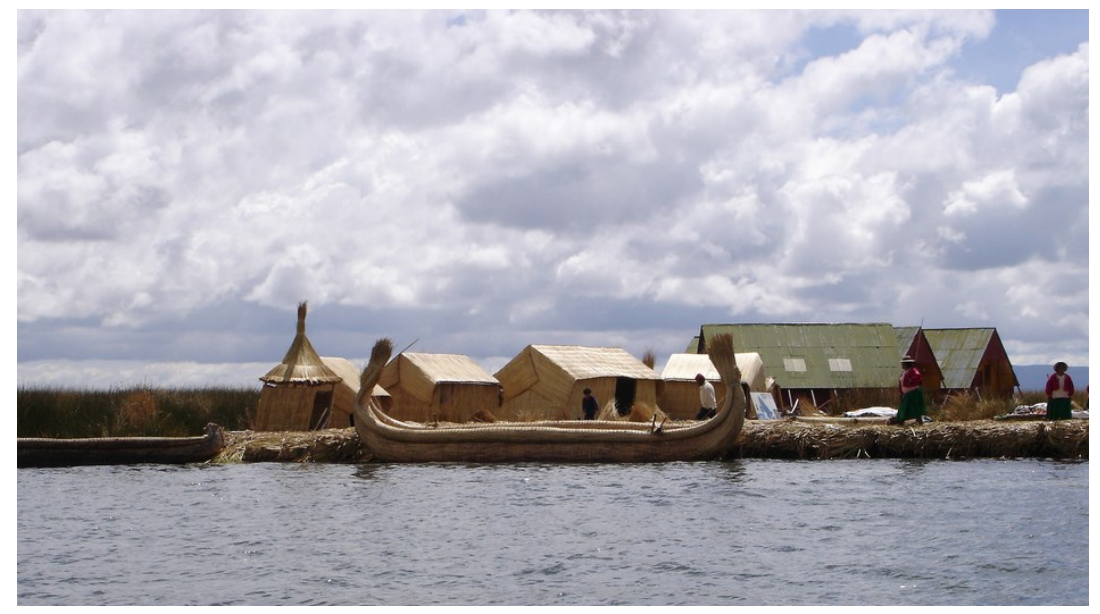

Foto 11 - Casas de palha no Lago Titicaca, Bolívia. ${ }^{51}$

As populações caiçaras (fruto da mestiçagem entre colonos europeus, escravos africanos e índios locais), presentes na região litorânea dos Estados do Paraná, São Paulo e Rio de Janeiro (Brasil), conservam ainda em tempos atuais um modo de vida particular,

\footnotetext{
${ }^{48}$ Fonte: http://pt.wikipedia.org/wiki/Ficheiro:CappadocciaCaves.jpg. (Consultado em 02/04/2014). Foto: Niels Elgaard Larsen.

${ }^{49}$ Fonte: http://commons.wikimedia.org/wiki/File:Maison_obus.jpg?uselang=fr. (Consultado em 02/04/2014). Foto: J. et M.F. Ostorero.

50 Fonte: http://commons.wikimedia.org/wiki/File:El_Molo_at_Lake_Turkana.JPG?uselang=fr. (Consultado em 02/04/2014). Foto: Jens Klinzing.

51 Fonte: http://pt.wikipedia.org/wiki/Ficheiro:Titicaca-isola.jpg. (Consultado em 02/04/2014). Foto: Mathias Ripp.
} 
essencialmente baseado em uma intensa interação, integração e dependência da natureza local e de seus recursos naturais. ${ }^{52}$

Segundo Alain Mantchev (2010, p.21), "os períodos de baixa atividade econômica correspondem aos períodos de fortalecimento da cultura caiçara. A mestiçagem cultural é essencial para a construção dos elementos do cotidiano. A influência indígena contribuiu ao domínio dos conhecimentos ligados à carpintaria marítima, ao artesanato de bambu $e$ às coberturas de palhas, a cultura portuguesa e africana influenciaram a arquitetura (domínio da técnica do "pau-a-pique"), a agricultura, a religião, entre outras."

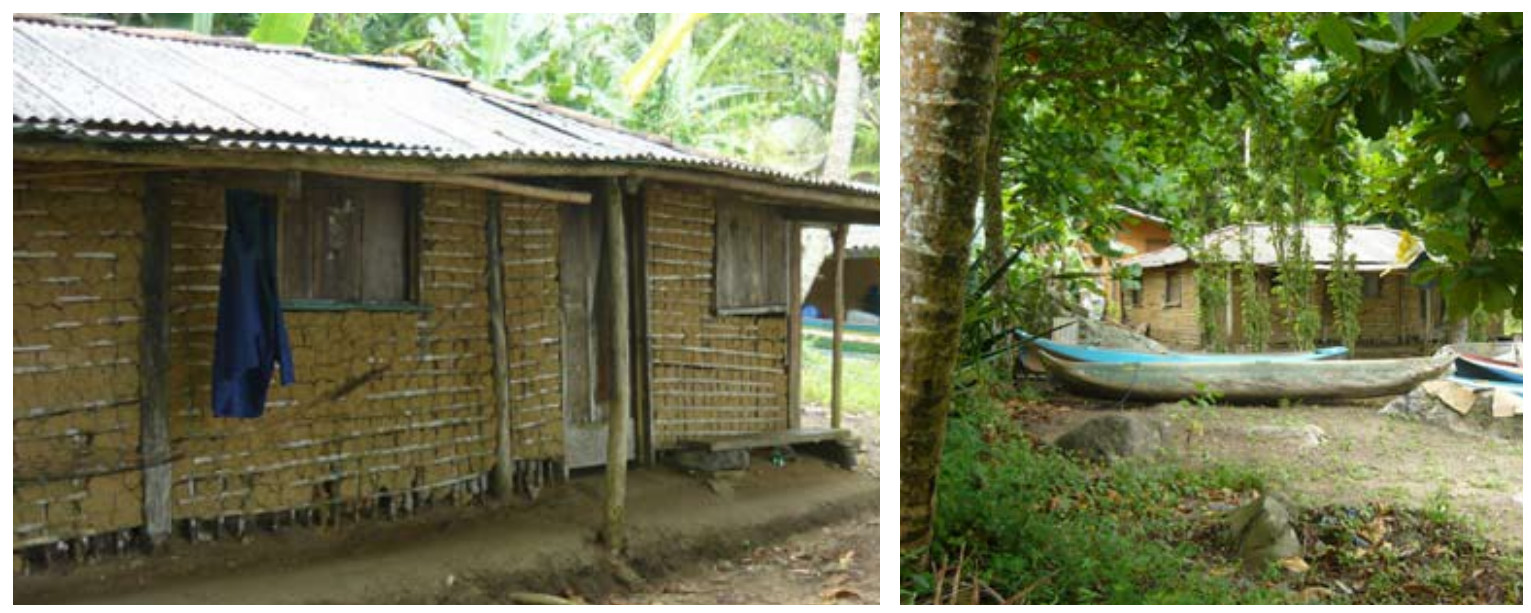

Fotos 12 e 13 - Casas caiçaras em terra, madeira e bambú, no litoral de São Paulo. ${ }^{53}$

\section{Sistemas construtivos}

Direcionamos nossa leitura para a reflexão sobre os fatores que tornam possível a organização das diferentes modalidades específicas dos processos produtivos. As relações possíveis entre o saber e o saber-fazer, a execução dos gestos e suas respectivas etapas de experimentação, adaptação, sistematização e aprimoramento, e ainda os procedimentos relativos aos mecanismos de reprodução, marcam e caracterizam a

\footnotetext{
52 Ver MANTCHEV, Alain B., Quel habitat en terre pour demain sur Ilhabela, Brésil ? Un regard sur l'habitat traditionnel caïçara. Culture constructive - Habitat - Paysage, Mémoire du Diplôme de Spécialisation et d'Approfondissement Architecture de terre, Ecole Nationale Supérieure d'Architecture de Grenoble, septembre 2010.

${ }^{53}$ Fonte: MANTCHEV, ibid., 2010. Foto: Alain B. Mantchev.
} 
natureza da produção do ato construtivo, alimentado, ainda, pelos aspectos culturais trazidos e evocados pelas mãos que manipulam a matéria e produzem os objetos.

Como se articulam nesta rede produtiva tais mecanismos que possibilitam a transformação da matéria em material e, em seguida, em objeto construído? Como se operam as interações, dentro dos processos criativos, entre a concepção, as relações forma-estrutura, a linguagem estética, os fenômenos imateriais, os materiais disponíveis e os saberes-fazer?

Para o grupo de pesquisa Cultures Constructives, o fato de vislumbrar o ato construtivo a partir do ponto de vista cultural conduz a nos interrogar sobre a essência da experiência engajada, questionando tanto a natureza das organizações sociais, a repartição das competências distribuídas e as instituições que ganham corpo, como ainda os tipos dos saberes que se formalizam e se transmitem:

“O status da experimentação pode ser reinterpretado de maneira bem sucedida nesta linha de reflexão, retomando o significado primeiro deste termo, ou seja, a construção empírica de um conhecimento. Assim formulada, esta definição da experiência permite requalificar, no campo da arquitetura, a noção de experimentação construtiva." (CULTURES CONSTRUCTIVES, op.cit., p.13)

Assim, a perspectiva antropológica evidencia a importância e o status da ação na realização da experiência. E, é essa perspectiva que nos permite questionar em termos da constituição de uma cultura, sobre a problemática da transmissão e da memorização de uma experiência operatória.

"O estudo dos procedimentos construtivos é suscetível de uma descrição que coloca em evidência a passagem do gesto técnico ao traçado, e assim do traçado ao plano, e então do plano às formas arquitetônicas. Nesta estratificação representativa que leva do concreto ao abstrato, do prático ao teórico, é importante analisar como se memoriza e se transmite a experiência adquirida: ensinamento, difusão de informação, memória escrita ou oral, rede de atores relacionados, etc. Desta forma, é possível de 
descrever culturas construtivas em via de sedimentação." (CULTURES CONSTRUCTIVES, ibid., p.40)

Todos os anos o mesmo ritual se repete. Durante a estação da seca, a população da cidade de Djenné, no Mali, se reúne em festa para a realização dos trabalhos de manutenção do reboco de terra da grande mesquita, um dos maiores monumentos construídos em terra no mundo, cujo início se deu no final do século XIII. Geração após geração, a realização deste necessário trabalho abriga o maior evento do calendário cultural da cidade.

Este evento dá lugar a uma grande mobilização popular em que a participação coletiva se tornou um ritual quase incontornável, onde os grupos sociais das mais diversas culturas e etnias locais se encontram em torno de um objetivo comum, reforçando a coesão do tecido social e marcando o funcionamento desta comunidade mulçumana. ${ }^{54}$

Assim, a arquitetura da mesquita de Djenné e sua trajetória construtiva estão intrinsecamente ligadas a uma prática regular de manutenção de seu reboco de terra. $A$ necessidade técnica transformou-se ao longo dos anos, em uma manifestação prática de cooperação coletiva, revelando os traços culturais desta sociedade muçulmana multiétnica, e marcando profundamente a essência do funcionamento desta cidade santa.

O patrimônio arquitetônico adquire uma dimensão mais abrangente do que seu valor como técnica construtiva. Configura-se como um instrumento de coesão social, cujo processo de compartilhamento e interação dos saberes reflete-se na valorização das identidades comuns.

Este enorme monumento foi construído sobretudo com terra, sob a forma de tijolos de adobes cilíndricos ${ }^{55}$, conhecidos como "Djenné ferrey". Estes, foram criados na

\footnotetext{
54 YAMOUSSA e JOFFROY, 2010, p.20.

55 Utilizando-se a terra como material de construção e as mãos como principal ferramenta de trabalho, os adobes são há séculos produzidos e usados como sistema construtivo na edificação da mesquita. Estes, foram transformando-se ao longo do tempo. No início, eles eram cilíndricos, moldados à mão sem o auxílio de fôrmas. Eram conhecidos como Djenné ferey, e foram substituídos na primeira metade do século XX
} 
região e utilizados na arquitetura tradicional de Djenné até o início do século $X X$, tendo sidos replicados em outras regiões do Mali e também utilizados nas construções de outras mesquitas. ${ }^{56}$

Com uma superfície de $6375 \mathrm{~m}^{2}$ e muros de 60 centímetros de espessura, em média, o plano da mesquita de Djenné é de estilo islâmico ortodoxo. Como a maior parte das mesquitas que apresentam este tipo de desenho, a mesquita de Djenné possui certas características particulares. Na cobertura, cento e quatro buracos de aeração e ventilação estão integrados à estrutura do telhado, formados por potes sem fundo. Uma tampa feita em terra cozida cobre cada um dos buracos. A manutenção do reboco da mesquita é possível graças a um sistema de andaimes permanentes inseridos nos muros desde sua construção, sob a forma de peças de madeira suficientemente longas que possibilitam a subida em escalada ao longo das fachadas. Esses elementos funcionais e estéticos são permanentes e conferem uma aparência própria às mesquitas do estilo árabe-sudanês. ${ }^{57}$
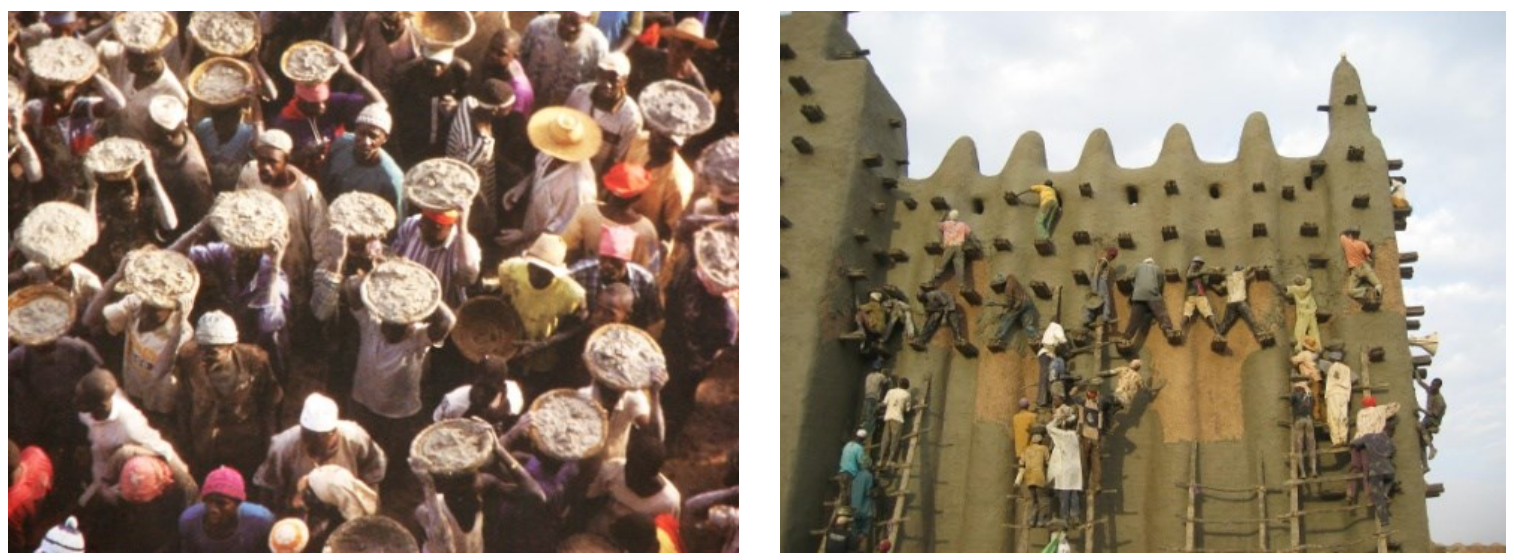

Fotos 14 e 15 - Evento de reaplicação do revestimento externo em terra na mesquita de Djenné. ${ }^{58}$

"O conjunto deste patrimônio humano gera um patrimônio construído. Este constitui a transcrição espacial, vivida e experimentada das culturas construtivas. De um lado, é uma testemunha material do estado das práticas em um momento dado de sua evolução, em um contexto preciso.

pelos adobes de formato retangular, moldados com o auxílio de fôrmas e conhecidos como Toubabou ferey.

${ }^{56}$ YAMOUSSA e JOFFROY, ibid., p.13.

57 YAMOUSSA e JOFFROY, ibid., p.18.

${ }^{58}$ Fonte: CRAterre. 
De outro, é uma ferramenta de adaptação dos saberes e saberes-fazer dentro do processo de evolução de uma cultura construtiva." 59

Tais processos produtivos se manifestam como motor, palco e instrumento da formação e desenvolvimento das culturas construtivas. Estão presentes nos mais diversos grupos sociais, nas mais diferenciadas regiões do planeta e em todos os períodos históricos.

A cultura construtiva caiçara se desenvolveu em um contexto de dominação portuguesa, com forte influência de seus estilos e linguagens arquitetônicas. A habitação caiçara revela o pau-a-pique como a técnica construtiva mais utilizada, assumida pelo estilo colonial português e marcada por elementos construtivos típicos de sua arquitetura, como a presença de telhas cerâmicas coloniais e do uso das janelas e portas em madeira, muitas delas recuperadas das antigas fazendas produtoras de cana de açúcar da região. ${ }^{60}$

Esta mestiçagem formadora da cultura construtiva caiçara soube em seu processo construtivo, criar, reproduzir e adaptar suas arquiteturas a partir de uma estreita relação com o meio ambiente (o sítio, os materiais, os recursos, o clima) e sua história. Suas práticas construtivas selecionaram as características necessárias e as codificaram segundo uma tradição construtiva que atravessou gerações de construtores.

Segundo Marluci Menezes (1996, p. 272), "O ato de construir reflete a existência de um pensamento indutor daquilo que se objetiva fazer, bem como daquilo que se deseja fazer face as necessidades e as características físicas e culturais do contexto em que se insere $o$ ato. Daí que as habitações humanas serem construídas, em concordância com a diversidade das circunstâncias físicas, naturais e sociais, de modo que às sociedades humanas tem-se subjacente um habitat formalizado peculiarmente."

Os Korowai são um grupo étnico de uma província da Indonésia na Nova Guiné Ocidental. Este grupo esteve recluso do resto do mundo até os anos 1970. Na língua

\footnotetext{
${ }^{59}$ Comentários do professor Hubert Guillaud (CRAterre) em seus cursos sobre culturas construtivas, 2008. Arquiteto e professor HDR da Escola Nacional Superior de Arquitetura de Grenoble / França. Codiretor da unidade de pesquisa "Architecture, Environnement et Cultures Constructives".

${ }^{60}$ Ver MANTCHEV, op.cit., 2010.
} 
Korowai, suas casas são chamadas de "chem" (ou kchaim). Elas são feitas de madeira, bambu e folhas, e, em sua maioria, são construídas no alto das árvores, à uma altura entre oito e doze metros, o que as protege de inundações, bichos ou ataques de inimigos. ${ }^{61}$
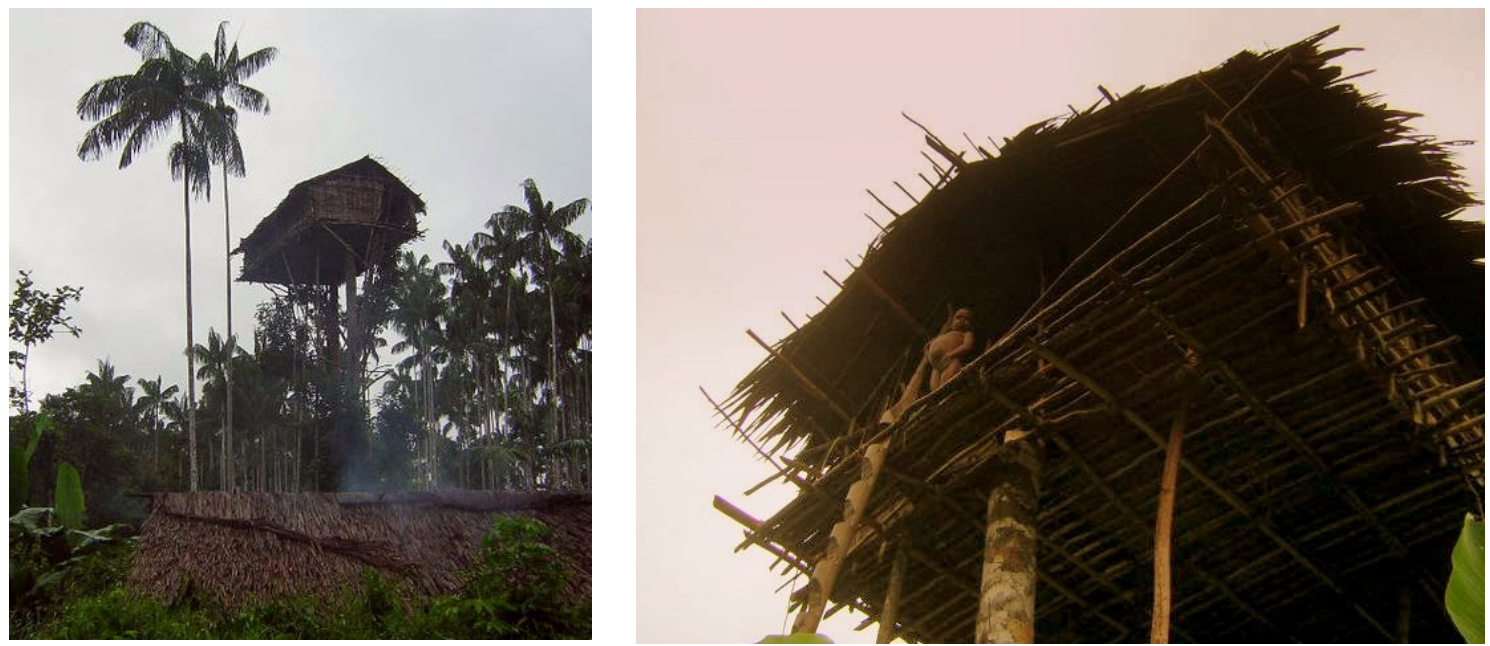

Fotos 16 e 17 - Casas Korowai construídas nos topos das árvores. ${ }^{62}$ e 63

A construção de uma casa nas árvores começa pela escolha de uma árvore vigorosa que possa constituir o pilar central. Trabalhando com andaimes temporários em volta da árvore, o piso é montado de maneira apoiada sobre diversas outras árvores secundárias. Ele é composto por pequenos troncos cobertos por cascas de palmeiras. As paredes são feitas com folhas trançadas, a cobertura de folhas de palme e o acesso se faz por uma escada em tronco de palmeira. As casas são divididas em dois ou três cômodos, sendo um reservado às mulheres. Os materiais necessários são recolhidos no entorno imediato, a zona é desflorestada e alargada em forma de um círculo de algumas dezenas à uma centena de metros, com o intuito de proteger a área, tornando-a visível. ${ }^{64}$

Uma casa Korowai é construída em um ou dois dias e dura cerca de 3 a 5 anos. Ela é realizada de maneira coletiva, com a ajuda dos membros do clã. Quando a quantidade de palmeiras existentes no local torna-se insuficiente para o crescimento do clã, este

\footnotetext{
${ }^{61}$ Ver http://fr.wikipedia.org/wiki/Korowai. (Consultado em 25/03/2014)

62 Fonte: Korowai Treehouse. http://commons.wikimedia.org/wiki/File:Korowai_Treehouse_3.jpg. (Consultado em 25/03/2014)

${ }^{63}$ Fonte: Korowai Treehouse. http://commons.wikimedia.org/wiki/File:Korowai_Treehouse.jpg?uselang=fr. (Consultado em 25/03/2014)

${ }^{64}$ Ver http://fr.wikipedia.org/wiki/Korowai. (Consultado em 25/03/2014)
} 
muda-se para outro território onde recomeça com as construções de suas casas penduradas. O tempo de vida das casas constitui uma referência do calendário Korowai. A vida social é marcada pelo número de casas habitadas. ${ }^{65}$

Os mecanismos de reprodução de uma tipologia construtiva e seu desenvolvimento empírico progressivo se faz através da integração de uma cultura particular com seu meio ambiente natural. O ponto de referência não é a humanidade, mas o grupo cultural. Assim como Pierre Frey (2010) observa em suas análises sobre as arquiteturas vernáculas, as técnicas compreendem os saberes-fazer mais profundos, amplos e complementares. A eficácia comprovada destes saberes e saberes-fazer, é transmitida e desenvolvida no interior das sociedades que as produziram, compreendidas as sociedades fundadas na tradição oral.

"A manifestação do fazer é a construção, a fabricação, o artefato. Entretanto, ele não é somente o testemunho de nível técnico, do domínio dos procedimentos e dos saberes-fazer. Ele denota da parte dos arquitetos, um olhar fundamentalmente diferente sobre a arquitetura e sua relação com o mundo." (FREY, 2010, p. 97)

\section{Sistemas de mediação e organização}

Outros elementos também adquirem importância na trajetória onde determinados processos construtivos tornam-se embriões das posteriores culturas construtivas. Boa parte deles são encontrados nas instâncias relativas aos sistemas de mediação e de organização do trabalho. Tais instâncias contribuem para a emergência de modelos e estratégias que fortalecem a constituição e a valorização de identidades, de sentidos, de objetivos e de utopias.

Neste processo devemos nos esforçar para compreender como "(...) certa organização material da produção infere modalidades especificas de concepção, tanto ao nível dos modos de comunicação e de controle dos processos quanto ao nível das próprias

\footnotetext{
${ }^{65}$ Ver http://fr.wikipedia.org/wiki/Korowai. (Consultado em 25/03/2014)
} 
formas de expressão, privilegiadas pelo conceptor em seu trabalho". (UNESCO, 1993, p.56)

Esses sistemas são marcados por diversos procedimentos e mecanismos de atividades, como: os métodos de gestão, de comunicação, de interação social, assim como os acordos e pactos que se estabelecem através da identificação ideológica, da militância, etc. A organização do trabalho é essência e instrumento dentro do processo de produção, e determina as condições e os níveis de cooperação, conscientização e empoderamento dos respectivos grupos sociais.

Geralmente, tal organização repousa sobre regras (normas) que são utilizadas no planejamento dos mecanismos de comunicação. Segundo Amos Rapoport:

“(...) tais regras variam sobretudo em função da cultura. De fato, as regras servem em parte para definir grupos (de indivíduos que compartilham regras) e constituem um aspecto importante da cultura. As regras ditam igualmente os comportamentos e possuem um papel central nos modos de vida e dos sistemas de atividades." (RAPOPORT, 2000, p.37)

A corporação dos artesãos de Djenné sempre foi reconhecida na região por sua qualidade, sendo regida por um código restrito. 0 barey ton $^{66}$ toma as decisões relativas à distribuição dos canteiros de obras e às devidas remunerações, assegurando através de um sistema de patronagem a formação dos aprendizes. Assim como nas corporações de ofício tradicionais, distingue-se uma estrutura interna hierarquizada e bastante restrita, formada pelos aprendizes, os jovens artesões (que terminaram sua primeira fase de aprendizado) e os mestres artesões. Estes últimos detém o conhecimento de maneira mais completa, e até mágica, em relação às tradições da profissão. ${ }^{67}$

Estes conhecimentos e práticas compartilhadas e também protegidas, ilustram o que Scott Francisco (2007, p.979) se refere quanto ao nível de qualidade dos trabalhos dos mestres artesãos, que possuem uma relação com a matéria, implicitamente especificada pelas tradições realizadas coletivamente por uma comunidade de artesãos.

\footnotetext{
${ }^{66}$ Corporação de artesões cuja criação remonta ao século XV, e que está na origem do estilo arquitetônico chamado sudanês.

${ }^{67}$ YAMOUSSA E JOFFROY, op.cit., p.14.
} 
Quando das atividades de manutenção dos rebocos em terra realizadas na mesquita de Djenné, após a estação das chuvas, a organização do trabalho é feita atentamente e seguindo certas regras locais de repartição de tarefas. Os grupos são separados por bairros e começam as atividades logo no início da manhã, sendo estas executadas sob a direção dos mestres artesões. A maior parte das pessoas está encarregada pelo transporte e pela aplicação da massa de reboco, contudo são os mais velhos e experientes que supervisionam os trabalhos e asseguram o respeito e a boa aplicação das considerações técnicas. As ferramentas de trabalho utilizadas são bastante simples. O essencial do trabalho, compreendendo a aplicação do reboco, é feito à mão. ${ }^{68}$

Tais atividades de manutenção da mesquita são acompanhadas de rituais mágicoreligiosos. Ao final do dia, realiza-se uma cerimônia que é sempre concluída por uma grande oração seguida de bênçãos.

\section{Sistemas de representação}

"O primeiro que traçou o plano da casa entorno de si, sobre o chão, desenhava uma fronteira ínfima entre o interior e o exterior, o espaço doméstico e o espaço selvagem, mundo dos espíritos ou dos ancestrais. Somente o muro da casa, como uma roupa protetora, isola do exterior." (LAFFOND, 2004, p.57)

O patrimônio arquitetônico adquire uma dimensão mais abrangente que seu valor como técnica construtiva. Como parte do processo produtivo, configura-se em um instrumento de coesão social, cujo compartilhamento e interação dos saberes se reflete na valorização de identidades comuns.

“O reagrupamento é também uma noção primordial para a emergência de uma cultura. Certamente, deve-se construir coletivamente lugares de interação refletindo uma identidade comum, mas deve-se antes de tudo, reagrupar-se com o intuito de se proteger, constituir um habitat resistente

\footnotetext{
${ }^{68}$ YAMOUSSA e JOFFROY, Ibid., p.20.
} 
tanto às intempéries quanto aos conflitos armados. Desta forma, a constituição de um grupo permite distribuir os saberes e os saberes-fazer, em uma lógica de especialização (a técnica do artesanato, as corporações, etc.) que possibilita aprofundar os conhecimentos no interior de um território, de um sistema de atores, de um funcionamento social e de modos de vida." 69

O processo de constituir e desenvolver sistemas de representação ocorre de maneira simultânea, complementar e interativa ao próprio processo produtivo. $\mathrm{O}$ ato de criação que assume e transforma a matéria, parte de um processo que anuncia e coloca em evidência a origem, a história e o acúmulo do sujeito criador, e atravessa processos outros de constituição e desenvolvimento de sentidos, significados, linguagens, identidades, entre outros.

No âmbito da análise dos sistemas de representação, os aspectos culturais ocupam amplo espaço dentro dos processos de produção. Compreendendo grupos particulares com situações, ambientes e momentos específicos, tais aspectos culturais contribuem, não somente com a elaboração do produto do processo tecnológico, tal qual, como definem igualmente, as características deste processo. Aquilo que em arquitetura chamamos de linguagem, reside nas características próprias do processo de produção, sendo em grande parte oriundas das escolhas e condições norteadas pelos aspectos culturais locais.

Para compreendermos melhor os elementos e aspectos constitutivos das culturas, propomos estabelecer como referência o trabalho realizado por Amos Rapoport, objetivando decompor o conceito de cultura, amplo e vasto, em um conceito mais operacional, baseado em seus elementos constituintes, mais específicos e mais facilmente relacionáveis, entre si e com outros elementos - como as matérias primas, os sistemas construtivos, o meio ambiente, etc.

A ideia de que as dimensões sociais e culturais podem ser separáveis como método de análise foi trabalhada por Rapoport. Segundo ele:

\footnotetext{
${ }^{69}$ Comentários do professor Hubert Guillaud (CRAterre) em seus cursos sobre as culturas construtivas,
} 2008. 
"O cultural é um conceito idealizável, um modelo para as variáveis sociais que são as manifestações e os resultados tangíveis da cultura. As expressões sociais potencialmente observáveis da cultura, tais quais a família e o parentesco, as redes sociais, os papéis, os status sociais, as instituições sociais, são particularmente importantes. Além de potencialmente observáveis, elas foram amplamente estudadas. Podemos, assim, relacioná-los com os ambientes construídos de maneira concreta, enquanto que com a cultura, seria impossível." (RAPOPORT, 2000, p.119)

Neste sentido, ele propõe o seguinte esquema:
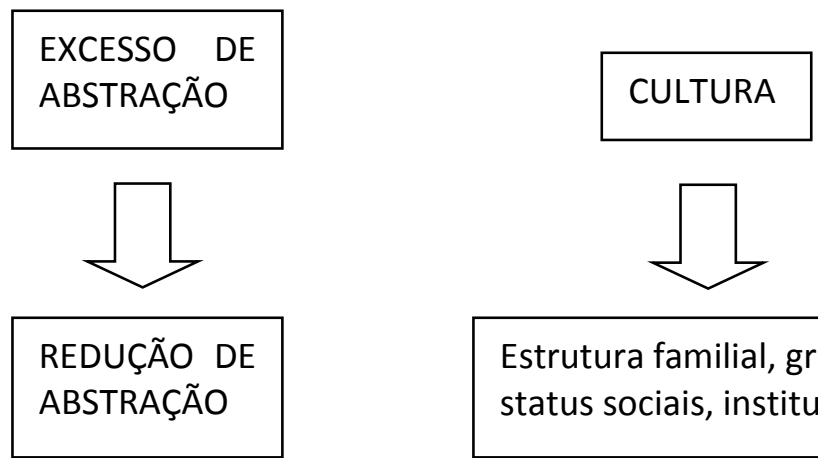

Expressões sociais mais concretas e potencialmente observáveis.

Figura 3 - Esquema proposto por Rapoport para analisar conceitualmente as culturas. ${ }^{70}$

Rapoport continua sua reflexão reafirmando que a cultura é uma construção teórica que existe por definição. Segundo ele:

“(...) (Cultura) é uma abreviação conceitual, uma proposição de explicação para conjunturas particulares de uma grande variedade de fenômenos humanos. Ninguém viu nem poderá jamais observar a cultura, somente seus efeitos, suas expressões, seus produtos. Fazemos então hipóteses ao sujeito de uma entidade não observável, nos fundamentando em elementos observáveis." (RAPOPORT, 2000, p.119)

A decomposição proposta por Rapoport busca estabelecer uma sequência de componentes ou elementos cada vez mais específicos, sendo também, cada vez mais

\footnotetext{
${ }^{70}$ RAPOPORT, op.cit., p.118.
} 
operacionais para as análises, tais como: as visões de mundo, os valores, as normas, os modos de vida e sistemas de atividades, etc. O gráfico a seguir ilustra seu método de análise.

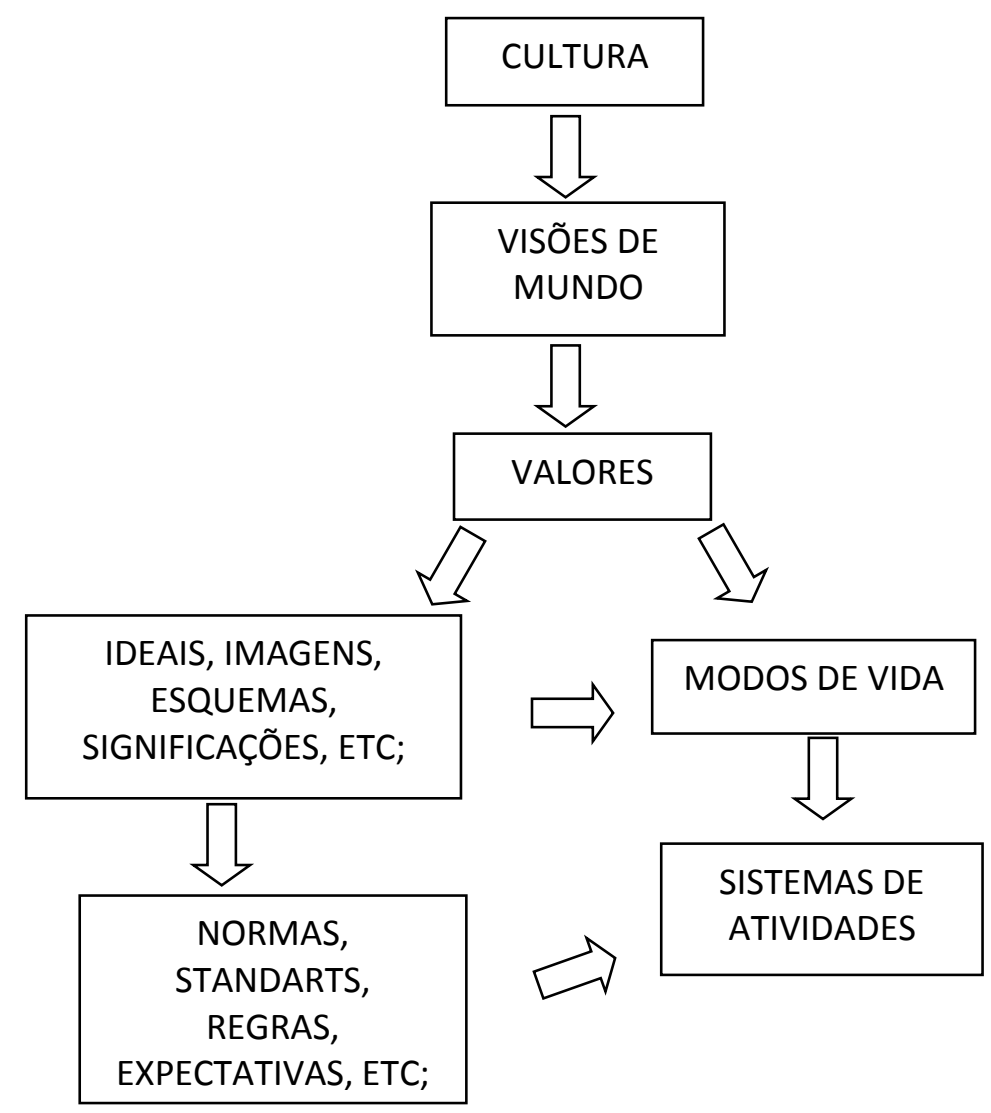

Figura 4- Método de decomposição conceitual do termo cultura, proposto por Rapoport. ${ }^{71}$

As formas como os membros de uma cultura veem o mundo, ou seja, suas visões de mundo são muito úteis em termos analíticos, segundo observa Rapoport. Mais precisos e ainda mais úteis são os aspectos presentes nas visões de mundo, como os valores. Os estudos sobre a essência das preferências ou sobre as razões que nos levam a fazer certas escolhas são interessantes neste sentido, pois repousam explicitamente sobre os valores sociais. Um exemplo disso refere-se ao domínio da publicidade e do marketing, onde percebemos claramente como determinados valores influenciam e muitas vezes indicam os preços atribuídos a diferentes bens de consumo, inclusive aqueles tidos como fundamentais para o funcionamento da economia.

\footnotetext{
${ }^{71}$ RAPOPORT, ibid., p.121.
} 
Estes valores relacionam-se com o modo de vida de um dado grupo social, contribuindo, muitas vezes, na orientação de certas escolhas e estratégias tomadas. Entendendo esta engrenagem, podemos compreender com maior facilidade os mecanismos que motivam a realização de certas ações, como por exemplo, as razões pelas quais muitas vezes os desejos são mais importantes que as necessidades ou porque certas escolhas aparentam ser irracionais.

Seguindo o esquema proposto, os valores são frequentemente expressos através dos ideais, das imagens, dos esquemas, das significações, etc. Estes, por sua vez, conduzem as normas, regras, expectativas, entre outros, que por serem mais operantes para as análises, influenciam determinantemente na estruturação dos sistemas de representação, contribuindo e influenciando os comportamentos e os modos de vida.

A definição de "modos de vida" evoca, para Rapoport, o resultado das escolhas feitas sobre as formas de se alocar os diversos recursos existentes, não somente os econômicos, mas também aqueles referentes ao tempo, aos esforços, ao envolvimento das pessoas, etc. Esta definição torna o conceito operante, sobretudo por ser associada à noção de "escolha". Por sua vez, os modos de vida nos conduzem às atividades e seus sistemas de atividades, expressões culturais concretas e frequentemente utilizadas em análises. Os estudos sobre as atividades culturais de um grupo social e seus sistemas de atividades são de extrema utilidade nos processos de concepção dos projetos e de produção das tecnologias.

“(...) os modos de vida são particularmente úteis por múltiplas razões. Primeiramente, se eles são suficientemente precisos para serem operacionalizados, restam mais gerais que os sistemas de atividades. Em seguida, a maior parte dos outros critérios determinantes para o pertencimento a um dado grupo, tais quais a idade, o sexo, a raça, a etnia, a casta, a tribo, a religião, a educação, a profissão, a ideologia, a classe social, etc., podem ser expressos em termos de modos de vida." (RAPOPORT, 2000, p.124)

Por outro lado, podemos também tecer análises sobre os diversos grupos sociais através do estudo de seus diferentes sistemas de regras, normas, códigos, 
regulamentações, entre outros. Estes podem ser formais ou informais, escritas ou orais, e podem produzir estilos, linguagens e identidades próprias a um ambiente.

Os ambientes construídos, tanto como produtos quanto como processos de produção, demonstram diferentes expressões de uma mesma cultura ou de diversas culturas conjugadas. Quando estas regras e normas são mais específicas, elas permitem também a definição dos diferentes grupos e guiam seus comportamentos no ambiente, definindo aquilo que será aceitável, tolerável, proibido ou razoável, em quais lugares, em qual período, por quais grupos de pessoas, etc.

Assim, como nas relações existentes entre os comportamentos sociais e o meio ambiente, a interação entre o habitat e a família é extremamente forte e ocorre de maneira recíproca. As características familiares e o modo de vida de seus membros influenciam na configuração do habitat e este último, por sua vez, produz diferentes efeitos sobre a família.

"A moradia e a família são essenciais no processo de assimilação cultural e possuem um papel central para assegurar a continuidade cultural $e$ sobrevivência de um grupo." (RAPOPORT, 2000, p.139)

No caso dos Batamaribas, nota-se que o habitat apresenta uma dualidade masculino-feminino marcada por uma separação das construções segundo seu eixo LesteOeste. A metade Sul, caracteriza-se como um espaço referente ao sagrado, sendo assim destinado aos homens. Já a metade Norte, conforma-se como um espaço onde as mulheres se tornam as responsáveis. ${ }^{72}$

"O essencial não está somente na forma e na função, mas também no valor, o papel instrumental que assume um elemento como modo de exaltação de uma característica particular da sociedade. Aquilo que construímos é somente uma pequena parte do sistema de relações arquitetônicas potenciais elaborados por uma sociedade dada." (GUIDONI, 1994, p.10)

\footnotetext{
72 JOFFROY e DJANGUENANE, 2005, p.26.
} 
A realização original da takienta (habitação tradicional Batamariba) reside numa perfeita interação entre os elementos profanos e sagrados pertencentes a esta particular cultura. Símbolos, funções, imagens e regras ditam os sistemas de atividades ligados aos seus processos construtivos. As quantidades de cômodos a serem construídos, seus respectivos tamanhos e os estilos de suas decorações variam em função do status e das características dos habitantes.

A espiritualidade é um aspecto extremamente forte na cultura Batammariba. Seu habitat é um local que abriga tanto os familiares vivos quanto os espíritos de seus ancestrais. Desta forma, ele é planejado e construído prevendo diferentes espaços dedicados aos cultos, dispostos de maneira separada dos espaços habitados pela família. Como regra geral, tais espaços de culto situam-se no térreo das construções, reservando assim o primeiro andar da takienta para a vida cotidiana dos habitantes vivos.

"A construção de uma casa é objeto de cinco cerimônias. A primeira se faz no momento da realização da fundação, a segunda durante a colocação da soleira da entrada, a terceira durante a realização da parede do lado masculino, a quarta quando o terraço do primeiro andar é realizado, e a quinta e última quando a casa estiver inteiramente terminada." (JOFFROY e DJANGUENANE, 2005, p. 26)

Cabe aqui ressaltar a importância de tais rituais e decisões construtivas para o processo de preservação e reprodução cultural dos grupos sociais. Esses rituais surgem assim como uma forma de retenção e memorização dos acontecimentos, dos símbolos e, inclusive, dos procedimentos operatórios dos processos construtivos. Eles demonstram como as relações e adequações entre a representações de mundo e os territórios habitados se realizam.

O habitat planejado e construído assume também a função de relembrar e manter vivos, para as gerações posteriores, alguns eventos do passado, bem como alguns rituais importantes para o grupo. Desta forma, o processo de produção do habitat constitui-se como elementar contribuição para a preservação da identidade comunitária. 


\section{Sistemas de memorização}

"O conceito fundamental da arquitetura autêntica consiste no fato de que 0 significado espiritual não se encontra exclusivamente na construção mesma, que deste modo se torna um símbolo autônomo do interior, mas que este significado, inversamente, já adquiriu fora da arquitetura a sua existência livre." (HEGEL, 2008, p.139)

Dentro dos estudos sobre os processos de formação e desenvolvimento das culturas construtivas tradicionais, a análise dos sistemas e mecanismos de memorização é extremamente crucial. Tais mecanismos se apoiam nas experiências de nossa construção cognitiva, onde além da aquisição dos novos conhecimentos externos, estabelece-se um processo de assimilação daquilo que é captado em nossa percepção interior. O ser humano reforça sua identidade existencial interagindo com o resto do grupo e com o meio ambiente em que vive.

A experiência operatória é fundamental nesta etapa. De um lado, ela nos permite entrar em contato com as relações concretas existentes entre o sujeito criador, a matéria, e sua transformação. Do outro, ela proporciona "novas experiências", no sentido do constante aprimoramento dos saberes adquiridos.

“(...) Apoiando-se nessa análise, é interessante observar a maneira na qual o procedimento arquitetônico transforma progressivamente uma prática em um "esquema operatório", e depois em desenho e em imagem, sem perder, no entanto, a dimensão performativa inicial." (CULTURES CONSTRUCTIVES, 2005, p.40)

Philippe Potie teceu uma relação entre a instrumentalização da memória operatória no campo da produção da arquitetura e os mecanismos de memorização trabalhados por Leroi-Gourhan em seu livro "A memória e os ritmos". Ele sugere que:

"A descrição da relação entre a oralidade e sua prática regular foi revelada por Gourhan quando ele mostra como o ritmo, a rima, o metro, a repetição, etc., formam de alguma forma o primeiro grau de uma instrumentalização, 
de uma externalização da memória, permitindo o desenvolvimento das capacidades. Pode-se então fazer a hipótese de que o ritmo, a simetria, as proporções, que formam uma das bases da composição arquitetônica, encontrem da mesma forma sua razão na instrumentalização de uma memória operatória". (POTIE, 2005, p.70)

Tal instrumentalização ganha força através da realização, repetição e transmissão das habilidades manuais. A memória operacional adquire substância e conteúdo com o movimento gestual e corporal que muitas vezes é articulado de modo não verbal. Nesta perspectiva, a memória social também é transmitida através da encenação e dos gestos, sendo captada através da visualização das imagens representativas dos acontecimentos, tornando-se importante instrumento a ser utilizado na manutenção, valorização e reprodução das culturas construtivas.

Sem esta memória, a experiência de pertencimento ao lugar não se realiza. Segundo Norberg-Schulz (1997), a memória enquanto conhecimento ou reconhecimento é o pressuposto do sentido de orientação. Ela possui um papel fundamental na identificação de um lugar. Assim, segundo ele, "Cada época revela certas qualidades do lugar e envia outras para a sombra. Se uma tradição é feita de normas, ela também o é de possibilidades. É neste sentido que deve ser compreendido o aspecto existencial da memória. Pois a memória não é unicamente uma lembrança pessoal, ela é igualmente conhecimento das estruturas fundamentais da vida em relação à terra e ao céu. $A$ memória que se manifesta enquanto redescoberta e projeto, inclui além do passado, $o$ presente e o futuro." (Norberg-Schulz, 1997, p.56)

Os processos de memorização nos mostram, para além das tipologias construtivas, conhecimentos de modelos de funcionamento, práticos e simbólicos, que nos auxiliam numa melhor compreensão dos processos produtivos tradicionais e seus usos sociais. 


\section{Sistemas de transmissão e difusão}

A compreensão das arquiteturas, do traçado urbano e das culturas construtivas da velha cidade de Djenné passa pela referência e compreensão do modo de funcionamento do barey ton - corporação secular dos artesões. Tal engrenagem funcional permitiu a transmissão de geração em geração dos saberes e saberes-fazer ligados à arte de construir que coroaram com qualidade o habitat tradicional de Djenné. Seus altos níveis técnicos possibilitaram aos artesões serem reconhecidos ao longo de todo o delta interior do Níger, influenciando fortemente os estilos arquitetônicos de toda a região. ${ }^{73}$

Tal corporação de artesãos é considerada como sendo o "veículo" principal de transmissão dos saberes e saberes-fazer que constituem a base dos processos de produção dos patrimônios culturais construídos. Tais sistemas de transmissão, essencialmente orais e gestuais, constituíram-se durante muito tempo como engrenagens quase solitárias dos processos de "materialização" e reprodução das culturas construtivas tradicionais.

Nestes termos, a força da tradição de um povo reside substancialmente nas capacidades dos processos e sistemas de transmissão e ensinamento dos diferentes saberes e conhecimentos. A reprodução e trajetória das culturas construtivas dependem da qualidade dos processos de transmissão inter-geracional, que se fazem de maneira gradual e continua, e formam as bases de uma determinada identidade coletiva.

Estes diferentes sistemas de transmissão e compartilhamento dos conhecimentos cristalizam a capacidade de uma sociedade de mobilizar seus potenciais tanto nas dimensões espaciais quanto temporais.

"Além destas noções de identidade, de tradição e de prática, a noção de culturas construtivas refere-se igualmente à dimensão do "cultivar", quer dizer, da transmissão pelo ensinamento, aprendizagem, criação, etc. Ela constitui uma herança carregada de sentidos e de valores que oferece uma reinterpretação constante do mundo, num jogo entre o passado, o presente

\footnotetext{
${ }^{73}$ YAMOUSSA e JOFFROY, 2010, p.14.
} 
e o futuro, e então entre o patrimônio e o projeto, entre a memória e a criação." ${ }^{\prime 4}$

\section{Período histórico}

Do ponto de vista histórico, as estruturas das culturas construtivas tradicionais não apresentam uma tendência de modificação acelerada. $O$ processo evolutivo se dá de maneira gradual, mais ou menos constante através das sucessivas gerações, salvo no caso de bruscas rupturas dos sistemas políticos vigentes, como por exemplo, nos processos de dominação e colonização, com a imposição de novas culturas construtivas em substituição àquelas existentes anteriormente.

"Os edifícios em si não refletem diretamente a história. São apenas caricaturas da ideia particular que cada época se faz da história e mais precisamente das suntuosas ideias da classe dominante a uma dada época. A atividade arquitetônica em si é uma expressão direta da história e é através desta atividade e de seus objetivos em uma sociedade e numa época bem determinadas que a história é transmitida à produção." (HILLER, 1971)

O período histórico torna-se, assim, elemento essencial nas reflexões sobre os processos evolutivos das culturas construtivas. Para compreendê-las é necessário entender tanto as conjunturas de uma determinada época, através de seus contextos políticos, sociais, econômicos, culturais, etc., como também, os reflexos que tais contextos exerceram sobre as produções, manutenções e reproduções das culturas construtivas.

Neste sentido, elas estão inseridas dentro das dinâmicas de transformação das sociedades. E a riqueza que nos faz admirá-las reside nas inteligências adaptativas e evolutivas que souberam produzir respostas às exigências mutáveis dos diferentes contextos societários.

\footnotetext{
${ }^{74}$ Comentários do professor Hubert Guillaud (CRAterre) em seus cursos sobre as culturas construtivas, 2008.
} 
Tomemos novamente como exemplo a cidade de Djenné. Devido à sua posição estratégica de entroncamento de diferentes rotas comerciais que atravessavam esta região do continente africano, ela foi cobiçada por praticamente todos os impérios que por ali passaram ao longo dos séculos, e encontrou-se sob sucessivos e diferentes domínios ao longo de sua história. Assim, conheceu a dominação do "Império do Gana, do Mali (século XIII), do Songhay (1470), do Marrocos (do século XVI ao XIII), do império do Macina (a partir de 1819) e do império d'El Hadj Omar Tall (1866), antes de passar em 1893 ao domínio francês." (YAMOUSSA e JOFFROY, op.cit., p.10)

Estas diferentes dominações aportaram diversas influências e novos elementos culturais à região. Em 1988, a cidade de Djenné foi inscrita na lista do patrimônio mundial da UNESCO segundo dois critérios. O primeiro refere-se ao testemunho excepcional existente sobre as civilizações pré-islâmicas do delta do Níger. E o segundo referente ao riquíssimo exemplo de conjunto arquitetônico que ilustra as múltiplas influências assimiladas ao longo de sua história, tendo sido considerada uma das mais belas cidades da África. ${ }^{75}$

A própria população local consiste em um testemunho desta diversidade cultural, que se formou de maneira recomposta ao longo dos séculos, abrangendo múltiplas etnias que vivem nesse mesmo território santo. Esta mestiçagem étnica formada pelos grupos Bambaras, Bozos, Sonraï, Markas e Peulhs, aprendeu a conviver de maneira respeitosa face às diferenças culturais e seus espaços sociais.

A cidade de Djenné não se resume somente à sua notável riqueza de arquiteturas em terra. O fruto do encontro entre o mundo islâmico e a África negra, produziu outro primoroso conhecimento construtivo ligado à arte da carpintaria. Introduzida no século XVI com a ocupação marroquina, a produção de portas e janelas decoradas com motivos em formas e cores diversificadas, inclusive com a técnica do "moucharabieh"76, foi muito bem assimilada pela população local que soube desenvolver ao longo do tempo tais técnicas construtivas, tornando-se referência por suas qualidades, elegância e beleza.

\footnotetext{
${ }^{75}$ YAMOUSSA e JOFFROY, op.cit., p.30.

${ }^{76}$ Dispositivo de ventilação natural frequentemente utilizada na arquitetura tradicional árabe, geralmente em janelas e portas, que consiste em desenhos de formatos geométricos complexos, e que devido à sua malha com pequenas superfícies de abertura, acelera a passagem do vento, possibilitando também ver do outro lado sem ser visto.
} 
"A evolução e a adaptação das culturas construtivas no decorrer do tempo não podiam ser ignoradas sob o risco de não integrarem, nesta dimensão temporal, um processo que excede a experimentação na aquisição de uma "experiência" onde se conjugam os saberes e os saberes-fazer "adquiridos" (o que "produz" cultura), e constantemente transformados na confrontação aos recursos e as necessidades e expectativas das sociedades, e então, das mutações que marcam a história das sociedades." 77

Em cada ciclo histórico, as culturas construtivas transformam o território adaptando as heranças deixadas pelas gerações anteriores, atualizando ou reforçando as antigas estruturas de produção em favor daquilo que Magnaghi chamou de "verdadeira simbiose" entre os elementos humanos e naturais.

"Quando eu defino o território como um sujeito vivo altamente complexo, eu não me refiro ao ecossistema terra que, com o tempo, reproduz suas próprias condições de vida, nem à sociedade presente que vive hoje em um lugar dado, nem mesmo ao meio concebido como o acúmulo sociocultural de um lugar. O território o qual me refiro é um sujeito produzido pela interação, a longo prazo, do estabelecimento humano e de um meio, transformados pelas sociedades e culturas que se sucederam." (MAGNAGHI, 2003, p. 49)

Nessa transversalidade temporal percebemos a "transformação" das arquiteturas vernáculas em verdadeiras culturas construtivas, revelando a materialização coletiva do conteúdo social de um momento específico, em suas construções e práticas construtivas.

\footnotetext{
77 Comentários do professor Hubert Guillaud (CRAterre) em seus cursos sobre as culturas construtivas, 2008.
} 


\section{Ensaios e compreensões 1}

"Se a cultura pode ser entendida como a forma pela qual as sociedades humanas se manifestam no espaço, a arquitetura poderá, então, ser entendida como a manifestação da capacidade de uma cultura em se documentar." (PINAGLI, in MENEZES, 1996)

O ser humano que aspira à satisfação de suas necessidades mais básicas é produto de uma natureza socialmente construída. Sua atividade produtiva está na origem de tudo que se constitui e acontece ao longo de seu processo histórico. E a partir de um longo percurso transversal a numerosas gerações, este ser humano organizado coletivamente, herda um acúmulo de conhecimentos e experiências que uma vez manipulados de maneira adequada e criativa, permitem invenções, adequações e inovações que constituirão seu patrimônio cultural.

Neste processo, são os grupos organizados em torno de uma atividade produtiva comum, os detentores de uma memória coletiva e os vetores de transmissão dos conhecimentos e práticas que responderão da maneira mais apropriada às próprias necessidades e assim às suas estratégias de reprodução social.

Nesta intrínseca relação entre a existência (histórica), a técnica (social), a natureza (humana) e a Natureza (cósmica), as culturas se formam e se estruturam, e em um âmbito particular se materializam e expressam-se, inclusive, através do que conhecemos como culturas construtivas.

"A arquitetura resulta sobretudo de fatores socioculturais. Ela é entendida como relação físico-simbólica entre os dados do real, o mito e a história, do fato de que seu centro de interesse não é especificamente técnicoconstrutivo, mas se concentra na relação entre 'arte do espaço' e poder." (GUIDONI, 1994, p.07)

Ao evocar as diversidades e características das culturas construtivas tradicionais, ressaltamos a importância de compreendê-las a partir de uma leitura que evidencia seu caráter identitário. Esta identidade, particular a um determinado grupo social, é 
constituída por uma série de elementos que the são próprios ou the são disponibilizados, e que uma vez apropriados, tornam-se parte da essência formadora das culturas construtivas. Modos de vida, laços sociais, normas, regras, valores, ideais, etc., são exemplos de elementos que estão em constante dinâmica e que caracterizam as identidades dos mais variados grupos sociais e assim, as características de suas culturas construtivas.

Segundo Rapoport (2000, p.151), praticamente todos os elementos podem ser investidos de sentidos e utilizados para estabelecer e preservar uma identidade. Elementos tais como as roupas, o corte de cabelo, a linguagem, o comportamento, os componentes não visuais, etc., são potencialmente aptos para designar identidades particulares próprias de um grupo social específico. Tais identidades são estreitamente ligadas ao habitat, uma vez que tanto o patrimônio material quanto o imaterial influenciam e condicionam os mais diferentes modos de habitar.

Assim, as culturas construtivas se constroem a partir da materialização das experiências adquiridas ao longo de um constante e dinâmico processo onde interagem múltiplos sistemas de elementos técnicos, simbólicos, representativos, mediáticos, de memorização, etc.

"Em todo contexto social, a arquitetura assume então um papel relativo, variável historicamente. De maneira alguma ela pode se isolar enquanto tecnologia, sem considerar as relações com a generalidade dos problemas que estão em conexão. Entretanto, é fato que a arquitetura de um conjunto histórico-cultural determinado compreende uma série de soluções variadas, derivadas das relações históricas particulares do grupo, mas das quais a significação no interior deste último depende da totalidade do sistema." (GUIDONI, 1994, p.06)

A decomposição do fenômeno de produção das culturas construtivas nos permitiu perceber com mais clareza que estas não são um fim em si mesmas. São, por sua vez, constantes processos dialéticos que evocam coesão social e fortalecem identidades coletivas. Através do desenvolvimento de seus gestos construtivos, as culturas construtivas "lapidam" conhecimentos e inteligências que acompanham sua história, 
adaptando-se aos tempos sobrepostos e às sucessivas gerações. E com mais ou menos intensidade, suas periódicas transformações rompem com as ordens construtivas estabelecidas.

Segundo Hubert Guillaud, a constante evolução dos modos de utilização dos espaços, através de suas novas necessidades e formas de organização, nos impedem de dissociar a evolução das culturas construtivas da evolução da arquitetura, sobretudo com relação à organização social e econômica dos territórios.

"Uma cultura construtiva é o resultado de um lento processo de experimentação para configurar um habitat, em um meio ambiente particular (contexto, sitio, clima, recursos), em um tempo, e em um espaço do território. Este processo de experimentação adaptativa e evolutiva, em trajetória sempre recomposta, resulta na aquisição de uma experiência que liga o saber e o saber-fazer em capacidades de produção de respostas construtivas (materiais, elementos e sistemas), e arquitetônicas (estruturas, espaços, formas) sob a forma de modelos e de tipos elaborados que respondem às necessidades das sociedades (economia, funções, usos, modos de vida, bem estar) e às suas expectativas (aspirações, elevação, espiritualidade). Estes modelos transmitidos de geração em geração de construtores, nas sociedades tradicionais, asseguram também a identidade e a coesão das sociedades que as produzem em torno de um conjunto de valores culturais materiais e imateriais compartilhados. Desta forma, deveríamos falar de uma noção plural de cultura(s) construtiva(s), diversas e situadas, onde o sentido local está hoje alterado pela dominação de uma macro cultura construtiva global que gera raridades culturais. "78

A teorização sobre a produção das arquiteturas vernáculas nos fornece as bases para uma melhor compreensão a respeito da natureza dos fenômenos de produção das culturas construtivas, consideradas materializações das práticas construtivas e identidades socioculturais, transcritas no espaço e experimentadas e vividas em

\footnotetext{
78 Comentários do professor Hubert Guillaud (CRAterre) em seus cursos sobre as culturas construtivas, 2008.
} 
temporalidades acumuladas. Suas tipologias construtivas e relações com a natureza expressam suas identidades culturais, práticas de funcionamento, usos sociais e as formas internas de reprodução ideológica.

O intuito primeiro deste Momento 1 da tese foi o de fomentar reflexões e compreensões a respeito das noções de arquiteturas vernáculas e culturas construtivas tradicionais, evocando uma série de referências que ilustraram os elementos principais constituintes de seus processos produtivos. Sem esgotar o assunto, nem mergulhar em um exemplo específico, meu interesse foi traçar uma primeira perspectiva analítica que servirá como base para o próximo Momento deste trabalho. 
MOMENTO 2

\section{EM DIREÇÃO À HOMOGENEIZAÇÃO DO HABITAT?}

"Desde a formação do Estado moderno, persiste esta tendência de alcançar a unidade por meio da anulação da diversidade. (...) rechaça-se assim a unidade por meio da diversidade." (Faundez, 2002) 


\section{Processos e reversos}

"Na origem dessas transformações espetaculares, nós reencontramos a separação entre pensamento e sentimento; já aparente na arte Renascentista e teorizada por Descartes, esta separação modela o comportamento do homem a partir do lluminismo e dá lugar à uma nova visão de mundo que culmina em uma reestruturação radical da presença. $O$ pensamento, agora liberto das formas de unidade existencial, persegue os objetivos que se manifestam na redução da compreensão à racionalidade e eficacidade. A relação com o passado é suplantada pela ciência e a tecnologia; quanto à natureza, ela é considerada como um simples fundo de recursos exploráveis para satisfazer necessidades imediatas. Não podemos negar que esta satisfação acarretou progressos em diferentes domínios - o progresso sendo a palavra de ordem dos projetos da nova era." (NORBERG-SCHULZ, 1997, p.263)

As relações do homem com a Natureza, contínuo processo transformador, alteram-se com os significados que esta assume ao longo do tempo. Cada sociedade interpretou, interagiu, se apropriou, se serviu, protegeu, etc., sua natureza local, de forma generalizada, da maneira que a representava e a necessitava. Os meios e processos para transformá-la sempre foram adaptados e modificados em função dos interesses daqueles que os realizavam ou os possuíam. Tais processos transformaram-se de maneira tão intensa que já são hoje questionavelmente reversíveis.

De mesmo, as relações de natureza social são constantemente transformadas e recriadas. Percebemos tais fenômenos, por exemplo, através das modificações que se manifestam nas relações e organizações do mundo do trabalho. Embora tais dinâmicas sempre tenham ocorrido ao longo dos períodos históricos, as engrenagens produtivas dos diferentes grupos sociais modificaram-se radicalmente com a chegada dos "tempos modernos" e a articulação entre capital, ciência e tecnologia.

Assim, dentro do atual modelo capitalista de sociedade, torna-se parcial pensar a questão da cultura, e então das culturas construtivas, fora de uma perspectiva de classe, 
sem fazer referência às relações de força e poder. Ligada ao poder econômico e político, a cultura dominante tende a impor sua hegemonia às demais expressões culturais, provocando uma inevitável derrocada na multi-culturalidade das diversas sociedades espalhadas pelos continentes.

As análises sobre as influências, rupturas e consequências instituídas pelo processo de produção industrial capitalista sobre a reprodução e transformação das culturas construtivas são essenciais para nossa compreensão. Neste sentido, nossa reflexão será orientada por uma série de "diálogos" tecidos entre diferentes autores que nos permitem revelar, através de conceitos e ideias, alguns elementos importantes para o avanço deste trabalho.

Foram, sobretudo, as sociedades burguesas e capitalistas dos últimos séculos as responsáveis por inserir, assegurar, reproduzir e legitimar, numa tendência hegemônica, um novo projeto de sociedade onde a razão técnica configura-se como ideologia ${ }^{79}$. Esta, se apoia no desenvolvimento técnico como horizonte produtivo e na organização do processo de produção estruturado, entre outras coisas, pela divisão social do trabalho ${ }^{80}$, manifestada na divisão parcelar do trabalho ${ }^{81}$.

A divisão do trabalho, fragmentado nas especializações de seus processos produtivos, e ainda, o apoderamento e controle dos meios de produção nas mãos de um

\footnotetext{
${ }^{79}$ Heilbroner $(1988$, p.78) compreende a ideologia como sendo "as opiniões da classe dominante mantidas de maneira profunda e inconsciente em qualquer ordem social. (...) as ideologias como sistemas de pensamento e de crença por meio das quais as classes dominantes explicam a si mesmas como funciona seu sistema social e que princípios ele subentende. Por conseguinte, os sistemas ideológicos existem não como fições, mas como "verdades" - e não apenas verdades probatórias, mas verdades morais. A ideologia capitalista tem exatamente a mesma função explicativa que a dos sistemas feudal ou tributário de crença". 80 Segundo Braverman (1981, p.71), "a divisão do trabalho é aparentemente inerente característica do trabalho humano tão logo ele se converte em trabalho social, isto é, trabalho executado na sociedade $e$ através dela". A divisão do trabalho sempre existiu, seja em função do sexo, do vigor corporal, da idade, ao acaso, etc. Com o aprofundamento do sistema de trocas entre diferentes grupos e sociedades, a divisão do trabalho social passou a designar a especialização das atividades presentes em todas as sociedades complexas, independente dos produtos do trabalho circularem como mercadoria ou não.

${ }^{81}$ Segundo Braverman (1981), "a divisão parcelar do trabalho ou divisão manufatureira do trabalho é típica do modo de produção capitalista. Refere-se à fragmentação de uma especialidade produtiva em numerosas operações limitadas, de modo que o produto resulta de uma grande quantidade de operações executadas por trabalhadores especializados em cada tarefa. Surge em meados do século XVIII com a manufatura e caracteriza o sistema de fábricas." Aprofunda-se ai a divisão entre trabalho manual (que transforma o objeto) e intelectual (a consciência que o trabalhador tem sobre o trabalho), separando-se a concepção da execução. Os trabalhadores ficam especializados em parcelas (tarefas) do processo de produção dentro de uma mesma especialidade produtiva, e o controle do processo passa para a gerência.
} 
agente externo e, muitas vezes, independente ao próprio processo (regido pelo modo de produção capitalista); a perda de autonomia, conhecimento e decisão dos trabalhadores nas etapas de produção; seu acentuado afastamento ao produto de seus trabalhos e à sua compreensão sobre a totalidade do processo produtivo, entre outros fatores, alimentaram as rupturas e as transformações dos sistemas de produção, considerados como tradicionais, por um outro, convencionado e fundamentado pela racionalização técnica, propulsora do hoje estabelecido modelo capitalista de produção.

Analisando o funcionamento da produção capitalista, Jurgen Habermas (1968) defende a ideia da cientificação da técnica numa busca pela intensificação da produtividade e aumento do controle produtivo. A fragmentação do trabalho se acentua na mesma intensidade desses dois fatores e o novo sistema produtivo, ao ser legitimado, domina e redefine sistemas culturais inteiros, desconstruindo antigas relações baseadas e legitimadas na tradição cultural.

Se o processo de racionalização da técnica ${ }^{82}$ implementa uma racionalidade própria que se apodera das esferas institucionais da sociedade e as transforma, legitimando assim uma nova forma de dominação política, devemos tentar compreender melhor como esta racionalização técnica desconfigura e muitas vezes elimina as antigas formas de legitimação, baseadas na tradição cultural, que agora se apresentam como o reverso desta racionalidade crescente.

Parte desta explicação reside na ideia de que a racionalidade do sistema está associada ao progresso técnico científico, que possibilita um maior domínio sobre a natureza, e ao mesmo tempo aumenta a produtividade e proporciona às sociedades uma vida mais confortável. Segundo Habermas (1968, p.51), “A natureza compreendida e dominada pela ciência, surge de novo no aparelho de produção e de destruição, que mantém e melhora a vida dos indivíduos e, ao mesmo tempo, os submete aos senhores do aparelho. A ciência, em virtude de seu próprio método e dos seus conceitos, projetou e fomentou um universo no qual a dominação da natureza se vinculou com a dominação dos homens. Assim a hierarquia racional funde-se com a social e, nesta situação, uma

\footnotetext{
82 Em sua obra "A ética protestante e o espirito do capitalismo", Max Weber (1996) apreende as repercussões do progresso técnico-científico na estruturação institucional das sociedades modernas, através do conceito de racionalização (ligada à organização racional do trabalho e da produção).
} 
mudança na direção do progresso, que conseguisse romper este vínculo fatal, influenciaria também a própria estrutura da ciência - o projeto de ciência."

Ainda segundo o autor (1968, p.63, grifo meu), "O limiar que existe entre a sociedade tradicional e uma sociedade que entrou no processo da modernização não se caracteriza pelo fato de, sob a pressão de forças produtivas relativamente desenvolvidas, se ter imposto uma mudança estrutural do marco institucional (este foi, desde o início, o mecanismo da história evolutiva da espécie). Novo é, pelo contrário, um estado evolutivo das forças produtivas que torna permanente a expansão dos subsistemas de ação racional teleológica ${ }^{83}$ e que, deste modo, impugna a forma que as culturas tradicionais têm de legitimar a dominação mediante interpretações cosmológicas do mundo."

Vivemos assim um modelo de sociedade imposto e ditado pela complexa realidade econômico-política estabelecida, que se legitima, entre outros fatores, pela afiliação simbólica inquestionável aos valores representativos da ideologia hegemônica das classes dominantes. Estas condições controlam e determinam praticamente todas as decisões e escolhas que fazemos, influenciando enormemente nossos modos e condições de habitar, convencendo de que suas ideias são as soberanas e que representam a totalidade da sociedade. Este louvor ao progresso técnico passa a impor as formas do novo (convencionado) como algo de absoluto, sob o pretexto da satisfação a partir dos seus reflexos estéticos.

"O capitalismo define-se por um modo de produção que oferece uma legitimação da dominação que já não desce do céu da tradição cultural, mas que surge da base do trabalho social." (Marcuse, 1996)

O trabalho, sua compreensão, seu tempo, seus instrumentos, seus produtos, foram pouco a pouco separados de seu trabalhador, agente criador, tornando-se peças manipuláveis por decisões externas. Seriam estas condições que André Gorz compreende

\footnotetext{
${ }^{83}$ Segundo Habermas, a racionalidade teleológica ou a "racionalidade por relação a um fim" se refere à utilização dos meios adequados aos fins em vista. Os efeitos justificam assim as causas. Constitui num aspeto característico da sociedade moderna (na economia, no direito, na ciência, na filosofia, na política, etc.).
} 
como "esfera de heteronomia" 84 e que segundo ele, cortam a atividade produtiva de seu significado, de suas motivações e de seu objetivo, para se tornar uma simples maneira de ganhar um salário, "ganhar a vida".

Nesta nova engrenagem, o trabalhador vende cada vez menos os "frutos" de seu trabalho, orientando-se para a venda da força de seu trabalho. 0 antigo artesão transforma-se em assalariado, as inovações técnicas entram em um constante estado de progresso, o novo sistema se estabelece com a racionalização do trabalho e aumento da produtividade, onde a maior preocupação passa a ser o controle do processo de produção e a acumulação e aumento dos lucros.

Os modos de vida tradicionais, as antigas relações sociais e econômicas, a natureza dos seres humanos e de seus processos produtivos, as representações simbólicas coletivas e localizadas, os valores familiares e sociais, etc., passam à dominação do ethos capitalista, sujeitando os indivíduos ao imperativo de ajustar suas aspirações conforme à nova ordem estabelecida.

São tais transformações as tratadas por Mészáros (2008, p.90) como "um metabolismo dominado pela inversão mistificadora das relações reais de intercâmbio sócio reprodutivo sob o fetiche usurpador da hegemonia supostamente legitimada do capital 'produtivo' e da dependência total do trabalho capitalisticamente 'empregado', assim impondo com êxito à consciência da sociedade como um todo e de seus indivíduos efetivamente trabalhadores e produtivos a falsa consciência da 'personificação das coisas e reificação das pessoas".

Assim, no sistema capitalista de produção as dinâmicas das sociedades estão subordinadas às redes de mercado, e passam a dar sentido às nossas vidas. Os valores de uso e valores de troca fundam-se nas disputas pela apropriação privada dos valores sociais e se fazem de tal maneira que os poderes materiais e simbólicos passam a ser aferidos pelo sistema de preços, agora inseridos no mundo globalizado das mercadorias.

\footnotetext{
84 André Gorz (2010, p.59) compreende como esfera de heteronomia, "o conjunto de atividades especializadas que os indivíduos têm a realizar como sendo funções coordenadas do exterior por uma organização pré-estabelecida. No interior desta esfera de heteronomia, a natureza e o conteúdo das tarefas assim como suas relações são heterodeterminadas de maneira a fazer funcionar os indivíduos e os coletivos, eles mesmos complexos, como rodas de uma grande máquina (industrial, burocrática, militar)".
} 
Tais condições criam um ciclo vicioso de produção e consumação, onde a primeira cria a segunda, que por sua vez, recria a primeira, etc. A produção fornece assim os produtos às necessidades, assim como cria as necessidades dos produtos. Tal processo faz parte, para Theodor Adorno, de uma racionalidade que se manifesta como racionalidade da própria dominação. Porém, para ele, isso não deve ser atribuído a uma lei evolutiva da técnica enquanto tal, mas à sua função na economia atual. "A necessidade de que talvez pudesse escapar ao controle central já é recalcada pelo controle da consciência individual." (ADORNO, 1985, p.100)

Obviamente, com as rupturas das ordens sociais tradicionais, as relações sociais com o território, com o local, com o lugar, sofrem mutações e transformam ou perdem suas identidades anteriores, suas características, seus significados. A alienação do homem com a produção, com o trabalho, com a sociedade, se manifesta na alienação com o lugar, com o território, com o habitat, com o pertencimento ao local próprio.

O processo de globalização desterritorializa as culturas e implica a perda daquilo que Norberg-Schulz evoca como a "arte do lugar"85. Para ele, "a desvalorização dos símbolos faz com que as figuras arquitetônicas sejam reduzidas a signos do reconhecimento social. Tudo são coincidências sintomáticas da ruptura com a tradição cultural, acarretando a disparição das tradições construtivas vitais e das significações do estilo, o que nos faz dizer que elas causaram a perda do lugar." (NORBERG-SCHULZ, 1997, p.262)

Pouco a pouco, os territórios foram perdendo (e continuam) suas características próprias e essenciais que os fazem particulares: suas morfologias, suas naturezas, suas paisagens, seus recursos, entre outros. Os desenraizamentos geográficos e sociais se fazem proporcionalmente ao alastramento do domínio do modelo de produção industrial/capitalista e seu crescimento econômico ilimitado.

\footnotetext{
85 O termo "arte do lugar" designa para Norberg-Schulz (1997, p.194) "as totalidades maiores e menores pertencentes seja à paisagem, seja ao interior de uma habitação ou uma construção, estimando que somente uma pequena parte delas sejam obras de arte." Para ele, é através da "arte do lugar" que uma construção adquire um sentido. Isso implica que "as construções estejam condicionadas enquanto natureza, tradição construtiva e estilo, pelo lugar ao qual elas pertencem."
} 
As características culturais, étnicas, linguísticas, etc., dos mais variados grupos sociais e suas relações com os territórios foram sendo substituídas por uma racionalidade crescente que transforma o "lugar" em suporte técnico para atividades, serviços e funções econômicas que não necessitam mais relacionar-se com as características locais do território e substituem o habitante pelo residente/consumidor.

Estes processos foram bastante estudados por Alberto Magnaghi em seus trabalhos sobre diversas cidades italianas. Para ele (2003, p.16), "cortando-a de seu contexto vivo, de seu [rizoma], a cidade interrompe o processo que produz a paisagem garantindo sua reprodutibilidade e sua identidade." Assim, as particularidades locais vão sendo apagadas e as diversidades culturais fusionadas em "tipos ideais" da ordem capitalista.

"Deve-se notar que hoje o global não permite nenhuma relação dialética biunívoca, pois suas regras excluem a sustentabilidade do local, privilegiando a competitividade mais do que a cooperação, a exploração dos recursos mais do que a valorização do patrimônio, a polarização social mais do que a complexificação, etc." (MAGNAGHI, 2003, p.112)

Esta racionalização técnica encontra através do Movimento Moderno sua materialização na produção das cidades, de suas arquiteturas e de suas edificações. Os valores simbólicos e cósmicos das culturas construtivas tradicionais foram sendo substituídos pelos valores econômicos de uma nova cultura construtiva, onde o "novo homem" é o mesmo em todos os locais, possui as mesmas necessidades, transcendeu as diferenças culturais e seus aspectos regionais. Este homem mundializou-se, globalizando os modos de habitar e os fenômenos de produção de suas cidades.

Em tempos do fordismo, a cidade foi reorganizada em sequências correspondentes às funções básicas humanas como: habitar, trabalhar, divertir, comer, reproduzir, etc. Esta condução se fez segundo uma racionalidade de tipo linear, sem mais necessidades de possuir alguma relação com as características naturais do território. Além disso, a mercantilização das terras urbanas, fator determinante da perpetuação da lógica heterônoma, implica de maneira incisiva no fenômeno de acentuação das segregações urbanas e de proliferação das favelas em geral. 
Mike Davis em seu extenso e profundo trabalho sobre o "Planeta das favelas", surpreende pela quantidade de dados referentes aos mais diversos e contínuos cinturões de moradias informais e de extrema pobreza, localizados geralmente na periferia urbana, conhecidos como favelas. Segundo ele, "Existem provavelmente mais de 200 mil favelas, cuja população varia de alguma centenas a mais de 1 milhão de pessoas em cada uma delas. Sozinhas, as cinco grandes metrópoles do sul da Ásia (Karachi, Mumbai, Délhi, Calcutá e Daca) contém cerca de 15 mil comunidades faveladas distintas, cuja população excede os 20 milhões de habitantes." (DAVIS, 2006, p.37)

Como pensar a noção de projeto nesses "lugares comuns"? Pedro Fiori Arantes tece este questionamento lembrando que as ações públicas oscilaram entre dois paradigmas: "(...) um modernizador e outro mais liberal. Num prevalece a forma-conjunto (habitacional), ainda seguindo preceitos modernistas, do plano e do projeto. Noutro, prevalece a aceitação da forma-favela, da autoconstrução como regra, da informalidade como norma." (ARANTES, 2008, p.07)

A cidade planejada é delimitada pela cidade informal. O ilegal rodeia, atravessa e sustenta, o outro - o legal. As habitações irregulares, moradias dos que não são exceção, mas maioria, avançam sobre os espaços dos cinturões das cidades e vão também, na medida em que as lacunas se abrem, ocupando a cidade formal e revelando as contradições, segregações e lutas de classes dentro do mesmo território urbano.

A tendência de análise da produção urbana é fundada, segundo Manuel Castels, na prévia da correspondência entre um certo tipo técnico de produção (definido pela atividade industrial), um sistema de valores (o "modernismo") e uma forma específica de organização do espaço (a densa cidade metropolitana). Segundo ele, "O elemento dominante é a indústria, que organiza inteiramente a paisagem urbana. Esta dominação, todavia, não é um fato tecnológico, mas a expressão da lógica capitalista que é a base da industrialização. A "desordem urbana" não é uma desordem, ela representa a organização espacial oriunda do mercado, e que resulta da ausência de controle social da atividade industrial." (CASTELS, 1975, p.27) E continua, "A difusão urbana equivale justamente à perda do particularismo ecológico e cultural da cidade." (Ibid., p.26) 
A disseminação da ideologia de produção da máquina de morar desterritorializada, redutora das heranças culturais e das especificidades do território, provoca segundo Jean-Paul Loubes, a perda da geografia e da poética presente no fenômeno do habitar tradicional. Para ele, a arquitetura torna-se "deslocalizada", reduzida às funções biológicas do comer, dormir, circular, se oxigenar, etc.

“(...) o espaço construído será então pensado como um instrumento de reforma e de controle social. Quando a perspectiva universalista for colocada no centro do pensamento arquitetônico, orientada para a construção de um homem novo universal, o empoderamento com relação à um lugar será então consumado. A máquina de morar não terá mais sua forma, nem do local, nem das características próprias (cultura) do grupo habitante à quem ela é destinada. Ao final do percurso, de vernácula, a arquitetura tornou-se deslocalizada." LOUBES (2010, p.41)

Neste sentido, a transformação da casa em mercadoria, e em seguida em especulação financeira; a ressignificação do habitat em máquina de morar, e assim, a evolução de um modelo homogêneo de moradia à uma ideologia hegemônica de um certo modo de morar; a substituição dos materiais naturais destinados à construção pela reprodução incessante de novos materiais, industrializados e cada vez mais distantes do domínio popular de sua produção; o reordenamento das multitudes culturais em uma "monocultura" globalizada, obediente e cada vez mais alienada; entre diversas outras novas condições, constituem parte estrutural dos atuais sistemas de produção da habitação popular contemporânea.

Nos deparamos com a estruturação de uma nova cultura construtiva, globalizada e hegemônica, que se propagou com o processo de produção industrial/capitalista, se afirmou com as reconstruções europeias do pós-guerra e com o crescimento urbano massivo ${ }^{86}$, e se materializou através da hegemonia do uso do concreto armado e do ferro.

\footnotetext{
${ }^{86}$ Evidentemente, este processo se deu de maneira diferenciada nos diversos países. Na Europa e nos países latino-americanos, por exemplo, enquanto ocorria a reconstrução europeia do pós guerra, a crise habitacional latino-americana revelava as desigualdades e segregações sociais, as violências urbanas, os massivos crescimentos demográficos e de expansão das metrópoles e megalópoles, o crescimento desordenado das habitações informais e dos complexos de favelas, entre outros. Os modelos europeus exerceram enorme influência nas atitudes, planejamentos e gestões realizadas pelos estados latino-
} 
Obviamente, tudo isso foi validado por processos de normalização e estandardização de materiais e técnicas que contribuíram para a manifestação de novas formas de expressões construtivas e arquitetônicas.

Assim, aceleram-se os processos de desconfiguração das pluralidades culturais das diversas "inteligências construtivas" espalhadas pelos continentes, com a crescente abstração do trabalho concreto que atinge seu ápice na modelagem das consciências e homogeneização das culturas. A ideologia capitalista molda um elemento inerente a uma das condições fundamentais da nossa existência cultural: o modo de habitar - de viver socialmente em um habitat emergido pelas particularidades culturais dos diferentes grupos sociais existentes.

A produção do habitat marcada pela ordem econômica neoliberal capitalista incorpora o trabalho social não aplicado diretamente em sua produção, sujeitando-a às regras de mercado e sufocando ao máximo os mecanismos contra hegemônicos de produção habitacional.

Para Loubes (Ibid., p.21), "(...) a redução do habitat a um produto financeiro é o coroamento de uma destruição violenta, até mesmo de um extermínio nos espíritos daquilo que é verdadeiramente o habitar na plenitude de suas dimensões ontológica e antropológica."

Evidentemente, as transformações dos modos de habitar se devem à uma enorme complexidade de fatores e conjunturas existentes nos sistemas societários. Os numerosos processos colonizadores mostram em suas produções arquitetônicas parte dos encontros entre as mais diversas culturas construtivas com suas trocas, adaptações, transformações e erradicações. As culturas ibéricas ao se confrontarem com as culturas indígenas presentes no território brasileiro, por exemplo, transformaram-nas, inserindo uma série

americanos face à problemática habitacional. Embora tais posicionamentos se alinhassem como os paradigmas gerais da modernidade, suas ações práticas ocorreram sem processos de transição, sem adaptações aos contextos locais, e em curtos espaços de tempo. Segundo Víctor Saúl Pelli, tais práticas constituíram-se em "versões ajustadas e estritas quanto às formas e postulações arquitetônicas (do Movimento Moderno), mas igualmente categóricas com relação à materialização de um padrão cultural. Não se tratou certamente de uma opção por estilos arquitetônicos, mas sim de uma opção geral, mais ou menos consciente, por um modelo de sociedade, de cultura, e de estratégia de produção e acumulação, coerente com as estratégias de desenvolvimento, fortemente "modernizadores." (PELLI, 2007) 
de elementos construtivos, como as telhas de barro cozido em substituição ao uso da palha, a introdução dos tijolos de barro cru e barro cozido, entre outros. Técnicas construtivas como a taipa de pilão, por exemplo, também foram trazidas pelos portugueses e adotadas nas construções das cidades do período colonial brasileiro. ${ }^{87}$

Com os desmatamentos das áreas de floresta, a sociedade Batammariba, no Togo (CRAterre, 2010), vive cada vez mais sob a influência das culturas vizinhas, sobretudo a ocidental, e dos materiais de construção. As dificuldades crescentes em encontrar madeiras para as construções e em muitos casos as palhas, foram incitando a adoção de novas soluções técnicas. O uso de telhas onduladas, mais leves, torna-se cada vez mais comuns, pela praticidade de troca, pelo preço comparado ao esforço de buscar madeiras, e pela assimilação a um modelo produtivo cujos novos materiais são tidos pelas sociedades modernas como sinônimos de qualidade, status social e longa durabilidade.

Tal modelo moderno de habitat, símbolo da prosperidade e do progresso, se impõe cada vez mais face às culturas construtivas endógenas, fragilizando e modificando seus usos, seus materiais, suas percepções, suas configurações, suas reproduções, etc. Tais mutações se fazem com tamanha intensidade, velocidade e abrangência, que vem suscitando questionamentos sobre as manifestações evolutivas das culturas construtivas tradicionais.

\section{Engrenagens produtivas}

"A técnica por si mesma pode promover tanto o autoritarismo quanto a liberdade, tanto a escassez quanto a abundância, tanto a extensão quanto a abolição da labuta." (MARCUSE, 1996, p.113)

"A mercadoria, para manter a face, esconde o que é e empresta o que não é. Esconde as relações de produção de que é fruto, intermediária e expressão, e põe as relações como epifenômeno de sua movimentação que finge autônoma." (FERRO, 2005, p.56)

\footnotetext{
${ }^{87}$ Para mais informações acerca da constituição da arquitetura popular no Brasil e as influências indígenas, africanas, europeias ou asiáticas, ver Gunter WEIMER (2005).
} 
Neste momento, mais do que ensaiar a recuperação do significado etimológico do termo "tecnologia", tentamos entende-lo a partir de suas práticas sociais cujos significados (cultural, político, social e econômico) são definidos dentro das relações de força e poder entre as classes sociais e suas ideologias em disputa. ${ }^{88}$

Segundo David Dickson (apud DAGNINO, 2010, p.79), “A partir da Revolução Industrial, e particularmente durante os últimos 50 anos, passou a ser geralmente aceito $o$ fato de que uma tecnologia em continuo desenvolvimento tecnológico, que inicialmente consistiu na melhora das técnicas artesanais tradicionais, e que posteriormente se estendeu à aplicação do conhecimento abstrato aos problemas sociais, prometeu conduzir a sociedade pelo caminho que leva a um prospero e brilhante futuro. $O$ desenvolvimento da tecnologia tem servido inclusive como indicador do progresso geral do desenvolvimento social, fazendo com que se tenda a julgar as sociedades como avançadas ou atrasadas segundo seu nível de sofisticação tecnológica."

No modelo capitalista de produção, a tecnologia assume uma posição privilegiada nas relações de manutenção e afirmação das disputas de classe e poder, revelando duas características marcantes evocadas por Gaudêncio Frigotto (apud PEREIRA, 2009): o fetiche do determinismo tecnológico e a pura negatividade da tecnologia sob o capitalismo. Segundo ele, as noções de "sociedade pós-industrial", "sociedade do conhecimento" e "era tecnológica" revelam a forma mais apologética do fetiche que envolve o determinismo tecnológico, pois expressam a tese de que "a ciência, a técnica $e$ as novas tecnologias nos conduziram ao fim do proletariado e, consequentemente, à superação da sociedade de classes sem acabar com o sistema capital, mas, pelo contrário, tornando-o um sistema eterno."

Por sua vez, o caráter negativo da tecnologia seria consequência de sua subordinação aos processos de exploração e alienação do trabalhador e de seu uso como força cada vez mais diretamente produtiva do metabolismo e da reprodução ampliada do capital. Assim, segundo Frigotto (apud PEREIRA, 2009), tanto o fetiche do determinismo tecnológico, quanto a negatividade da tecnologia capitalista, "decorrem de uma análise

\footnotetext{
88 O filósofo brasileiro Álvaro Vieira Pinto (2005) aborda o tema a partir de seu significado etimológico, dentro de sua abrangência e complexidade, revelando seus diferentes significados ao longo do tempo, e suas relações dentro da sociedade capitalista de produção.
} 
que oculta o fato de que a atividade humana, que produz a tecnologia e seus vínculos imediatos ou mediatos com os processos produtivos, define-se e assume o sentido de alienação e exploração ou de emancipação no âmbito das relações sociais determinadas historicamente. Ou seja, a forma histórica dominante da tecnologia que se constitui como força produtiva destrutiva e alienadora do trabalho e do trabalhador, sob o sistema capital, não é uma determinação a ela intrínseca, mas, como a mesma, é dominantemente decidida, produzida e apropriada na lógica da propriedade privada e da reprodução ampliada do capital."

A constituição de equipes reduzidas de trabalhadores parcelados é condição para a dominação e redução do trabalho concreto a trabalho abstrato, possibilitando o intercâmbio dos produtos do trabalho como mercadorias. Esta "estranheza" entre o homem, a matéria, o trabalho e seus produtos sínteses, caracterizadora da lógica capitalista, vêm alimentar os processos especulativos que determinam os inconstantes valores de uso e de troca que vestem as, então, "arquiteturas-mercadorias".

A separação entre o conhecimento comum e o conhecimento especializado, o "embrutecimento" da força de trabalho - submetida a procedimentos rotineiros, o controle abrangente sobre todos os processos produtivos, entre outros, fazem parte da natureza do modo de produção capitalista. Para Sérgio Ferro, a repetição do mesmo gênero de operações miúdas no interior das equipes, muitas vezes "idiotizantes", mas que demandam certa habilidade, dispensa ao conhecimento a busca de generalidade. Para ele, "é necessário confundir na mesma forma o trabalho explodido em mini especializações, em habilidades divergentes." (FERRO, 2005, p.60)

Nesta ambição enveredada à um projeto de totalidade histórica, de um mundo determinado e eternizado pelos valores capitalistas de produção, a tecnologia se torna agente promotor da reprodução e legitimação desta nova ideologia. É ela a responsável por conceber os modelos, assegurar as escolhas e frear as reações explosivas. Herbert Marcuse nos alertou sobre o fato da tecnologia não ser somente um meio pelo qual a dominação eterniza-se, mas se demonstrar inclusive, como sendo a própria dominação.

"A tecnologia como modo de produção, como totalidade de instrumentos, dispositivos e invenções que caracterizam a era das máquinas é assim ao 
mesmo tempo um modo de organizar e perpetuar (ou mudar) relações sociais, uma manifestação de padrões de pensamento e comportamento dominantes, e um instrumento de controle e dominação." (MARCUSE, 1996, p. 113)

Segundo ele, a racionalidade individualista ${ }^{89}$ transformou-se em submissão eficiente à sequência previamente dada de meios e fins, não havendo espaço para a autonomia. O trabalhador torna-se assim, um simples acessório da máquina e uma peça substituível do sistema. "Esta [racionalidade] absorve os efeitos libertadores do pensamento e as várias funções da razão convergem para a manutenção incondicional do aparato." E continua, "Não há escapatória do aparato que mecanizou e padronizou o mundo. É um aparato racional, combinando a máxima eficiência com a máxima conveniência, economizando tempo e energia, eliminando desperdício, adaptando todos os meios ao fim, antecipando consequências, mantendo a calculabilidade e a segurança." (MARCUSE, ibid., p.119)

Marcuse intitula "mecânica da conformidade" este "governar" do desempenho que ocorre em todas as instâncias da sociedade, não apenas nas fábricas e oficinas, mas também nos escritórios, escolas, associações e por fim na esfera do lazer e do entretenimento. E este fluxo se faz a partir da ordem tecnológica em direção à imposição e aceitação social. Assim, na medida em que a racionalidade tecnológica ${ }^{90}$ se difunde e é aceita pelas sociedades, ela desenvolve um conjunto próprio de valores que valem como verdades, legitimando seu funcionamento ilimitado.

"A racionalidade, antes uma força crítica, transforma-se numa força de ajustamento e submissão. A autonomia da razão perde seu significado na mesma medida em que os pensamentos, sentimentos e ações dos homens são moldados pelas exigências técnicas do aparato por eles mesmos criado. A razão encontrou seu túmulo no sistema de controle, produção e consumo padronizados. Neste lugar, ela reina através das leis e mecanismos que

\footnotetext{
${ }^{89}$ A racionalidade individualista, evocada por Marcuse (Ibid., p.135), é a forma que a liberdade assume numa sociedade em que a aquisição e utilização da riqueza é dependente da labuta competitiva.

90 A racionalidade individualista transforma-se em racionalidade tecnológica uma vez conformada sob o domínio do aparato racional do sistema capitalista. Tal aparato designa para Marcuse (Ibid.) as instituições, os dispositivos e as organizações da indústria na sua situação social predominante.
} 
garantem a eficácia, a eficiência e a coerência do sistema." (MARCUSE, ibid, p.122)

Numa governança magistral, a tecnologia capitalista rege o ritmo do tempo histórico e cria as "ligaduras" entre o passado, o presente e o futuro. Entretanto, em seu projeto pelo desvendar das relações entre homem e natureza, a tecnologia, que por Kōstas Axelos "detém os segredos das amarras que unem a teoria e a prática, o pensamento e a ação, o logos e a techné", acaba separando os homens do produto de seu trabalho. Segundo ele, "o regime da propriedade privada aliena o homem do trabalho, seu ser e seu fazer são separados um do outro e esmagados os dois pela potência desumana do possuir. (...) O homem perde como consequência seu ser tentando ganhar sua vida." (AXELOS, 1961, p.195)

A atividade científica não constitui para Axelos um processo autônomo possuidor de uma lógica interna própria. "O tornar real da atividade produtora determina a história do saber e da atividade científica. (...) As ciências são ainda mais alienadas pois se desenvolveram no interior da divisão do trabalho. Pois, é a divisão alienante do trabalho social que condiciona de uma maneira geral e segundo as modalidades particulares os trabalhos da ciência, ela mesmo dividida." (AXELOS, ibid., p.62)

Em nome da produtividade e de seu controle, da eficiência e de sua legitimação, dos ganhos e de seu empoderamento, a racionalidade técnica burocratiza os processos e as mentes, sufoca as autonomias criativas dos produtores, limita os acessos e usos dos resultados (produtos) e justifica seus meios pelos fins antecipadamente estipulados, adaptados, difundidos e assimilados pelas sociedades.

Para Habermas, o núcleo ideológico desta consciência é a eliminação da diferença entre práxis e técnica. "Os modelos coisificados das ciências transmigram para um mundo sociocultural da vida e obtêm ali um poder objetivo sobre a autocompreensão." (HABERMAS, 1968, p.82) Assim, a evolução técnica passa a ser alimentada com o progresso das ciências modernas. "Com a investigação industrial de grande estilo, a ciência, a técnica e a revalorização do capital confluem num único sistema." (HABERMAS, ibid., p.72) 
O postulado de que a ciência e o desenvolvimento técnico podiam resolver os problemas sociais, ambientais, econômicos, e assim, de moradia, saúde, alimentação, etc., foi pautado como indissociável da melhoraria da qualidade de vida das pessoas. Neste raciocínio, o progresso social caminha junto com o avanço do progresso técnico. 0 triunfo do formalismo racional revela a dominação que este implica nas sociedades. A razão serve ao sujeito, mas o domina, o dirige e o "impotencializa" face às suas condições.

Desta forma, as sociedades tendem a reduzir, em seus processos produtivos, a expressão de seus aspectos simbólicos, míticos, místicos, etc., padronizando e normalizando suas etapas, e asfixiando a criatividade humana. Essa tendência impulsiona a transformação das pessoas naquilo que Adorno qualificava como a "coisificação" do sujeito, a eliminação de sua consciência. Para ele, a racionalidade tecnológica converte o mito em esclarecimento ${ }^{91}$ e a natureza em objetividade. "O preço que os homens pagam pelo aumento de seu poder é a alienação daquilo sobre o que exercem o poder." (ADORNO, 1985, p.21)

O modelo da moradia urbana-moderna não carrega mais, a rigor, respostas espontâneas dos grupos sociais a suas necessidades habitacionais gerais, objetivas e/ou subjetivas. O modelo de "casa-tipo" imprime, por sua vez, formatos habitacionais funcionais e equivalentes, que prometem a satisfação social por meio da imposição de certas condições de produção do habitat, como requisito para pertencer à uma cultura de referência. Este cenário de comportamento da produção habitacional moderna revela em sua forma e conteúdo, a transformação da casa em mercadoria especulativa.

O processo transforma o canteiro de obras em um espaço segregado e segregador. A divisão do trabalho social e técnico é inflada de maneira proporcional à hierarquização estrutural da produção. Os trabalhadores separados em equipes de

\footnotetext{
${ }^{91} \mathrm{Na}$ "dialética do esclarecimento", Adorno não alimenta dúvidas sobre a liberdade ser inseparável do pensamento esclarecedor. Entretanto, ele acredita reconhecer com a mesma clareza que "o próprio conceito desse pensamento, tanto quanto as formas históricas concretas e as instituições da sociedade com as quais está entrelaçado, contém o germe para a regressão que hoje tem lugar por toda parte." (ADORNO, 1985, p.13). A racionalidade esclarecida torna-se neste sistema, a racionalidade da própria dominação. Para ele, o projeto do esclarecimento era o desencantamento do mundo, era dissolver os mitos e substituir a imaginação pelo saber. "Mas a terra totalmente esclarecida resplandece sob o signo de uma calamidade triunfal." (ADORNO, ibid., p.17)
} 
capacetes coloridos revelam suas posições no tabuleiro produtivo da construção civil. Técnicos qualificados, com acessos privilegiados às tomadas de decisões, contracenam com um exército de trabalhadores em precárias condições de trabalho, substituíveis se representarem riscos aos ganhos do capital.

"No canteiro, os planos e memoriais - dos arquitetos, dos engenheiros, da "equipe-pluridisciplinar", tanto faz -, decodificados pelos mestres e comunicados como ordens de serviço, comandam o trabalho dividido. Nesse momento, repetimos, não representam mais que uma forma particular do despotismo da direção capitalista. "92 (FERRO, 2005, p.27)

A indústria da construção, segundo Pierre Frey, ao racionalizar e otimizar seus processos, os uniformiza, e assim desloca massivamente os centros de gravidade das tomadas de decisões. O canteiro passa a não ser mais do que o lugar formal das construções, dedicado, algumas vezes, à montagem dos elementos concebidos e construídos fora.

"A mercadoria e o produto matam a produção, e o trabalhador da construção é desprovido do espaço no qual ele podia fazer a prova de seu talento e de sua criatividade. Ele é desprovido da obra da qual poderia orgulhar-se. Ele é alienado e rejeitado à margem." (FREY, 2010, p.32)

Quanto às características da tecnologia capitalista, Renato Dagnino (2010) elenca esta mesma como sendo mais poupadora de mão de obra do que seria conveniente (o lucro aumenta com a redução da mão de obra ou do tempo de trabalho socialmente necessário); mais intensiva em insumos sintéticos do que seria conveniente; ambientalmente insustentável; alienante pois suprime a potencialidade criativa do

\footnotetext{
${ }^{92}$ Sérgio Ferro em sua obra "O canteiro e o desenho" analisa a engrenagem da produção capitalista da construção civil e o uso do desenho como instrumento de dominação, divisão do trabalho e alienação dos trabalhadores no canteiro de obras. Segundo Ferro (2005, p.95), "Da regulamentação da produção à sua organização, da mensuração externa à sistematização das operações - é nessa passagem que o desenho faz-se adotar como instrumento capital, momento em que se torna urgente definir as parcelas da produção com mais rigor. Questão de organização, portanto que o generaliza como documento de trabalho. $O$ objetivo de seu uso não é nem a qualidade do produto (as normas da corporação eram muito mais rígidas $e$ detalhadas), nem sua constância (a ausência do desenho fazia, se fosse o caso, da cópia direta um método mais fiel). O que constrange a história do desenho é a divisão desigual do trabalho que avança - e seu outro polo, o acordo a ser imposto aos componentes produzidos pelos trabalhadores divididos."
} 
produtor direto; hierarquizada a partir da demanda da figura do chefe e subchefes; segmentada pois não permite o controle do produtor direto; delimitada por controles coercitivos; irradiada pelas empresas dos países do norte e absorvida de forma acrítica pelas empresas dos países subdesenvolvidos; entre outras características.

O fator "coerção"93 é elencado por Dagnino como "elemento chave" para o funcionamento constante do sistema produtivo. O capitalista não busca apenas a acumulação de capital. Ele se interessa também pelo controle do processo produtivo. E o faz a partir de suas tomadas de decisões que operam com o objetivo de reforçar seu poder e continuar a tomar todas as decisões de maneira semelhante. Dagnino (2010, p.95) ilustra da seguinte maneira: "Se alternativas tecnicamente comparáveis têm implicações distintas em termos da distribuição do poder, e se ocorre alguma disputa entre trabalhadores e capitalistas (ou seus representantes técnicos, os engenheiros), tende a ser escolhida aquela que favorece o controle do processo por estes últimos."

Obviamente, a coerção (também física) já existia nos processos produtivos das sociedades anteriores ao capitalismo. Para Dagnino (ibid., p.186), "É em virtude da dissociação que passa a existir no capitalismo, entre a propriedade dos meios de produção e o exercício da violência (que passa a ser monopolizado pelo Estado), que o controle, ao deixar de estar associado à coerção, pode aparecer de forma encoberta. E passar a ser visualizado como um atributo técnico da forma de produzir capitalista."

A partir desta ótica, Dagnino questiona a capacidade das tecnologias de romperem com a lógica do capital somente com a abolição da propriedade privada dos meios de produção. Segundo ele, "Numa perspectiva histórica e analista, é fácil perceber que é a propriedade privada dos meios de produção, legitimada no ambiente socioeconômico, o que viabiliza a existência do controle capitalista no âmbito do ambiente produtivo. Mas é pouco provável que as características que esse controle incorporou na tecnologia capitalista possam ser alteradas simplesmente pela abolição da

\footnotetext{
${ }^{93}$ Dagnino (2010) analisa a coerção como uma categoria de mediação no processo de produção capitalista. Segundo ele, "Existiria, então, uma categoria de mediação entre a variável forma de propriedade (adstrita ao contexto socioeconômico) e as variáveis controle e cooperação (adstritas ao ambiente produtivo). Essa categoria de mediação seria a variável coerção (adstrita ao contrato social), que seria também responsável pela determinação das características da tecnologia." (Dagnino, 2010, p.208)
} 
propriedade privada e pela instauração da propriedade coletiva dos meios de produção." (DAGNINO, ibid., p.216)

O processo de produção tecnológica passa a ser entendido como um espaço de lutas sociais, de classes e ideológicas. Projetos de sociedade disputam espaço e poder a partir da produção tecnológica, que instrumentaliza-se como operadora da hegemonia capitalista de dominação (econômica, social, política e cultural). A tecnologia, criação social que objetiva resolver os problemas sociais, aumentar a qualidade de vida das pessoas e facilitar os processos de trabalho, orienta-se com a finalidade de aumentar o lucro, assegurar o controle do processo produtivo e ampliar a esfera de dominação social.

"Na medida que se vai expandindo o modo de produção capitalista industrial e se consolidando a superestrutura ideológica que garante a manutenção de sua base econômico-produtiva, naturaliza-se, como tantas outras características intrínsecas a esse modo de produção, o exercício do controle sobre o processo de trabalho e sobre o trabalhador direto no ambiente produtivo." (DAGNINO, ibid., p.185)

A tecnologia além de promover e assegurar, materialmente, os interesses e as posições dos grupos sociais dominantes das sociedades, promove, na dimensão simbólica, sua aceitação e seus valores. Os setores culturais e educacionais, manipulados e orientados segundo os interesses da ordem estabelecida do capital, legitimam e perpetuam tais visões de mundo. 


\section{Ensaios e compreensões 2}

"Não existe muito conhecimento que proporciona poder, mas existe muito conhecimento que só é proporcionado através do poder." (BRECHT, 1967, p.98)

Os modelos de sociedades criados e imaginados pelas classes dominantes das mais variadas épocas, se empenharam em estabelecer mecanismos que contribuíram e/ou moldaram os diferentes processos de produção das culturas construtivas. Essa compreensão é de grande importância se discutimos a hegemonia que o atual modelo de produção capitalista exerce sobre os processos de produção das novas culturas construtivas.

No seio da concorrência capitalista, os grupos sociais entram em contato, de forma rápida e imponente, com aquilo que o sistema estabelece como necessário, o que compreende obviamente as questões de habitação. Eles aprendem que formas de satisfazer suas necessidades habitacionais podem ser realizadas ou são recomendáveis, e quais são reprováveis ou condenáveis.

Assim, tanto dentro do espaço privado como no espaço público, uma série de mecanismos de controle, regulação e regulamentação, determinam aquilo que é aceitável ou não dentro do modelo de estrutura societária proposto. Isso engloba as escolhas referentes aos materiais de construção, aos elementos construtivos, aos móveis e equipamentos, e ainda aos usos de energia, de água, de salubridade e higiene, entre outros.

Passando pelas indústrias da construção civil, escolas de arquitetura e engenharias, fornecedores de materiais, sociedades profissionais, empresas privadas e públicas das áreas da construção, revistas especializadas, estabelecimentos financeiros, publicitários e de marketing, entre outros, uma enorme rede econômica e financeira é tecida naquilo que Frey (2010) chamou de "rede de consanguinidade vasta e coerente", produtora de um abundante e contínuo discurso documentado, fundamentado e bem ilustrado, convencedor e mantenedor das condições e escolhas estabelecidas. 
Ao lançarmos um olhar mais atento sobre as culturas construtivas tradicionais percebemos que estas são uma espécie de "reflexo" das sociedades que as produziram. Tais arquiteturas materializam uma enorme quantidade de elementos culturais presentes em suas sociedades. Aspectos religiosos, simbólicos, de gênero, militares, entre tantos outros, nos mostram através de suas materializações construtivas partes importantes das relações sociais estabelecidas dentro de uma sociedade particular.

E hoje isso não é diferente. Entretanto, como consequência de um conjunto de transformações ocorridas nas estruturas societárias, em escala global, intensificadas pelos processos de industrialização, urbanização, modernização, globalização, etc., modificaram-se profundamente as engrenagens de produção dos habitats populares.

Sobre este processo, Loubes (Op.cit., p.44) chama a atenção para o fato de que durante o século XX com a migração rural em direção aos centros urbanos, "numerosas sociedades de diversos países emergentes passaram de uma organização rural, onde cada habitante sabia construir sua casa, à uma organização onde uma instituição especializada assume este papel (o setor da construção: poderes públicos, empreiteiras, conceptores, industriais, profissionais especializados, circuitos financeiros). Este setor centraliza a função de construir no lugar dos habitantes. Uma das consequências do desenvolvimento deste setor especializado é, de um lado, ter despossuído de seu saber-construir aqueles que o possuíam e, de outro lado, ter selado o fim das arquiteturas tradicionais vernáculas."

Submetidos ao esforço de "assimilação" das culturas das classes dominantes, os fenômenos de produção das culturas construtivas tradicionais vão sendo reordenados, resignificados e reinterpretados pouco a pouco, transformando, num primeiro momento, suas próprias essências e, então, sua materialidade. Obviamente, não foram as necessidades humanas que modificaram-se, mas sim os modos de satisfazê-las.

Assim, os modos de habitar foram (e ainda estão) se desconectando gradativamente de seu ecossistema, resultando em profundas mutações e rupturas, e numa crescente perda de autonomia. Um sistema globalizado e hegemônico assume o direcionamento do funcionamento produtivo do habitat. As diversidades das culturas construtivas, de seus repertórios técnicos, de seus saberes-fazer e de suas criatividades 
específicas, vem sendo substituídas progressivamente por uma cultura construtiva única, mundializada e baseada na utilização de produtos (em sua forma mercadoria) manufaturados, estandardizados e normatizados, independentemente de seu contexto.

Estas características recobrem o território de funções e de "não lugares", como intitula Magnaghi (2003.), desconstruindo e destruindo as identidades locais, suas complexidades, suas singularidades e suas diferenças. $O$ desenraizamento das arquiteturas de seu meio ambiente próprio (solo, subsolo, clima, história, memória, etc.) gera pouco a pouco o que ele chama de "amnésia territorial" e obriga a viver em lugares que nos são indiferentes, servindo às funções de uma sociedade que rompeu subitamente com a memória dos lugares.

"A hipertrofia da metrópole contemporânea não é considerada uma patologia. Não é uma questão de degeneração cancerígena a combater dentro de um corpo saudável, mas sim uma regra inerente à estrutura e ao caráter do corpo urbano contemporâneo." (MAGNAGHI, op.cit., p.14)

Tais transformações são inseridas na nova realidade social e vão pouco a pouco consumindo e esgotando as antigas realidades, e na medida em que ganham espaço na sociedade vão sendo aceitas e legitimadas. As crenças e ideologias são, como observa Roberto Moreira (2007, p.72), elementos da realidade social. "São componentes dos processos políticos na medida em que influenciam nossa compreensão da realidade social e informam nossas ações cotidianas. Dito de outra forma, as visões e imagens que temos do mundo são elementos componentes da realidade deste mundo."

Também observamos estas rupturas, transformações e ressignificações, por exemplo, no campo da cultura a partir dos embates sobre as diferentes noções de natureza. Moreira nos explica como a dominação cultural da terra mercantil implica a desvalorização das noções de natureza associadas às culturas indígenas. "O embate cultural associado a territorialização do capital na Amazônia envolve a desvalorização da cultura dos povos da Amazônia, de seus mitos e imagens sobre a natureza. No tempo do trator nada vale o domínio da técnica do manejo do boi de aração, associada à cultura cabocla." (MOREIRA, ibid., p.45) 
O utilitarismo da modernidade consolidou, segundo Moreira, os usos do mundo natural sob o domínio hegemônico da razão científica, da ordem política das revoluções burguesas e das tecnologias das revoluções industriais. "Um campo hegemônico tridimensional de domínio da Razão, do Estado e da Técnica, concebido pelo Iluminismo, que hoje parece deslocar-se para o domínio do Mercado, do Estado e da Natureza, concebido pelo Neoliberalismo." (Ibid., p.205)

Esta engrenagem, estabelecida pela ordem social capitalista, não acolhe senão aquilo que contribui para a manutenção do sistema estabelecido, para sua continuidade. As inovações são aceitas e realizadas até o limite das renovações, sem entretanto conduzir para transformações sociais. Neste processo, se cria e se estabelece uma perspectiva na qual a evolução do sistema social-produtivo parece estar determinada pela lógica do progresso técnico-científico.

Pode-se insistir no fato do arcabouço tecnológico ser indiferente face os fins políticos. Ela pode servir, como ressalta Marcuse (apud Habermas, op.cit., p.54), "Tanto de acelerador quanto de freio a uma sociedade. Uma calculadora pode servir tanto a um regime capitalista como a um regime socialista. No entanto, se a técnica se transforma na forma englobante da produção material, define então uma cultura inteira; e projeta uma totalidade histórica - um mundo."

Nestes processos de rupturas e ressignificações nota-se que embora os elementos estruturais dos fenômenos de produção das culturas construtivas venham sofrendo mutações, impostas por um outro modelo de hegemonia inquestionável, seus processos produtivos não cessaram e nem esgotaram-se em si mesmos. Necessitam manifestar-se, redescobrir-se, reinventar-se, construir criticamente uma compreensão que aporte novas experimentações, experiências, vivências, reaproximações aos elementos fundamentais dos processos sociais de produção cultural dos habitats humanos. 
MOMENTO 3

\section{OUTROS PROCESSOS / NOVAS TECNOLOGIAS}

"Os tempos mudam, felizmente, para os que não sentam em mesas de ouro." (Brecht, 1967) 


\section{Resistências e continuidades}

"Apenas como trabalho coletivo autonomamente organizado, como livre razão coletiva, a arquitetura produzirá seu "verdadeiro conceito" e sua beleza própria. Nessa transformação se dará a substituição do ego do arquiteto, manifesto no virtuosismo de seu desenho, pelo sujeito coletivo que adquire "consciência de si" como produtor do espaço. Este sujeito deixará como índice de sua presença, seu "traço" da produção liberada, impresso no material". (FERRO, 2006)

Ao longo do Momento 1, busquei tecer algumas reflexões que permitissem compreender melhor as noções de arquiteturas vernáculas e culturas construtivas tradicionais através de seus processos produtivos. Para isso, assumi como método a decomposição dos fenômenos de produção das culturas construtivas tradicionais, revelando assim certos elementos estruturantes e algumas relações intrínsecas. Tal decomposição não esgota a possibilidade de adicionarmos outros elementos e de analisarmos inclusive cada elemento de maneira mais profunda e completa. $\mathrm{O}$ objetivo foi colocar em evidência certos elementos fundamentais presentes, de maneira geral, nos mais diversos fenômenos de produção das culturas construtivas tradicionais para, com referência a eles, traçar reflexões sobre os atuais processos de produção dos habitats contemporâneos.

No Momento 2, direcionei as reflexões para as mutações dos processos de produção habitacionais baseados nas tradições culturais, quando da implementação de novos processos orientados, por sua vez, pela racionalização técnica dos sistemas produtivos, dentro do modelo capitalista de sociedade. Mais uma vez, o intuito principal foi elencar alguns caminhos teóricos que possibilitassem evidenciar as engrenagens do sistema capitalista de produção habitacional e suas consequências face as culturas construtivas tradicionais.

Agora, no Momento 3, trabalharei com uma série de reflexões referentes às manifestações de criação e produção das arquiteturas vernáculas contemporâneas. Como podemos compreendê-las dentro da lógica capitalista de produção? Como podemos 
produzi-las dentro da ordem capitalista da sociedade? Como podemos, através de sua práxis produtiva, fomentar novos processos de construção habitacional e de formação profissional?

Recorro, mais uma vez, ao método de decomposição dos fenômenos de produção para salientar princípios e experiências que buscaram em suas realizações, alternativas ao determinismo histórico do processo de produção industrial/capitalista. Estas reflexões nortearão nossas análises ao longo do Momento 4, quando da apresentação do processo de produção habitacional por nós trabalhado.

Ainda no Momento 1, a proposta de decomposição dos fenômenos de produção das culturas construtivas tradicionais colocou em evidência os seguintes elementos: período histórico, localização, recursos disponíveis, processos construtivos, sistemas de representação, sistemas de mediação e organização, sistemas de memorização e sistemas de transmissão e difusão. Para as reflexões deste Momento 3, serão usados os mesmos elementos evocados, porém reunidos dentro de outras classes de elementos. Isso se deve à tentativa de aproximar os fenômenos de produção das culturas construtivas locais às reflexões teórico-conceituais que permitirão explicitar com mais clareza certas relações possíveis com experiências práticas que vem ocorrendo tanto no Brasil quanto no exterior.

Desta forma, fazendo referência ao elemento "período histórico", abordado no Momento 1, tratamos do período atual em que vivemos sob a égide da ordem capitalista de sociedade e produção. Todos os outros elementos, obviamente, inserem-se neste contexto e realidade, sendo então abordados a partir das atuais relações e condições de existência. Os elementos "localização" e "recursos disponíveis", serão tratados dentro do âmbito das compreensões sobre "contextos" e "territórios". Já os elementos "processos construtivos", "sistemas de representação" e "sistemas de mediação e organização", serão tratados junto às "tecnologias", dentro das esferas das "tecnologias sociais" e "processos experimentais". Por fim, os elementos "sistemas de memorização" e "sistemas de transmissão e difusão" serão tratados dentro das dimensões "educacionais e pedagógicas" e de suas relações com as esferas do "trabalho". 
Com isso, a intenção orienta-se em direção a uma contribuição para com as reflexões relativas às produções das culturas construtivas contemporâneas, inserindo certos princípios ou elementos tradicionais dentro de dinâmicas contemporâneas de formação profissional e produção habitacional.

\section{Contextos e territórios}

"Nenhuma arquitetura popular tradicional é anti-funcional. Jamais os homens construíram abrigos, templos, armazéns, silos, que não fossem adaptados funcionalmente ao papel que se esperava deles. O empirismo que conduziu a lenta elaboração das formas jamais selecionou aquilo que não funcionava. Ele se define, ao contrário, como um caminho de conhecimento que progride pela recondução da melhor resposta." (LOUBES, 2010, p.54)

De uma forma geral, a arquitetura vernácula foi, e continua sendo, apresentada na cultura ocidental moderna pelas oposições tradicional-moderno, não mecanizadomecanizado, atrasado-desenvolvido, etc. A hegemonia dos processos produtivos na ordem social capitalista levou assim a arquitetura vernácula a ser vista como uma arquitetura ultrapassada, não mais adaptada à nova ordem social. O vernáculo passou a ser considerado como uma questão a ser tratada nas esferas do patrimônio tradicional, não nas esferas de suas novas configurações e significações no período atual.

Ao olhar para as culturas construtivas tradicionais, não existem intuitos "passeístas" de retorno ao que hoje, muitas vezes, já não faz mais sentido. A intenção reside na busca por pistas de certas "inteligências construtivas" tradicionais, que durante séculos foram capazes de abrigar sociedades inteiras, adaptando-se aos ecossistemas locais, potencializando tecnicamente o uso dos recursos disponíveis, e representando em suas materializações as expressões culturais de seus grupos sociais. Neste sentido, busco nas essências de tais processos aquilo que a partir de sua readaptação ou reinvenção, nos permitirá criar o novo - a arquitetura vernácula contemporânea. 
Entretanto, limitar as arquiteturas vernáculas contemporâneas à produção de uma arquitetura com responsabilidade ecológica, a partir da utilização de materiais de construção locais e naturais, significa flexibilizar, mesmo que de maneira importante, as margens estabelecidas pelo atual sistema produtivo, mas sem rompê-las. Sem direcionar os esforços numa perspectiva de superação da ordem estabelecida, tais arquiteturas acabam por ser corrigidas e re-apropriadas posteriormente pelo próprio capital, revelando-se arquiteturas capitalizadas, onde termos como "sustentáveis" e "ecológicas" passam a ser rótulos de mercado.

Em seu tratado, Jean-Paul Loubes tece uma compreensão de "retorno ao local" que reforça a importância de se reestabelecer a relação com o local a partir de todos os sentidos e dimensões. Seria assim, a manifestação da "arquitetura situada" aquela ligada a um território, a uma história, a um projeto de lugar. Nas palavras de Loubes (op.cit., p.82), "É na "experiência de lugar" que a arquitetura situada procura se restabelecer num território, mais do que na reativação de uma memória histórica."

"Alguns criadores (...) tentam superar uma visão folclórica da tradição se perguntando se esta pode tornar-se novamente vivificante e alimentar as pesquisas contemporâneas. É toda a questão de patrimônio que é colocada: O que é que o homem pode fazer do legado dos períodos passados? Faz-se referência aqui de uma reinterpretação de patrimônio, em termos do processo de fabricação que é a arquitetura, e não de uma recuperação de formas desatualizadas, como se o tempo tivesse parado." (Loubes, ibid., p.36)

No processo de "reconexão" com os territórios, as manifestações contemporâneas das arquiteturas vernáculas devem, segundo Pierre Frey, realizar-se através de uma abordagem empírica e muito atenta à natureza das necessidades materiais e simbólicas. Esta, consistiria em uma confrontação direta entre os materiais, as inteligências, a força de trabalho e os capitais disponíveis. Para ele, neste momento histórico, "vernáculo é, em suma, tudo que se mantém periférico ou exterior ao fluxo mundial do capital e tudo que voluntariamente ou involuntariamente, escapa ao seu controle". (FREY, op.cit., p.45) 
Desta forma, a produção do habitat reorienta-se como fruto de um processo social constante e dialético - e não como uma mercadoria de morar, movida pela especulação financeira e pela fetichização cultural. Todavia, reforço uma característica que acredito ser extremamente importante para as manifestações de produção contemporânea das culturas construtivas. Durante o processo de restabelecimento das relações essenciais com o território, e no fomento às iniciativas que busquem romper com a ordem estabelecida, as culturas construtivas devem assumir em seus processos embrionários de produção, uma vertente pedagógico-conscientizadora e uma postura políticoemancipatória.

E assim, buscar desconstruir a lógica do capital, fomentando o rompimento da subordinação estrutural-hierárquica de sua organização e da dominação do trabalho social, seja pela propriedade dos meios de produção, dos produtos do trabalho realizado, ou ainda pela coerção exercida através do poder simbólico dominante, buscando assim, promover práticas conscientizadoras e emancipatórias em seus processos produtivos.

É na apropriação plena e consciente dos processos de produção, nas mãos dos produtores livres, que a arquitetura vernácula contemporânea se faz e desenvolve. Ela se torna facilitadora de processos embrionários de desenvolvimento de novas culturas construtivas, na medida em que se esforça por superar o trabalho alienado, regrado e controlado heteronomamente.

Assim, nesta busca pelo inventar da re-significação dos processos de produção do habitat popular contemporâneo, me indago sobre como se daria a produção das arquiteturas vernáculas contemporâneas naquilo que István Mészáros (2008) evoca como "para além do capital"94.

Como seriam as novas arquiteturas vernáculas para além do capital? Quais suas condições, significados e perspectivas? Como potencializar seus sistemas de memorização e transmissão dentro dos nossos atuais programas educacionais? Como dispor e nos

\footnotetext{
${ }^{94} \mathrm{O}$ conceito "para além do capital" é, para Mészáros (2008), um conceito inerentemente concreto que tem em vista a superação da ordem capitalista de sociedade. A educação "para além do capital" é para ele a ferramenta na construção de uma ordem social qualitativamente diferente, com função de transformar o trabalhador em um agente político, que pensa, que age, e que usa a palavra como arma para transformar o mundo.
} 
servir dos saberes científicos, técnicos e populares na formação dos futuros profissionais, particularmente nas áreas da arquitetura e engenharias? Como inseri-las dentro da lógica heterônoma da competição intercapitalista ou ensaiar sua superação?

Numerosos questionamentos são tecidos neste novo adaptar, inventar, experimentar e recriar de nossas arquiteturas populares. Nestas reflexões, a compreensão das identidades territoriais é de fundamental importância, assim como uma leitura crítica sobre os acúmulos oriundos dos sucessivos processos de formação territorial ao longo do tempo. Tais abordagens se fazem ora contrárias e de resistências à ordem capitalista de produção, ora assumindo e esboçando novas perspectivas de análises e ações. Para Loubes (op.cit., p.18) se revelariam com "(...) o fim da máquina de morar cara ao Movimento Moderno como modelo universal, e sua substituição por "fabricações" que procuram reconectar-se com o local".

"Em obra no Movimento Moderno, o paradigma da modernidade pôde exacerbar o princípio de autonomia da obra conduzindo precisamente a não reconduzir o que já teve lugar." (Loubes, ibid., p.40)

Entendendo o espaço como um "fato social", assim como propõe Milton Santos ${ }^{95}$, observamos na organização espacial os processos econômicos, sociais, culturais e políticos que interagem sobre uma base física. "O espaço é formado por um conjunto indissociável, solidário e também contraditório, de sistemas de objetos e sistemas de ações, não considerados isoladamente, mas como o quadro único no qual a história se dá". (SANTOS, 1996)

Em uma leitura convergente à de Milton Santos, Marcelo Lopes de Souza (1995) analisa o conceito de território como sendo os espaços sociais determinados e delimitados por e a partir de relações de poder, que definem limites operantes sobre um

\footnotetext{
95 O geógrafo Milton Santos (1996) sugere que devido à abrangência do conceito de espaço, este deva ser analisado por meio de categorias como: a forma, a função, a estrutura e o processo. A forma, segundo ele, é o aspecto visível de um objeto ou de um conjunto de objetos, neste caso, formando um padrão espacial. Assim, uma cidade, uma área rural e uma casa são exemplos de formas espaciais. Já a função, é uma tarefa ou atividade desempenhada por uma forma (objeto ou aspecto). As características sociais e econômicas de uma sociedade, em um dado momento, produzem a estrutura, ou seja, a natureza histórica do espaço, onde as formas e as funções são criadas e justificadas. E, finalmente, o processo é uma ação, frequentemente contínua, que possui um resultado qualquer (mudança).
} 
substrato referencial. Assim, torna-se importante olharmos com atenção para as operacionalidades das dinâmicas sociais nos processos de metamorfoses territoriais. "Enquanto relações sociais projetadas no espaço, os territórios podem desaparecer mesmo que os espaços correspondentes continuem inalterados". (SOUZA, 1995).

Segundo ele, o conceito de território é percebido como uma construção social, operacionalizada de forma coletiva e comungada pelos indivíduos e instituições que ali demarcam sua presença e estabelecem códigos de pertencimento. São nos momentos de participação social coletiva que os territórios podem ser criados, fortalecidos, reconstruídos ou, até mesmo, destruídos com base na consciência social do conjunto de sujeitos e agentes envolvidos. Neste sentido, o território pode tornar-se uma mediação entre o lugar e o mundo exterior (regional, nacional e mundial), na tentativa de reprodução social e econômica dos indivíduos.

Relacionados à construção das identidades territoriais estão os princípios de sustentabilidade territorial. Sem mergulhar no debate sobre as compreensões e os significados históricos do termo "sustentabilidade", evoco a seguir algumas reflexões que considero pertinentes no contexto destas reflexões.

As bases para uma compreensão mais profunda dos processos históricos de formação dos territórios devem, segundo Alberto Managhi, perceber as invariâncias, as permanências, sedimentações físicas e mentais. Esta compreensão produzirá as aproximações conceituais sobre a sustentabilidade do desenvolvimento. Managhi (op.cit., p.29) entende que como o termo "sustentabilidade" "traduz a obsolescência do conceito de desenvolvimento tomado como sinônimo de crescimento econômico ilimitado, o termo "desenvolvimento" é então articulado à palavra "sustentabilidade" para designar sistemas econômicos e modelos de ocupação suscetíveis de considerar o caráter esgotável, degradável e limitado dos recursos ambientais."

Desta maneira, seu significado vem se reduzindo à uma justaposição de medidas corretivas e de restrições visando limitar as atividades produtivas e os modelos de ocupação que, regidos por regras heterônomas e insustentáveis, continuam a produzir degradação. Tais ajustes, porque ainda derivados da concepção de território como 
suporte técnico e funcional da produção, se limitam a avaliar a capacidade de resistência dos territórios face aos usos realizados sobre os mesmos.

Tratar a questão ambiental de forma setorial e instrumental consiste, para Managhi, um dos maiores obstáculos para a superação da dicotomia entre os paradigmas do desenvolvimento e da sustentabilidade. Segundo ele, "a dicotomia operada entre desenvolvimento e sustentabilidade tem por efeito tornar lentas, parciais e, finalmente, ineficazes, as políticas de sustentabilidade." (MANAGHI, ibid., p.29)

Analisando com atenção o conceito de desenvolvimento sustentável dentro da ordem capitalista, Roberto Moreira (2007) atenta para o fato dos Estados nacionais aceitarem implicitamente a propriedade privada da ordem capitalista, bem como a distribuição da base de recursos entre os diferentes agentes sociais, respeitando obviamente as legitimações dos Estados. Desta maneira, as violências que deram origem a este domínio e as assimetrias de poder vigentes nos territórios não são de forma alguma questionadas.

Para Moreira, o conhecimento associado à questão ecológica contemporânea e à possibilidade da configuração de um capitalismo ecológico, com a incorporação dos constrangimentos ambientais à lógica capitalista, reintroduz a questão da apropriação privada dos recursos naturais na ordem dos debates atuais.

"A sustentabilidade ambiental capitalista e seus desdobramentos - teórico, técnico, cultural e político - apontarão assim para a incorporação dos constrangimentos ecológicos à lógica competitiva intercapitalista, agora de caráter globalizado e planetário, de poderes assimétricos, entre nações e classes sociais." (MOREIRA, 2007, p.212)

No sistema capitalista e nas correlações de forças entre os Estados nacionais, a lógica de mercado é quem dita as regras de uso dos ecossistemas. O desenvolvimento sustentável assume um papel regulador das políticas ambientais, legitimadas por acordos internacionais e especuladas como mercadorias pelas bolsas financeiras do mundo inteiro. 
No esforço de superação desta visão, principalmente reguladora e funcionalista, e de ampliação da compreensão crítica e política do termo "sustentabilidade", assim como, no fomento de novas práticas projetuais e construtivas, Alberto Managhi sugere que a produção de um alto nível de qualidade ambiental possa se tornar o novo "capital fixo social" e condição estrutural do desenvolvimento sustentável. "Assim, os termos da aproximação funcionalista são revertidos e a sustentabilidade torna-se condição estrutural do desenvolvimento econômico." (MANAGHI, op.cit., p.32)

"Sendo assim, a sustentabilidade do desenvolvimento depende da forma na qual um modelo socioeconômico se revela na medida de assegurar a conservação e o crescimento dos lugares graça às ações capazes de valorizar ou preservar sua "tipologia territorial" e sua individualidade." (MANAGHI, op.cit., p.32)

Torna-se importante, para avançarmos nas análises, refletir sobre certas práticas, processos produtivos, métodos e instrumentos de viabilização e operacionalização de ações neste sentido.

\section{Tecnologias sociais e processos experimentais}

"A forma instruída de utilizar uma máquina consiste em avaliar seus poderes, em modelar seus usos, à luz de nossos limites mais do que de seu potencial. Não devemos rivalizar com ela. Uma máquina como todo modelo, deveria propor mais que mandar, e a espécie humana deve seguramente se afastar do comando de imitar a perfeição." (SENNETT, 2010, p.147)

No âmbito das reflexões referentes à produção de novas tecnologias e processos experimentais, procurarei acionar alguns conceitos e práticas realizadas com o intuito de "abrir" e "ocupar", com novas perspectivas analíticas e outras realizações concretas, espaços dentro do sistema de produção capitalista. Tais frentes de trabalho tecem uma rede de cooperação entre instituições acadêmicas, cooperativas populares, movimentos 
sociais, órgãos governamentais, comunidades locais, entre outros, e vem somando experiências e referências transformadoras das realidades sociais excludentes.

Em um primeiro momento, proponho algumas reflexões acerca da produção tecnológica, tendo como orientação as características produtivas e os princípios teóricos das chamadas "tecnologias sociais". Estas, surgem do olhar analítico e prático de perceber a produção tecnológica como produção social e cultural, a partir do envolvimento direto, ativo, crítico e participativo de todos os envolvidos no processo produtivo. Nesta vertente pela inclusão social universal, a ideia de se produzir e transferir conhecimento e tecnologia, é substituída pela prática da construção coletiva dos conhecimentos e com a incorporação dos valores, interesses e saberes dos grupos sociais produtores e usuários das tecnologias.

As tecnologias sociais não funcionam simplesmente porque resolvem um dado problema. Segundo Hermán Thomas (2009), estas tecnologias inserem-se na geração de processos de transformação social, pois propõem a construção de novos caminhos para a resolução de problemas sócio-técnicos, supondo uma visão crítica do produto tecnológico e de sua produção. Para ele (2009, p.74), a maior parte da população vê a tecnologia como uma caixa preta, "como uma esfera autônoma e neutra que determina o próprio caminho de desenvolvimento, gerando inexoráveis efeitos, construtivos ou destrutivos no seu caminho."

"Se as tecnologias não são neutras, se existem alternativas tecnológicas, $e$ é possivel eleger, entre elas, se os atores sociais podem participar desses processos, e se as tecnologias constituem a base material de um sistema de afirmações e sanções que determina a viabilidade de certos modelos socioeconômicos, de certos regimes políticos, assim como a inviabilidade de outros, parece óbvio que é imprescindivel incorporar a tecnologia como um aspecto fundamental de nossos sistemas de convivência democrática. Resulta tão ingênuo pensar que semelhante nível de decisões possa ficar exclusivamente em mão de "peritos", assim como conceber que a participação não informada pode melhorar as decisões. Parece 
insustentável continuar pensando que a tecnologia não é um tema central de nossas democracias." (THOMAS, ibid., p.75)

Compreendendo as tecnologias como processos culturais implicamos a necessidade de produzi-las aproveitando-se dos conhecimentos científicos, técnicos e populares, locais e externos, codificados e tácitos, críticos e transformadores. Assim, a racionalidade do processo produtivo das tecnologias sociais acaba por confrontar-se com a racionalização da razão técnica, questionando e propondo alternativas ao modelo estabelecido.

Sobre o processo histórico da produção tecnológica de cunho mais social e voltada para as camadas populares da sociedade, Renato Dagnino (et. al, 2010) recupera certos aspectos da origem de tal processo, passando pelas atividades promovidas por Gandhi, pelas tecnologias conhecidas como "intermediárias", "apropriadas", "alternativas", entre outras. Segundo ele, a expressão "tecnologia intermediária" foi cunhada por Schumacher para designar uma tecnologia, adequada aos países pobres, caracterizando-se por apresentar reduzido custo de capital, adequação à pequena escala, certa simplicidade produtiva e respeito à dimensão ambiental e territorial.

Tais tecnologias além de incorporarem em suas concepções características relativas ao custo reduzido e à simplicidade de produção em escalas de pequeno e de médio porte, fomentavam, em suas produções, a participação comunitária nos processos decisórios das escolhas tecnológicas, e promoviam ações relacionadas aos problemas de saúde, habitação, alimentação, educação, geração de renda, etc.

Entretanto, Dagnino (et. al, ibid., p.82) ressalta que "embora centrada no objetivo do desenvolvimento social, sua postura (da tecnologia) era defensiva, adaptativa e não questionadora das estruturas de poder dominantes nos planos internacional e local." Para ele, por estas tecnologias terem sido difundidas em grande escala próximas aos grupos sociais mais desfavorecidos ou mais afastados, lugares estes onde a tecnologia convencional ainda não era hegemônica, tais ações também resultaram em um beneficiamento funcional para o próprio sistema capitalista. 
"Essa funcionalidade (aportada pela tecnologia apropriada) para o modelo de acumulação capitalista dos países periféricos seria consequência do fato de que, ao permitir o aumento da produção e o barateamento da força de trabalho, amenizava a já preocupante marginalização social e atenuava o desemprego estrutural socialmente explosivo. Dado que era fundamental para aqueles interesses a manutenção da baixa remuneração dos trabalhadores não qualificados demandados pela expansão do modelo urbano-industrial implementado." (DAGNINO, et al., ibid., p.82)

Sem a adoção e a forte demanda pelos governos, ou outros agentes com força política, deste tipo de tecnologia como alternativa à tecnologia convencional capitalista, as tecnologias apropriadas foram perdendo espaço e ganhando críticas do mundo científico. Foram criticadas por terem construído uma ideia de que as tecnologias apropriadas poderiam ser produzidas por pessoas que, mesmo compartilhando de valores mais equitativos e humanos, fossem capazes de abandonar procedimentos técnicos profundamente arraigados pelas condições das tecnologias convencionais capitalistas.

"Talvez a principal crítica à tecnologia apropriada é o pressuposto de que o simples alargamento do leque de alternativas tecnológicas à disposição dos países periféricos poderia alterar a natureza do processo (e dos critérios capitalistas) que preside à adoção de tecnologia." (DAGNINO, et al., ibid., p.81)

Essas reflexões são interessantes pois facilitam nossa compreensão da tecnologia como espaço de luta social onde projetos políticos estão em disputa. Orientações sobre os hábitos culturais, as escolhas religiosas, a valorização ou substituição das tradições, os poderes de compra e consumo, etc., são materializados e naturalizados pelas orientações tecnológicas, ou melhor, pelas decisões daqueles que possuem a posse e o controle da produção tecnológica. Tal poder capital, assegura e legitima a hierarquia social e a alienação dos produtores e consumidores.

Considerando a propriedade privada dos meios de produção como um elemento exógeno ao ambiente produtivo, Dagnino analisa que embora esta propriedade condicione o tipo de organização e gestão do trabalho e de seus processos produtivos, a 
produção capitalista é assegurada e legitimada por outro elemento, este interno ao próprio processo produtivo, a coerção. Segundo ele, não basta a abolição da propriedade privada dos meios de produção para se construir formas solidárias de produção.

"A propriedade dos meios de produção é uma relação social que se estabelece no contexto que cerca o ambiente produtivo. É como se essa relação social, para poder interferir no processo de trabalho e para moldar a tecnologia, precisasse de algo que a "representasse" no ambiente produtivo. Esse "tradutor" é o controle. É ele, e não a propriedade dos meios de produção, que determina diretamente as características do modo de produzir e da tecnologia." (DAGNINO, et al., ibid., p.187)

Neste sentido, Dagnino tece uma comparação com a situação vivida em uma cooperativa de produtores associados, que também demanda de controle em seus processos produtivos. Embora a propriedade seja coletiva, são as participações democráticas nos processos decisórios que irão estabelecer os contratos sociais orientadores da organização do trabalho e das relações sociais diferenciadas das produções capitalistas.

É dentro de um processo de construção sociocultural que a tecnologia social ganha potencialidades transformadoras, assumindo um caráter político, reflexo das interações de todas as condições e todos os envolvidos no processo produtivo. Esta construção social, experimenta, segundo Dagnino (et al., ibid., p.100), um primeiro processo de adequação sócio técnica. "A adequação sócia técnica pode ser compreendida como um processo que busca promover uma adequação do conhecimento científico e tecnológico (esteja ele já incorporado em equipamentos, insumos e formas de organização da produção, ou ainda sob a forma intangível e mesmo tácita) não apenas aos requisitos e finalidades de caráter técnico-econômico, como até agora tem sido o usual, mas ao conjunto de aspectos de natureza socioeconômica e ambiental que constituem a relação ciência e tecnologia social."

Ele ainda sugere certos critérios que conformariam um novo código sócio técnico (alternativo ao código técnico-econômico convencional capitalista) a partir do qual a tecnologia convencional seria desconstruída e projetada dando origem a tecnologia 
social. Seriam eles, “(...) a participação democrática no processo de trabalho e o atendimento a requisitos relativos ao meio ambiente (mediante, por exemplo, o aumento da vida útil das máquinas e equipamentos), à saúde dos trabalhadores e dos consumidores e à sua capacitação auto-gestionária." (DAGNINO, et al., ibid., p.101)

Assim, a tecnologia social seria o "resultado da ação de um coletivo de produtores sobre um processo de trabalho que, em função de um contexto socioeconômico (que engendra a propriedade coletiva dos meios de produção) e de um acordo social (que legitima o associativismo), os quais ensejam, no ambiente produtivo, um controle (auto gestionário) e uma cooperação (de tipo voluntária e participativa), permite uma modificação no produto gerado passível de ser apropriada segundo a decisão do coletivo." (DAGNINO, et al., ibid., p.210). E aportaria condições não discriminatórias, bem adaptadas a pequenos e médios produtores e consumidores de baixo poder econômico, orientadas para a satisfação das necessidades humanas universais, fomentadoras do potencial criativo dos produtores e usuários, abrangentes às escalas locais e regionais, organizadas de maneira associativa e solidária, entre outras características.

Como comentei anteriormente, as iniciativas práticas de experimentação e desenvolvimento de novas tecnologias vem ocorrendo a partir de uma extensa rede social composta por instituições acadêmicas, órgãos governamentais, movimentos sociais, comunidades locais, instituições do terceiro setor, cooperativas, entre outras. Os esforços desses grupos estão sendo orientados para a satisfação de demandas concretas, inseridas em um contexto de inclusão social, mediante a realização de metodologias de trabalho concebidas para combinar capacidades locais e iniciativas coletivas de participação e gestão nas mais diversas áreas sociais, como por exemplo a agricultura familiar, habitação popular, reciclagem de resíduos, armazenamento de água, saneamento ambiental, entre outras.

No tema da habitação popular, o grupo de pesquisa Habitação e Sustentabilidade - HABIS/IAU/USP, além de possuir um grande acúmulo referente às produções científicas oriundas das pesquisas realizadas sobre o tema, possui uma relevante experiência no tocante às ações de assistência técnica na produção habitacional, em comunidades rurais. Englobando os processos de concepção de projetos arquitetônicos, as ações orientam-se 
aos métodos participativos de organização do trabalho e autogestão, passando por capacitações em técnicas construtivas não convencionais e produção de novas tecnologias sociais.

Uma dessas experiências refere-se à assistência técnica realizada pelo grupo HABIS no âmbito da produção das moradias do assentamento rural Sepé Tiaraju, localizado em Serra Azul, interior do estado de São Paulo. Reconhecido e formalizado pelo Estado Brasileiro em 2004, este assentamento rural foi criado para assentar 80 famílias de pequenos agricultores familiares, distribuídas em 4 núcleos de moradias.

A base de trabalho do HABIS, segundo Rosana Folz (2012, p.25), estava calcada na organização coletiva em conjunto com os moradores do assentamento. Segundo ela, "Somente com esta organização seria possível a gestão e a produção das habitações, bem como as ações de saneamento ambiental. A intrincada relação entre os diversos moradores e destes com o HABIS e com os órgãos públicos fez com que esta organização fosse se moldando conforme o momento, e mesmo desaparecendo em algumas fases da obra."

Neste processo, o HABIS acompanhou tecnicamente a construção de 77 casas de moradores assentados. Uma das iniciativas foi a realização de oficinas de capacitação referentes às diferentes etapas da construção. Tais oficinas além de terem como objetivo a formação dos moradores do assentamento, proporcionando condições potenciais para a autoconstrução das moradias, possibilitavam a geração de trabalho e renda entre as famílias assentadas.

"Ao longo de todo o processo de construção das casas, as oficinas de capacitação foram métodos utilizados para transferir conhecimentos técnicos aos moradores do assentamento. Assim, foram realizadas oficinas das seguintes etapas de obra: fundação e alvenaria; instalação hidráulica; instalação elétrica; instalação das esquadrias; instalações sanitárias com o sistema de tratamento de esgoto e produção de painéis pré-fabricados para cobertura." (FOLZ, ibid., p.56) 
Tais oficinas além de abordarem os temas citados, foram palco de ensino e aprendizagem em torno de técnicas ecológicas e alternativas às convencionais estimuladas pelo modelo de produção vigente. Temas como a preparação e montagem de pórticos em eucalipto roliço para o sistema denominado pilar-viga e os painéis de cobertura pré-fabricados em madeira foram tecnologias sociais desenvolvidas com e pelas famílias moradoras do assentamento. Com relação às técnicas construtivas com terra, duas casas em adobe e uma casa contendo múltiplas técnicas (adobe, bloco de solo-cimento, taipa de pilão e taipa de mão) foram construídas e serviram de palco para oficinas de capacitação e práticas coletivas de trabalho.

Segundo Folz (Ibid., p.66), as características presentes nas tecnologias construtivas com terra, como por exemplo: o baixo custo de capital, a pequena escala, o processo participativo de construção, a simplicidade e o respeito à dimensão ambiental, entre outras, aproximam-se dos critérios elencados por Rodrigues e Barbieri (2008, p.1076) quanto ao quadro produtivo das tecnologias sociais. Seriam eles: atende as demandas sociais concretas vividas e identificadas pela população; é democrático e desenvolvido a partir de estratégias especialmente dirigidas à mobilização e à participação da população; fomenta a apropriação e o aprendizado por parte da população e de outros atores envolvidos; permite o planejamento, a aplicação e a sistematização das ações de forma organizada; incentiva a produção de novos conhecimentos a partir da prática ; visa à sustentabilidade econômica, social e ambiental, além de gerar aprendizagens que servem como referências para novas experiências.
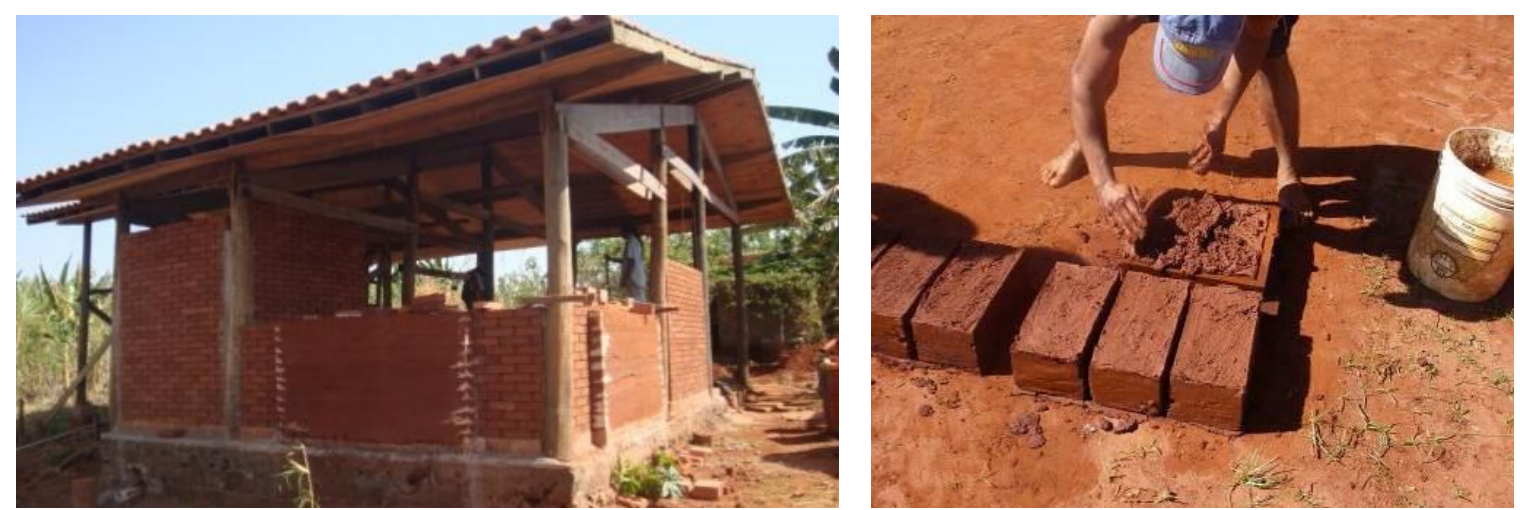

Foto 18 - Casa de pilar-viga com vedação em taipa de pilão, taipa de mão e BTC, outubro de $2010 .^{96}$ Foto 19 - Produção e secagem dos adobes. ${ }^{97}$

\footnotetext{
${ }^{96}$ Fonte: Acervo HABIS, 2010, consultado em FOLZ (op.cit., pg.68).

${ }^{97}$ Fonte: Acervo HABIS, 2010, consultado em FOLZ (op.cit., p.46).
} 
Os painéis de cobertura pré-fabricados em madeira foram a opção escolhida pelas famílias moradoras com relação ao projeto de cobertura de suas habitações. Tais painéis são compostos por caibros e forros de pinus e ripas de eucalipto ${ }^{98}$.

Em função da origem das madeiras utilizadas na produção dos painéis (replantios florestais), de sua adequação dimensional, de sua simplicidade de produção e por ser executado em larga escala, Folz ressalta que o painel de cobertura pré-fabricado em madeira propiciou eficiência e produtividade no canteiro e facilitou a administração da obra, mesmo em situações adversas encontradas nos diferentes momentos do projeto.

Segundo ela (Ibid., p.78), "para a pré-fabricação de componentes em um sistema de mutirão, podem ser destacadas as seguintes recomendações: considerar no cronograma de execução os possíveis contratempos que surgem em organizações coletivas; a assessoria técnica precisa estar atenta para realizar constantes e necessárias adequações no processo de produção, de acordo com os acontecimentos envolvendo a comunidade; considerando a escassez de recursos nos custos do projeto e a característica intrínseca do processo de produção pré-fabricado de elementos em madeira é necessária a instalação de um centro de produção e substituição eventual de equipamentos."
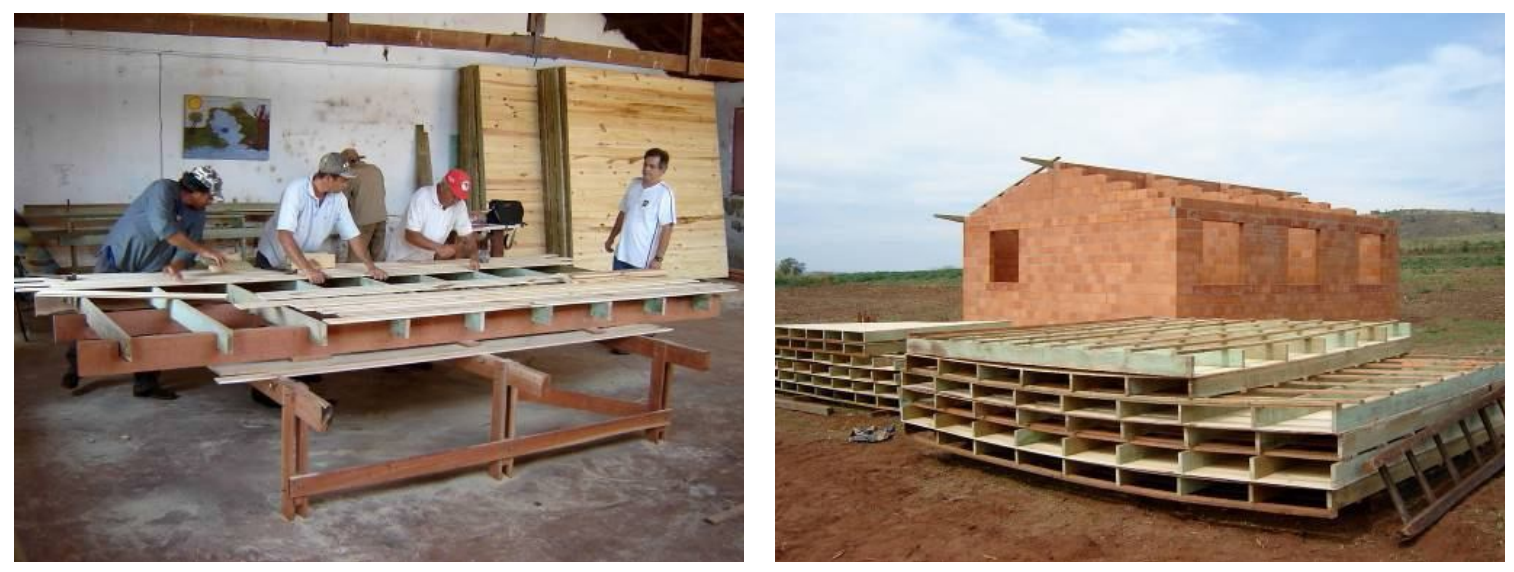

Foto 20 - Montagem do painel na Mesa de Produção de Painéis. ${ }^{99}$ Foto 21 - Preparação para a instalação dos painéis. ${ }^{100}$

\footnotetext{
98 Os painéis, construídos pelos moradores, com assessoria do grupo HABIS, foram pesquisados e desenvolvidos pelo professor e pesquisador Ivan Manoel Rezende do Valle, que escreveu sua tese de doutorado analisando os sistemas de cobertura desenvolvidos para as casas das famílias assentadas nos dois assentamentos rurais que o HABIS realizou assistência técnica. Para mais informações ver VALLE, 2011. ${ }^{99}$ Fonte: Acervo HABIS, 2010, consultado em FOLZ (op.cit., p.77).

${ }^{100}$ Fonte: Acervo HABIS, 2010, consultado em FOLZ (op.cit., p.77).
} 
Outro sistema construtivo desenvolvido pelo HABIS juntamente com as famílias assentadas foi o sistema estrutural com pórticos de eucalipto roliço que ficou conhecido como "pilar-viga". Segundo Folz, este sistema foi desenvolvido tendo em vista a dificuldade de articulação das famílias para a produção dos tijolos de adobe e o período das chuvas que estava se aproximando. "A ideia principal era montar os pórticos, erguêlos e travá-los, e instalar os painéis de cobertura que iam ser produzidos. Com a estrutura erguida e coberta era possível escolher diferentes tipos de vedação e materiais de acabamento, podendo inclusive ser produzido o adobe e utilizar a estrutura coberta como área para a secagem dos blocos." (FOLZ, ibid., p.79)

Apesar de serem de fácil compreensão e montagem, os pórticos necessitam ser fixados às fundações já realizadas previamente. Deve-se então pensar em uma maneira de fixá-los, protegendo-os do contato com o solo e com as possíveis origens de umidade.

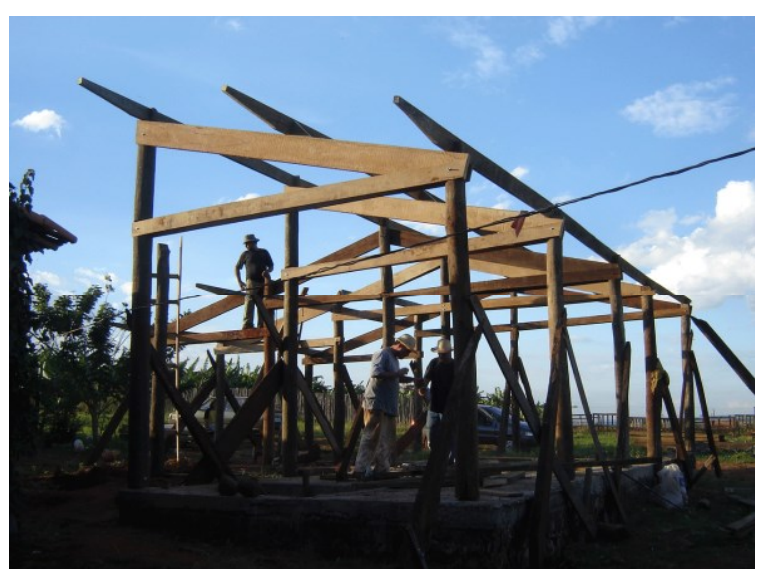

Foto 22 - Fixação das terças nos pórticos. ${ }^{101}$

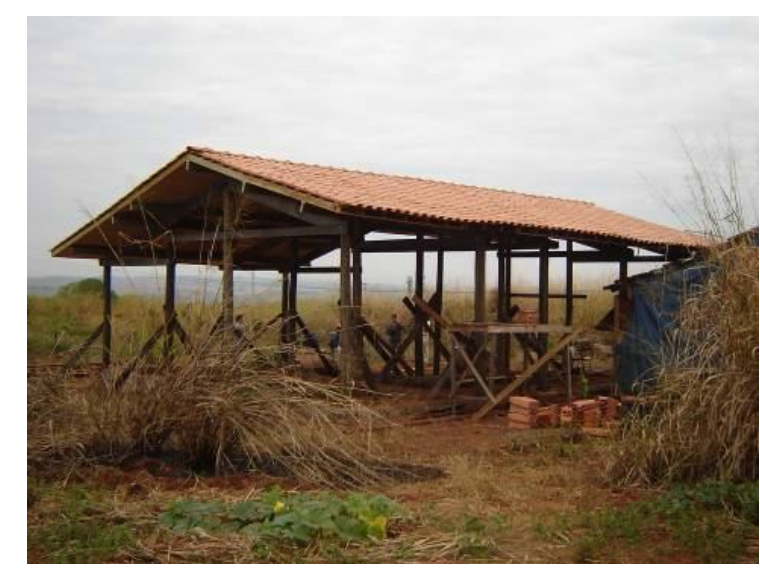

Foto 23- Estrutura coberta com os painéis. ${ }^{102}$

O sistema "pilar-viga" consiste em uma estrutura de Eucalyptus spp formada por pilares contínuos de $15 \mathrm{~cm}$ de diâmetro, vigas horizontais duplas de $2,5 \mathrm{~m} \times 15 \mathrm{~cm}$ que abraçam os pilares e as vigas inclinadas de $5 \mathrm{~m} \times 25 \mathrm{~cm}$ que estão apoiadas sobre os topos dos pilares. O conjunto de pilares e vigas sustenta as terças que por sua vez recebem os painéis pré-fabricados da cobertura. Ao todo, o sistema é composto por cinco pórticos, que uma vez erguidos e calçados, recebem a terça de cumeeira e as terças de frechal e

\footnotetext{
${ }^{101}$ Fonte: Acervo HABIS, 2010, consultado em FOLZ (op.cit., p.81).

102 Fonte: Acervo HABIS, 2010, consultado em FOLZ (op.cit., p.81).
} 
intermediárias. Por fim, com a fixação dos painéis de cobertura a estrutura do sistema pilar-viga fica devidamente travada.

Anterior à atuação junto às famílias moradoras do Assentamento Sepé Tiaraju, o grupo de pesquisa HABIS havia participado de um outro projeto, sendo este junto às famílias moradoras do Assentamento Rural Pirituba II, em Itapeva, interior do Estado de São Paulo.

Tal projeto, intitulado Inovarural, aconteceu entre os anos 2004 e 2007, e foi palco de uma série de práticas que possuíam como estratégias ações orientadas às novas perspectivas no campo da produção habitacional rural. Segundo Akemi Ino (2008), os princípios norteadores deste projeto de construção das 42 habitações, basearam-se em três aspectos principais: o incentivo aos processos sociais participativos nas tomadas de decisões e, a formação e capacitação de pessoas nas etapas da produção das habitações, possibilitando a geração de trabalho e renda; a gestão com participação organizada das famílias na articulação com os diferentes agentes envolvidos na cadeia de produção da habitação e; o desenvolvimento de componentes e sistemas construtivos a partir dos recursos locais e regionais, assim como a implementação de alternativas de infraestrutura e de saneamento com custos reduzidos e materiais adequados ambientalmente.

Uma das ações realizadas foi a constituição de um empreendimento cooperativo solidário com a implementação de uma marcenaria coletiva destinada, num primeiro momento, à produção de componentes construtivos para as habitações locais. Tal marcenaria foi responsável pelo desenvolvimento dos projetos e a produção das esquadrias e das vigas VLP (Viga Laminada Pregada) para as coberturas, utilizando-se das madeiras de plantios florestais.

Segundo Ino (2008), entre os principais resultados obtidos, destacam-se:

- A construção de 42 moradias de $75 \mathrm{~m}^{2}$, com área coberta de $104 \mathrm{~m}^{2}$ no valor de $\mathrm{R} \$$ $9.500,00$ reais;

- O aumento do envolvimento e da compreensão das famílias nas discussões acerca dos projetos e suas etapas de elaboração; na articulação para obtenção de financiamento habitacional e seus respectivos programas; nos processos de organização para construção 
de unidades habitacionais; na gestão do canteiro; nas compras coletivas dos materiais de construção, entre outros;

- O aumento da compreensão dos pesquisadores em relação ao modo e às condições de vida no meio rural, e o aumento do conhecimento com relação aos programas habitacionais e seus trâmites necessários;

- A produção de dissertações de mestrado, doutorado e outras pesquisas;

- A implantação da Marcenaria Coletiva Auto-gestionária - Marcenaria MADEIRARTE;

- A formação do Grupo Tô de Olho, formado por jovens do assentamento para produção de vídeos e documentários;

- A produção de 36 casas com cobertura em sistema VLP (produziram-se 4.054 vigas), a partir da capacitação de grupos de famílias para a execução no canteiro e fabricação dos componentes VLPs na marcenaria;

- A produção, na marcenaria coletiva, de todos os batentes de portas e das folhas das janelas para as 42 casas;

- A construção de uma casa em adobe, com um custo reduzido comparado às habitações feitas com materiais convencionais.

Dentre os diversos fatores condicionantes à realização de tal projeto, destaca-se o estabelecimento de um espaço de diálogo aberto entre as famílias e o grupo de assessores, onde foram expostos e discutidos os limites, as dificuldades e as potencialidades existentes, possibilitando assim, serem traçados e definidos os objetivos comuns ao grupo como um todo. Segundo Ino et al. (2007, p.7), isso ocorre porque "o que se coloca aqui não é um processo convencional de construção de habitação, no qual ou se constrói individualmente ou se contrata uma empreiteira. Trata-se aqui de um processo de construção de habitação baseado no trabalho coletivo entre famílias $e$ assessores, no qual seus próprios participantes precisam definir seus objetivos e acordos comuns a fim de se consolidar um grupo."

"A principal referência adotada no assentamento foi a ideia dos temas geradores, tendo como referência a pedagogia do oprimido, de Paulo Freire: partindo-se das histórias de vida das famílias e procurando-se discutir aquilo que para estas famílias e para os pesquisadores parecia ser importante. Traduzindo isto para o projeto da casa e para seu contexto, a 
ideia era discutir aquilo que os participantes consideravam como essencial para se chegar a uma concepção de moradia. O desafio colocado era traduzir as ideias e os sentimentos das pessoas em um desenho e uma definição concreta de moradia." (INO et al., ibid., p.21)

Como explicado no início deste capítulo, os sistemas de memorização e transmissão dos conhecimentos serão tratados dentro das dimensões pedagógicas e educacionais. Obviamente, não serão abordadas todas as formas possíveis de construção dos processos pedagógicos, ora por não serem pertinentes ao tema tratado, ora por não haver espaço nem tempo hábil neste trabalho, para fazê-lo com satisfatória competência. O interesse, visto as características do canteiro de produção habitacional que será analisado, é evocar uma série de reflexões referentes aos exemplos de processos pedagógicos quando estes se inserem dentro dos espaços de produção habitacional. Ou seja, quando o trabalho e o aprendizado convergem para um mesmo horizonte, em um espaço comum, e se complementam em suas ações práticas e reflexões críticas.

\section{Outras relações entre educação e trabalho}

"Só um novo objetivo pode conduzir a uma nova arte. O novo objetivo é a pedagogia." (BRECHT, op.cit., p.48)

"Um dos temas complexos e de difícil compreensão para aqueles que vivem da venda de sua força de trabalho, ou fazem parte dos milhões de desempregados, subempregados ou com trabalho precário, é, sem dúvida, o do trabalho como princípio educativo. Como pode ser educativo algo que é explorado e, na maior parte das vezes, se dá em condições de não escolha? Como extrair positividade de um trabalho repetitivo, vigiado e mal remunerado?" (FRIGOTTO, et al., 2005, p.01)

Inicio este tópico no esforço de organizar e articular algumas reflexões relacionadas ao trabalho como princípio educativo e à educação como trabalho social. Este assunto é bastante tratado e vem sendo analisado por um grande número de 
intelectuais que se empenham em "decifrar" o direcionamento que a relação entre trabalho e educação vem assumindo no atual momento histórico da conjuntura neoliberal. O tema interessa às nossas reflexões por fazer parte das relações entre capital e trabalho, no conjunto das forças produtivas e nos processos de formação e educação.

De acordo com Gaudêncio Frigotto, se analisarmos as relações dos seres humanos para produzirem os meios de vida, através do trabalho que transforma a natureza, perceberemos que a atividade prática é o ponto de partida do conhecimento, da cultura e da conscientização humana.

A partir da "Ontologia do ser social”"103, desenvolvida por Georg Lukács, Frigotto (et al., 2005, p.02) pensa as questões do trabalho em suas propriedades educativas. Segundo ele, "A aquisição da consciência104 se dá pelo trabalho, pela ação sobre a natureza. O trabalho, neste sentido, não é emprego, não é apenas uma forma histórica do trabalho em sociedade, ele é a atividade fundamental pela qual o ser humano se humaniza, se cria, se expande em conhecimento, se aperfeiçoa. O trabalho é a base estruturante de um novo tipo de ser, de uma nova concepção de história."

Assim, o trabalho é tido como um princípio educativo na medida em que proporciona a ampliação das capacidades e condições humanas através da compreensão do processo de produção, científica e tecnológica, como conhecimentos desenvolvidos coletivamente e apropriados socialmente.

"O trabalho como princípio educativo deriva do fato de que todos os seres humanos são seres da natureza e, portanto, têm a necessidade de alimentar-se, proteger-se das intempéries e criar seus meios de vida. É fundamental socializar, desde a infância, o princípio de que a tarefa de prover a subsistência e outras esferas da vida pelo trabalho é comum a todos os seres humanos, evitando-se, desta forma, criar indivíduos ou

\footnotetext{
${ }^{103}$ A questão da ontologia está ligada à identidade do ser. Lukács trabalha a ontologia como práxis humana, e assim como a forma dialética pela qual o homem produz sua própria existência na relação com a natureza e com os outros homens, produzindo conhecimentos.

${ }^{104}$ Segundo Frigotto (et al., 2005, p.7), “(...) é a consciência moldada pelo agir prático, teórico, poético ou político que vai impulsionar o ser humano em sua luta para modificar a natureza. A consciência é a capacidade de representar o ser de modo ideal, de colocar finalidades às ações, de transformar perguntas em necessidades e de dar respostas a essas necessidades."
} 
grupos que explorem e vivam do trabalho de outros, ou se caracterizem como, segundo a afirmação de Gramsci, mamíferos de luxo." (FRIGOTTO, et al., ibid., p.09)

Parece interessante relacionarmos esta compreensão teórica sobre o trabalho com o exercício de realização da "práxis educativa". Tais reflexões podem nos orientar quanto à leitura crítica de nossas práticas no canteiro de obras, assim como à percepção da educação como instrumento essencial para a transformação humana num horizonte emancipador.

As práxis educativas são, segundo Lucicléia Lins (2010), o conjunto de ações pedagógicas, organizadas sob a perspectiva de encontros formais ou não formais que se constituem em espaços de politização, de socialização e apreensão de saberes. Essas práxis, quando vivenciadas nos processos de organização produtiva sob o princípio da autogestão, onde o conjunto de trabalhadores(as) possuem o controle dos meios de produção e a prerrogativa de decidir de modo colegiado sobre seu uso, definem-se em espaços potencializadores da emancipação política e cidadã.

A prática da autogestão consiste, também para István Mészáros, num elemento inseparável do processo educativo. Nos princípios reguladores da transição de nossa realidade social "para além do capital", como ele diz, a universalização da educação e a universalização do trabalho como atividade humana auto realizadora, tornam-se condições essenciais e necessárias.

“(...) os princípios orientadores da educação formal devem ser desatados do seu tegumento da lógica do capital, de imposição de conformidade, e em vez disso mover-se em direção a um intercâmbio ativo e efetivo com práticas educacionais mais abrangentes." (MÉSZÁROS, op.cit., p.58)

Estando a natureza educativa e o destino do trabalho vinculados aos interesses da lógica capitalista, Mészáros propõe a reestruturação de nossas condições de existência, através do próprio trabalho, com a superação da alienação no processo produtivo. Ele, evocando Marx, se utiliza do termo "produtores livremente associados" para conferir 
uma alternativa de organização e produção do trabalho a partir de uma ótica diferente de ordem metabólica social, onde a prática da autogestão adquire grande importância.

"O que está em jogo não é apenas a modificação política dos processos educacionais - que praticam e agravam o apartheid social -, mas a reprodução da estrutura de valores que contribui para perpetuar uma concepção de mundo baseada na sociedade mercantil." (MÉSZÁROS, ibid., p.11)

Nesta perspectiva de coletivização autogerida do trabalho, intelectual e manual, os processos pedagógicos se aproximam das práticas do trabalho e transformam, sobretudo através dos diálogos ${ }^{105}$, os trabalhadores em sujeitos autônomos e protagonistas das decisões desta nova circunstância.

Pensando criticamente sobre as ações realizadas pelos indivíduos e grupos sociais, entendemos melhor como estas reproduzem suas ideias, suas formas de enxergar o mundo e, seus posicionamentos dentro das esferas de correlações de forças e interesses existentes nas sociedades. Os gestos e os produtos do trabalho concreto nos mostram como as ideologias são operadas na realidade social e são apropriadas por seus grupos através, também, de processos formadores. Através das práxis percebemos como as ideologias se cristalizam nas práticas cotidianas.

Complementar às reflexões sobre o trabalho enquanto princípio educativo, a educação como trabalho social também contribui na construção de nossa linha de raciocínio. Neste sentido, a extensão universitária se torna um dos instrumentos que potencializa esta aproximação entre educação e trabalho, entre teoria e prática, entre a academia e a realidade social.

A prática da extensão universitária tem origem na concepção de universidade como detentora do saber verdadeiro que, deveria de alguma forma, ser "transferido" ou colocado à disposição da sociedade, financiadora da produção dos conhecimentos científicos. Esta concepção onde a universidade é quem "sabe" e leva os

${ }^{105}$ Faço aqui referência às práticas dialógicas trabalhadas por Paulo Freire (ver "Pedagogia do oprimido", 1970). Práticas estas que baseadas no diálogo educativo, crítico, respeitoso e curioso possibilitam ações e atividades fomentadoras de processos conscientizadores e humanos de ensino e aprendizagem. 
conhecimentos àqueles que "não sabem", consiste naquilo que José Francisco de Melo Neto (2001) chamou de "extensão como via de mão única".

Segundo Folz (op.cit., p.05), a extensão universitária assumiu diversas formas e formatos ao longo de sua existência: extensão como cursos, como serviços, como assistência, como mão dupla entre universidade e sociedade e, como extensão cidadã. Estes formatos conceituais e de ação delimitaram quatro eixos principais: o modelo da transmissão vertical do conhecimento; o voluntarismo, a ação voluntária sóciocomunitária; a ação sócio-comunitária institucional; e o acadêmico institucional.

Com o passar do tempo, as atividades de extensão passam a ser vistas como possibilidades de se realizar pesquisas que surgem a partir da descoberta da realidade, da observação dos problemas sociais. A produção do conhecimento passa pela busca por respostas aos problemas existentes e pela democratização e apropriação do conhecimento, o que também envolve a produção, a posse e a aplicação dos resultados.

Compreendendo a extensão universitária como um processo de caráter educativo, científico e cultural, passamos então a percebê-la como trabalho social, onde além das problematizações teóricas formuladas a partir da realidade concreta, são construídas respostas às necessidades dos diversos setores da sociedade, sobretudo das classes sociais mais desfavorecidas e desprovidas. Este processo possibilita a construção de um diálogo permanente, complementar e democrático na produção dos conhecimentos científicos, técnicos e populares.

Segundo José Francisco de Melo Neto (2001), a extensão seria como "um trabalho que não tem um tempo definido mas está dentro de uma perspectiva de trabalho permanente, trabalho continuado. (...) Extensão como trabalho que envolva pesquisa e um trabalho que tenha uma finalidade social bastante definida".

Este novo enfoque metodológico (enquanto instrumento de construção do conhecimento) e epistemológico (enquanto leitura da realidade) insere a extensão como necessária atividade formadora e de contribuição ao desenvolvimento social. Os trabalhos sociais frutos de sua realização são cada vez mais correntes, tanto no país quanto no exterior. Uma nova referência de desenvolvimento e produção dos 
conhecimentos começa a surgir como marco analítico a partir do aprofundamento das questões teóricas e das experimentações práticas em curso.

Serão tratados a seguir alguns exemplos que ilustram tais reflexões. De maneira nenhuma são os únicos e nem se realizam como deterministas ou como modelos perfeitos. São práxis educativas que vêm ganhando cada vez mais espaços e suscitando novas reflexões sobre os modelos vigentes de produção tecnológica e de desenvolvimento.

São exemplos que embora possuam naturezas e formatos diferenciados, o que é extremamente rico visto o largo leque de possibilidades de realização, se completam porque buscam produzir a aproximação entre a educação e o trabalho, entre o pensar e o fazer, entre a academia e a realidade social.

\section{“Grands Ateliers" de l'Isle d'Abeau, Villefontaine/França}

A primeira referência que evoco, diz respeito aos trabalhos desenvolvidos pelo "Grands Ateliers" de I'Isle d'Abeau, Villefontaine/France. Polo de experimentações e de criações, os "Grands Ateliers" servem como ferramenta e instrumento pedagógico aos estudantes, professores e pesquisadores, onde os conhecimentos e as culturas se aproximam através da pedagogia e criação. Os "Grands Ateliers" possuem como missão o ensino no senso largo do termo, desde a formação inicial, passando pela formação profissional, pesquisa, difusão e sensibilização.

Esta estrutura possui como objetivo principal viabilizar o encontro entre a formação, a pesquisa e a profissionalização; entre o pensamento e a matéria em torno do tema da construção; e entre os atores que intervém no processo construtivo. Eles possuem como missão, tornar-se um centro de produção e difusão das culturas construtivas, onde as pesquisas, os ensinamentos e os objetos produzidos poderão também se endereçar a um público mais abrangente que o acadêmico. ${ }^{106}$

\footnotetext{
${ }^{106}$ Informações retiradas do site: http://www.lesgrandsateliers.org/. (Consultado em 26/06/2014)
} 
Os "Grands Ateliers" são um Agrupamento de Interesse Público reunindo: o Ministério da Cultura e Comunicação; oito Escolas Nacionais Superiores de Arquitetura (ENSA); a Escola Nacional de Trabalhos Públicos do Estado (ENTPE); o Centro Científico e Técnico da Construção (CSTB); a rede de Escolas Superiores de Arte de Rhône-Alpes (ADERA); a Câmara da Indústria e do Comércio (CCI); a Federação Francesa de Construção (FFB); a Confederação dos Artesões e Pequenas Empresas da Construção (CAPEB) e o Polo de Inovações Construtivas (PIC).

Em 1995 foi publicado um protocolo de acordo e apresentação do projeto dos "Grands Ateliers"107. Este documento continha os seguintes objetivos:

- Entrosar as diversas disciplinas relacionadas com a construção;

- Desenvolver a formação aliando teoria e prática, o pensar e o fazer, o espírito e o gesto, a concepção e a execução;

- Desenvolver conjuntamente formação e pesquisa para assegurar a atualização permanente dos conteúdos;

- Criar condições de enriquecimento mútuo entre a atividade e as práticas experimentais de formadores-pesquisadores de um lado e as dos construtores de outro, para uma redefinição constante de necessidades em formação, pesquisa e desenvolvimento;

- Aprimorar e valorizar o ensino, a pesquisa e a experimentação sobre os materiais, considerados em todas suas diversidades: concreto, metal, vidro, pedra, madeira, terra, gesso, materiais sintéticos, etc.;

- Compartilhar os recursos entre os estabelecimentos de formação e de pesquisa, no domínio da construção;

- Experimentar uma integração formativa, mesmo que parcial, entre os profissionais da arquitetura, engenharia e artes.

Tais objetivos foram agrupados posteriormente em ${ }^{108}$ :

- Encontrar - Encontro entre os atores que intervém na construção, desde a aplicação dos materiais até o espaço construído: aproximando conhecimentos historicamente afastados

\footnotetext{
${ }^{107}$ Ver : "Architecture \& Cultures Constructives - pôle d'enseignement de la construction. L'évidence d'un grand projet, 1995, Paris. Protocolo de acordo e apresentação do projeto dos "Grands Ateliers".

108 Informações retiradas do site: http://www.lesgrandsateliers.org/. (Consultado em 26/06/2014)
} 
do gerenciamento de projetos em conjunto: que são a arte, a arquitetura, a engenharia e o design.

- Aproximar - Encontro entre a formação, a pesquisa e as profissões: aproximar pedagogia e pesquisa, universidade e indústria, desenvolvendo a complementaridade entre os conhecimentos das diferentes áreas: arte, arquitetura e engenharia.

- Realizar - Encontros entre o pensar e o realizar em torno das questões referentes a construção: utilização dos materiais, realização das formas, criação e inovação trabalhando com a realidade concreta (materiais e técnicas), construção de estrutura e espaços, confrontação de abordagens.
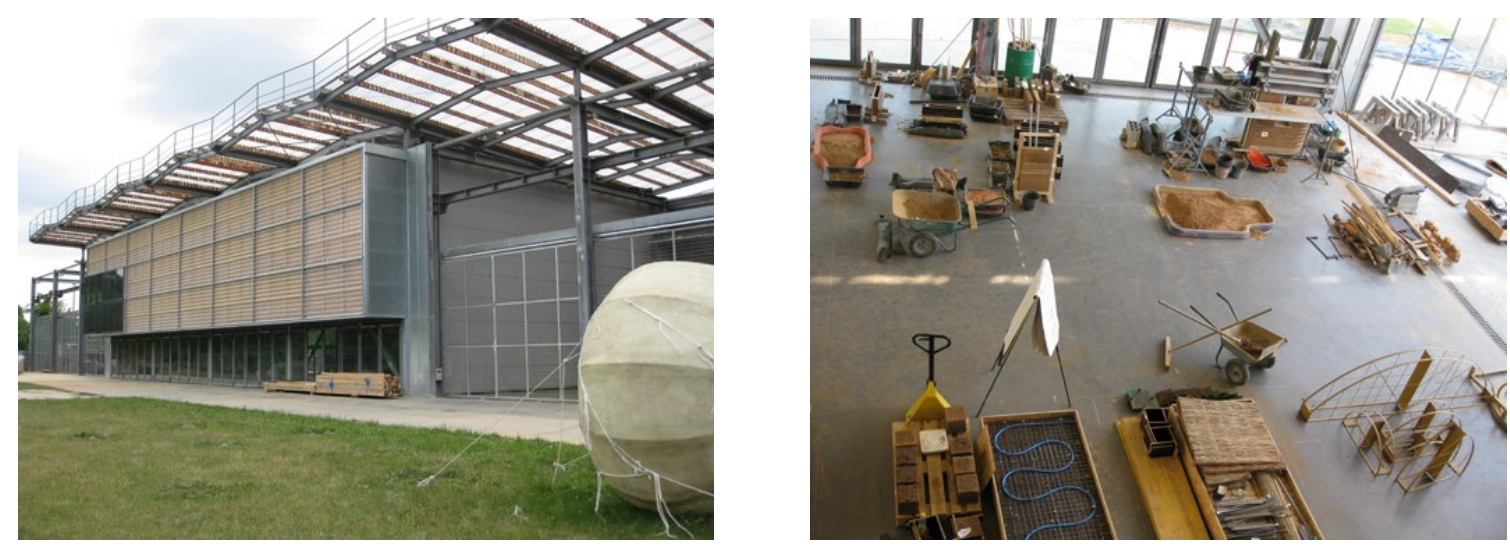

Fotos 24 e 25 - Vistas geral e interna dos “Grands Ateliers”, 2010. Fotos Thiago Lopes Ferreira.
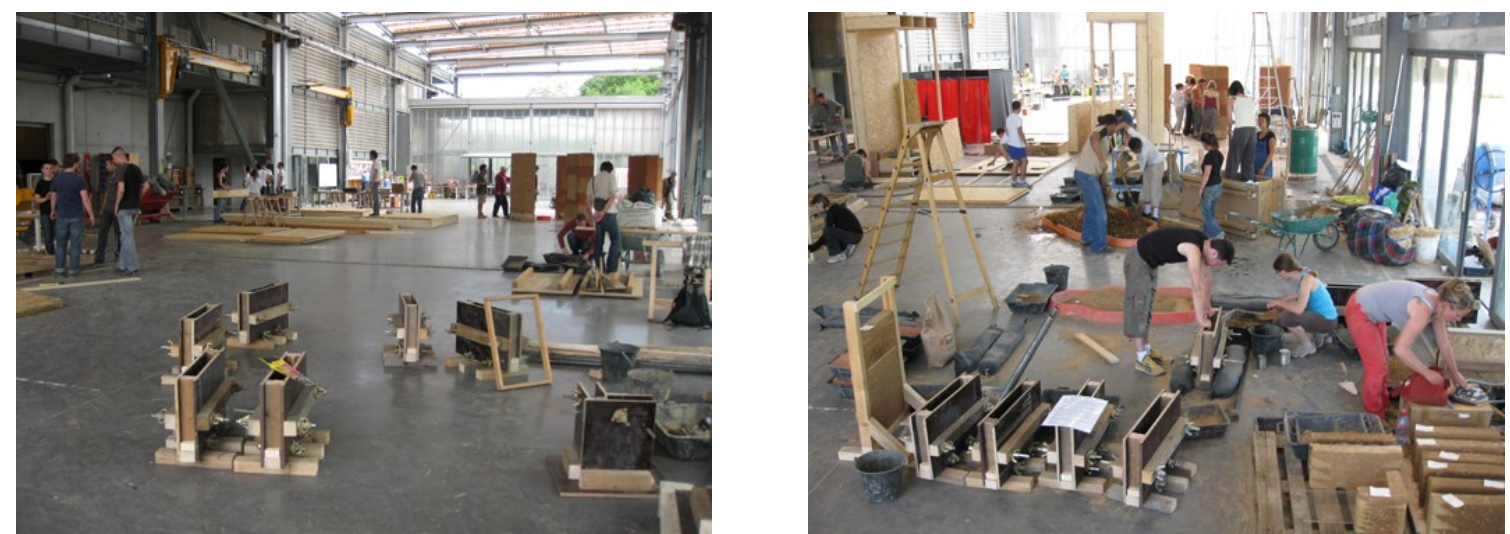

Fotos 26 e 27 - Atividades pedagógicas sobre sistemas construtivos com terra, "Grands Ateliers", 2010. Fotos Thiago Lopes Ferreira.

Desta forma, os "Grands Ateliers" pretendem ser experimentais e inovadores em cada uma de suas missões, propondo uma pedagogia ativa que relaciona a concepção e a matéria, criando novas práticas de pesquisa, utilizando novas técnicas de comunicação para a difusão das culturas construtivas. 


\section{Canteiro Experimental}

A evolução das reflexões críticas sobre um novo modo de produção do espaço gerou iniciativas que buscaram criar novas experiências, apontando para o desenvolvimento de outros tipos de relações sociais possíveis nos processos produtivos dos canteiros de obras.

As atividades dos "Canteiros Experimentais" também fazem parte do bojo de referências das práxis educativas. Refiro-me a uma série de análises teóricas e ações práticas que vem sendo desenvolvidas nas últimas décadas, com a implementação de espaços chamados "Canteiros Experimentais" dentro das faculdades de Arquitetura e Urbanismo no Brasil. Elas envolvem professores e pesquisadores dedicados a criar melhores condições para o contato dos alunos com as realidades dos canteiros de obras, constituindo espaços propícios a uma apropriação crítica dos saberes que envolvem projeto e obra em sua totalidade, possibilitando a análise dos processos e dos métodos durante o próprio exercício construtivo.

Nestes espaços, a formação e qualificação não são questões que se referem unicamente ao indivíduo, mas ao coletivo, o que torna imprescindível a habilidade de atuar em conjunto e enfatizar o trabalho em equipe. Maior autonomia, polivalência, novas responsabilidades, são variáveis trabalhadas neste processo construtivo. Existe, na prática diária do canteiro experimental, o contato simultâneo de todo o conjunto de partes que compõem o exercício da construção.

"Todos estes processos de criação, experimentação, constatação $e$ modificação (aperfeiçoamento) agregam ao sistema aberto e não linear de se construir, uma dimensão ainda mais abrangente e mais rica de elementos, permeada pelas condições particulares do espaço de obra." (RONCONI, 2002)

Reginaldo Ronconi (2008) observa que os espaços dos canteiros experimentais tornam-se locais adequados para a produção dos conhecimentos e aprendizagens, possibilitando a criação e o desenvolvimento intelectual e manual dos estudantes. Nestes 
espaços são fomentadas as análises críticas dos acertos e erros, das decisões e escolhas, através de práticas socialmente integradas, responsáveis e mais emancipadas.

Ali, são dadas ênfases aos processos socializadores decorrentes da educação no seu sentido mais amplo, potencializando a ampliação do conhecimento abstrato e o cumprimento de funções de raciocínio lógico, bem como um sistema de produção baseado na força de trabalho mais cooperativa, comunicativa, com maior autonomia, e identificação com o processo de trabalho. As ações criadoras e, sobretudo, as de caráter transformador passam a ser estimuladas neste processo de aprender a aprender.

Assim, o canteiro experimental se diferencia do canteiro de obras convencional. No novo espaço de trabalho, a produção e a apropriação do conhecimento passa a ser a base do método pedagógico adotado e praticado. A reflexão crítica confere resistência às práticas opressoras e exploratórias do trabalho. O "saber" e o "fazer" buscam a reaproximação em sua práxis educativa, restituindo a produção crítica e disputando espaços nas transformações da realidade.

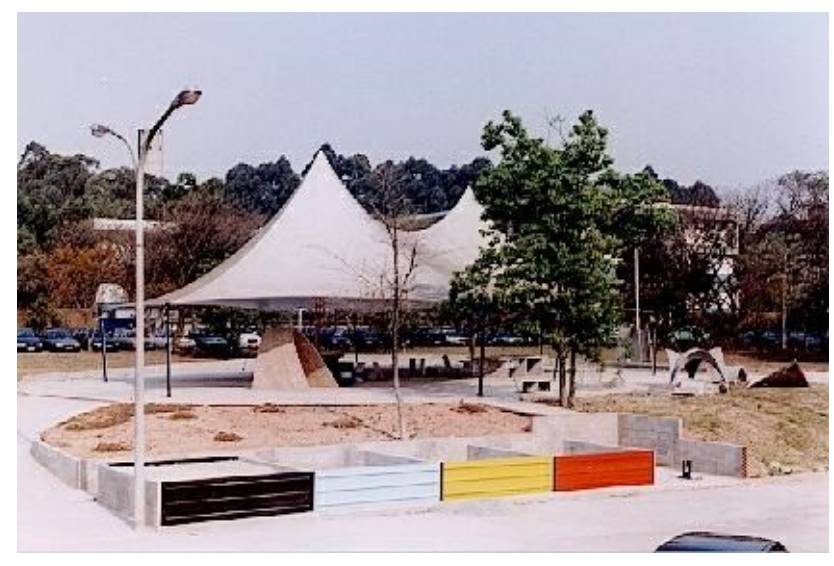

Foto 28 - Vista do Canteiro Experimental da Faculdade de Arquitetura e Urbanismo/USP, 1999.109

Este desafio de superação da ordem de produção estabelecida passa, segundo Pedro Arantes (2008), pelo exercício do "estranhamento" da divisão social do trabalho (sobretudo entre trabalho intelectual e manual). São, inclusive, nas relações sociais

${ }^{109}$ Fonte: http://www.fau.usp.br/cante/index.html. (Consultado em 26/06/2014) 
construídas através dos diálogos e ações coletivas que arquitetos e operários superarão o caráter heterônomo do canteiro de obras.

Para isso o canteiro tem de ser democratizado, tanto em seu processo quanto em seu acesso. Ele deve ser espaço de aprendizado para estudantes e pesquisadores, mas também para trabalhadores da construção civil: pedreiros, encanadores, eletricistas, carpinteiros, entre tantos outros. "A experiência do Canteiro não pode ser reduzida a "experimentalismo" de classe média, (...) trata-se justamente de se contrapor à privatização do saber, a favor do uso público do conhecimento, para esclarecer novas técnicas e processos de trabalho e, ao mesmo tempo, colaborar para solucionar problemas que afligem a maioria da população." (ARANTES, op.cit., p.30)

Ainda segundo Fiori, o canteiro experimental surge com a tarefa de disputar o sentido do ensino e the restituir a possibilidade de práxis crítica e transformadora. " $O$ esforço de interpretação, por um novo ângulo, da história e das manifestações contemporâneas, bem como a constituição de um marco teórico próprio, com a delimitação de seu campo, são tarefas necessárias para estabelecer um movimento dialético interno ao Canteiro." (ARANTES, op.cit., p.32)

\section{Canteiro-Formação}

Outras referências que alimentam nossas reflexões relativas aos formatos e métodos de trabalho utilizados nos canteiros de caráter pedagógicos, são os projetos de "canteiro-formação" desenvolvidos pela Associação CRAterre, ligada ao laboratório CRAterre, situado na Escola Nacional Superior de Arquitetura de Grenoble ENSAG/França.

Existente há mais de 30 anos, este grupo de pesquisadores e técnicos desenvolve projetos em todos os continentes, através de parcerias com governos locais, instituições públicas, privadas, associações, organizações, etc. Coordena a cátedra UNESCO "Arquiteturas de terra", com quem trabalha tanto nas questões ligadas ao habitat, quanto naquelas relacionadas à proteção do patrimônio cultural. Tais projetos são geralmente 
articulados com a realização de programas de formação de mão de obra profissionalizante e sensibilização das populações locais.

Exponho rapidamente um exemplo de projeto desenvolvido pelo CRAterre no âmbito da formação profissional com o objetivo de melhorar as condições habitacionais existentes em localidades específicas. Como participante deste projeto, elenco algumas características principais com o intuito de ilustrar melhor minhas reflexões. ${ }^{110}$

O projeto intitulado "Melhoria do habitat e prevenção de catástrofes naturais no campo de refugiados Saharauis" foi realizado através da parceria entre a Associação CRAterre e a organização OXFAM/Solidariedade da Bélgica, durante o ano de 2009-2010, dentro do campo de refugiados Saharauis, no sul da Argélia. Financiado pela Comissão Europeia ECHO (European Community Humanitarian aid Office), teve como principal atividade a constituição de um canteiro de formação profissional no qual foram construídas três edificações com técnicas construtivas em terra.

O objetivo geral do projeto era melhorar as qualidades das casas de adobes existentes, reduzindo a vulnerabilidade da população local face às intempéries climáticas, através da difusão e da aplicação de técnicas construtivas baseadas nos conhecimentos, ferramentas e recursos disponíveis localmente.

A estratégia principal constituiu-se num programa de formação de mão de obra local em técnicas de construção com terra (adobes estabilizados e sistemas de coberturas em cúpulas e abóbodas), e técnicas de reabilitação do habitat existente.

Em 2009-2010, foram formados 19 trabalhadores em técnicas construtivas com terra e 10 trabalhadores nas técnicas de arcos, abóbodas e cúpulas com adobes. Este processo resultou na construção de três edificações em 10 semanas de trabalho.

Complementarmente, foram construídas seis outras edificações nos seis bairros existentes no local, onde alguns trabalhadores formados anteriormente transformaramse em formadores de novos trabalhadores em seus bairros de residência. Esta atividade serviu para qualificar e validar o aprendizado dos primeiros formados, formar novos

\footnotetext{
${ }^{110}$ As análises de tal projeto podem ser vistas no trabalho intitulado: "Canteiro-formação e melhorias do habitat nos campos de refugiados Saharauis", de Anaïs Guéguen Perrin e Thiago Ferreira, 2010.
} 
trabalhadores aumentando assim a rede de profissionais qualificados, sensibilizar a população local através da demonstração das melhorias realizadas no habitat local, além de repertoriar a continuidade dos trabalhos e a localização dos trabalhadores outrora formados à disposição da população, por região de residência.

Foram ainda realizados controles e validações das competências desenvolvidas; seções de sensibilização junto à população local; desenvolvimento e difusão de uma "maleta pedagógica" contendo as técnicas utilizadas; disponibilização para o governo local dos kits de materiais e seus projetos, necessários para a construção de cúpulas e abóbodas; avaliação de projetos realizados em anos anteriores ao nosso; entre outras atividades.
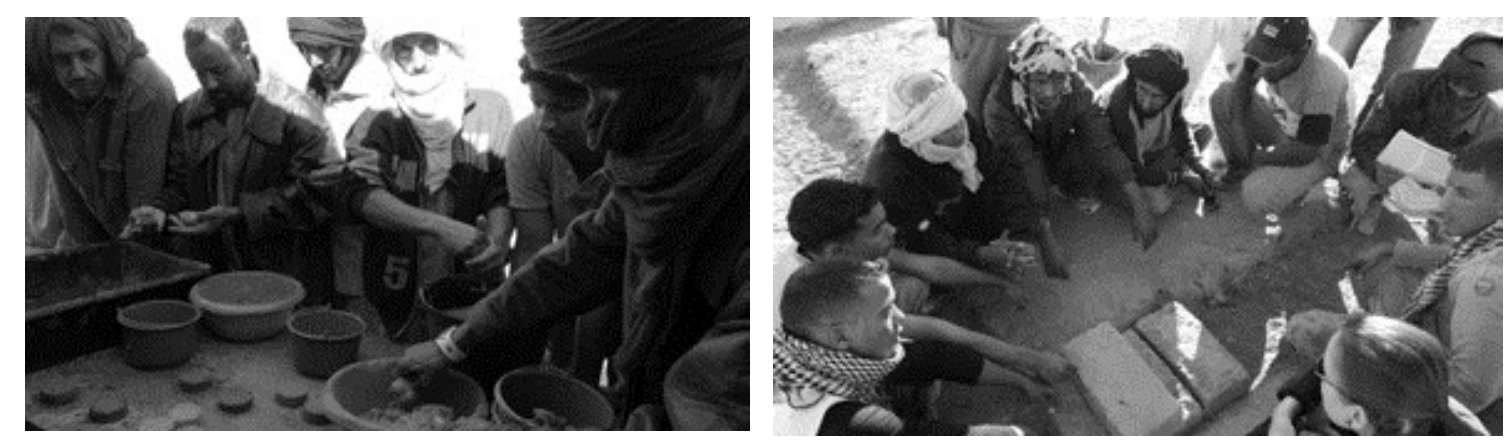

Fotos 29 e 30 - Atividades pedagógicas do Canteiro-formação, Tindouf/Argélia, 2009. Fotos Thiago Lopes Ferreira.
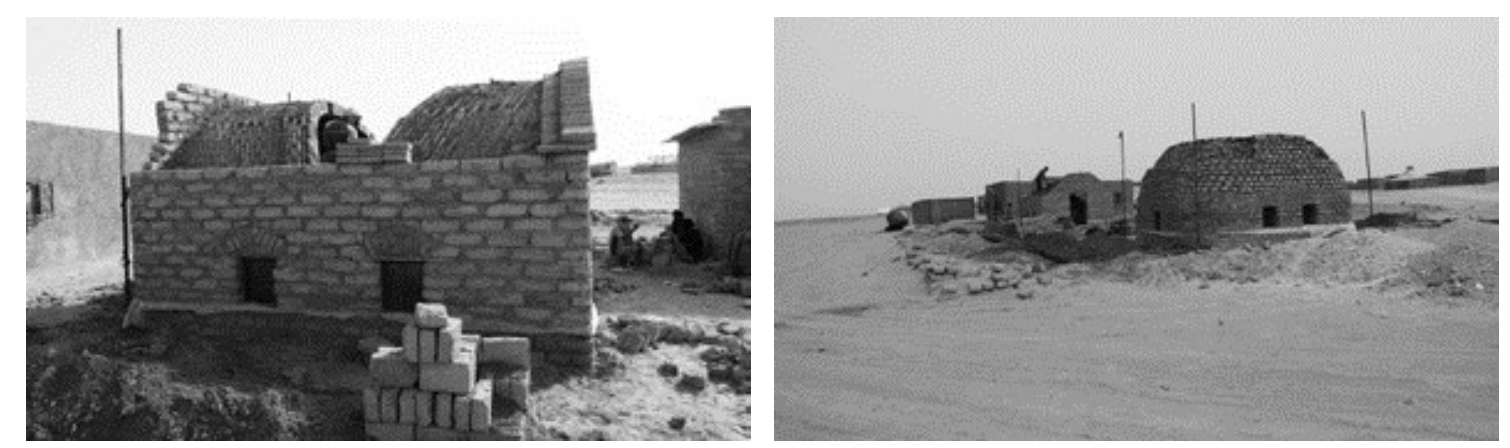

Fotos 31 e 32 - Atividades construtivas do Canteiro-formação, Tindouf/Argélia, 2010. Fotos Thiago Lopes Ferreira.

Este tipo de canteiro-formação é diferenciado do canteiro experimental citado anteriormente pelas suas condições de existência. De caráter profissionalizante, o canteiro-formação se realiza dentro da realidade social, na construção de edificações, através da formação local de jovens profissionais da construção civil. 
O fato do canteiro ter-se realizado dentro de um campo de refugiados, onde a economia se faz de maneira informal há quase 40 anos, acentuado pelas dificuldades extremas vividas pela população Saharauis, evidencia o caráter democrático de se propiciar acesso aos programas de formação profissional na construção civil, condizentes com as condições sociais, culturais, econômicas, políticas e ambientais do território em questão.

A orientação metodológica converge para o estímulo a processos produtivos que apoiando-se em técnicas e sistemas construtivos locais, valorizem as culturas populares; facilitem o acesso aos mais desprovidos de condições estruturais e financeiras; democratizem e coletivizem a produção e o aprendizado dos processos construtivos; melhorando as condições habitacionais do grupo social em questão.

\section{Canteiro-Escola}

Ainda dentro das possibilidades metodológicas e de formatos possíveis a serem implementados na constituição de espaços pedagógicos dentro dos canteiros de produção, menciono a seguir as experiências do programa de "Canteiro-Escola" desenvolvidos sob a coordenação do grupo de pesquisa HABIS/IAU/USP.

O grupo HABIS possui como estratégia de atuação o tripé: pesquisa, ação na realidade social e aprendizagem. Na pesquisa, a produção de conhecimentos está diretamente relacionada com a realidade social, envolvendo diferentes áreas das ciências sociais e tecnológicas. A ação, na realidade, constitui justamente na inserção das pesquisas desenvolvidas pelo grupo dentro de uma conjuntura concreta específica, com o envolvimento direto dos pesquisadores com os grupos sociais em questão. Esta condição implica num processo de trabalho dinâmico, cujo objetivo é contribuir para o desenvolvimento de ações que beneficiem direta e positivamente a população com a qual se trabalha. A aprendizagem envolve os processos pedagógicos e conscientizadores dos diversos sujeitos envolvidos, como estudantes de diferentes níveis e áreas, profissionais, pesquisadores e a população usuária. Este processo se faz a partir da troca de conhecimentos, no embate com uma determinada realidade, e no desejo de buscar 
conjuntamente soluções para as questões que surgem, a partir da compreensão desta realidade.

A primeira experiência realizada dentro do quadro do Canteiro-Escola, ocorreu em 2008, numa parceria entre o grupo de pesquisa HABIS e a organização não-governamental TEIA - Casa de Criação. Esta parceria resultou na criação do curso de Difusão "Canteiro-Escola: formação complementar em Arquitetura e Construção", dirigido aos estudantes de graduação em Arquitetura e Urbanismo e Engenharia Civil (15 vagas), bem como aos trabalhadores da Construção Civil (também 15 vagas), mobilizados através da Prefeitura Municipal de São Carlos e de seu Balcão de Empregos. O Curso foi realizado ao longo de 11 semanas somando 122 horas-aula, alternando suas atividades entre a sala de aula, com conteúdos mais teóricos, e o canteiro de obras. ${ }^{111}$

O objetivo central foi reunir, no mesmo ambiente didático, os conhecimentos sistematizados, próprios do ambiente acadêmico - e, de certo modo, mais familiares aos estudantes de graduação -, e os conhecimentos práticos, próprios do canteiro de obras, muito mais consolidados como de domínio dos profissionais da Construção Civil.
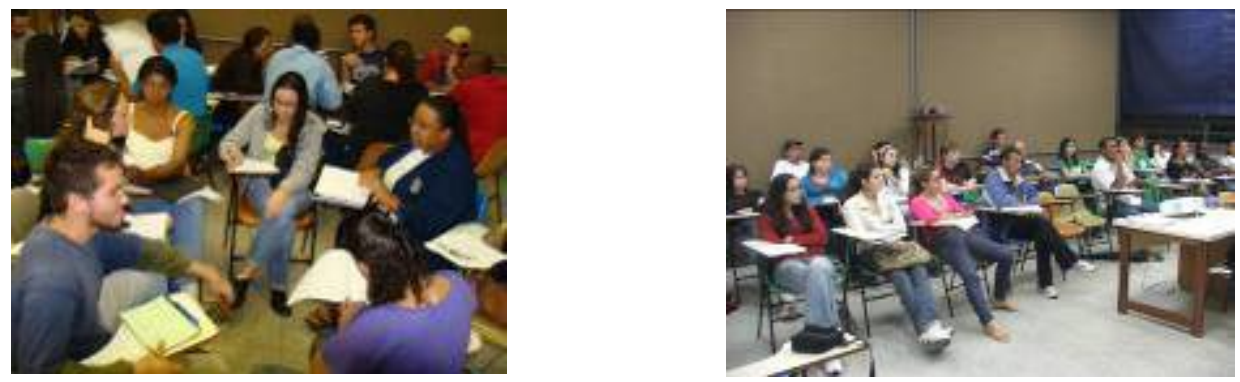

Fotos 33 e 34 - Atividades pedagógicas teóricas relacionadas à construção civil, $2008{ }^{112}$
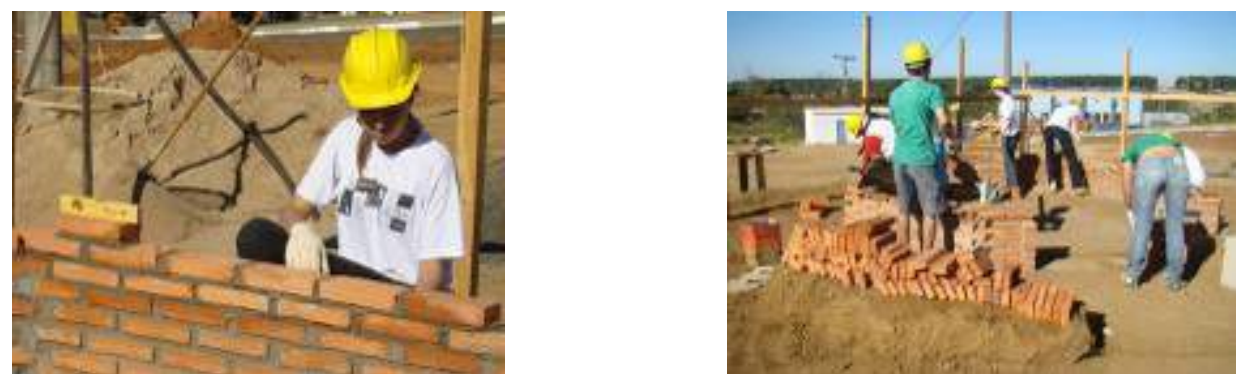

Fotos 35 e 36 - Atividades pedagógicas práticas do canteiro de obras, $2008 .{ }^{113}$

\footnotetext{
111 Informações obtidas do grupo HABIS: “Projeto Escola de Construção - IAU/USP: formação profissional, produtos e processos inovadores, Edital 2012-2013, Ampliação e Melhoramento da Infraestrutura de Pesquisa - INFRA-USP, Pró-Reitoria de Pesquisa, Universidade de São Paulo, 2013."

112 Fonte: Ibid., 2013.
} 
Em 2011, o HABIS promoveu uma segunda edição desta atividade, porém agora no formato de um "workshop", ministrado pelo arquiteto mexicano Ramón Aguirre, especialista na construção de uma modalidade de abóbadas sem utilização de escoramentos (formas). Novamente, foi propiciada e incentivada a participação de profissionais da construção civil, juntamente com estudantes de graduação, tanto do Curso de Arquitetura e Urbanismo do IAU-USP, como também da Universidade Central Paulista - UNICEP. Nesta oportunidade, foi possível confirmar o potencial didático propiciado pela convivência entre estudantes e trabalhadores da construção civil num mesmo processo de ensino-aprendizagem. ${ }^{114}$
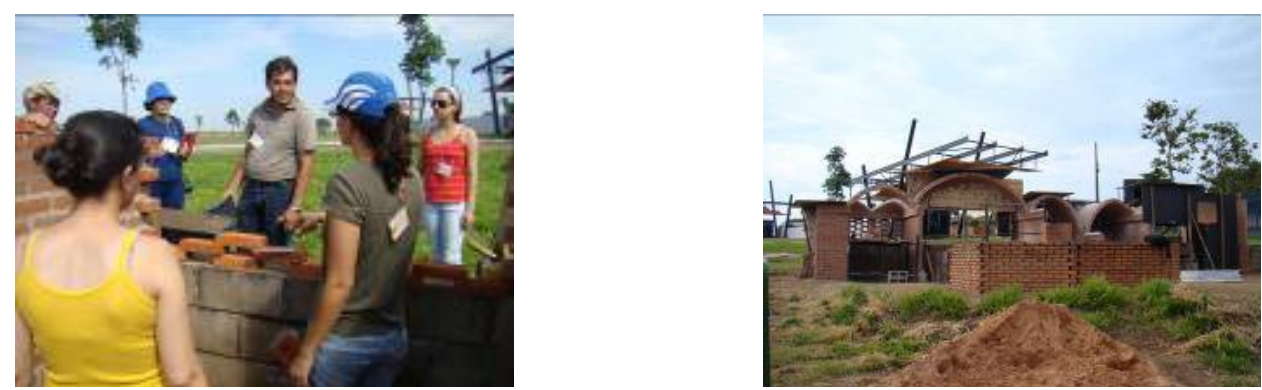

Fotos 37 e 38 - Atividades práticas do Canteiro-Escola, 2011. ${ }^{115}$
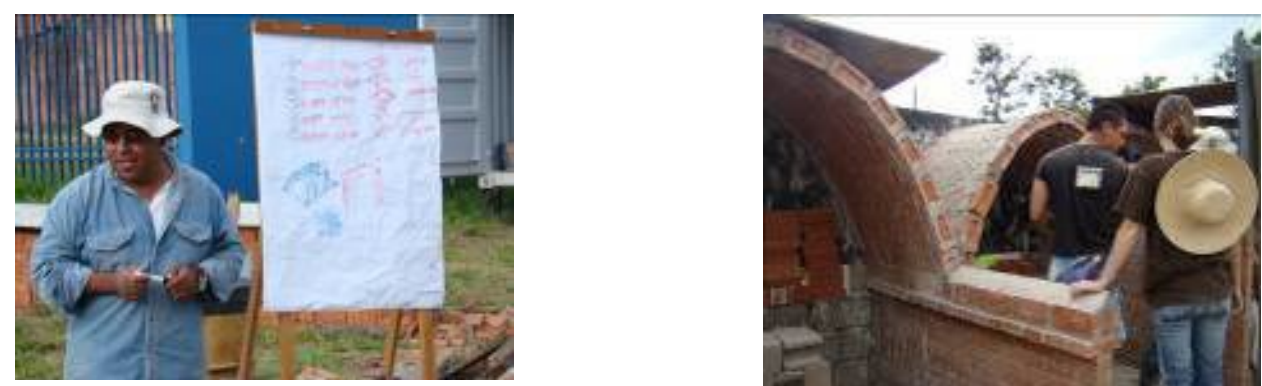

Fotos 39 e 40 - Atividades teórico-práticas do canteiro de abóbodas, $2011 .^{116}$

Mais uma vez, a ideia central era a aproximação entre os estudantes e os trabalhadores da construção civil dentro do mesmo processo pedagógico, onde a produção do conhecimento teórico se faz concomitantemente com a produção dos conhecimentos práticos. "Não adianta a universidade produzir processos e sistemas inovadores para aplicação na construção civil ou mesmo propagar tal conhecimento

\footnotetext{
${ }^{113}$ Fonte: Ibid., 2013.

114 Fonte: Ibid., 2013.

115 Fonte: Ibid., 2013.

116 Fonte: Ibid., 2013.
} 
apenas através da indústria e do mercado, se no outro extremo não há profissionais habilitados, capacitados e formados para lidar com eles." (HABIS, 2013, p.06)

A terceira edição do "Canteiro-Escola" foi realizada em 2013, dentro do mesmo formato de "workshop" através de um curso de Difusão em Cultura e Extensão do Instituto de Arquitetura e Urbanismo-IAU, da Universidade de São Paulo-USP. O curso teve como tema a "Taipa de mão japonesa - "Tsuchikabe" e seu processo produtivo. As oficinas foram centradas no aprendizado das técnicas de carpintaria, uso do bambu e uso da terra, todos vinculados à técnica construtiva proposta.

Através de uma cooperação entre a Universidade de São Paulo, a Fundação Japão - organização vinculada ao Ministério das Relações Exteriores do Japão - e a Tajima Techinical University, do Japão, um grupo de professores japoneses, mestres na técnica do Tsuchikabe e coordenados por Kinzo Nakao, estiveram em São Carlos / Brasil para ministrar as atividades desse Canteiro-Escola.

As oficinas consistiram na produção de diversos painéis de parede em taipa japonesa, demonstrando as várias etapas do processo construtivo deste sistema, passando pelas montagens das estruturas de madeira dos painéis, preparação dos bambus e fixação nos painéis, preparação das diferentes terras a serem utilizadas, aplicação da primeira e segunda camada de terra nos painéis, aplicação do revestimento final, entre outras atividades.

Participaram 20 estudantes do curso de arquitetura e urbanismo e de cursos afins e 10 pessoas externas à comunidade acadêmica. De forma complementar, o curso serviu como mecanismo sensibilizador da comunidade local com relação ao legado arquitetônico de grande valor técnico, histórico e cultural presente nas habitações existentes nas comunidades japonesas espalhadas pelo Brasil.

"Desvendar os processos singulares aplicados nestas edificações pode contribuir para sua preservação, para demonstrar a possibilidade de construir edificações duráveis e saudáveis utilizando terra no Brasil e, por fim, trazer o conhecimento atrelado às questões ambientais da sustentabilidade." (Akemi Hijioka, 2013) 

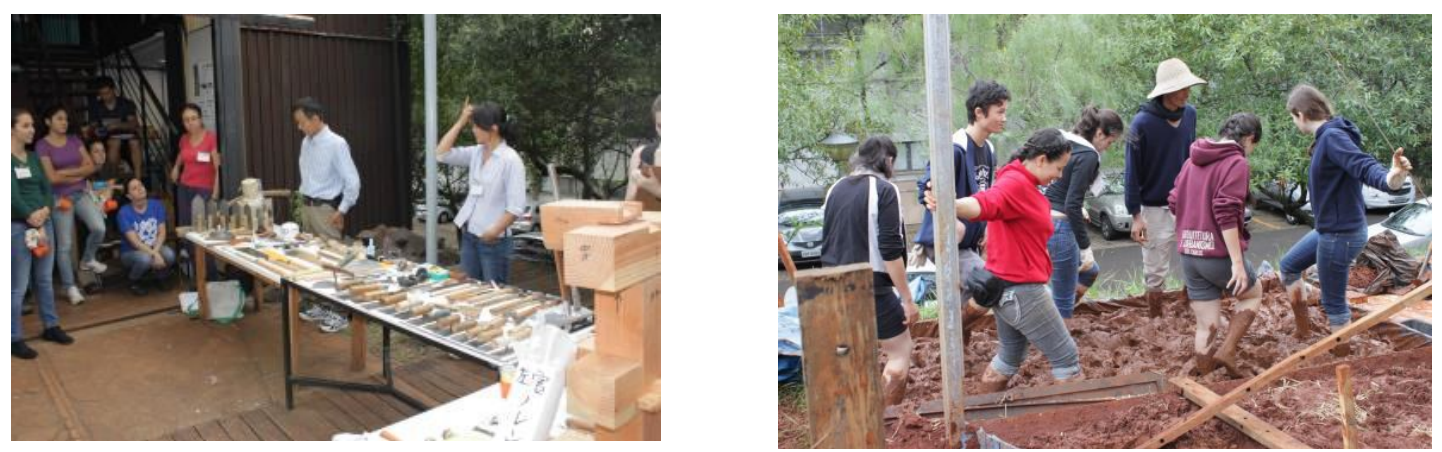

Fotos 41 e 42 - Atividades teórico-práticas do Canteiro-Escola de taipa japonesa, 2013. ${ }^{117}$
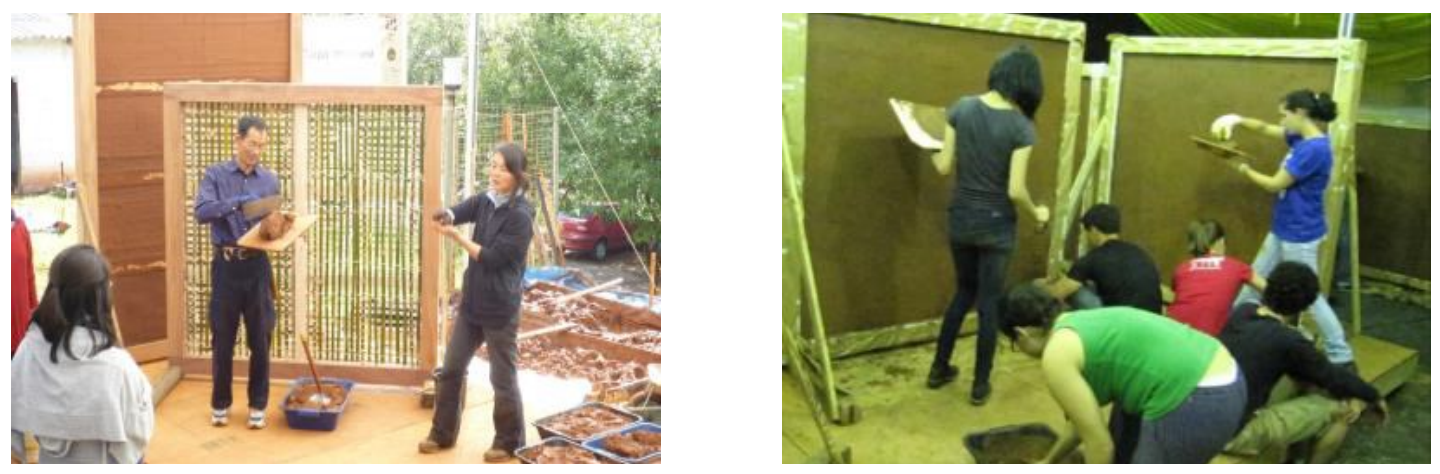

Fotos 43 e 44 - Produção dos painéis de taipa japonesa, 2013. ${ }^{118}$

A quarta edição do Canteiro-Escola iniciou suas atividades em agosto de 2013, como continuidade de um curso optativo de graduação do Instituto de Arquitetura e Urbanismo de São Carlos. O curso intitulado: “Canteiro-Escola: Produzindo uma habitação com técnicas em madeira e terra" é o objeto de análise detalhada deste trabalho de pesquisa, e consistirá no conteúdo de seu Momento 4.

\section{Ensaios e compreensões 3}

"Ao mesmo tempo em que estamos impedidos de relacionar democraticamente pessoas que idealizam com pessoas que executam para decisão do futuro a ser construído, resultado do privilégio da formação de classe, estamos também impedidos de avançar sobre a criação da beleza plástica das coisas." (BARROS, 2008)

\footnotetext{
${ }^{117}$ Fonte: Akemi Hijioka, Canteiro Escola: Taipa Japonesa, Relatório Final de bolsa de pesquisa, Pró-Reitoria de Cultura e Extensão Universitária, Instituto de Arquitetura e Urbanismo IAU, 2013.

118 Fonte: Ibid.
} 
Sendo a arquitetura, em sua essência primeira, produto e instrumento de coesão social, as responsabilidades associadas aos seus potenciais de transformação territorial e de condicionamento do espaço, são anteriores ao seu valor adquirido enquanto técnica construtiva. Dentro de uma perspectiva de reconexão do habitat com seus elementos territoriais, culturais, ambientais e políticos, torna-se essencial reintroduzir em sua produção, mecanismos que estimulem dimensões pouco a pouco sufocadas pelo funcionalismo racional, moderno e capitalista.

As dimensões da experimentação, educação, conscientização, criação, autonomia, socialização, coletivização, expressão, emancipação, dentre outras, são condições existenciais para além da produção do habitat. São as bases para o reapoderamento da técnica pelos trabalhadores, pela reapropriação das tecnologias por eles produzidas e, pela reaproximação do trabalho com seus princípios educativos e culturais. São condições para a produção autônoma das próximas expressões das culturas construtivas localizadas.

O cenário tratado neste Momento do trabalho indicou uma série de experiências que ocupam cada vez mais espaços nas produções das tecnologias e das práxis educacionais. Nos mostram também tendências de possíveis transformações, embora ainda em estágios embrionários e dependentes de esforços localizados e oriundos de certos grupos de pesquisa, de organizações não governamentais, de associações comunitárias, de cooperativas locais, de movimentos sociais, entre outros.

Todavia, precisamos ficar atentos para não nos confundirmos com as múltiplas facetas que o capital adquire em tempos atuais. As discussões sobre as arquiteturas ecológicas, as ecovilas, os urbanismos verdes, entre outros tantos, raramente permeiam as dimensões que vão para além dos debates técnicos e ambientais. Em grande parte não discutem outros modelos de produção, outros projetos de sociedade, outras relações de trabalho, outra produção científica, etc. Não será pintando de verde velhos programas que potencializaremos a autonomia criativa do trabalho social autogerido, condição primeira para uma expressão completa e localizada do habitat em seu sentido essencial: de um processo social inserido em seu tempo, espaço, sentido e significado.

"O recurso às "culturas construtivas" permite pretender a arquitetura, em geral a produção arquitetônica mobilizando os recursos territoriais $e$ 
fazendo as escolhas esclarecidas quanto aos impactos sociais, econômicos e culturais à todos os estágios do ciclo de vida da construção. Ele permite conter certos efeitos perversos de uma mundialização culturalmente alienante." (AE\&CC, 2014, p. 02)

Evidentemente, nos potenciais de transformação residem boa parte das disputas de classe e de modelos de sociedade, justamente por serem os potenciais, os espaços onde encontramos as utopias, as idealizações, os sonhos, mas também as ganâncias, os fantasmas e os medos. Neste campo de lutas sociais, o trabalho é a atividade da produção humana que em seu princípio educativo nos fazem diferentes, complementares, diversificados, únicos e sociais.

Segundo Mészáros (op.cit.), a transformação social emancipadora é inconcebível sem uma concreta e ativa contribuição da educação no seu sentido amplo. Assim, evidencia-se a necessidade ao estímulo de nossas capacidades de mobilizar, reatualizar e reinventar nossas práxis educativas e nossos processos de produção tecnológica.

A dualidade estrutural do sistema educativo no modo de produção capitalista ${ }^{119}$, reduz a dimensão educacional aos interesses de classe, explicitando a divisão entre os que concebem e controlam os processos de produção e os que os executam.

Neste contexto, os projetos de extensão podem assumir uma perspectiva crítica e transformadora na possibilidade de se pensar extensão como trabalho social. As práticas educacionais são assim orientadas às dinâmicas produtivas que estimulem a aproximação das atividades do trabalho com os processos de formação.

As tecnologias sociais enquanto processos produtivos não mercadológicos ou especulativos, e adequados às dinâmicas localizadas acenam para um cenário possível de transformação do processo produtivo do habitat, ensaiando novas formas e modos de morar, e nos orientando para novas expressões de produção das arquiteturas vernáculas contemporâneas e posteriormente, culturas construtivas contemporâneas localizadas.

\footnotetext{
${ }^{119}$ Faço referência à dicotomia histórica entre os estudos de natureza teórica (escola de formação das elites) e os estudos de natureza prática (escola de formação do proletariado). Assim, dois campos educacionais ganham espaço: os da formação científico-acadêmica e os da formação técnica e profissional.
} 


\section{MOMENTO 4}

\section{CASA SUINDARA: PRODUÇÃO E FORMAÇÃO EM UMA EXPERIMENTAÇÃO DIALÉTICA}

"Quando o ofício é pautado pela autonomia, criatividade e consciência, o trabalho se aproxima da arte, revelando em seus gestos mais livres as belezas ocultas da natureza humana." 


\section{O palco e seu quadro histórico}

"Dos campos, das cidades, das frentes dos palácios, os sem-terra, este povo de beira de quase tudo, retiram suas lições de semente e história. Assim, espremidos nessa espécie de geografia perdida que sobra entre as estradas, que é por onde passam os que têm para onde ir, e as cercas, que é onde estão os que têm onde estar, os sem-terra sabem o que fazer: plantam. E plantam porque sabem que terão apenas o almoço que puderem colher, como sabem que terão apenas o país que puderem conquistar." (Trecho do filme "O canto da terra", de Paulo Rufino, 1991)

Antes de iniciarmos as análises do processo de produção da casa Suindara, farei uma breve contextualização em torno do quadro histórico tratado e suas conjunturas manifestadas em nossas atividades. Isso inclui algumas reflexões acerca do "mundo rural" brasileiro e suas novas "ruralidades", englobando questões referentes ao habitat popular rural e sua produção.

Conforme os dados do Censo $2010^{120}$, o Brasil possui 190.755.799 de habitantes, sendo que $84,36 \%$ desta população vive em áreas urbanas. Assim sendo, nas áreas rurais vivem $15,64 \%$ da população brasileira. Conforme estas estatísticas, a região sudeste do país concentra 80.364 .410 de habitantes, sendo que $92,95 \%$ desta população vivem em áreas urbanas.

Ainda conforme o estudo, $43 \%$ da população rural do país vivem em municípios com menos de 20 mil pessoas, número que desobriga os governos locais a elaborarem e seguirem um plano diretor de ordenamento das cidades, de acordo com a Lei Federal Estatuto da Cidade (Lei $\mathrm{n}^{\circ}$ 10.257/2001). Sem possuírem um planejamento estratégico de desenvolvimento, estas cidades passam a contar como população urbana todas as pessoas que possuem residências dentro dos perímetros urbanos dos municípios, sem considerar a natureza de suas atividades produtivas e econômicas. Os municípios com

\footnotetext{
120 O censo ou recenseamento demográfico é um estudo estatístico, realizado a cada dez anos pelo Instituto Brasileiro de Geografia e Estatística (IBGE). Através dele, reúnem-se diversas informações sobre toda a população brasileira e os resultados são usados pelo governo no desenvolvimento de políticas públicas e na destinação dos fundos governamentais para os estados da Federação. Servem, também, como importantes subsídios as pesquisas socioeconômicas.
} 
população inferior a 20 mil pessoas representam cerca de $70 \%$ do total dos municípios brasileiros, sendo que suas superfícies territoriais, somadas, correspondem à metade do território nacional.

Estes dados são explorados e colocados em evidência por Alexandre Valadares (2014, p.17) que nos chama a atenção para o fato da regra oficial definir as áreas urbanas e rurais a partir de premissas discutíveis, na medida em que as classificações delas nem sempre refletem as características espaciais e demográficas das áreas a que se referem. Segundo Valadares (Ibid., p.32), se conjugássemos, no método estatístico, os critérios referentes ao número absoluto de habitantes, à densidade populacional e à natureza da ocupação de trabalho das pessoas, a população rural constituiria cerca de 43,1 milhões de pessoas (22,6\% do total), ao invés dos cerca de 29,8 milhões contabilizados pelo Censo 2010, ou seja, quase 14 milhões de pessoas a mais.

Minha intenção aqui é mostrar que longe de haver uma compreensão clara, completa e resolvida com relação aos conceitos de urbano e rural, e de existir um consenso sobre os métodos estatísticos mais eficazes e eficientes de trabalhar e expor os dados que representam o universo populacional brasileiro, inseridos em suas múltiplas particularidades, existem divergências, dúvidas e diferenças que são cada vez mais discutidas e que reafirmam a dualidade rural/urbana dentro das dinâmicas contemporâneas das sociedades, em especial da sociedade brasileira.

É bastante vasta a literatura existente sobre os temas correlatos ao mundo rural brasileiro ${ }^{121}$. Abordagens críticas e aprofundadas vem ganhando cada vez mais espaço nas produções acadêmicas, nas mais variadas áreas. Passando pela formação e consolidação do latifúndio no país; pelos processos de exploração da natureza e capitalização de seus recursos; pelas relações e organização social do trabalho; pela produção industrial e tecnológica; pelo surgimento dos sindicatos e dos movimentos sociais rurais; pela segurança alimentar e direitos humanos; pelas culturas camponesas e patrimônios culturais, entre tantos outros, múltiplas são as possibilidades existentes de análises de um dos países com maior concentração de terras do mundo, imensos

\footnotetext{
${ }^{121}$ Ver autores como: CARDOSO (1980), GUIMARÃES (1963), MARTINS (1975), PRADO JR. (1981), STEDILE (2005), MEDEIROS (1989), ABRAMOVAY (1992), DELGADO (1985), entre outros.
} 
latifúndios ${ }^{122}$ com raízes históricas, remontando ao início da ocupação portuguesa no século XVI.

Evidentemente, em consequência às formas de ocupação e exploração empregadas pelos diversos colonizadores e exploradores ao longo dos séculos subsequentes, as raízes estruturais das desigualdades sociais fortaleceram-se nos processos crescentes de concentração de terras, e revelaram-se nas mais diversificadas formas de ausência ou de desrespeito aos direitos sociais, de falta de emprego, de exploração do trabalho, de pobreza no campo, incentivando o já conhecido êxodo rural, e sua esperançosa migração em direção aos bolsões periféricos urbanos, na busca por melhores oportunidades e qualidade de vida.

A partir da década de 1930, a agricultura brasileira se modernizou, intensificando os investimentos capitalistas no campo. Segundo João Pedro Stédile (2012), a entrada da economia no capitalismo industrial desenvolveu, também, as forças produtivas do capital na produção agrícola, excluindo milhões de trabalhadores rurais, que migraram em busca de trabalho, para novas terras agrícolas ou nos centros urbanos.

No início dos anos 60, durante o governo João Goulart (1961-1964), houve uma tentativa de realização de Reforma Agrária, clássica, distribuidora de terras para quem nelas trabalhassem e assegurassem sua função social. Entretanto, com o golpe militar e os anos de ditadura, o que ocorreu foi o aumento da concentração de terras com o fortalecimento da propriedade privada, através do alinhamento dos aparelhos do Estado aos interesses empresariais capitalistas.

O predomínio de grandes empresas agrícolas mobilizando mão de obra barata em grandes extensões de terra, com o intuito de produzir mercadorias dentro de um regime de monocultura agrícola, constitui elemento "chave" na consolidação do latifúndio e da exploração do trabalho, no projeto de modernização do país.

\footnotetext{
122 Propriedade agrícola de grande extensão pertencente a uma única pessoa, família ou empresa. Ela se caracteriza seja pela exploração intensiva dos recursos, seja pelo caráter especulativo de manutenção das terras inexploradas. Atualmente, independentemente de seu tamanho, seu significado orienta às articulações complexas da agroindústria que contribuem na determinação dos parâmetros de funcionamento do mercado imobiliário. Ver CALDART (org.), 2012, p.447.
} 
Ainda segundo Stédile, com a retomada do regime democrático, a partir de 1984, novos movimentos sociais camponeses começaram a aparecer em cena, transformando os debates e as práticas relativas ao mundo rural, porém sem a acumulação suficiente de forças políticas para implementar um grande programa de reforma agrária no Brasil. Nas duas últimas décadas, o que se viu foi o fortalecimento do poder nas mãos das agroindústrias, controladoras da provisão de insumos e do escoamento das produções. Para ele, a visão burguesa argumenta a existência de um intenso desenvolvimento do capitalismo na agricultura brasileira, o que aumenta a produção e a produtividade da terra.

"Para essa concepção, a concentração da propriedade e seu uso já não representam um problema agrário no Brasil, pois as forças capitalistas resolveram os problemas do aumento da produção agrícola a seu modo, $e$ a agricultura se desenvolve muito bem, do ponto de vista capitalista. Ou seja, a agricultura é uma atividade lucrativa, com aumento permanente da produção e da produtividade agrícolas." (STÉDILE, ibid. p.645)

Todavia, este processo gera uma população explorada e destituída de possibilidades e acessos aos direitos que lhe são necessários à reprodução individual e familiar. Neste lado do campo, situam-se grupos sociais que questionam e lutam por transformações nas engrenagens produtivas da sociedade. De acordo com Stédile (Ibid., p.645), "esses problemas aparecem no elevado índice de concentração da propriedade da terra-apenas $1 \%$ dos proprietários controla $46 \%$ de todas as terras; no elevado índice de concentração da produção agrícola, em que apenas $8 \%$ dos estabelecimentos produzem mais de $80 \%$ das Commodities Agrícolas exportadas; na distorção do uso de nosso patrimônio agrícola, pois $80 \%$ de todas as terras são utilizadas apenas para produzir soja, milho e cana-de-açúcar; na pecuária extensiva; na dependência econômica externa à que a agricultura brasileira está submetida, por causa do controle do mercado, dos insumos e dos preços pelas empresas agrícolas transnacionais; e na subordinação ao capital financeiro, pois a produção agrícola depende cada vez mais das inversões do capital financeiro, que adianta recursos, cobra juros e divide a renda gerada na agricultura." 


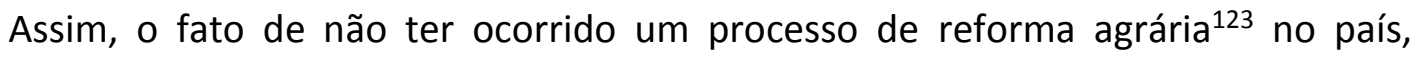
acentuou as disputas de classes, aglomerando famílias de trabalhadores sem-terra em torno de uma luta conjunta. Esta, assumiu novos significados ao longo dos anos, no esforço de acompanhar as transformações ocorridas nas sociedades, sobretudo quanto às novas formas de configuração e manifestação do capital. Às demandas por distribuição de terras, foram adicionadas outras reivindicações que, pouco a pouco, constituíram uma proposta de Reforma Agrária Popular, inserida na atual realidade brasileira.

Combinada à desapropriação dos grandes latifúndios e à distribuição de suas terras, a reforma agrária, para Stédile (Ibid., p. 666), "compreende a necessidade de adoção de novas técnicas agrícolas, baseadas na agroecologia, que consigam aumentar a produtividade das áreas e do trabalho em equilíbrio com a natureza e sem uso de venenos agrícolas. Prevê, ainda, a democratização da educação formal, (...) um programa nacional de mecanização agrícola, (...) que permita aumentar a produtividade do trabalho, diminuindo o esforço físico humano, sem expulsão da mão de obra do campo. E, finalmente, compreende um amplo programa de valorização das manifestações culturais do meio rural em geral vinculado aos hábitos alimentares, músicas, cantorias, poesias, celebrações religiosas e festas rurais."

Segundo o Relatório DATALUTA Brasil $2012^{124}$, a estrutura fundiária brasileira tem apresentado constante crescimento de sua área e do número de imóveis rurais. Entre 1998 e 2012 a estrutura fundiária brasileira foi acrescida de 181,5 milhões de hectares e entre 2011 e 2012 este aumento foi de 6,3 milhões de hectares. O aumento considera as propriedades e as posses, indicando o grau de concentração fundiária existente no país.

Face a esta realidade, as trabalhadoras e trabalhadores rurais vêm ao longo dos anos transformando as ocupações de terras na principal estratégia coletiva de ação para

\footnotetext{
${ }^{123}$ Segundo o Dicionário da Educação do Campo (CALDART [org.], 2012, p.659), a Reforma Agrária é um programa de governo que busca democratizar a propriedade da terra na sociedade e garantir o seu acesso, distribuindo-a a todos que a quiserem fazer produzir e dela usufruir. "Para alcançar esse objetivo, $o$ principal instrumento jurídico utilizado em praticamente todas as experiências existentes é a desapropriação, pelo Estado, das grandes fazendas, os "Iatifúndios", e sua redistribuição entre camponeses sem-terra, pequenos agricultores com pouca terra e assalariados rurais em geral."

124 O DATALUTA é um Banco de Dados da Luta pela Terra no Brasil, produzido pela Universidade Estadual Paulista (UNESP) e pela Universidade Federal de Uberlândia, que permite apreender o quadro geral das principais informações concernentes à luta pela terra no campo brasileiro. Para mais informações, acessar: http://www.lagea.ig.ufu.br/relatoriosdatalutabrasil.html
} 
pressionar o Estado a realizar a desapropriação de fazendas para fins de reforma agrária. Pouco a pouco, tais práticas passaram a ser adotadas pela diversidade dos movimentos sociais $^{125}$ existentes no país, como uma forma de atrair a atenção do Estado e da sociedade em geral para suas realidades e reivindicações.

Segundo Marcelo Carvalho Rosa (2012), o sentido das ocupações mudou seu significado quando o Movimento dos Trabalhadores Rurais Sem Terra (MST) passou a usar o termo "ocupação" como estratégia na formulação das bases de justificativa e legitimação na demanda pela realização da Reforma Agrária.

"Ao usar o termo ocupação, o MST se refere ao direito constitucional de todo cidadão brasileiro de ter acesso à terra, conforme o Estatuto da Terra (lei no 4.504, de 30 de novembro de 1964), que, em seu artigo 2ㅇ, assegura " a todos a oportunidade de acesso à propriedade da terra, condicionada pela sua função social." (Brasil, 1964, in ROSA 2012, p. 513).

\begin{tabular}{|c|c|c|c|c|}
\hline \multicolumn{5}{|c|}{ TABELA 1 - BRASIL - NÚMERO DE OCUPAÇÕES E DE FAMÍLIAS POR } \\
ESTADO E MACRORREGIÕES 1988-2012 \\
\hline REGIÃO/UF & No OCUPAÇÕES & $\%$ & № FAMÍLIAS & $\%$ \\
\hline BRASIL & 8.789 & 100 & 1.221 .658 & 100 \\
\hline SUDESTE & 2.334 & 26,56 & 295.242 & 24,17 \\
\hline SP & 1.451 & 16,51 & 199.853 & 16,36 \\
\hline
\end{tabular}

Tabela 1: Fonte DATALUTA - Banco de Dados da Luta Pela Terra, 2013. www.fct.unesp.br/nera

125 Segundo o DATALUTA (2012), entre os anos 2000 e 2012, 116 movimentos sócio territoriais realizaram ocupações de terra no Brasil. http://www.lagea.ig.ufu.br/relatoriosdatalutabrasil.html. (Consultado em 26/06/2014) 


\begin{tabular}{|c|c|c|c|c|}
\hline \multicolumn{5}{|c|}{ TABELA 2 - BRASIL - NÚMERO DE OCUPAÇÕES E DE FAMÍLIAS POR } \\
ESTADO E MACRORREGIÕES 2012 \\
\hline REGIÃO/UF & № OCUPAÇÕES & $\%$ & № FAMÍLIAS & $\%$ \\
\hline BRASIL & 253 & 100 & 23.145 & 100 \\
\hline SUDESTE & 53 & 20,95 & 4.110 & 17,76 \\
\hline SP & 36 & 14,23 & 1.314 & 5,68 \\
\hline
\end{tabular}

Tabela 2: Fonte DATALUTA - Banco de Dados da Luta Pela Terra, 2013. www.fct.unesp.br/nera

As tabelas 1 e 2 nos indicam o universo quantitativo das ocupações de terras entre os anos 1988 e 2012, assim como durante o ano de 2012 separadamente. Nestes números percebemos a enorme quantidade de pessoas que se encontram em situações de extrema precariedade e que, sem alternativas, expõem suas vidas e famílias na luta, por vezes violenta, pelo acesso à terra para plantar e se reproduzir socialmente. Os números demonstram o protagonismo dos movimentos sociais no processo de realização das políticas de reforma agrária, sendo tanto na indicação das terras improdutivas através das próprias ocupações, quanto na pressão e reinvindicação junto aos órgãos responsáveis pela implantação e fiscalização das políticas públicas específicas. Mostrei os números relativos ao Brasil e ao Estado de São Paulo, em função de ser neste Estado onde se encontra o assentamento rural palco de nosso trabalho prático e analítico.

Ainda segundo o DATALUTA (Ibid.), dentre os movimentos sociais, o Movimento dos Trabalhadores Rurais Sem Terra (MST) é quem mais realiza ocupações de terras no país, tendo feito mais de 2700 entre os anos 2000 e 2012. Para se ter uma noção da escala representativa, o segundo movimento social que mais realizou ocupações de terra entre os anos 2000 e 2012 foi a Confederação Nacional dos Trabalhadores na Agricultura (CONTAG) com pouco mais de 500 ocupações, sendo o total de 5344 ocupações feitas pelo conjunto dos movimentos sociais. Ou seja, mais da metade das ocupações de terra no Brasil, entre 2000 e 2012, foram realizadas pelo MST. Referente ao número de famílias, no total estas ocupações representaram um conjunto de 708.706 famílias. 
O MST, desde a sua fundação, realiza ocupações de terra reivindicando a desapropriação, para fim de reforma agrária, de fazendas consideradas improdutivas, que não realizam sua função social, que degradam o meio ambiente, ou ainda que possuam relações de trabalho similares ao trabalho escravo ou com trabalho infantil.

Nesse sentido, Rosa (Ibid., p.514), sugere que "as ocupações de terra têm servido ao menos para dois fins: a) promover o direito do acesso à terra para quem deseje fazer um uso social justo de sua propriedade; b) estabelecer limites ao direito de propriedade em casos de uso meramente especulativo do solo brasileiro, de cultivos ilegais e da exploração ilegal de trabalhadores (trabalho escravo)."

Neste momento, farei uma rápida contextualização sobre o Movimento dos Trabalhadores Rurais Sem Terra (MST), com a intenção de apresentá-lo aos leitores que ainda não o conhecem, mas sem a intenção de avançar sobre o tema, pois já é bastante abrangente a literatura existe ${ }^{126}$.

Fruto do processo relatado nas reflexões expostas, o Movimento dos Trabalhadores Rurais Sem Terra (MST) foi fundado oficialmente em 1984, durante o I Encontro Nacional do Movimento dos Trabalhadores Rurais Sem Terra, ocorrido na cidade de Cascavel, Estado do Paraná. Hoje, o MST está organizado em 24 das 27 unidades federativas do Brasil, e consiste no maior movimento social da América Latina.

Considerado por Bernardo Mançano Fernandes como um movimento sócio territorial, ele reúne em sua constituição diferentes categorias de camponeses pobres como parceiros, meeiros, posseiros, mini fundiários e trabalhadores assalariados chamados de sem-terra.

"Sua história (MST) está associada à luta pela Reforma Agrária e ao desenvolvimento do Brasil. Nasceu da ocupação da terra e se reproduz por meio da espacialização e da territorialização da luta pela terra. As conquistas de frações do território do latifúndio e a sua transformação em

\footnotetext{
126 Ver autores como: BOGO (1999), FERNANDES (2000), SILVA (1971), STEDILE e FERNANDES (1999), ROCHA e BRANFORD (2003), entre outros.
} 
assentamento acontecem pela multiplicação de espaços de resistências $e$ de territórios camponeses." (FERNANDES, ibid., p.498)

De acordo com o próprio $\mathrm{MST}^{127}$, o Movimento conta com mais de 100 cooperativas e mais de 1.900 associações dentro dos assentamentos, trabalhando de forma coletiva na produção de alimentos, geração de renda no campo e elevação da qualidade de vida das famílias. São mais de 350 mil famílias assentadas em 8 milhões de hectares, em 1200 municípios no país.

Entretanto, entre o momento da ocupação de terra, do reconhecimento pelo Estado Brasileiro ao direito à terra e, da efetiva criação do assentamento rural, as famílias atravessam um período, geralmente longo, em acampamentos construídos com lona preta sobre as terras reivindicadas ou nos limites de suas cercas, esperando o posicionamento do governo e a determinação da justiça.

Ainda segundo o MST (2010), existem aproximadamente 90 mil famílias (aproximadamente 400 mil pessoas), ligadas ao movimento, acampadas em mais de mil acampamentos no Brasil. Geralmente, os acampamentos são resultado de ocupações, o que muitas vezes significa mais chances de êxito, outras vezes, são feitos nas beiras das estradas, como em casos de estratégias políticas.

Para Fernandes, o acampamento é um espaço de luta e resistência pois materializa a ação popular coletiva que torna pública a reivindicação do direito à terra para produção e moradia.

"A ocupação coloca em questão a propriedade capitalista da terra, quando do processo de criação da propriedade familiar, pois ao conquistarem a terra, os sem-terra transformam a grande propriedade capitalista em unidades familiares." (FERNANDES, ibid., p.25)

Nas ocupações, as famílias que desejam ter acesso à terra ${ }^{128}$ passam a integrar as listas de possíveis beneficiários de projetos de assentamento rural. As principais

\footnotetext{
127 Para mais informações ver: http://www.mst.org.br/inicial

128 A Constituição Federal define que a propriedade da terra está subordinada ao cumprimento da sua função social. O Estatuto da Terra, Lei 4.504, de 30 de novembro de 1964, já considerava que o acesso à
} 
condições que diferenciam os acampamentos rurais dos assentamentos rurais, são suas respectivas situações fundiárias, o que permite, ou não, o acesso a créditos, bens de consumo, infraestrutura básica e serviços gerais.

No momento em que o acampamento é regularizado, tornando-se assentamento rural, as famílias passam a ser reconhecidas legalmente pelo Estado, permitindo-as solicitar acesso a certas políticas de créditos financeiros, obras de infraestrutura, energia elétrica, parcelamentos dos lotes de moradia e produção, entre outras coisas.

De forma genérica, Sônia Bergamasco e Luís Norder (1996) consideram os assentamentos rurais como a "criação de novas unidades de produção agrícola, por meio de políticas governamentais, visando o reordenamento do uso da terra em benefício de trabalhadores rurais sem terra ou com pouca terra, envolvendo também a disponibilidade de condições adequadas ao uso da terra e, o incentivo à organização social e à vida comunitária."

A emergência dos assentamentos rurais no cenário brasileiro modificou estruturalmente a luta pela reforma agrária no país. Antes sujeitos históricos invisíveis, os movimentos sociais rurais ganharam espaço e tornaram-se os representantes de centenas de grupos sociais que vivem fora dos centros urbanos e buscam, dia a dia, estratégias para manter e reproduzir suas famílias no meio rural.

Dentro das esferas do governo federal, o órgão responsável pela reforma agrária e seus temas diretamente relacionados é o Instituto Nacional de Colonização e Reforma Agrária - INCRA. Este, vinculado diretamente ao Ministério do Desenvolvimento Agrário (MDA), é uma autarquia federal criada pelo Decreto n. 1.110 de 9 de julho de 1970, e possui como missão prioritária, realizar a reforma agrária, manter o cadastro nacional de imóveis rurais e administrar as terras públicas da União. Encontra-se implantado em todo o território nacional por meio de 30 Superintendências Regionais, responsáveis pela coordenação e execução das ações nos respectivos estados.

terra deve ser para quem nela vive e trabalha, sendo um direito do trabalhador rural e uma obrigação do Estado de promovê-la. 


\begin{tabular}{|c|c|c|c|c|c|c|}
\hline \multicolumn{7}{|c|}{ TABELA 3 - BRASIL - NÚMERO DE ASSENTAMENTOS RURAIS: 1979 - 2012} \\
\hline REGIÃO/UF & ASSENTAMENTOS & $\%$ & No FAMÍLIAS & $\%$ & $\begin{array}{c}\text { Área } \\
\text { (hectares) }\end{array}$ & $\%$ \\
\hline BRASIL & 9.070 & 100 & 933.836 & 100 & 81.781 .828 & 100 \\
\hline SUDESTE & 815 & 9 & 45.412 & 4,9 & 1.486 .148 & 1,8 \\
\hline SP & 257 & 2,8 & 16.390 & 1,8 & 334.425 & 0,4 \\
\hline
\end{tabular}

Tabela 3: Fonte DATALUTA - Banco de Dados da Luta Pela Terra, 2013. www.fct.unesp.br/nera

\begin{tabular}{|c|c|c|c|c|c|c|}
\hline \multicolumn{7}{|c|}{ TABELA 4 - BRASIL - NÚMERO DE ASSENTAMENTOS RURAIS: 2012} \\
\hline REGIÃO/UF & ASSENTAMENTOS & $\%$ & No FAMÍLIAS & $\%$ & $\begin{array}{c}\text { Área } \\
\text { (hectares) }\end{array}$ & $\%$ \\
\hline BRASIL & 117 & 100 & 4.854 & 100 & 317.597 & 100 \\
\hline SUDESTE & 14 & 12 & 634 & 13,1 & 37.681 & 11,9 \\
\hline SP & 4 & 3,4 & 176 & 3,6 & 975 & 0,3 \\
\hline
\end{tabular}

Tabela 4: Fonte DATALUTA - Banco de Dados da Luta Pela Terra, 2013. www.fct.unesp.br/nera

As tabelas acima, retiradas do relatório DATALUTA (Op.cit.) mostram as dimensões demográficas e territoriais que representam as áreas dos assentamentos rurais de reforma agrária no Brasil. Quase 1 milhão de famílias (933.836) foram assentadas nos últimos 35 anos.

Se cruzarmos os dados das quatros tabelas expostas, percebemos que, embora tenhamos uma diferença de quase 10 anos entre as tabelas referentes às ocupações (1988-2012) e aos assentamentos (1979-2012), existe ainda um enorme contingente de famílias acampadas, aguardando ações governamentais e decisões judiciais de regularização de suas condições fundiárias, mantendo-se expostas às condições precárias de sobrevivência. 
Segundo as tabelas, somente no ano de 2012, foram assentadas no Brasil 4.854 famílias. Entretanto, 23.145 famílias ocuparam terras buscando a titulação de assentadas. Isso significa que somente cerca de $1 / 5$ das famílias acampadas tiveram suas situações regularizadas. No Estado de São Paulo esta diferença ainda é mais drástica. Dentre as 1.314 famílias que ocuparam terras ao longo do ano de 2012, somente 176 famílias foram contempladas, cerca de $1 / 7$ do total.

Os estudos realizados sobre assentamentos rurais, por Leonilde Medeiros e Sérgio Leite (2004), mostram que essas unidades têm sido criadas a partir de uma lógica de intervenção governamental que tem privilegiado a ação pontual em situações de conflito, segundo sua gravidade e/ou a visibilidade dos diferentes interesses envolvidos.

"O acesso à terra e assim, à condição de assentado, permite às famílias moradoras, uma maior estabilidade e rearranjos nas estratégias de reprodução familiar que resultam, de modo geral, em uma melhoria das condições de vida, especialmente quando se considera a situação de pobreza e exclusão social que caracterizava muitas destas famílias antes do seu ingresso nos projetos de assentamento." (MEDEIROS, Ibid., 2004)

É importante ressaltar a inegável ascendência no padrão de qualidade de vida das famílias moradoras dos assentamentos de reforma agrária, através do acesso, com condições especiais de financiamento, aos programas governamentais de créditos rurais. O que nos interessa à discussão, refere-se ao nível de melhoria de vida que as famílias atingem, às circunstâncias em que o fazem, e aos instrumentos de políticas públicas disponibilizados.

Os resultados dos estudos também indicam que os assentamentos, até o momento existentes, são espacialmente dispersos, muitas vezes sem nenhuma infraestrutura viária, com apoios financeiros, de assistência técnica, sanitário e educacional em geral muito deficientes.

"Essa precariedade, que marca a situação da maior parte dos assentamentos de reforma agrária (...), indica que uma política pontual de criação de assentamentos não é suficiente para superar as carências 
infraestruturas e a pobreza característica do meio rural brasileiro." (Ibid., 2004)

Com relação ao habitat rural e seu processo produtivo, o quadro é de grande precariedade e necessita de maiores investimentos públicos no tocante tanto à infraestrutura básica (distribuição de rede elétrica, de água, esgotamento sanitário, vias de circulação, entre outros) quanto à habitação propriamente dita. As políticas públicas existentes são insuficientes para engendrar um quadro de melhoria significativa nas condições das habitações rurais.

Embora não tenhamos estudos estatísticos quantitativos nem qualitativos aprofundados com relação às condições e conjunturas habitacionais existentes nos assentamentos rurais do Brasil, temos alguns dados gerais e complementares que indicam um quadro aproximativo das condições existentes.

O censo demográfico de 2010 aponta um déficit habitacional de 6,94 milhões de unidades no Brasil, o correspondente a $12,1 \%$ dos domicílios do país. A região Sudeste concentra $38 \%$ desse déficit habitacional, o que corresponde a 2,674 milhões de unidades, mais da metade (1,495 milhões) no estado de São Paulo ${ }^{129}$.

A tabela abaixo mostra, com mais clareza, os principais números referentes ao déficit habitacional no Brasil. É dentro do quadro estatístico das 1.055 .163 famílias que ainda buscam estratégias para a construção de suas residências no meio rural, que orientamos nossas reflexões.

\footnotetext{
129 Informações obtidas do "Déficit habitacional municipal no Brasil, 2010", documento produzido pela Fundação João Pinheiro.
} 


\begin{tabular}{|c|c|c|c|}
\hline \multicolumn{3}{|c|}{ TABELA 5 - DÉFICIT HABITACIONAL - 2010 (números absolutos) } \\
\hline REGIÃO/UF & URBANO & RURAL & TOTAL \\
\hline BRASIL & 5885528 & 1055163 & 6940691 \\
\hline$\%$ & 84,79 & 15,21 & 100 \\
\hline SÃo PAULO & 1464295 & 31248 & 1495542 \\
\hline$\%$ & 97,91 & 2,09 & 100 \\
\hline
\end{tabular}

Tabela 5: Déficit habitacional de 2010. Fonte: Fundação João Pinheiro.

De uma maneira geral, as políticas públicas existentes para a habitação rural nos assentamentos são viabilizadas através das políticas dos créditos rurais. Essas políticas são extremamente necessárias visto as precárias situações em que as famílias assentadas se deparam ao acessarem a terra, não possuindo, na maioria dos casos, nenhuma capacidade de investir em melhorias de seu lote.

De acordo com Folz (Op.cit., p.02), "O conjunto de fatores econômicos (descapitalização das famílias e recursos governamentais insuficientes) dificultam o acesso à moradia com padrões de habitabilidade mínima e saneamento básico (abastecimento de água, tratamento de águas residuais, águas pluviais e resíduos sólidos e líquidos). Após a regularização da terra e ocupação do solo as famílias moram em "barracos" feitos de papelit, costaneira e de madeira com sérios problemas construtivos e de durabilidade, com uma infraestrutura básica precária, insalubre (sem água, luz e esgoto) e em alguns casos sem nenhuma infraestrutura. $O$ acesso ao crédito e subsídios na fase inicial da inserção social, econômica e produtiva das famílias assentadas é fundamental, pois, possibilita a construção do primeiro abrigo/definitivo, alimentação, melhoria na subsistência econômica, dinamização do comércio regional, enfim, garante sua subsistência básica e o potencial de permanência no campo." 
No ano de 2005, foi criado pelo governo federal um programa de créditos intitulado "Programa Crédito Instalação", no âmbito dos Projetos de Assentamento integrantes do Programa de Reforma Agrária. A aplicação dos recursos deste crédito era realizada com a participação das associações ou representantes dos assentados, sendo os pagamentos feitos diretamente aos fornecedores - mercados locais, lojas de material de construção e de implementos agrícolas, etc. O programa também fazia parcerias com instituições financeiras governamentais (Banco do Brasil e Caixa Econômica Federal).

Dentro deste Programa existiam cinco modalidades, sendo a de "Aquisição de Materiais de Construção" a principal dentre os créditos para a produção das habitações em assentamentos rurais. Essa linha de crédito permitia a aquisição dos itens necessários à construção e reforma da habitação rural, possibilitando também, a utilização dos recursos no pagamento de mão-de-obra.

Esta modalidade de créditos se tornou a principal fonte de recursos para a viabilização da construção de casas rurais. Até 2013 , o valor referente a este crédito era de $\mathrm{R} \$ 15.000,00$ reais (cerca de $€ 5.000,00$ euros) por unidade habitacional nova. Farei rapidamente algumas contas para entendermos melhor o que podemos construir com $\mathrm{R} \$ 15.000,00$ reais.

Todos os meses, os Sindicatos da Indústria da Construção Civil (Sinduscon) de todo o país calculam e divulgam o principal indicador dos custos do setor da construção brasileiro, chamado de CUB - Custo Unitário Básico ${ }^{130}$. Cada estado calcula seu próprio CUB em função de seus mercados específicos. No mês de Junho de $2014^{131}$, o Sinduscon do Estado de São Paulo publicou seu Boletim Econômico indicando o custo médio por $\mathrm{m}^{2}$ da construção no valor de $\mathrm{R} \$ 1.247,35$ reais, referentes ao padrão de habitação popular.

\footnotetext{
130 O CUB determina o custo global da obra de maneira aproximativa à realidade dos custos, sem grandes distorções. Sua variação percentual mensal tem servido como mecanismo de reajuste de preços e principal indicador dos custos das construções, em função de diferentes padrões de qualidade e diferentes tipos de construções.

131 Para maiores informações ver:

http://www.sindusconsp.com.br/downloads/estprod/economia/2014/06_boletimEconomico_junho2014.p df (Consultado em 08/07/2014).
} 
Se considerarmos estes valores, com o crédito de $\mathrm{R} \$ 15.000,00$ reais pode-se construir uma casa com $12 \mathrm{~m}^{2}$. Inversamente, se quisermos construir uma casa com $70 \mathrm{~m}^{2}$,

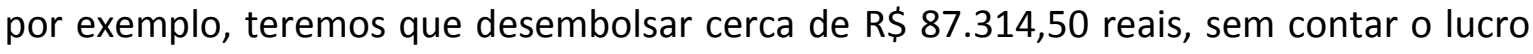
das empreiteiras, os valores com o terreno e os encargos sociais.

Se tomarmos o padrão mais baixo indicado pelo CUB, referente às habitações de interesse social, o custo médio por $\mathrm{m}^{2}$ da construção cai para o valor de $\mathrm{R} \$ 778,76$ reais. Isso significa que com os mesmos $\mathrm{R} \$ 15.000,00$ reais pode-se construir $19,26 \mathrm{~m}^{2}$. Ou então, dentro da mesma ideia de se construir uma casa com $70 \mathrm{~m}^{2}$, seriam necessários $\mathrm{R} \$ 54.513,2$ reais.

Obviamente, estes indicadores contam com os custos de mão de obra. Estes custos giram normalmente entre $55 \%$ e $60 \%$ dos custos da obra, segundo o indicador. Então, somente como exercício reflexivo, proponho retirarmos $55 \%$ do valor do CUB, assumindo que a mão de obra será familiar ou de mutirões, para vermos quanto poderíamos construir com os $\mathrm{R} \$ 15.000,00$ reais do crédito habitacional.

O CUB de padrão popular ( $R \$ 1.247,35$ reais) subtraído da mão de obra (55\%) ficou em $\mathrm{R} \$ 561,30$ reais por $\mathrm{m}^{2}$ construído. O que possibilitaria construir cerca de $27 \mathrm{~m}^{2}$. Se agora subtrairmos os $55 \%$ da mão de obra referentes ao padrão de interesse social (R\$ 778,76 reais), teremos o valor de $\mathrm{R} \$ 350,44$ reais por $\mathrm{m}^{2}$ construído. O que nos possibilitaria construir cerca de $43 \mathrm{~m}^{2}$.

Este exercício de cálculo serve para demonstrar a extrema insuficiência existente nos créditos rurais disponibilizados pelo governo para a construção das moradias dentro dos assentamentos rurais de reforma agrária. Como resultado, observamos casas de baixíssima qualidade, fruto do trabalho precarizado e do uso de materiais de inferior qualidade. Geralmente, ou são casas muito pequenas para os tamanhos das famílias, ou iniciam-se com maiores dimensões mas interrompem suas obras antes do término das construções. Muitas vezes, devido à falta de conhecimento ou de assistência técnica, as casas apresentam problemas estruturais ou de acabamento, ou ainda erros nas quantificações e compras dos materiais necessários, ocasionando perdas e desperdícios. 
Esses dados conduzem a um entendimento sobre programa de crédito para a Aquisição de Materiais de Construção, como parte de uma política de ajuda de custo, por meio de crédito, e não de inclusão social, tendo por finalidade apenas contribuir para que as famílias possam começar a construir suas casas e não qualificar o processo de construção de casas nos assentamentos, reduzindo o déficit habitacional e elevando a qualidade de vida dos moradores.

Atualmente, em meados de 2014, o Crédito Instalação, na modalidade "Aquisição de Materiais de Construção" está sendo extinto. As questões relativas aos créditos financeiros para as habitações rurais estão sendo transferidas para o programa do Governo Federal, intitulado Programa Nacional de Habitação Rural - PNHR, vinculado ao programa federal "Minha Casa Minha Vida", dentro da modalidade "Minha Casa Minha Vida Rural"132, cujo banco Caixa Econômica Federal é o agente financeiro e gestor operacional.

Este programa está voltado para a população que vive no campo, como os agricultores familiares, trabalhadores rurais, comunidades tradicionais, etc. Regulamentado pelo Ministério das Cidades, suas ações atendem a todos os municípios do país e englobam tanto construções novas quanto reformas. Possui 3 faixas diferenciadas de atendimento em função do valor da renda dos beneficiários.

Para as famílias assentadas da reforma agrária, que ganham até $\mathrm{R} \$ 15.000,00$ reais ao ano, o montante destinado para a construção de uma nova unidade habitacional é de $\mathrm{R} \$ 28.500,00$ reais e para a reforma da unidade habitacional, de $\mathrm{R} \$ 17.200,00$ reais. Até $35 \%$ deste valor pode ser utilizado com o pagamento de mão de obra. O programa prevê também o valor de $R \$ 600,00$ reais para a assistência técnica e $R \$ 400,00$ para trabalhos de assistência social. Deste montante, $96 \%$ do valor é subsidiado pelo Orçamento Geral da União - (OGU) e 4\% do valor é financiado e devolvido pelos beneficiários.

Assim, para a construção nova, a família beneficiária recebe $\mathrm{R} \$ 28.500,00$ reais e paga $R \$ 1.140,00$ reais parcelados, e para a reforma, a família recebe $R \$ 17.200,00$ reais,

\footnotetext{
${ }^{132}$ As informações foram obtidas do site do Banco Caixa Econômica Federal. Consultado em 09/07/2014. http://www1.caixa.gov.br/gov/gov_social/municipal/assistencia_tecnica/produtos/repasses/pnhr_ogu/ind ex.asp
} 
pagando $\mathrm{R} \$ 688,00$ reais. Entretanto, para acessar o programa as famílias devem compor grupos de no mínimo quatro famílias e estarem organizadas por Entidades Organizadoras (EO) de caráter público (prefeituras, governos estaduais, e respectivas companhias de habitação), e de caráter privado como entidades representativas dos grupos associativos (entidades privadas sem fins lucrativos, sindicatos, associações, cooperativas, etc.).

Farei rapidamente o mesmo exercício de custos feito anteriormente para sabermos o que está mudando com relação à qualidade da unidade habitacional rural proposta pelo novo programa federal.

Partindo do custo médio por $\mathrm{m}^{2}-\mathrm{CUB}$, visto anteriormente, referente ao padrão de habitação popular, no valor de $\mathrm{R} \$ 1.247,35$ reais, e podendo agora acessar um montante no valor de $\mathrm{R} \$ 28.500,00$ reais, consegue-se então construir uma casa com cerca de $23 \mathrm{~m}^{2}$. Na mesma linha do exercício feito anteriormente, se tomarmos o padrão mais baixo indicado pelo CUB, referente às habitações de interesse social, com seu custo médio por $\mathrm{m}^{2}$ da construção estimado em $\mathrm{R} \$ \mathbf{7 7 8 , 7 6}$ reais, e se retirarmos também o valor da mão de obra de $55 \%$, assumindo o custo do $\mathrm{m}^{2}$ em $\mathrm{R} \$ 350,45$ reais, poderiam ser feitas novas habitações com cerca de $81 \mathrm{~m}^{2}$. Contudo, pagando a mão de obra, mas ao invés da porcentagem de $55 \%$ a $60 \%$ sugerida pelo índice, utilizarmos o valor de $35 \%$ $(R \$ 272,55)$ permitido pelo programa habitacional, a área construída passaria a ser de $56 \mathrm{~m}^{2}$.

Obviamente, são apenas estimativas amplas que não incluem outros custos diretos e indiretos existentes na produção habitacional. Servem, entretanto, para nos indicar qual o quadro habitacional rural que estamos discutindo quando da implementação das políticas públicas federais existentes para o acesso ao habitat digno e com qualidade para as pessoas do campo.

Devemos nos atentar para o fato das condições, regras, normas e padrões impostos, que condicionam o acesso à moradia, revelarem as contradições existentes entre o direito a morar de uma maneira e a impossibilidade de fazê-lo. A produção do habitat se afasta cada vez mais de sua realização enquanto fruto das disponibilidades dos materiais e dos conhecimentos técnicos locais, das prioridades e valores familiares, alinhados às características culturais dos grupos sociais. E passam a ser rigorosamente 
pautadas por formas heterônomas de satisfação das necessidades, balizadas pelos custos operacionais e pelos interesses financeiros e de classe.

Por outro lado, os assentamentos rurais de reforma agrária, espalhados por todo o país, nos demonstram, também, as possibilidades realizadas, as utopias concretizadas e os sonhos alcançados, mesmo que somente em partes. Sérgio Leite (2004) tem destacado que mesmo reduzido ante a forte concentração fundiária que marca o caso brasileiro, o número de projetos de assentamentos rurais vem aumentando, permitindo afirmar a existência de certa "irreversibilidade" do processo. Para além da compreensão de que as políticas públicas para os assentamentos rurais vêm a reboque da ação dos setores organizados em torno da luta pela da Reforma Agrária, Leite (Ibid., p.110) evoca a "necessidade de compreender melhor o significado e a dimensão que esses novos sujeitos e essas novas unidades (de produção, consumo, trabalho, moradia, lazer, vida etc.) passam a cumprir no seio da chamada questão agrária brasileira."

Os assentamentos rurais não podem então ser considerados como um ponto final na problemática das questões envolvendo as famílias de pequenos agricultores rurais, mas pelo contrário, tornam-se elementos de partida fundamentais para a compreensão das novas conjunturas estabelecidas, que marcam o mundo rural brasileiro.

Percebemos que pouco a pouco o mundo rural vem sendo reconhecido de maneira diferente pelas sociedades. Tido, durante todo o século $X X$, como fonte de recursos primários e territórios atrasados e, selvagens, a percepção positiva do meio rural começa a reconquistar espaços, e a buscar, nele, alternativas para a melhoria da qualidade de vida, para a falta de trabalho nos centros urbanos, para novas relações com a natureza, entre outros.

O desenvolvimento rural e local dentro das chamadas "novas ruralidades", a partir de novas percepções e compreensões sobre os territórios urbanos e rurais e, suas relações intrínsecas estabelecidas, são temas cada vez mais tratados nos espaços acadêmicos, sociais, militantes, institucionais, etc., em grande parte dos países do mundo. 
O termo "pluriatividade"133 é cada vez mais empregado e não constitui, necessariamente, um processo de abandono da agricultura e do meio rural. Pelo contrário, segundo Maria de Nazareth Wanderley (2001), as famílias que vivem no meio rural, pluriativas ou não, são depositárias de culturas, cujas reproduções são necessárias para a dinamização técnico-econômica, ambiental e sociocultural do meio rural. O patrimônio fundiário continua sendo um elemento de referência e de convergência nas formulações das estratégias de reprodução familiar e nos processos de valorização das identidades territoriais rurais.

"Quando estou falando de mundo rural, refiro-me a um universo socialmente integrado ao conjunto da sociedade brasileira e ao contexto atual das relações internacionais. Não estou, portanto, supondo a existência de um qualquer universo isolado, autônomo em relação ao conjunto da sociedade e que tenha lógicas exclusivas de funcionamento $e$ reprodução. Porém, considero que este mundo rural mantém particularidades históricas, sociais, culturais e ecológicas, que o recortam como uma realidade própria, da qual fazem parte, inclusive, as próprias formas de inserção na sociedade que o engloba." (WANDERLEY, 2001)

Essa forma de compreender o mundo rural não mais como um espaço exclusivo das atividades agrícolas, mas como um território de sociabilidade complexa onde surgem cada vez mais novas redes sociais em diferentes escalas de atuação, amplia as conexões entre o rural e o urbano, flexibilizando ainda mais suas fronteiras e misturando os dois espaços. A incorporação de populações urbanas no espaço rural aporta elementos culturais e simbólicos novos, o que por sua vez são expressos nos novos contextos, nas práticas individuais e nos valores coletivos, constituindo novas identidades territoriais ${ }^{134}$.

\footnotetext{
133 Para Maria de Nazareth Wanderley (2001), o termo "pluriatividade" expressa o leque das estratégias familiares adotadas, quando as condições as permitem, sobretudo quanto às questões econômicofinanceiras e às escolhas de trabalho e produção, de modo a garantir a permanência no meio rural e os vínculos mais estreitos com o patrimônio familiar.

134 Roberto Moreira (2007) fala em "ambiências de identidades", os contextos em que percebemos, nas identidades, os elementos resultantes dos valores e das práticas de convivência de pessoas de origem urbana e rural. Isso nos remete aos elementos que sustentam os sentimentos de pertencimento e as relações de alteridade no grupo.
} 
Este novo quadro estaria também associado, para Moreira (Op.cit., p.181), a um novo paradigma técnico e a uma nova ordem competitiva ainda não claramente explicitada nas esferas produtivas. "As expectativas frente ao futuro, postas pela ciência dos ecossistemas, pela biotecnologia e pelos movimentos ambientalistas tendem a levar à revalorização da natureza e dos direitos de propriedade privada a ela associada."

Para ele, os grandes latifúndios, além de estocarem terras, estocam possibilidades de usos. Estes, são cada vez mais flexíveis e incorporam diferentes formas de capitalizar as terras, de maneira não mais limitada à produção de mercadorias propriamente agrícolas, mas através da assimilação de novos valores ligados aos usos urbanos, como por exemplo, o lazer e o turismo.

\section{Sobre os métodos de ação}

"O método é um conjunto de princípios que tem de ser permanentemente recriados, na medida em que a realidade outra e sempre diferente exige que esses princípios sejam lidos de maneira diversa. E enriquecidos de maneira diversa." (FREIRE e FAUNDEZ, 2002, p.41)

Estas novas possibilidades de configurações e usos dos territórios rurais vem sendo também percebidas, refletidas, planejadas e trabalhadas em outros países e continentes, por profissionais e pesquisadores em suas mais diversas áreas de atuação. Na França, por exemplo, a Rede "Espaço Rural \& Projeto Espacial" - ERPS, composta sobretudo por pesquisadores e profissionais da área da Arquitetura e Urbanismo, vem se destacando no desafio de organizar e divulgar tais trabalhos.

A perspectiva conduzida por esse grupo parte do princípio da existência de uma relação dialética de complementaridade entre os espaços rurais e urbanos. O desafio reside na compreensão desta relação e de suas modalidades de funcionamento. A noção de "prospectiva territorial" surge nas reflexões como uma orientação do corpus teórico e como método de trabalho. Segundo Xavier Guillot (2010, p.109), “Em sua futura prática da profissão, o estudante arquiteto será engajado em um trabalho de transformação do 
espaço para os próximos vinte, trinta, cinquenta anos. Assim, nos pareceu pertinente introduzir no ensinamento do projeto uma reflexão de natureza a antecipar as configurações deste espaço a médio e longo prazo."

Assim sendo, torna-se diferencial a aproximação com o local, com os elementos que interferem no território específico. Segundo ele (Ibid., p.109), a noção de "sustentabilidade arquitetônica" é acionada para contribuir na escala do espaço habitado. "Sobre a questão do futuro dos territórios, uma prioridade deveria ser levada em consideração: a integração de uma "consciência ecológica" na concepção dos estabelecimentos humanos com, um "retorno" à questão territorial em termos de recursos para a produção de materiais de construção inclusive."

Nessa nova perspectiva de produção arquitetônica, os projetos e as análises teóricas orientam-se aos modos de habitar e às técnicas construtivas adequadas às culturas locais, adaptadas às realidades econômicas existentes e apropriadas pelos grupos sociais locais. Esse movimento, percebido por Alain Findeli (2012) como uma orientação do olhar "sobre o habitat para o habitar", revela uma questão antropológica fundamental, de maior amplitude, que articula campos do conhecimento complementares como a geografia, a filosofia, a sociologia, a psicologia, a ecologia, dentre outros.

Segundo Alain Findeli e Anne Coste (2007), tal movimento, dentro da perspectiva de se constituir uma tradição de pesquisa arquitetônica, necessita realizar-se sobre o terreno da prática pedagógica, mais do que no terreno da prática de pesquisa propriamente dita. É ai que a construção empírica e a realização da práxis de pesquisa se fazem mais do que fundamentais, tornando-se decisivas dentro dos projetos de pesquisa sobre arquitetura.

"Efetivamente, para que serve a pesquisa se ela não conduz à uma melhor prática da arquitetura, se ela não permite à prática do projeto de arquitetura de melhor responder aos diagnósticos que ela realiza sobre o mundo?" (FINDELI e COSTE, ibid., p.145) 
O método trabalhado por eles se orienta a uma transformação da problemática arquitetônica em problemática de pesquisa e, assim, do projeto de concepção/construção em projeto de conhecimento. Em seu quadro teórico, o método de "pesquisa-projeto" resulta "(...) de uma transposição para as disciplinas de projeto dos princípios da pesquisaação, mais também da teorização fundamentada, da etnometodologia e da fenomenologia, transferência que considera as particularidades das situações e dos terrenos próprios às nossas disciplinas". (FINDELI E COSTE, ibid., p.153)

Assim, o método adota para as disciplinas de projeto de arquitetura, o quadro teórico e conceitual da práxis, considerando o projeto para além de sua prática de âmbito criativa. Segundo eles, a "pesquisa-projeto" implicaria as seguintes características: estar fundamentada no projeto, apoiando-se em uma situação singular com o objetivo de modificar as coisas; ser empírica e permitir a observação tanto do mundo exterior que contextualiza o projeto, quanto do interior com os sujeitos do projeto (intenções, valores, expectativas, etc.); consistir em um trabalho reflexivo "em ação" e interpretativo "fora de ação"; e conduzir a conclusões que englobem, se possível, os planos da teoria, da prática profissional e do ensino.

Este exercício conceitual, prático, social, permanente e dialético, de aproximar a produção de pesquisa (conhecimento) com a construção da realidade social (ação), tem na pesquisa-ação um campo vasto e desenvolvido de atuação. Seja nas áreas da educação, sociologia, psicologia, trabalho, antropologia, entre outras, o método de pesquisa-ação é utilizado em trabalhos que se desenvolvem de modo a possibilitar diferentes abordagem dos fenômenos das sociedades em suas complexidades.

A participação ativa do pesquisador dentro da problemática social, construindo juntamente com os outros sujeitos participantes as ações práticas e suas compreensões teóricas, reforça a finalidade da pesquisa-ação de contribuir com as ações de transformação social a partir da intensa implicação de todos os envolvidos. O que permite gerar o desenvolvimento das ações em concomitância com a produção de conhecimentos. 
Tal processo possui como manifesto operatório o diálogo e o respeito às culturas e contextos locais. Sua finalidade é propiciar a interação construtiva entre todos os sujeitos atuantes, de forma a pensar e agir conscientemente e de maneira crítica.

A pesquisa-ação, segundo Khalid Andaloussi (in Thiollent, 2004), com sua presença constante tanto no plano da pesquisa quanto no da ação, consegue diagnosticar uma situação, iniciar uma ação, acompanhá-la, observá-la, significá-la e avaliá-la, com a intensão de desencadear novas ações em seguida. E isso acontece devido, entre outras coisas, à observação e interação com o contexto cultural local, produzindo também, novos saberes e novas significações culturais entre todos os envolvidos na pesquisa-ação.

"Sob essa perspectiva, a relação entre pesquisadores e atores é orgânica, porque é geradora do trabalho de ambos. É somente nessa ótica que parece mais justo declarar que não se pode haver pesquisa sem ação $e$ ação sem pesquisa." (ANDALOUSSI, 2004, p.102)

Andaloussi enfatiza o fato de, na pesquisa-ação, a produção do saber demanda um vaivém entre os momentos de trabalho prático e de trabalho intelectual, provocando desvios, avaliações, críticas, análises, reações, etc., que transformam constantemente as abordagens realizadas.

"Em um movimento circular entre pesquisa e ação, os participantes visam a estabelecer uma parceria que permita gerir o difícil equilíbrio entre pesquisa, ação e decisão. Essas três dimensões são geradas por um conjunto de parceiros seguindo tempos definidos por todos e um calendário que articule momentos de pesquisa com momentos de ação." (ANDALOUSSI, ibid., p.88)

Por não possuírem uma orientação linear e unidimensional, as práticas da pesquisa-ação se encontram dentro da complexidade concreta da constante negociação entre todos os envolvidos do grupo, com seus tempos e prioridades. Essas relações são geridas no coletivo e suas tendências são constantemente reanalisadas e readaptadas. Contudo, tais característica, quando apropriadas, possibilitam extrair melhor as relações 
simbólicas, as práticas gestuais, as perspectivas latentes e adormecidas, entre outros elementos essenciais na construção do que se propõe.

É na ambiência das reflexões tecidas até o momento, e no âmbito das conceituações e princípios expostos e discutidos, que proponho o mergulho analítico em nossa experimentação produtiva. Acredito que já exista um acúmulo teórico suficiente, embora não esgotado, de reflexões que permitirão melhor compreender e analisar nossa práxis de pesquisa-ação.

O processo de produção da Casa Suindara consiste em um estudo de caso que nos permitirá reavaliar certas compreensões, evoluir algumas análises e evidenciar outras tantas pistas conclusivas sobre nossos questionamentos e hipótese de pesquisa. Sua generalização é possível no âmbito das proporções teóricas e não na "amostragem" de populações e universos. Nosso objetivo é elencado por Robert Yin (2005), como sendo a expansão e generalização analítica de teorias e não a enumeração de frequências estatísticas.

"Um estudo de caso é uma investigação empírica que investiga um fenômeno contemporâneo dentro de seu contexto da vida real, especialmente quando os limites entre o fenômeno e o contexto não estão claramente definidos." (YIN, 2005, p.32)

Sigamos então para a Casa Suindara.

\section{Olhares em choque}

"E, partindo disso, abrimos um espaço para que ele [o povo] desenvolva ainda mais sua tecnologia, seus conhecimentos para responder a suas necessidades, nesse jogo de redescobrir necessidades e reinventá-las, ou de recriar técnicas, ou utilizar ao máximo técnicas e conhecimentos que permitam solucionar essas necessidades." (FREIRE, 2002, p.102) 
Localizado no município de São Carlos, estado de São Paulo, o assentamento rural Comunidade Agrária Nova São Carlos obteve sua regularização fundiária em agosto de 2009, cerca de um ano após a ocupação e o início do acampamento, que chegou a abrigar mais de cem famílias. Atualmente, 83 famílias estão assentadas vivendo cada qual a partir de suas estratégias familiares de reprodução social. Elas se encontram mal organizadas socialmente e politicamente, apresentando dificuldades em construir projetos coletivos de desenvolvimento ${ }^{135}$. São pessoas que convivem e resistem às condições dispostas e impostas em suas realidades sociais, e com grande dificuldade buscam acessar alguns créditos financeiros para viabilizar aquilo que deveria ser assegurado para 0 desenvolvimento dos assentamentos rurais de reforma agrária, entre os quais: habitação, energia, água, saneamento, transporte e políticas públicas de apoio à produção familiar.

Os lotes familiares possuem uma área entre 7ha e 12 ha cada um, distribuídos em aproximadamente 1.158,5ha do assentamento. As famílias estão divididas, teoricamente, em três grupos ( $A, B$ e $C$ ) separados em função de suas atividades principais de produção, a saber: as famílias que cultivam produtos agrícolas, aquelas que criam animais e as que se interessam por técnicas ecológicas e agroecológicas de produção. Cada grupo conta com um coordenador representante.

A Comunidade Agrária Nova São Carlos encontra-se próxima ao Distrito Industrial de São Carlos e cerca de $8 \mathrm{~km}$ do centro de sua cidade. Possui sua área territorial cortada em duas glebas, no sentido norte-sul, pela rodovia Domingos Innocentini e por uma linha de alta tensão em seu quadrante sudoeste. A leste, o assentamento é delimitado pela linha férrea que também atravessa a cidade.

\footnotetext{
${ }^{135}$ Algumas iniciativas (internas e externas) foram fomentadas e iniciadas dentro do assentamento, sendo porém, sua maior parte, interrompidas ou finalizadas aquém de suas expectativas. É o caso de alguns cursos gratuitos propostos pelo SENAR (Serviço Nacional de Aprendizagem Rural) que tiveram em seu contexto a problemática da falta de participantes interessados e, algumas iniciativas locais de trabalho coletivo e de constituição de uma associação de produtores rurais.
} 


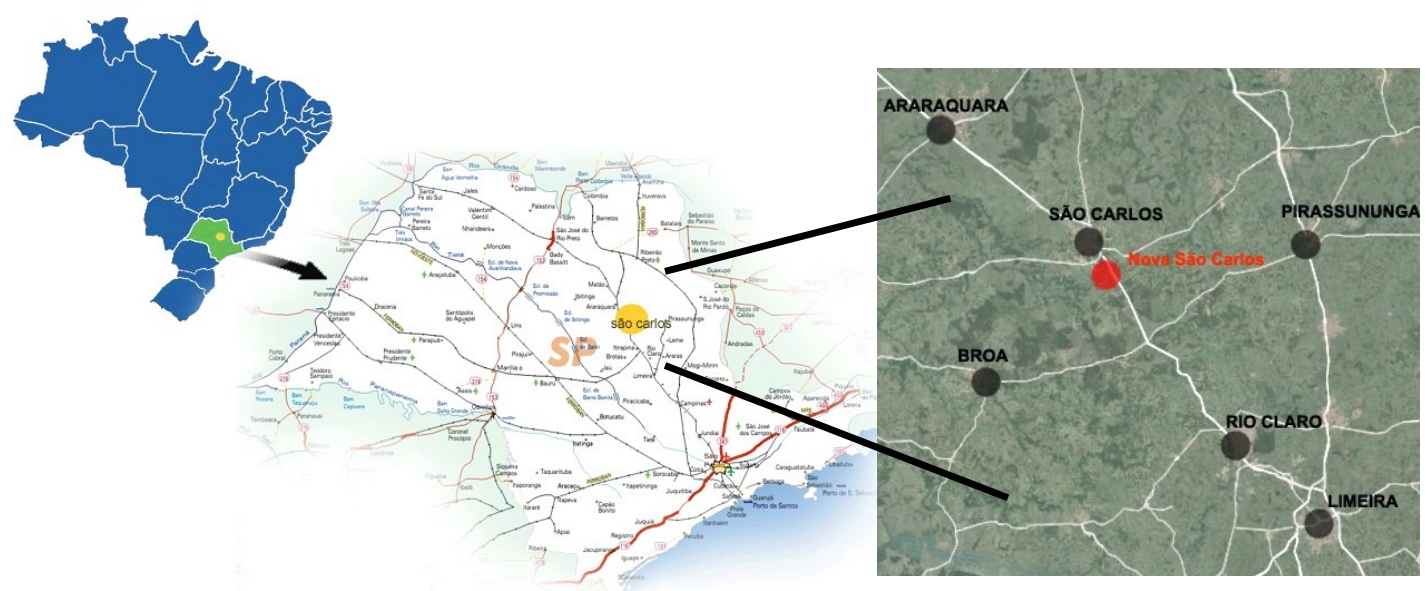

Figura 5 - Mapas de localização do assentamento rural Comunidade Agrária Nova São Carlos, 2013.
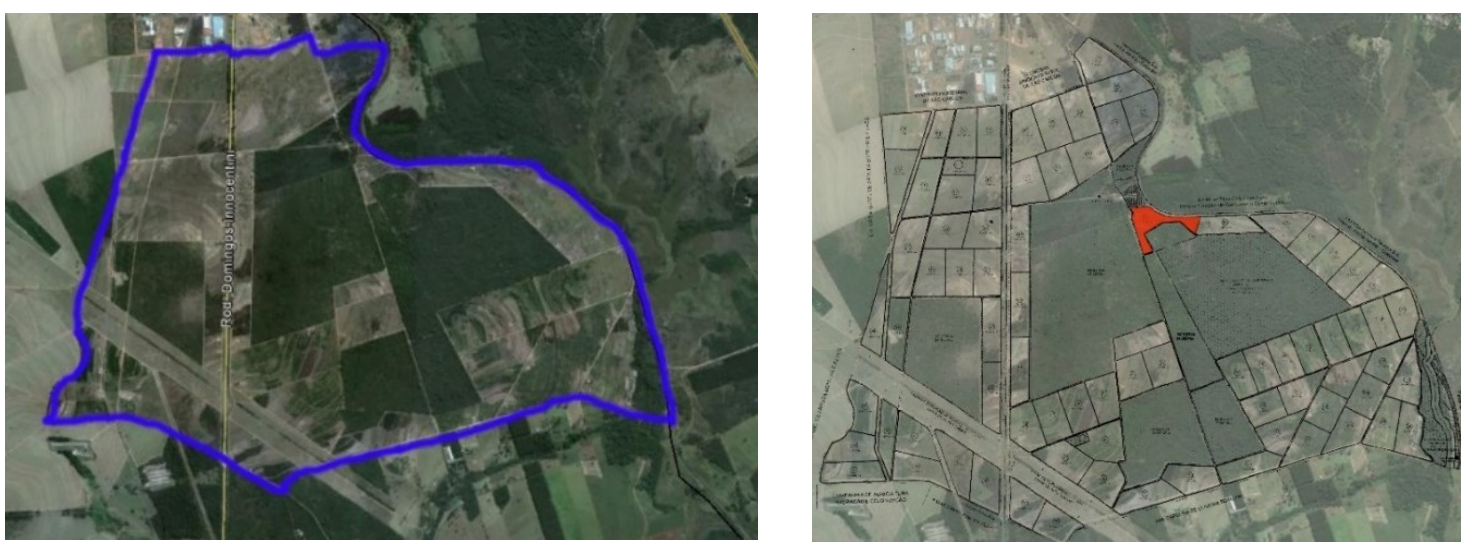

Figuras 6 e 7 - Mapas do assentamento com sua área total delimitada e com seus lotes demarcados. 0 destaque em vermelho refere-se ao lote onde está localizada a Casa Suindara, 2013.

O histórico recente referente às terras destinadas a compor o assentamento rural Comunidade Agrária Nova São Carlos é complexo, tendo passado "pelas mãos" de diferentes proprietários nos últimos anos. De acordo com os documentos ${ }^{136}$ pesquisados sobre a área, em 1986 a FEPASA ${ }^{137}$, então proprietária do terreno, firmou um contrato de

\footnotetext{
${ }^{136}$ Foram pesquisados uma série de documentos disponibilizados pelo Instituto Nacional de Colonização e Reforma Agrária - INCRA/SP, referentes ao processo de desapropriação da fazenda e incorporação da área no Programa Nacional de Reforma Agrária - PNRA. Foram analisados documentos, ofícios institucionais e relatórios técnicos, além dos processos de compra, venda e concessão de uso do terreno.

${ }^{137}$ A Ferrovia Paulista S.A. (FEPASA) era uma empresa ferroviária que pertencia ao Estado de São Paulo, embora sua malha se estendesse pelos Estados de Minas Gerais e Paraná. Foi extinta ao ser incorporada à Rede Ferroviária Federal Sociedade Anônima (RFFSA) em 1998.
} 
arrendamento com a RIPASA ${ }^{138}$, para uso da área na produção de eucaliptos destinados à indústria de celulose. Em 1998, a FEPASA foi incorporada à Rede Ferroviária Federal Sociedade Anônima (RFFSA) ${ }^{139}$ que manteve o contrato com a RIPASA até 2004, quando esta entrou em liquidação e teve seus ativos transferidos para o consórcio CONPACEL 140 em 2004.

Em 2007, com a extinção e liquidação da RFFSA, seu patrimônio foi transferido para a Secretaria do Patrimônio da União - SPU, incluindo seus bens imóveis classificados em não operacionais, como os Hortos Florestais. Estes, localizados em diferentes regiões são passíveis de aproveitamento para fins de assentamentos de Reforma Agrária. O terreno que tratamos foi então transferido para a Gerência Regional do Patrimônio da União em São Paulo - GRPU, que manteve em vigor o contrato de uso e exploração do solo pela CONPACEL até 2010 , data limite para que o consórcio retirasse todos os eucaliptos e entregasse a área.

O Instituto Nacional de Colonização e Reforma Agrária - INCRA manifestou, então, interesse na incorporação destes imóveis ao PNRA e em junho de 2009, a Gerência Regional do Patrimônio da União - GRPU transferiu a guarda do Horto Florestal São Carlos para o INCRA, com o intuito de regularizá-la como assentamento rural Comunidade Agrária Nova São Carlos, o que ocorreu em agosto do mesmo ano, como vimos anteriormente.

De acordo com o relatório técnico de vistoria do terreno ${ }^{141}$, dentro da área de 1.158,5ha, cerca de 85ha são destinados a composição da Área de Reserva Legal. Somada a esta área coletiva, cada lote possui faixas diferenciadas de Preservação Permanente, em função de sua localidade e das características específica do terreno. A vegetação natural

\footnotetext{
138 RIPASA Papel e Celulose era uma empresa sediada no interior do Estado de São Paulo, na cidade de Americana, produtora de papel e celulose.

${ }^{139}$ A Rede Ferroviária Federal Sociedade Anônima (RFFSA) era uma empresa estatal brasileira de transporte ferroviário que cobria boa parte do território brasileiro. A RFFSA existiu por 50 anos, sendo oficialmente extinta em janeiro de 2007.

${ }^{140}$ Criado em 2008, o Consórcio Paulista de Papel e Celulose CONPACEL é formado por três empresas do ramo da produção de papel e celulose.

141 O Relatório de Vistoria do Instituto Nacional de Colonização e Reforma Agrária - INCRA / Superintendência Regional de São Paulo é um documento técnico que contém uma série de informações relevantes sobre a área que abrigará o futuro assentamento rural. Seu objetivo é reconhecer e verificar as condições físicas, sociais, geográficas, climáticas, dentre outras, existentes na área, de forma a dotar com informações o processo de regularização fundiária.
} 
do assentamento é caracterizada como de cerrado, tipo de vegetação predominante nesta região do Estado.

A área, na época da regularização fundiária, era totalmente ocupada pelo cultivo de eucalipto, sendo dividida por estradas de circulação interna destinadas ao escoamento das árvores cortadas. Mesmo não possuindo um mapa técnico de solos, a vistoria do INCRA na época, verificou visivelmente o predomínio de solos arenosos e podzólicos, de textura média, com tendência a serem distróficos e ácidos, naturalmente pouco férteis, em consonância com a vegetação de cerrado presente na área. Obviamente, esta característica vem somada à perda de fertilidade do solo ocasionada pelos plantios em monoculturas de eucaliptos durantes mais de duas décadas.

Quanto à disponibilidade de água, existem duas nascentes que formam um pequeno riacho cortando a fazenda. A problemática do acesso à água talvez seja a maior dificuldade vivida pelas famílias assentadas até hoje. Na realidade, existem cinco poços instalados pelo INCRA em lugares diferentes do assentamento, destinados a atenderem um certo número de famílias cada um. Estes poços já contém as bombas e todos os equipamentos necessários para seus funcionamentos. Entretanto, legalmente eles não podem ser utilizados pois como não existem canalizações de distribuição de água para as casas, não haveria controle sobre o consumo (e então pagamento pela utilização) se as famílias tivessem acesso livre às bombas de água. E ademais, quem pagaria a energia por fazer funcionar a bomba, se não há controle de consumo? Como o INCRA alega não ser o responsável por assegurar a distribuição de água em cada lote, existe um "empurraempurra" de responsabilidades sobre a questão entre o INCRA (governo federal) e a Prefeitura local, que não quer assumir os custos. A solução apresentada pelo governo municipal seria uma pessoa assumir o nome como responsável pelo assentamento, perante as companhias de distribuição de água e energia, para que as contas pudessem ser enviadas à ela.

Vista a inviabilidade de tal alternativa e diante do impasse existente, as famílias seguem sendo abastecidas semanalmente por um caminhão pipa da prefeitura, porém sendo sua frequência menor do que sua necessidade. E enquanto isso, os equipamentos instalados nos poços construídos vão sendo deteriorados pelo tempo e inutilidade. 
As benfeitorias existentes na antiga fazenda antes desta tornar-se um assentamento rural, contabilizam as seguintes construções: cincos casas de alvenaria de tijolos, dois depósitos, duas edificações em madeira, uma casa de bombas e um estábulo.

O antigo estábulo ou agora "galpão" consiste em uma construção em alvenaria de tijolos, com cobertura em telha de barro cozido com uma área de aproximadamente $190 \mathrm{~m}^{2}$. Usada como sede durante o período de acampamento das famílias, servia como espaço coletivo multiuso. Sua condição estrutural está em bom estado, necessitando porém de uma série de reformas no telhado, nas paredes de fechamento interno, nos pisos, nos revestimentos, entre outros. A edificação não possui nenhuma instalação sanitária ou elétrica, sendo atualmente utilizada como espaço para encontros e reuniões.

Nossa aproximação com as famílias assentadas se deu em um momento importante do processo histórico da comunidade. Momento em que as famílias estabeleciam o acesso ao chamado Crédito Instalação na modalidade Aquisição de Materiais de Construção, crédito que tratamos anteriormente. Este, conhecido como crédito habitação, é concedido pelo INCRA no valor de $\mathrm{R} \$ 15.000,00$ para cada família, pagos diretamente ao fornecedor dos materiais de construção, no caso as lojas de materiais. Estas, passam por um processo licitatório de concorrência, tendo ao final, um contrato firmado entre o governo, as famílias assentadas e a loja vencedora do processo.

O crédito habitação foi acessado pela quase totalidade das famílias assentadas, exceto algumas que não quiseram acessar ou não concordaram com o processo licitatório, suspeitando das condições do contrato e da capacidade da loja em fornecer todos os materiais necessários. De qualquer forma, a loja vencedora, por receber o pagamento do INCRA somente após a retirada dos materiais pelos assentados, não conseguiu assegurar a quantidade de materiais demandados e teve de encerrar seu funcionamento. Diversas famílias estão, assim, com suas casas inacabadas, com o acesso aos materiais necessários interrompido e, sem perspectiva estabelecida de finalização das obras. Além disso, vimos anteriormente que mesmo com o acesso ao crédito restabelecido, estes são insuficientes para a finalização das construções das casas.

Como me referi anteriormente, nossa entrada na comunidade se fez através de um casal de professores que nos apresentou à uma família moradora do assentamento. 
Foi na primavera de 2012, que conhecemos a M. Silva ${ }^{142}$, o G. Silva e seus dois filhos. Ela, originária da região, é técnica em enfermagem e agricultora, e ele, originário do Estado do Paraná, é trabalhador na construção civil e agricultor. Hoje assentados, estão desde o início entre as famílias da ocupação, e optaram por não acessar o crédito habitação do governo por não concordarem com o processo licitatório ocorrido.

No momento de nosso encontro, a família vivia em uma casa de estrutura em troncos de eucaliptos e tábuas de madeira, fechada por lonas plásticas e coberta por telhas de fibrocimento. Já possuíam a rede de energia elétrica chegando até a entrada do lote, porém dependiam, como ainda hoje, da passagem do caminhão pipa para o acesso à água do consumo familiar e da produção agrícola. Esta solução, a princípio de caráter temporário, é evidentemente insuficiente para que a família tenha condições de produzir alimentos em escala comercializável. Mesmo para o consumo familiar o volume de água disponibilizado é muitas vezes insuficiente, visto a frequência de atendimento.
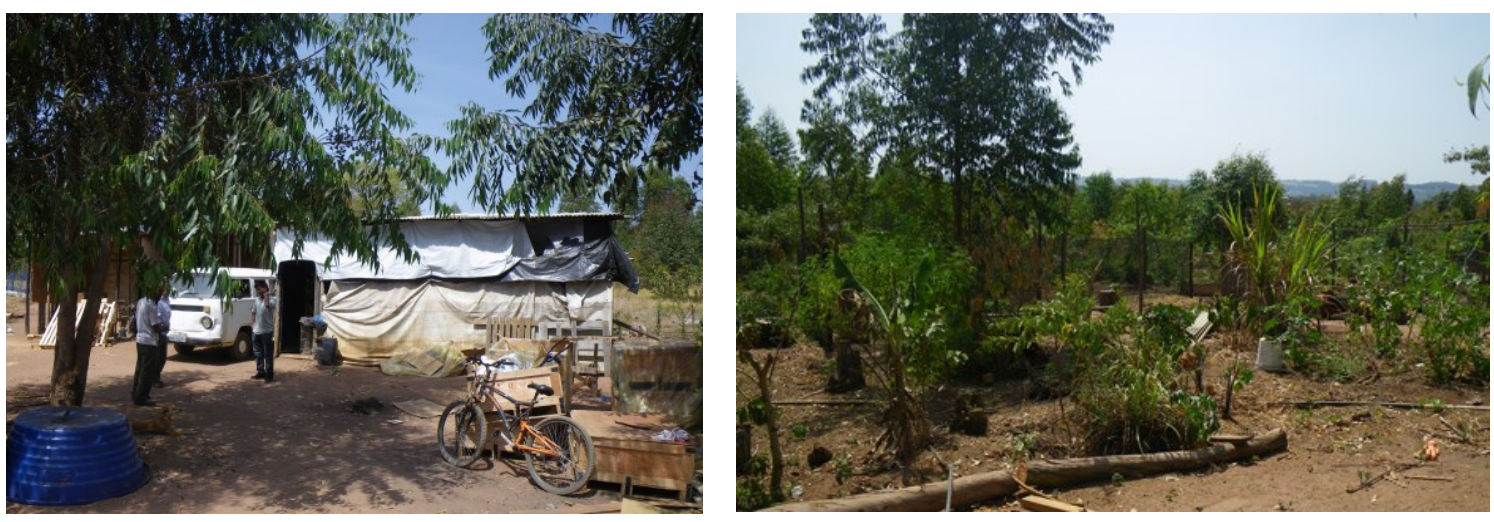

Fotos 45 e 46 - Primeira visita ao assentamento rural e encontro com a família em seu lote de moradia.

Na ocasião, ainda não existia nada de concreto de nossa parte, além da intenção e motivação em contribuir com a melhora do quadro de vida daquelas famílias ali assentadas, além de aprofundar as pesquisas e atividades em torno da produção do habitat rural.

Naquela visita, já foi possível perceber a íntima relação que a família possuía com a natureza local. A constituição de sua identidade passa pela construção de seu território

\footnotetext{
142 Neste trabalho, os participantes serão citados pela letra inicial de seus nomes, seguida por seus sobrenomes.
} 
- assentamento rural - e pelas transformações que suas práticas cotidianas realizam no lote de vida e produção. Essa interação se dá por um contínuo processo de descobertas e aprendizagens, que pela práxis efetiva os acertos e orienta as escolhas. O caráter fundador das relações espaciais aparece assim indissociável das formas familiares e coletivas de representações sociais.

As questões que começavam a se revelar naquele momento diziam respeito ao "o que realizar?" e "como fazê-lo?". Para o grupo, a importância do envolvimento e da participação das famílias assentadas em qualquer tipo de iniciativa já estava madura, e o desenvolvimento das relações pessoais seria o fator determinante para a viabilização das atividades em torno da produção habitacional.

Nosso primeiro grupo de pesquisadores envolvidos no projeto contava com a participação de A. Guéguen, arquiteta citada anteriormente, G. Delduque, arquiteto e pesquisador do HABIS, além da minha e dos respectivos professores e orientadores.

Quando o casal nos contou sobre a distribuição das famílias do assentamento em três grupos, uma questão importante surgiu com relação ao nosso processo de aproximação com as famílias assentadas. Como realizar um primeiro encontro com elas? Faríamos isso somente com o grupo da M. Silva e do G. Silva? Ou com todas as 83 famílias? E os coordenadores locais, como eles veriam tais possibilidades e como participariam e potencializariam as atividades?

A ideia era convidarmos as famílias assentadas interessadas pelas questões relacionadas à construção das casas a participarem de uma conversa onde pudéssemos discutir de forma coletiva a respeito das dificuldades vividas por elas naquele momento de acesso ao crédito habitação e como, nós arquitetos e pesquisadores, poderíamos contribuir para a melhora deste quadro.

Em seus estudos sobre tecnologias sociais, Amílcar Herrera (2010) constata que na maioria dos casos a utilização do conhecimento local não consiste simplesmente em adotar ou atualizar certas tecnologias tradicionais. O desafio consiste em extrair as ideias originais que elas podem conter, estudando-as e aplicando os recursos disponíveis na atualidade. 
"O aporte local mais importante provavelmente seria, mais do que tecnologias específicas concretas, novas aproximações à solução de velhos problemas que poderiam estimular a investigação científica em direções inexploradas até agora." (HERRERA, 2010, p.38)

Tanto M. Silva quanto G. Silva se disponibilizaram e ajudaram a encontrar algumas famílias mais próximas e a conversar sobre as situações habitacionais em que viviam. Conhecemos os três coordenadores dos grupos do assentamento e explicamos nossas intenções, nos preocupando em saber se achavam pertinentes e interessantes nossas propostas. Visto a grande dificuldade em visitar e explicar às 83 famílias, individualmente, nossas intenções, ficou combinado que cada coordenador falaria com as famílias de seus respectivos grupos e as convidaria para uma primeira conversa coletiva,

Próximo ao assentamento existe um conjunto de edificações que fazem parte do Centro Tecnológico da Agricultura Familiar (CEMOSAR), ligado à Secretaria Municipal de Agricultura e Abastecimento de São Carlos. Estes espaços abrigam atividades diversas, como: cursos, exposições, reuniões, seminários, encontros, entre outros. Assim, solicitamos o uso de uma sala para nossa reunião e marcamos a data de nosso encontro coletivo.

No dia 19/01/2013 fizemos nossa primeira conversa em grupo. Participaram oito pessoas, representando sete famílias do assentamento, mais nosso grupo de pesquisadores. Rapidamente, vale ressaltar uma condição que influenciou este encontro. No final do ano anterior haviam ocorrido as eleições municipais em todo o país, mudando o grupo e o partido no governo da cidade. Assim, a nossa reunião coincidiu com o início das atividades da nova prefeitura e quando o funcionário chegou no local para abrir as portas do Centro, as chaves não abriam os cadeados, que haviam sido trocados. Desta maneira, não pudemos entrar nos espaços internos, realizando nossas conversas do lado de fora do local. 

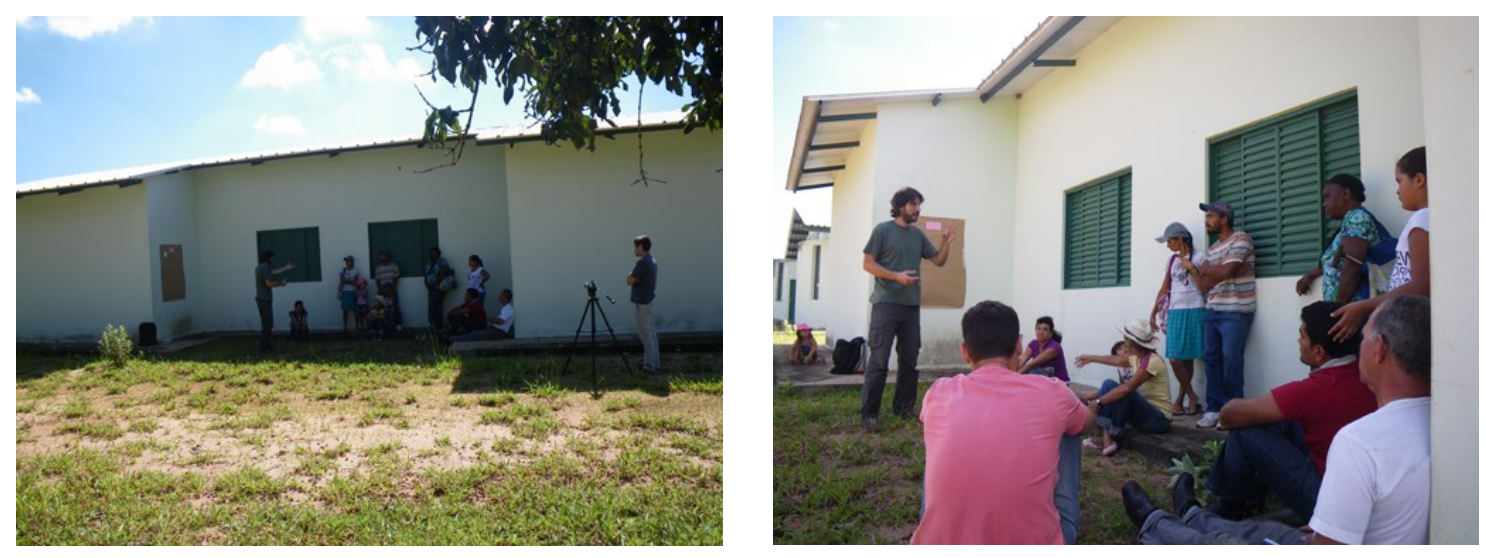

Fotos 47 e 48 - Primeira reunião com as famílias do assentamento.
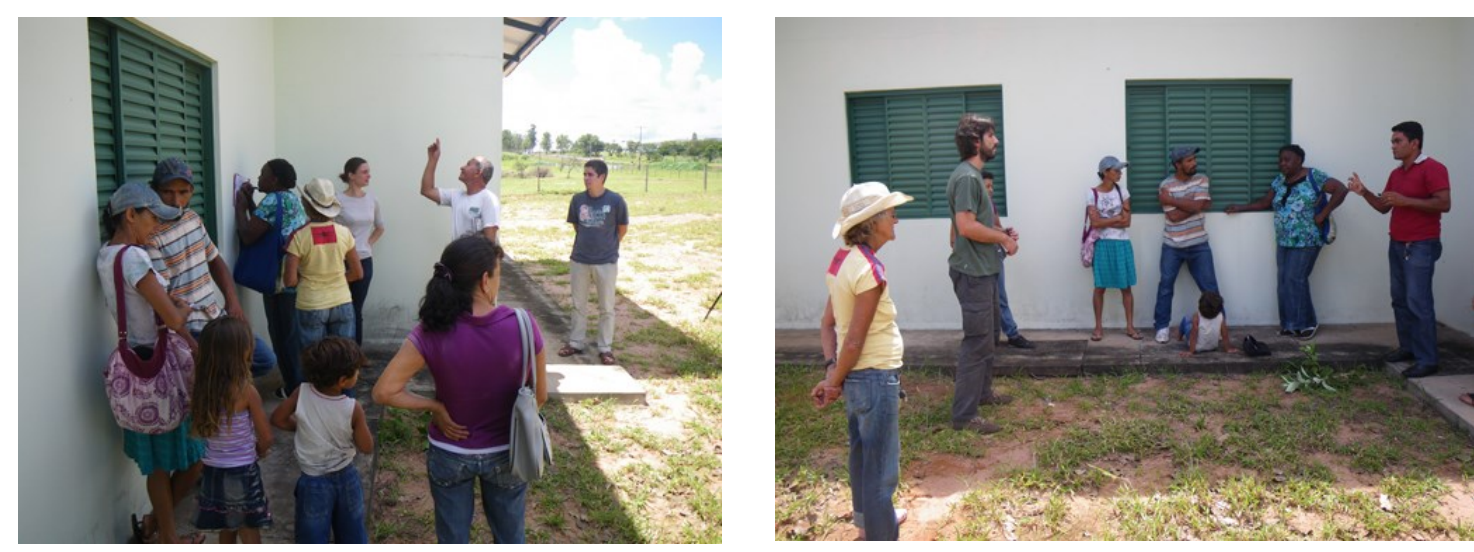

Fotos 49 e 50 - Conversas sobre a situação da construção das casas do assentamento.

Após a apresentação de cada um dos participantes, explicamos nosso processo de entrada na comunidade e começamos então a discutir sobre o propósito de nosso encontro. A intenção era criar uma série de atividades práticas e conversas técnicas ligadas à produção do habitat a partir de demandas levantadas pelo grupo interessado nas atividades.

Assim, propusemos um rápido exercício de elaboração coletiva de um "Quadro de Dificuldades", com o intuito de conhecermos melhor a realidade e as considerações de cada participante e de uma forma geral, as principais necessidades identificadas no conjunto do assentamento. Este exercício revelou algumas dificuldades que embora já fossem esperadas, contribuíram com a construção de um planejamento coletivo a respeito das atividades que poderiam ser pensadas e realizadas quanto à construção das casas. 

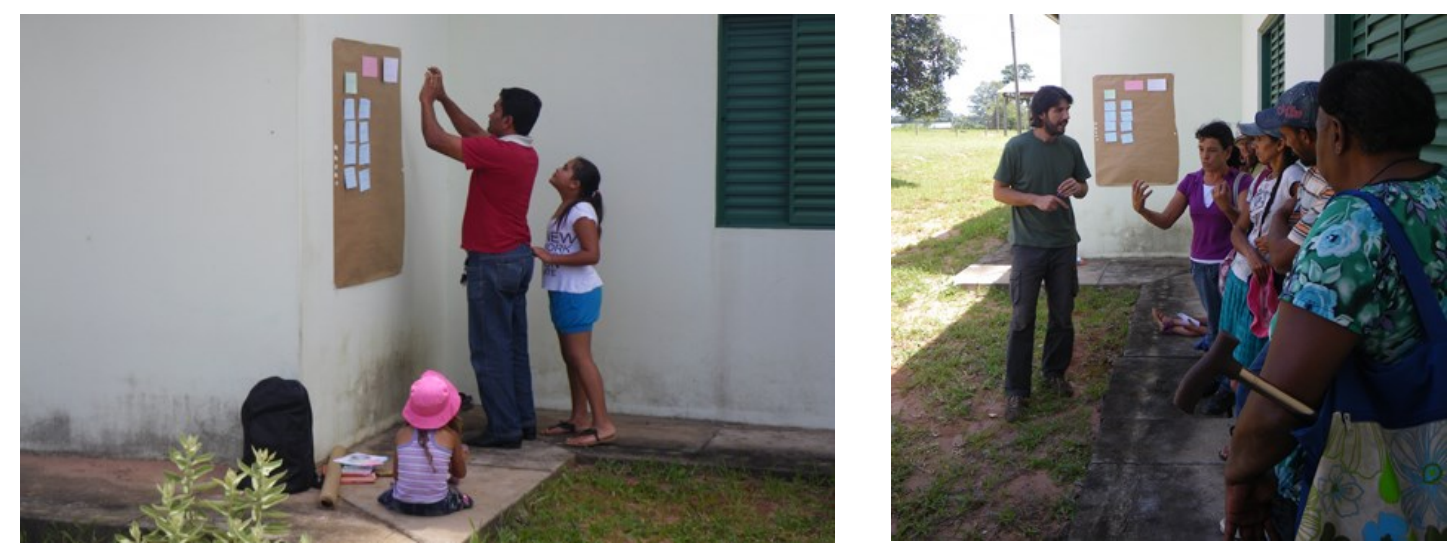

Fotos 51 e 52 - Elaboração e conversa sobre o "Quadro de Dificuldades".

De acordo com a opinião das famílias presentes, as dificuldades encontradas envolviam os seguintes temas: orçamento e quantitativo dos materiais necessários para uma construção; acesso a mão de obra qualificada; acesso a água; fundação e estrutura em função do tipo de solo; tratamento das águas sujas; acabamentos; implantação da casa e tipos de materiais existentes para a construção.

Embora os temas citados não representassem a totalidade das dificuldades vividas pelas famílias, a prática do diálogo foi de grande riqueza e boas perspectivas. Entre os participantes estavam presentes dois coordenadores de grupos que demonstraram interesse pelas ideias apresentadas. Os participantes escolheram um nome e o nosso novo grupo da habitação foi criado: "Conquista e Transformação". Este grupo teria o caráter coletivo, participativo e baseado em acordos de compromisso social. A partir dele, pensaríamos as ações prioritárias em prol da melhoria do quadro habitacional local.

Ficou também decidido, em grupo, que faríamos nossos encontros a cada 15 dias, nos sábados de tarde, sendo que a próxima reunião já seria no sábado seguinte, com o intuito de sensibilizar mais pessoas a participar. Foi sugerido, por uma assentada, a criação de convites para espalhar entre as famílias. Decidimos então que imprimiríamos os convites e deixaríamos com os coordenadores para que distribuíssem entre as famílias de seus grupos. Outra decisão tomada foi a de realizar as reuniões no galpão do assentamento (antigo estábulo e local do acampamento), ficando então mais próximas dos lotes familiares, além de potencializar o uso do espaço coletivo e assim uma maior participação das pessoas. 
Esse primeiro encontro aportou, por um lado, boas perspectivas de projeto baseadas na receptividade e participação das famílias presentes, embora pouco representativas quantitativamente. O fato de proporem o nome do grupo da habitação, planejarem a frequência dos encontros, seu local e sugerirem a confecção e distribuição de convites para sensibilizar as outras famílias a participarem dos diálogos, foi uma ótima surpresa para todos. Somado a isto, o "Quadro das Dificuldades" mostrou o interesse das pessoas a refletirem coletivamente as ações referentes a cada item elencado.

Por outro lado, tínhamos a consciência das dificuldades que teríamos para manter este grupo motivado e participando dos encontros, além de atrair outras famílias e ainda propor atividades que fossem realmente úteis para todos e produzissem resultados concretos. Nossas dificuldades começavam pela compreensão de como definir a operacionalidade de nossas ações, como fazê-las funcionar na realidade do assentamento.

Partindo das compreensões de Paulo Freire (2002), os projetos de apoio ao desenvolvimento dos grupos sociais oprimidos devem se propor não só a descobrir junto ao povo suas próprias necessidades, mas também a descobrir as formas tradicionais de satisfazê-las. Segundo ele, o processo educativo de resolver os problemas do povo, deve começar a partir do conhecimento empírico, que é o poder do povo de resolver seus problemas.

"O intelectual deve inserir-se, tomar parte ativa na participação das massas, e as massas tomarem parte ativa na participação do intelectual, para irem construindo juntos esse sonho possível e realizável, porque é a única maneira de responder às exigências que as massas se propõem." (FREIRE, op.cit., p.70)

No dia 26/01/2013 fizemos nossa segunda conversa em grupo. Participaram doze pessoas, representando onze famílias do assentamento, mais nosso grupo de pesquisadores. Das pessoas presentes, apenas três haviam participado do encontro anterior de modo que decidimos fazer novamente as apresentações de cada participante e explicar a nossa presença na comunidade, neste caso já inserindo a recuperação das atividades realizadas na semana anterior e as decisões tomadas pelo grupo presente 
naquele momento. A maior parte das pessoas expressou não ter tido conhecimento da realização de nosso primeiro encontro, o que nos chamou a atenção para o fato de que no início, a divulgação de nossa presença não tivera o êxito esperado. Entretanto, os convites funcionaram melhor já que novas pessoas apareceram em maior quantidade. Ainda assim, a maior parte daquelas que vieram no primeiro dia não pode aparecer ou perdeu a motivação pelo projeto.

Recuperamos os principais pontos tratados na semana anterior e os temas do "Quadro de Dificuldades" traçado. Em seguida, foi levantada a necessidade de fazermos uma atividade objetiva prática e não somente sessões de discussão, senão correríamos sérios riscos de ter as atividades esvaziadas e sem continuidade. $\mathrm{O}$ grupo expressou a vontade de criar atividades ligadas ao aprendizado de técnicas construtivas a partir da recuperação do galpão coletivo. A ideia seria realizar ações de renovação do espaço a partir de oficinas de formação ligadas às mais diferentes técnicas construtivas e às demandas das famílias.

O galpão coletivo poderia servir assim como espaço de experimentação e formação. As pessoas aprenderiam e praticariam diferentes técnicas construtivas na renovação do galpão, e depois poderiam reutilizá-las nas construções e melhorias das próprias casas.

O exercício realizado com as pessoas presentes consistiu na construção de um "Quadro de Prioridades do Galpão". Seguindo o mesmo método utilizado anteriormente, conversamos sobre como poderia ser este espaço. Foram discutidas diferentes possibilidades de uso coletivo do galpão, assim como as visões de cada um quanto aos materiais necessários e aos acabamentos desejados. Foi levantada a necessidade da construção de um banheiro e assim a possibilidade de fazermos uma fossa bioséptica, que poderia também servir como atividade de formação e referência para que as famílias construíssem suas próprias fossas sépticas. Entretanto, antes de construirmos o banheiro foram priorizadas outras ações.

As prioridades levantadas pelo grupo, em ordem de realização, foram: limpeza do entorno do galpão; reforma do telhado; construção de um banheiro e de uma fossa bio- 
séptica. A partir dali os próximos passos seriam novamente reavaliados. Foi também mencionada a necessidade de instalação de uma caixa d'água no galpão.
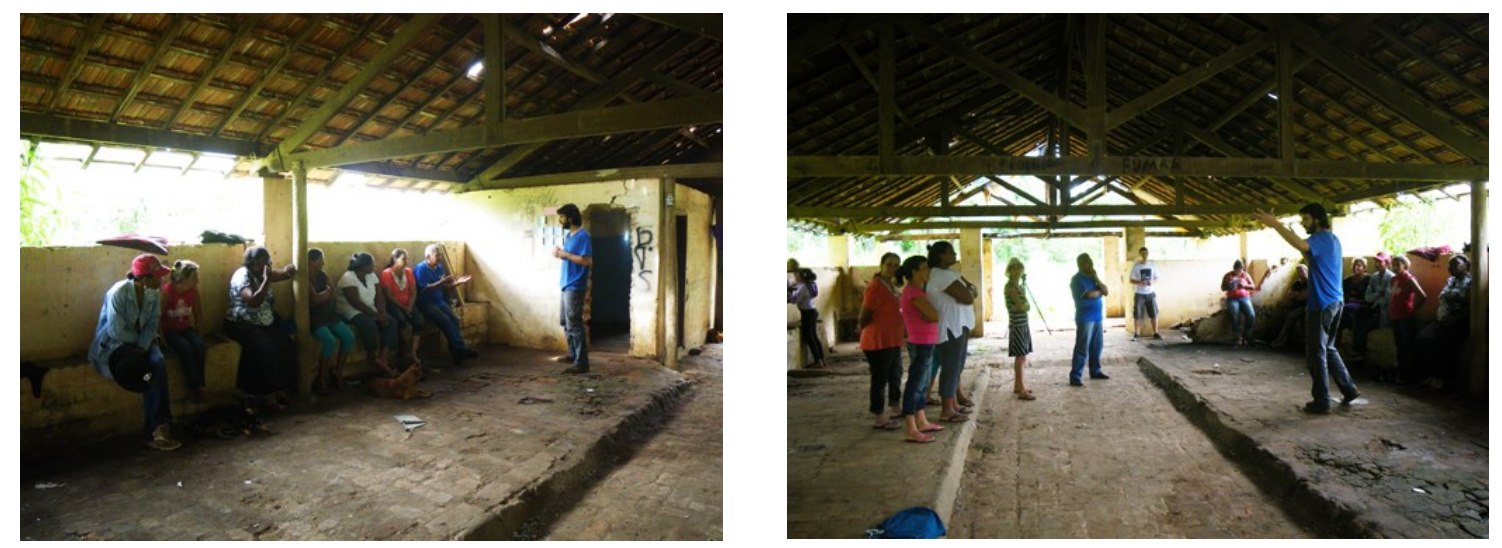

Fotos 53 e 54 - Segundo encontro coletivo de atividades sobre os temas do habitat.
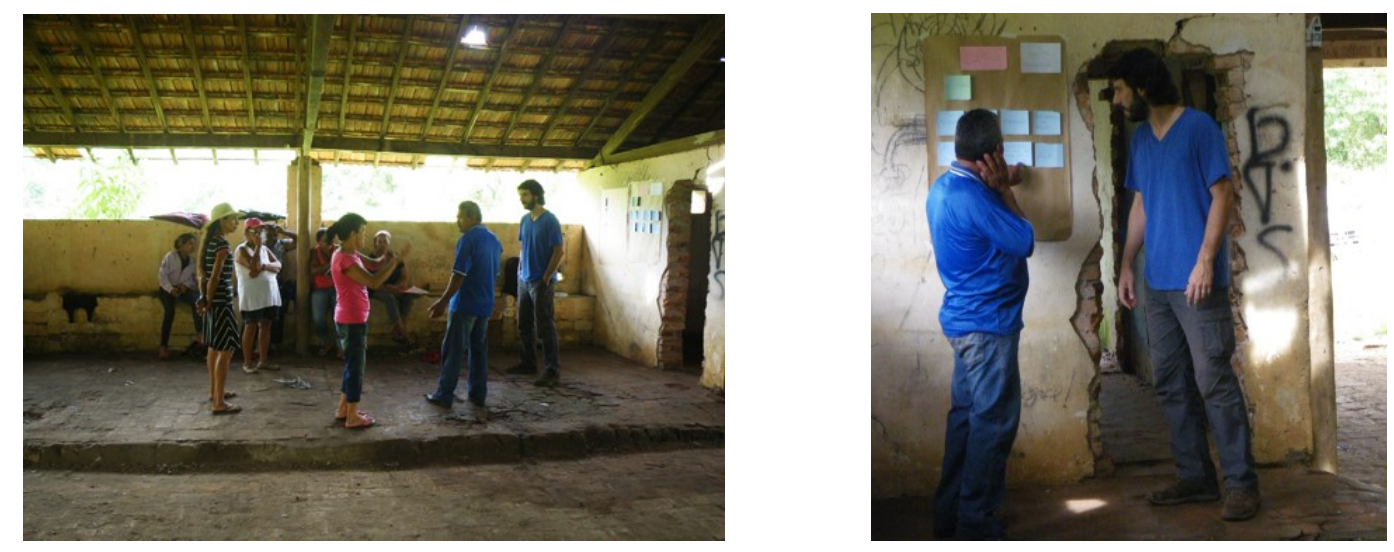

Fotos 55 e 56 - Elaboração do "Quadro de Prioridades do Galpão" e conversa sobre as ações.

É interessante notarmos como nestas discussões coletivas as diferenças entre as pessoas se revelam. Os desejos, os sonhos, assim como os medos e os comodismos afloram nos discursos e mostram posições ora complementares ora contraditórias. Há momentos em que a motivação ganhava espaço e todos acreditavam ser possível renovar o galpão. Eles se mostravam dispostos, discutindo sobre os passos para a execução das tarefas. Falaram até da necessidade de pintar as paredes e colocar um ventilador no teto do local. A descontração passou a ser observada com a participação de todos do grupo.

Outras vezes, contudo, as pessoas desacreditavam que as atividades pudessem atrair mais famílias a participar. Os depoimentos delas foram, em sua maior parte, 
direcionados a uma compreensão de individualidade por parte das pessoas assentadas. Segundo elas, não existe ambiência para o trabalho coletivo e solidário no assentamento. Cada um trabalha para si e não são raras as inimizades no local. Segundo o grupo presente, existem pessoas com interesses em dificultar o desenvolvimento do assentamento. O que se percebe, é a existência de um território dividido em grupos com diferentes afinidades e muitas divergências. Todos ressaltaram a importância da iniciativa, porém sem ilusão quanto à real inserção do coletivo de famílias no projeto.

Há de ressaltar que não é simples a condução destes tipos de encontros. As conversas são frequentemente cortadas por outros assuntos que se misturam e interrompem a linha de condução das reflexões. Às vezes, os debates são prolongados e as decisões de planejamento necessitam de um tempo maior para serem por todos compreendidas. Fruto, evidentemente, da própria dialética do processo proposto.

Foram discutidas novamente algumas estratégias para atrair mais famílias ao projeto. E cada pessoa presente se comprometeu a convidar e trazer um vizinho na atividade seguinte. A agenda dos encontros foi sendo acertada e ficou combinada que a próxima ação seria a limpeza do galpão. Cada um traria suas ferramentas de trabalho para capinar o entorno da construção e limpar sua parte interna. A ideia era fazer uma atividade prática para perceber o envolvimento das pessoas que participavam dos encontros e observar como seriam as reações de outras famílias do assentamento, que sabendo das ações realizadas, poderiam se interessar em participar.

No dia 02/02/2013 fizemos nosso terceiro encontro do grupo. Participaram seis pessoas, representando duas famílias do assentamento, mais nosso grupo de pesquisadores. Das pessoas presentes, apenas duas haviam participado dos encontros anteriores. A atividade marcada era a limpeza do galpão e durante toda a tarde quase ninguém passou pelo espaço.

O galpão serve também como lugar onde as pessoas deixam coisas como doações. Então, frequentemente roupas são largadas pelo chão esperando serem recolhidas pouco a pouco pelas pessoas interessadas. A ideia foi arrumarmos as roupas sobre alguns paletes de madeira que o G. Silva trouxe de seu lote, varrer o chão e cortar o mato em frente à entrada do galpão. 

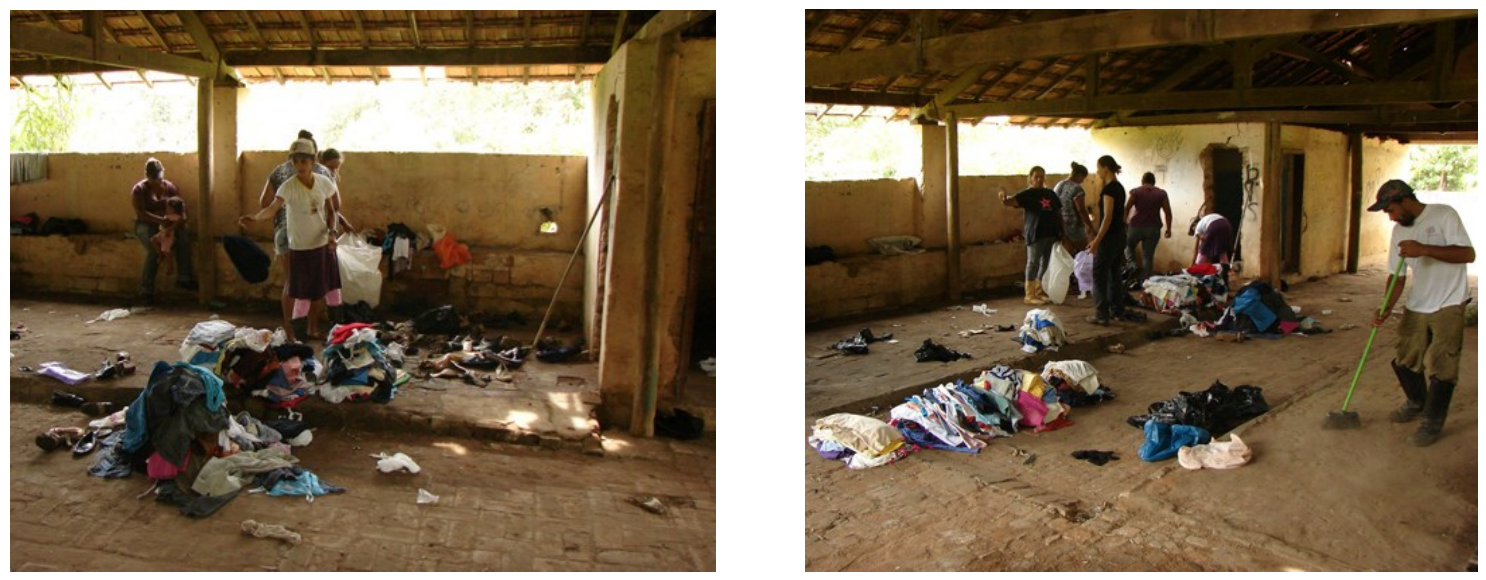

Fotos 57 e 58 - Atividades de limpeza e arrumação do galpão coletivo.
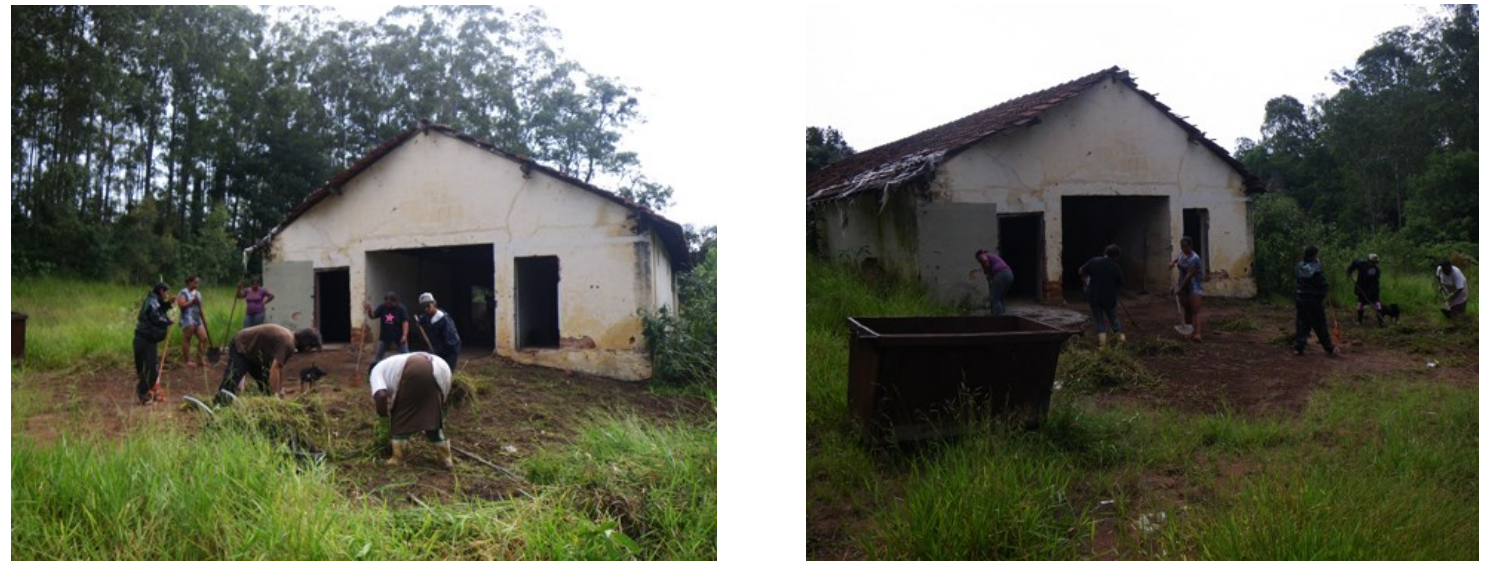

Fotos 59 e 60 - Capinagem e limpeza da entrada do galpão.

Esta atividade serviu para reanalisarmos nossas ações. Discutimos com o grupo os possíveis "porquês" do desinteresse das famílias pelas atividades; a eficiência ou não da divulgação e distribuição dos convites; os comentários entre as famílias no dia a dia do assentamento; as possibilidades de influências contrárias à nossa presença no local; e as alternativas ainda possíveis de serem tentadas por nós.

De fato, as atividades realizadas não surtiram o efeito desejado. Por um lado, as famílias não estavam organizadas socialmente, nem politicamente, sendo que as estratégias de sobrevivência ocorrem a nível familiar e não de forma coletiva e organizada. De outro, nosso grupo de pesquisadores não possuía estrutura e nem estava preparado a agir sem a comunidade organizada, participando das atividades e das tomadas de decisões. Somente duas famílias vieram nas três atividades realizadas, sendo uma antiga moradora da fazenda, anterior à existência do assentamento, e que foi 
autorizada a morar em uma casa já existente no local e, a outra, a família da M. Silva e do G. Silva. Ninguém mais participou consecutivamente das atividades e nem avisou das ausências, mesmo tendo demonstrado motivação num primeiro momento.

Foram relatadas pelas pessoas presentes algumas iniciativas já realizadas no assentamento com o intuito de fomentar o trabalho coletivo ou tentar a associação entre algumas famílias parceiras. Mesmo alguns cursos do governo, propostos de forma gratuita, estão constantemente esvaziados e não conseguem atrair o interesse das famílias locais.

O que nos fez realmente parar e repensar as atividades foi um fato ocorrido durante a semana após a atividade de limpeza do galpão. Este, apareceu bagunçado, com as roupas que haviam sido arrumadas espalhadas pelo chão. Era um sinal de que nossas ações poderiam não ser perenes e serem até destruídas por algumas pessoas não contentes ou não interessadas em nossa presença.

Estava claro que se continuássemos com a mesma estratégia de ação rapidamente perderíamos todas as pessoas participantes, pois necessitávamos de um projeto maior, com mais técnicos participando, com outros recursos envolvidos e com uma melhor articulação política para que construíssemos uma atividade abrangendo o coletivo das famílias assentadas.

Para nossa surpresa, na semana seguinte ocorreu um encontro no galpão entre a empresa contratada pelo INCRA para prestar assistência técnica no assentamento e a maior parte das famílias moradoras. O tema das discussões era a possibilidade das famílias acessarem um crédito financeiros de apoio à produção. Seria uma oportunidade para encontrar e conversar com as famílias. No dia previsto, fomos ao encontro e depois das discussões encerradas pedimos licença ao grupo da assistência técnica e fizemos um convite para os interessados em aprender sobre a construção de fossas biosépticas.

Como estavam no momento de construção de suas casas, as famílias teriam que construir suas fossas sépticas e, seria interessante realizar um curso sobre construção de fossas bioséptica articulado a algumas atividades de saneamento ambiental. Talvez nossa primeira atividade prática fosse articulada aos tratamentos das águas sujas. 
Para nossa satisfação, 14 famílias vieram discutir e se interessaram pelo possível curso. Todas demonstraram bastante curiosidade e vontade em aprender gratuitamente a construir uma fossa bioséptica. Ficou, então, combinado que no sábado seguinte faríamos uma conversa entre os interessados no próprio galpão e montaríamos nosso calendário do curso. Dois dias antes do encontro, telefonamos para confirmar com as famílias nossa atividade e apenas nove pessoas confirmaram presença.

No dia do encontro, somente quatro pessoas compareceram (sendo dois da família da M. Silva, a coordenadora de um dos grupos do assentamento e um morador do acampamento vizinho que nunca participara de nossos encontros e viera conhecer a atividade). Mais uma vez evidenciou-se o desinteresse pelas atividades por parte das famílias. Mesmo assim realizamos nossa atividade sobre a fossa bioséptica, com os presentes.
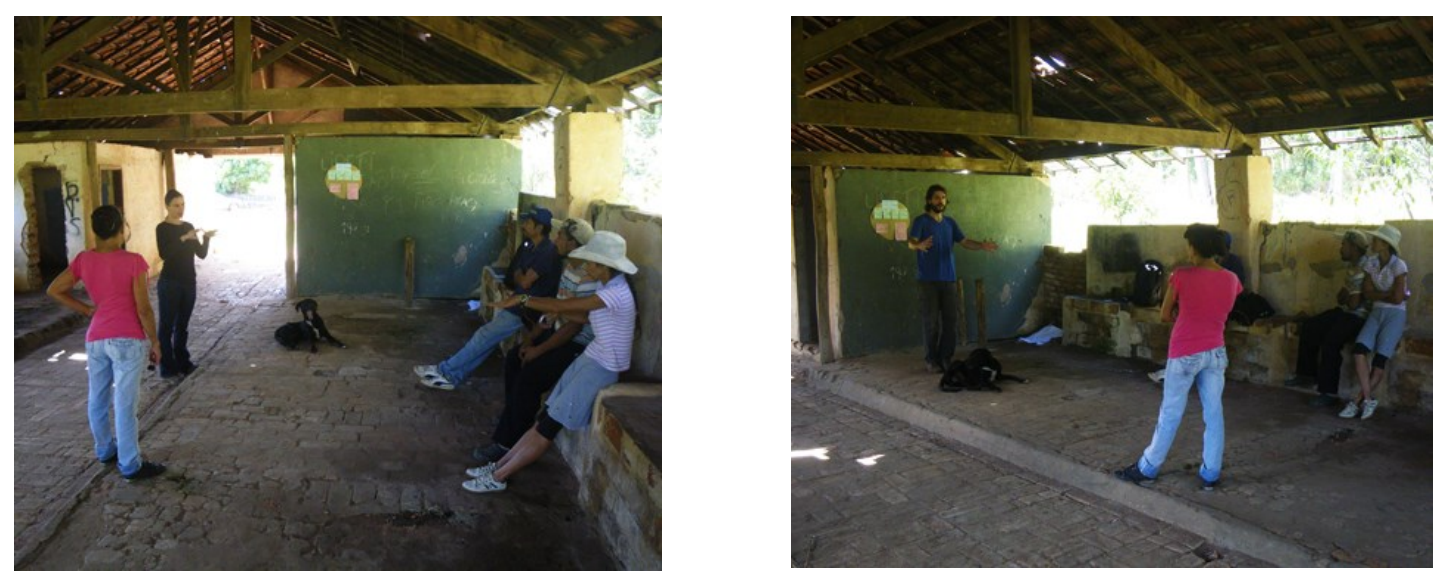

Fotos 61 e 62 - Conversa sobre a fossa bioséptica no galpão do assentamento.

Neste dia ficou decidido com o grupo presente que faríamos uma primeira fossa bioséptica na casa de I.Lurdes (coordenadora de um dos grupos do assentamento). Como ela já possuía um banheiro construído em sua casa e ainda não tinha tratamento das águas sujas, pensamos em fazer o curso em seu lote, convidando as pessoas para participar e aprender a construir a fossa a partir de um primeiro protótipo concreto.

Fizemos, então, uma visita ao lote da moradora escolhida. Conversamos sobre a localização da futura fossa e passamos o tamanho do buraco que seria necessário realizar para construirmos a fossa bioséptica. Combinamos que depois da família abrir o buraco, 
voltaríamos ao lote para planejarmos o curso. Entretanto, a família não deu seguimento às atividades e o projeto acabou não ocorrendo.

Neste momento, o grupo de pesquisa se encontrou numa realidade desprovida de boas perspectivas. As tentativas não haviam atingido o resultado esperado e as atividades mais objetivas e de curto prazo, como a construção da fossa bioséptica, não foram suficientes para mobilizar as famílias assentadas em torno de um processo coletivo de produção. O momento era de repensar nossa presença dentro do assentamento.

Surgiu a possibilidade de mudar a orientação das estratégias de ação. Ao invés de trabalharmos com o coletivo de famílias, seja através de práticas construtivas na renovação do galpão ou na construção de fossas bioséptica, pensamos na possibilidade de trabalhar em um lote específico. Poderia ser esta uma primeira atividade com potenciais mais concretos e quem sabe fomentadores da aproximação, sensibilização e novos engajamentos das demais famílias.

Das famílias que participaram dos encontros realizados, somente a família da M. Silva e do G. Silva veio em todos os momentos. Somente esta família, entre as participantes, não acessou o crédito habitação e ainda mora em uma situação bastante precária. Quando a chuva chega e os ventos mostram suas forças, a habitação resiste em não desmontar e levar consigo os poucos pertences familiares. O casal, sempre esteve motivado em continuar tentando realizar alguma atividade coletiva, mesmo com a baixa participação dos outros assentados. Somado a isso, o fato do G. Silva ser trabalhador da construção civil e possuir bastante interesse em aprender técnicas ecológicas de construção com madeira e terra, nos parecia um potencial a ser explorado em novas parcerias e trocas de conhecimento. Certa vez, ele nos revelou sua vontade em morar em uma casa de pedra, citando o desenho animado dos "Flintstone", e sua expectativa em construir a fossa bioséptica e de reproduzi-la na casa de sua mãe.

Assim, avançamos na reflexão sobre a possibilidade de trabalhar uma parceria com esta família na construção de sua casa. Mas, como isto poderia acontecer? Quais as condições de realização? E os recursos necessários? E as outras famílias como veriam tudo isso? Enfim, uma série de novos questionamentos começaram a surgir e a primeira ação feita foi a elaboração de um "Quadro de Condições Favoráveis e Desfavoráveis" para 
a realização do projeto tanto no galpão quanto no lote familiar. Foram pensadas condições como: governabilidade, segurança, potencial de replicabilidade, tempo das decisões e ações, coesão social, arbitrariedade, imprevistos, controle de frequência, financiamento externo, maior participação coletiva, motivação das pessoas, representatividade das tomadas de decisões, possibilidades de experimentações, impactos do projeto, financiamento da família e apoios.

Cruzando as informações começamos a desenhar a viabilidade de nossas ações. $\mathrm{Na}$ perspectiva da construção da habitação familiar, teríamos o possível quadro, comparado com a renovação do galpão:

Pontos potenciais: Maior governabilidade no processo de produção do habitat; maior segurança nas atividades (para os participantes); maior segurança para guardar os materiais e ferramentas; grande motivação por parte da família; maior facilidade nas tomadas de decisões; maior rapidez no calendário das atividades (a agenda se faz com uma única família); menos riscos de não concluir o projeto; maior possibilidade de experimentações (pois será uma nova construção); possibilidades de melhor equilíbrio entre tempo/\$/energia; maior possibilidade de utilizar processos de produção ecológicos (a família está disposta); o pai da família trabalha na construção civil; etc.

Pontos limitantes: Menor participação coletiva das famílias assentadas; menor escala de replicabilidade do projeto; menor potencialidade de coesão social no assentamento; maior risco de inveja ou inimizades com outras famílias da comunidade; maior risco de rompimento do compromisso (pois é somente uma família quem decide); maior dependência das possibilidades financeiras da família; etc.

Esse processo de análise dos caminhos a seguir permitiu definir as orientações principais, clarificando os objetivos e as prioridades. Possibilitou, também, legitimar as escolhas a partir das análises feitas sobre a realidade social e seus elementos influentes. Parecia mais viável realizarmos uma atividade num lote familiar naquele momento. Talvez, com uma prática concreta e uma nova referência pudéssemos, posteriormente, alavancar novas práticas coletivas junto a outras famílias do assentamento. 
O passo seguinte foi conversar com a família em questão. Saber suas opiniões, expectativas, e discutir quais possibilidades poderíamos construir. Foi um momento de avaliação de nossas atividades, das diversidades de situações vividas, das escolhas feitas, das necessidades percebidas, dos limites e potencialidades existentes, entre outros. A família demonstrou interesse em experimentar, na construção de sua casa, materiais ecológicos e práticas coletivas de trabalho e aprendizagem.

Conversando com a professora Akemi Ino (Coordenadora do Grupo Habis), surgiu a ideia de propormos no Instituto de Arquitetura e Urbanismo um curso optativo, num primeiro momento, e levarmos os estudantes para o assentamento com o intuito de pensarmos todos juntos a construção da nova casa. Essa ideia foi sendo amadurecida e foi dando corpo a uma proposta com enorme potencial de realização. Fomos planejando e delineando o formato do novo curso através das possibilidades abertas na Universidade e das condições e opiniões da família. Ao invés de continuarmos buscando sensibilizar as famílias do assentamento a participar das atividades, pensamos em construir uma "ponte" a partir da Universidade e trazer pessoas interessadas em experimentar uma prática diferenciada de produção do habitat.

Pouco a pouco, nossas perspectivas de ação foram apreendendo novas formas e revelando a conexão com outras possibilidades. A dimensão pedagógica começou a ampliar-se e nosso horizonte de atuação começou a transformar-se. Como pensarmos as questões da produção do habitat à luz do paradigma experimental de novas perspectivas pedagógicas? A experimentação construtiva enquanto método pedagógico poderia materializar novas possibilidades externas aos muros da Universidade, realizando-se sob as conjunturas da realidade social de um assentamento rural de reforma agrária. Como se dariam as atividades, seus tempos, seus modos, suas faces, seus códigos, seus acordos, suas perspectivas e contradições, etc.? 


\section{A Casa Suindara em suas primeiras práticas}

"Cada canteiro livre é uma universidade. (...) No canteiro livre a discussão é permanente - e, como então toda posição autoritária é abolida, a necessidade de explicação, de argumentação lógica empurra a autoconsciência para frente." (FERRO in BENOIT, 2002, p.149)

Foi no exercício de se adaptar ao formato e às características de um curso optativo que nossas práticas começaram a considerar e delinear novas perspectivas: um espaço de sala de aula com 1h40min. de atividades por semana, ao longo de um semestre, com possibilidades de viagem a campo nos finais de semana e de abertura metodológica à prática dialógica de construção das reflexões relacionadas ao habitat rural. A ementa do curso anunciava: "Pretende-se desenvolver junto com uma família assentada o projeto de sua nova residência utilizando-se sistemas construtivos de madeira e terra, a partir dos materiais disponibilizados localmente. Serão projetados e construídos tais sistemas construtivos dentro do assentamento, com o intuito de serem analisados e desenvolvidos para posterior construção da unidade habitacional."

Assim, iniciou-se o curso "Parâmetros para projetos de elementos de madeira IAU693", do Instituto de Arquitetura e Urbanismo da USP/São Carlos, sob a coordenação e responsabilidade da professora Akemi Ino e do grupo de pesquisa em Habitação e Sustentabilidade - HABIS. Nossa expectativa por 15 participantes foi superada por 34 inscritos que demonstrando interesse e motivação concordaram em participar do desafio de conceber uma habitação a partir da produção local de tecnologias, compartilhando das condições, recursos, conjunturas e formas, existentes e criadas no lote, no canteiro e no próprio processo produtivo.

O eixo central era incentivar o exercício de criar, experimentar e desenvolver, a partir do uso e transformação dos materiais, ferramentas, recursos e inteligências disponíveis, alguns sistemas construtivos que nos orientassem em nossas escolhas produtivas. Neste desafio metodológico, a pesquisa-ação continua sendo o eixo central da articulação entre o espaço acadêmico e o espaço rural do assentamento. A parceria estabelecida entre o grupo e a família através das práticas dialógicas e conversas coletivas 
propunha aos envolvidos a participação proativa como sujeitos atuantes, que pensam e agem em direção a uma intenção crítica do projeto de habitat e de seus processos construtivos. Ademais, o processo de reflexão e ação coletiva necessita, constantemente, adaptar-se ao imprevisível presente no dia-a-dia, e se organizar e reorganizar a partir das situações relevantes que emergem regularmente deste processo.

Os acordos estabelecidos entre o grupo de participantes previam duas atividades semanais. Às segundas-feiras, os encontros teóricos se dariam em sala de aula, através de discussões teóricas e elaboração dos projetos, e aos sábados à tarde, o trabalho se faria no lote familiar do assentamento, através das diversas práticas construtivas e vivências experimentais que o lote e seus elementos forneceriam a cada nova visita. No total foram previstos 15 encontros em sala de aula e 14 idas ao assentamento durante o semestre.

Esta perspectiva de atuação onde exercitamos a aproximação da reflexão científica universitária com a prática concreta na realidade social, aproximando o "mundo dos estudantes" do "mundo dos assentados", em suas múltiplas faces, através das diversas idas, vindas e permanências, nos permitiu conjugar na mesma experiência produtiva diferentes elementos de ação e de análise.

As estratégias dos encontros teóricos e do desenrolar das atividades práticas se dividiram e assumiram duas vertentes. O encontro na sala de aula estabeleceu seus acordos, compromissos, calendários, objetivos e métodos de ação. A intenção era criar espaços de debates sobre temas, como: habitação popular, assentamentos rurais, arquiteturas vernáculas, culturas construtivas, técnicas construtivas em madeira, construções com terra, entre outros, além de conceber junto ao grupo de participantes diferentes propostas de projetos para a nova casa da família. Isso aconteceria a partir de uma série de trocas e diálogos que faríamos com os mesmos através de suas vindas à Universidade.

Os projetos arquitetônicos possuíam alguns princípios norteadores. O primeiro deles indicava para o melhor aproveitamento das possiblidades de utilização dos materiais disponíveis localmente e na região, nos processos de concepção dos projetos, assim como, nas produções dos diferentes sistemas construtivos. Assim, os estudantes 
projetaram sistemas construtivos com os materiais disponíveis, articulando-os aos projetos arquitetônicos, delineados, por sua vez, pelos diálogos em grupo e com a família.

O outro princípio norteador indicava a necessidade de inserir o projeto dentro de sua realidade social, ou seja, dentro das dinâmicas que envolvem e interferem nas realidades dos assentamentos rurais. Para isso, era necessário revelar as características, valores, condições, históricos, elementos culturais, entre outros, presentes naquele mundo rural, e suas relações estreitas para com o mundo urbano de São Carlos. Assim, as relações sociais construídas entre os participantes (entre si e com a família) foram fundamentais para uma melhor compreensão dos "por quês" e "como" daquela realidade, de modo a enriquecer nossas reflexões e escolhas de projetos.

Num primeiro momento, havíamos observado a possibilidade de utilizarmos a terra encontrada no lote - de caráter arenoso -, as toras de eucalipto do local e da região, assim como, pensarmos na viabilidade de usar os paletes de madeira que frequentemente são encontrados no entorno, devido à proximidade do assentamento com o distrito industrial da cidade, zona onde regularmente trafegam e são descartados centenas de paletes utilizados nos transportes dos produtos das indústrias ali instaladas.

Assim, as atividades práticas aos sábados propunham a construção de um espaço de trabalho coberto, onde pudéssemos armazenar os materiais e montar uma bancada de trabalho para o grupo. Paralelamente, a ideia foi de construir um banheiro seco para que os participantes pudessem utilizá-lo ao longo do semestre. Como desafio, ele poderia ser realizado com os paletes encontrados no lote, numa primeira tentativa de explorar as possibilidades de trabalhar com os mesmos. Já num segundo momento, com estes dois espaços prontos, os trabalhos práticos se orientariam em direção às criações e experimentações dos sistemas construtivos concebidos pelos grupos em sala de aula.

Fizemos então nossa primeira ida ao lote familiar. Trinta e quatro participantes mais alguns membros do grupo HABIS e a família iniciaram o processo a partir de uma apresentação coletiva com as expectativas e históricos de cada um, seguido de uma conversa sobre as condições do curso, as conjunturas do assentamento, os problemas estruturais vividos pela família em seu lote de vida e produção, entre outros. 
A série de fotos abaixo ilustra as explicações abordadas. A intenção é expor, através das imagens, o caminho percorrido ao longo do semestre, tecendo algumas reflexões na medida em que avançamos e que acumulamos os elementos de análises.
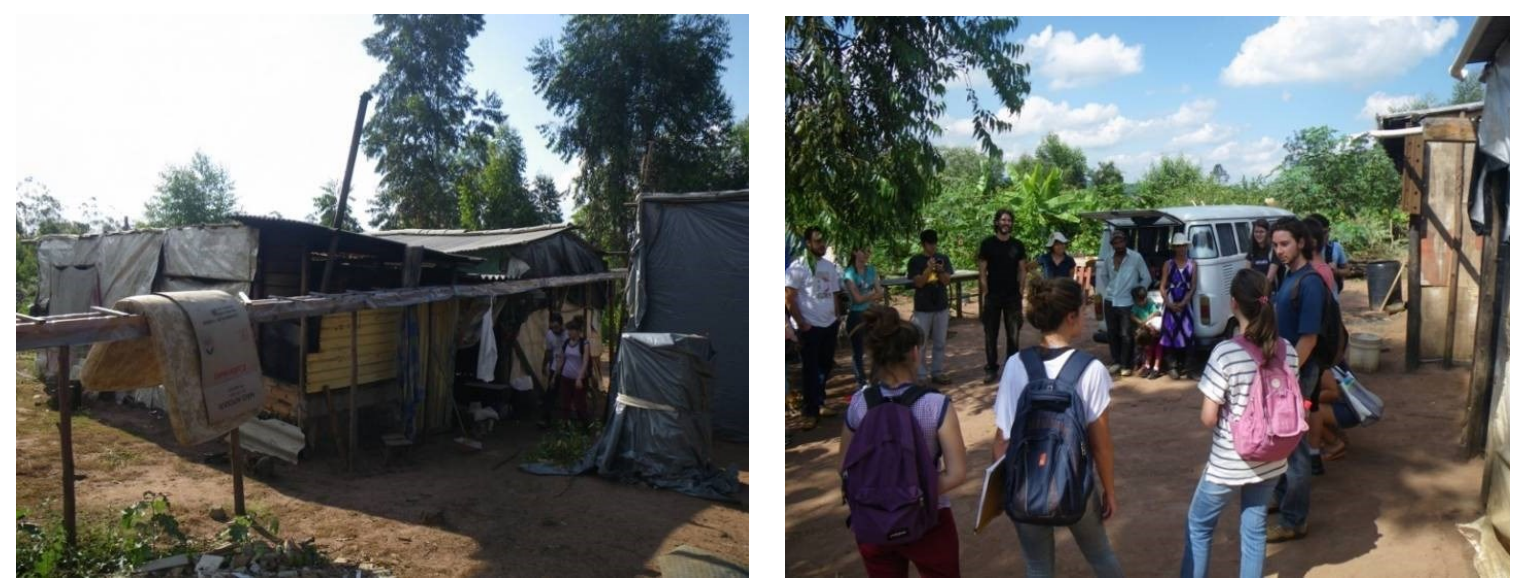

Fotos 63 e 64 - Primeira visita coletiva ao lote familiar e apresentação dos participantes do curso. Após as primeiras impressões, foram expostas as atividades, os objetivos e os grupos de trabalho.

O formato do curso foi rediscutido entre os participantes, desta vez com a participação da família. Os diferentes tempos (do curso, dos participantes, da família, da produção, dos recursos financeiros, das pesquisas relacionadas, assim como da relação entre todos estes diferentes tempos) influenciavam e "orientavam" nossas escolhas e nossos posicionamentos. E essas condições deviam ser discutidas coletivamente para que todos se apropriassem do debate e dos encaminhamentos, e pouco a pouco amadurecessem seus diferentes olhares críticos sobre a complexa realidade que estavam vivenciando.

Num "equilíbrio" de condições de ação e no esforço de estabelecermos certos acordos e compromissos a partir de nossas expectativas, possibilidades e engajamentos, uma espécie de "contrato social" começou a ser tecido em prol do bom desenvolvimento das atividades. Esse "contrato social" foi sendo revisto e transformado coletivamente ao longo do tempo, sempre que necessário. Os compromissos acertados para a realização do projeto foram organizados em itens, como: "por parte do grupo de participantes"; "por parte da família"; "entre a família e o grupo de participantes"; "condutas durante as atividades" e "proibições e recomendações". 
O lote familiar faz divisa com uma área de reserva legal (área do assentamento destinada à reserva florestal), ao sul e a oeste, e com a linha férrea, ao norte e leste. Desta maneira, ele se encontra reservado e mais distante dos demais vizinhos. Orientados por G. Silva, o grupo fez um passeio de reconhecimento do lote, passando pelos espaços de criação dos porcos, galinhas, hortas e outros pontos referenciais da família, visitando o sistema de captação das águas das chuvas através dos longos canos erguidos por toras de madeira até uma bacia cavada no chão como reservatório, chegando por fim, ao limite leste do lote onde aproveitamos da bela vista da região do entorno do assentamento. A conversa foi orientada pela vontade do grupo de conhecer a trajetória da família. Como eles vieram parar ali? Como foi o processo de acampamento e de assentamento? As dificuldades vividas quanto à educação das crianças, do acesso à energia e água, dos créditos bancários? As perspectivas e motivações? As relações com os moradores do bairro urbano vizinho? Dentre inúmeras questões levantadas.
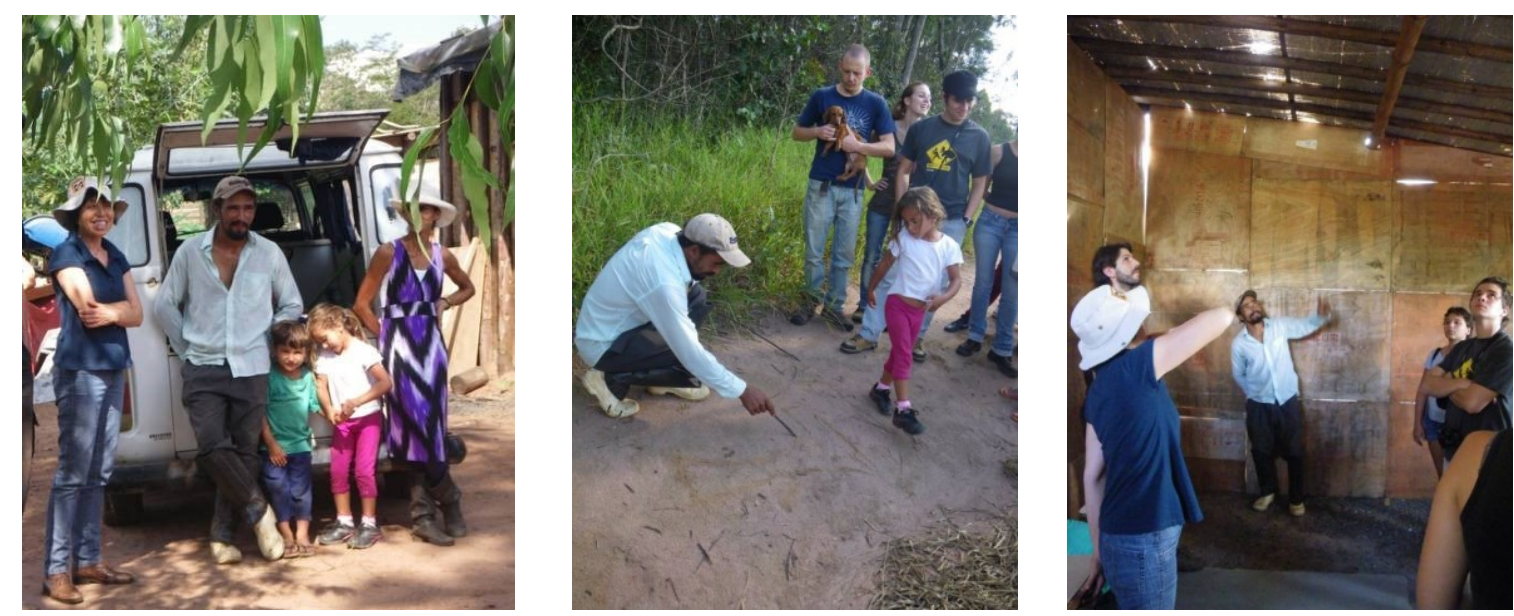

Fotos 65, 66 e 67 - Foi realizada uma caminhada de reconhecimento pelo lote e seus espaços construídos e cultivados. A família explicou o processo vivido durante o acampamento e a realidade que enfrentam diariamente.

As atividades começaram, então, a ser discutidas em grupos e os primeiros acordos e ações foram sendo colocados em prática. Os grupos foram se organizando segundo as tarefas e afinidades pessoais, e os trabalhos iniciaram-se com o intuito de compreender o lote em que estávamos. Como era sua forma, seus limites, suas vegetações? Onde passavam as curvas de níveis, os caminhos e os acessos? Qual era a orientação do lote com relação às trajetórias do sol e dos ventos predominantes? Quais eram as construções existentes e onde estavam os espaços de produção? 
O primeiro exercício consistiu na realização de um diagnóstico parcial do lote, medindo algumas distâncias importantes para a escolha dos lugares onde seriam construídos o espaço de trabalho, o banheiro e posteriormente a casa.

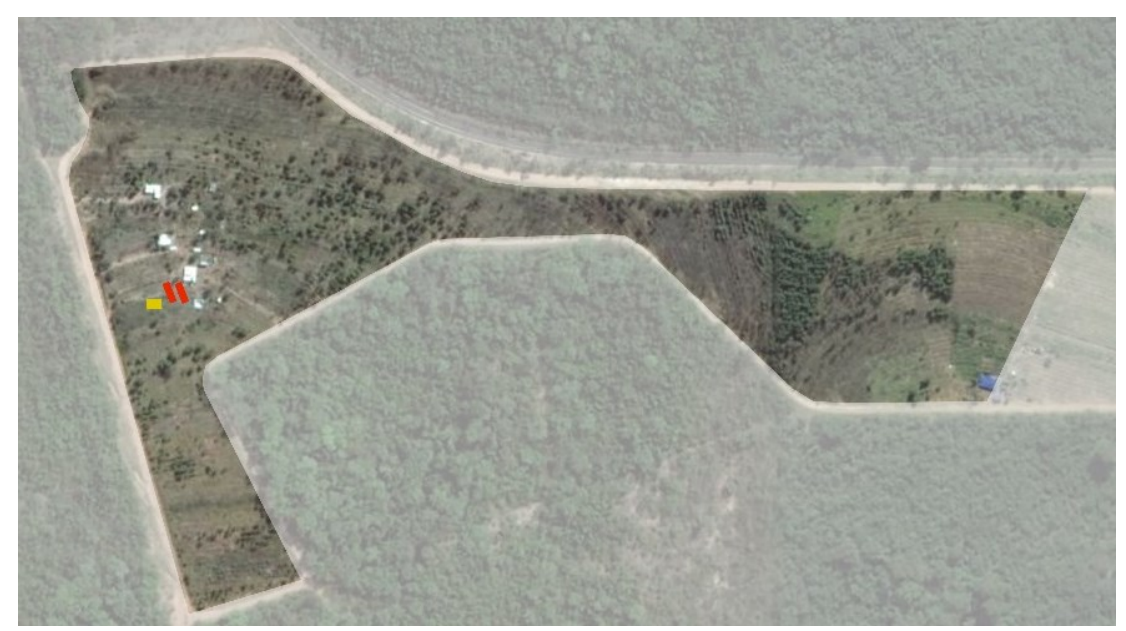

Figura 8 - Foto aérea do lote familiar com as construções existentes em branco, a inserção do galpão de trabalho em amarelo e da futura casa em vermelho.
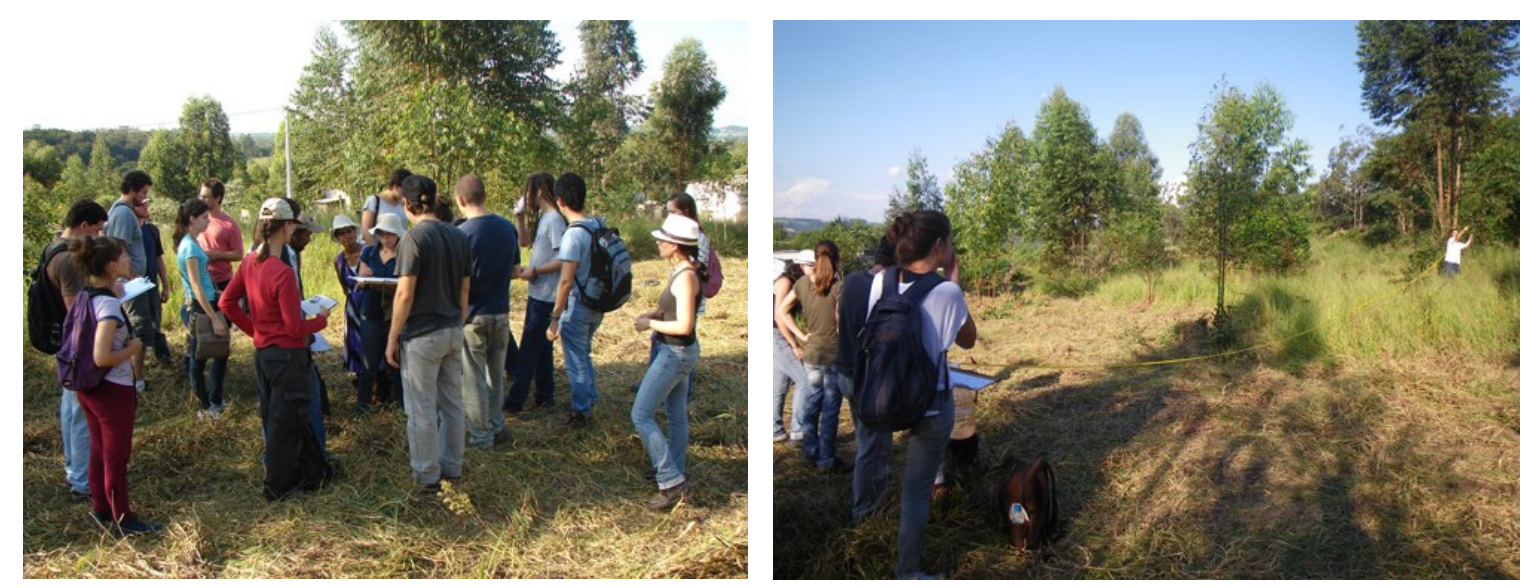

Fotos 68 e 69 - Percepção e debate em grupo sobre os elementos principais encontrados no lote e primeiras medições e opções para a locação do espaço de trabalho.

Localmente, os materiais disponíveis eram: a terra, arenosa com cerca de $70 \%$ entre grãos finos e médios, $20 \%$ de siltes e argilas pouco ativas; os eucaliptos, que embora fossem destinados às indústrias de celulose, não sendo recomendados para o uso na construção civil, nos serviriam de forma satisfatória para o espaço de trabalho temporário; e os paletes de madeira de pinus, que descartados pelas fábricas do entorno já eram utilizados tanto pela família (no chiqueiro e galinheiro) quanto por outros moradores do assentamento. 
As ideias gerais para o espaço de trabalho consistiam na construção de um ambiente livre, sem paredes, formado de uma estrutura em trocos de eucaliptos e uma cobertura, provisória, em lona de plástico. Precisávamos pensar nos encaixes e junções entre as peças da estrutura, e entre estas com o solo e a lona. A princípio, o espaço teria cerca de $6 \mathrm{~m} \times 9 \mathrm{~m}$. O banheiro seco, por sua vez, poderia ser uma estrutura simples, com fechamentos laterais e uma cobertura, prevendo uma abertura de acesso. Suas dimensões poderiam ser adaptadas aos materiais disponíveis, buscando justamente otimizar o tempo da construção e a quantidade de materiais. A ideia era que estas construções pudessem ser feitas rapidamente para que iniciássemos os processos de experimentação dos sistemas construtivos.

Com as primeiras escolhas feitas, os grupos avançaram em suas atividades. Um deles catalogou e caracterizou os paletes disponíveis e outros materiais existentes, como por exemplo, as diversas caixas de madeira utilizadas para o transporte de motores de automóveis e que também eram descartadas. Outro grupo iniciou a busca, corte e transporte de troncos de eucaliptos encontrados no lote da família para serem posteriormente descascados. E assim, os trabalhos foram se desenvolvendo.

As ações começaram a delinear suas perspectivas na medida em que foram sendo assumidas e apropriadas pelos participantes. Cada um começava a se perceber, a seu tempo, como sujeito atuante e produtor, com menor ou maior intensidade. As curiosidades, criatividades, engajamentos e intensões foram compondo a diversidade das participações e o caráter mutável de organização das atividades.

O desafio de pensar como utilizar os paletes, as caixas de madeira, os troncos de eucaliptos e a terra, misturava práticas experimentais com processos de criação tecnológica, onde os envolvidos se indagavam sobre as relações entre os tempos, as energias de produção, os conhecimentos necessários, os custos agregados, as viabilidades técnicas, os acordos entre os participantes dos grupos, etc. Nossa intenção era experimentar sistemas construtivos para depois avaliarmos, desenvolvermos e escolhermos aqueles que poderiam ser utilizados na construção da casa. 


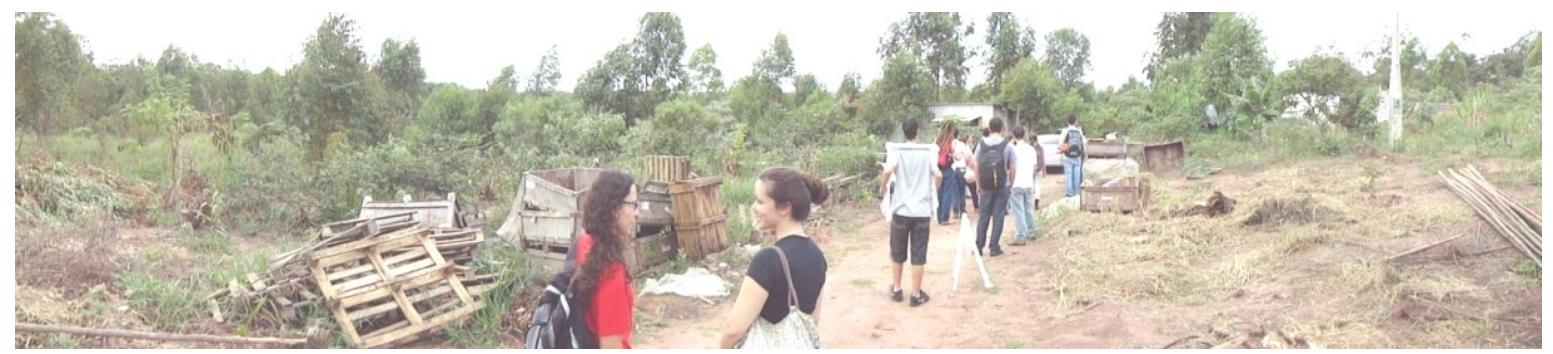

Foto 70 - Chegada dos participantes e início dos trabalhos práticos no lote familiar.
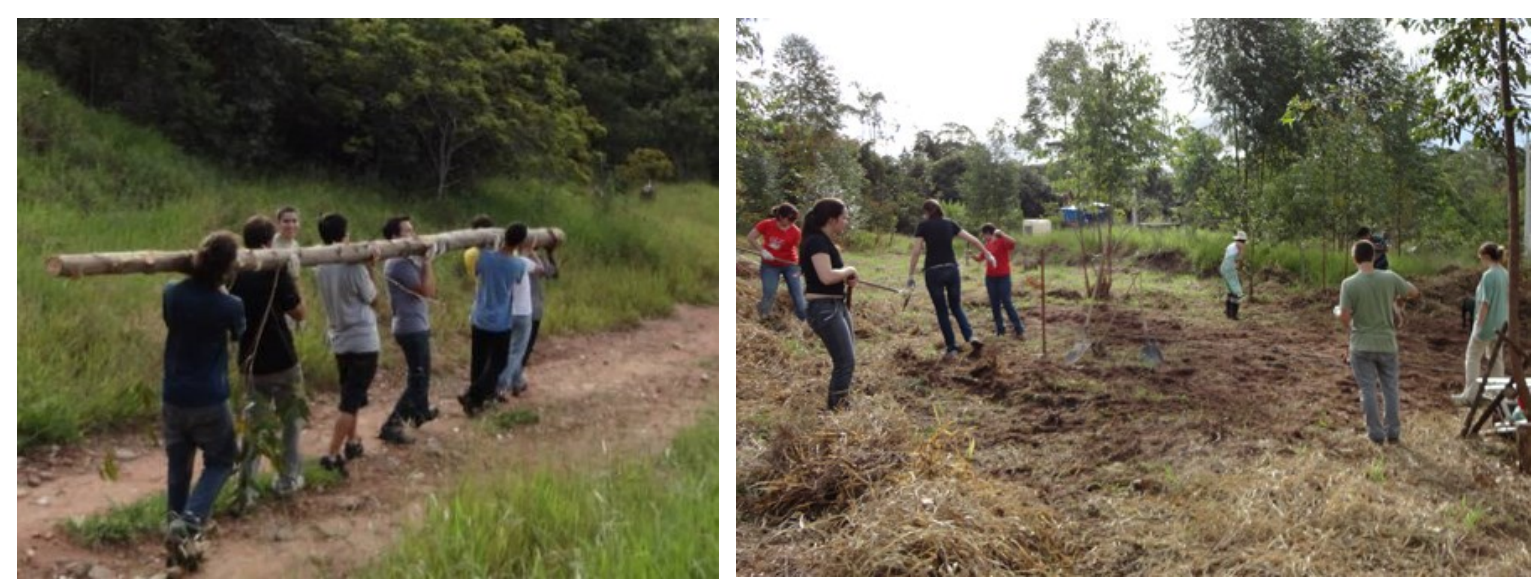

Fotos 71 e 72 - Transporte dos eucaliptos e preparação do terreno do espaço de trabalho.

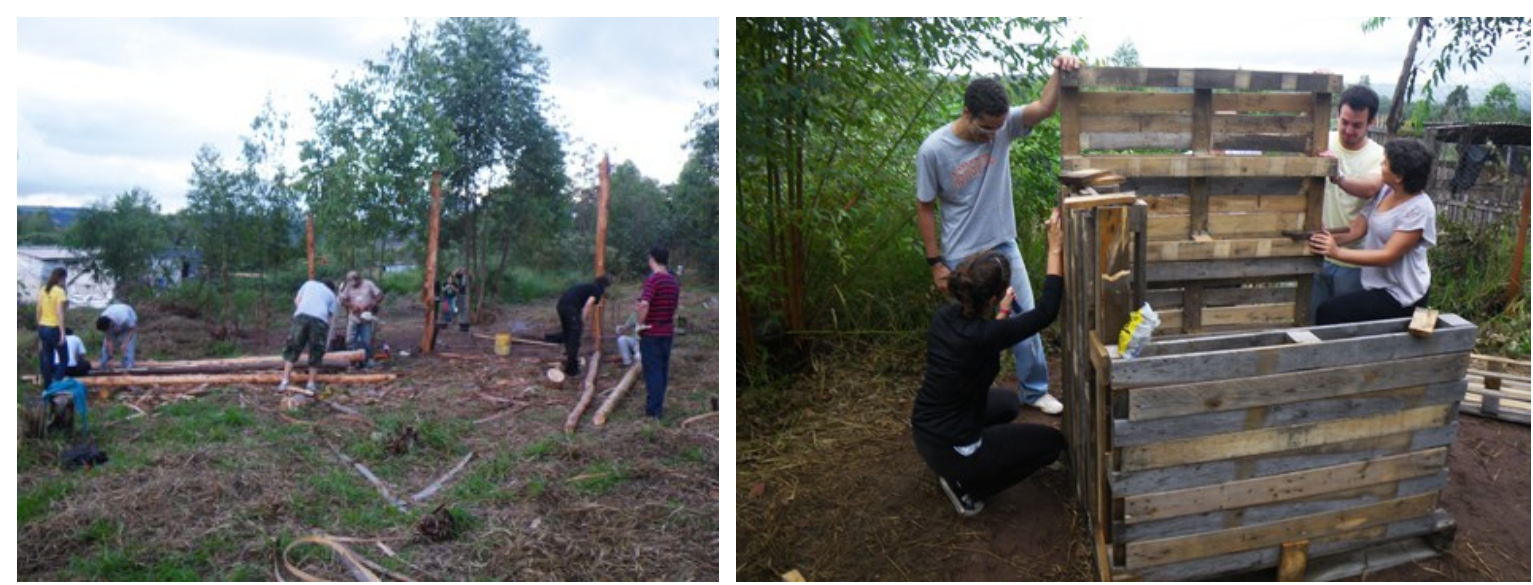

Fotos 73 e 74 - Depois de descascados, os eucaliptos foram fincados na terra como pilares da estrutura. 0 banheiro seco começou a ganhar forma a partir das discussões do grupo responsável.

A escolha pela construção de um processo de pesquisa-ação inserido em atividades de extensão universitária, dentro da realidade social de um assentamento rural, potencializa a ênfase ao caráter formativo, conscientizador e questionador da realidade vivida. Conforme Maria Amélia S. Franco (2005, p.486), “mediante a 
participação consciente, os sujeitos da pesquisa passam a ter oportunidade de se libertar de mitos e preconceitos que organizam suas defesas à mudança e reorganizam a sua auto concepção de sujeitos históricos."

Dentro da proposta de alternarmos a sala de aula com o terreno do assentamento, a família veio à Universidade para apresentar, no "mundo dos estudantes", seus projetos e suas vontades. Provocar o diálogo entre a família assentada e o grupo de alunos dentro do espaço acadêmico, era uma ótima oportunidade para defrontar os dois "mundos" em um espaço diferente, agora não mais no lote familiar. Ademais, provocar o diálogo do mestre pedreiro, grande conhecedor de seu ofício e hierarquizado em seu cotidiano dentro dos espaços de trabalho, com alguns "aspirantes" aos postos de futuros chefes de outros tantos mestres pedreiros, nos pareceu extremamente rico para nosso processo questionador e formador. Vale lembrar que nosso intuito era modificar esta probabilidade em possibilidades outras, onde os futuros arquitetos tornem-se, ao contrário, sujeitos transformadores da lógica exploradora e alienadora do trabalho social.

Integrar a família às atividades teóricas dentro do ambiente universitário, possibilitando a eles participar e intervir nos debates, reflexões e escolhas, consistiu neste contexto, em ampliar as dimensões da pesquisa-ação. Neste sentido, fortaleceram-se as relações sociais e os compromissos acordados entre o grupo de estudantes e a família; aproximaram-se os conhecimentos científico/acadêmicos dos conhecimentos populares e técnicos da realidade social, atuando numa perspectiva de superação das condições de opressão e alienação dos sujeitos sociais; potencializaram-se as ressignificações sobre o ato de projetar e suas relações com a execução da obra, além de estabelecer o acesso comum ao grupo nos dois ambientes (universidade e assentamento) onde as reflexões e as práticas se faziam.

Esta perspectiva de atuação reconhece a práxis como mediadora na construção do conhecimento. Sua realização veicula teoria e prática, pensar e agir, formar e produzir. A família esteve presente, num primeiro momento, para explicar sua maneira de viver, de se organizar no âmbito do habitat e do lote de produção. Assumiram o giz e as palavras, e desenharam a casa onde viveram anteriormente à vinda ao acampamento. Relataram 
suas condições estruturais (acesso à água, energia, financiamentos, etc.) e seus "sonhos" quanto à nova residência. Tornaram-se, enfim, "participantes-facilitadores" de um exercício coletivo que englobava as reflexões sobre seu habitat e o planejamento de nossas ações.

Esta perspectiva se alinha à de Franco (Ibid., p.492) que vislumbra dentro do agir comunicativo as condições propícias para que os "participantes cheguem a um saber compartilhado que vai tecendo uma estrutura interacional de confiança $e$ comprometimento."

As reflexões em torno das questões do habitat rural foram abordadas pelo grupo a partir de temas tratados no diálogo com a família. Temas, que em sua abrangência geral tocam questões relacionadas aos: espaços e cômodos da casa (Quem mora na casa? Há quantos anos? Quais cômodos ela possui? Onde passam a maior parte do dia quando estão em casa? Por quê? etc.); conforto ambiental e térmico (Acham a casa fria ou quente? Porque? Como podemos melhorar a situação? Qual o pé direito da casa? Consideram ela alta ou baixa? Como preferem? Quanto à iluminação, acham a casa clara ou escura? Como é a ventilação? Acham a casa arejada? Como podemos melhorar a situação? Qual a espessura da parede? Acham que o tipo de parede (em madeira, tijolo, terra, etc.) e o tipo de cobertura (de cerâmica, fibrocimento, etc.) influenciam no conforto interno da casa? Por que? etc.); sistemas construtivos (A casa foi construída com quais materiais de construção? Como escolheram estes materiais? Quem a construiu? Como é a fundação? Cobertura? Piso? Paredes? Teto? Estrutura? E a planta baixa? Qual é seu estado de conservação? Estão abertos à utilização de novas técnicas construtivas? Já construíram outras casas? Como? Acham importante haver assistência técnica de arquitetos e engenheiros na hora de construir? Como ela deve ocorrer? etc.); infraestrutura e salubridade (Como é o sistema de esgotamento sanitário? O que fazem com o lixo? Cozinham com gás (bujão), lenha ou ambos? Possuem acesso à energia elétrica? etc.); percepção do espaço (Gostam da casa onde moram? Por quê? O que o lugar representa? Essa casa é melhor que a anterior onde moravam? O que não pode faltar na casa? E no terreno? O que na casa mais satisfaz? Por quê? Construiriam diferente se possível? O que trocariam? Por quê? etc.); sonho da casa ideal (Como deve ser a sala? Quarto? Cozinha? Banheiro? Varanda? Outros cômodos? etc.). 
Como resultado foram elencadas pistas que orientaram diferentes grupos de estudantes (cinco no total) em um primeiro esboço de um programa arquitetônico compatível com o desejo da família, com as condições financeiras, com o contexto cultural e ambiental do assentamento, com os materiais disponíveis e com os princípios norteadores do curso. A inclusão da família nos processos dos desenhos, diálogos, questionamentos e reflexões, desde o início do projeto, gerou possibilidades de desenvolver certas dimensões, nas relações sociais do trabalho, potencializadoras de processos solidários, formadores e dialógicos entre os participantes. A coletivização dos debates, das escolhas e das opiniões fortaleceu o envolvimento do grupo, reforçando as reflexões sobre os projetos e as práticas construtivas.
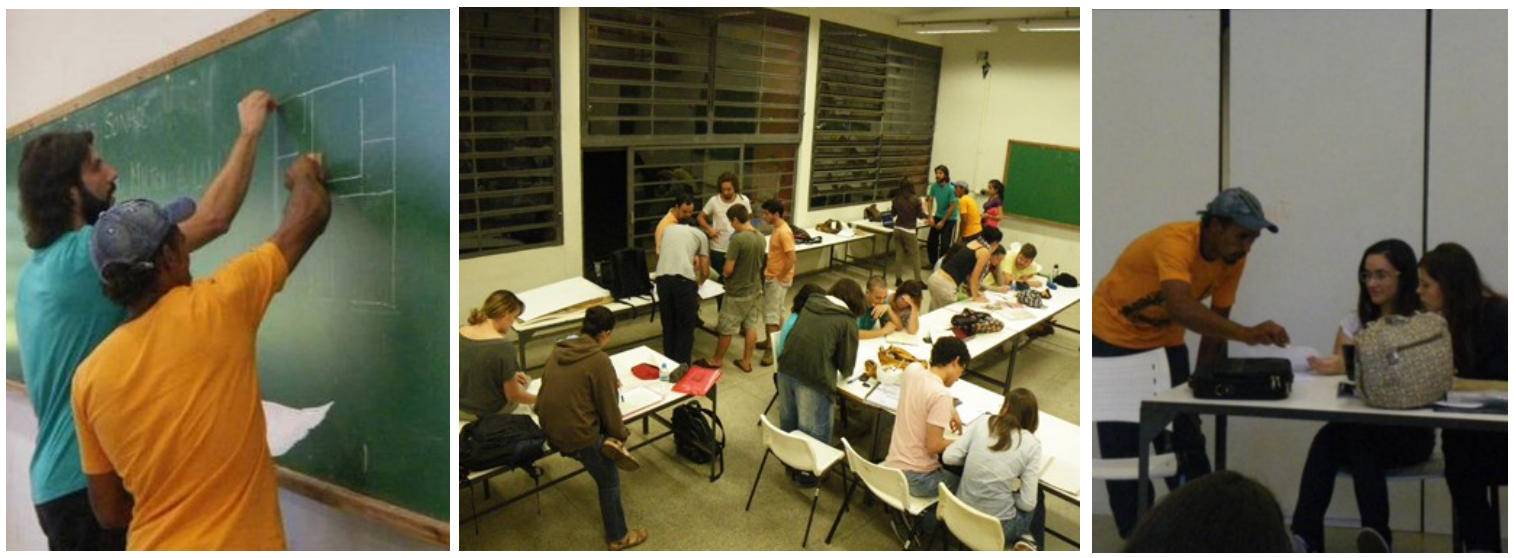

Fotos 75, 76 e 77 - Visita da família e diálogo coletivo sobre os projetos arquitetônicos. As casas antiga e atual foram desenhadas e seus espaços foram discutidos no grupo.
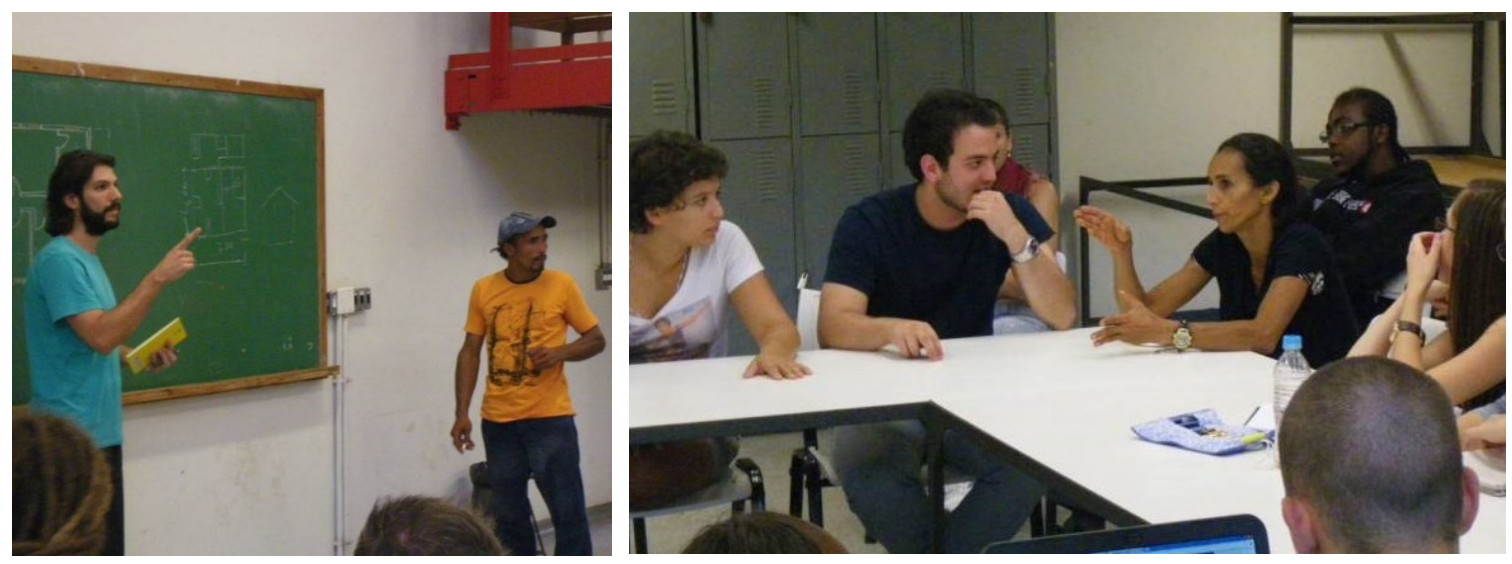

Fotos 78 e 79 - Diálogos sobre as vontades e sonhos da família, as condições financeiras e técnicas e as impressões do grupo de estudantes. 


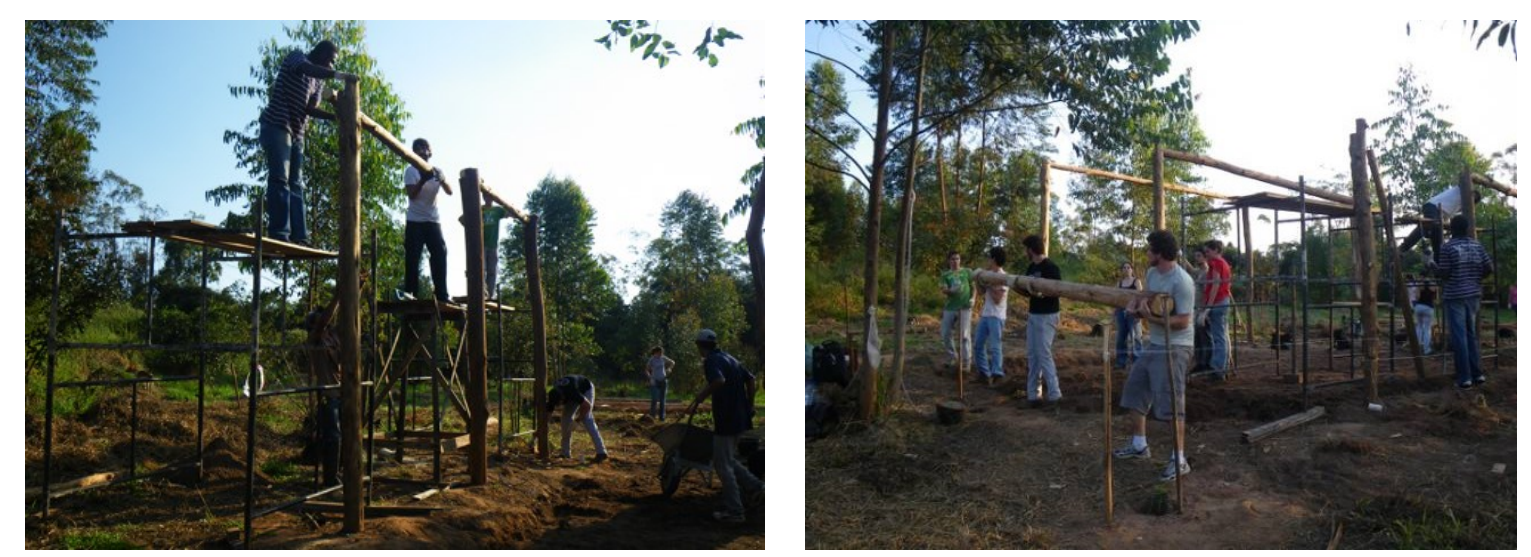

Fotos 80 e 81 - As toras de eucaliptos, com cerca de $15 \mathrm{~cm}$ de diâmetro, foram pouco a pouco sendo colocadas como pilares e vigas, estruturando assim o espaço de trabalho.
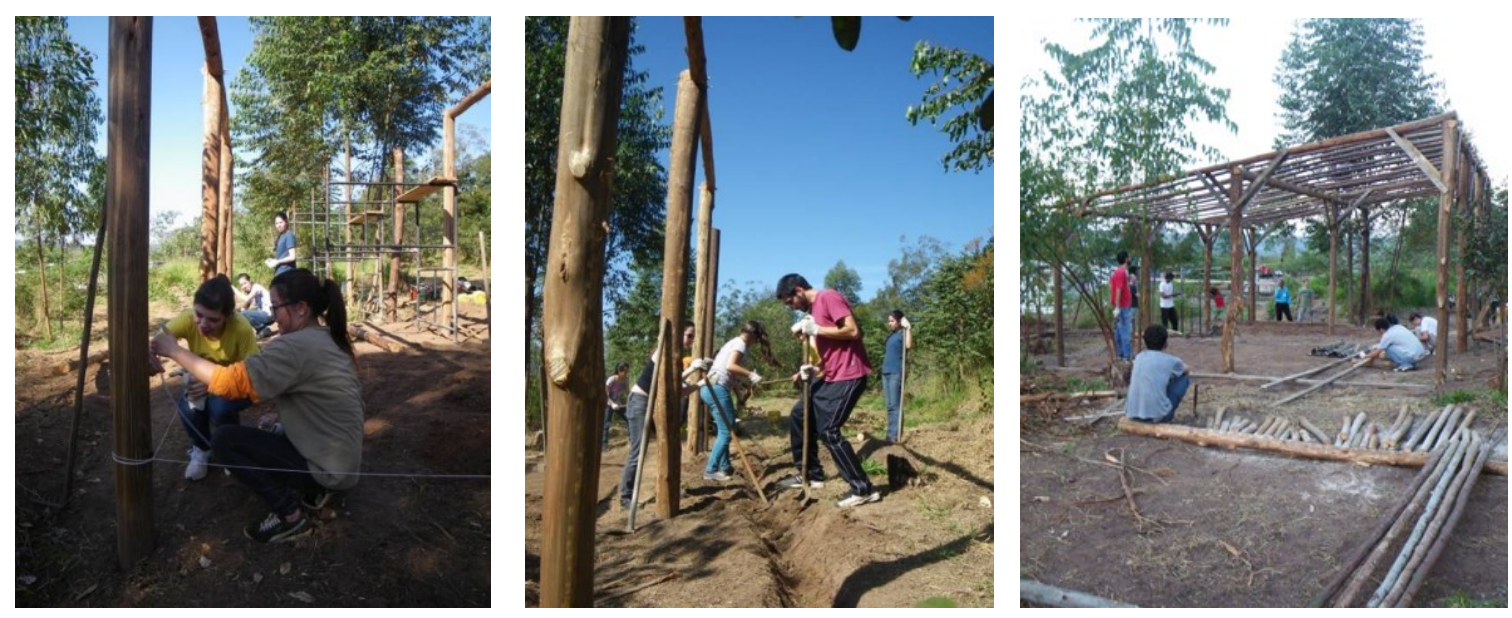

Fotos 82, 83 e 84 - Após a marcação do nivelamento do piso e a realização das calhas para o escoamento das águas das chuvas, a cobertura do espaço começou a ser montada com eucaliptos mais finos, também do lote.
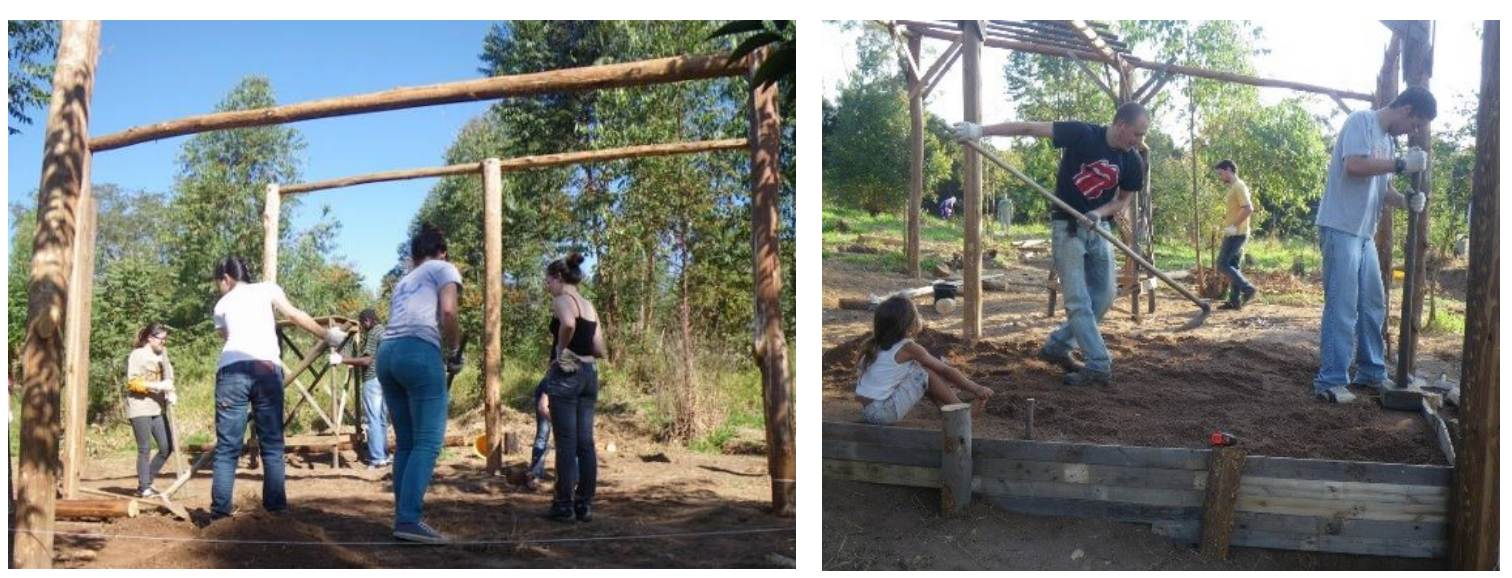

Fotos 85 e 86 - A limpeza e nivelamento do solo começaram a ser feitos e o espaço foi ganhando sua forma. 
A primeira parte das atividades práticas do curso foi concluída com a finalização da construção do espaço de trabalho e do banheiro seco. Como o assentamento rural é vizinho ao distrito industrial da cidade, fizemos uma parceria com uma indústria que aceitou apoiar o projeto e destinar os paletes descartados para nosso lote familiar. Assim, uma carga de paletes e caixas de madeira nos foi entregue e, depois de caracterizadas e organizadas, começaram a ser utilizadas nos projetos dos estudantes referentes aos sistemas construtivos desenvolvidos.
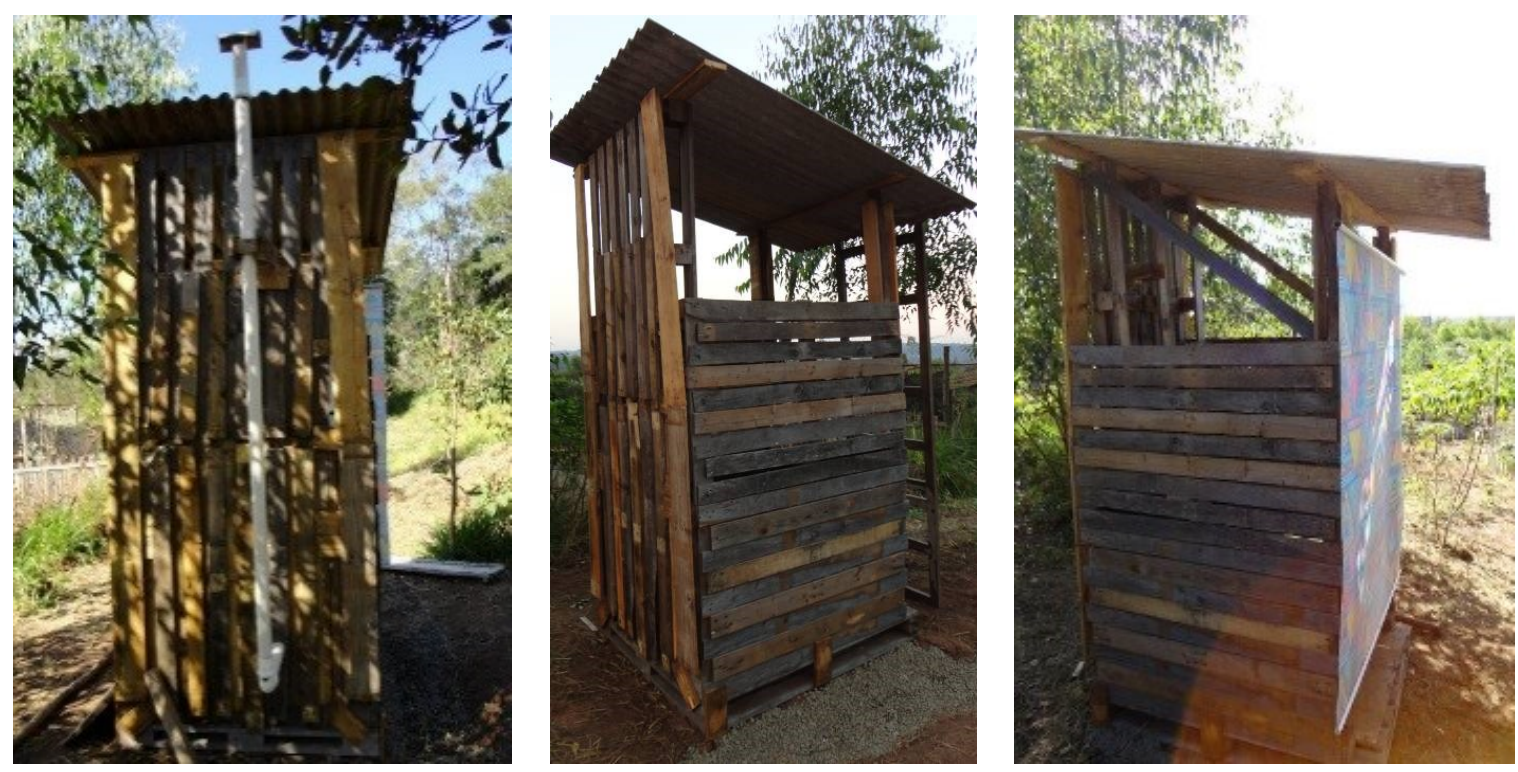

Fotos 87,88 e 89 - O banheiro seco construído com os paletes encontrados no lote familiar ficou pronto e as possibilidades de trabalhar com este material foram gerando debates coletivos.
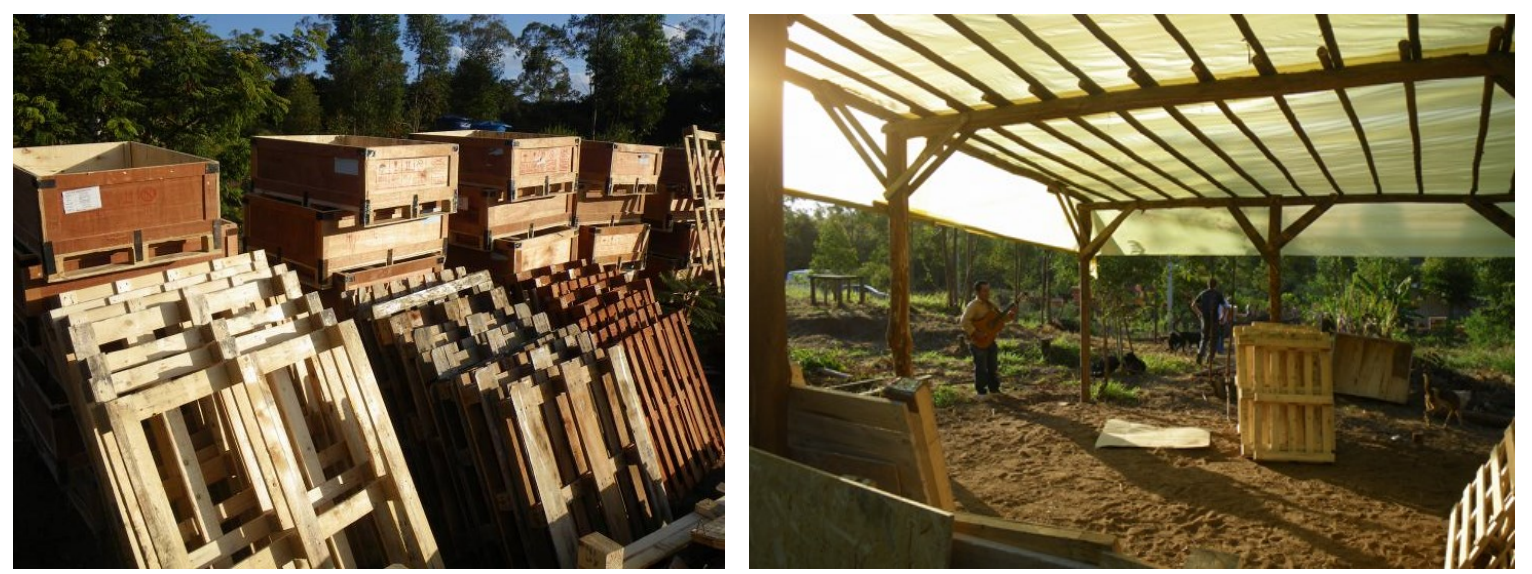

Fotos 90 e 91 - Os paletes doados foram caracterizados e organizados. O espaço de trabalho pronto recebeu a visita de um músico que passava pelo assentamento e nos acompanhou durante uma tarde de atividades. 
Do lado teórico, em sala de aula, as relações entre os esboços, desenhos e projetos, deveriam ensaiar também outras relações com os espaços da obra e seus trabalhadores. Em suas análises sobre os canteiros de obras e suas relações de produção, Sérgio Ferro destaca a orientação que o desenho e seu ato de criação exercem como mediadores dos processos produtivos, dentro das relações de classes existentes nos canteiros de obra. Segundo ele, o desenho tornou-se (sobretudo na sociedade capitalista) uma ferramenta burguesa de uso cotidiano, assumida como ordens de serviços e prescrição de tarefas. Para ele, "entre o gesto e o propósito entra a vontade de um outro. Entre a mão que faz e seu objetivo se insere o desenho do projetista." (FERRO in BENOIT, 2002, p.05).

Nossa intenção passava pelo ensaio do uso do desenho dentro de suas perspectivas pedagógicas e facilitadoras. Os grupos começaram a pensar em como apresentar suas ideias e esboços à família, de modo que o desenho pudesse ser ferramenta técnica de troca e diálogo, que pudesse ser simples e se utilizar desta perspectiva para inserir as escolhas da família e alimentar sua apropriação sobre a construção que estava sendo concebida e desenvolvida.

A presença da família na Universidade se deu em mais uma ocasião, desta vez para acompanhar, discutir, avaliar e desenvolver junto com os alunos, as diferentes propostas que ganhavam forma pouco a pouco. Os projetos foram então evoluindo e as discussões se deram num quadro agradável com a presença da família na sala de aula. G. Silva começou então a mostrar outras faces de sua personalidade, para além daquela ligada ao ofício de pedreiro. Ele foi se soltando e se mostrou falador e interessado naquele processo que vivíamos ali. Fomos dando "oxigênio" e ele foi se revelando um grande facilitador, mesmo professor, visto a grande quantidade de orientações que foi dando aos alunos, referentes às questões ligadas ao canteiro de obras. Falava das possibilidades e dificuldades de algumas escolhas técnicas assumidas por um ou outro projeto, e questionava os alunos quanto aos desenhos e suas escalas. Plantas baixas simples e fáceis de se trabalhar e modificar, somadas a algumas perspectivas, alimentavam os debates e aproximavam as compreensões de todos a respeito dos espaços que estávamos concebendo. 

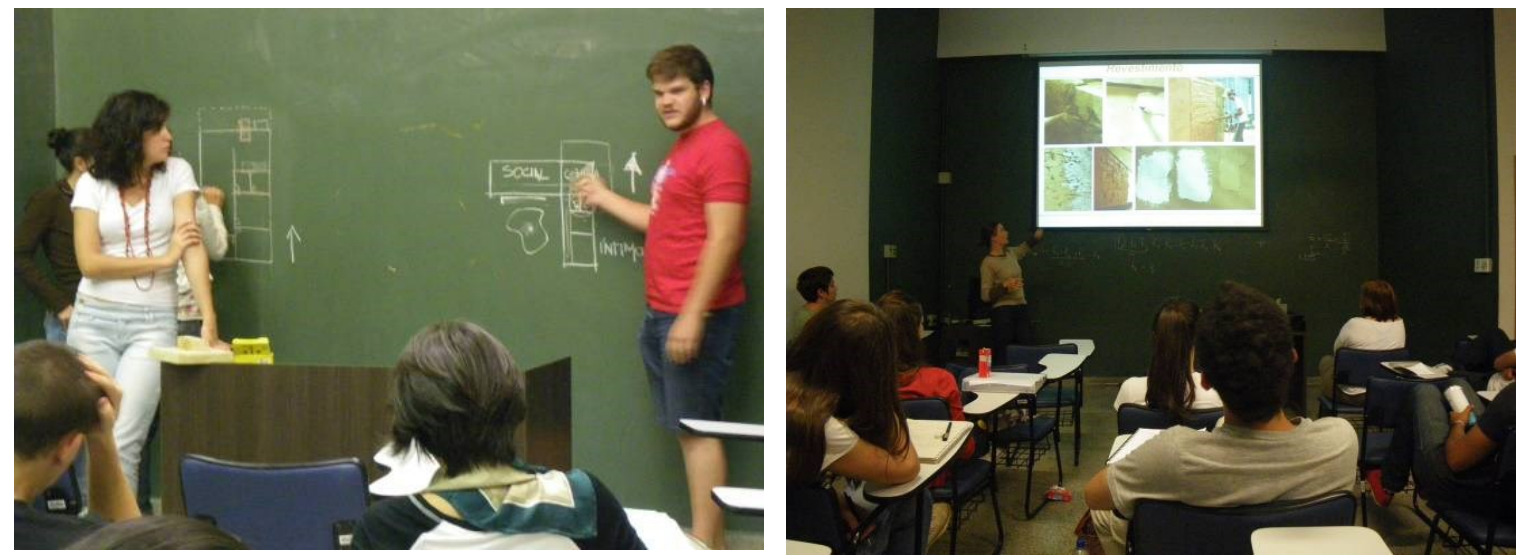

Fotos 92 e 93 - Discussão em sala de aula sobre os avanços dos projetos arquitetônicos e dos sistemas construtivos propostos. Uma das aulas teve como tema uso da terra nas construções, suas características minerais, suas relações com a água e seus sistemas construtivos mais usuais.
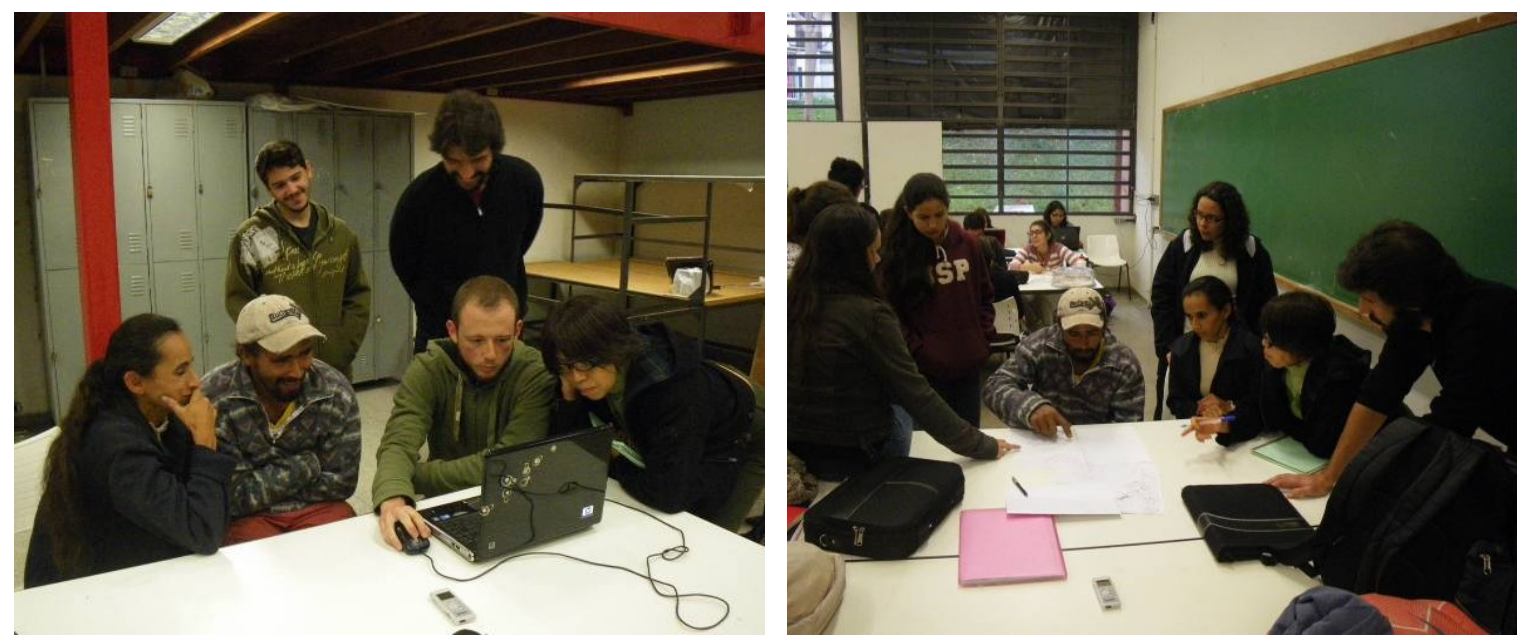

Fotos 94 e 95 - Visita de acompanhamento feita pela família para conversar sobre os avanços dos projetos e algumas escolhas técnicas. Eles deram ideias, ouviram sugestões, desenharam e responderam a questionamentos, souberam adaptar suas opiniões e enriquecer cada projeto, e por fim se mostraram, assim como nós, satisfeitos com o percurso do curso.
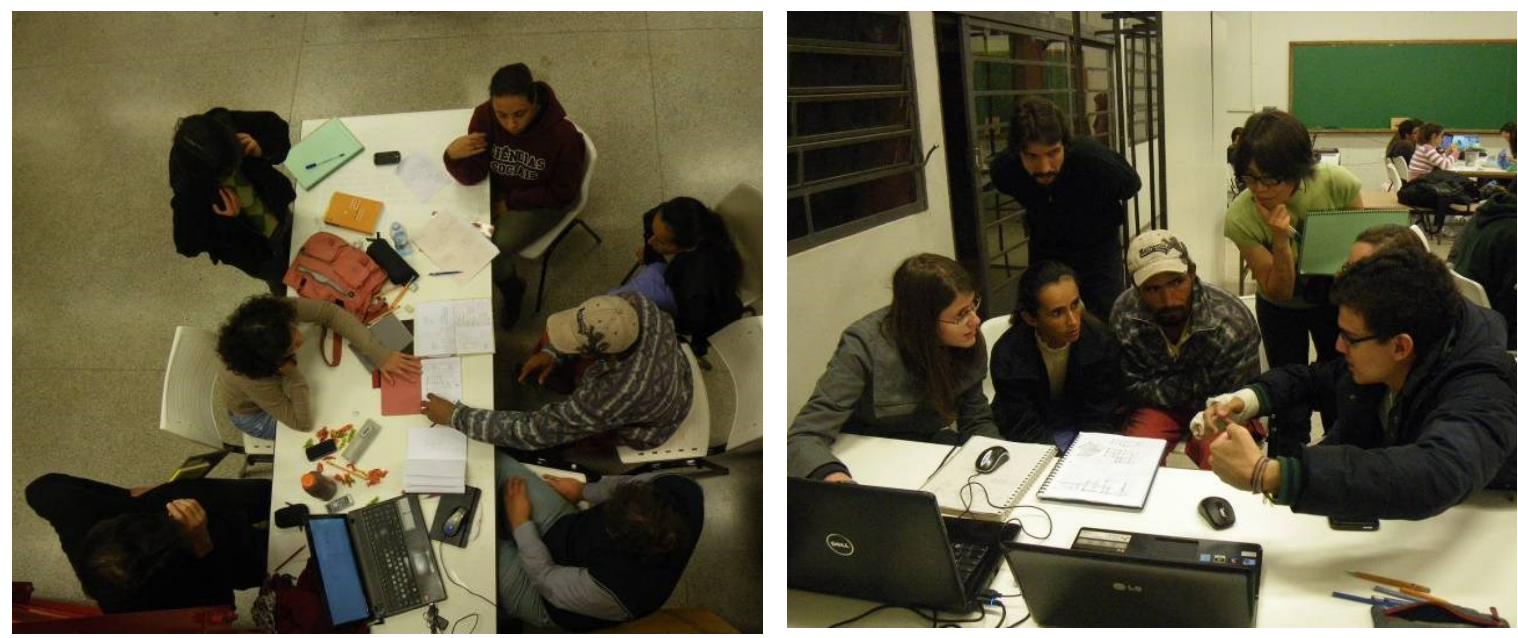

Fotos 96 e 97 - A família conversou com cada grupo e discutiu cada projeto que estava sendo desenvolvido. G. Silva explicou a respeito de algumas etapas presentes na obra, verificou certas escolhas técnicas feitas pelos alunos e junto com M. Silva aprovava ou redirecionava os desenhos feitos e as orientações propostas. 
Uma aula sobre culturas construtivas tradicionais espalhadas pelo mundo, articulada com novas experiências e usos de materiais naturais e de reciclagem nas construções, alimentou novas perspectivas sobre a utilização de materiais não convencionais no canteiro e nos projetos. Por que não desenhar a casa de paletes? E as estruturas de eucaliptos? E as paredes de terra, como detalhá-las nos desenhos? Realizamos uma aula sobre a matéria prima terra, suas características e possibilidades de uso. A opção em realizar taipas de pilão na casa dava abertura e fomentava o aprendizado e uso da terra como material de construção entre os alunos e com a família.

Os grupos de trabalho começaram então a experimentar na prática a construção dos sistemas construtivos que estavam desenvolvendo em sala de aula. Como desmontar os paletes? Como cortá-los? Quais são seus pesos e as facilidades de trabalhá-los? Qual o tamanho dos pregos para os trabalhos com madeira? E a terra, como trabalhar com ela? É necessário estabilizá-la misturando outros materiais? E as ferramentas, como utilizar as serras manuais e elétricas? dentre inúmeros outros questionamentos.

Ao final, o desconhecimento face aos materiais, por muitos nunca antes trabalhados, foi dando lugar à curiosidade e motivação em sua transformação e criação de novas possibilidades. Como fazer paredes com os paletes? E vigas? E fôrmas? Algumas referências de outros trabalhos circulavam entre os grupos: sites de internet, fotos de arquiteturas ecológicas, vídeos de sistemas construtivos, etc. As referências existentes quanto ao uso de paletes em mobiliários e objetos são bem numerosas no mundo virtual da internet. Entretanto, ainda é necessário desenvolver melhor as possibilidades de utilizá-los em sistemas construtivos nas edificações dos mais diversos usos.

O desafio estava lançado e cada grupo desenvolveu um projeto diferenciado de sistema construtivo para explorar suas possibilidades. Naquele momento, a carga de paletes doada contava com peças de diferentes tamanhos, formatos e pesos, com ripas de diferentes espessuras, larguras e comprimentos. Assim, os projetos foram sendo adaptados à realidade dos paletes encontrados.

Os erros viravam acertos e as validações foram tecidas a partir do constatado na realidade, fruto do pensar-fazer-avaliar-refazer, processo constante e naquele momento coletivizado pelo trabalho, sua organização e seus sujeitos participantes. 

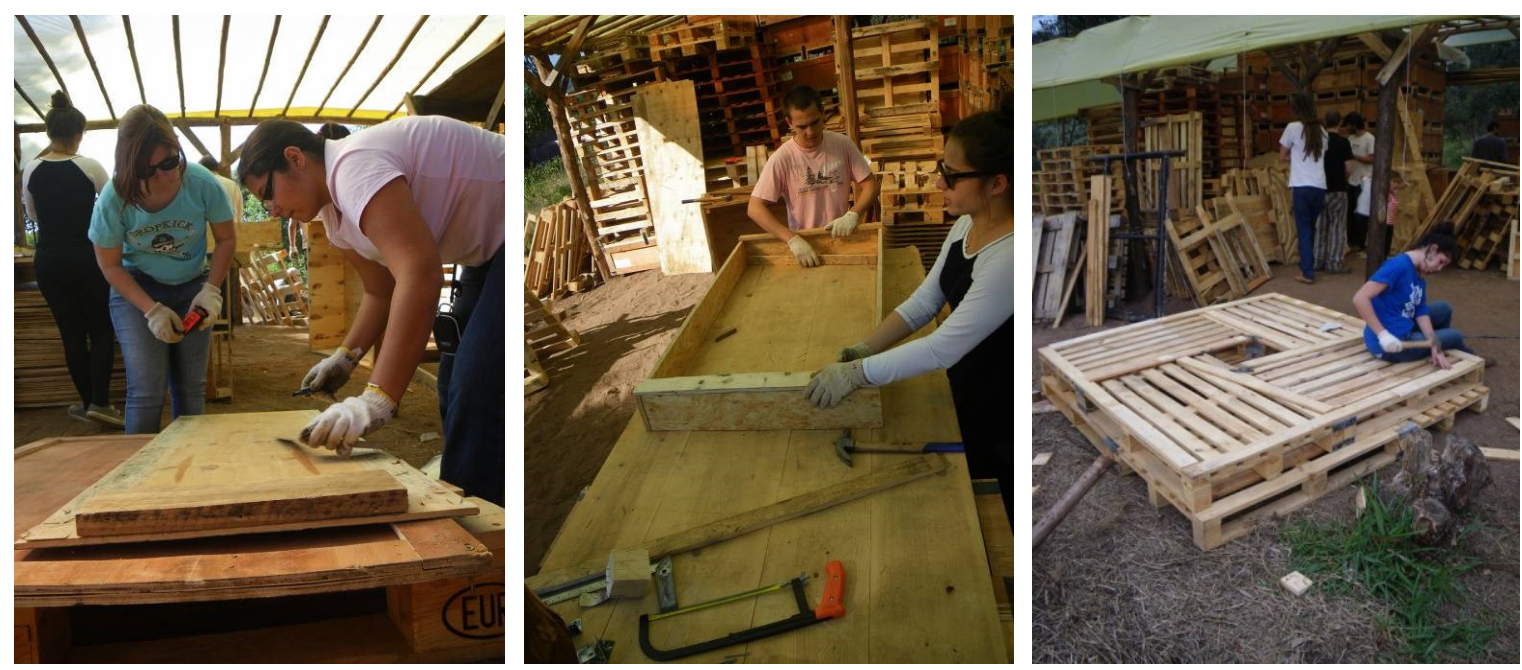

Fotos 98, 99 e 100 - Os grupos começaram a explorar os materiais disponíveis para trabalhar. Alguns partiram para a construção em escala 1:1. Outros, preferiram fazer primeiramente um modelo em escala menor para avaliação e aprimoramento.
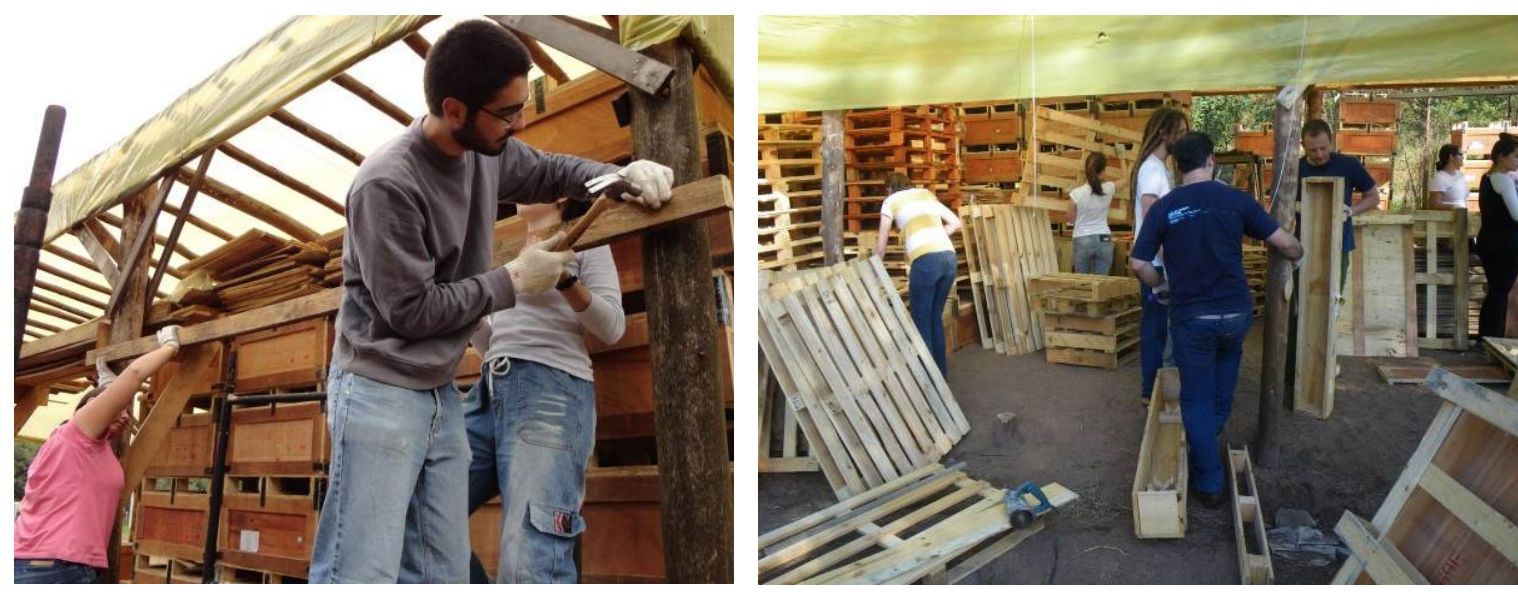

Fotos 101 e 102 - Além dos paletes, recebemos outras peças de madeira, que também serviram para o transporte de produtos. Cada país possui sua regulamentação quanto à produção de paletes, de modo que recebemos paletes de diferentes tamanhos e formatos, vindos não só do território nacional mas de outras partes do mundo, principalmente Europa e Ásia.
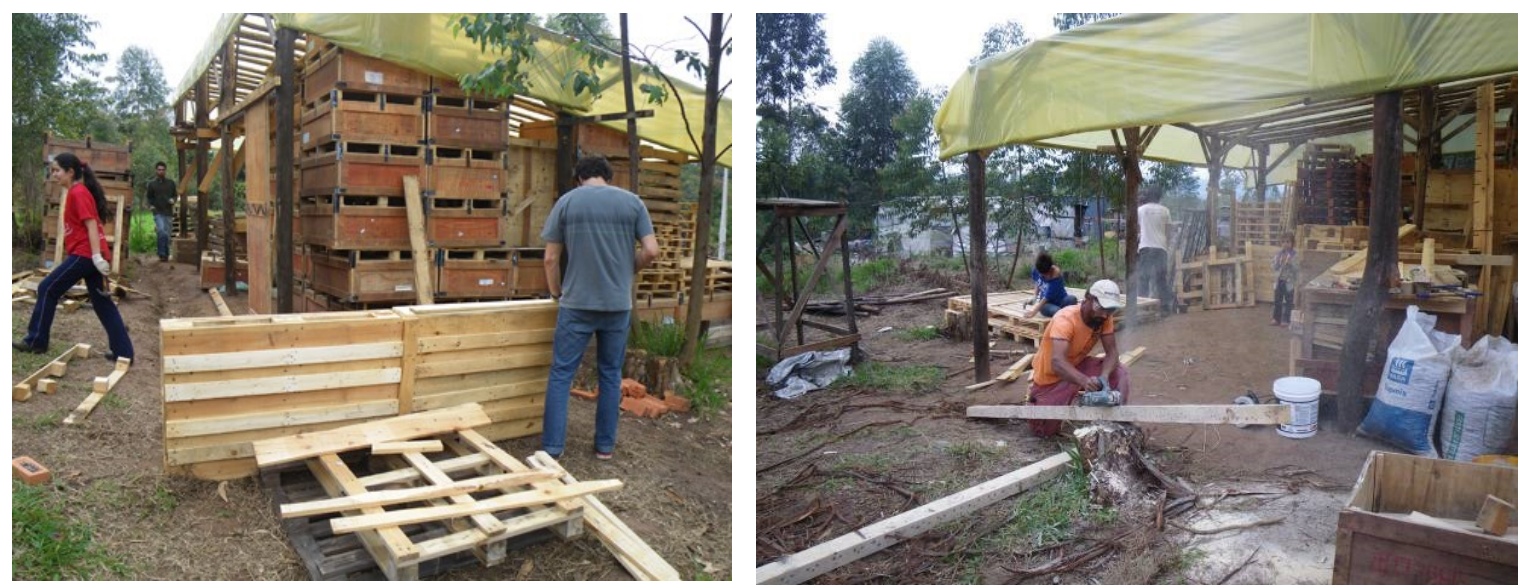

Fotos 103 e 104 - Os painéis começaram a ganhar suas formas e com poucas ferramentas os estudantes passaram a aprender e a descobrir diferentes maneiras de realizar cortes, montagens e fixações. G. Silva ensinava e demonstrava aos alunos como utilizar o martelo, as máquinas e os esforços físicos. As trocas entre os participantes continuavam a fortalecer as confianças e a potencializar as parcerias no canteiro. 

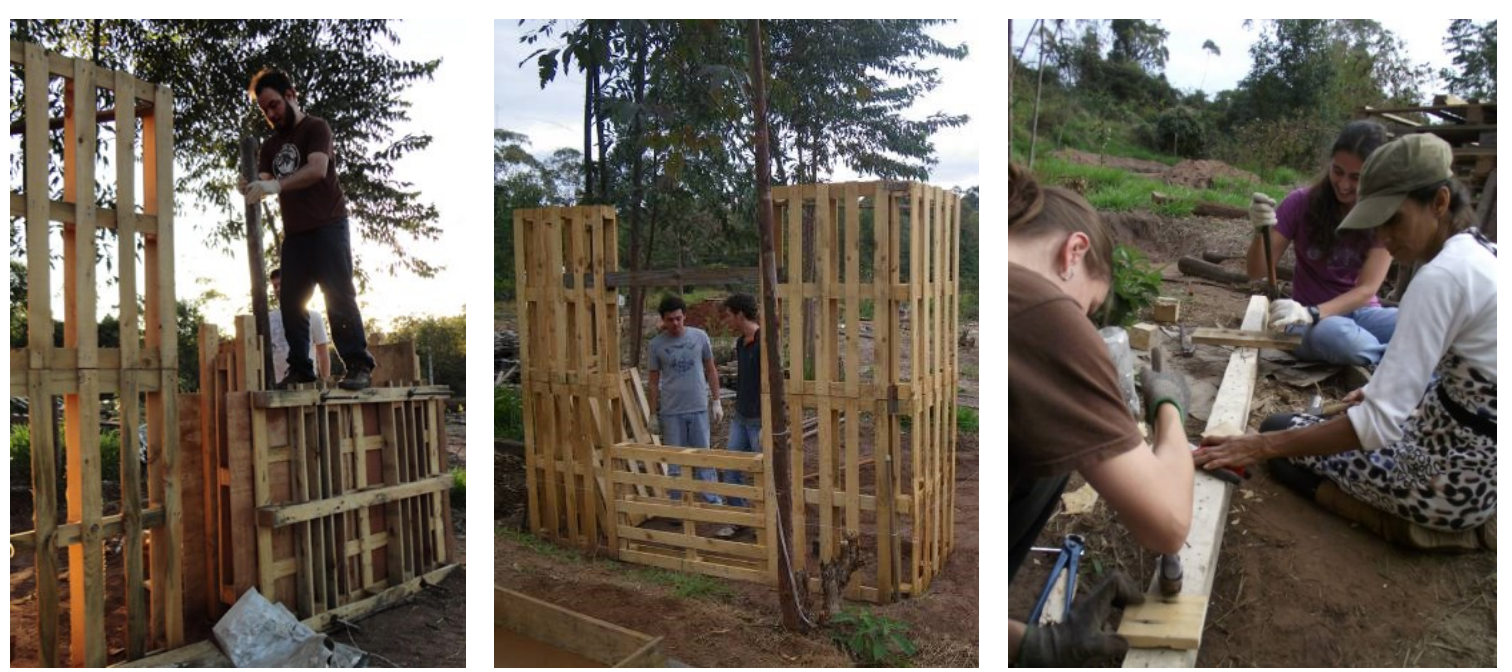

Fotos 105, 106 e 107 - Painéis de canto e fôrmas para a taipa de pilão também foram desenvolvidos. O objetivo era experimentar diferentes possibilidades para cada etapa que encontraríamos na construção da casa. O fechamento com painéis de paletes foi a solução indicada pelos diferentes grupos de trabalho.

O lote familiar de produção se transformou, naquele período, num espaço de trabalho e formação a partir dos diferentes processos experimentais. Os recursos mobilizados foram os materiais disponíveis no local e região, com custos nulos ou toleráveis para nossa realidade. O que ganha valor em sua existência são as variedades de competências envolvidas num processo compartilhado, onde as aprendizagens ocorrem concomitantemente com as práticas e seus modos de trabalho em grupos. Os resultados buscavam novas linguagens de projeto a partir do exercício de se produzir o habitat com os materiais disponíveis no local, inclusive reaproveitando descartes industriais.

A potencialidade não reside somente na intenção de uso dos recursos encontrados em escala local, mas nas possibilidades de rupturas com o modo hegemônico de pensar, projetar e produzir arquitetura. São os questionamentos quanto às tipologias e as reinterpretações de princípios que nos motivam no experimentar de formas coletivas e dialógicas de trabalho. A compreensão do "tipo ideal modernista", modelo determinista que aporta soluções universais, vai sendo pouco a pouco desconstruída pela compreensão do protagonismo que o material adquire quando não pode ser "formatado" pela indústria da construção civil e tem suas regras de usos 
herdadas pelos acúmulos dos saberes técnicos desenvolvidos pelos sujeitos, grupos sociais e sociedades ao longo do tempo ${ }^{143}$.

As formas e os princípios dos sistemas construtivos propostos iam sendo condicionados pelos contextos físicos, ambientais, culturais, sociais, econômicos e políticos influentes em nossa realidade social, tanto do canteiro, quanto do lote familiar e do assentamento. O esforço se dava por inserir os sistemas construtivos nos projetos, e estes, naquela conjuntura particular.

As experimentações práticas resultaram por fim, no desenvolvimento de cinco novos sistemas construtivos a partir da utilização dos paletes descartados e por vezes consorciados com a utilização de terra. Como conclusão das atividades práticas do curso, foi realizada uma apresentação coletiva dos sistemas criados a partir das análises dos diferentes grupos a respeito dos protótipos construídos, complementada por uma avaliação sobre as atividades do curso e experiências vividas a partir de cada percepção pessoal.

Sucessivamente, cada grupo apresentou seu sistema construtivo, explicando seus princípios de produção, funcionamento, potencialidades e limites percebidos, expondo suas percepções quanto às vivências, experiências, contribuições e críticas. Pudemos praticar junto com a família o exercício de refletir sobre os acontecimentos passados ao longo do semestre, reconstruindo seu histórico, inserindo o processo dentro da perspectiva de nosso primeiro contato com as famílias assentadas, bem como procurando as próximas justificativas na construção dos passos seguintes. Quais perspectivas os potenciais apresentados poderiam almejar, orientando a novos, mas ainda incertos, passos?

No ambiente da sala de aula, os diferentes grupos também prepararam suas apresentações dos projetos arquitetônicos desenvolvidos ao longo do curso. Estes projetos foram entregues contendo as plantas arquitetônicas e seus memoriais

\footnotetext{
${ }^{143}$ Complemento a ideia do material portador de características particulares que dão pistas sobre os sistemas construtivos mais adequados, com a compreensão de Sérgio Ferro quanto à existência de uma espécie de "memória cultural" no material. Este, segundo o professor, seria uma "síntese da matéria e história condensada na produção". Compreender o material não apenas como matéria, mas como processo histórico de ação humana sobre a natureza nos ajudará a compreender melhor os conteúdos subjetivos presentes nas manifestações das culturas construtivas, e então, reconhecê-los, respeitá-los e valorizá-los.
} 
descritivos, contextualizando, justificando e explicando as escolhas assumidas, além dos desenhos dos projetos dos sistemas experimentados nas práticas construtivas realizadas no lote familiar.

Foi proposto para os alunos, a realização de uma avaliação do curso e uma autoavaliação de cada um, como forma de compreendermos melhor o que significou o curso realizado, seus limites, potenciais, aprendizados, entre outros. Assim, nas páginas seguintes exponho, de maneira sucinta, os resultados finais teóricos e práticos produzidos por cada um dos cinco grupos, e ao final, relato as principais considerações feitas com relação ao curso e às experiências vividas.
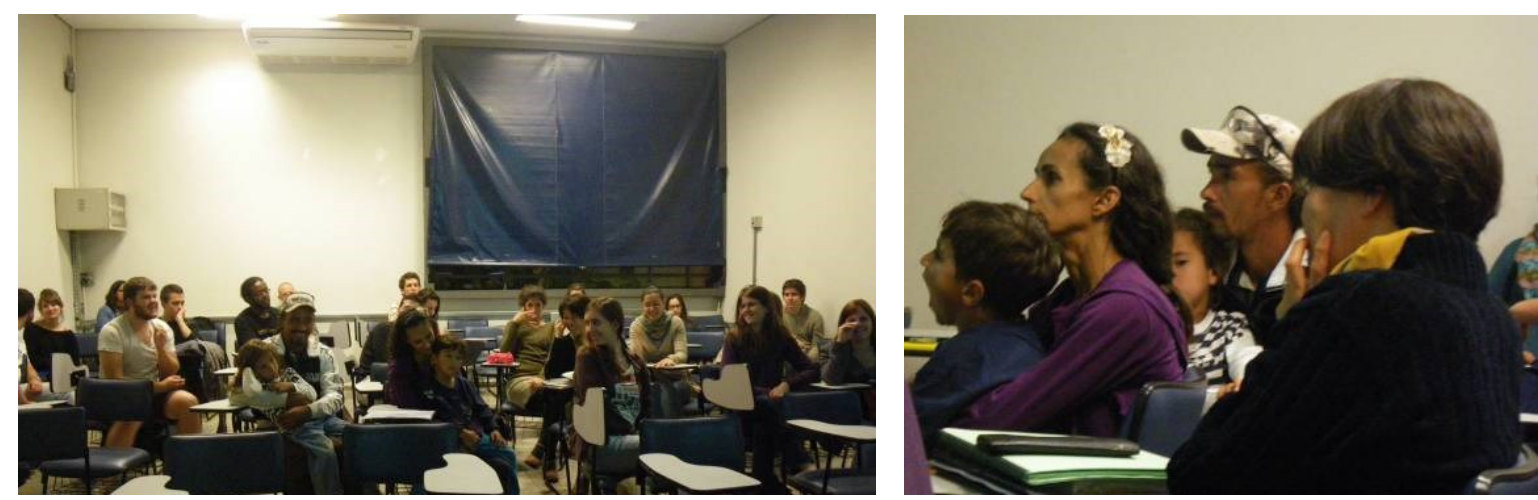

Fotos 108 e 109 - Mais uma vez a família foi à Universidade participar da apresentação final dos projetos realizados pelos alunos. Depois da exposição de cada grupo, estabeleceu-se um diálogo sobre as percepções, interpretações e expectativas da família e do grupo quanto aos projetos concebidos.
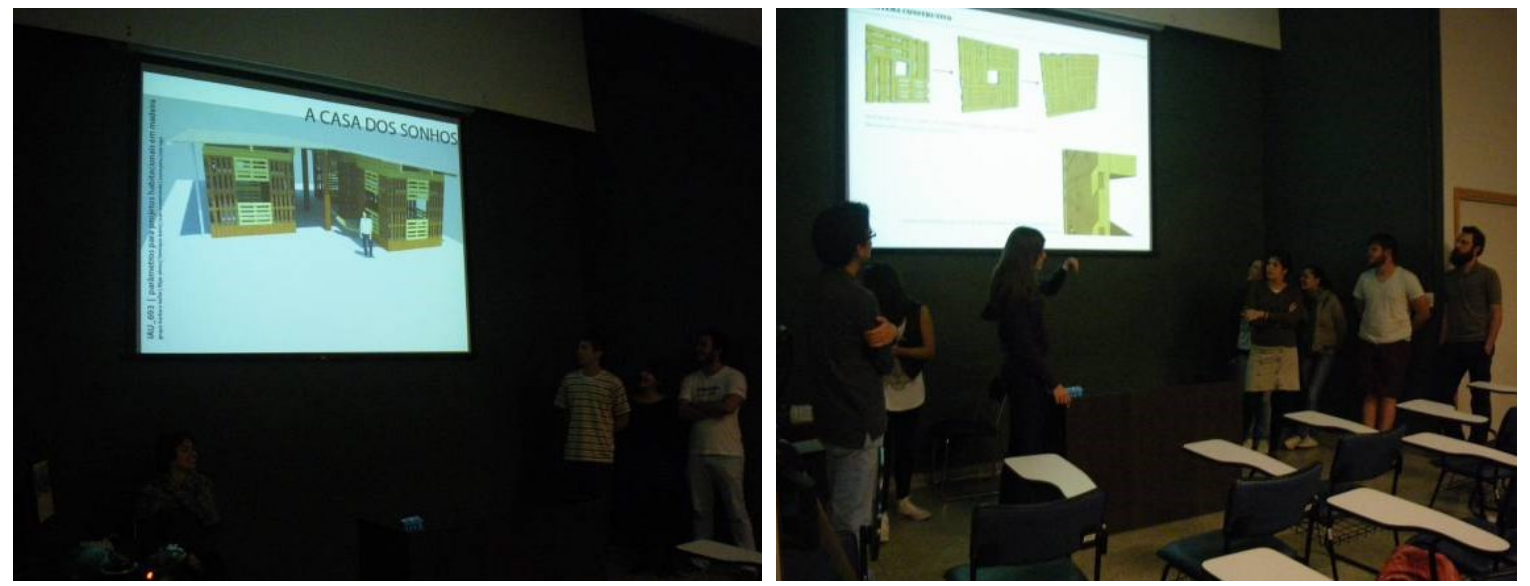

Fotos 110 e 111 - Foram discutidas questões conceituais e técnicas de cada proposta. Ao final, foi decidido amadurecer as reflexões e os projetos ao longo do mês de julho. A ideia era conversar com a família sobre cada proposta e ver com eles qual projeto poderia ser realizado. Uma boa pista era misturar as melhores ideias de cada projeto. 


\section{Grupo $1^{144}$}

A proposta de projeto do grupo apresentou um volume único com seus cômodos distribuídos em função da orientação do sol, das características do terreno e dos acessos existentes.

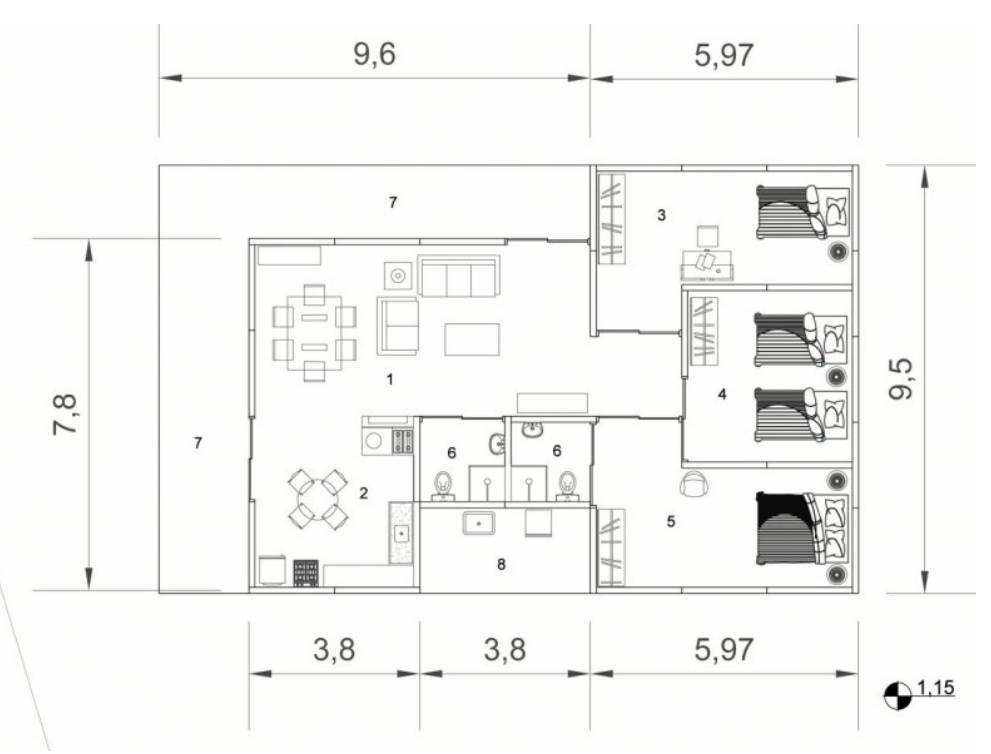

Figura 9 - Planta baixa do projeto com três quartos voltados a leste. A cozinha e a sala são acessadas por uma varanda em " $\mathrm{L}$ " disposta ao longo das fachadas norte e oeste.
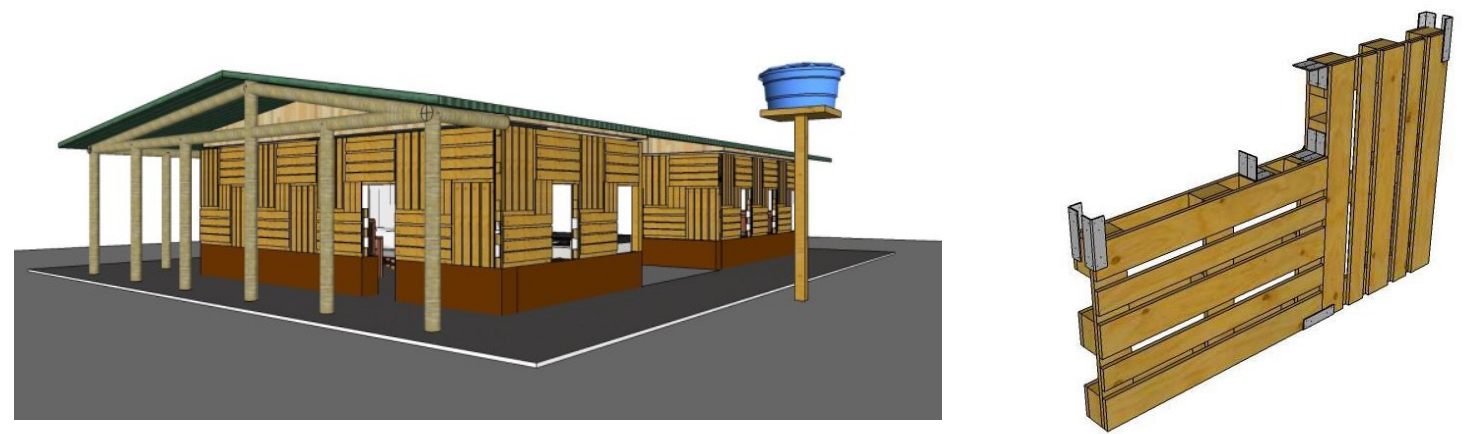

Figuras 10 e 11 - O projeto propunha o uso de eucaliptos roliços como estrutura da casa através de pilares e vigas, independentes da vedação. Estas, foram pensadas a partir de painéis produzidos com os paletes disponíveis. A conexão entre os paletes seria feita com as cantoneiras metálicas retirada das caixas de motores. $\mathrm{O}$ centro do painel poderia ser fechado completamente ou formar uma janela.

144 As informações analisadas a seguir (Grupos 1, 2, 3, 4 e 5), incluindo todas as figuras expostas, foram retiradas dos trabalhos finais dos alunos do curso optativo "Parâmetros para projetos de elementos de madeira - IAU693", do Instituto de Arquitetura e Urbanismo de São Carlos, realizado ao longo do primeiro semestre de 2013. 

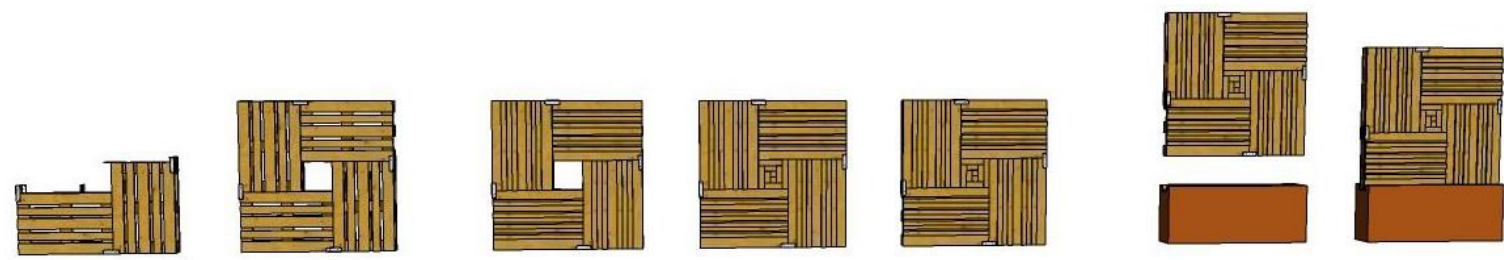

Figura 12 - Os painéis experimentados foram construídos a partir de uma composição feita com quatro paletes de dimensões similares unidos lateralmente em posições invertidas (o que aporta maior rigidez). Com tamanhos de $2 \mathrm{~m} \times 2 \mathrm{~m}$, seus fechamentos foram realizados com ripas de outros paletes pregadas lado a lado como mata-juntas. As ripas instaladas na horizontal receberam um corte chanfrado para o melhor escoamento das águas das chuvas.
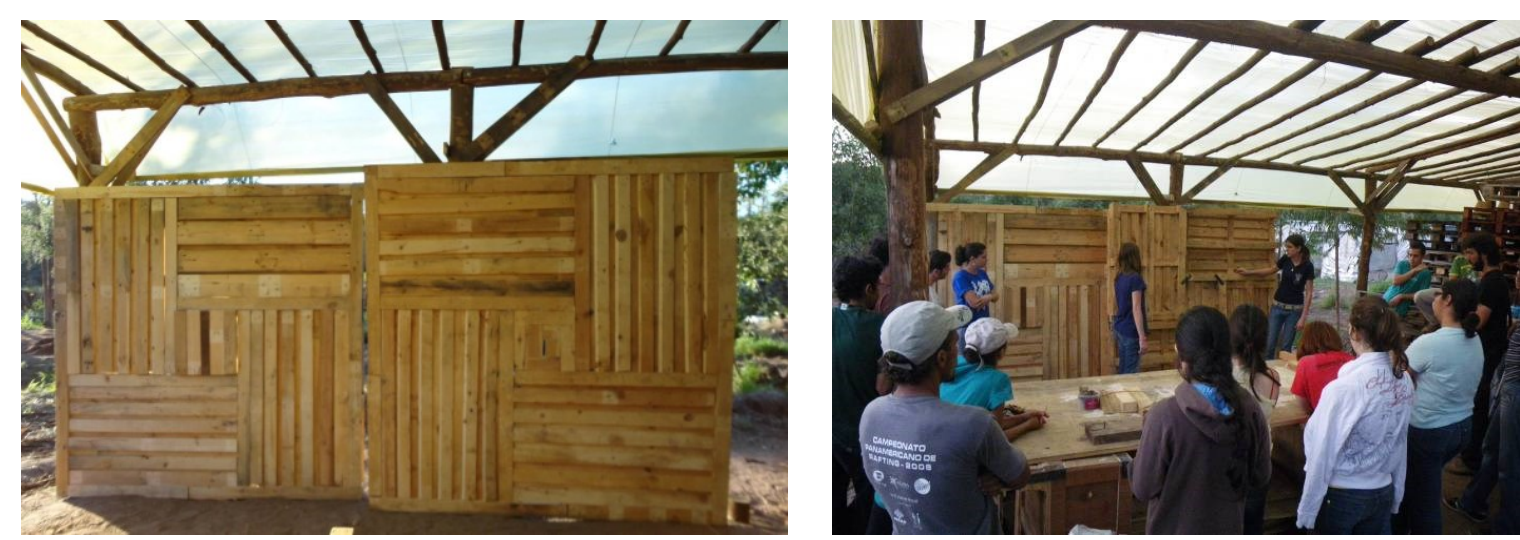

Fotos 112 e 113 - Apresentação dos painéis fabricados com os relatos sobre os processos de produção, dificuldades encontradas, potencialidades e impressões gerais. As fotos mostram o lado externo dos painéis. Em seu lado interno, a ideia foi preencher com terra, fechando sua face com telas finas para posterior revestimento também em terra.

\section{Grupo 2}

A proposta do grupo consistiu em dois blocos retangulares separados mas conectados pela cobertura, formando um espaço livre central. O projeto considerou as condições do terreno e o uso dos materiais locais em sua concepção. 

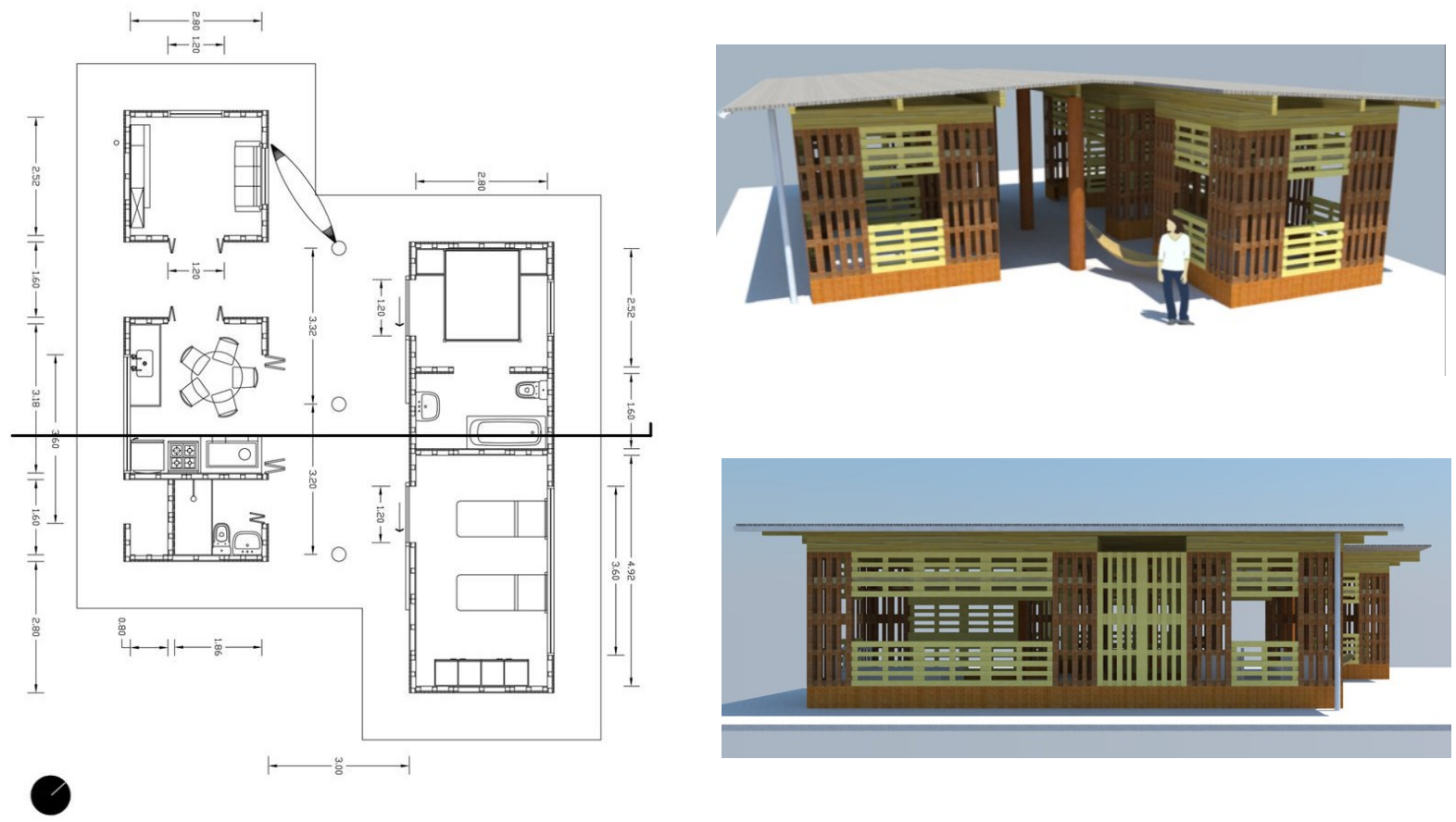

Figuras 13, 14 e 15 - A planta sugere os quartos dispostos no bloco leste, captando o sol da manhã, e a área social organizada no bloco oeste, sendo a sala voltada para norte. O projeto propõe os painéis de paletes como sendo estruturais a partir de diferentes tipos de painéis. Como uma espécie de cinta de amarração, o projeto propõe a produção de vigas em perfil I com as ripas dos paletes.
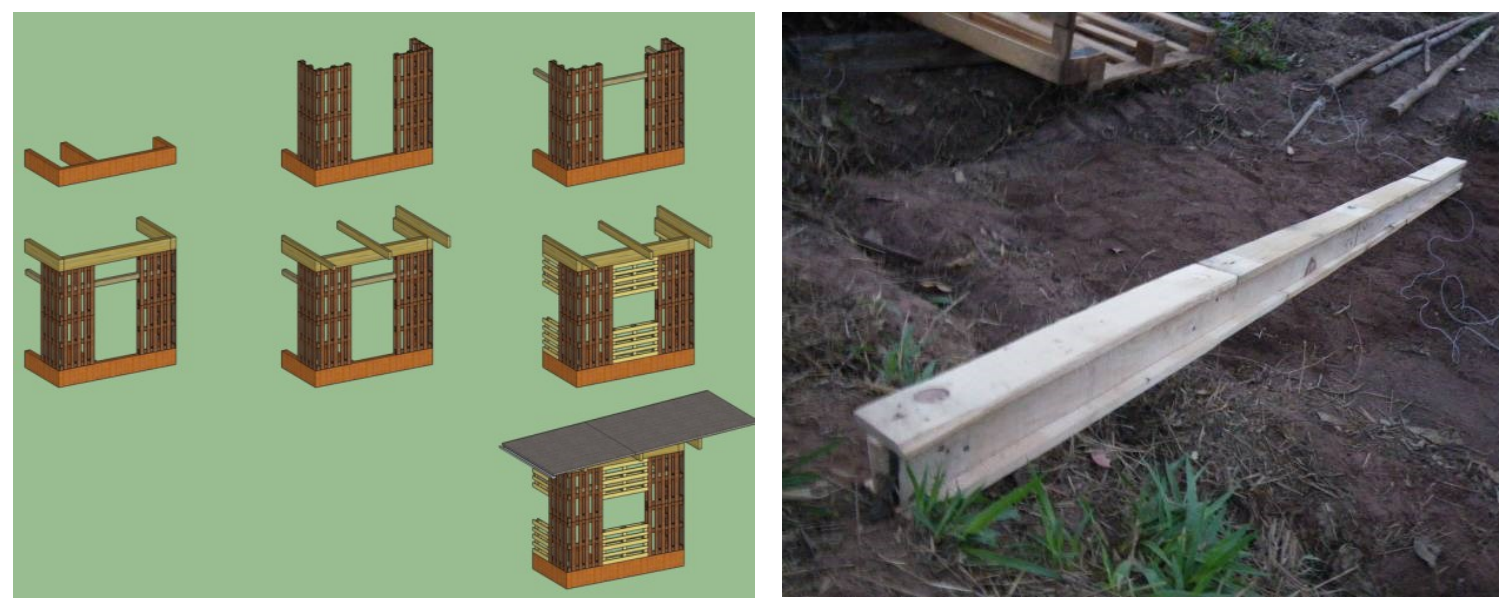

Figura 16 e Foto 114 - O painel experimentado pelo grupo foi o painel de canto, composto por quatro paletes. Assim foram produzidos dois painéis de canto e uma viga com perfil I. Os painéis foram solidarizados com peças de madeiras em seu interior ligando verticalmente dois pares de paletes. Cantoneiras metálicas foram utilizadas em sua fixação. A viga em I foi inspirada na viga laminada pregada (VLP), sendo adicionados os perfis perpendiculares ao longo de suas duas extremidades. 

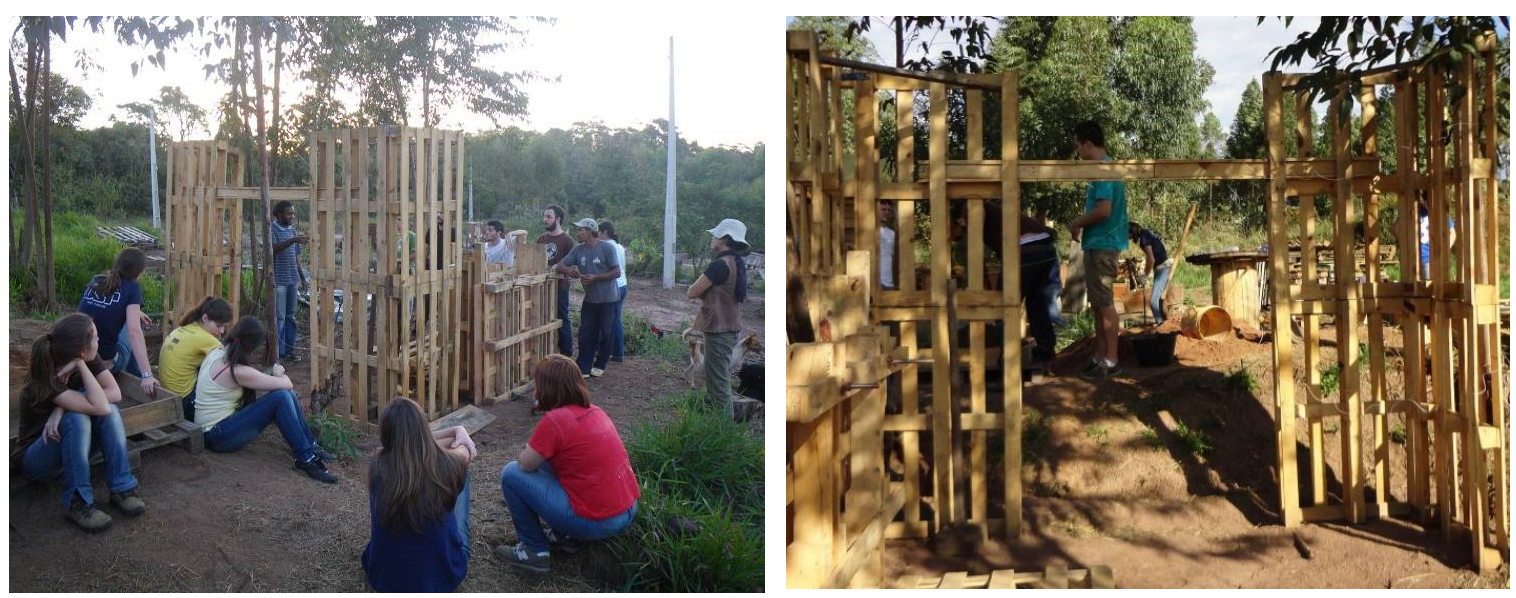

Fotos 115 e 116 - Apresentação dos painéis fabricados e da viga em perfil I com os relatos sobre os processos de produção, dificuldades encontradas, potencialidades e impressões gerais. 0 contraventamento dos painéis foi algo sugerido, pelo grupo, a ser desenvolvido mais profundamente.

\section{Grupo 3}

A proposta do grupo consistiu em um projeto de bloco único com dois quartos orientados a sul e a sala como grande espaço de chegada da casa. O projeto considerou o uso dos materiais locais em sua concepção e as condições do terreno. A utilização dos paletes foi pensada a partir da produção de painéis autoportantes.
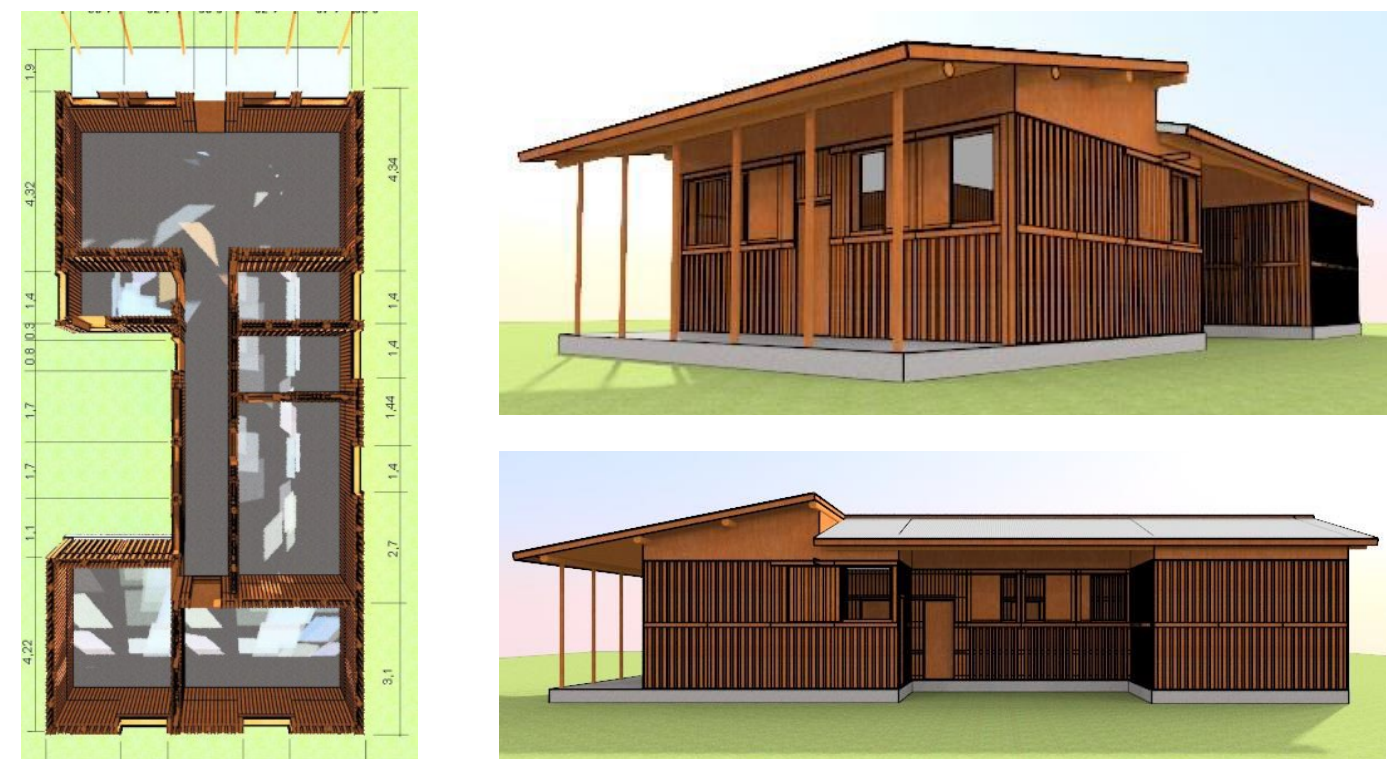

Figuras 17, 18 e 19 - A planta baixa mostra a sala voltada para o norte, tendo a varanda externa como extensão, marcando a chegada e lugar de convívio. Os cômodos são ligados por um corredor que atravessa toda a casa. $O$ telhado é dividido em três águas. 


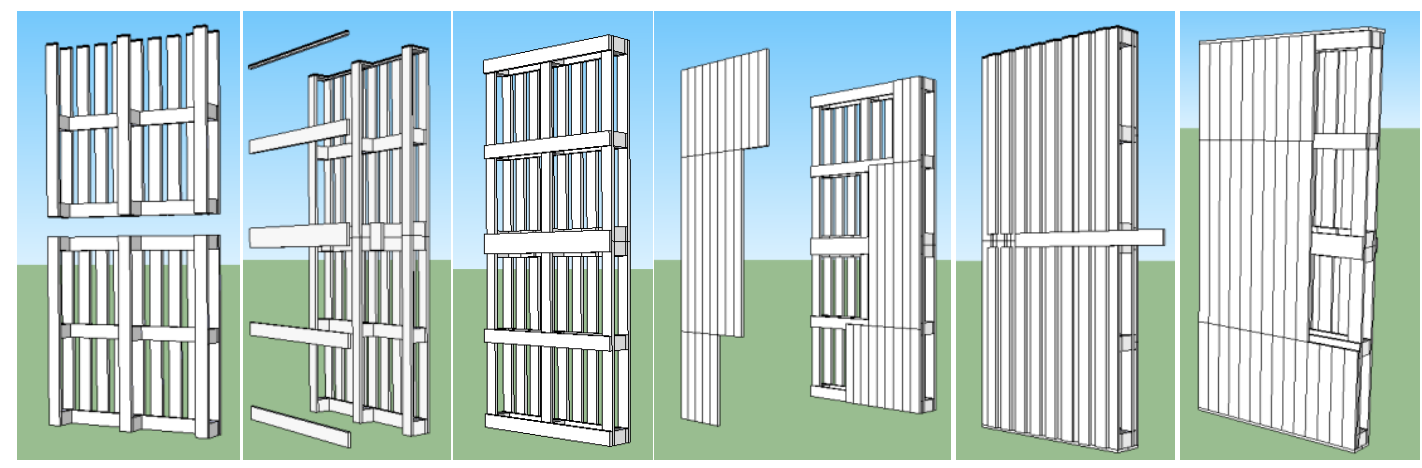

Figura 20 - O painel foi criado a partir de dois paletes unidos verticalmente. Uma peça de madeira foi fixada no encontro entre os paletes, reforçando a junção. Do lado externo, foram pregadas novas ripas entre as ripas existentes dos paletes, fechando a superfície como uma mata-junta. Do lado interno, ripas foram fixadas verticalmente lado a lado fechando os espaços numa superfície plana. As ripas maiores são dispostas no centro do painel de modo a estruturar melhor o mesmo.


Fotos 117 e 118 - Apresentação do painel fabricado com os relatos sobre os processos de produção, dificuldades encontradas, potencialidades e impressões gerais. O problema do peso final foi bastante comentado, assim como a irregularidade dos paletes e a diversidade dos mesmos. O sistema de contraventamento também precisa ser melhor analisado.

\section{Grupo 4}

A proposta do grupo consistiu em um único módulo com $92 \mathrm{~m}^{2}$ divididos em três blocos. A estrutura da casa foi pensada a partir do uso dos eucaliptos roliços como pilares e vigas, e de painéis de vedação a partir dos paletes disponibilizados. Segundo o grupo, a forte relação da família com o lote de produção motivou o desenvolvimento de um sistema de portas de correr com o intuito de valorizar esta relação. 

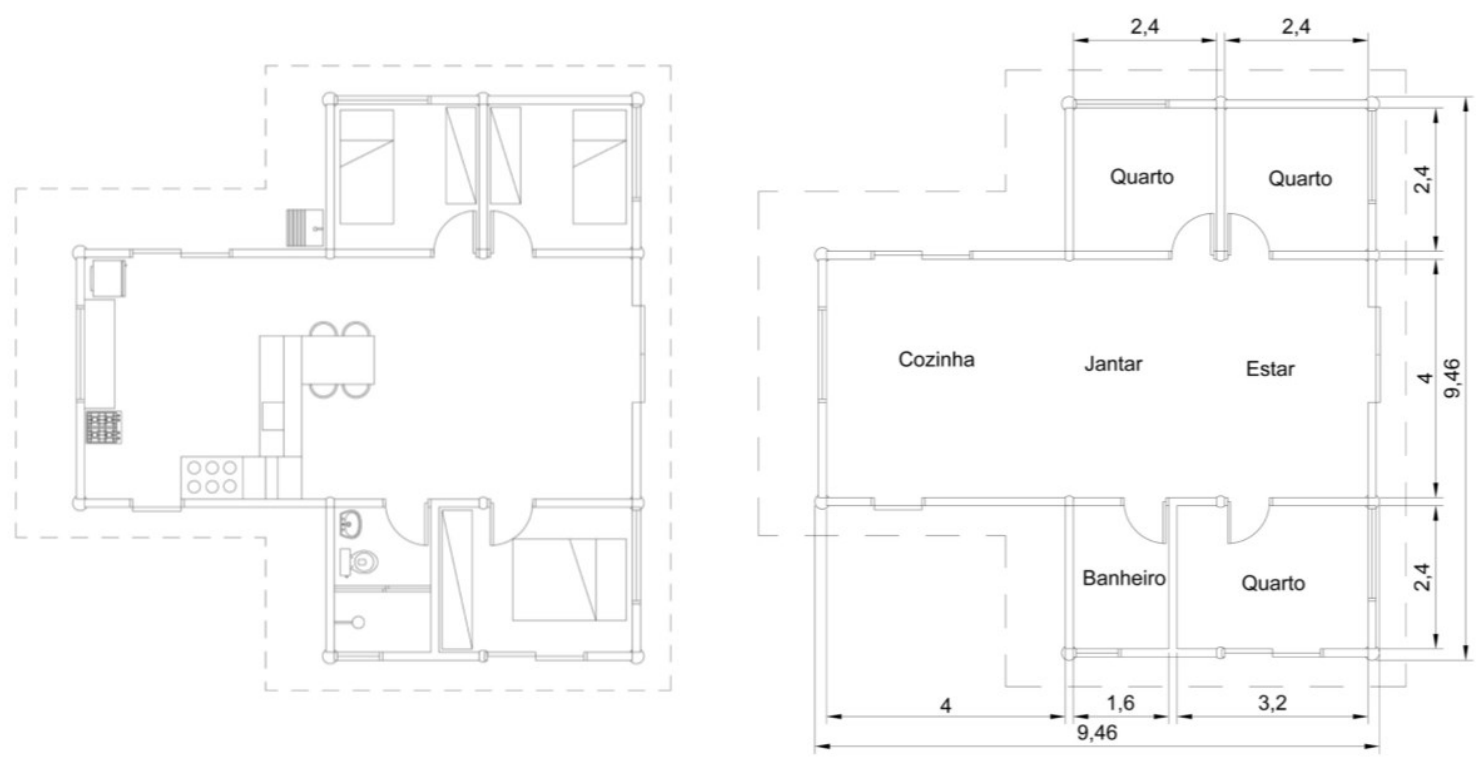

Figuras 21 e 22 - A sala e a cozinha formam o espaço central e comum da casa. Os outros dois blocos com os quartos e o banheiro estão dispostos de forma adjacente a este grande espaço central. $O$ acesso da casa acontece pela fachada leste.
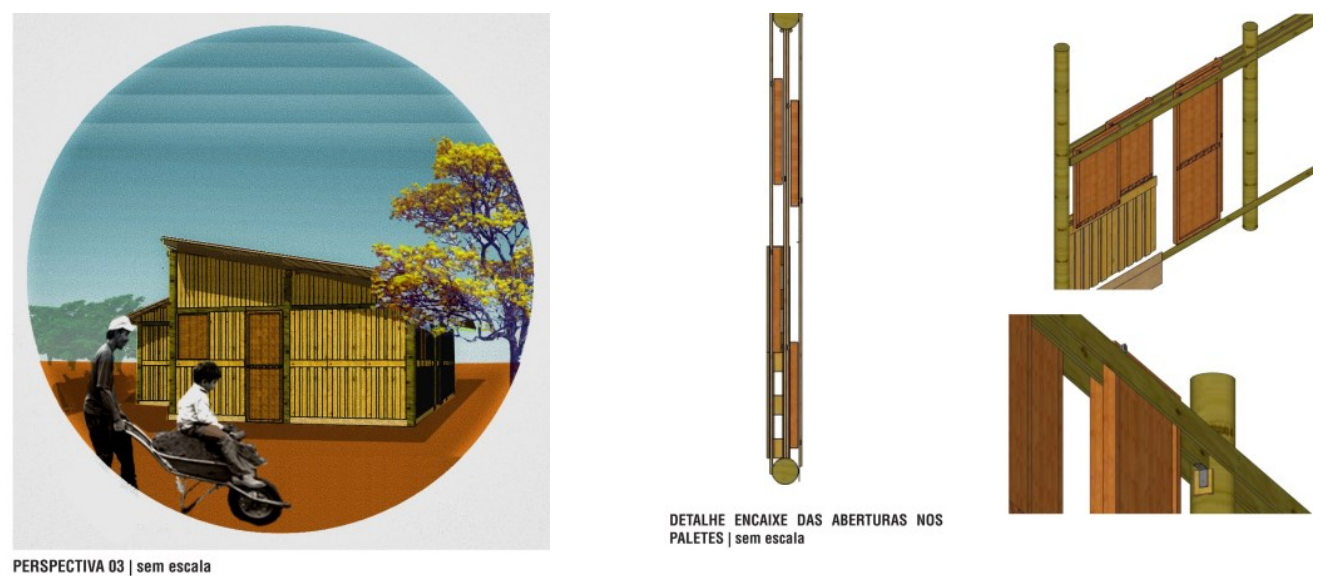

Figuras 23 e 24 - Perspectiva da casa e dos detalhes do sistema construtivo das janelas e portas de correr. Todas as aberturas foram pensadas no princípio de trilhos fixados em peças planas de madeira que ligam os pilares, permitindo a abertura e o fechamento dos espaços da casa.
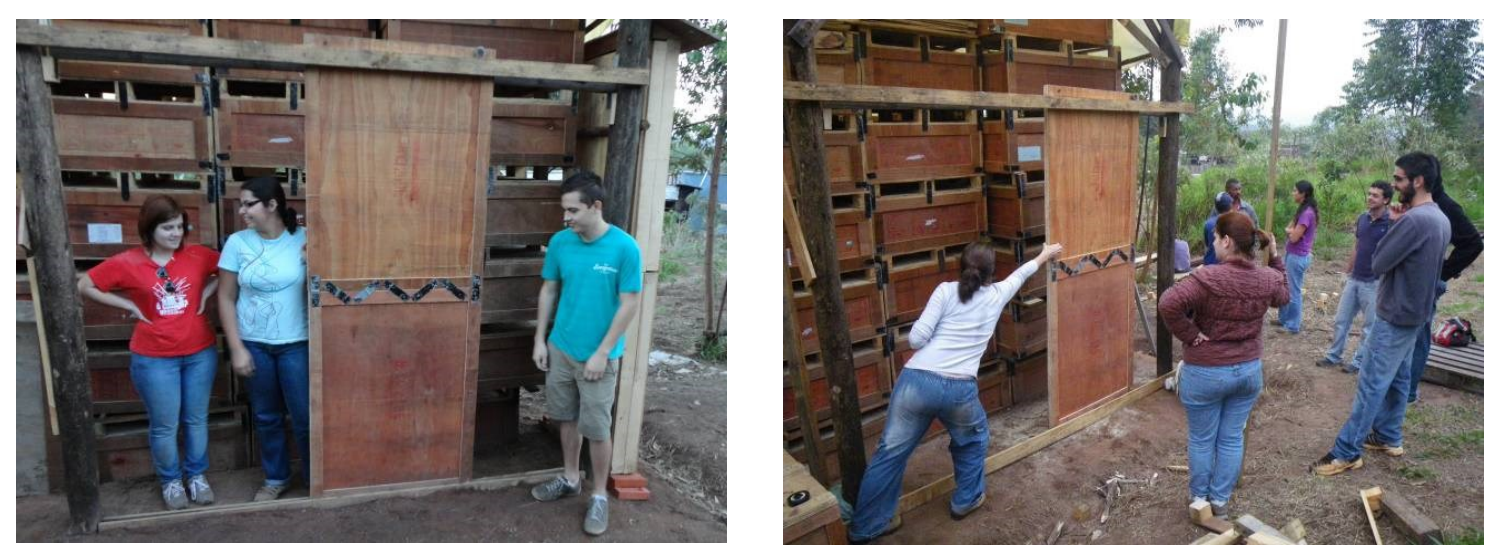

Fotos 119 e 120 - O sistema de porta de correr foi feito a partir das caixas de madeira destinadas a transportar motores de automóveis. A porta foi feita com duas peças da caixa fixadas entre si por cantoneiras metálicas retiradas também da caixa. Um sistema de rodinhas foi fixado na parte superior da porta, que corre através de "trilhos" feitos com peças de madeira. 


\section{Grupo 5}

A proposta do grupo consistiu em um único módulo composto por dois blocos deslocados um do outro. A estrutura da casa foi pensada a partir do uso dos eucaliptos roliços como pilares e vigas, e de painéis de vedação a partir dos paletes disponibilizados. Os painéis foram previstos para serem fixados em cima de uma base de solo-cimento feita a partir da técnica da taipa de pilão, cuja altura atinge a base das janelas.
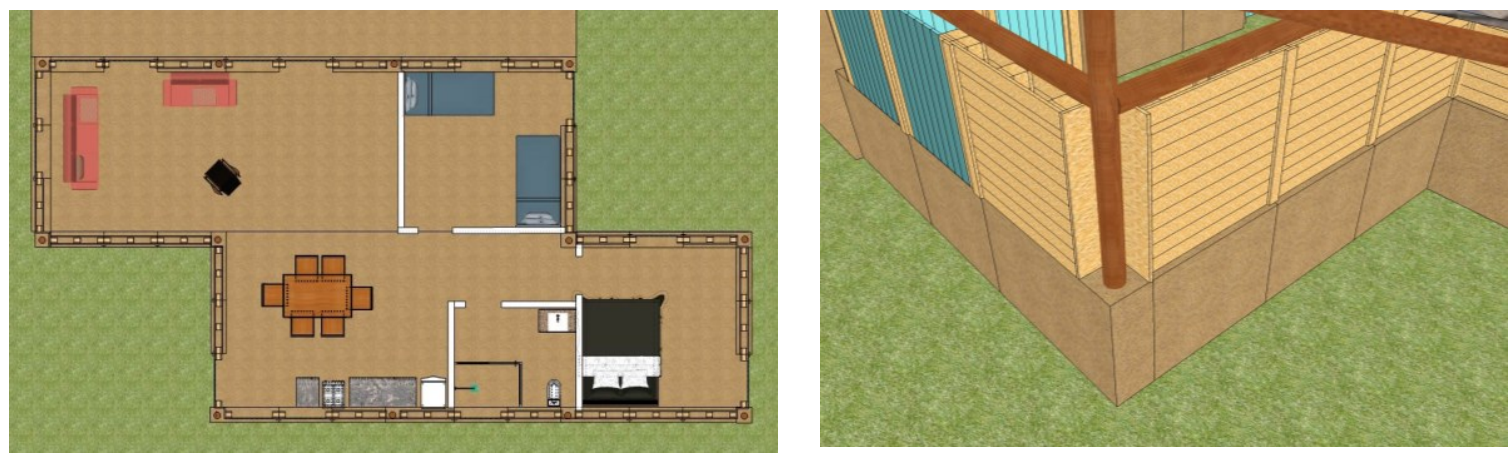

Figuras 25 e 26 - A planta baixa mostra a sala voltada para o norte, tendo a varanda externa como espaço de chegada e lugar de convívio. Os cômodos são dispostos para leste e norte, e a cozinha voltada para o sul e oeste.
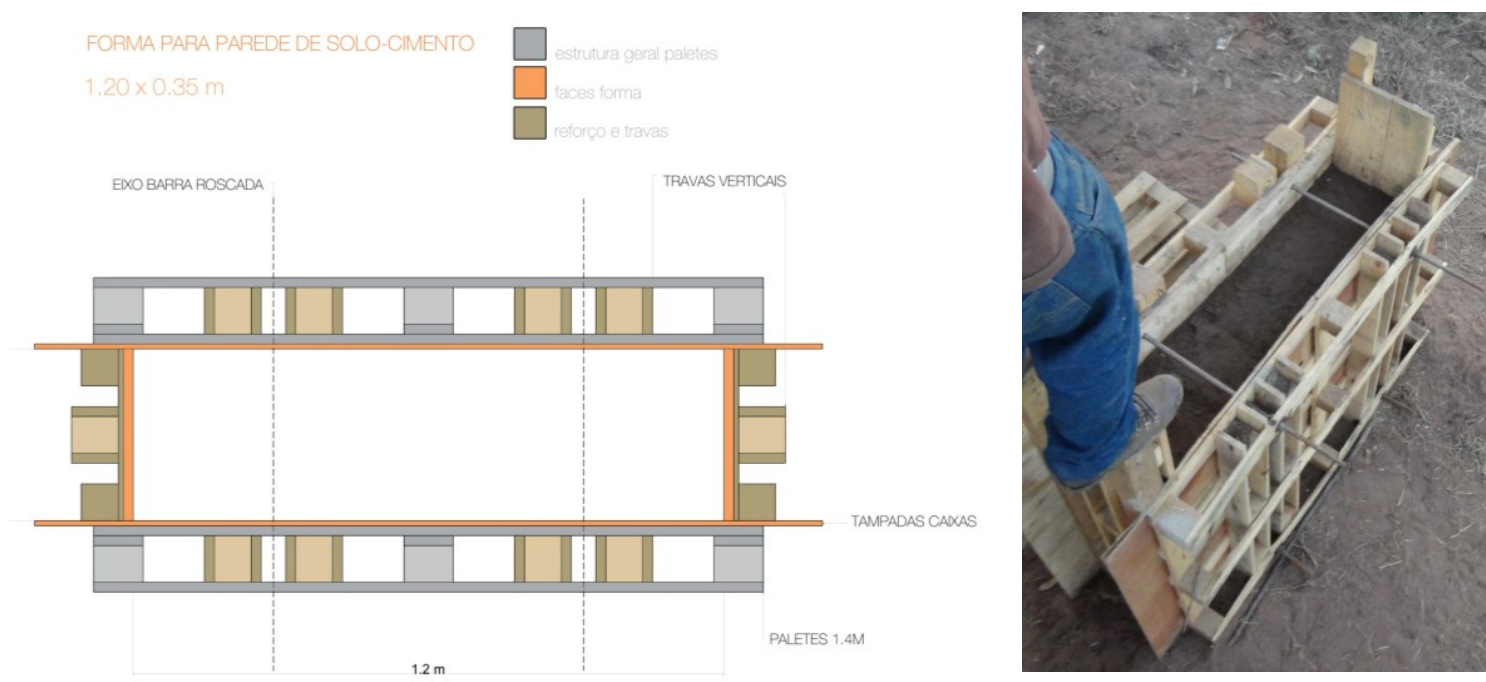

Figura 27 e foto 121 - O grupo decidiu criar e experimentar a produção de fôrmas para a taipa de pilão que seria construída como base da casa e apoio para os painéis de paletes. As fôrmas foram feitas a partir das tampas das caixas de madeira disponíveis, reforçadas com peças de paletes. As dimensões testadas foram de $1,2 \mathrm{~m} \times 1,2 \mathrm{~m}$, sendo o muro realizado com $35 \mathrm{~cm}$ de espessura. 

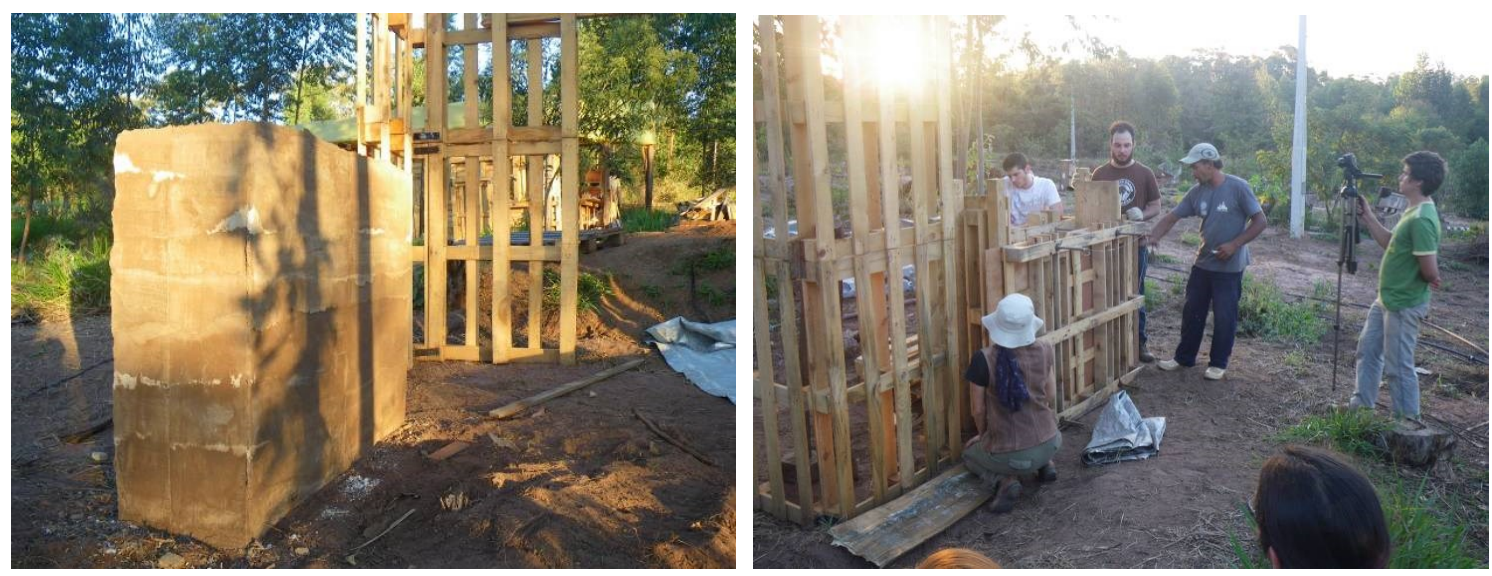

Fotos 122 e 123 - Apresentação da taipa de pilão construída. Esta foi feita a partir da mistura do solo arenoso do lote com cerca de $10 \%$ de cimento como estabilizante. 0 diálogo foi alimentado pelos relatos sobre o processo de produção das fôrmas e da taipa, as dificuldades encontradas, potencialidades e impressões gerais. Foi expressada a dificuldade de trabalhar com a fôrma, considerada grande e pesada para o manuseio. Os travamentos com as barras horizontais também necessitam ser melhor desenvolvidos. O grupo relatou a percepção coletiva da importância da qualidade das fôrmas na produção da taipa. O tempo para produzi-la foi maior do que o tempo de realização da taipa.

De forma geral, os envolvidos apreciaram e aprovaram a proposta do curso de promover a experimentação de diferentes práticas construtivas no desenvolvimento de um projeto habitacional inserido na realidade social de um assentamento rural de reforma agrária, tendo ainda a família moradora como participante, parceira e facilitadora no processo.

De maneira enfática, os participantes expressaram a importância deste tipo de atividade na formação dos futuros arquitetos. "Projetar para uma família é muito importante pois coloca os estudantes próximos da atividade prática do arquiteto.", afirmou um dos alunos. O contato com o canteiro de obras (este não convencional) e suas práticas construtivas é fundamental para os processos de aprendizagem técnica dos profissionais, e as vivências no assentamento abrem outras perspectivas formadoras para além dos campos diretamente ligados a arquitetura.

O sentido social destas atividades também foi bastante ressaltado pelo grupo. Pelas avaliações realizadas, penso ter sido apropriada, por parte dos participantes, a importância de se procurar compreender a família a partir de suas modalidades culturais, práticas cotidianas, condições materiais, contexto social, etc., de modo a pensar o habitat 
inserido numa realidade localizada, porém articulada e dependente de outras conjunturas tanto locais, como regionais, nacionais e mesmo internacionais.

Desta maneira, foi entendido como positivo para o curso estabelecer nosso "contrato social" no início das atividades, com os limites e acordos de convivência coletiva. A satisfação dos participantes com o desenvolvimento dos projetos dentro de uma demanda real foi lembrada como um diferencial nos cursos existentes na Universidade.

Este processo de refletir e projetar o espaço a partir das apreensões sobre a realidade local, nos remete ao sentido contrário da produção do tipo modelo de habitat, de seu projeto genérico e de suas lógicas de produção capitalistas. "Como foi trabalhar com paletes? Muito interessante para perceber que fazer é diferente de desenhar." (P. Ivo)

Dentro das críticas construtivas consideradas pelos participantes, foi expressa a problemática enfrentada quanto aos diferentes "tempos" existentes no contexto deste processo de extensão universitária. O tempo dos cursos obrigatórios no calendário acadêmico dita o tempo dos estudantes que acabam por ter de conjugar as idas ao canteiro com as atividades dos finais de semana. A família também possui seu tempo de vida e trabalho arranjado com o tempo do curso, que por ocorrer no próprio lote, sobrecarrega os finais de semana e transforma seu cotidiano. Os tempos dos recursos financeiros, advindos da família e das políticas públicas, também são pouco administráveis dentro do planejamento do curso, acarretando como consequência, constantes modificações e adaptações na organização e andamento das atividades.

Assim, nesse equilíbrio entre diferentes "tempos", seriam os sábados os melhores dias para as idas ao canteiro? Os alunos sugeriram que não. Disseram ter sido fastidioso ir todos os sábados, e que isso pode ter desmotivado certas pessoas. Além disso, as atividades avançaram lentamente visto o pouco tempo de trabalho dedicado a cada atividade prática (somente no período da tarde). Sugeriram, para a continuação, estabelecer as idas em finais de semana alternados, como foi inicialmente previsto para o curso, mas com uma duração mais longa. 
O fato evidencia a necessidade de pensarmos um curso mais extenso e constante para que pudéssemos atingir todos os objetivos considerando os frequentes conflitos dos "tempos" existentes e influentes em nossa realidade. Nas condições em que foi realizado, o curso ficou condensado, com muitas tarefas a serem feitas em pouco tempo. Vale lembrar, que a família necessitava de uma casa para morar e, mesmo disposta a flexibilizar sua necessidade com a assimilação do tempo do curso em seu tempo de vida, possuía prioridades dentro deste equilíbrio disposto.

Outra consideração importante remarcada pelo grupo fez referência à necessidade de um maior número de aulas teóricas antes das idas ao canteiro, relacionadas sobretudo aos usos dos materiais trabalhados. Como o fato de terem sido priorizadas as atividades práticas também foi bastante valorizado, o que parece faltar é uma maior inserção das dimensões técnicas e práticas, de maneira articulada com a formação teórica, nos programas curriculares do ensino acadêmico. Fica evidenciada a demanda por aprender a trabalhar com materiais naturais e ecológicos, assim como, com ferramentas e equipamentos no processo de instrumentalização e formação dos alunos.

O processo de trabalho da disciplina também foi comentado. Muitos questionaram a falta de uma orientação previamente determinada que facilitasse certas etapas do curso. A construção coletiva do processo sempre foi uma intenção previamente quista pelo grupo coordenador do projeto. Isso, entretanto, não é fácil de se alcançar, sobretudo dentro da complexa e dialética realidade descrita, a partir de uma experiência primeira em seu formato de atuação.

"O caráter não rígido e experimental de construção da disciplina ao mesmo tempo em que ela se desenvolvia, foi um fator que transmitiu insegurança para muitos dos alunos que não "compraram" a ideia de construção da disciplina junto com seus idealizadores." (A. Martins)

Os limites e as potencialidades desta primeira experiência foram alimentando as reflexões quanto aos novos passos necessários a serem feitos. $\mathrm{O}$ curso demonstrou a capacidade dos participantes em criar e produzir suas próprias intenções, e ainda revelou a participação do G. Silva na produção do conjunto das possibilidades construtivas. 
Um dos processos mais importantes a ressaltar desta fase foi o desenvolvimento embrionário de diferentes inteligências construtivas com potenciais de realização. Ou seja, a partir do entendimento dos princípios técnicos, da evolução do trabalho com o material e da criação com intensão livre, conseguir produzir daquilo que é possível fazer. É importante salientar que este processo se fez dentro de práticas dialógicas de pesquisaação, onde as decisões sobre o que foi realizado foram tomadas em grupo, onde o projeto da casa foi elaborado com a participação da família, onde o processo de construção dos sistemas construtivos foi cooperado e solidário, e onde a avaliação da experiência vivenciada foi auto realizada e discutida coletivamente.

"A experiência foi do caramba, o contato com os materiais. Eu sempre evitei usar a luva, eu queria sentir, mexer com a terra." (G. Alves)

"Quando vinha pra cá dava uma relaxada. A gente desenha muito e por mais que façamos maquetes é difícil a gente mexer mesmo. (...) Somos amadores, mas com o tempo fomos aperfeiçoando nossas técnicas em desmontar paletes, realizando em menos tempo com menos perdas." (P. Ivo)

Os resultados obtidos nestas atividades do curso abriram duas novas perspectivas. De um lado, as experiências vividas indicavam boas possibilidades de continuidade, sendo necessário aprofundar as ações no intuito de escolher um projeto arquitetônico e planejar a viabilidade de sua construção. De outro lado, era preciso repensar o formato e as condições desta nova intervenção. Seria dentro de outra optativa que as atividades se realizariam? Tudo indicava à necessidade de mudarmos nosso formato pedagógico. As aulas teóricas em sala foram sendo substituídas por novas intenções que buscavam transformar o canteiro no espaço dos debates e das práticas. Além disso, tínhamos interesse em abrir nossas atividades a outros possíveis interessados, externos ao Instituto de Arquitetura e Urbanismo.

Desta maneira, o planejamento começou a ser desenhado em dimensões mais amplas, inserido agora no formato de um curso de Cultura e Extensão Universitária, aberto aos estudantes, profissionais e ao público em geral. 
O objetivo principal era dar continuidade às atividades realizadas durante 0 primeiro semestre, promovendo, nesta etapa, a construção da casa. A partir dos projetos de arquitetura elaborados pelos estudantes e das experimentações com os sistemas construtivos em paletes e terra, o novo curso trataria de cada etapa construtiva, passando pelas fundações, estruturas, coberturas, paredes, revestimentos, entre outros.

Assim, cada etapa se torna palco da aproximação entre as discussões teóricas e técnicas, e suas práticas construtivas. Neste ambiente, todos os participantes interagem e realizariam as atividades. $\mathrm{O}$ arquiteto aprende com o pedreiro, que dialoga com 0 estudante, que reexplica ao assentado, e assim por diante. Este cruzamento de opiniões, saberes e intenções, possibilita o permanente reajuste dos meios para com seus objetivos. E então, ao se apoderarem de tais mecanismos, os sujeitos desenvolvem suas respostas adequadas, podendo produzir novos saberes e saberes-fazer.

Nesta nova perspectiva, criamos o curso de difusão e extensão universitária "Canteiro-Escola: Produzindo uma habitação popular com técnicas em madeira e terra", do Instituto de Arquitetura e Urbanismo e da Comissão de Cultura e Extensão do IAU/USP/São Carlos, sob a organização do grupo de pesquisa em Habitação e Sustentabilidade - HABIS, em cooperação com a unidade de pesquisa Arquitetura, Meio Ambiente \& Culturas Construtivas, da Escola Nacional Superior de Arquitetura de Grenoble/França.

O curso propunha promover um Canteiro-Escola dentro de um assentamento rural de reforma agrária, através do processo de produção de uma habitação popular, utilizando-se dos materiais disponíveis localmente como materiais de construção. Suas atividades estavam abertas a estudantes, profissionais, pesquisadores, trabalhadores da construção civil, moradores assentados e público em geral, interessados em experimentar práticas participativas e auto gestionárias de organização do trabalho, de transformação e uso de materiais locais e ecológicos na construção, e de intercâmbios sociais e culturais. 0 curso seria realizado no lote familiar do assentamento rural Comunidade Agrária Nova São Carlos.

Entre seus objetivos estavam: fortalecer os programas de extensão universitária aproximando os conhecimentos desenvolvidos nas universidades dos conhecimentos 
populares desenvolvidos na realidade social; contribuir com a ampliação da formação técnica dos profissionais e estudantes das diversas áreas da construção civil envolvidos nas atividades; fomentar processos participativos entre os estudantes, a família e outros assentados; construir uma habitação rural ecológica utilizando-se dos materiais disponíveis localmente, bem como reaproveitando materiais descartados pelas fábricas do entorno do assentamento, principalmente os paletes de madeira; e contribuir com o desenvolvimento tecnológico de novos sistemas construtivos a partir dos paletes de madeira, por vezes consorciados com a terra.

O curso foi organizado em três oficinas complementares e divididas em função das etapas construtivas da casa, ao longo de dois semestres. Foram disponibilizadas 30 vagas para o Canteiro-Escola, correspondentes ao número de inscritos, anteriormente, no curso optativo. A partir dos debates e avaliações realizados com os alunos sobre a frequência das atividades práticas nos finais de semana (todos os sábados durante a optativa), resolvemos espaçar as idas e realizá-las quinzenalmente, porém com um calendário préestabelecido, que incluía sábados, domingos e feriados, dividindo os inscritos em dois grupos de 15 participantes. Os participantes não seriam mais avaliados por notas de participação, mas receberiam um certificado por cada oficina realizada. Por ser um curso de longa duração, realizamos novas inscrições a cada oficina, possibilitando um maior número de participações.

As atividades foram previstas para o período de agosto de 2013 e abril de 2014, totalizando 8 meses, com 34 dias de atividades no canteiro, representando 238 horas de curso (7 horas/dia). A programação das oficinas estava assim organizada:

Oficina 1: Fundações + Bases em taipa de pilão + Estruturas em eucaliptos (Agosto, Setembro e Outubro/2013).

Oficina 2: Coberturas + Bases em taipa de pilão (Novembro e Dezembro/2013).

Oficina 3: Execução das paredes + Revestimentos e acabamentos (Fevereiro, Março e Abril/2014). 
Desta maneira, o curso foi ganhando sua forma e suas delimitações. A divulgação foi realizada e as inscrições abertas. Paralela à organização das atividades, continuamos avançando nos testes construtivos realizados no assentamento e nas avaliações e desenvolvimento das propostas arquitetônicas elaboradas pelos estudantes. Isso foi realizado em conjunto com a família. Por um lado, a taipa de pilão estabilizada com cimento nos pareceu uma boa opção de técnica construtiva a realizar, de modo que continuamos a desenvolver as fôrmas de madeira e fizemos alguns testes no galpão. Por outro lado, os diferentes projetos arquitetônicos foram sendo analisados e resultaram em um projeto "final", que propunha, a partir da proposta escolhida, adaptar alguns espaços e reagrupar as ideias mais pertinentes e adequadas, dos outros grupos, tanto a nível de projeto quanto de sistemas construtivos.
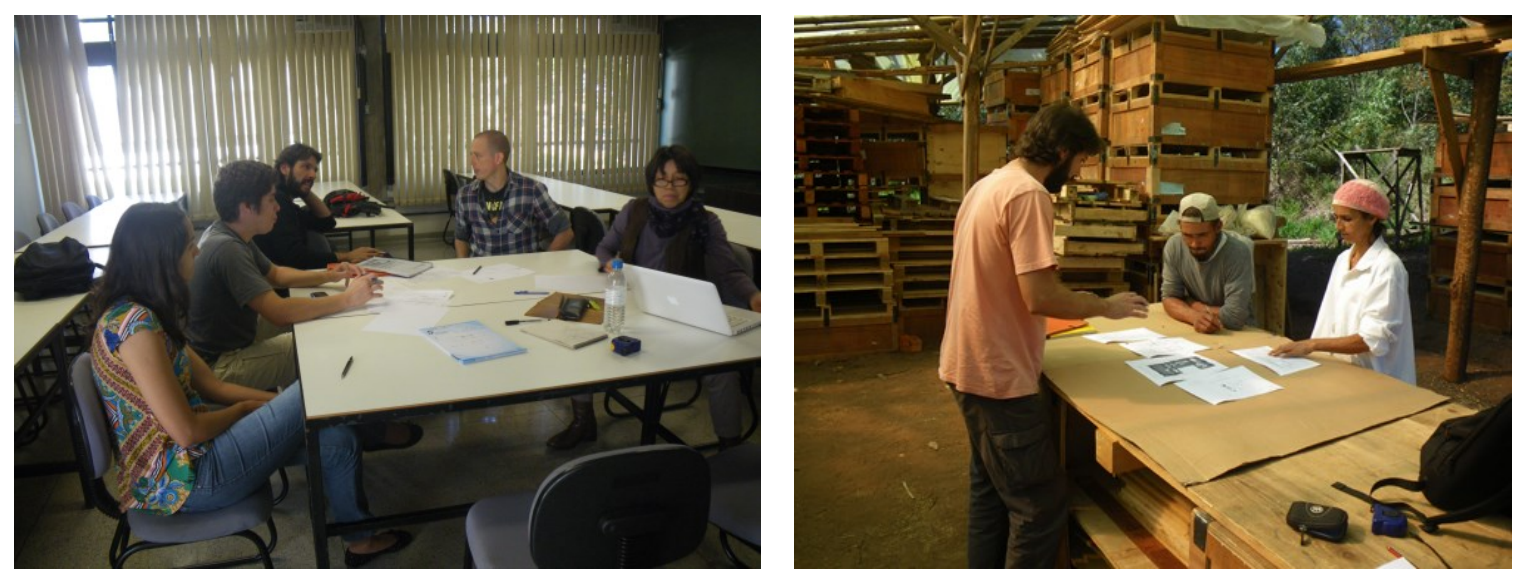

Fotos 124 e 125 - Os projetos continuaram a ser desenvolvidos tanto na universidade, pelos interessados em participar, quanto no assentamento com a família em seu lote. As propostas foram sendo analisadas e novas ideias foram surgindo com o intuito de adaptar e tentar reunir aspectos construtivos de todos os projetos realizados.
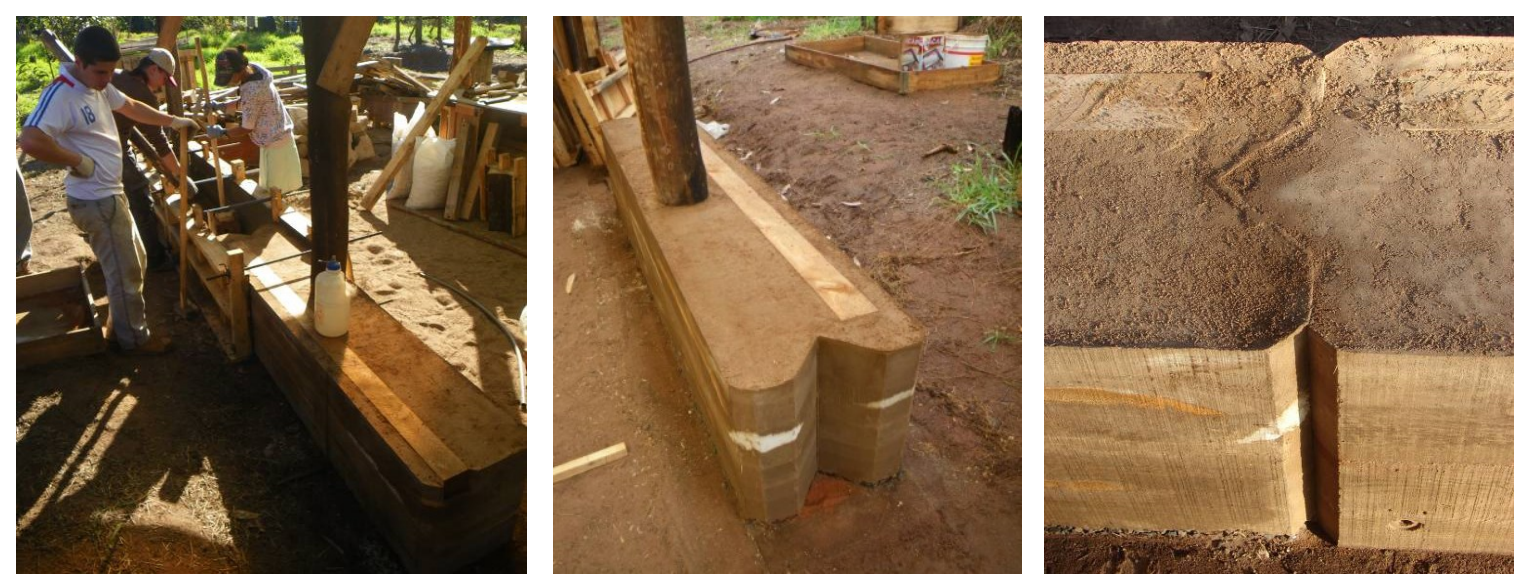

Fotos 126, 127 e 128 - As fôrmas das taipas de pilão continuaram a ser desenvolvidas e alguns elementos em taipa foram realizados com o intuito de se testar certas condições técnicas. Uma delas, foram os encaixes macho-fêmeas experimentados nos encontros entre duas taipas. Os cantos chanfrados também foram testados com o intuito de proteger os ângulos "vivos" do bloco. Experimentamos encrustar uma peça de madeira na taipa para testar formas de conexão com os painéis de paletes das paredes, e observamos também o comportamento do pilar quando envolto por uma base de taipa estabilizada. 

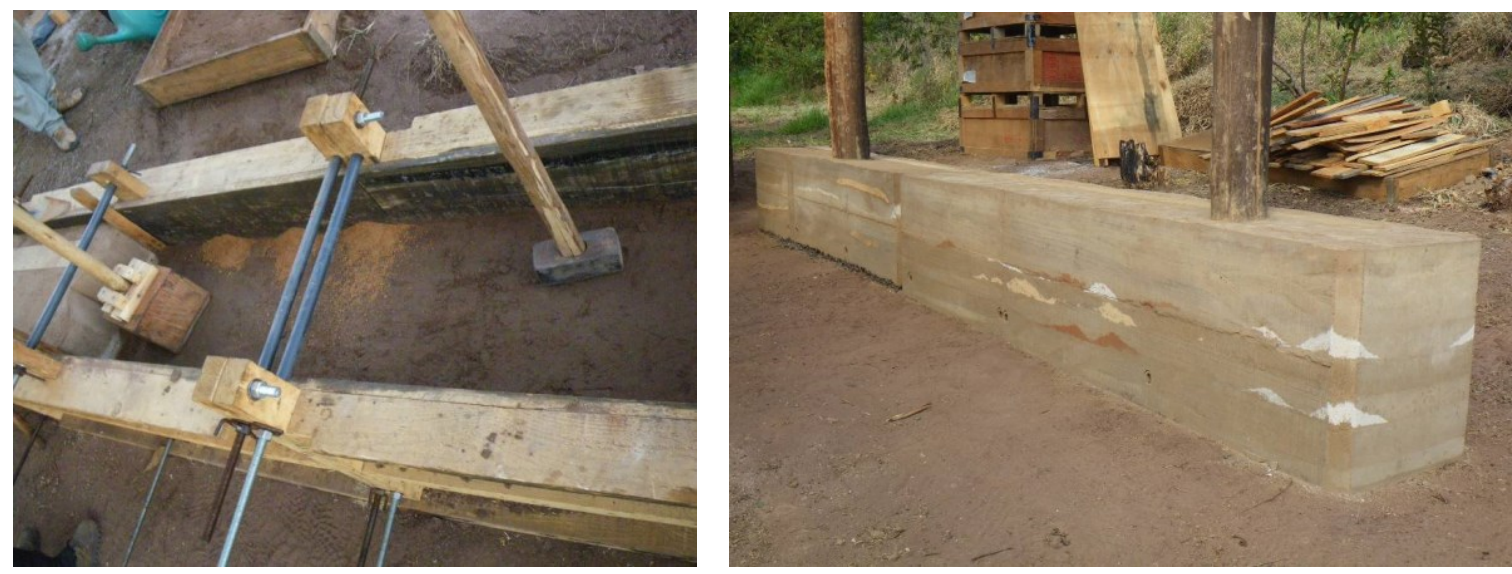

Fotos 129 e 130 - As taipas de pilão foram estabilizadas com 10\% de cimento, visto o caráter arenoso da terra do lote. Foram testadas a inserção de outras terras de coloração diferente, no exercício de criarmos efeitos coloridos para a base da casa. Pilões de formatos e tamanhos diferenciados começaram a ser produzidos, assim como o planejamento e a construção de todas as fôrmas necessárias ao curso.

\section{Canteiro-Escola: por um espaço do trabalho livre}

"Não há ensino sem teoria explícita, não há teoria sem verificação experimental, ou seja, não há progresso teórico sem avanço experimental." (FERRO, 2008, p.21)

O canteiro do trabalho livre, a partir das compreensões de Sérgio Ferro, seria aquele cujo norte indica às práticas em prol do trabalho não alienado, consciente, formador, libertário, coletivo e autonomamente organizado. Seria o espaço de trabalho social onde as práticas produtivas buscam outras relações de produção para além da composição mecânica dos trabalhadores isolados.

O caráter heterônomo do canteiro de obras convencional, cuja determinação vem de fora, impõe ao mesmo, os tempos e ritmos necessários à sua realização, bem como seus modos operantes e seus códigos embutidos, válidos ao controle exigido e à finalidade do modelo. A fragmentação e especialização do processo produtivo, condição do modelo capitalista, torna-o mais eficiente, na medida em que insere em seu mecanismo a figura necessária do chefe e patrão, ou ainda, do arquiteto e engenheiro, controladores da decodificação necessária para a realização completa da produção. 
Como observou Silke KAPP (et al., 2012), o método de trabalho utilizado pelos técnicos (incluindo arquitetos), quando estes ainda conseguem participar de sua elaboração, na maior parte das vezes não considera a vontade dos beneficiários diretos do projeto. Consiste em uma atuação tecnocrática que busca enquadrar situações novas às antigas rotinas administrativas, financeiras e jurídicas, e não se orienta em direção à mobilização do conhecimento para outras práticas de planejamento e produção do espaço. Esse quadro é visto de maneira significativa na produção do habitat social através do acesso aos créditos financeiros articulados com as políticas públicas.

"A atuação tecnocrática é, assim, marcada pelo embate entre uma racionalidade técnica (burocrática) e o conhecimento vivido de moradores que tradicionalmente produzem os seus próprios espaços, domésticos e urbanos. Os protocolos dessa racionalidade, sempre considerada superior, interditam de antemão a maioria dos elementos essenciais à experiência cotidiana dos autoprodutores, como, por exemplo, a possibilidade de que uma construção não seja precedida por um projeto, mas pensada à medida que evolui." KAPP (et al., 2012, p.03)

Estas reflexões críticas, e necessariamente permanentes, inspiram e incitam as práticas cotidianas e as fundamentações teóricas de nossas experimentações coletivas. Nos apontam para um processo produtivo que, para além de seu produto (casa), possa ser visualizado como um dinâmico processo de sociabilidades, com valores rurais e urbanos, e como um espaço de encontro de diversidades e assimetrias culturais e de classes. Nosso marco vincula o ambiente social ao processo de formação e de produção tecnológica, através das dimensões do habitar.

A construção do Canteiro-Escola configura-se então como um ambiente onde os processos produtivos e formadores se entrelaçam, buscando conciliar os diferentes interesses e pontos de vistas, propondo e discutindo as transformações e imprevistos, cujo processo mesmo, dialético e histórico, revela constantemente. 


\section{OFICINA 1}

Suindara. O nome foi dado pela família à nova habitação. Ele faz alusão à coruja Suindara, encontrada na região e de maneira abrangente em todo o Brasil, e que representa em muitos mitos e crenças populares o símbolo de esperteza e sabedoria.

É importante ressaltar que nos compromissos estabelecidos com a família nunca houve nenhum tipo de remuneração financeira. As pessoas participavam com seu trabalho amador e dentro de um processo de formação. E a família, se responsabilizava por aportar a maior parte dos recursos financeiros necessários a construção da casa.

Por mais que utilizássemos materiais locais e naturais em sua produção, necessitávamos comprar outros tantos itens como: pregos, parafusos, brita, cimento, telhas, etc., e uma série de ferramentas. Ainda assim, o montante necessário era maior do que a possibilidade da família em assumir tais custos. O que fizemos foi estabelecer parcerias com lojas e empresas que atuam na região, e que apoiaram com a doação de certos materiais. Ao longo do curso fizemos parcerias com oito empresas e recebemos apoios diversos das duas instituições acadêmicas e de grupos de particulares, todos fundamentais para a concreta viabilização do curso e construção da casa.

Mais uma vez, nossa expectativa por 30 participantes foi superada por 45 inscritos. Todos foram aceitos, uma vez que seria possível organizar dois grupos com cerca de 25 participantes cada (inscritos + grupo de pesquisa + família). Assim, modificamos o limite de participantes das oficinas que se seguiram a esta primeira.

Durante a optativa, o local de implantação da nova casa havia sido decidido pela família com as observações e considerações do grupo. Naquele momento, ela seria construída próxima ao limite do lote, ao lado do galpão feito durante a optativa. Entretanto, após refletir melhor sobre o planejamento do espaço e as distâncias entre as construções e a estrada, a família resolveu modificar seu local de implantação. Foi optado por construí-la entre a atual moradia e o galpão, próxima também das demais construções. Seu projeto arquitetônico, resultado das atividades do curso, teve seu desenho e medidas acertadas com a família e alguns princípios e técnicas construtivas confirmadas a partir das pistas estudadas ao longo do semestre. 
O projeto modular permite sua evolução ao longo do tempo com o acréscimo de novos cômodos à planta atual. Sendo arenosa a terra encontrada no lote, as fundações e as bases da construção foram previstas de serem realizadas em terra estabilizada com cimento, a partir da técnica da taipa de pilão, nas mesmas condições ensaiadas durante o curso optativo. A estrutura da casa foi prevista com troncos roliços de eucaliptos citriodora. As paredes de fechamento e os painéis de cobertura foram pensados a partir da reutilização dos paletes e madeiras descartadas por uma das empresas parceiras. 0 tratamento das águas negras e cinzas foi previsto para ser realizado através de processos biológicos de filtração e purificação das águas.

O desenho da casa é composto por dois blocos retangulares sendo, um disposto com os quartos e o outro com os espaços de vivência: sala, cozinha, banheiro e serviços. O primeiro deles orienta os quartos a leste (sol matinal) e o segundo dispõe a sala a norte e a cozinha a oeste. Os blocos serão cobertos por telhas cerâmicas e estão conectados por um espaço central de acesso aos cômodos, destinado ao convívio e a circulação. Este espaço com cobertura translúcida, propiciará melhor iluminação interna para a casa.
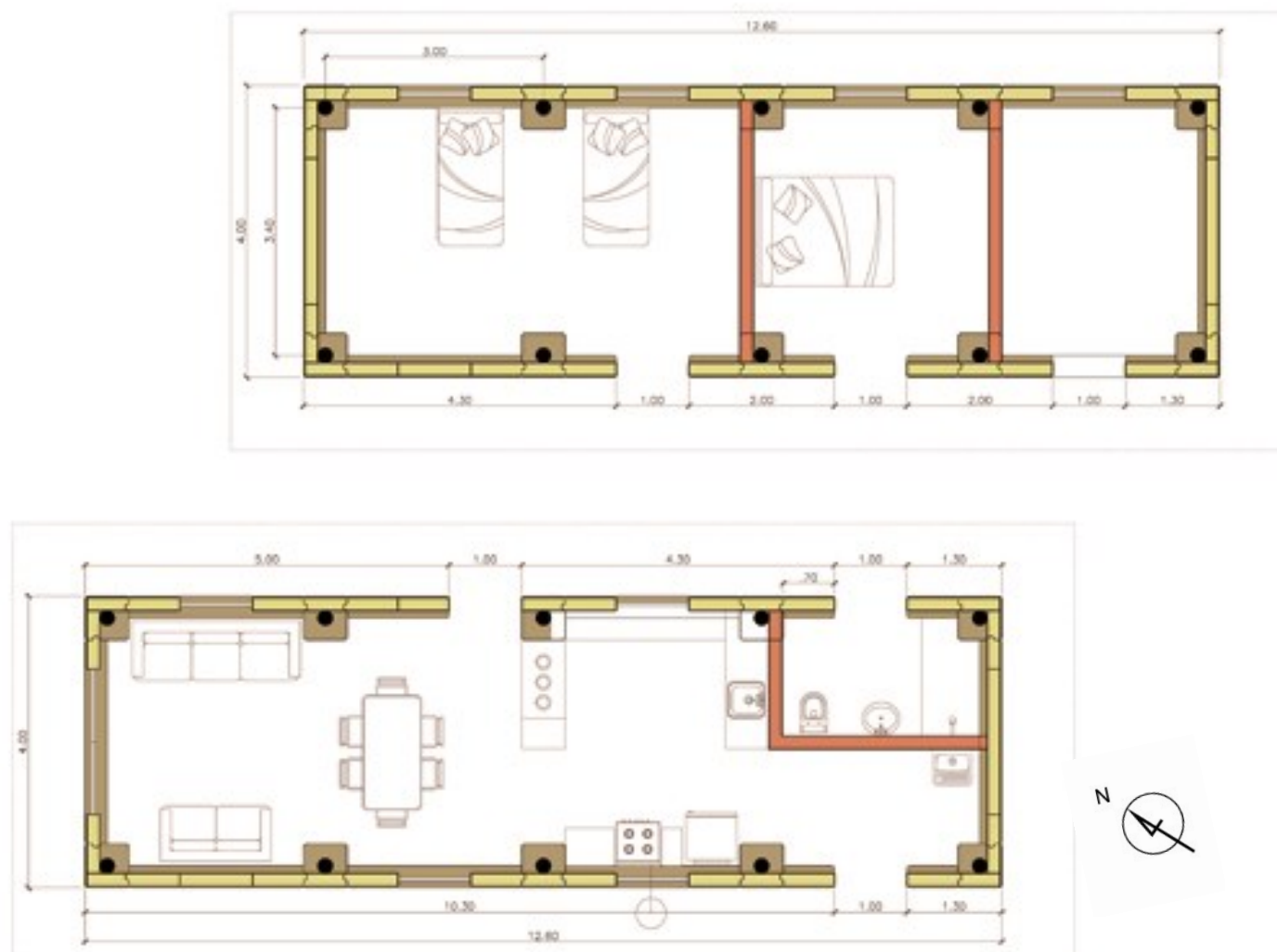

Figura 28 - Cada bloco é composto por quatro cômodos de 3,00m x 3,40m (eixo dos pilares). As paredes externas de fechamento são de painéis feitos a partir dos paletes, preenchidos com terra em seu interior. $O$ revestimento interno é de terra, sendo em algumas paredes de cal. Planta baixa: Anaïs Guéguen Perrin. 


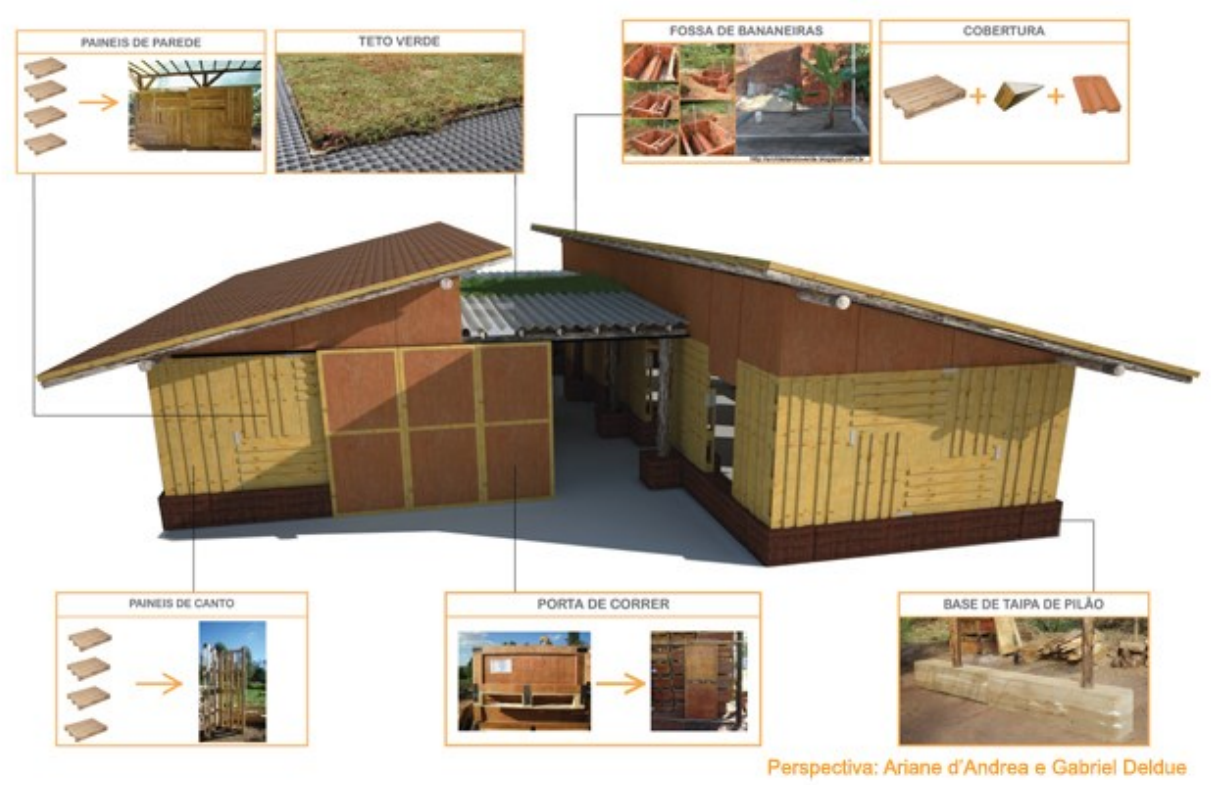

Figura 29 - O projeto da casa passou pelo exercício de agrupar os diversos sistemas construtivos experimentados durante o curso optativo, trabalhando com a taipa de pilão, os painéis de paletes e a porta de correr. A família havia demonstrado o interesse pela cobertura vegetal, o que foi, num primeiro momento, inserido no projeto. Também foi discutido o tratamento biológico das águas usadas, cinzas e negras, e a captação das águas pluviais. Perspectiva: Ariane d'Andrea et Gabriel Delduque.

24 de agosto de 2013. Esta foi a data de início dos trabalhos práticos de construção da casa Suindara. O dia começou com os primeiros contatos, percepções e impressões sobre o local. Este momento misturou a diversidade das informações que a realidade revelava com as perspectivas e motivações que cada um aportava, tornando-se um momento de abertura dos olhares sobre as conjunturas locais e de confecção coletiva das propostas trazidas.

\section{"Quem já conhecia um assentamento rural?"}

Esta questão orientou os primeiros diálogos coletivos com o propósito de dar as boas-vindas aos participantes e construir um panorama inicial sobre o curso e seus porquês. Estávamos fora dos "muros" da Universidade e não mais na cidade urbanizada, reconhecida e apreendida familiarmente pelos participantes. Embora inseridos formalmente no perímetro urbano do município de São Carlos, estávamos em seu território rural, mais precisamente dentro dos limites de um assentamento rural de reforma agrária, o que para muitos representava a primeira vez.

Foi então feita uma roda de apresentação das pessoas presentes e cada um pôde relatar parte de suas expectativas. A agenda do dia foi comentada e propusemos uma 
visita guiada pelo lote, pois a maioria do grupo não havia participado do curso optativo e não conhecia o lugar. Neste momento, uma primeira aproximação entre os participantes foi se costurando. Perguntas curiosas, comparações exageradas, questionamentos técnicos e olhares motivados facilitavam os diálogos e as impressões que se construíam naturalmente dentro do grupo. A intensão era proporcionar elementos para que cada participante pudesse tecer suas primeiras compreensões sobre o espaço de vida da família e o significado da nossa construção dentro das conjunturas influentes. Assim, como durante o curso optativo, através da visita aos lugares referenciais para a família, os participantes começaram a melhor entender seu modo de vida.

Após a apresentação e visita, o grupo se reuniu no galpão para aprofundar as conversas mais diretamente ligadas às atividades. Através dos mapas que dispúnhamos do assentamento, foi feita uma apresentação sobre seu processo histórico, anterior e posterior à chegada das famílias e ao processo de regularização fundiária e criação do assentamento rural. O casal de moradores mostrou no mapa o caminho percorrido durante a caminhada e relatou brevemente algumas situações vividas durante o período de acampamento e as dificuldades enfrentadas no momento presente, sobretudo quanto ao acesso a água e aos créditos financeiros para a produção agrícola e animal, e para a construção das habitações.

Foi relatado nosso processo de entrada na comunidade e as iniciativas de trabalho com as demais famílias. Foram expostas as razões pelas quais foram iniciadas as atividades neste lote específico e como o processo foi pouco a pouco ganhando forma e ampliando suas ações e perspectivas.

Foram apresentadas, também, as atividades realizadas ao longo do semestre anterior, quando do curso optativo, com seus resultados e métodos de trabalho utilizados. Foi mostrado o projeto que seria construído, comentando seu processo de criação, explicando as escolhas dos materiais trabalhados e expondo ao grupo os sistemas construtivos projetados e realizados pelos alunos durante a optativa.

A partir do diálogo sobre as etapas de nosso canteiro, organizadas nas diferentes oficinas sucessivas, foram explicados dois princípios importantes dos trabalhos. 0 primeiro, referia-se ao desenho arquitetônico que foi desenvolvido até a forma de 
projeto preliminar, contendo apenas seus aspectos gerais e diretrizes principais. Foi nossa escolha deixar o projeto pouco detalhado, em aberto, aguardando o momento onde as interrogações ganhassem espaço e forçassem a refletir e criar conjuntamente soluções para o avançar das atividades. Assim, seria possível descobrir e resolver coletivamente os detalhes construtivos na medida em que a obra avançasse. Além disso, em um canteiro onde os materiais utilizados eram em grande parte naturais, era necessário transformálos para serem utilizados, sendo que em alguns casos, a partir da criação daquilo que não havia sido ainda realizado, como no caso dos painéis de paletes para as coberturas e paredes. Foi assumida, de maneira proposital, a intensão de estar sempre modificando e adaptando o projeto à realidade apresentada.

O segundo princípio fazia referência à utilização dos materiais. Era nosso intuito, desde o início das atividades, procurar utilizar os materiais encontrados e disponíveis localmente. Isso não significava negar os materiais industrializados, mas limitar sua presença, utilizando-os quando necessário. Nos servir de certas qualidades técnicas que estes materiais poderiam aportar ao projeto, a partir dos limites identificados na utilização dos materiais naturais locais.

Haviam dois canteiros para experimentar e produzir. O galpão e a casa nos serviam como espaços complementares de trabalho, e assim, experimentávamos no galpão, aquilo que seria, num segundo momento, construído na casa. Essa era uma ideia interessante: dois canteiros no mesmo espaço e em tempos complementares.
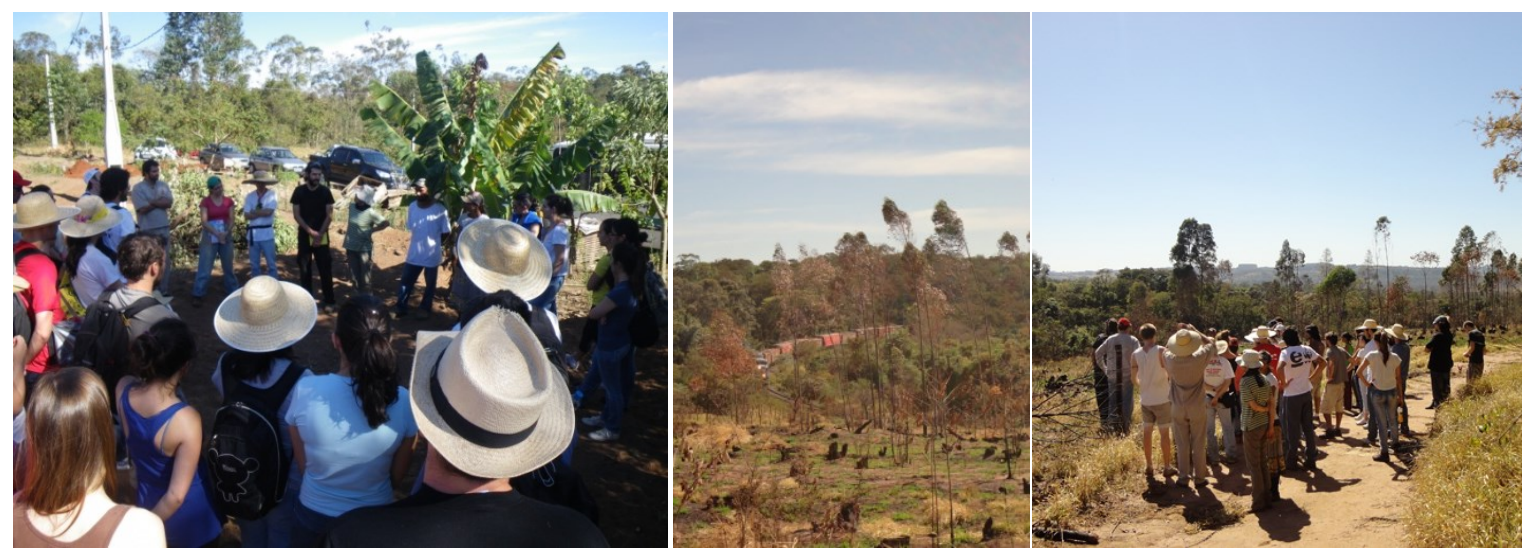

Fotos 131, 132 e 133 - Roda de apresentação dos participantes do curso. Em clima descontraído, as pessoas foram se conhecendo e entendendo melhor a realidade onde construiríamos a casa. A visita guiada foi uma excelente dinâmica para inserir o grupo no processo e dar condições para que a partir das dúvidas e observações fossem criados os laços sociais fundamentais para os trabalhos que iniciavam. 

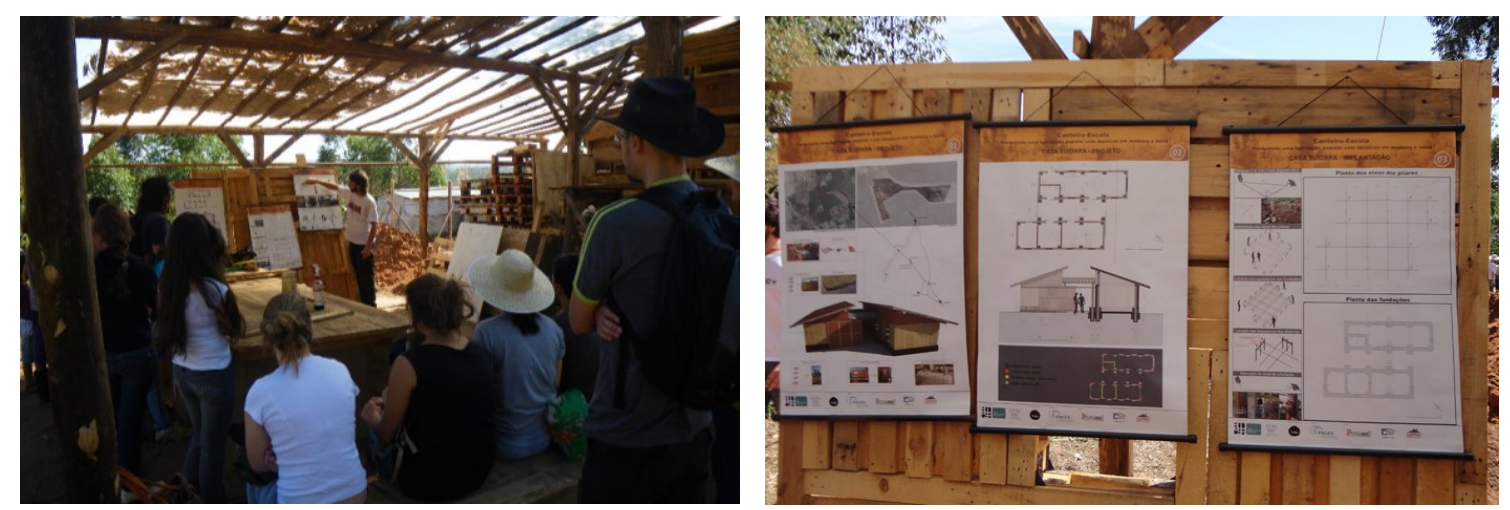

Fotos 134 e 135 - O projeto foi apresentado e seus processos construtivos relatados. Tanto as questões de organização e logística, quanto os detalhes técnicos foram discutidos. Os sistemas construtivos criados foram mostrados e seus limites comentados. O esforço orientou-se para a compreensão de como facilitar este processo evitando aportar muita complexidade, risco que se corre sempre que tratamos de múltiplas informações em pouco espaço de tempo.

As atividades da manhã foram completadas com explicações sobre a logística do curso: horários, transporte, refeições, ferramentas, calendário, questões de segurança, etc., sendo definida a meta das atividades para o restante do dia. Por último, foram lidos os acordos e compromissos estabelecidos durante o curso optativo e aberto para o debate, onde havia a possibilidade de adicionar novos termos ou modificar os existentes.

Ficou decidido que a meta para o dia seria marcar a implantação da casa. Para esta tarefa, o melhor facilitador seria aquele que mais conhece a atividade em seu ofício. Esta foi a primeira vez que G. Silva assumiu o papel de professor e foi ensinar aos participantes como marcar a obra. Como dispor os piquetes de marcação? Como passar o fio e amarrálo pela obra sem cortá-lo? Como montar os gabaritos e fixá-los. Como realizar os ângulos retos e encontrar os eixos dos pilares com poucas ferramentas? A ideia era assegurar as condições para que G. Silva guiasse o grupo nas práticas de implantação da futura casa.

Uma iniciativa desenvolvida para os métodos de ação pedagógica no canteiro foi a produção de painéis como suportes para as atividades práticas, onde a parte teórica, o projeto e as etapas construtivas eram explicadas de maneira rápida e simples. Estes painéis em tamanho A1 foram produzidos na medida em que avançávamos nos trabalhos e necessitávamos de novos suportes para as explicações e diálogos com o grupo. A intensão era utilizar os painéis pedagógicos ao longo das atividades do canteiro e, ao final do curso, compor uma espécie de caderno da obra, retratando cada etapa construtiva realizada. 

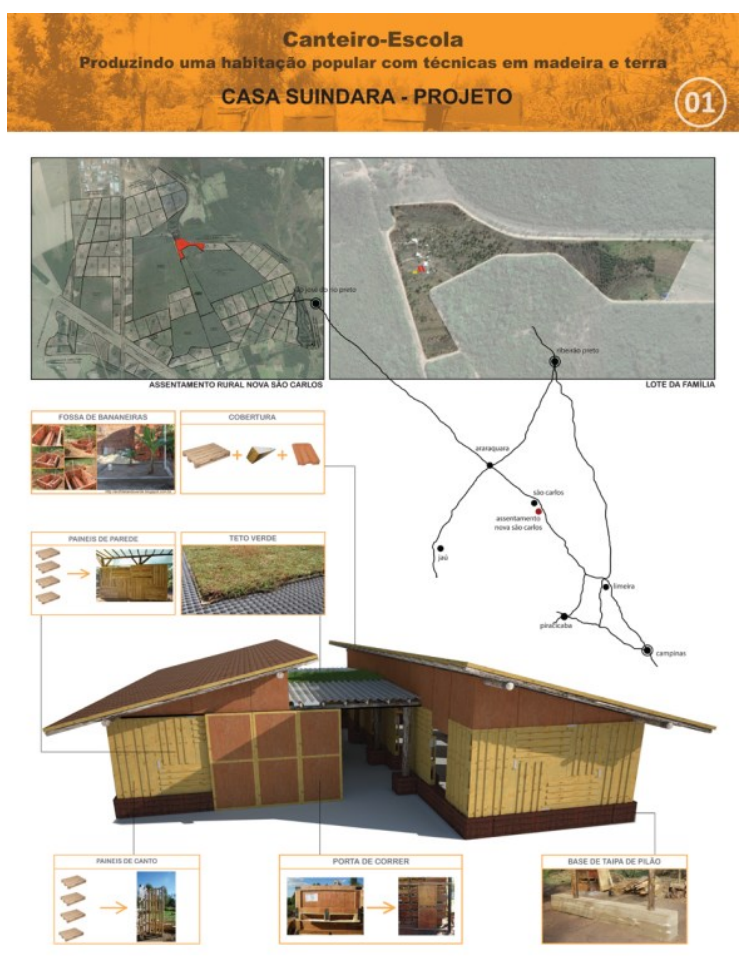

新非
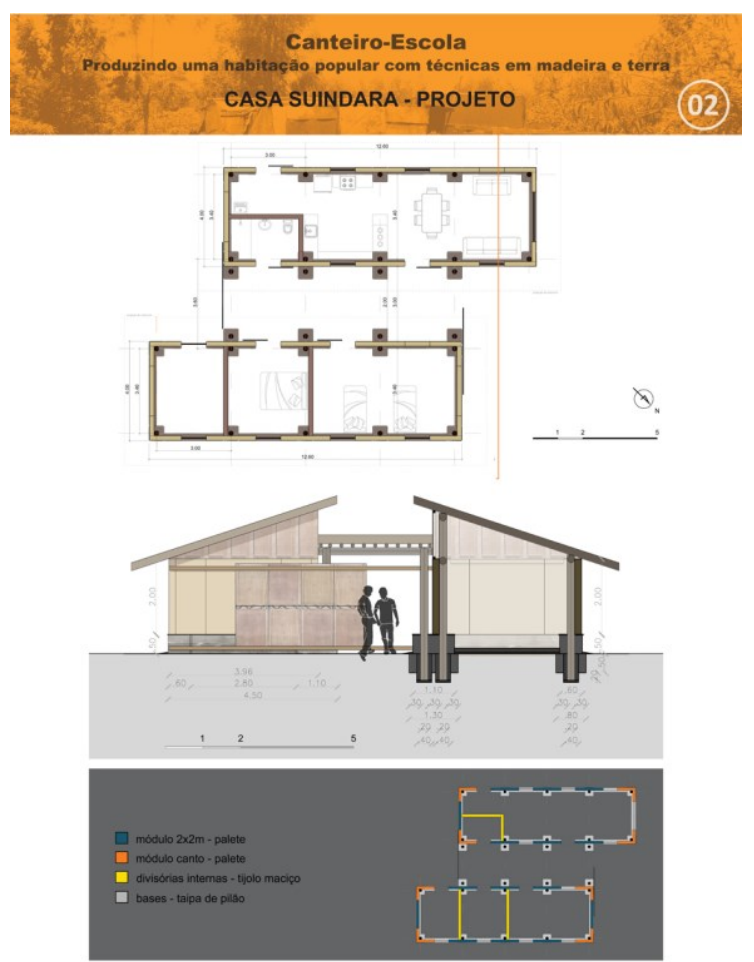

新望突

Figuras 30 e 31 - O primeiro e segundo painéis consistem em suportes de apresentação do projeto. Eles contêm a localização do assentamento e do lote, assim como o local de implantação da casa. Mostram o projeto preliminar e as informações básicas para sua compreensão. Painéis: Anaïs Guéguen Perrin.
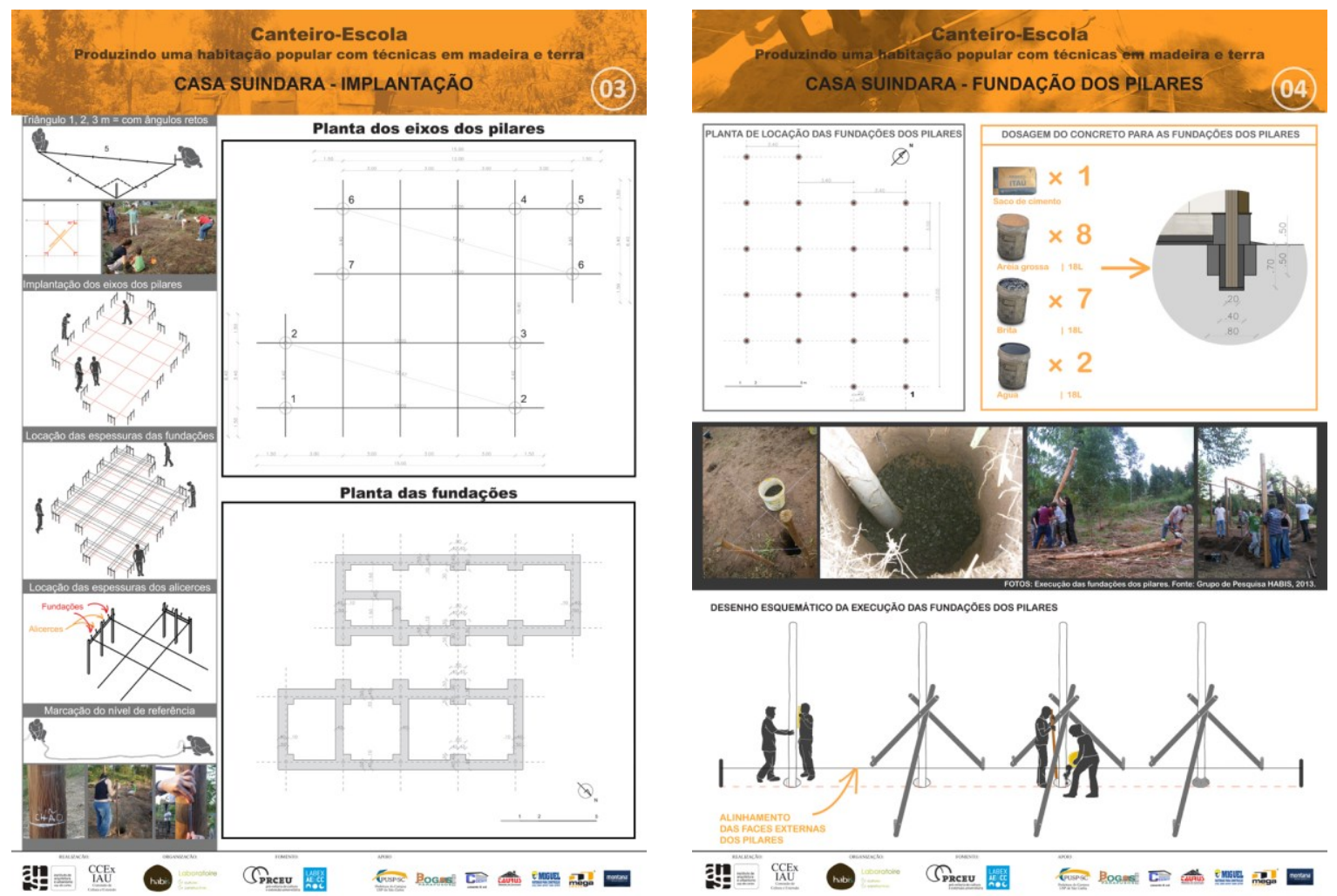

Figuras 32 e 33 - O painel 03 faz referência a atividade de implantação da casa com suas diferentes etapas: realização dos ângulos retos, marcação dos eixos dos pilares, nivelamento, entre outros. O painel 04 traz o processo de colocação dos pilares, assim como o processo de realização das fundações dos mesmos. Painéis: Anaïs Guéguen Perrin. 

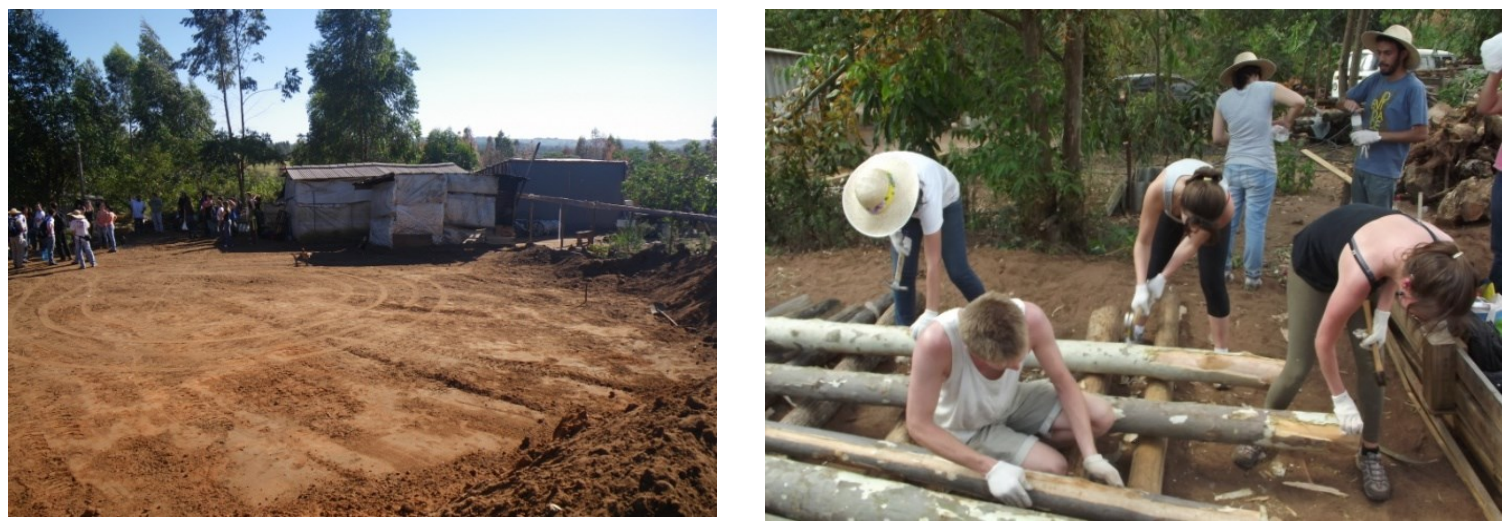

Fotos 136 e 137 - Os primeiros trabalhos foram organizados em equipes que começaram as atividades em diferentes frentes de ação. Uma delas iniciou a tarefa de descascar e preparar os eucaliptos para serem utilizados posteriormente como pilares e vigas.
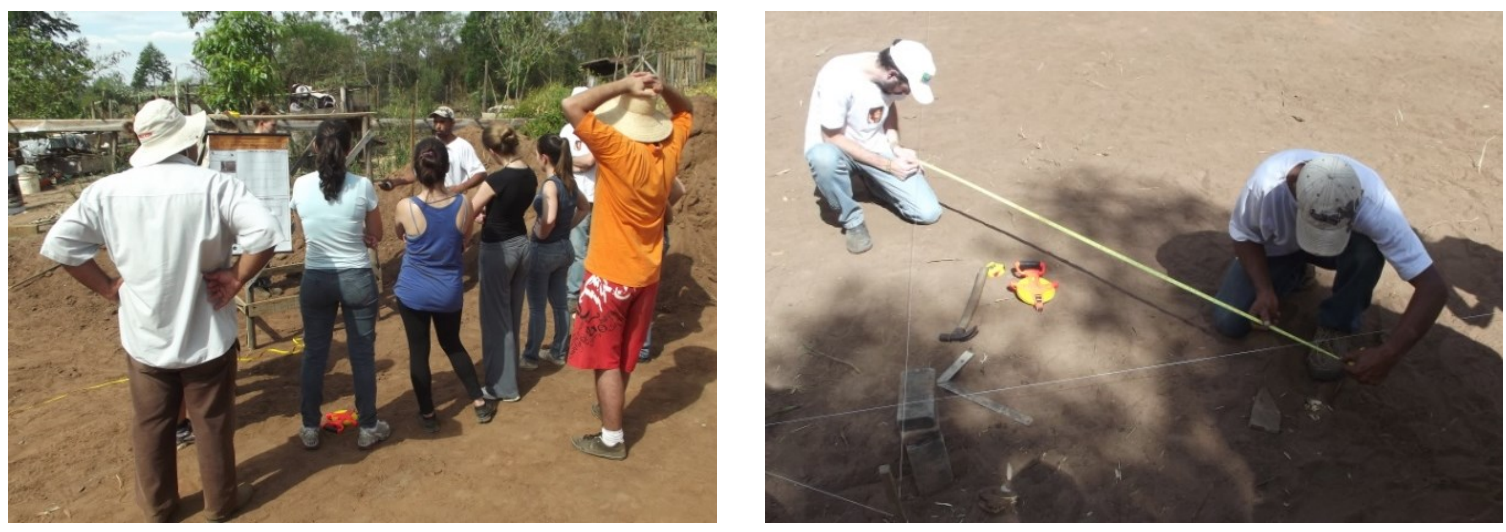

Fotos 138 e 139 - Outra equipe iniciou a marcação da casa sob a orientação do G. Silva, que assumiu o painel pedagógico, ensinando aos participantes o passo a passo desta etapa tão importante para a construção. Foi explicado como fazer o triângulo 3, 4, 5 para a obtenção dos ângulos retos, como achar os pontos principais da marcação, como preparar seu gabarito de apoio, dentre outras questões.
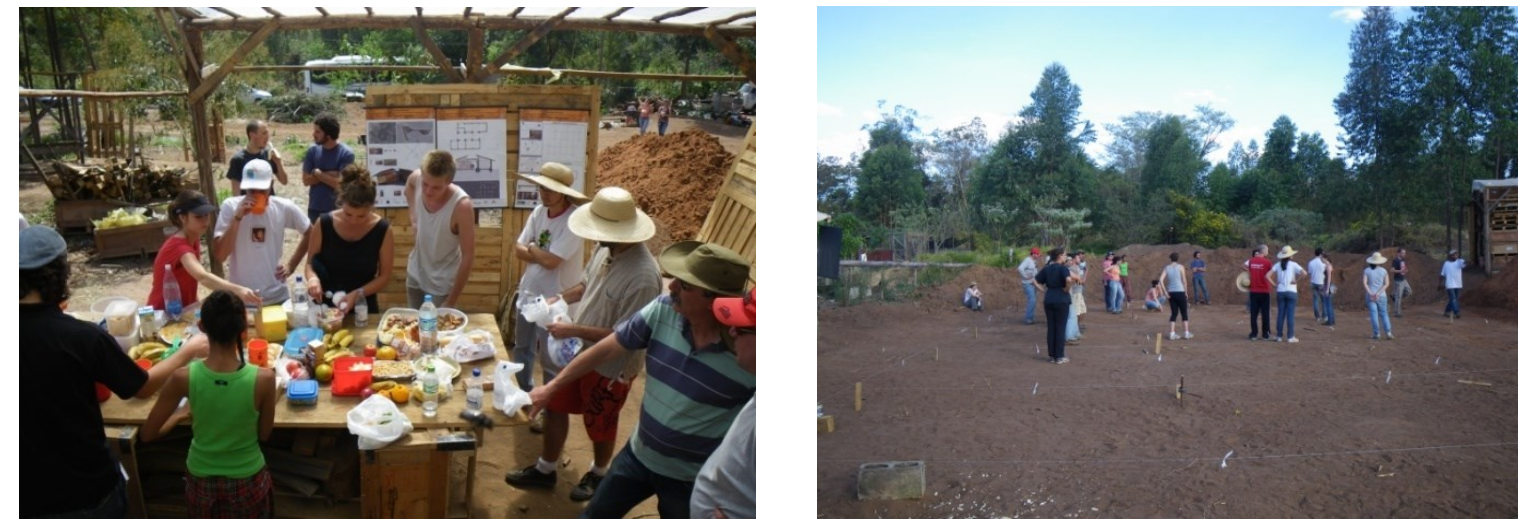

Fotos 140 e 141 - No primeiro dia cada participante levou uma contribuição em comida, o que permitiu o almoço coletivo. Ficou decidido, a partir dali, pagar um valor fixo para a família fazer o almoço e um lanche no final da tarde, ao longo do curso. Compromisso perfeito! Além de uma comida de excelente qualidade, contribuíamos com a família ao gerar um pequeno recurso financeiro a partir deste serviço. Ao final da tarde, a marcação da casa estava realizada, conforme previsto pela manhã. 

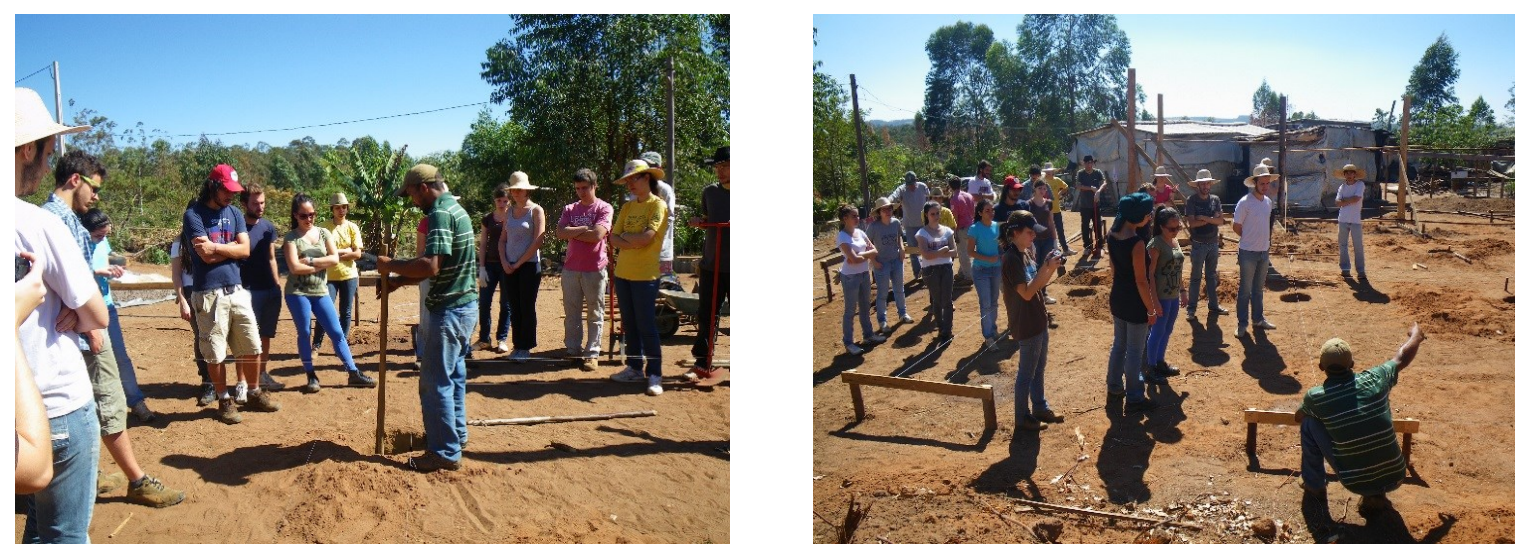

Fotos 142 e 143 - As atividades prosseguiram com a marcação de todos os pilares para a realização de suas fundações. Cada passo do processo construtivo era explicado por G. Silva, que fazia atenção em mostrar a melhor forma de utilizar cada uma das ferramentas necessárias.
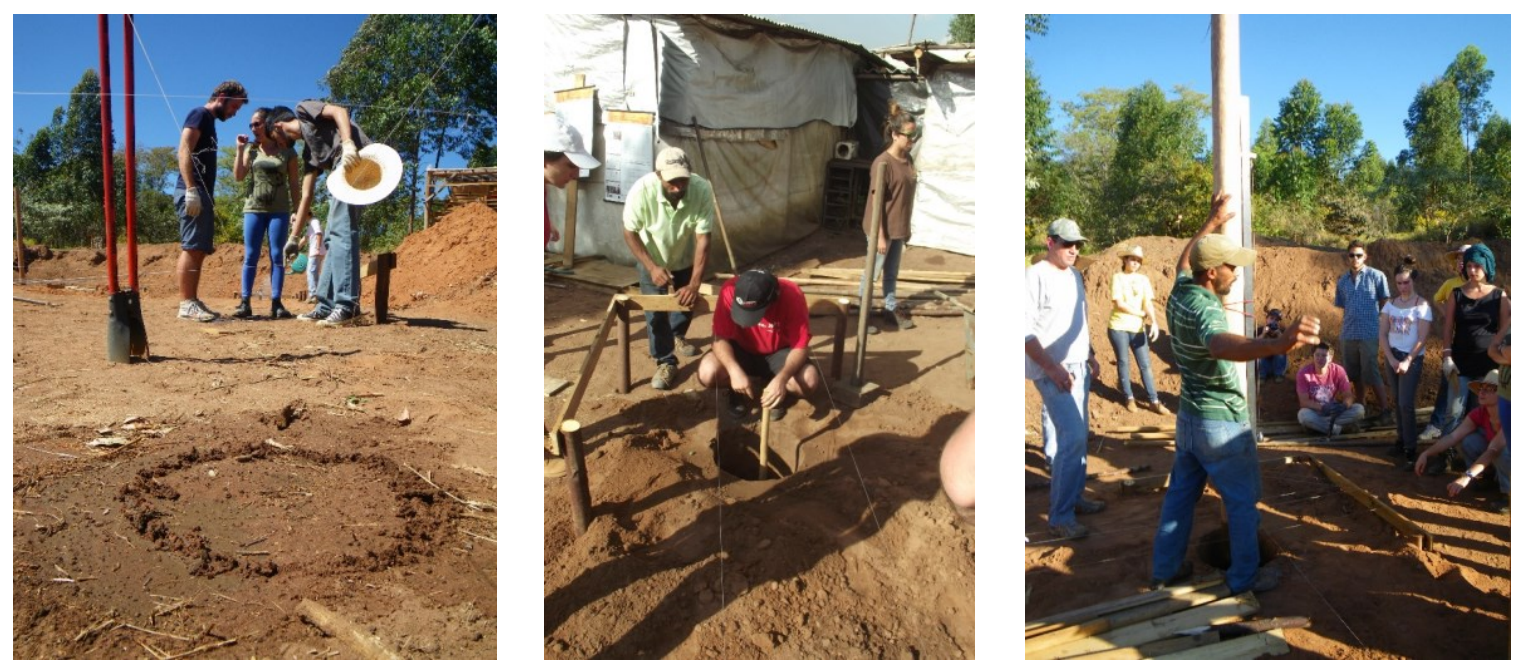

Fotos 144, 145 e 146 - Organizados em grupos, os participantes cavaram os buracos das fundações dos pilares e escolheram os eucaliptos a serem usados em função dos tamanhos, espessuras, características e alinhamentos. A etapa foi orientada por G.Silva, que ensinava a melhor maneira de colocar os pilares no prumo e os contraventar, fixando-os verticalmente.
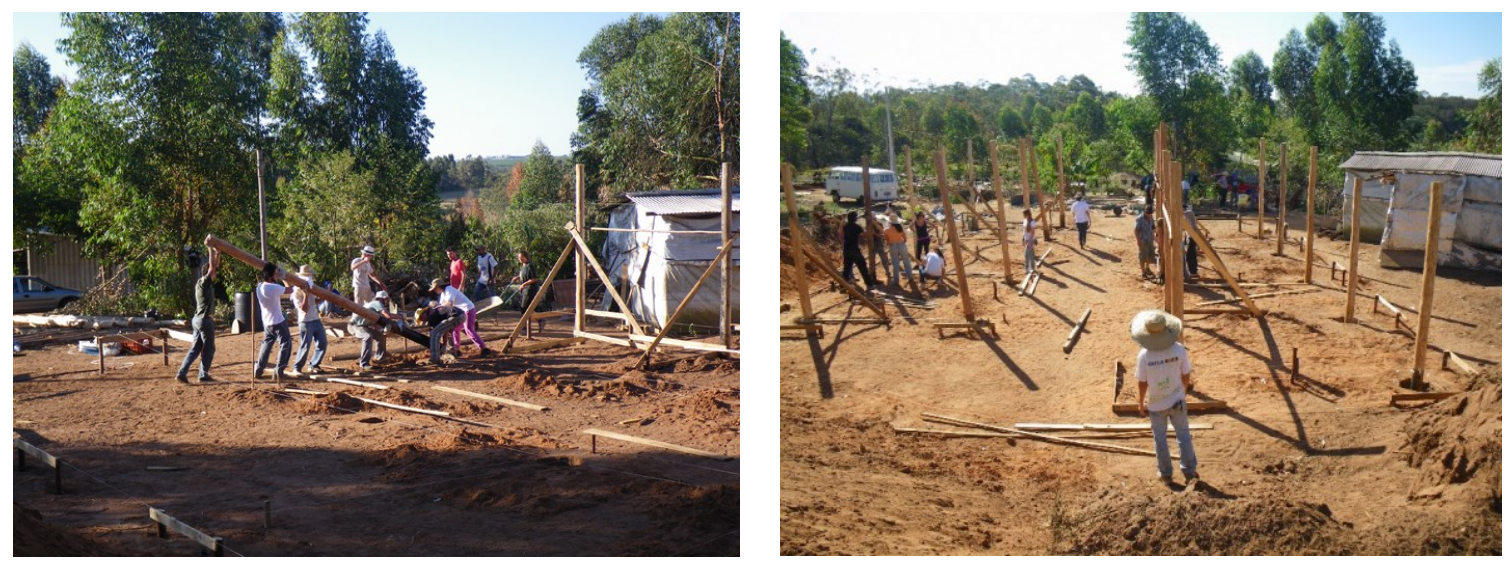

Fotos 147 e 148 - A partir daí, os grupos prosseguiram com a colocação dos pilares restantes. Ao final, tínhamos uma espécie de "floresta de pilares" pronta para receber a concretagem de sua fundação. A estrutura primária da casa começava assim a marcar seus espaços. 
Notamos ali um processo de transformação em que o futuro habitante se apropria do papel de produtor de seu habitat e, para além da participação nos processos decisórios e construtivos, se revela facilitador e instrutor nas sucessivas etapas do canteiro. O fato deste morador, assentado rural, com seu conhecimento técnico e profissional, ser aquele que explica e ensina os gestos e as posturas específicas das etapas de construção, contribui com a desconstrução de certas estruturas sociais hierárquicas estabelecidas cotidianamente nos processos produtivos.

Um processo então, onde o aspecto formador torna-se fomentador de outras relações de trabalho, com posturas que incentivam o fazer-ensinando e o aprenderfazendo. O primeiro, adotado por nosso pedreiro que com naturalidade assume posturas formadoras junto aos estudantes. E o segundo, tomado por estes últimos, que praticam o exercício de desconstruir a verticalidade das ordens do canteiro, e aprendem com aquele que na produção do habitat geralmente obedece e não questiona.

"Posso colocar uma coisa? A maneira que o G. Silva se aproxima da gente é uma maneira muito diferente de um mestre de obra que manda, que não dialoga. Nos ensina de uma maneira muito tranquila." (L. Marcelino)

Até aquele momento, as atividades práticas relativas à implantação da casa, escavação dos buracos dos pilares, preparação e colocação dos eucaliptos, realização de suas fundações em concreto, bem como as explicações, diálogos, debates técnicos, totalizavam cinco dias de Canteiro-Escola, com uma média de 22 participantes por dia.

Neste início de atividades optamos por realizar a mistura do concreto para as fundações dos pilares de maneira manual. A intenção era que os participantes, além de aprenderem a fazer a mistura, sentissem o trabalho que ela representa, com seu esforço físico, gestos do corpo e tempo de realização. São momentos práticos que possibilitam reflexões teóricas, compreensões questionadoras e novas práticas. Quem nunca tinha visto um prumo, percebia sua importância e relação com o posicionamento dos pilares. Quem nunca havia usado uma enxada, carregava os carrinhos com a massa preparada e preenchia a fundação dos pilares. As posturas iam mudando e os gestos ganhando respeito pelo trabalho. 

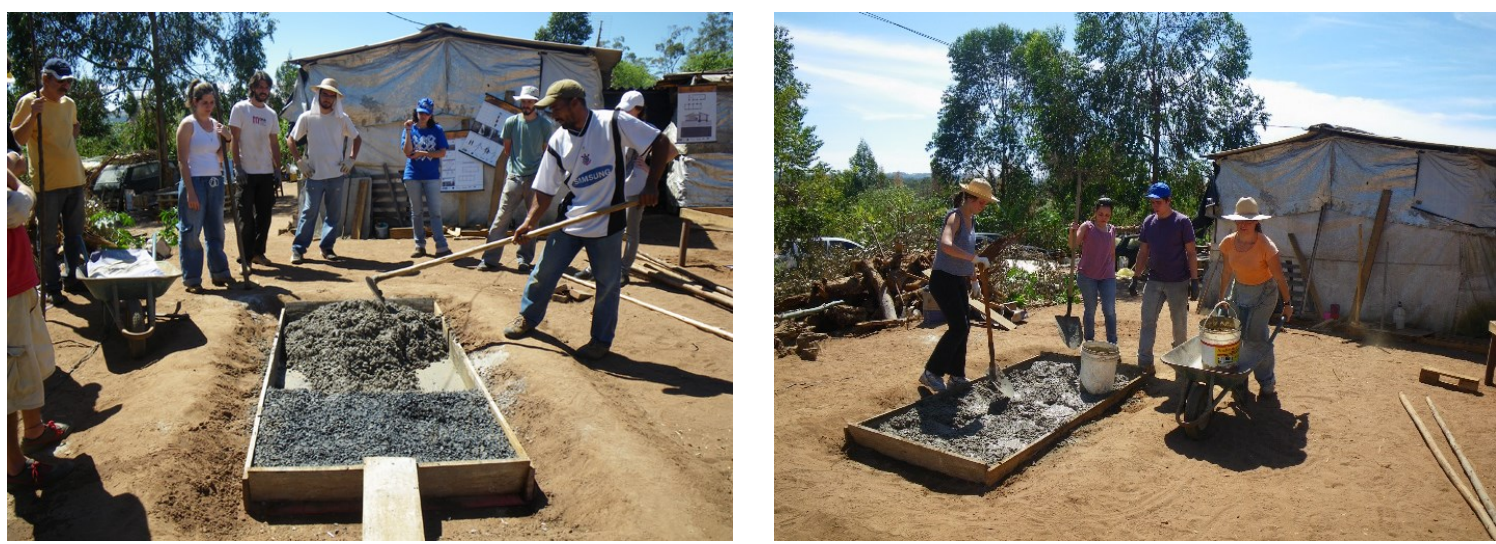

Fotos 149 e 150 - O processo de concretagem passou por uma primeira explicação de G. Silva sobre a melhor forma de preparar, à mão, a massa do concreto e de como trabalhar com as ferramentas. Em seguida, as pessoas se revezaram e os pilares foram sendo rapidamente concretados. Tendo os troncos de eucaliptos cerca de $16 \mathrm{~cm}$ de diâmetro, as fundações dos pilares ficaram com $40 \mathrm{~cm}$ de diâmetro por $70 \mathrm{~cm}$ de profundidade. $O$ traço do concreto utilizado foi de 3 volumes de cimento: 8 vols. de areia grossa: 7 vols. de brita: 2 vols. de água.
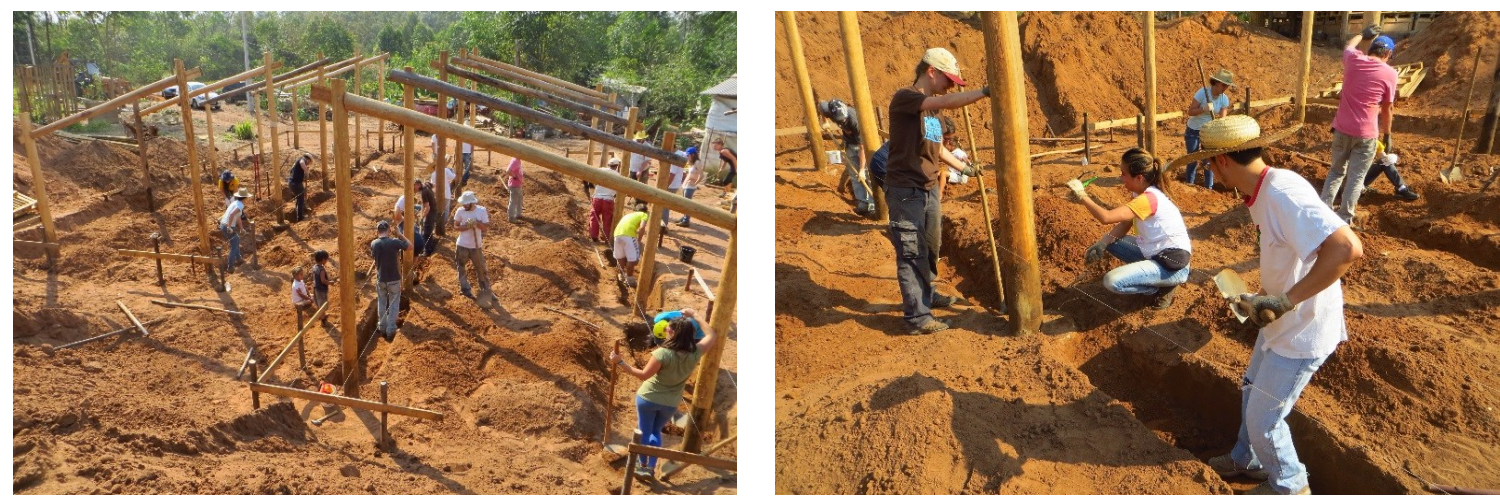

Fotos 151 e 152 - As estruturas transversais de eucaliptos foram fixadas, ligando os pilares entre si, e a etapa seguinte começou pelas escavações das fundações das paredes. Nesta atividade, foi ressaltado como estar em grupo faz diferença. As forças de trabalho em processos solidários se transformam em uma força coletiva comum, que as multiplica, avançando rapidamente o trabalho. Em dois dias as escavações de todas as fundações das paredes foram realizadas.
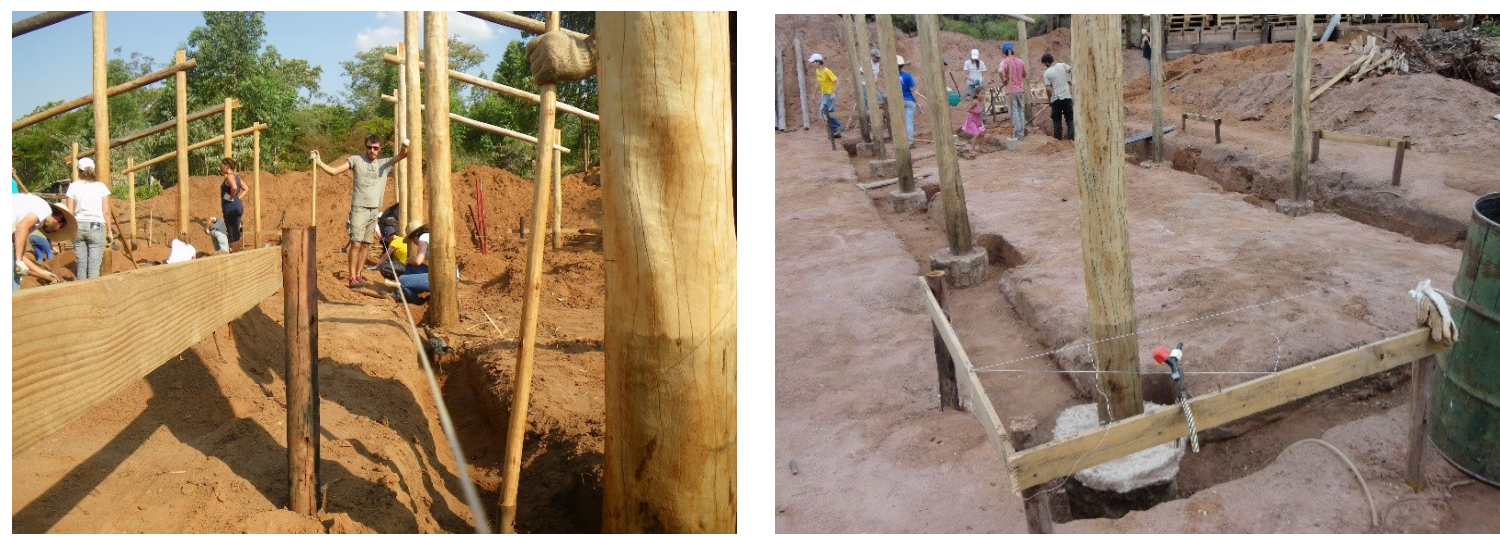

Fotos 153 e 154 - As fundações das paredes possuem $50 \mathrm{~cm}$ de largura por $30 \mathrm{~cm}$ de profundidade e foram preenchidas a partir da técnica da taipa de pilão. Em torno dos pilares foram abertas fundações quadradas de $80 \mathrm{~cm} \times 80 \mathrm{~cm} \times 30 \mathrm{~cm}$. As fundações das paredes foram escavadas fora do eixo dos pilares, de modo que os troncos de eucaliptos ficassem no lado interno da casa, protegidos externamente pelos painéis de paletes. 

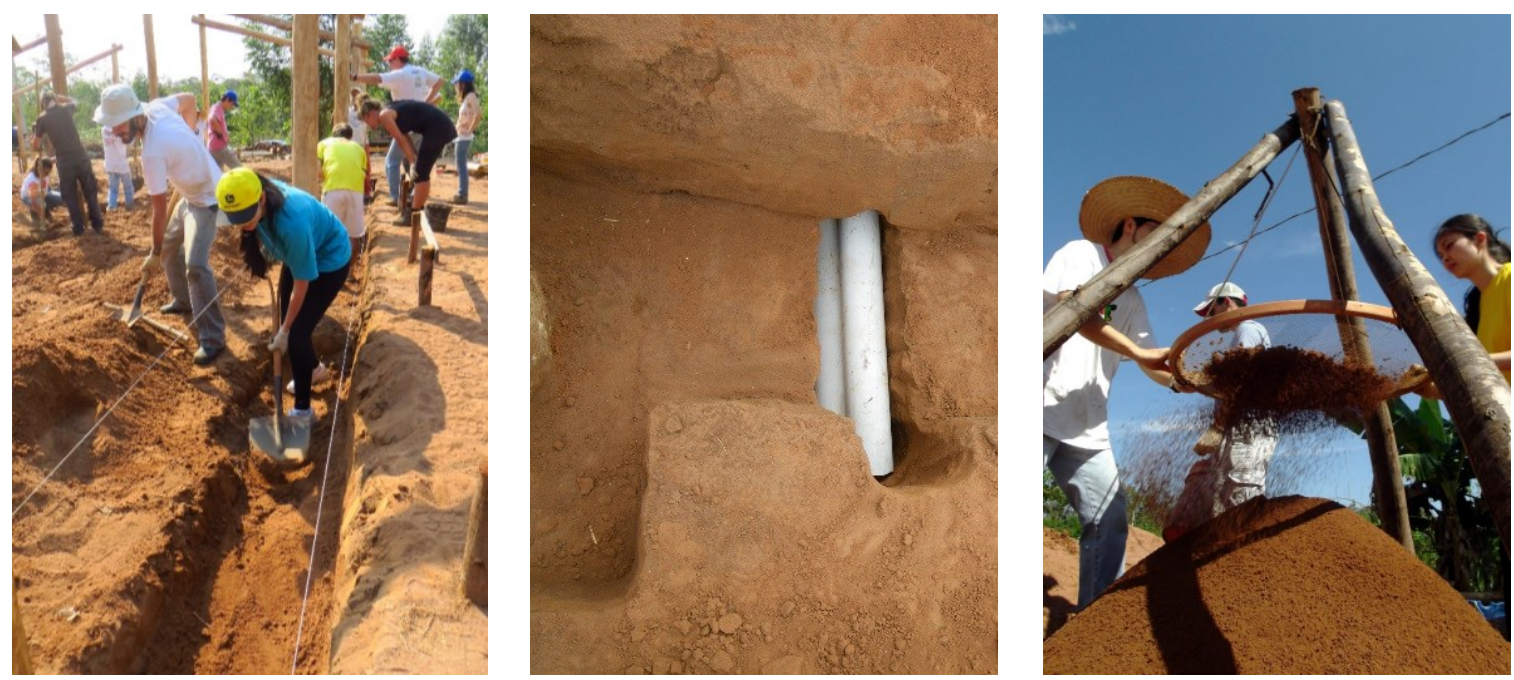

Fotos 155, 156 e 157 - Depois das escavações prontas e das reservas para as instalações hidráulicas colocadas, começamos a preparar a etapa de realização das fundações das paredes. Como a terraplanagem do terreno havia sido feita antes do início do curso, a camada vegetal presente na superfície do solo havia sido retirada e, desta maneira, foi utilizada nas fundações a mesma terra das escavações. Trouxemos uma betoneira verde que logo foi apelidada de "Shrek", e começamos a preparar a massa de solo cimento utilizada na técnica de taipa de pilão para as fundações das paredes.
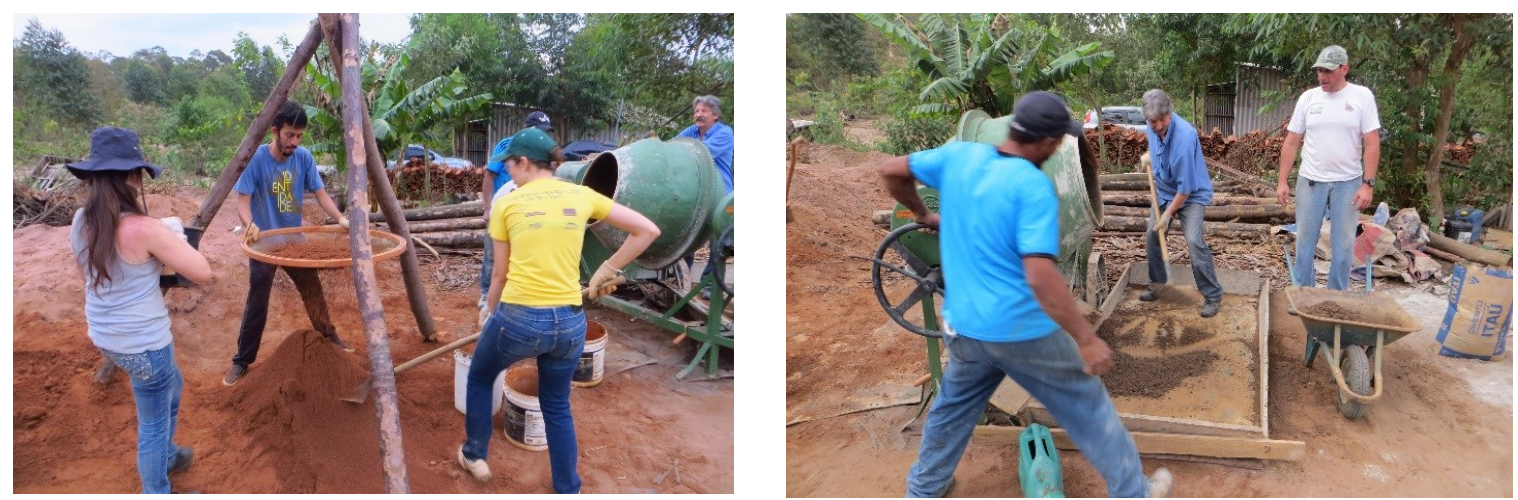

Fotos 158 e 159 - A estratégia de ação consistiu em peneirar a terra de um lado da betoneira, preenchendo-a com a mesma terra misturada com cimento e água, e virar a mistura do outro lado, pronta para ser levada pelos carrinhos de mão até as fundações da casa.
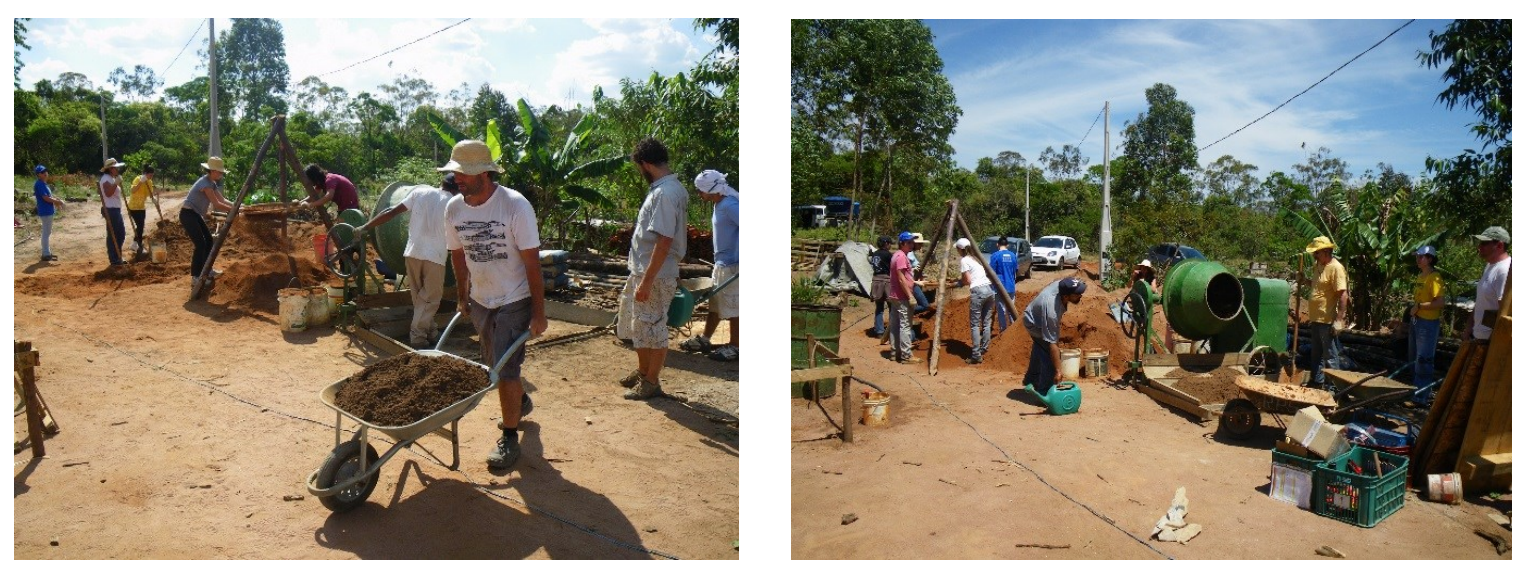

Fotos 160 e 161 - Carrinho após carrinho, as fundações foram sendo preenchidas. A mistura consistia em 10 volumes de terra: 1 vol. de cimento e água. Esta, necessária para assegurar à massa um teor de água, dito úmido, condizente com as condições necessárias para a realização da técnica da taipa de pilão, permitindo a coesão da mistura e seu trabalho de apiloamento. 
"Nesse segundo semestre eu acho que o mais importante está sendo sentir o peso das coisas. Para mim, as atividades foram mais difíceis quando a gente misturou, fez o concreto na mão mesmo, quando não tinha betoneira ainda, e a parte do pilão também. Tudo isso eu acho que desenvolve na gente uma coisa de respeito mesmo. De saber que não é porque a gente tem um nível de graduação, que a gente é maior que ninguém. Para mim foi o mais importante." (N. Balak)

A proposta de trabalho era que todos participassem de todas as tarefas que estavam sendo executadas, sempre a partir de seu perfil e disposição. Logicamente, visto a diversidade de características e habilidades presentes no grupo, pouco a pouco as pessoas foram se encontrando e preferindo umas tarefas mais do que outras. 0 importante era elas chegarem a esta percepção através das experimentações e vivências. Havia a intenção de deixar o grupo livre para escolher o que fazer dentro das atividades necessárias ao desenvolvimento do canteiro e como se organizar em equipes. Os ritmos, pausas, tarefas e seus arranjos eram elementos dispostos para apropriação e uso nas mãos dos participantes.

"Não só a experiência de manusear as ferramentas mas aprender a trabalhar coletivamente fora do atelier. E ainda conviver com a família." (C. Cardoso)

Visto a grande quantidade de mistura de solo cimento necessária para a realização das fundações e bases das paredes, foi trazida, por empréstimo, uma betoneira do grupo de pesquisa. Assim, as atividades se iniciaram pela demonstração de como realizar a mistura da terra com o cimento e qual a quantidade de água necessária para a técnica ser realizada. São testes de terreno, rápidos e simples, que indicam as características da mistura preparada.

Interessante notar como as pessoas vão se apropriando da técnica e de seus gestos. G. Silva nos havia dito que nunca fizera uma parede em taipa de pilão até as muretas realizadas durante o curso optativo. Naquele momento, foi explicado a ele como fazer a mistura, a quantidade de água necessária, as características que a terra devia ter para ser recomendada sua estabilização com cimento, entre outras coisas. 
Assim, durante a realização das misturas das fundações, por diversas vezes G. Silva explicou às pessoas como fazer, e estas, também, foram, pouco a pouco, assumindo a betoneira e a responsabilidade em preparar a massa de solo cimento para os grupos que estavam pilando a mistura nas fundações. Foi explicada a necessidade de dispor a massa em camadas finas e regulares para assegurar que o solo fosse bem compactado e assim o processo de trabalho se desenrolou de maneira pedagógica, autogerida e descontraída.

A cada etapa da obra, era solicitado que algumas pessoas explicassem o que estavam fazendo como atividade e para qual finalidade estavam fazendo aquilo. Como aquela atividade se relacionava com os próximos trabalhos que seriam feitos no canteiro? Esta foi uma forma encontrada de verificar se as pessoas estavam compreendendo aquilo que estavam fazendo ou se estavam somente repetindo um gesto mecânico demonstrado.

As atividades referentes à escavação das fundações das paredes, produção da mistura de solo cimento, preenchimento e apiloamento manual da massa produzida nos dois blocos da casa, durou outros cinco dias de Canteiro-Escola, com uma média de 20 participantes por dia.

Antes da conclusão da primeira Oficina foram dedicados dois dias para a organização dos paletes recebidos como doação, desmontagem e classificação das ripas de madeira para a execução dos painéis de cobertura, e realização da mesa de produção para os elementos pré-fabricados dos painéis. Foram ainda iniciadas a fixação das toras de eucaliptos longitudinais às estruturas verticais existentes. Desta forma, concluiu-se a estrutura primária da casa, agora pronta para receber os painéis de paletes na cobertura.

Infelizmente, até este momento nenhum outro assentado veio participar das atividades do canteiro. Alguns deles passaram para ver a obra, mas em horários diferentes das atividades. Observavam o que estava sendo feito mas não acreditavam na possibilidade de fazer uma casa com eucaliptos, paletes e terra. Se mostravam reticentes embora curiosos. O tempo vai mostrar como estas relações e posicionamentos vão se dar. 

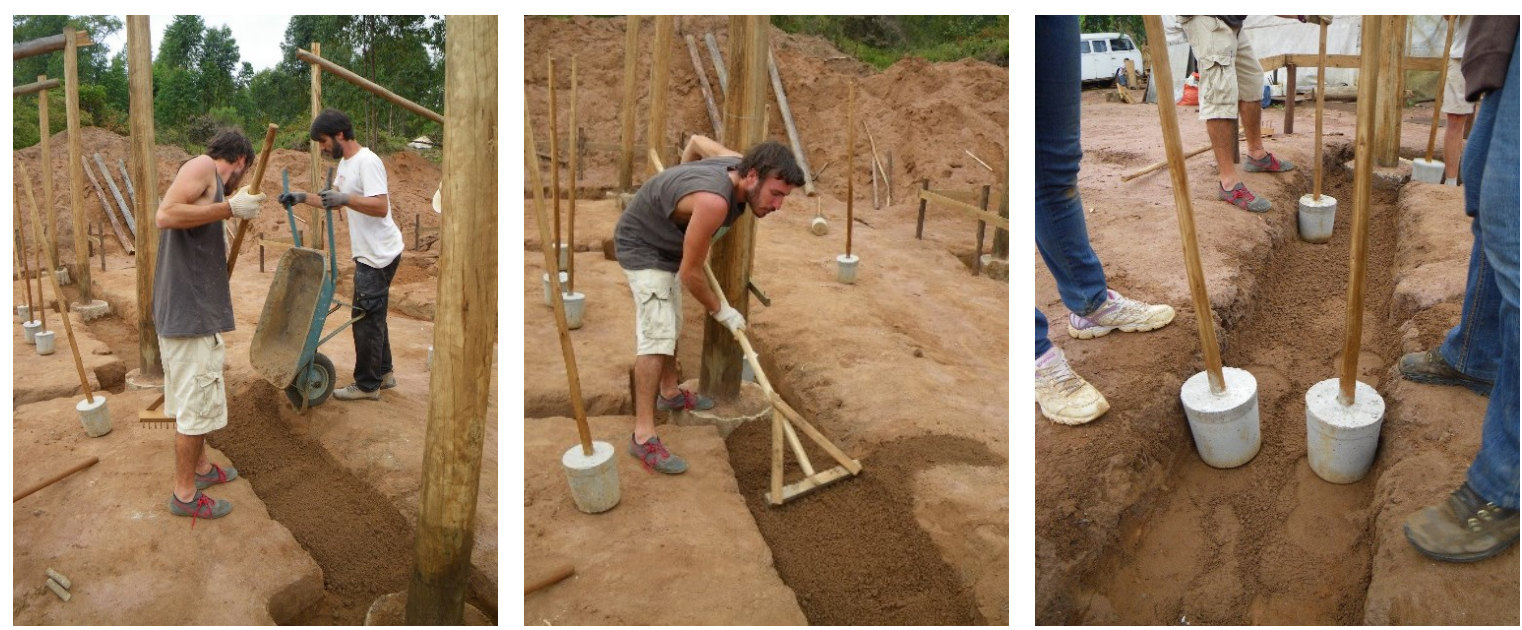

Fotos 162, 163 e 164 - A massa de solo cimento era disposta nas valas de fundação e espalhada de maneira homogênea em camadas de $12 \mathrm{~cm}$ de altura para que as forças verticais exercidas pelos pilões fossem empregadas em toda a espessura de massa. Os pilões foram fabricados e as primeiras fundações começaram a ser preenchidas.
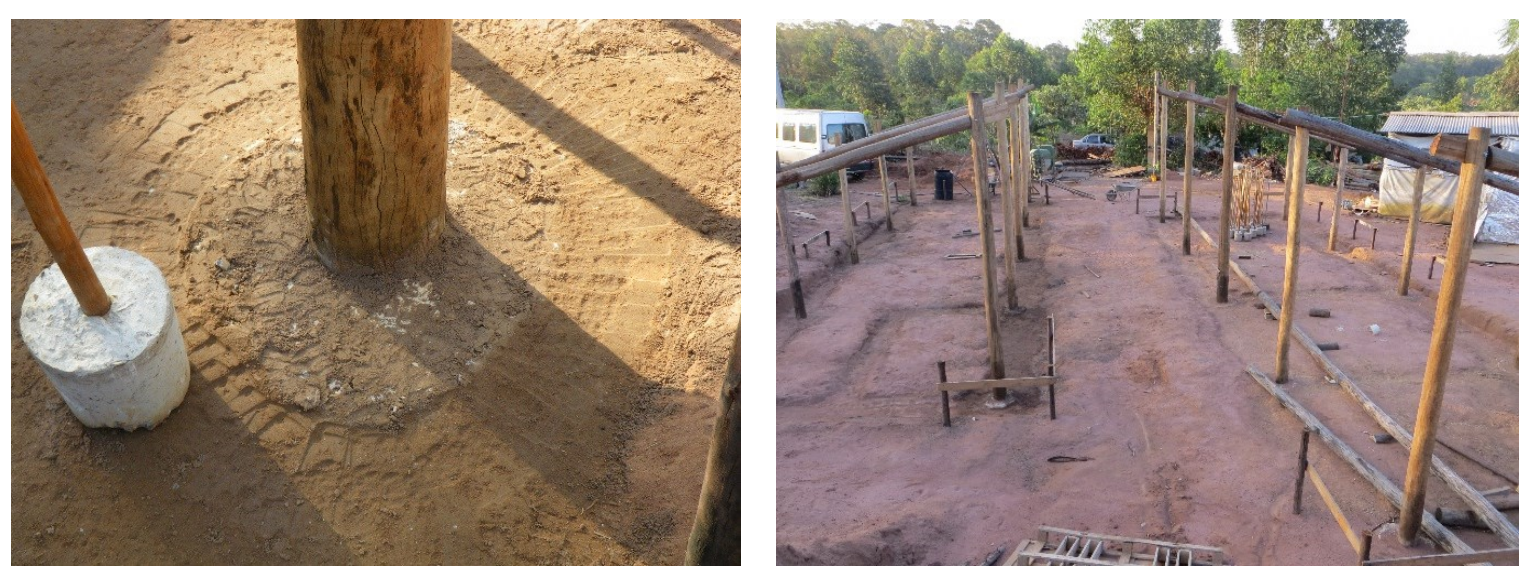

Fotos 165 e 166 - Pouco a pouco as fundações ficaram prontas e as primeiras experiências coletivas com a técnica da taipa de pilão no canteiro foram sendo analisadas pelo grupo. Os esforços gerados, as ferramentas empregadas, a qualidade das misturas, o tempo necessário, entre outras questões, foram discutidas, pensando nas melhorias a serem realizadas quando da etapa de produção das bases da casa, também em taipa de pilão estabilizada.
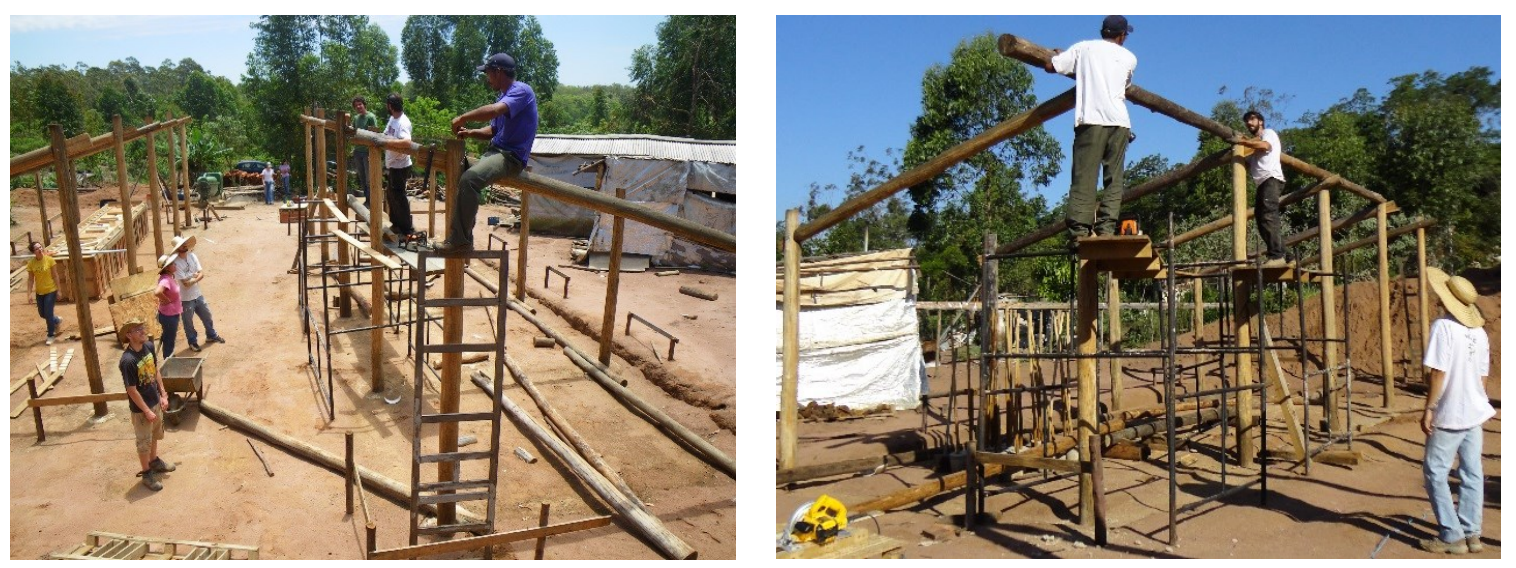

Fotos 167 e 168 - As vigas longitudinais em troncos de eucaliptos foram preparadas e fixadas, concluindo assim, uma etapa importante do Canteiro-Escola: as fundações e as estruturas primárias (pilares e vigas) foram realizadas em 12 dias de atividades. 

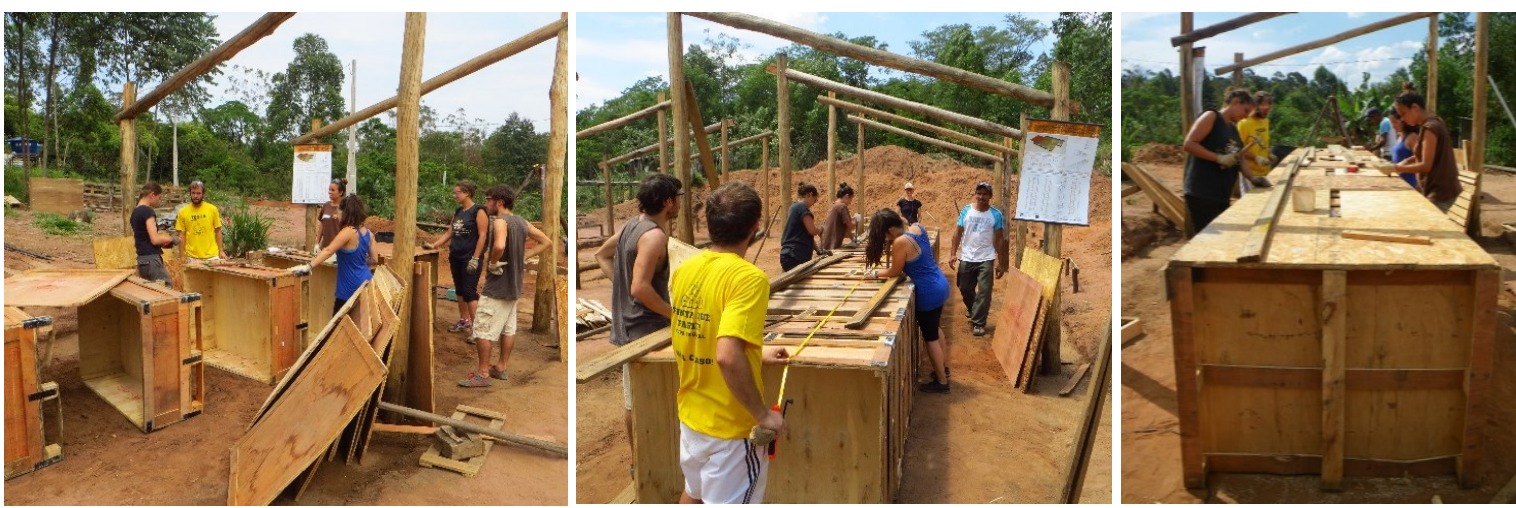

Fotos 169, 170 e 171 - No último final de semana de atividades da primeira Oficina, os participantes iniciaram a construção da mesa de produção para os painéis de cobertura a serem feitos com os paletes. A mesa foi construída a partir das caixas de motores vindas com a doação dos paletes. O projeto da mesa será apresentado mais adiante, durante as análises da Oficina 2.
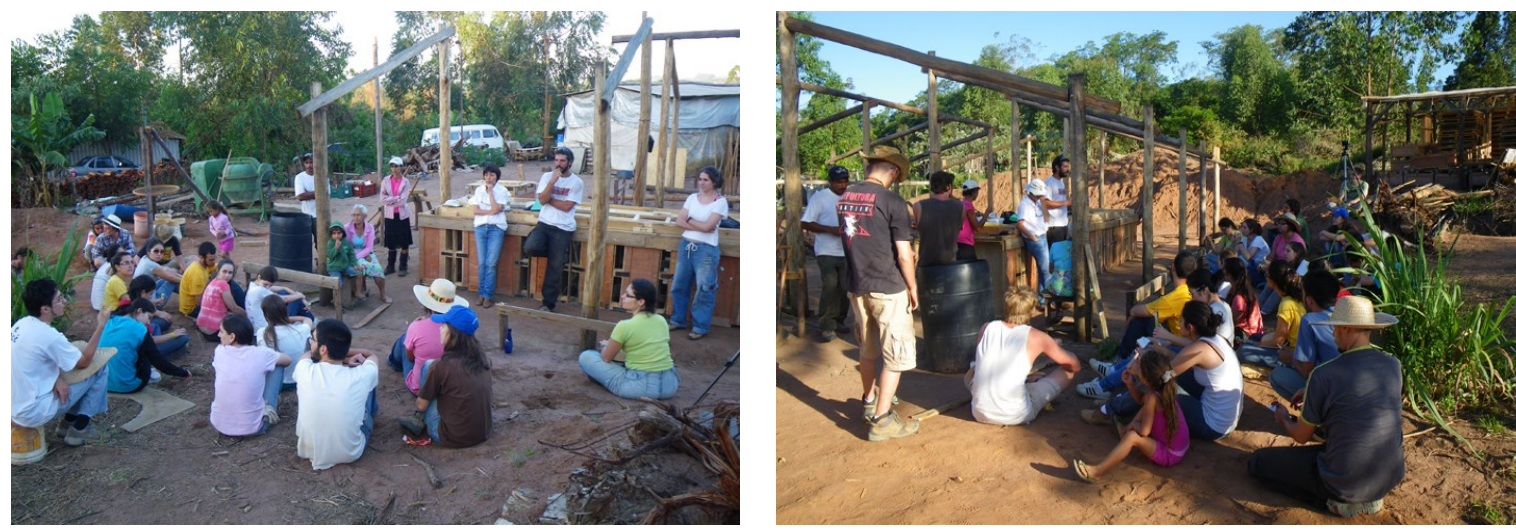

Fotos 172 e 173-A conclusão da Oficina 1 foi um momento de debates e trocas. A partir de uma conversa avaliadora, cada participante opinou e contribuiu reflexivamente sobre os processos experimentados e vivenciados durante o curso, inserindo o papel e função da formação realizada no processo produtivo de construção do habitat, ambientado e influenciado pelas condições próprias ao local.

A Oficina 1 terminou no final de outubro de 2013, com uma avaliação coletiva das atividades realizadas, seus limites, potenciais, perspectivas, aprendizados, descobertas, trocas, vivências, lições, etc. Todos os participantes presentes no encerramento puderam se expressar e avaliar as experiências. De maneira geral, as participações ao longo das atividades foram intensas. O grupo abraçou o projeto e o processo proposto, relevando frequentemente a importância de atividades desta natureza dentro do curso acadêmico de Arquitetura e Urbanismo. Alguns profissionais insistiram no fato de que na maior parte das vezes, os arquitetos são pouco preparados para a realidade dos canteiros de obras, lacuna que necessita ser preenchida por processos de formação mais amplos e inseridos nas diferentes realidades produtivas. 
Essas análises serão melhor desenvolvidas na conclusão deste Momento 4. A seguir, apresento alguns dados da Oficina 1 , complementados por algumas reflexões e depoimentos realizados pelos participantes durante os encontros.

Quanto ao perfil dos 45 participantes, 11 haviam participado do curso optativo do semestre anterior e 10 eram novos estudantes do próprio Instituto de Arquitetura de Urbanismo. Ainda entre os alunos de graduação, 04 vieram de outras Universidades, inclusive de outras cidades da região. Referente aos pesquisadores, 03 eram da pósgraduação do Instituto e 02 eram pesquisadores de outras Universidades. Vieram ainda 03 participantes do curso de Engenharia Ambiental, 05 profissionais - arquitetos e de outras áreas (publicidade, biologia, engenharias), e 07 estudantes estrangeiros intercambistas no Instituto (vindos do Chile, Uruguai, França e Alemanha).

Tal diversidade etária, de gênero, cultural, social, técnica e de opiniões, foi pouco a pouco modelando as relações em grupo, ensaiando o equilíbrio de suas diferenças e multiplicando as forças de seu trabalho coletivo. Quando propicia-se autonomia e inserese os participantes nas dinâmicas da realidade social, o trabalho de grupo amplia seu potencial e, assim como o produto realizado, seu processo ganha evidência e adquire significado crítico.

"Antes a gente não era um grupo, era um aglomerado de pessoas. Algumas já se conheciam, algumas não, mas não era um grupo de trabalho. Não sabíamos trabalhar juntos. Às vezes, alguns já sabiam como executar tal função mas sabia fazer sozinho. Mas ai, tinha que executar com outros dois ou três. Isso é um aprendizado. Olhar para o outro, pensar "esse meu movimento pode machucar o meu colega. Eu sei fazer assim, mas preciso trabalhar de outra forma senão vou não vou conseguir trabalhar com ele". É uma reflexão bem bacana que o canteiro trouxe e foi refletido na produção final porque a gente aprendeu a trabalhar junto." (C. Saravalle)

O quadro abaixo mostra uma série de dados sobre as atividades desta primeira Oficina: etapas realizadas com suas datas, materiais, serviços, custos, quantidades e números médios de participantes em cada etapa. 


\begin{tabular}{|c|c|c|c|c|c|c|}
\hline CANTEIRO-ESCOLA & ETAPAS & DATAS & MATERIAIS E SERVICOS & QUANTIDADES & CUSTOS R\$ & $\begin{array}{c}\text { PESSOAS } \\
\text { (média/dia) }\end{array}$ \\
\hline \multirow{20}{*}{ OFICINA 1} & \multirow{2}{*}{ Implantação } & \multirow{2}{*}{$24 / 08 / 2013$} & Terraplanagem & $6,5 \mathrm{~h}$ & 600 & \multirow{2}{*}{42} \\
\hline & & & Eucaliptos & 80 un. & 1200 & \\
\hline & \multirow{8}{*}{$\begin{array}{l}\text { Escavação, fundação dos } \\
\text { pilares, estruturas } \\
\text { verticais e transversais }\end{array}$} & \multirow{8}{*}{$\begin{array}{c}\text { 05, 06, } 07 \text { e } \\
08 / 09 / 2013 \text { (4dias) }\end{array}$} & Cimento (doação) & 10 sacos & 230 & \multirow{8}{*}{22} \\
\hline & & & Areia & $0,5 \mathrm{~m} 3$ & 40 & \\
\hline & & & Areia (doação) & $1,5 \mathrm{m3}$ & 100 & \\
\hline & & & Brita & $0,5 \mathrm{m3}$ & 40 & \\
\hline & & & Brita (doação) & $1,5 \mathrm{m3}$ & 100 & \\
\hline & & & Transporte (Areia/brita) & $3 \mathrm{m3}$ & 80 & \\
\hline & & & Pregos (doação) & & 30 & \\
\hline & & & Oleo queimado & & & \\
\hline & & & & & & \\
\hline & \multirow{4}{*}{ Escavação das paredes } & \multirow{4}{*}{$\begin{array}{c}28 \text { e } 29 / 09 / 2013 \\
\text { ( } 2 \text { dias) }\end{array}$} & Terraplanagem 2 & 2,5 horas & 250 & \multirow{4}{*}{21} \\
\hline & & & Paletes (doação) & & & \\
\hline & & & Barras roscadas (doação) & & 40 & \\
\hline & & & Arruelas (doação) & & 10 & \\
\hline & & & & & & \\
\hline & \multirow{4}{*}{$\begin{array}{l}\text { Fundação das paredes e } \\
\text { estruturas longitudinais }\end{array}$} & \multirow{4}{*}{$\begin{array}{c}12,13,26,27 \\
28 / 10 / 2013 \\
\text { (5 dias) }\end{array}$} & \begin{tabular}{|c|} 
Cimento \\
\end{tabular} & 3 sacos & 67,5 & \multirow{4}{*}{18} \\
\hline & & & Eimento fundação (doação & 10 sacos & 230 & \\
\hline & & & \begin{tabular}{|c|} 
Cimento fundação \\
\end{tabular} & 28 sacos & 672 & \\
\hline & & & Terra & Local & & \\
\hline TOTAL & & & & & 3689,5 & 23 \\
\hline
\end{tabular}

Figura 34 - Quadro com dados referentes às atividades, custos, tempos e participantes da Oficina 1.

Ao final, foram 12 dias de atividades referentes às etapas de implantação da casa, escavações, realização das fundações e montagem de sua estrutura primária em madeira. O custo estimado relativo aos materiais e serviços utilizados, incluindo os recursos da própria família, das Instituições de Ensino e das doações, representaram um pouco menos de $\mathrm{R} \$ 3.700,00$. Obviamente, o valor não incluiu outros custos diretos e indiretos como: transporte dos participantes, alimentação, ferramentas, equipamentos, e principalmente, mão de obra. Destes custos, a maior parte foi assegurada pelas Instituições para a realização do curso.

Após a breve recuperação comentada sobre os processos vividos nessa primeira oficina, os dados da tabela acima foram expostos ao grupo e a roda de diálogos aberta para a avaliação coletiva.

As questões formativas, construtivas e de trocas socioculturais foram as mais evocadas pelas pessoas presentes. A importância dada às práticas construtivas, ao manuseio das ferramentas, aos aprendizados e capacidades gerados, às trocas entre os participantes e a família, à responsabilidade de construir uma casa a partir das tecnologias produzidas no local, entre outras questões, expôs as reflexões e questionamentos que foram ganhando forma na compreensão de cada participante. A 
família expressou suas impressões e perspectivas, e fomos assim, comentando e exercitando a prática analítica de nossas participações. Abaixo, com o intuito de enriquecer as reflexões e o contexto descrito, transcrevo certos depoimentos dos participantes, referentes às atividades do Canteiro-Escola.

"Eu acho que quem sai daqui, sai com uma experiência muito diferente, com uma visão muito diferente de quem não participou de uma coisa desse tipo. (...) Foi uma experiência muito legal porque muda às vezes o jeito de pensar o projeto. E você sabe que aquilo pode não dar certo. E eu acho também que é muito válido para a gente aprender a dar valor para quem constrói mesmo a casa. (...) Eu acho que tem mais respeito com quem executa." (L. Brunaldi)

"Tem coisas que o engenheiro ou o arquiteto chega e fala "faz assim". Ai, as vezes o pedreiro ou o mestre de obra conversa com a proprietária ou o proprietário e muda tudo aquilo ali. Quer dizer, as vezes é uma maneira mais fácil de fazer, mais econômica e vai ficar bonito do mesmo jeito e resistente." (G. Silva)

"A escolha do material hoje é muito mais carinhosa pois a gente tem uma visão além, muito além do que: vou colocar um pilar de concreto aqui. Sabe não é mais isso, pois eu sei quanto pesa um balde de brita. É diferente, não é mais a mesma coisa. Tem uma relação de respeito às pessoas que vão trabalhar (...). Acredito que a gente não vai nunca mais colocar material só escolhendo a partir dos catálogos, sabe." (N. Balak)

"Aqui a gente começa a fazer uma coisa e ai faz de um jeito, e vai mudando, e descobrindo outras formas de fazer. A gente mesmo vai decidindo o que é melhor pra gente." (T. Heleodoro)

"Complementando essa ideia do quanto contribui, o quanto dialoga com a formação não só do arquiteto. Sou bióloga recém formada, já tive algumas experiências, em canteiros convencionais e canteiros de bioconstrução também, alguns como contratada, como paga pelo viés da nossa cooperativa e outros como aprendiz, nunca dentro de uma disciplina, e não sei se já aconteceu, mas para mim é uma experiência totalmente nova, e é impressionante como a galera sim, vai acompanhando." (L. Marcelino) 
"Eu fiz esse curso [de arquitetura] em outra escola e também tinha essa demanda, e a gente ficava correndo atrás para conseguir ter esse tipo de experiência. E a Universidade infelizmente em seu espaço institucional não oferece este tipo de experiência. (...) Aqui para mim aparecem várias contradições que existem que a gente geralmente não percebe, como o próprio papo que a gente está tendo aqui com um monte de pessoas que nunca segurou uma colher de pedreiro na mão ou virou uma massa, e a gente está tentando construir uma casa para um pedreiro. O G. Silva já construiu várias casas, mas infelizmente não teve condições de construir uma casa para ele e sua família." (J. Thiesen)

"E queria parabenizar a família por aceitar 30, 50 pessoas que não sabem nada [de construção] chegar falando "vamos construir a casa!" (...) A gente está numa sociedade super individualista, e o fato de ter um processo coletivo faz com que não tenha queda de motivação porque por fim estamos num processo onde temos relações sociais entre nós. $E$ acho que isso falta muito na sociedade de hoje, então eu acho muito importante esse processo coletivo, para mostrar que o coletivo alimenta." (A. Guéguen)

"A gente demora mais nessa construção coletiva mas eu acho também que tem o lado de ser uma experiência comunitária. (...) Uma velocidade que acompanha a prosa, que acompanha a coletividade." (M. Murillo)

Uma das dificuldades previsíveis durante o curso era a manutenção da assiduidade dos participantes. O curso era gratuito, durante os finais de semana (a cada duas semanas) e estendido ao longo de um ano. É normal, que os participantes oscilassem em suas frequências, visto a extensão das atividades e a concomitância com outras tantas, existentes na agenda de cada um dos inscritos.

Assim, o tempo gradualmente lento do avançar nas obras ensinava sobre a complexidade das relações que o determinam. O tempo é especifico de cada realidade e natureza das atividades. Na verdade, ele em si não foi tão lento visto o caráter formador de sua constituição. Tornou-se lento pois espaçou-se entre tempos outros (prioritários) que o fizeram encaixar-se nas lacunas do possível e realizar-se na "teimosia" de nossas perspectivas. Sobre este tema, será feita uma comparação estimada do ritmo de andamento do Canteiro-Escola com relação a um canteiro convencional nas conclusões deste Momento 4. 
E esse canteiro, é possível replicar esta experiência? Com estes materiais?

A pergunta foi posta em numerosas situações. E ainda não foi devidamente analisada e respondida. Vamos amadurecendo estes questionamentos ao longo das oficinas do canteiro. Entretanto, as reflexões partem da compreensão de que as produções habitacionais em canteiros de obras que possibilitem a aproximação entre os processos de criação e de formação, a partir de relações de trabalho solidárias e emancipatórias, podem ser repensadas e novamente realizadas, através de análises sobre seus produtos e seus processos. Pelos produtos, pensando a arquitetura a partir da realidade concreta onde está inserida. Considerando o lugar, o que está disponível e o que é possível realizar, segundo seus contextos culturais, econômicos, sociais, políticos e ambientais. Pelos processos, através do trabalho compartilhado, participativo, criativo e crítico, inserido em um programa pedagógico onde a experimentação prática aproxima a formação e a produção.

Voltaremos a estas análises nas partes conclusivas deste Momento 4, quando mais elementos estarão disponíveis para alimentar as reflexões e questionamentos.

\section{OFICINA 2}

Como a estação das chuvas estava iniciando e ainda não havíamos realizado as bases da casa em taipa de pilão, optou-se por alterar a ordem das etapas de construção e centrar as atividades na produção da cobertura da casa Suindara. Assim, cobrindo a casa deixaríamos a construção das paredes para a Oficina 3, marcada para depois das chuvas.

Quanto ao sistema de cobertura, a intenção também era aproveitar os paletes disponíveis, mesmo sem tê-los experimentado durante o curso optativo. A partir de conversas entre o grupo de pesquisa e a família, foi pensada a produção de painéis préfabricados compostos por paletes inteiros solidarizados por vigas, também produzidas com os paletes. Essas vigas foram inspiradas no sistema de Vigas Laminadas Pregadas (VLPs), já realizado pelo grupo de pesquisa HABIS e comentado anteriormente, sendo entretanto adaptado às condições das ripas de madeira extraídas dos paletes. 
Desta maneira, os painéis de cobertura foram projetados em duas etapas principais. A primeira delas, referente à produção das VLPS, foi pensada a partir do desmonte dos paletes e da utilização de suas ripas. Estas, dispostas lado a lado ao longo de suas extremidades, receberam mais duas camadas de ripas, totalizando três camadas desencontradas e pregadas entre si. Uma vez as vigas produzidas, a segunda etapa consistia na fixação das VLPs nos paletes inteiros dispostos um ao lado do outro, em sua menor face. Esses paletes foram solidarizados entre si, através de duas VLPs fixadas ao longo de suas extremidades, em seu lado interno, formando um grande painel.
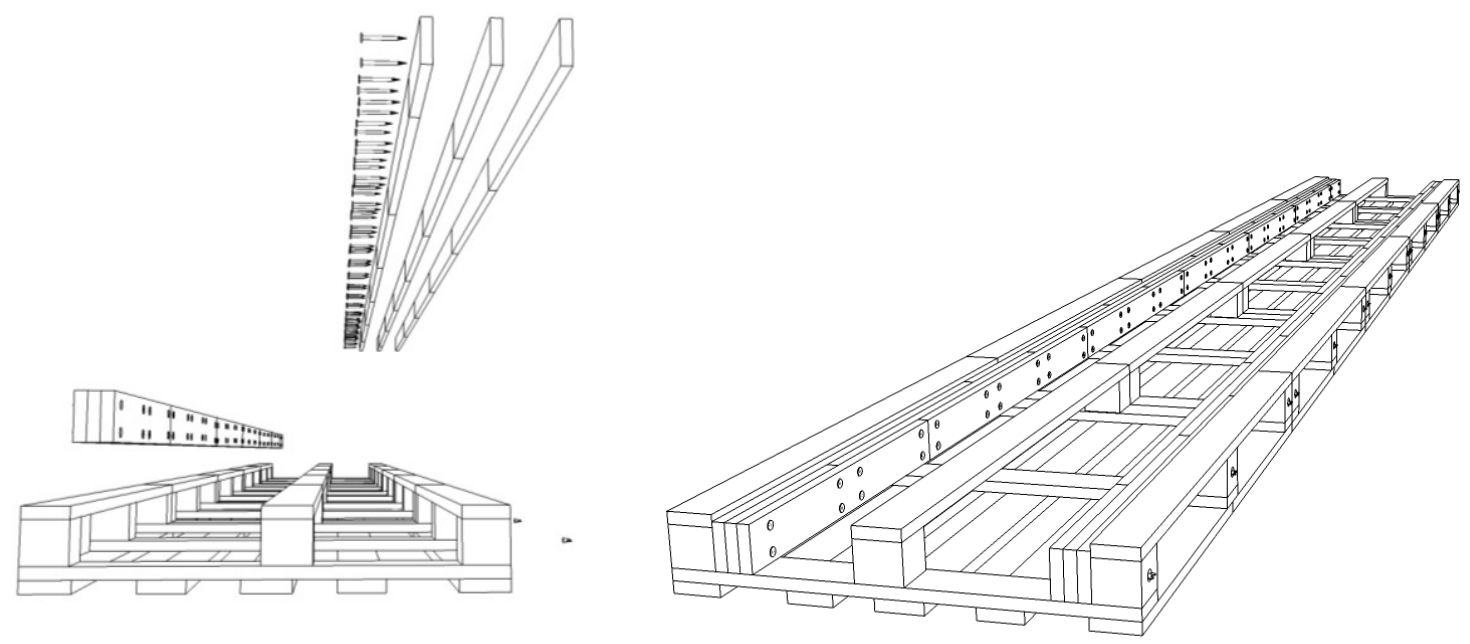

Figura 35 - Perspectivas do painel de cobertura concebido a partir dos paletes de madeira. As vigas laminadas pregadas (VLPs) foram fixadas nos paletes a partir de seus tocos de madeira estruturantes, totalizando seis pontos de fixação por palete. Perspectivas: Luisa Brunaldi.

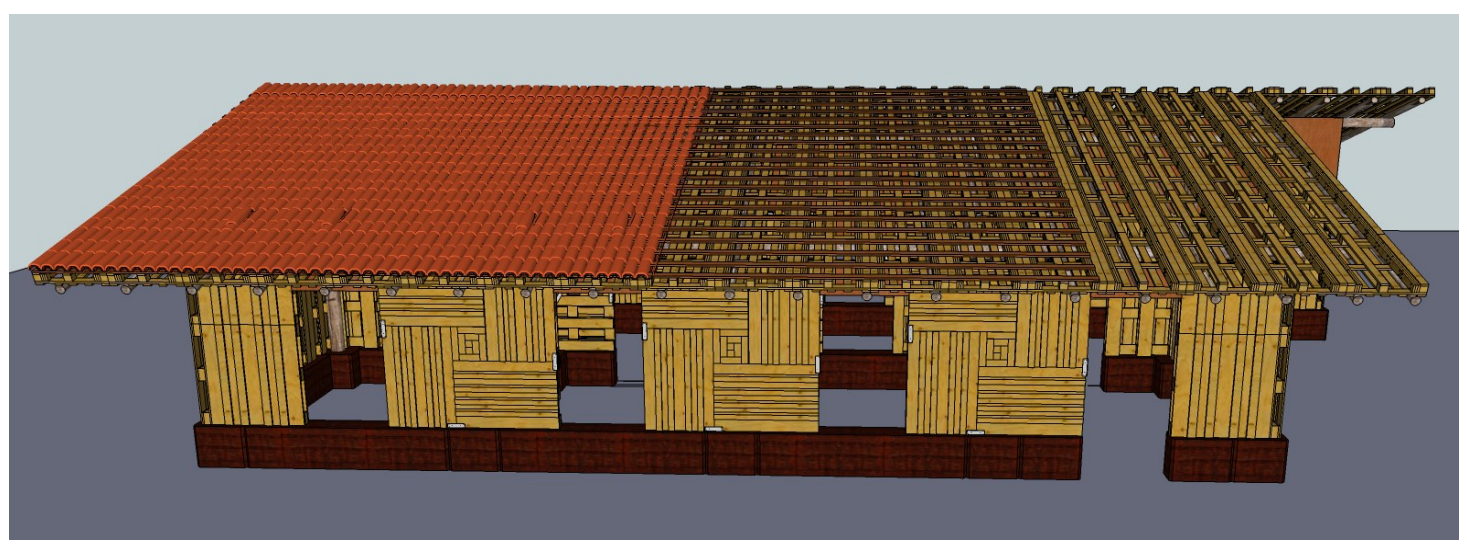

Figura 36 - Perspectiva da fachada oeste da casa com seus painéis de paletes na cobertura. Foi decidido fixar os painéis com as VLPs voltadas para o lado de cima e suas ripas orientadas para baixo, de modo que estas servissem como forro interno para a casa, ou facilitassem a fixação de outro material. Do lado externo (superior), os trabalhos restantes seriam referentes à fixação das ripas para a colocação das telhas. Perspectiva: Luisa Brunaldi. 

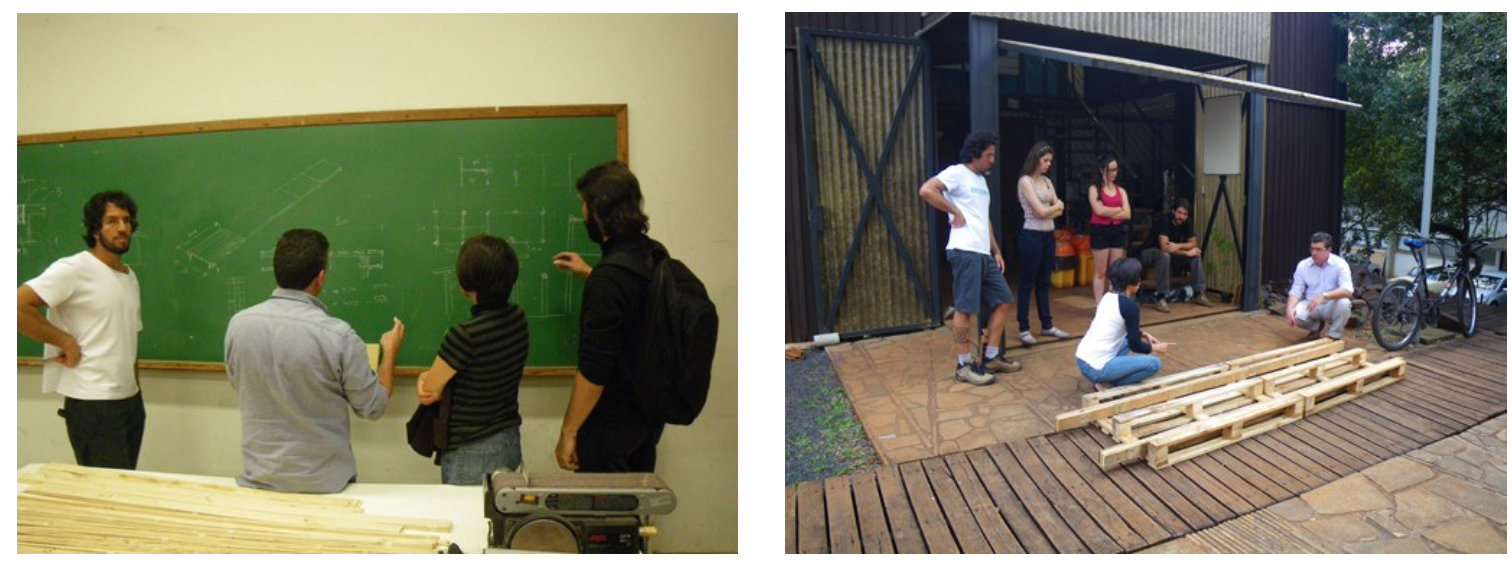

Fotos 174 e 175 - As primeiras discussões sobre as possibilidades de produção dos painéis de paletes para a cobertura começaram durante a Oficina 1. Alguns cálculos estruturais e as condições de fixação dos painéis foram discutidas de maneira a indicar pistas para a realização de um ensaio e verificação, num primeiro momento, da viabilidade técnica de realização deste projeto.
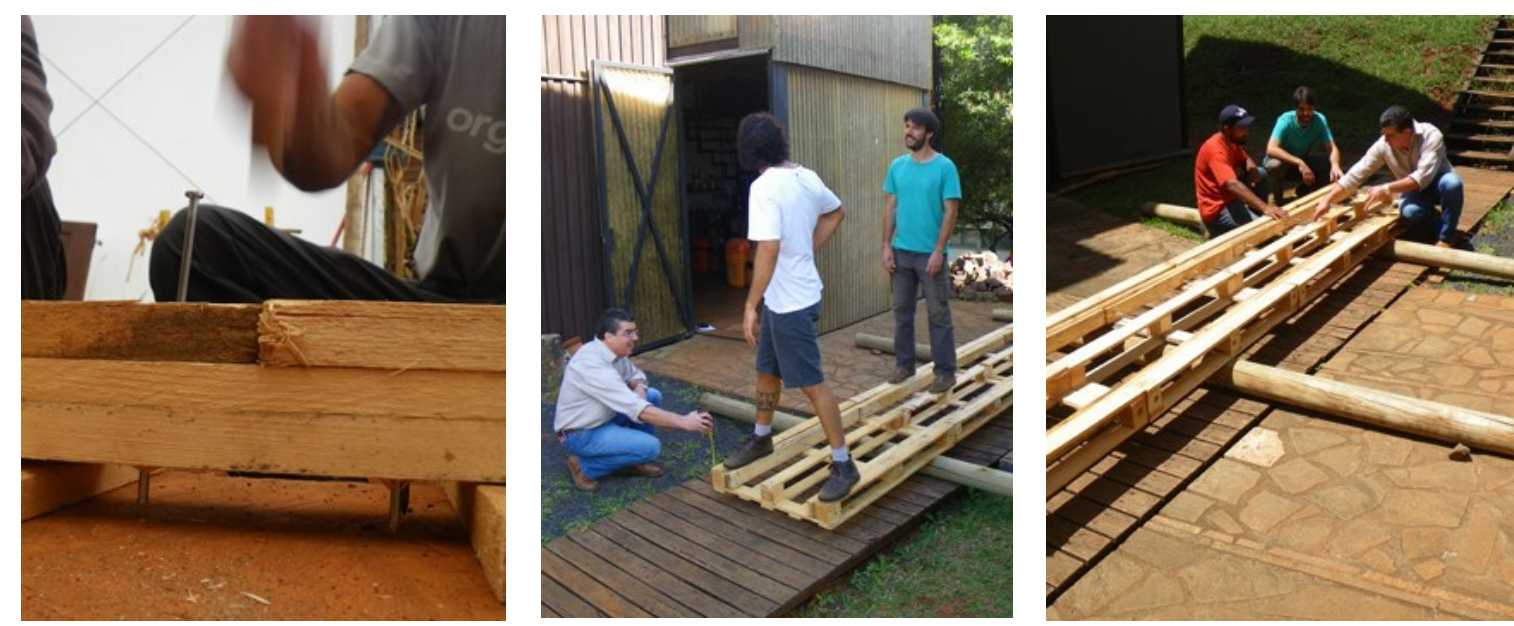

Fotos 176, 177 e 178 - Duas vigas laminadas pregadas foram produzidas e um primeiro painel foi realizado. O sistema de cobertura foi simulado dispondo troncos de eucaliptos e cargas sobre o painel. Mais uma vez G. Silva veio à Universidade e junto com a equipe foram discutidas as possibilidades de fixação das VLPs nos paletes, destes nas vigas de eucaliptos, os balanços máximos dos beirais, as possibilidades de forro interno, o peso do painel, a colocação das telhas, entre outras questões.

A segunda Oficina do Canteiro-Escola teve seu início no dia 02/11/2013. Foram 44 inscrições realizadas, dentre as quais 27 eram participantes da primeira Oficina. Dos 17 novos inscritos, 10 eram estudantes do Instituto de Arquitetura e Urbanismo, cinco eram estudantes de outras faculdades e dois eram estrangeiros participantes de programas internacionais de intercâmbio acadêmico.

Assim como na primeira oficina, as atividades foram iniciadas com as boas-vindas ao grupo e uma rodada de apresentação de cada participante com seus interesses e expectativas. Propusemos um processo mais participativo de inserção dos novos participantes, incentivando as pessoas presentes que já haviam participado das etapas anteriores, desde a optativa, a iniciarem os relatos e a explicarem ao novo grupo como 
ocorreram as atividades até aquele momento. Desta maneira, os processos realizados foram sendo descritos, com seus objetivos, condições, ritmos, resultados, impressões, etc., de modo a exercitar no grupo os diálogos sobre o processo histórico vivido através da prática de construção da memória coletiva.

Em seguida, foram tratados diferentes temas relacionados à organização do curso: etapas a serem realizadas ao longo da oficina, calendários, horários, grupo de e-mails, grupos de trabalho, refeições, transporte, segurança, entre outras questões. Os projetos da casa e dos sistemas construtivos foram explicados através dos painéis pedagógicos, que permitiam compreender melhor as etapas já realizadas.

Como fechamento deste primeiro período de apresentações, foi explicado ao novo grupo o documento dos "acordos e compromissos" estabelecidos para o curso. Foi entregue uma cópia entre os participantes para que cada um lesse um item do documento e, ao final, fossem feitas considerações sobre seu conteúdo.

Após o almoço, as práticas começaram. Pequenos grupos se formaram e se distribuíram nas atividades que já haviam iniciado durante o final da primeira oficina. Os trabalhos englobavam o término da construção da mesa de produção dos painéis de cobertura, a desmontagem dos paletes, extração de suas ripas, cortes, caracterização e organização das ripas para a produção das VLPs.
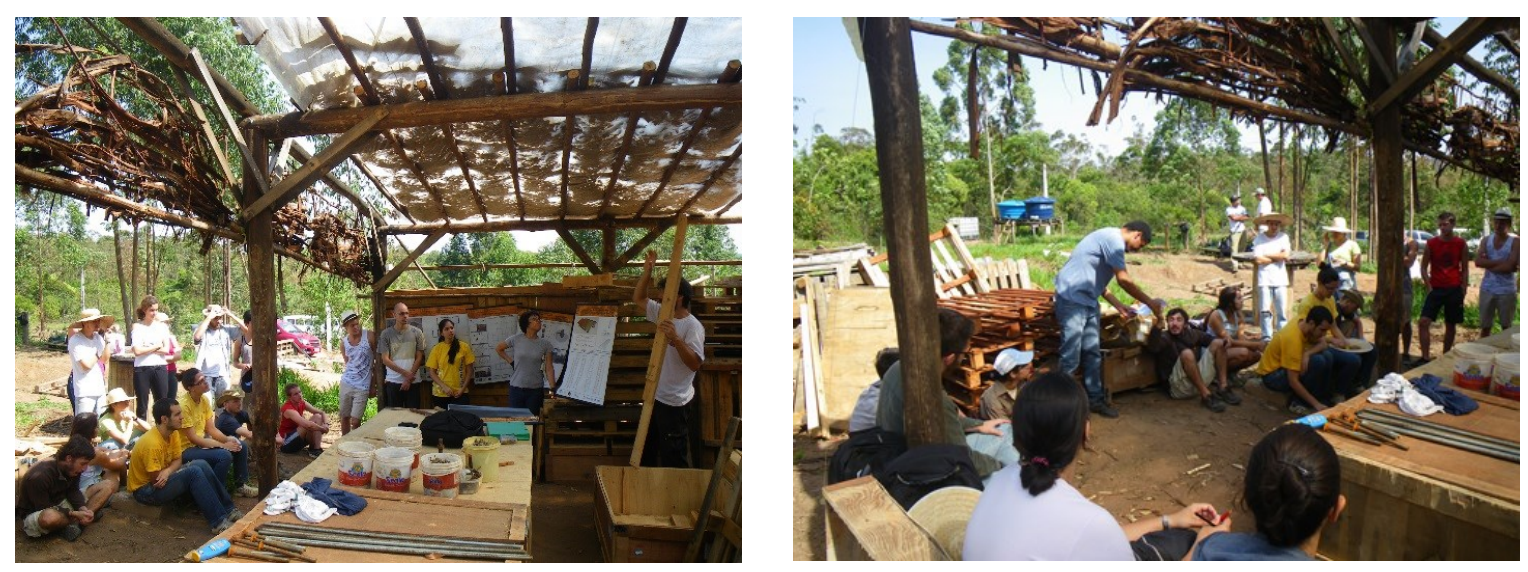

Fotos 179 e 180 - O primeiro dia de curso contou com a recuperação dos processos vividos e realizados até aquele momento, e a apresentação das atividades que seriam feitas ao longo da nova oficina. $O$ painel de cobertura foi explicado aos participantes através de seus sistemas construtivos e dos materiais que seriam utilizados em sua produção. 

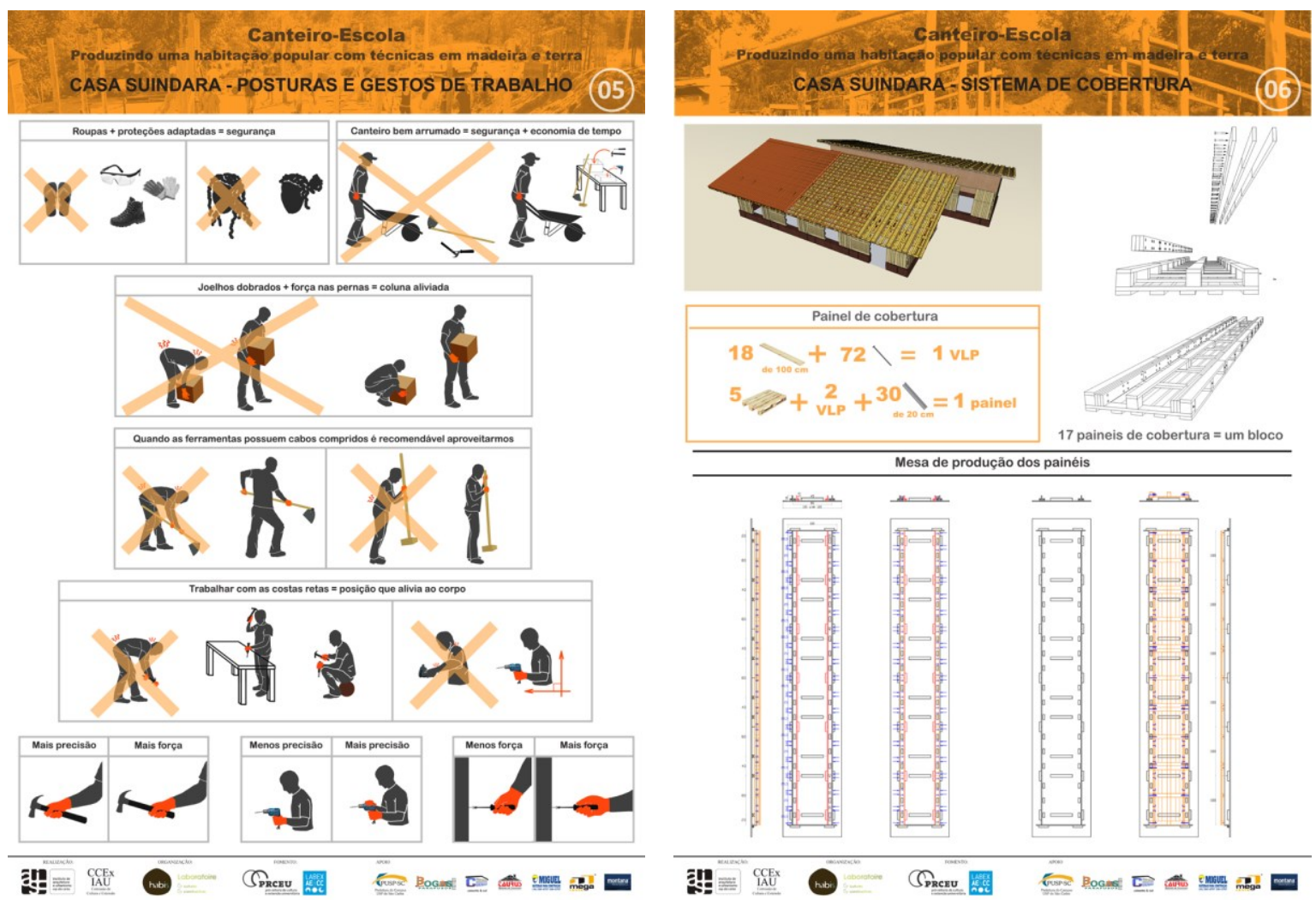

Figuras 37 e 38 - 0 painel 05 foi concebido em torno da segurança do trabalho, através de certas recomendações e cuidados a serem adotados em atividades de um canteiro de produção, onde há o manuseio de ferramentas e máquinas, com diferentes posições corporais. 0 painel 06 faz referência ao sistema de cobertura com seus princípios construtivos. Ele contém as perspectivas explicativas das VLPs e dos painéis, indicando os materiais e as quantidades necessárias para sua produção. Além disso, o suporte pedagógico traz os projetos da mesa de produção, com suas cotas e cortes respectivos. Painéis: Anaïs Guéguen Perrin.

A mesa de produção dos painéis de cobertura havia começado a ser construída durante a primeira Oficina e ainda precisava ser finalizada. Seu projeto indicava a possibilidade de serem montadas duas VLPs simultaneamente, uma em cada lado da mesa. Caibros previamente fixados serviam como guias para a produção das vigas que mediam seis metros de comprimento, tendo suas três camadas de ripas sobrepostas e pregadas entre si.

Uma vez as vigas produzidas, o projeto da mesa previa o espaço para que cinco paletes inteiros fossem dispostos lado a lado, ao longo de sua menor face, de modo a receber duas VLPs que seriam fixadas aos paletes, solidarizando-os e constituindo um único painel para a cobertura. 
Para a Oficina 2 do Canteiro-Escola, foi doado um conjunto de paletes que, uma vez caracterizado e organizado em lotes, totalizava mais de 300 unidades com 20 tipos diferentes, entre: formatos, tamanhos, espessuras, tipos de madeiras, pesos e origens. Naquele momento, compreendemos o quão difícil seria pensar um projeto modular com os paletes disponíveis. A diversidade destes confirmou a necessidade de adaptar e transformar o projeto e os sistemas construtivos a partir dos materiais disponíveis.

Os paletes em maior quantidade mediam $1,2 \mathrm{~m} \times 1,0 \mathrm{~m} ; 1,2 \mathrm{~m} \times 0,8 \mathrm{~m}$ e $1,13 \mathrm{~m} \times$ 0,75m. A opção foi separá-los e reservá-los para serem usados inteiros nos painéis de cobertura, e então, desmontar os demais paletes para extrair as ripas que seriam usadas na produção das Vigas Laminadas Pregadas (VLPs).

Foi decidido produzir as vigas com $6 \mathrm{~m}$ de comprimento, utilizando assim cinco ripas de paletes com 1,2m de comprimento. Como a fachada transversal ao painel media $4 \mathrm{~m}$, o beiral de um dos lados ficou com 0,70m, e do outro com 1,30m, criando uma espécie de varanda ao longo das fachadas longitudionais leste e oeste dos blocos.
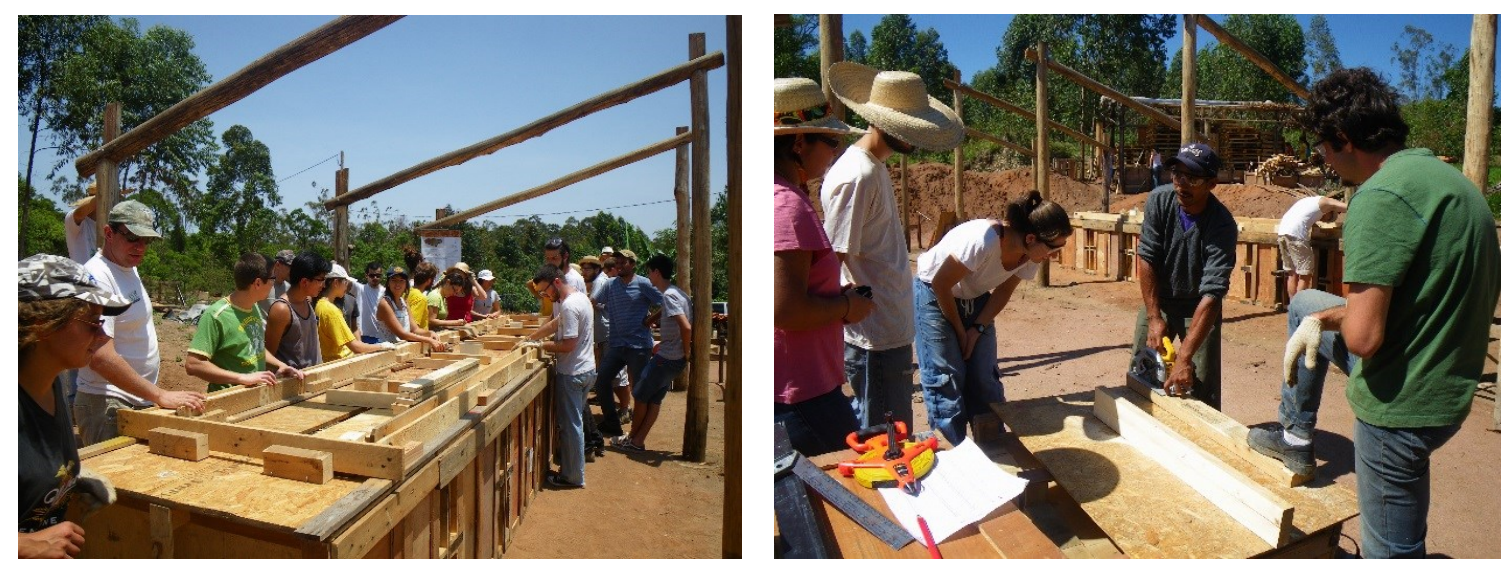

Fotos 181 e 182 - As atividades práticas iniciaram com a continuação da construção da mesa de produção dos painéis de cobertura. Após a explicação de seu projeto e das etapas necessárias à sua finalização, o grupo se distribuiu em equipes menores que foram pouco a pouco cortando as peças que faltavam, alinhando os caibros que demarcavam os posicionamentos das vigas e fazendo os primeiros testes de produção. 

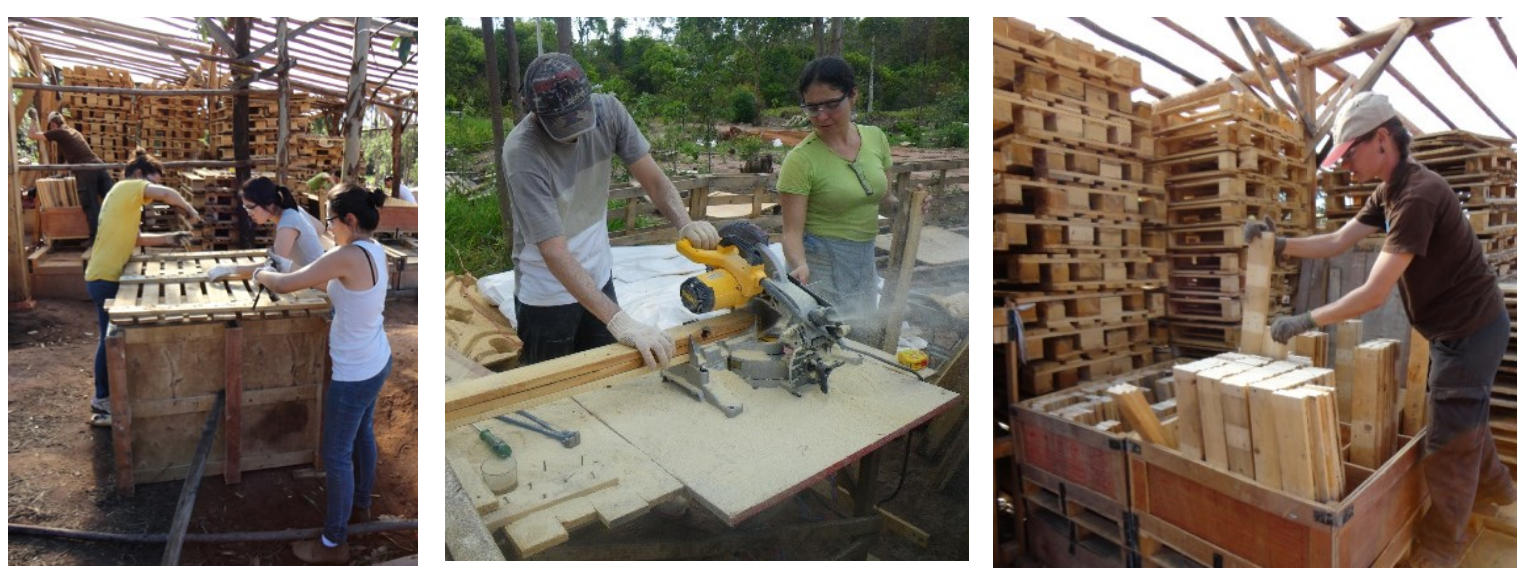

Fotos 183, 184 e 185 - A sequência de produção das vigas se iniciava pelo desmonte dos paletes e extração de suas ripas. Estas passavam pelo processo de alinhamento e corte nos tamanhos previamente estipulados. Posteriormente, eram caracterizadas e organizadas em função de suas seções, estando assim prontas para a produção das VLPs.
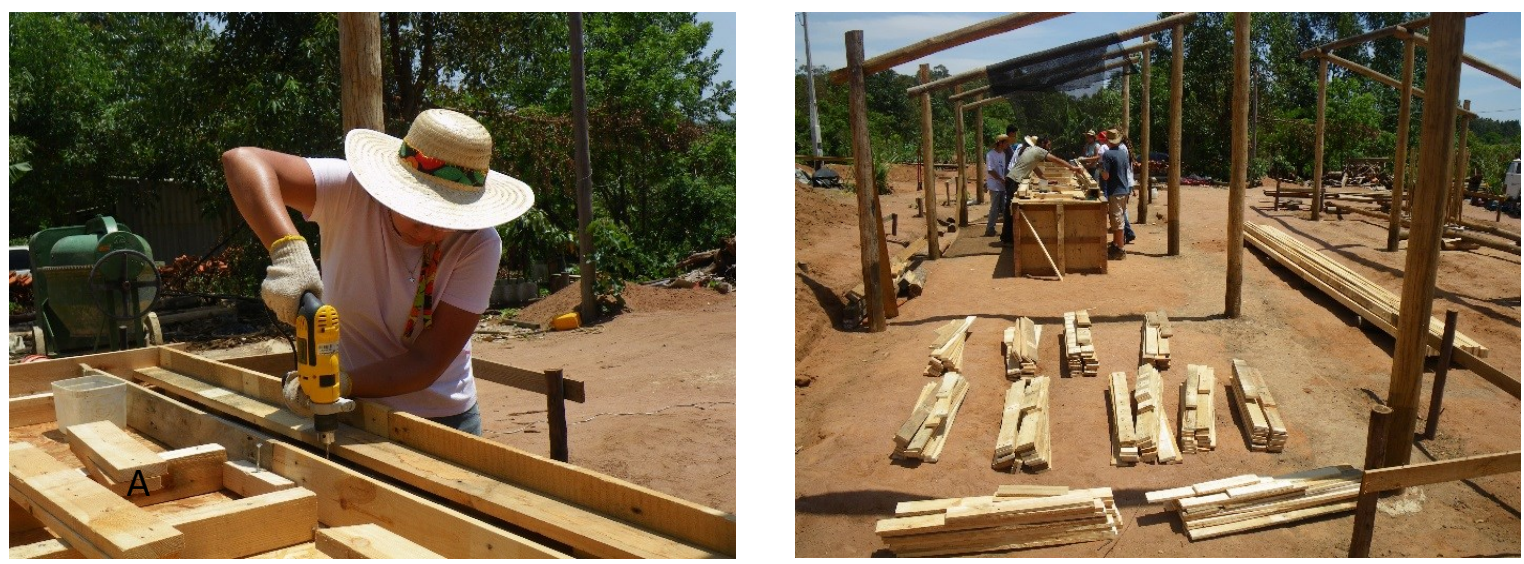

Fotos 186 e 187 - As primeiras VLPs foram produzidas e os últimos ajustes na mesa realizados. Enquanto os trabalhos de desmontagem dos paletes continuavam, um grupo de participantes iniciou a preparação de kits de VLPs com todas as peças necessárias para a sua construção, o que acelerou nosso processo produtivo.
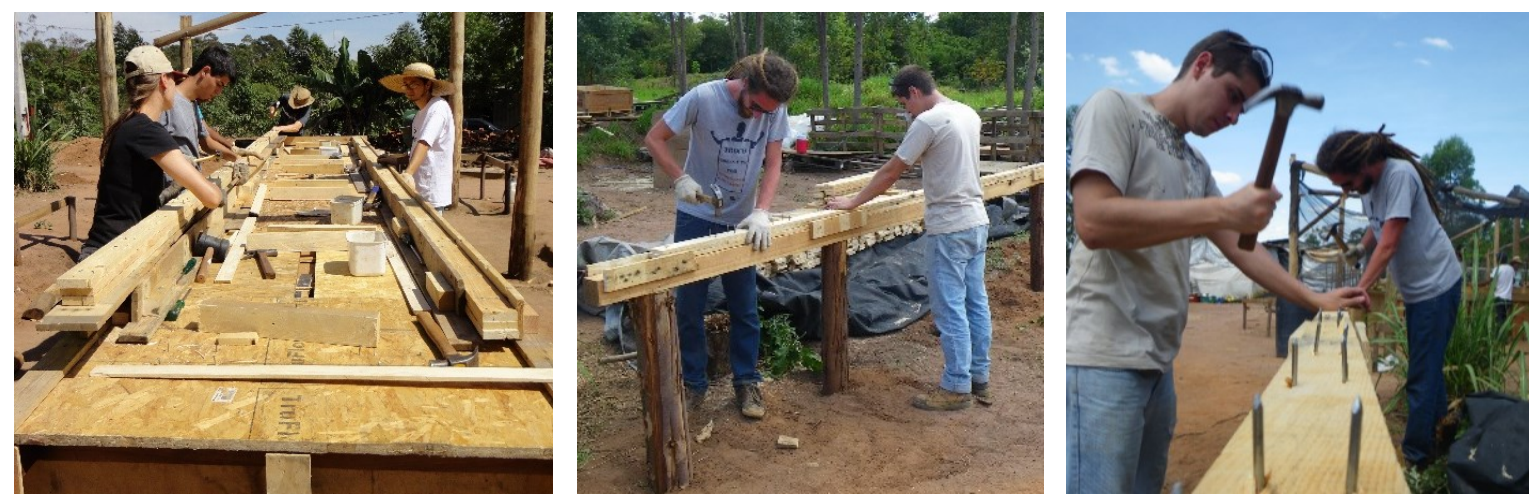

Fotos 188, 189 e 190 - Podendo produzir duas VLPs por vez na mesa de produção, percebemos que gastava-se muito tempo invertendo as vigas para dobrar os pregos que atravessavam o conjunto de três ripas. Foi então construída uma segunda mesa, da largura das vigas, destinada a dobrar tais pregos, melhorando assim o processo produtivo do sistema. 

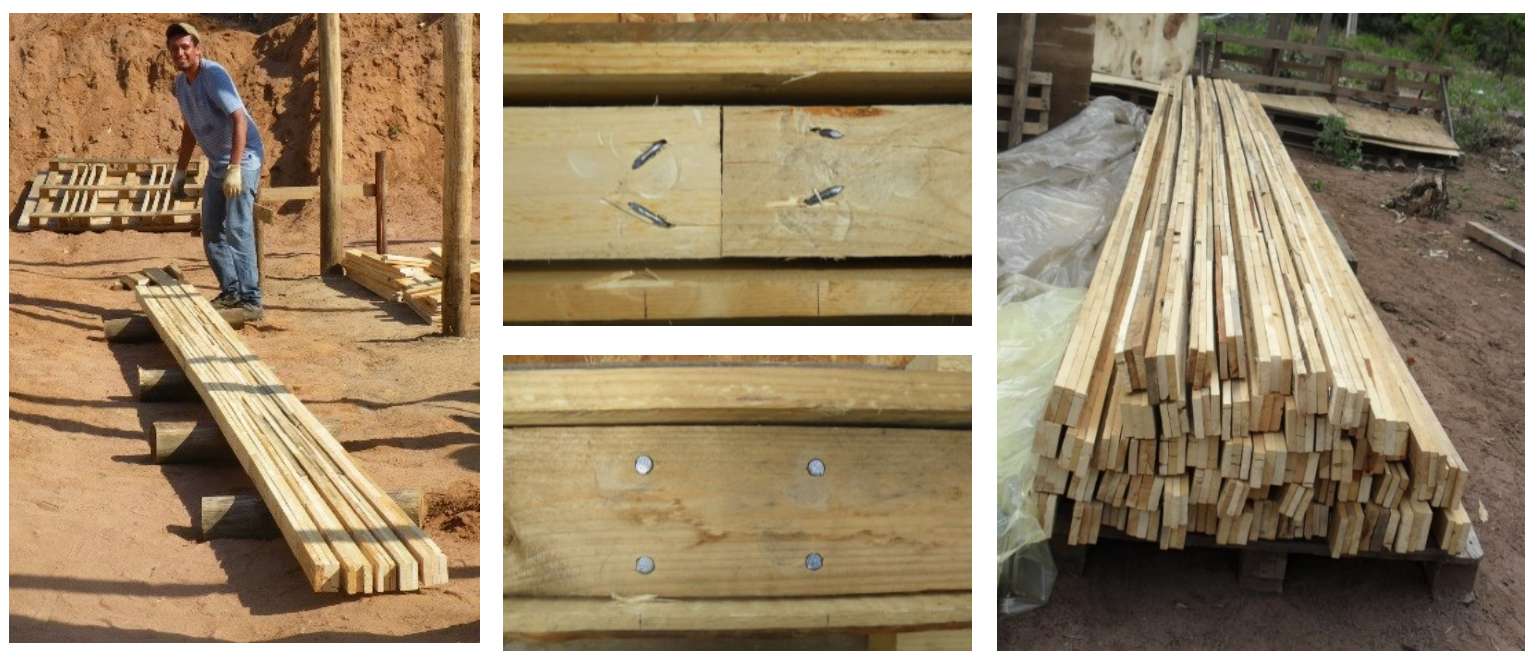

Fotos 191, 192, 193 e 194 - As vigas laminadas pregadas foram sendo produzidas e estocadas para posterior utilização nos painéis de cobertura. Ao todo foram produzidas 56 VLPs, com cerca de 1000 ripas retiradas dos paletes.
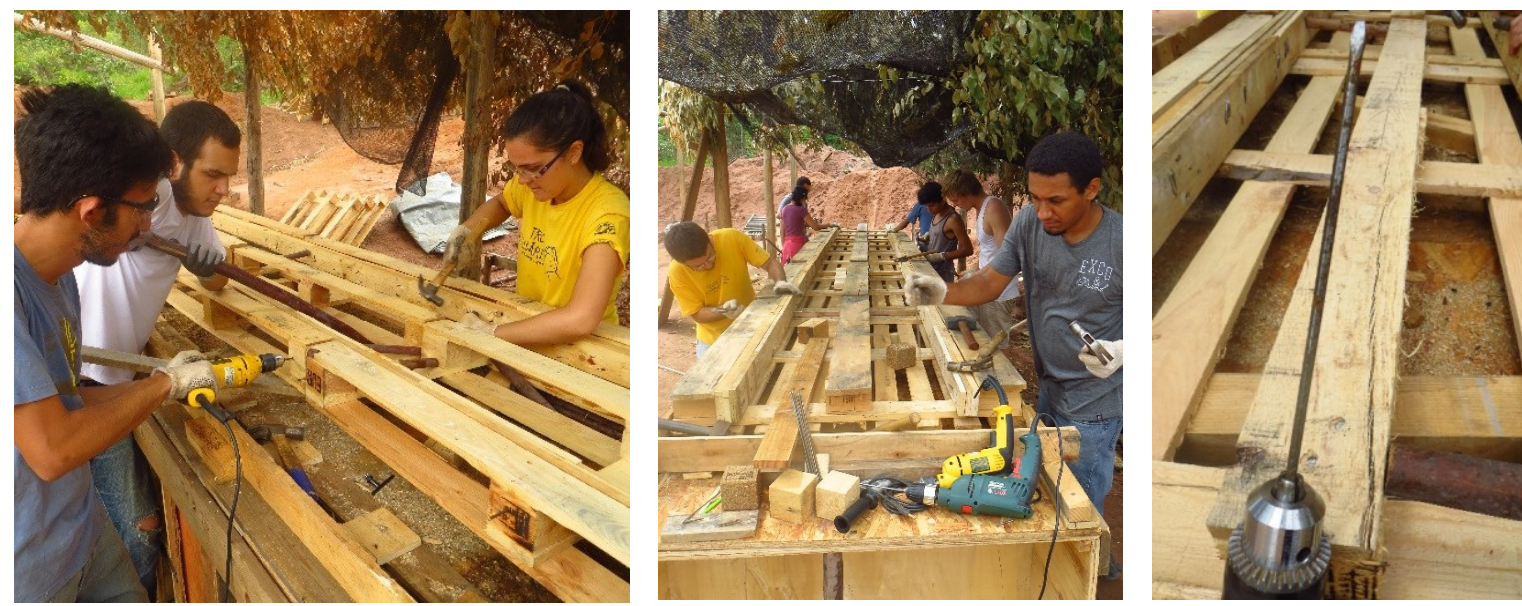

Fotos 195, 196 e 197 - Na produção dos painéis de cobertura, as VLPs eram dispostas junto às extremidades dos paletes, em seu lado interno. Primeiramente, elas seriam fixadas aos tocos de madeira dos paletes através de barras roscadas. Entretanto, visto o elevado custo das barras, optou-se por comprar barras lisas de ferro, cortá-las e adaptá-las para servir como elementos de fixação entre as vigas e os paletes. Suas pontas foram achatas e as barras colocadas como se fossem brocas com o auxílio de furadeiras. Uma vez inseridas, as barras eram dobradas dos dois lados e o painel estava enfim solidarizado e concluído.

Em suas práticas educativas, Paulo Freire explica o que ele chama "curiosidade epistemológica", como o processo em que as curiosidades ingênuas vão se superando, e sem deixar de ser curiosidades, vão se tornando mais críticas, indagadoras e produtoras de novos conhecimentos. Segundo ele, "Nas condições de verdadeira aprendizagem, os educandos vão se transformando em reais sujeitos da construção e da reconstrução do saber ensinado, ao lado do educador, igualmente sujeito do processo." (2011, p.28) 
Os processos tecnológicos de produção dos painéis de cobertura a partir dos paletes, foram processos sociais de trabalho e formação realizados no próprio canteiro, onde todas as etapas foram feitas pelos participantes, discutindo, experimentando, aprendendo, adaptando, desenvolvendo e produzindo as melhores soluções a partir dos materiais disponíveis, naquele momento, lidando com os imprevistos e reunindo como potencial, as capacidades cognitivas e técnicas da diversidade dos participantes.

Como em uma reação em cadeia, os acúmulos disponíveis vão se completando e indicando as alternativas mais viáveis a serem escolhidas a cada nova etapa construtiva, o que permite e potencializa a apropriação dos participantes dos processos de produção, e a percepção deles como sendo parte integrante da tecnologia social desenvolvida. Essa construção social da tecnologia ensaia a prática da desconstrução do controle no processo produtivo, da propriedade privada de seus meios e de seus conhecimentos técnicos, e da alienação de seu produto enquanto mercadoria.

Uma vez imbricada na realidade local, a tecnologia social dos painéis de cobertura em paletes foi resultado da ação de um coletivo de produtores que, desde a concepção à realização, participou das escolhas de suas características e condições. As constantes adaptações e transformações nos processos construtivos, revelavam as condições sociais da produção tecnológica, presentes nos tempos da produção, nos materiais doados, nos recursos financeiros disponíveis, nos processos de trabalho, nas expectativas e nos resultados alcançados.
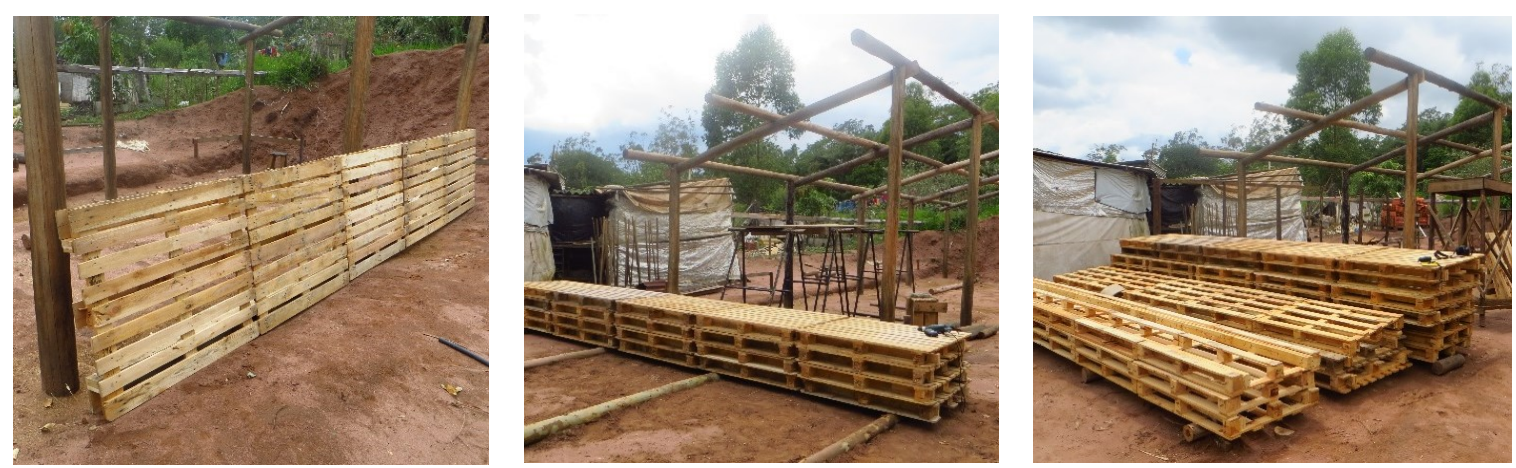

Fotos 198, 199 e 200 - Os painéis de cobertura foram então sendo produzidos e estocados ao lado da casa. Devido aos diferentes tamanhos de paletes existentes, houveram adaptações na produção dos painéis. Ao total foram produzidos 27 painéis de cobertura, com 135 paletes inteiros, mais os destinados às VLPs. 

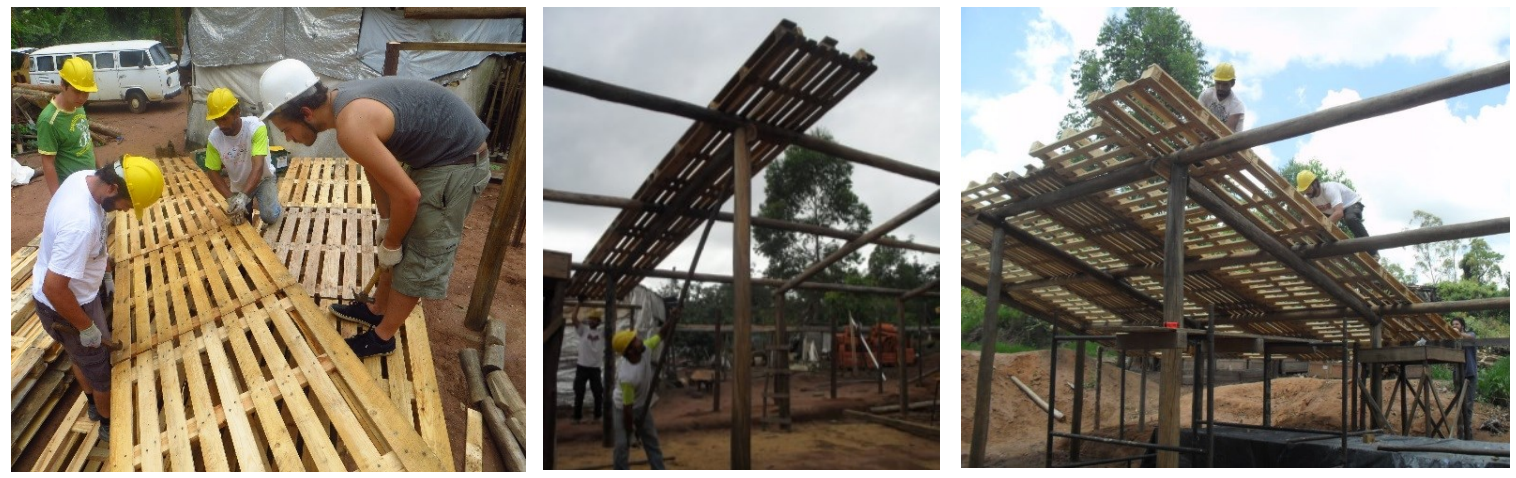

Fotos 201, 202 e 203 - Os painéis foram sendo posicionados e fixados nas vigas longitudinais. A técnica utilizada consistiu em erguer cada painel acima das vigas e empurrá-los até o encontro com o painel posicionado anteriormente, fixando-os na medida em que iam ocupando seus lugares. Cada painel pesava cerca de $100 \mathrm{~kg}$.
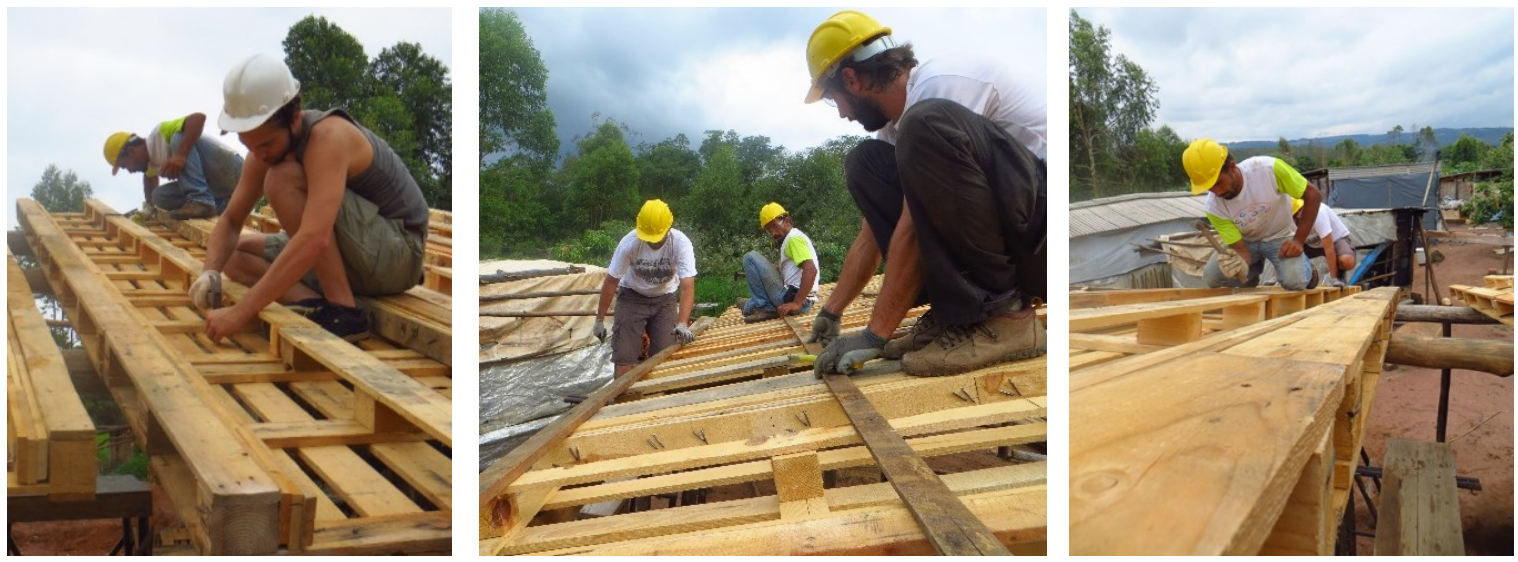

Fotos 204, 205 e 206 - Os painéis de cobertura foram pregados ao longo dos encontros com as vigas longitudinais em eucalipto. Após suas fixações, as ripas destinadas ao telhado começaram a ser dispostas na cobertura e seu posicionamento passou a ser discutido em grupo.
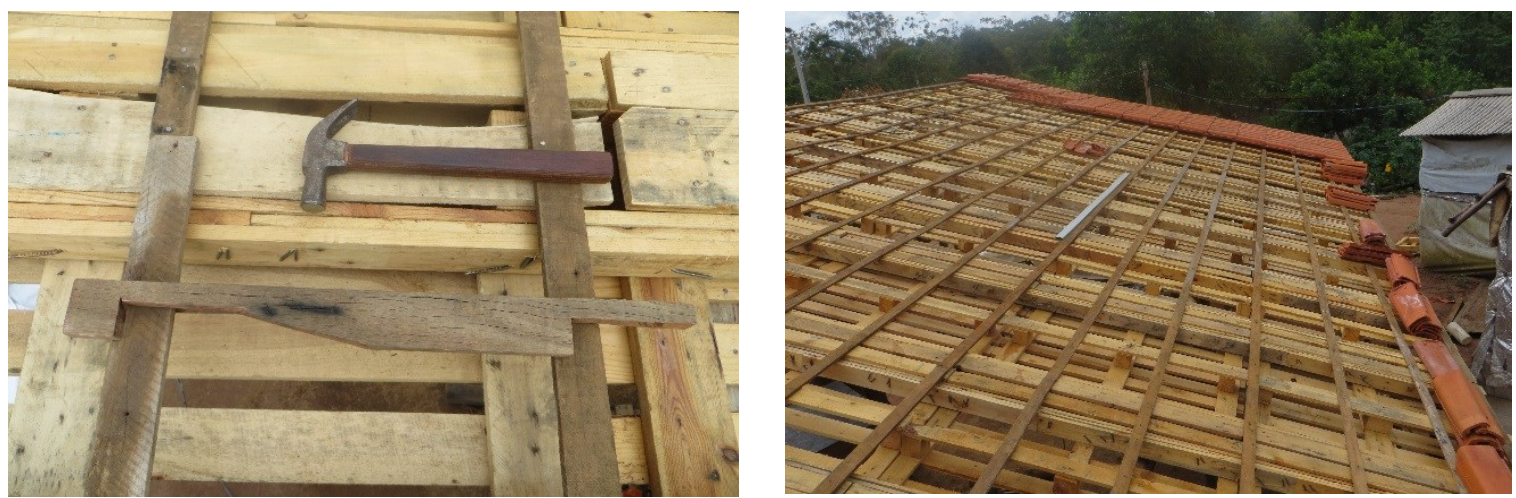

Fotos 207 e 208 - Para a fixação das ripas da cobertura foram produzidos gabaritos em função das telhas disponíveis para o telhado. Nesse caso, foram doadas telhas cerâmicas do tipo capa-canal, inseridas no projeto de cobertura cuja inclinação era de cerca de $28 \%$. 

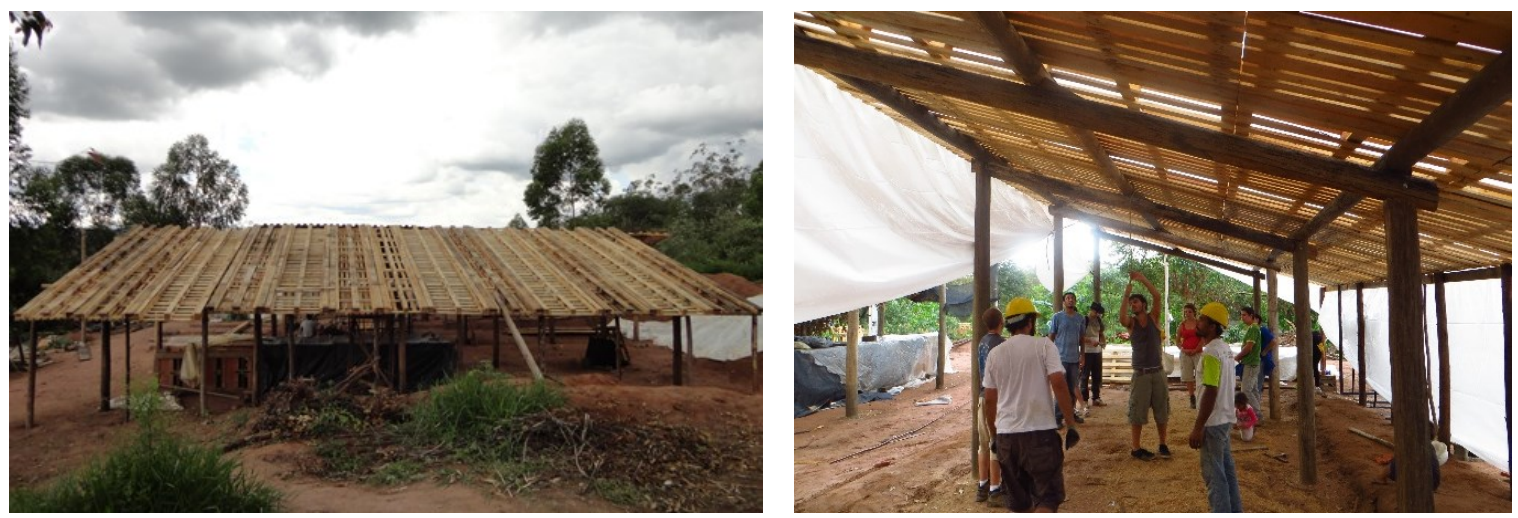

Fotos 209 e 210 - Após a fixação de todos os painéis de cobertura, foi esticada uma lona para a proteção dos paletes até a conclusão do telhamento, o que permitiu ter um espaço coberto, para trabalhar e estocar os materiais durante o restante do Canteiro-Escola.
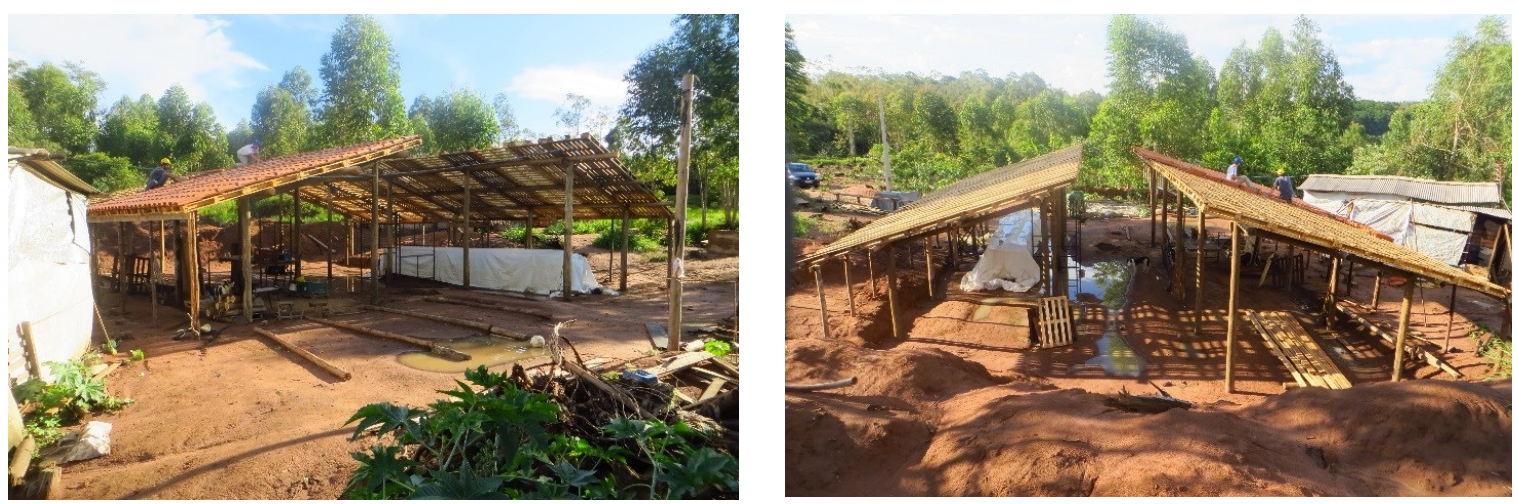

Fotos 211 e 212 - Ao final da Oficina 2, a casa Suindara se encontrava com os painéis de cobertura produzidos e fixados. Ao mesmo tempo em que as ripas do telhado iam sendo pregadas nos painéis, as telhas cerâmicas iam sendo dispostas e a cobertura ganhava sua forma final.
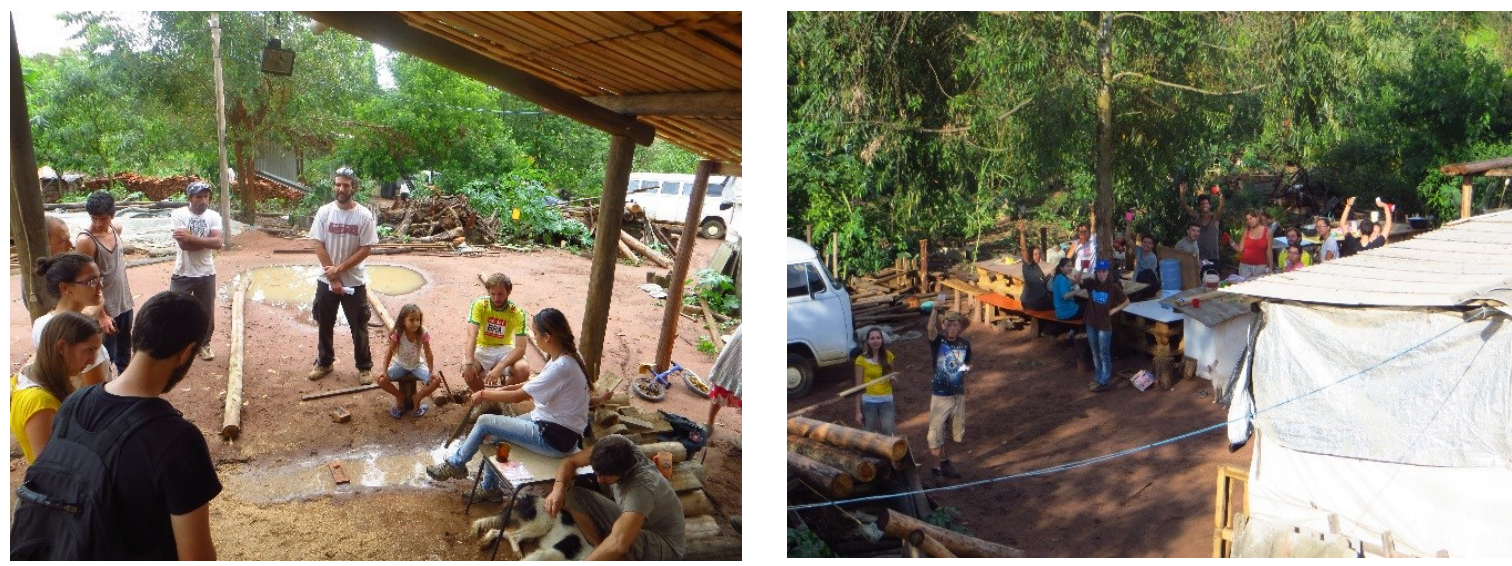

Fotos 213 e 214 - Assim como na primeira oficina, a conclusão das atividades referentes à Oficina 2 foi feita com o grupo presente a partir de análises individuais e coletivas sobre as etapas vividas e as práticas construtivas realizadas. O já "tradicional" lanche de final de tarde configurou-se como um momento de descontração, conversas e trocas entre os participantes e a família. 
A Oficina 2 do Canteiro-Escola terminou em meados de dezembro de 2013. Ao todo, foram 10 dias de atividades ligadas à produção da cobertura da casa Suindara. 0 custo estimado dos materiais construtivos utilizados nas atividades foi da ordem de $\mathrm{R} \$ 1.500,00$. A média de 15 participantes ficou abaixo daquela da primeira Oficina. De acordo com o grupo, o calendário de final de ano com entregas de trabalhos em outras disciplinas obrigatórias, dificultou a participação dos alunos nos finais de semana. Obviamente, outros fatores também influenciaram esta realidade. $O$ tema dos diferentes "tempos" já foi tratado antes e voltará a ser discutido ao longo das conclusões.

Assim como na Oficina 1, o quadro abaixo mostra uma série de dados referentes às novas atividades realizadas, com suas datas, materiais, serviços, custos e quantidades, além da média de participantes.

\begin{tabular}{|c|c|c|c|c|c|c|}
\hline CANTEIRO-ESCOLA & ETAPAS & DATAS & MATERIAIS E SERVICOS & QUANTIDADES & CUSTOS RȘ & $\begin{array}{c}\text { PESSOAS } \\
\text { (média/dia) }\end{array}$ \\
\hline \multirow{7}{*}{ OFICINA 2} & \multirow{7}{*}{ Cobertura } & \multirow{7}{*}{$\begin{array}{c}02,03,04,15,16 \\
17 / 11 / 2013 \text { e } 30 \\
01 / 12 \text { e } 07,08 / 12 \\
(10 \text { dias })\end{array}$} & Pregos & $37 \mathrm{~kg}$ & 256,3 & \multirow{7}{*}{ 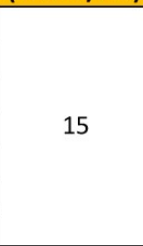 } \\
\hline & & & Transporte (Telhas e ripas) & & 240 & \\
\hline & & & Pentox (doação) & $2 \times 18$ litros & 214,2 & \\
\hline & & & Paletes (doação) & & & \\
\hline & & & Barras de ferro $3 / 16$ & 22 & 143 & \\
\hline & & & Pentox & 18 litros & 250 & \\
\hline & & & Lona p/estufa branca leitoso & $10 \mathrm{~m} \times 15 \mathrm{~m}$ & 360 & \\
\hline TOTAL & & & & & 1463,5 & \\
\hline & & & & \multicolumn{2}{|c|}{ environ $=€ 490$ euros } & \\
\hline
\end{tabular}

Figura 39 - Tabela reagrupando as datas, custos, materiais e participantes da Oficina 2.

Após a recuperação comentada das atividades realizadas ao longo da segunda oficina e da apresentação dos dados da tabela acima, foi aberto um espaço para as análises coletivas. Neste exercício, foi feito um debate sobre o processo de produção dos painéis de cobertura em paletes. A intenção era avaliar a mesa de produção, com seu conforto, tamanho, inteligência construtiva, etc., discutindo também os métodos de transformação dos paletes, através de seus desmontes, até o painel final produzido.

Segundo o grupo, a mesa respondeu bem às atividades de produção das vigas laminadas pregadas (VLPs) e dos painéis de cobertura. Porém, ela sofreu bastante com os trabalhos realizados, sobretudo pela baixa qualidade de suas madeiras de pinus. Precisaria ser reforçada e alterar certos detalhes construtivos se ela fosse continuar a ser utilizada para a produção de novos painéis. 
Pela quantidade e diversidade dos paletes trabalhados, cerca de 20 tipos diferentes, a ideia de se ter o forro interno pronto a partir das ripas dos paletes foi rediscutida. Como os paletes não eram homogêneos e muitos deles estavam tortos ou com algumas ripas lascadas, os encontros entre eles não eram contínuos. Muitas frestas se formaram entre os paletes, de modo que ficou recomendado refletir a respeito de como fazer o novo forro interno da casa.

Abaixo, seguem algumas reflexões dos participantes da Oficina com o intuito de contextualizar e enriquecer estas análises com as palavras de outros que, também, protagonizaram as atividades.

"Sobre o desmonte dos paletes, sempre dá a sensação de que a gente está gastando muita energia. Na verdade, gasta-se muito tempo para tirar uma ripa. Sabe, ainda que com a prática esse tempo vá diminuindo um pouco. Mas mesmo assim ainda é muito tempo para pouco resultado, né. No final, você desmontou poucos paletes e quebrou um monte de peças." (A. d'Andrea)

"Muitas peças eram diferentes, então tivemos que desmontar muitos paletes para que as peças ficassem mais parecidas. Senão as VLPs seriam uma salada de peças todas diferentes. Mas é muito difícil com tantos tipos de paletes diferentes, alguns tortos ou quebrados." (M. Jimena)

“- Como poderíamos desmontar melhor os paletes?

- Podemos pensar em um mecanismo com alavancas, onde pudéssemos encaixar e segurar os paletes, e vamos soltando com pés-de-cabra e martelos.

- As tábuas, tinha gente que com o pé-de-cabra quebrava as ripas inteiras. Então nesse caso não sei se seria muito bom. Teria que ver se tem esses pregos anelados tortos para desentortar primeiro. Pois depois que a gente começou a desentortar ficou mais fácil de tirá-los." (Diálogo entre participantes)

O desmonte dos paletes foi um assunto bastante levantado no fechamento da Oficina. Estava clara a dificuldade dos participantes quanto aos processos de extração das ripas inteiras para a produção das VLPs. Era preciso rever a forma de desmontar os paletes para a produção dos painéis de parede durante a Oficina seguinte. De modo, que 
este diálogo coletivo foi muito valioso para as reflexões sobre os métodos de trabalho utilizados.

Passar por processos de questionamento consiste num exercício bastante positivo neste tipo de atividade, onde a experimentação consciente aberta às transformações previsíveis ou não, é orientada para o trabalho formador, criando inteligências construtivas a partir dos recursos humanos, materiais e financeiros disponíveis. 0 aprendizado coletivo e coletivizado ganhava espaço no Canteiro-Escola.

"A gente produziu aqui. Foi aqui que a gente testou, construiu, viu que a barra não entrava, que ia ser o ferro, seus tamanhos, viu que os paletes mudavam. Processo construído no coletivo aqui em cima do canteiro." (participante)

"Acho que foi bom pois a gente teve que resolver muita coisa sobre o andamento ou como faríamos para fixar as VLPS nos painéis, pois as barras estavam muito caras. Acho que por termos solucionado coisas durante o canteiro foi muito bom. E conseguimos cobrir, não?" (M. Jimena)

\section{OFICINA 3}

Após o período correspondente às férias acadêmicas, o ano de 2014 iniciou com a nova divulgação e abertura das inscrições para a Oficina 3 do Canteiro-Escola. As atividades referentes contemplavam a realização das bases da casa em taipa de pilão, a produção dos painéis de parede em paletes e os revestimentos internos em terra.

A primeira mudança ocorrida no planejamento foi a extensão de seu calendário até o final do mês de junho, possibilitando quatro meses de curso, com 18 dias de atividades no assentamento.

Mais uma vez, para nossa surpresa, as 45 vagas disponíveis foram rapidamente preenchidas com 65 inscrições realizadas. Como anteriormente, todos os inscritos foram aceitos e organizados em duas turmas diferentes. Deste total, 28 já haviam participado de pelo menos uma das Oficinas anteriores, sendo que 20 haviam feito as duas Oficinas. 
Destes, seis participavam das atividades no lote desde o começo do curso optativo, ou seja, estavam há um ano envolvidos com a produção da casa.

A Oficina 3 do Canteiro-Escola teve seu início no dia 08 de março. A dinâmica deste primeiro dia de atividades foi similar aquelas realizadas no início das Oficinas anteriores, e contou com a introdução ao curso e boas-vindas aos participantes, seguida pela apresentação individual de cada um e pela definição da agenda de atividades daquele dia e do restante do semestre.

A recuperação das atividades realizadas anteriormente consistiu em um momento de grande importância dentro da metodologia de curso. E cada vez que as etapas do Canteiro-Escola avançavam, mais relevância ela adquiria, visto a chegada de novos participantes que necessitavam ser introduzidos aos contextos dessa realidade. Era fundamental que todos tivessem consciência do porquê de nossa presença, da chegada ali, das condições de desenvolvimento dos trabalhos, da experiência com a família, entre outras questões primordiais para a inserção consciente dos novos participantes.

Não bastava vir ao lote e construir algo durante o dia, tinha que haver inserção, entender o processo, participar, propor situações, voltar, questionar, dialogar, enfim, se assumir enquanto sujeito social constituinte do processo em curso, e consciente tanto das relações que influenciavam as atividades, quanto das influências das atividades em sua formação profissional.

Além disso, a recuperação coletiva das etapas de canteiro fomentava o exercício da memória coletiva entre aqueles que já participavam das oficinas, gerando por consequência, um maior empoderamento destes enquanto sujeitos produtores da nova realidade - a construção da casa.

Assim, depois de uma breve introdução referente ao processo de entrada do grupo de pesquisa no assentamento, o diálogo começou a ser guiado pelas pessoas que haviam participado de cada uma das etapas anteriores. A partir da optativa, passando pelas Oficinas 1 e 2, diferentes participantes foram construindo a linha do tempo das atividades realizadas, opinando sobre os resultados, comentando pequenos casos e 
histórias entre as pessoas, e projetando suas próprias leituras e compreensões sobre o que haviam vivido e aprendido.

Esse exercício de realizar as discussões sobre o projeto, as técnicas e os detalhes construtivos, de maneira complementar às suas práticas construtivas, foi muito presente no canteiro. Aquilo que fora desenhado ao final da optativa, base para o que tínhamos no momento, guardava seus elementos básicos, porém já intensamente transformados pelas propostas e novas condições das conjunturas constantemente em mutação.

Ademais, o que orientou fundamentalmente as escolhas técnicas, além das questões financeiras, foram os materiais disponíveis. Como determinar previamente os detalhes construtivos quando se dispõe de uma grande variedade de paletes? Até o início da etapa referente a produção dos painéis de parede, a variedade recebida no canteiro havia aumentado para 36 tipos diferentes de paletes. Era necessário pensar a partir dos materiais, dos limites de sua utilização, das possibilidades de consorciá-los entre si, da viabilidade de sua produção por grandes grupos de amadores e principiantes, e da qualidade dos resultados finais.

Os painéis pedagógicos com o projeto da casa e as etapas realizadas foram apresentados ao novo grupo. Seus princípios foram explicados e seus porquês relatados. Construir uma casa aprendendo enquanto se produz. Exercitar durante seu ritmo o diálogo, companheirismo e solidariedade. O esforço de desconstruir as relações de trabalho homogeneizadas na ordem vigente, lança também o desafio de deixar o projeto aberto às opiniões, sugestões, questionamentos e transformações. E aprender com isso.

Outro tema tratado foi o processo de mecanização no canteiro. Foram explicados os motivos que levaram à escolha por mecanizar até um certo ponto o trabalho realizado. Por um lado, havia o interesse de proporcionar aos participantes a oportunidade de experimentar diferentes maneiras de realizar a mesma técnica. Assim, o concreto produzido para as fundações dos pilares foi feito manualmente, mas a massa de solo cimento da fundação das paredes foi feita com a betoneira, visto a quantidade de mistura necessária. Da mesma forma, as taipas de pilão foram executadas, em sua maior parte, manualmente, dado a quantidade de participantes, mas também foi experimentada a 
compactação mecanizada, o que permitiu a comparação entre seus diferentes processos de produção.

Por outro lado, não havia o interesse em aportar máquinas que estivessem muito longe das possibilidades de acesso das outras famílias assentadas. As máquinas podem facilitar o trabalho, assim como, excluir do benefício de seus resultados aqueles que não conseguem acessá-las. Uma das intenções era aportar ferramentas e máquinas (furadeiras, parafusadeiras, betoneira, entre outras) acessíveis de maneira geral, com custos não muito elevados, e que não limitassem a demonstração às outras famílias das possibilidades construtivas, a partir dos materiais que eles dispõem localmente.

Foram também abordadas questões relacionadas aos cuidados necessários durante a realização dos trabalhos, às relações com os animais e com a vegetação existentes no lote, assim como, em relação ao respeito com o local de vida da família. A primeira atividade matinal foi concluída com a leitura do documento dos "acordos e compromissos", onde os participantes puderam fazer seus comentários.

Assim, os grupos se dividiram para as atividades seguintes: os novos participantes foram conhecer o lote de produção e moradia, enquanto as outras pessoas começaram a preparar o espaço para o almoço coletivo.
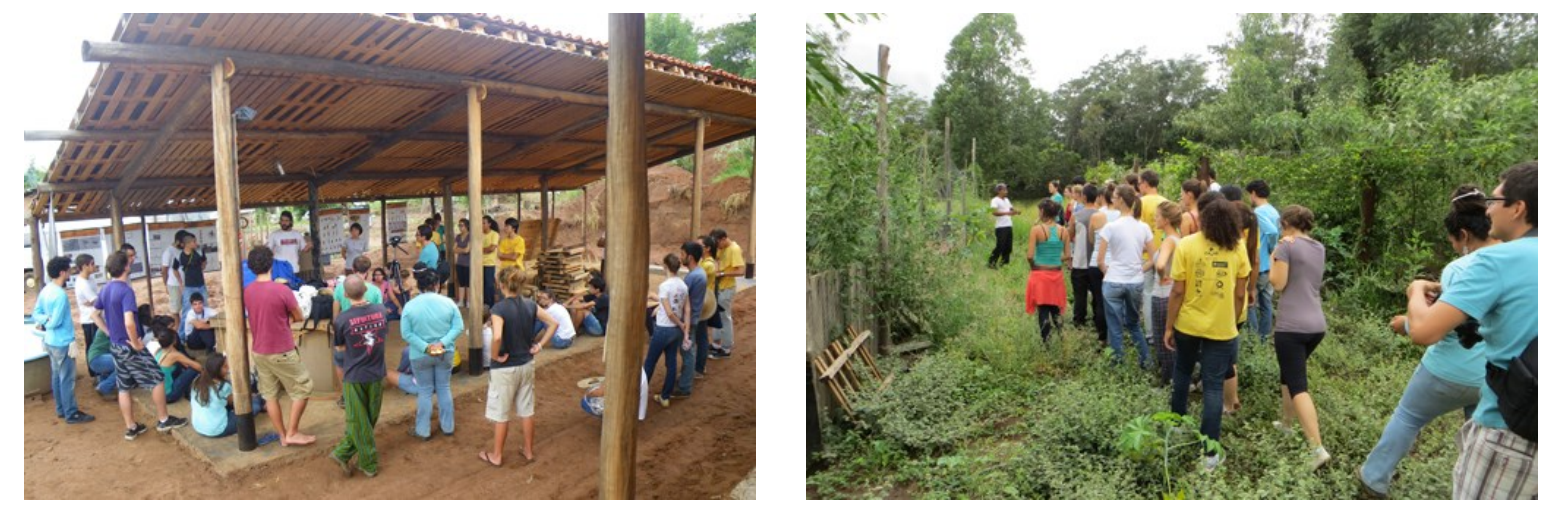

Fotos 215 e 216 - Como nas duas oficinas anteriores, o primeiro dia de atividades contou com a apresentação coletiva dos participantes e com diálogos a respeito das atividades ocorridas até aquele momento do curso. A visita guiada por G. Silva introduziu os participantes no mundo de seu lote de vida e produção. Histórias e espaços foram tecendo o enredo deste início de curso. 

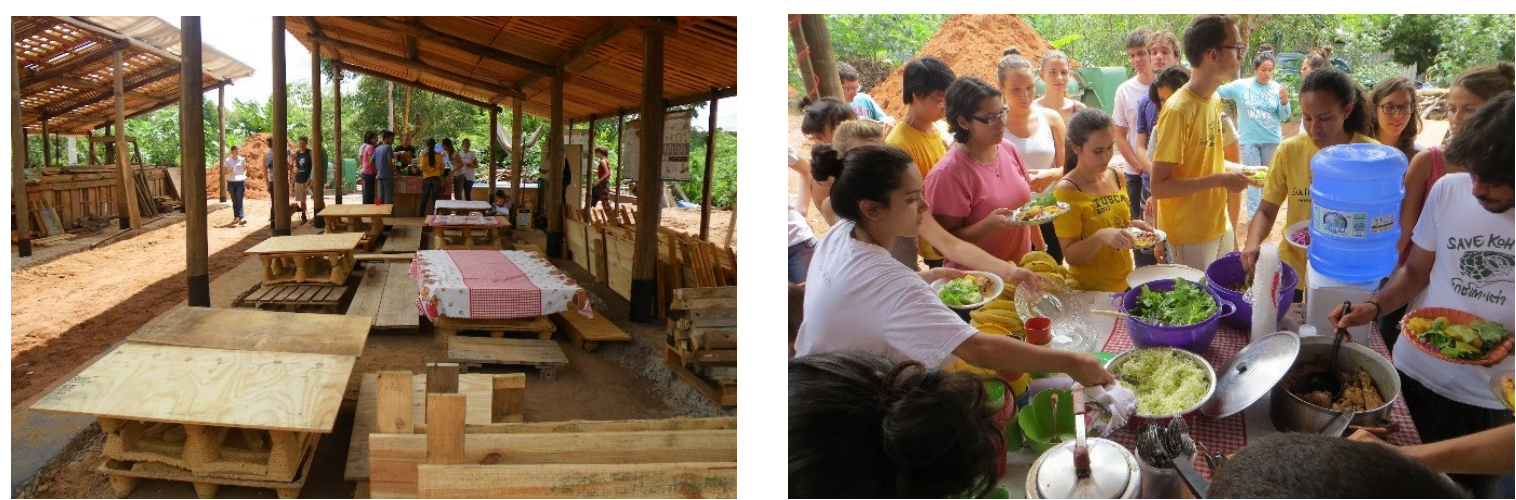

Fotos 217 e 218 - Enquanto o novo grupo realizava a visita no lote familiar, os antigos participantes preparavam o espaço da casa para o almoço coletivo. Os acordos referentes às refeições foram novamente assumidos pelo grupo e pela família.
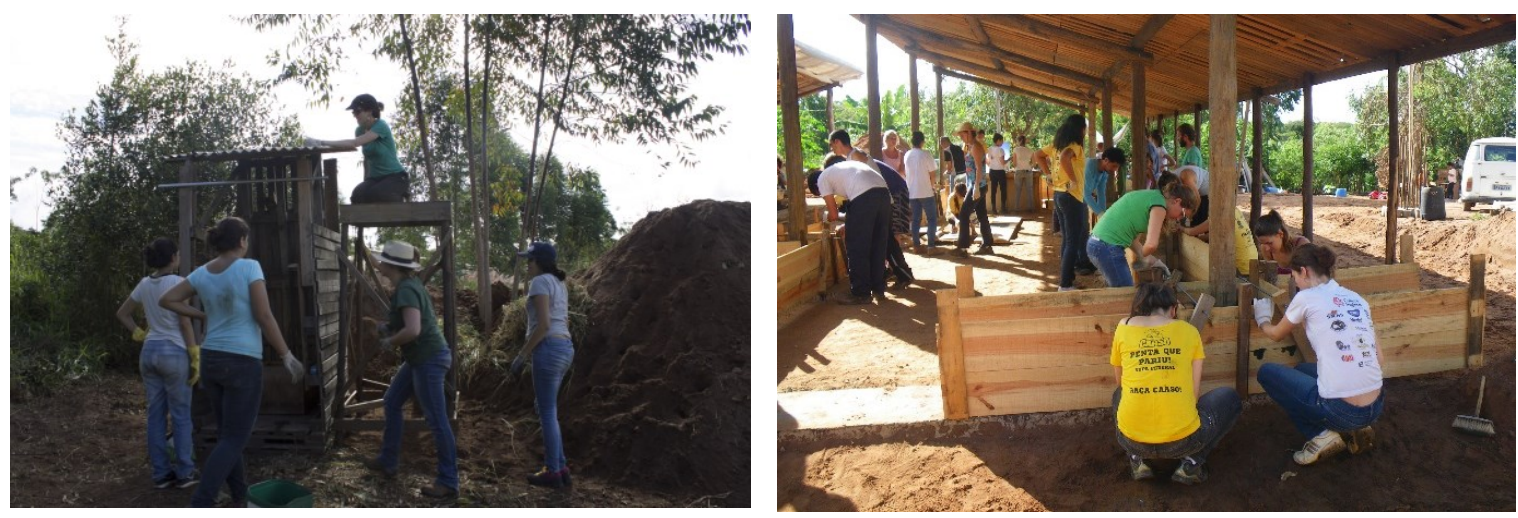

Fotos 219 e 220 - Na parte da tarde, os participantes se distribuíram em duas atividades. A primeira, era referente à reforma do banheiro seco que durante a estação das chuvas foi atingido por dois eucaliptos que caíram e deterioraram sua cobertura. A segunda atividade dava início às montagens das fôrmas das taipas de pilão em volta dos pilares da casa, para a produção de sua base.

Com relação às fôrmas para as taipas de pilão, suas montagens foram pensadas de modo a servir tanto para a produção das bases dos pilares, quanto para as bases das paredes. Elas foram feitas em pranchas de madeira estruturadas verticalmente por sarrafos. Foram cortadas de modo a serem facilmente recuperadas para outros fins. Nelas, foram fixadas cantoneiras para realizar os cantos chanfrados das bases em taipa, assim como, peças de eucaliptos que formavam os encaixes de tipo "macho-fêmeas" para as conexões entre as bases dos pilares e as das paredes.

Antes do grupo iniciar as montagens das fôrmas, foram realizadas explicações sobre a técnica da taipa de pilão, assim como havia sido feito durante a Oficina 1. As características da terra disponível foram consideradas, assim como as razões para sua estabilização com cimento. As etapas de produção foram novamente acordadas e foi demonstrado o passo a passo da montagem das fôrmas. 


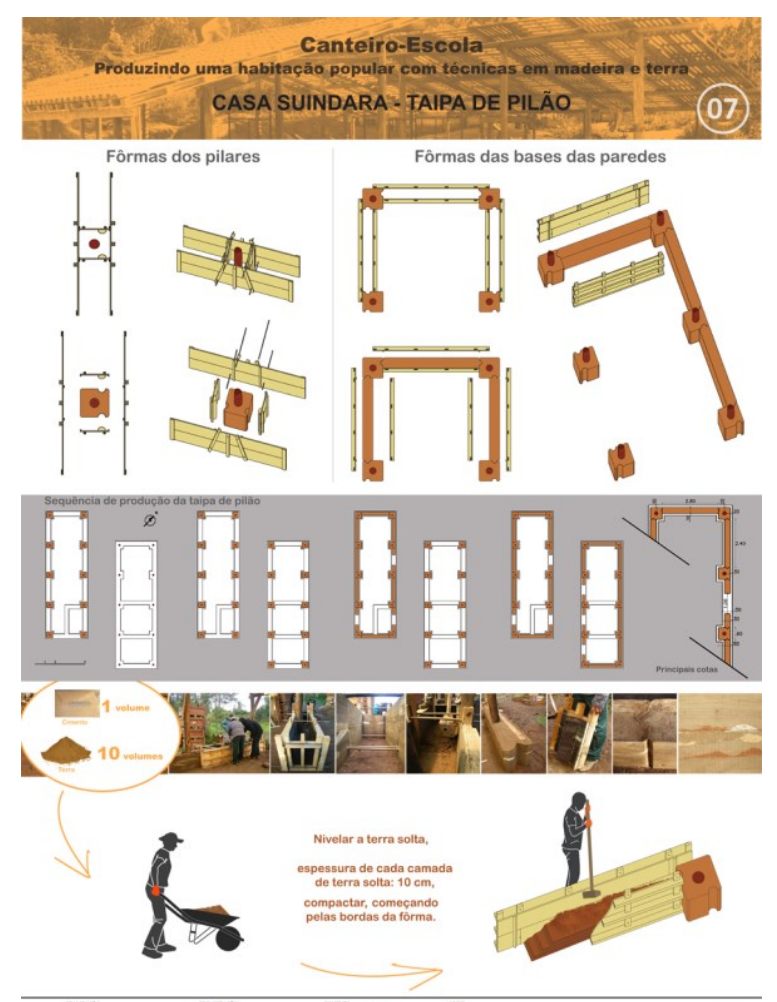

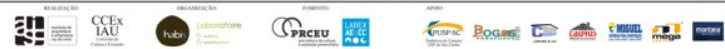
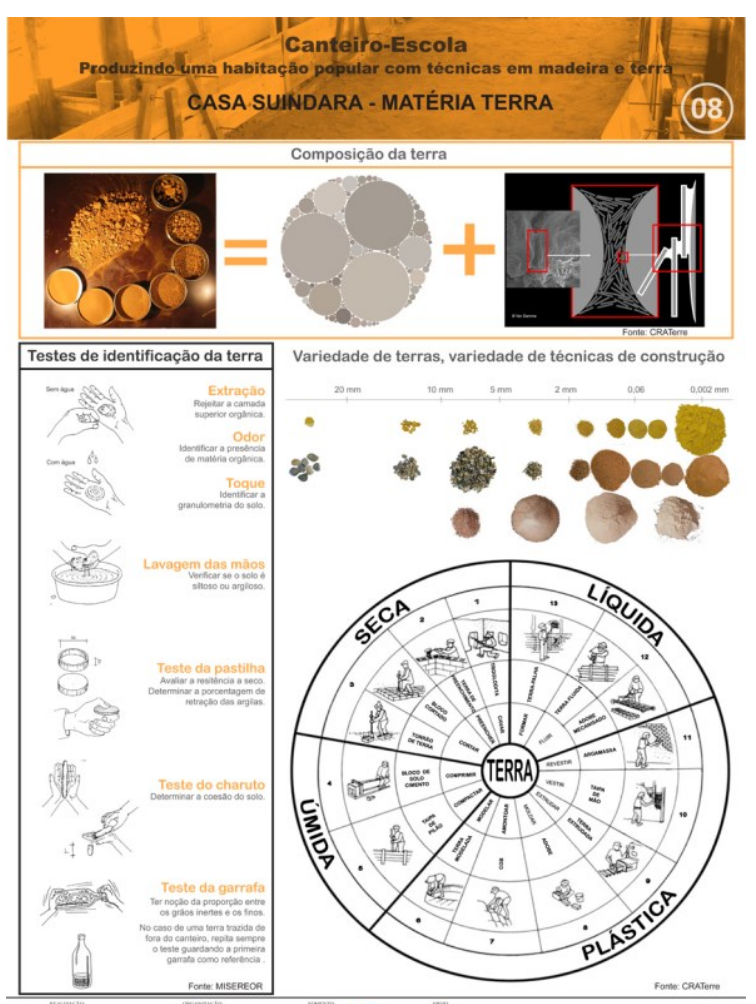

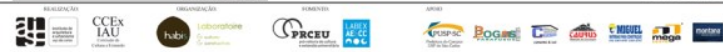

Figuras 40 e 41 - Dois painéis pedagógicos foram produzidos sobre as atividades com terra. 0 painel 07 explica o processo de montagem das fôrmas para a taipa de pilão, assim como o traço da mistura utilizada, com fotos ilustrativas. Já o painel 08 , traz o suporte para a aula sobre a terra como material de construção, com suas características, composição granulométrica, técnicas construtivas em função dos diferentes teores de água, assim como testes de terreno para verificação rápida e fácil das características de uma determinada terra dada. Painéis: Anaïs Guéguen Perrin.
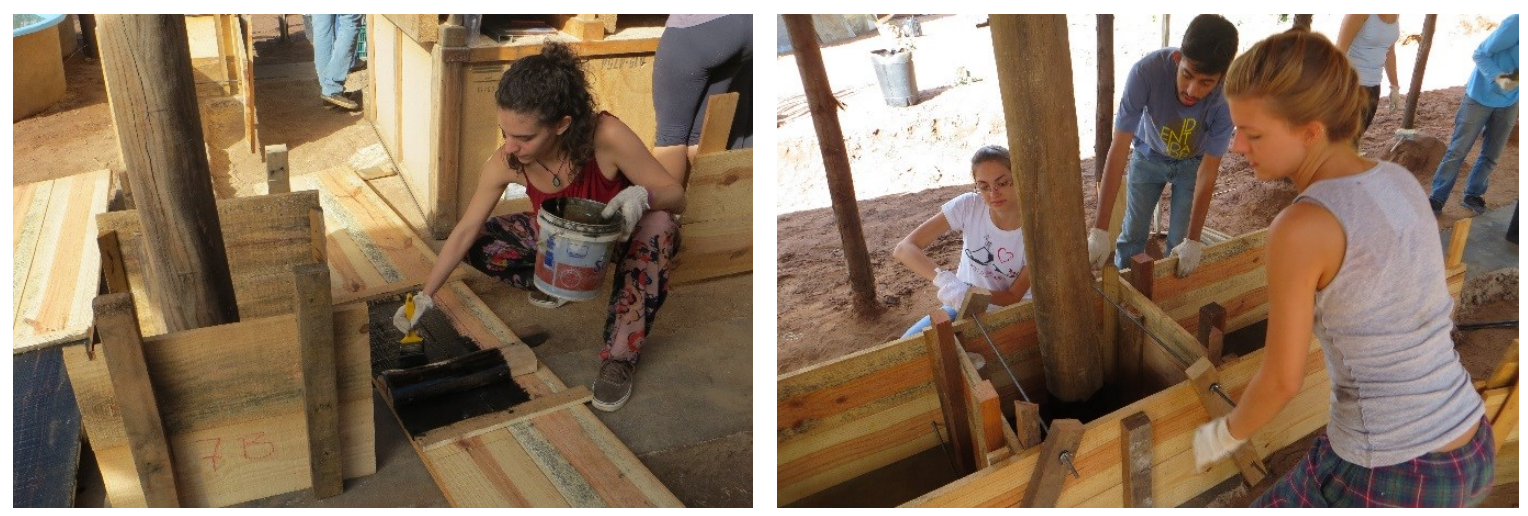

Fotos 221 e 222 - O processo de montagem das fôrmas iniciou-se pela pintura de uma camada de óleo queimado em suas faces internas, com a finalidade de facilitar a desforma posterior da taipa. Em seguida, as fôrmas foram dispostas pelos participantes em volta dos dez pilares de um dos blocos da casa, quando foram feitos os primeiros ajustes de travamento. 

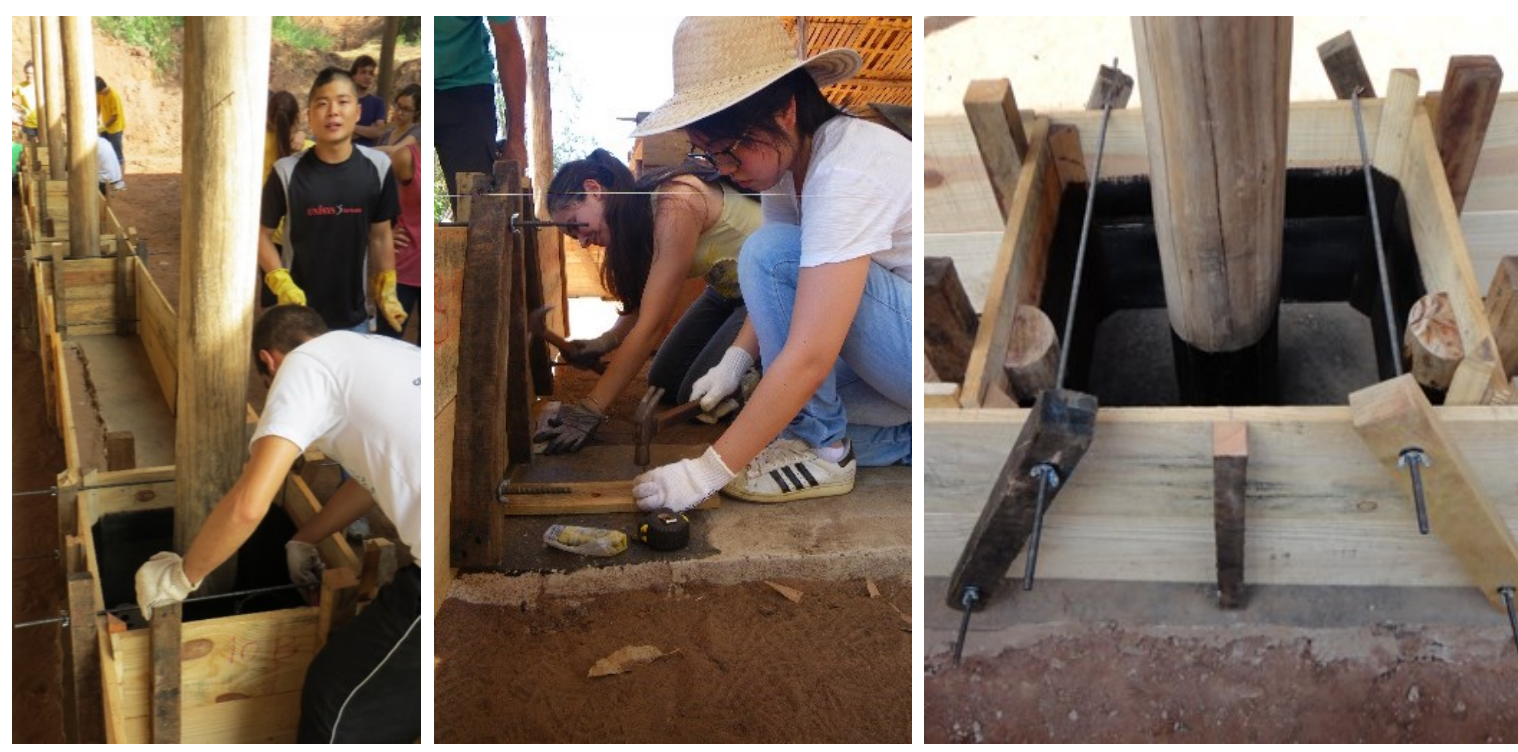

Fotos 223, 224 e 225 - As fôrmas foram sendo alinhadas ao longo dos pilares, travadas e fixadas ao solo pelos grupos formados no momento. Ao final, estas configuravam um quadrado de $0,60 \mathrm{~m} \times 0,60 \mathrm{~m}$ envolvendo cada pilar e contando com os encaixes de tipo "macho-fêmeas", para suas conexões com as bases das paredes da casa.
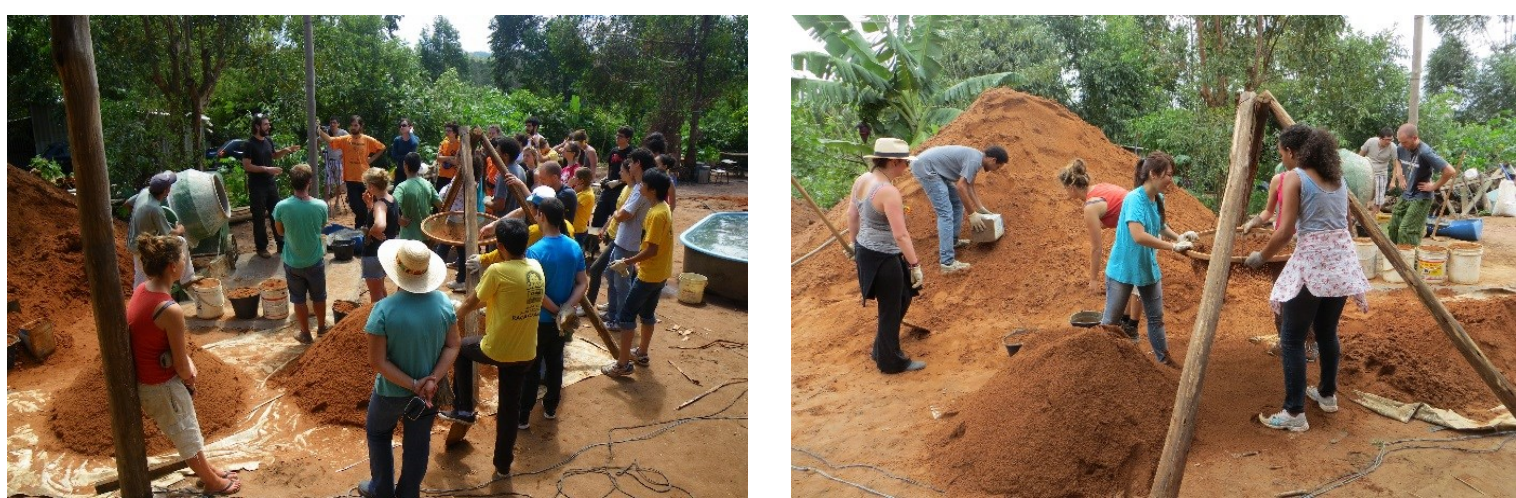

Fotos 226 e 227 - A produção da mistura de solo-cimento teve início com uma explicação sobre a terra disponível, sua composição e características granulares, seguida das explicações sobre a preparação da mistura, com seu teor de água e teste de terreno para avaliação da mistura.
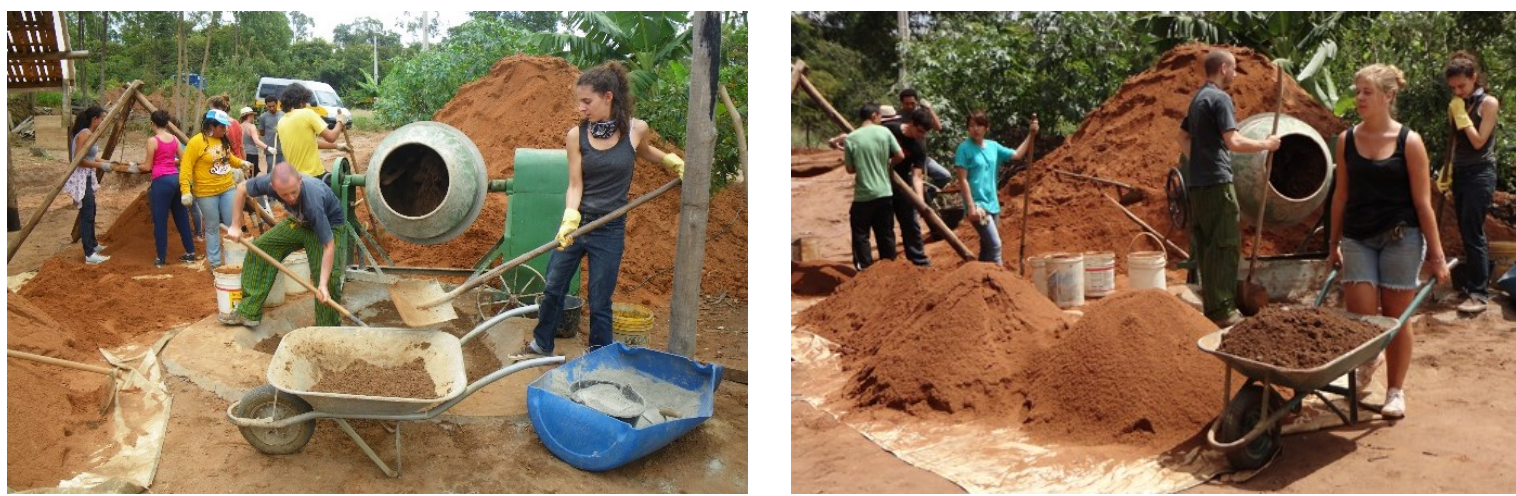

Fotos 228 e 229 - O processo de realização das taipas iniciava pelo peneiramento da terra e preenchimento dos baldes dosadores, seguidos pela mistura, na betoneira, com o cimento e a água na proporção de 10 terra: 1 cimento. Após abastecimento dos carrinhos de mão, as misturas eram levadas aos grupos de taipeiros. 

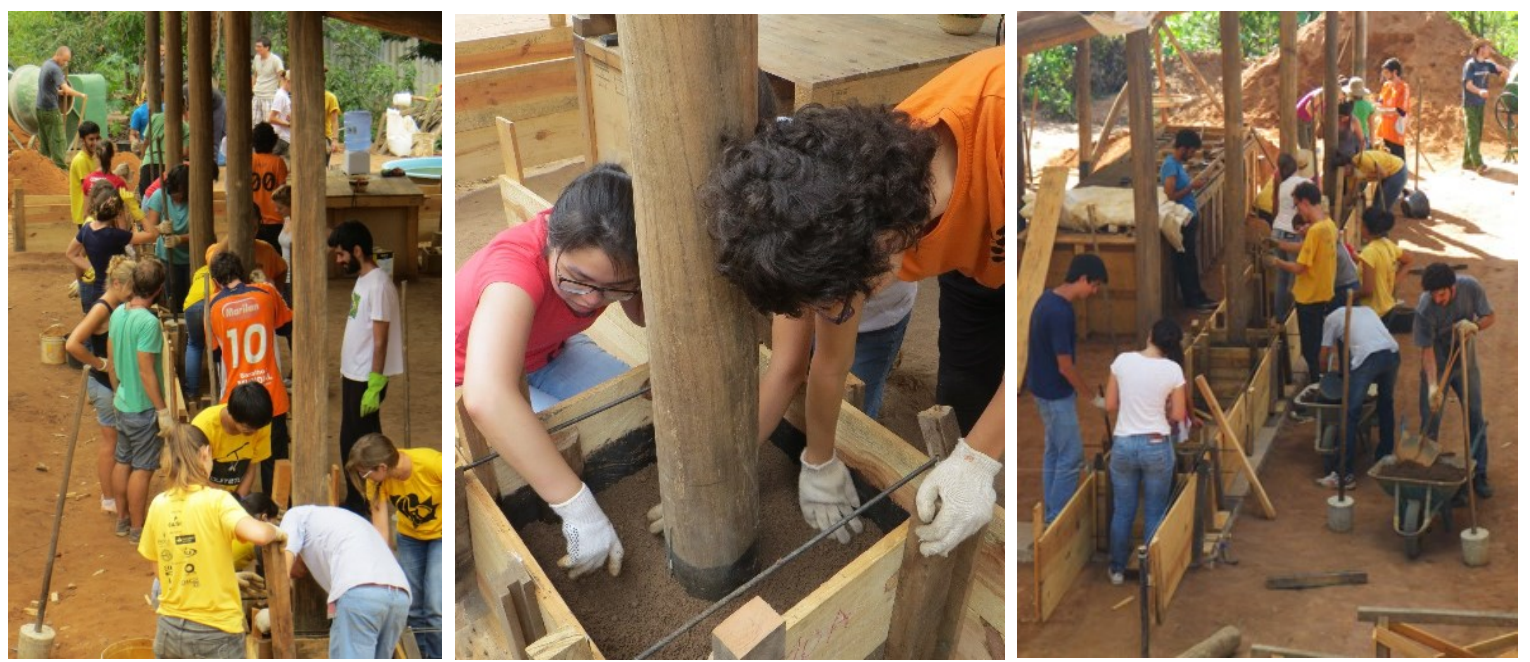

Fotos 230, 231 e 232 - Cada pilar possuía seu grupo de taipeiros responsável pelos trabalhos de apiloamento das misturas. Estas, eram distribuídas nas fôrmas que iam sendo pouco a pouco preenchidas e finalizadas. A rotatividade nas atividades e o reagrupamento entre as equipes foram estimulados. As pessoas participavam do conjunto de atividades, experimentando a técnica a partir da produção de seu material construtivo.
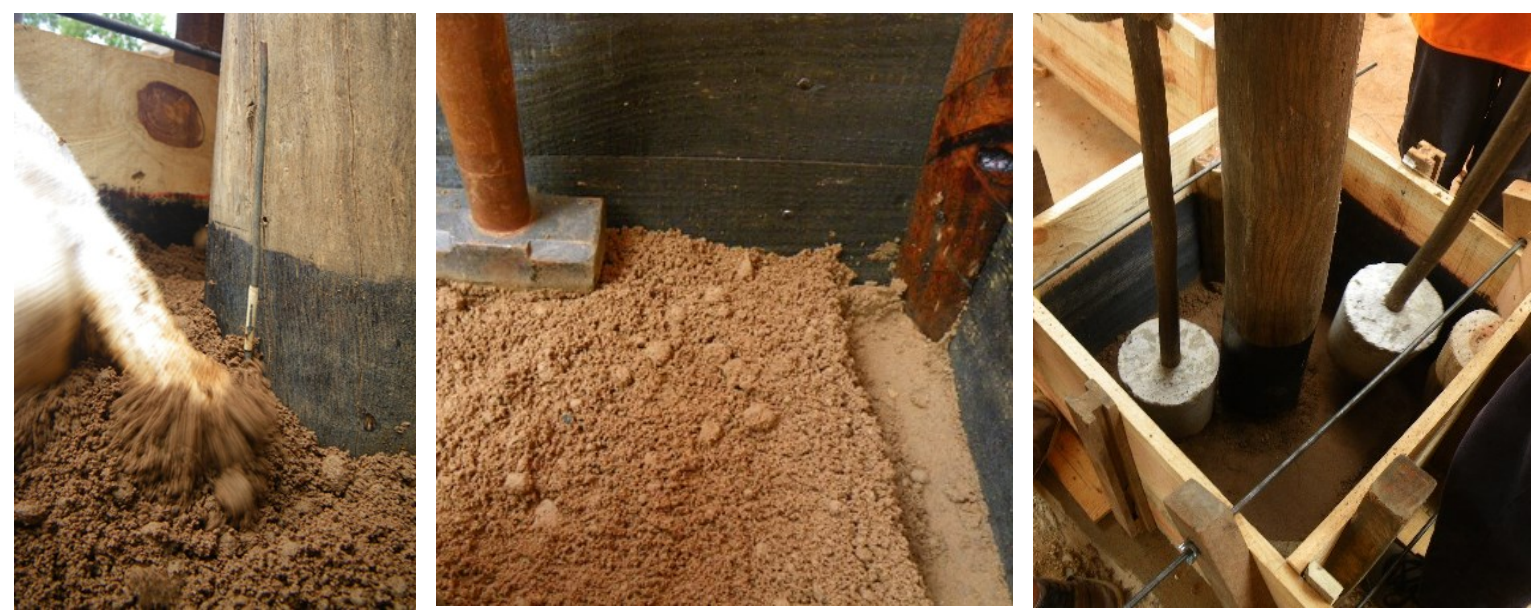

Fotos 233, 234 e 235 - A terra era disposta homogeneamente dentro das fôrmas em camadas de $10 \mathrm{~cm}$ de altura. Em seguida, o apiloamento era realizado primeiramente pelos cantos das mesmas, em direção ao centro. Diferentes pilões foram produzidos e utilizados nesta etapa dos trabalhos.
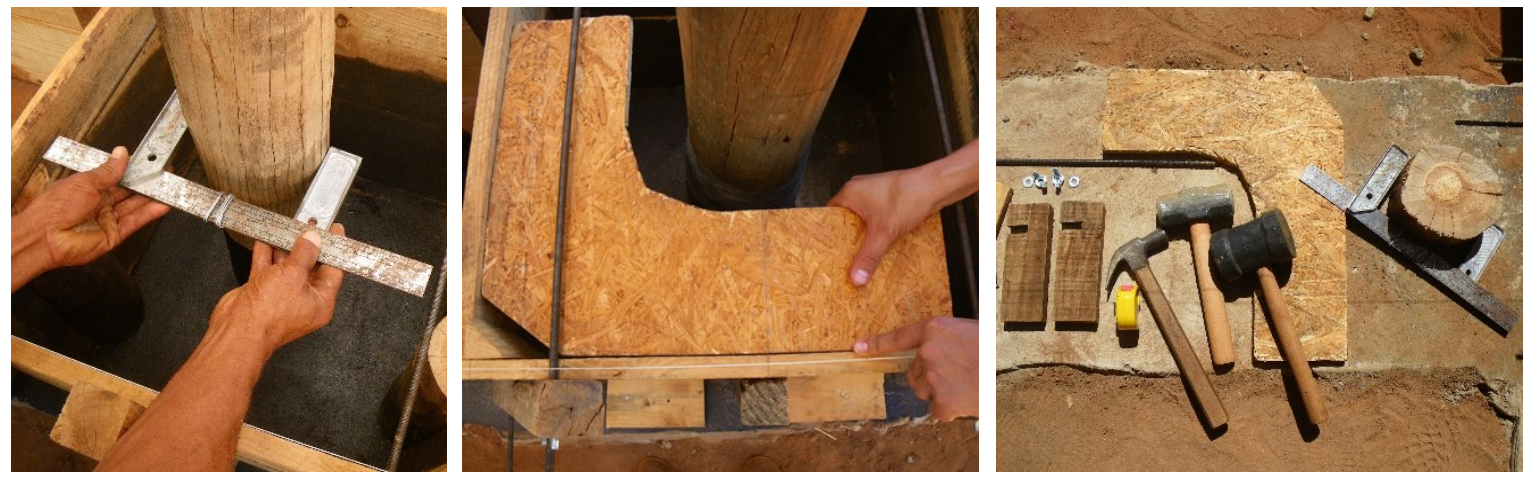

Fotos 236, 237 e 238 - Algumas ferramentas e instrumentos utilizados nos processos de trabalho foram adaptadas ou criadas no canteiro, as vezes no próprio momento. A disposição de madeiras de diferentes tipos nos abriu as possibilidades de adaptação aos imprevistos do Canteiro-Escola. 

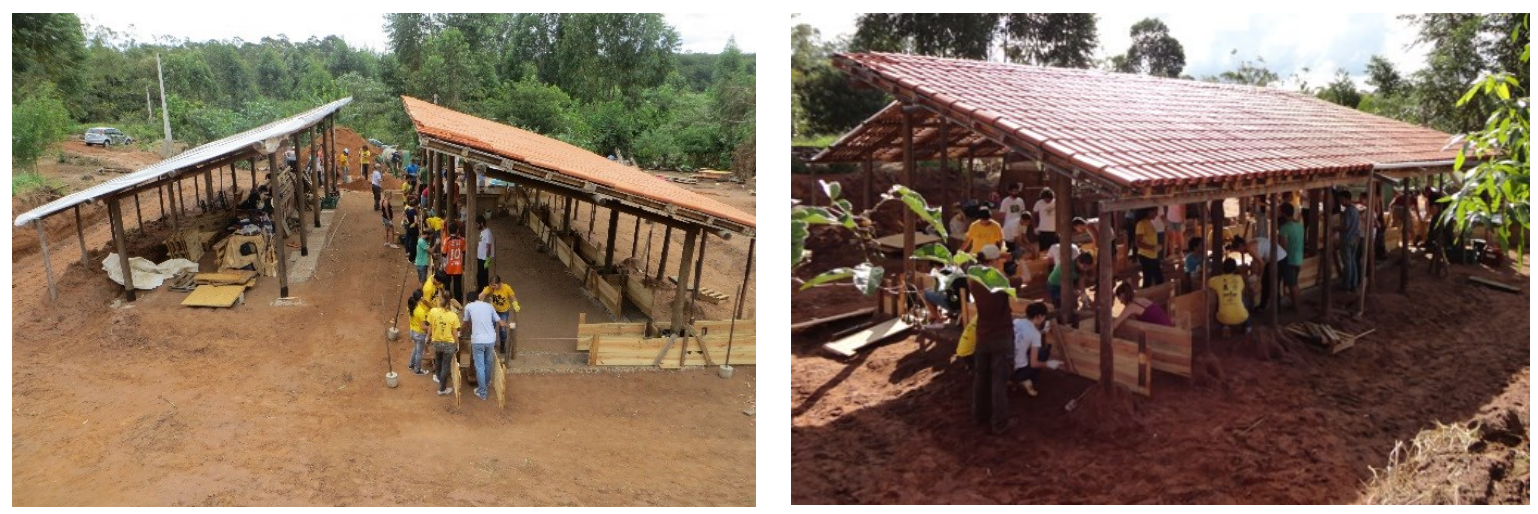

Fotos 239 e 240 - Como os participantes estavam divididos em duas turmas, uma em cada dia, um final de semana foi suficiente para realizar o primeiro bloco da casa. Assim, as bases em taipa de pilão que envolvem os 20 pilares da casa foram feitas em dois finais de semana de atividades.
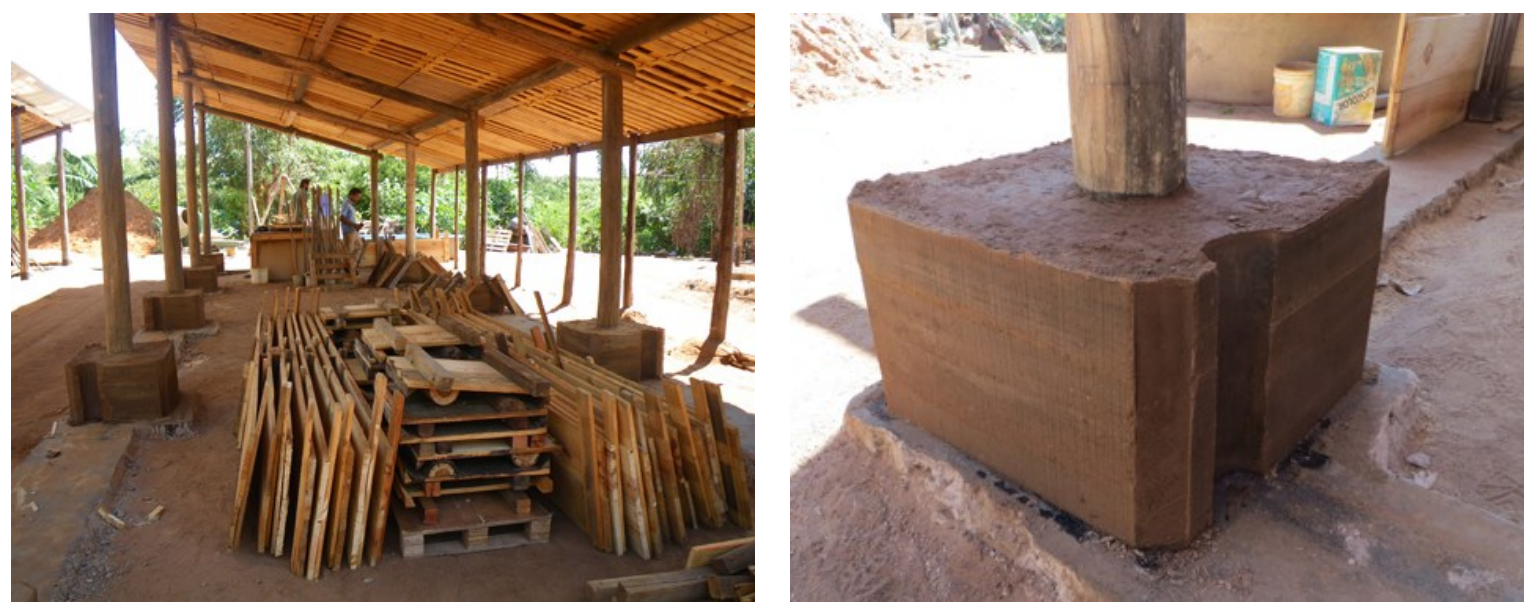

Fotos 241 e 242 - As fôrmas foram retiradas e as taipas apresentaram um bom resultado, com os encaixes de conexão macho-fêmeas realizados, necessitando secar para se observar os processos de retração dos blocos e eventual movimentação dos pilares de eucaliptos.
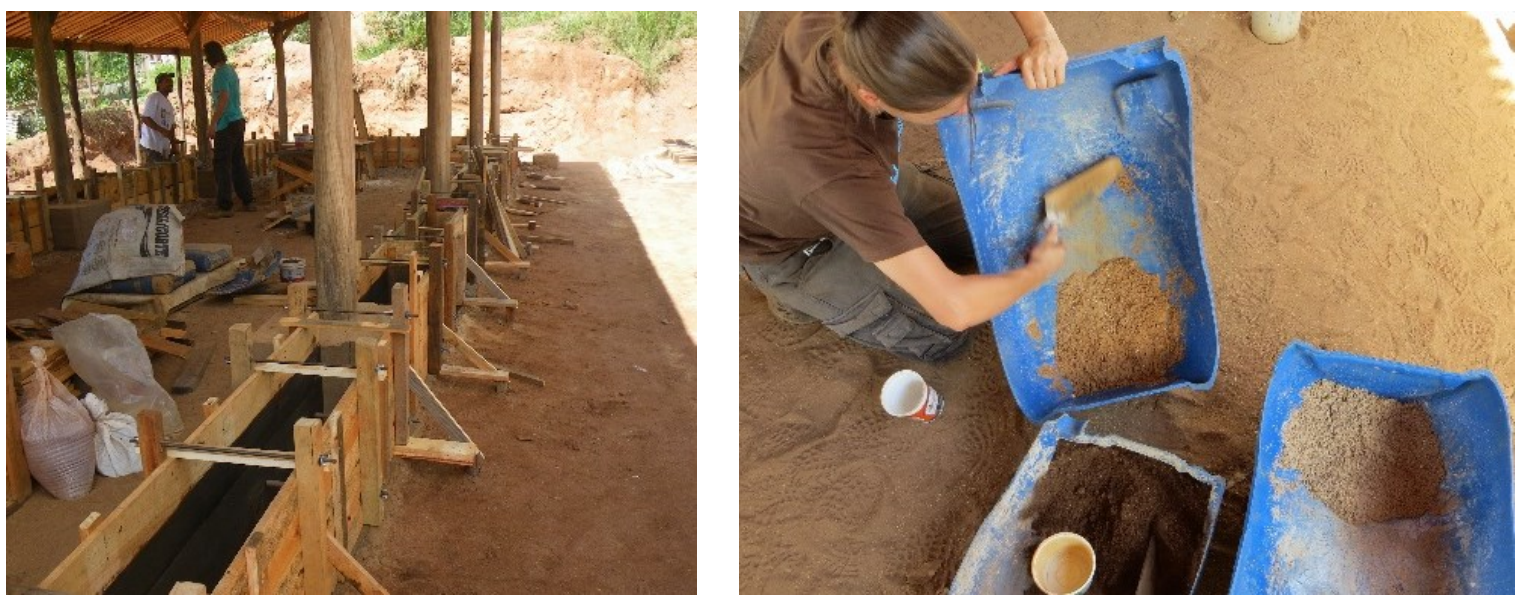

Fotos 243 e 244 - As fôrmas foram desmontadas e refeitas como fôrmas para as bases das paredes, agora com $30 \mathrm{~cm}$ de largura, alinhadas pelo lado externo dos pilares e ligando-os entre si. Para esta etapa, foi escolhido adicionar terras com diferentes cores, formando desenhos diferenciados para cada parede. 

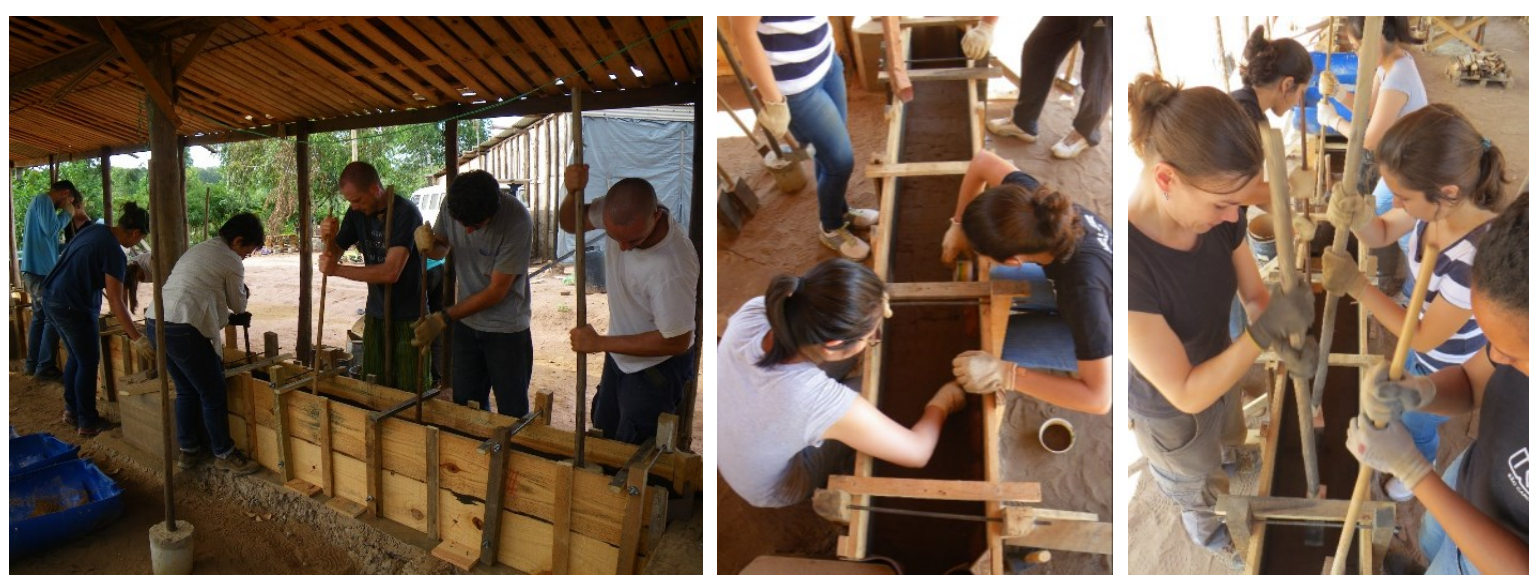

Fotos 245, 246 e 247 - Os grupos se formavam de maneira diferente a cada nova atividade. A cooperação e solidariedade foram práticas de trabalho experimentadas de maneira constante ao longo do curso. As conversas eram permeadas por debates teóricos, técnicos e pela descontração entre os participantes. Nessa força de trabalho social e coletiva as atividades avançavam rapidamente e os aprendizados aconteciam naturalmente pelas práticas e através dos diálogos.
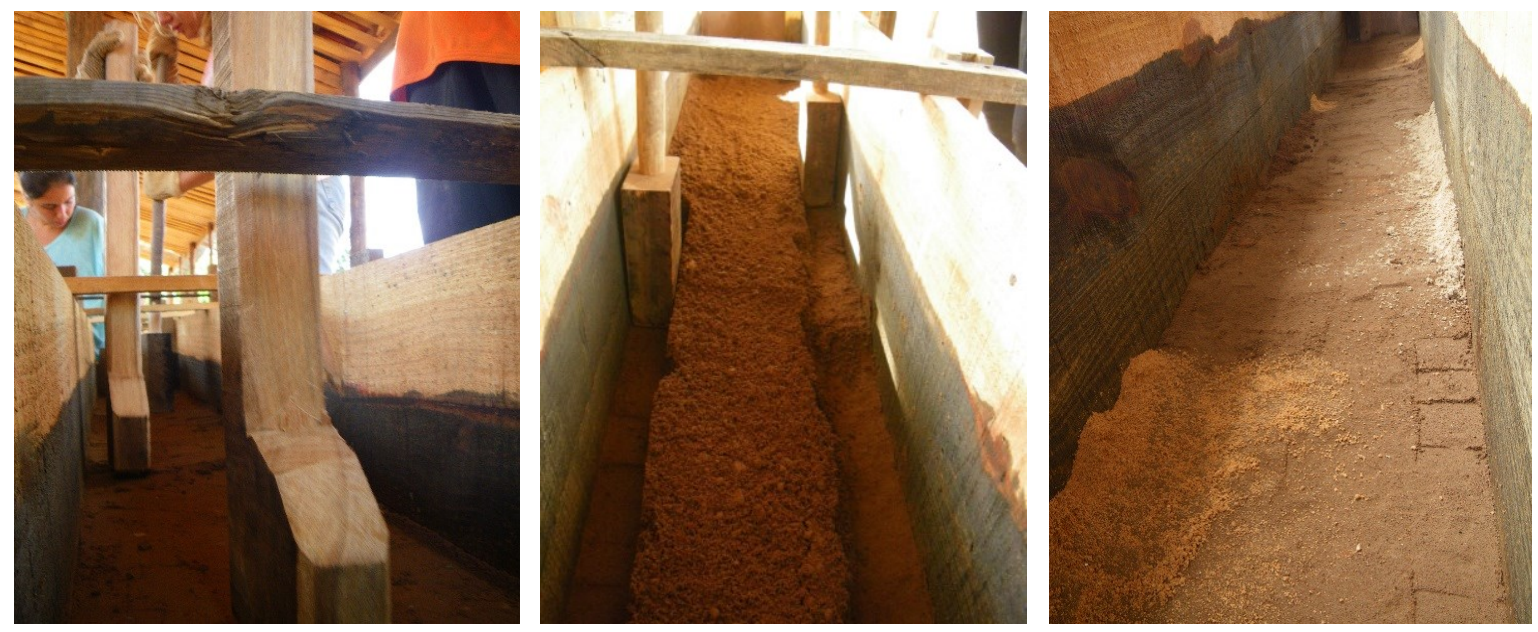

Fotos 248, 249 e 250 - O processo de produção das taipas das bases das paredes foi semelhante ao processo das bases dos pilares. As mudanças ocorridas foram a introdução de novos pilões para o trabalho de apiloamento das misturas e de terras coloridas na criação do embelezamento das taipas.

Neste momento do curso, foi organizada a vinda de dois arquitetos que possuem uma empresa especializada em construções em taipa de pilão, e que trouxeram seu equipamento de compactação pneumática para contribuir e participar das atividades do Canteiro-Escola. Com a compactação mecânica, os participantes puderam comparar as duas técnicas de realização da taipa de pilão, verificar o tempo de compactação, esforço utilizado, material consumido, organização do trabalho, entre outras questões. 

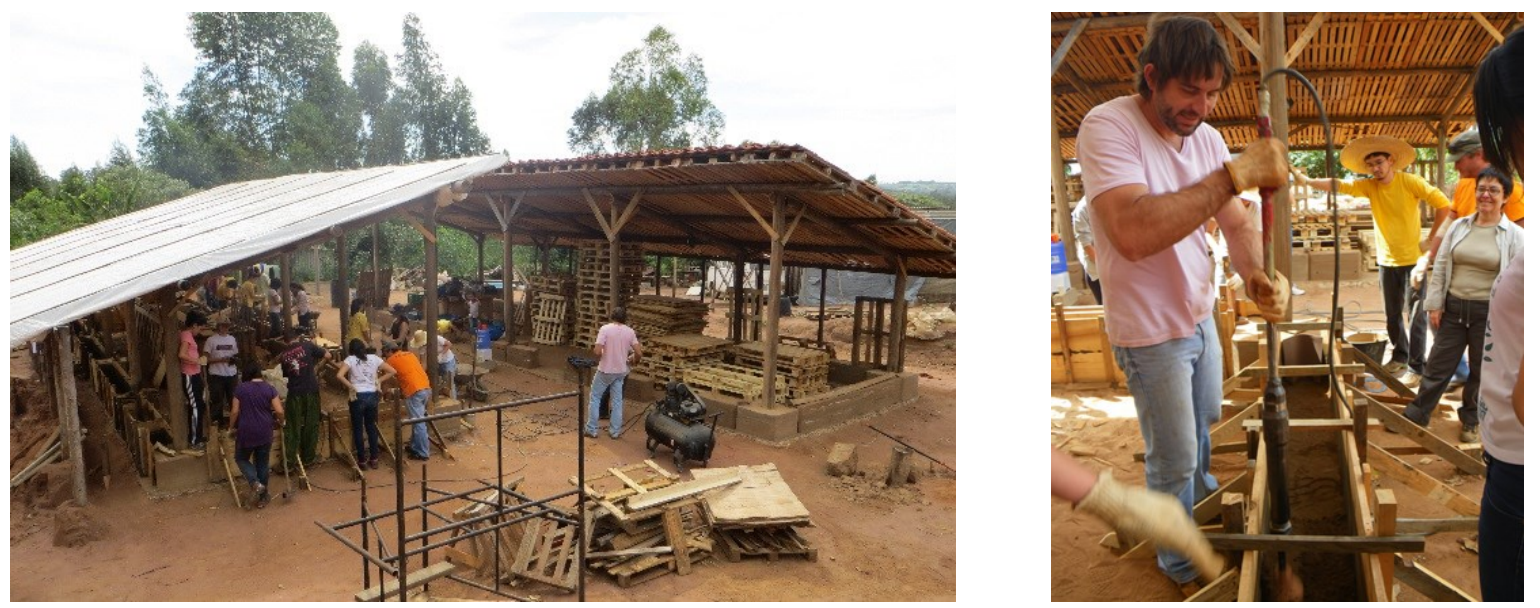

Fotos 251 e 252 - A vinda dos arquitetos que constroem com a técnica da taipa de pilão possibilitou ao grupo conhecer melhor as experiências vividas por quem trabalha neste ramo, com os desafios já encontrados, as equipes e equipamentos de trabalho, o mercado existente, entre outras questões relacionadas às arquiteturas de terra e suas técnicas construtivas.
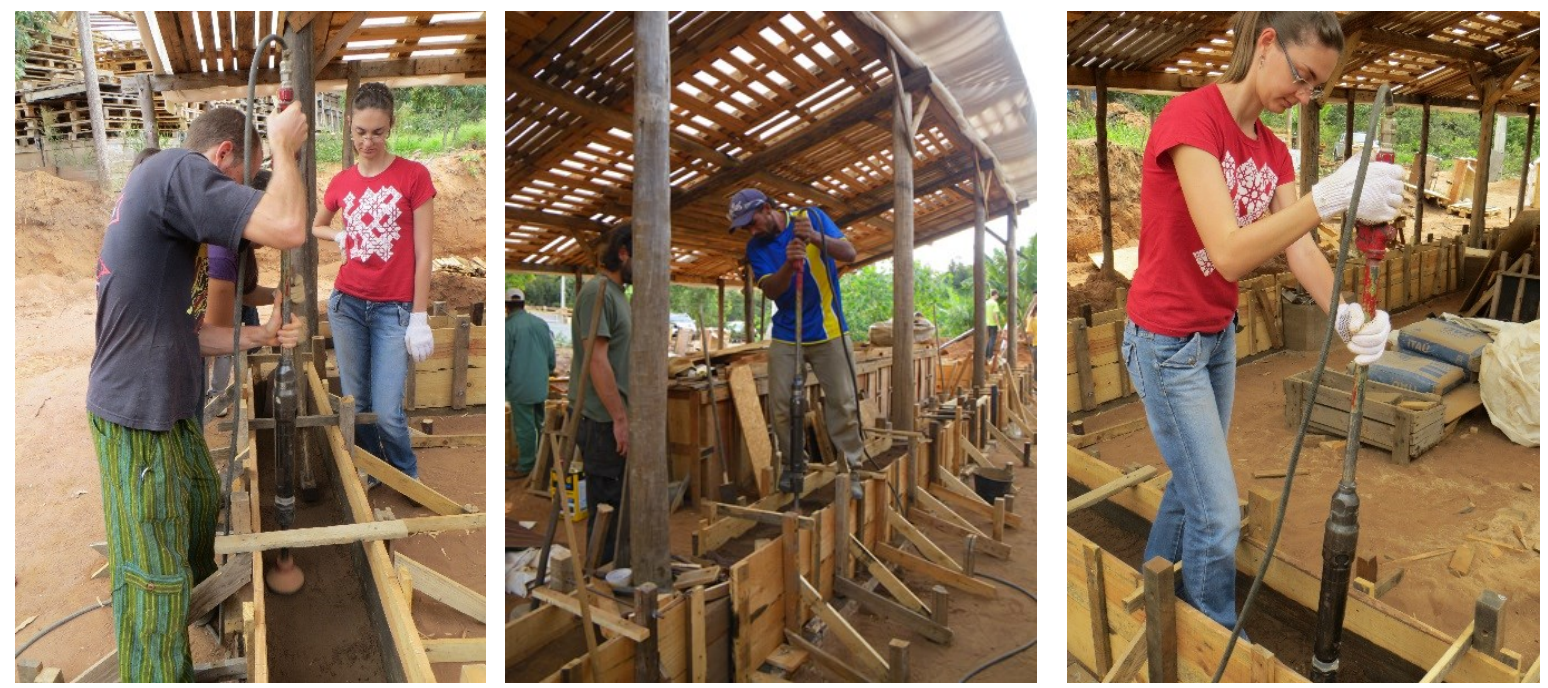

Fotos 253, 254 e 255 - O compressor de ar e o compactador pneumático foram montados e pouco a pouco os participantes foram experimentando sua utilização. Foram percebendo a força exigida e a atenção necessária para controlar a ferramenta sem se machucar. G. Silva também usou o compactador e rapidamente considerou a diferença de tempo necessário para a realização das bases. Foi de grande importância a experimentação coletiva dos processos manuais e mecânicos de compactação da taipa de pilão, com seus entendimentos e comparações possíveis.
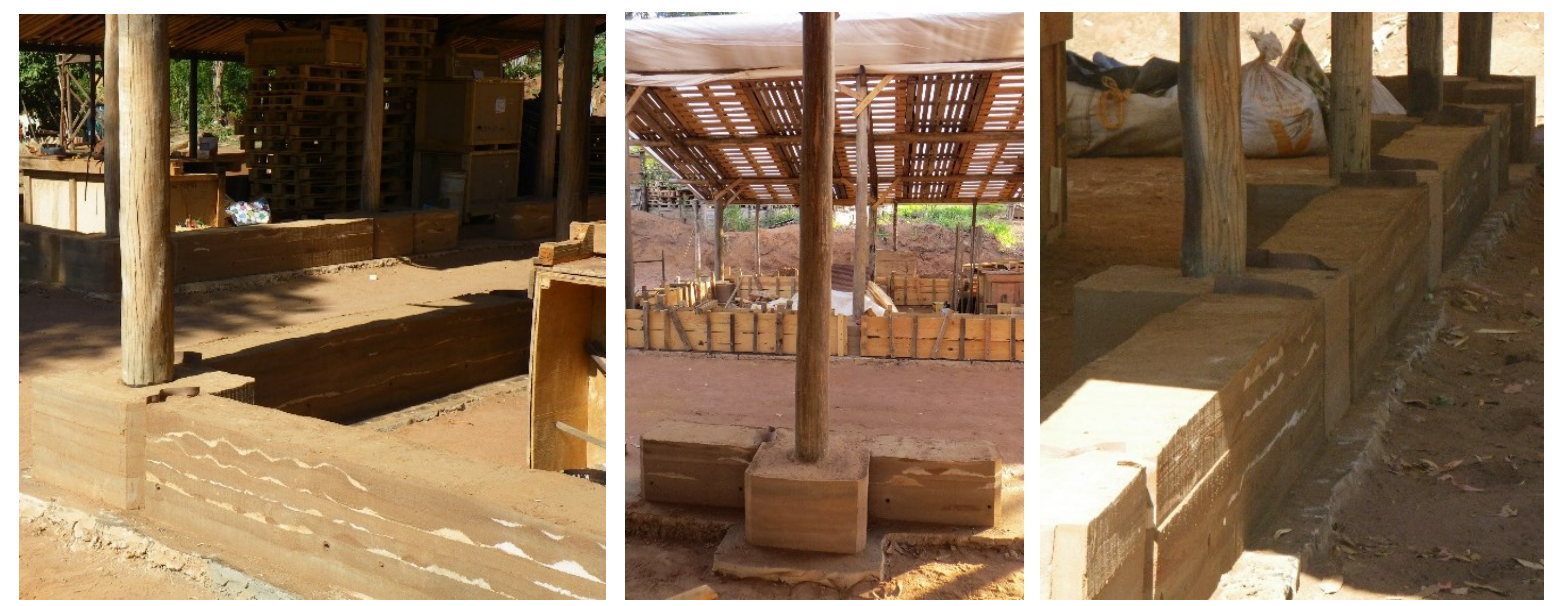

Fotos 256, 257 e 258 - As taipas foram sendo desformadas e suas formas apresentadas. A produção das taipas em módulos com os ângulos chanfrados e protegidos cria uma linguagem própria para a base da casa, onde cada trecho de parede revela uma surpresa em cores e desenhos diferentes. 

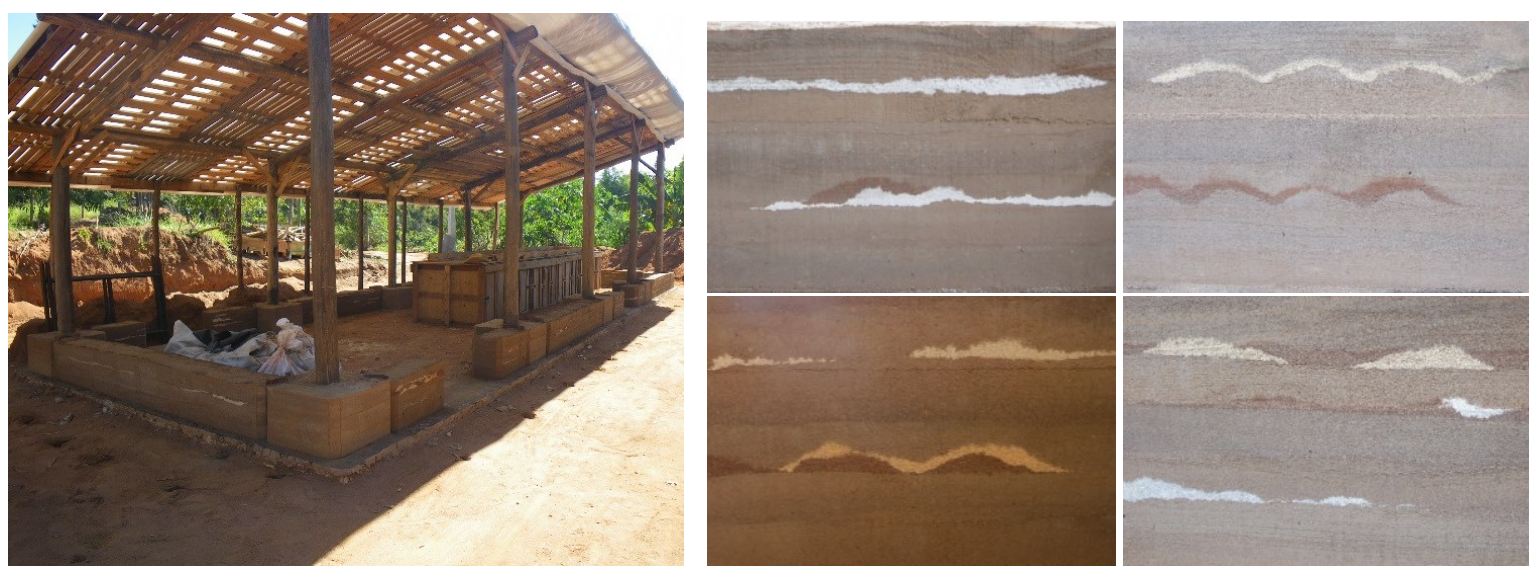

Fotos 259 e 260 - A possibilidade de criar formas diferentes, com cores e texturas diversas, buscando desenhos e detalhes particulares, mexeu com o imaginário do grupo, que a cada fôrma buscava outras misturas e disposições para as terras coloridas. A família também se motivou com o jogo de nuances, que vinha deixando suas marcas nos espaços construídos e expondo as expressões artísticas de seus taipeiros.

A preocupação estética é concebida não como uma dimensão a se acrescentar ao projeto, mas como condição intrínseca à tecnologia, incorporando ao processo produtivo a criatividade do produtor e as especificidades dos materiais.

As bases da casa em taipa de pilão estabilizada foram feitas em dez dias de atividades, sendo estas: montagens e remontagens das fôrmas, preparação das misturas de solo cimento e realização das taipas das bases dos pilares e das paredes. No final, foram preparados cerca de $14 \mathrm{~m}^{3}$ em volume de mistura ${ }^{145}$. Com relação aos participantes, a média de frequência foi de 22 pessoas por dia.
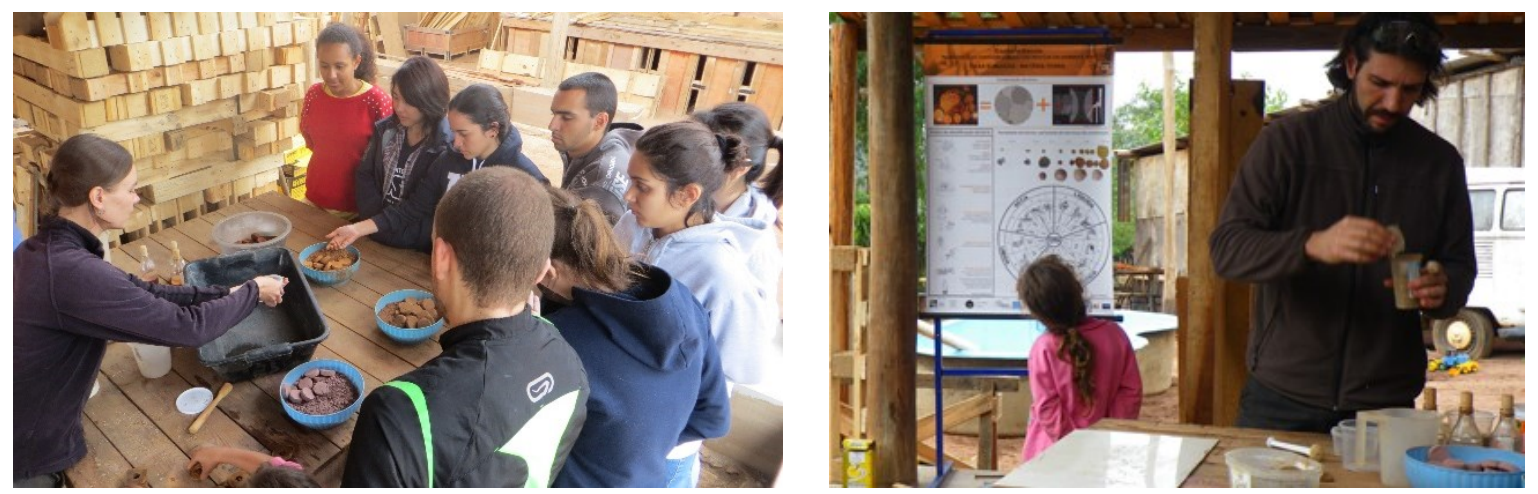

Fotos 261 e 262 - Antes do término das atividades com terra, foram realizadas duas aulas sobre suas características principais e seus usos nas construções. Através de pequenas demonstrações, diferentes terras foram apresentadas, sendo explicados princípios básicos com relação ao uso deste material.

145 Este número é uma estimativa. A princípio, o volume referente aos espaços internos das fôrmas representa cerca de $7 \mathrm{~m}^{3}$. Entretanto, quando apiloamos a mistura, estimamos que esta seja compactada em cerca de $50 \%$ de sua espessura. Isso, devido à pequena granulometria dos grãos presentes na terra. 

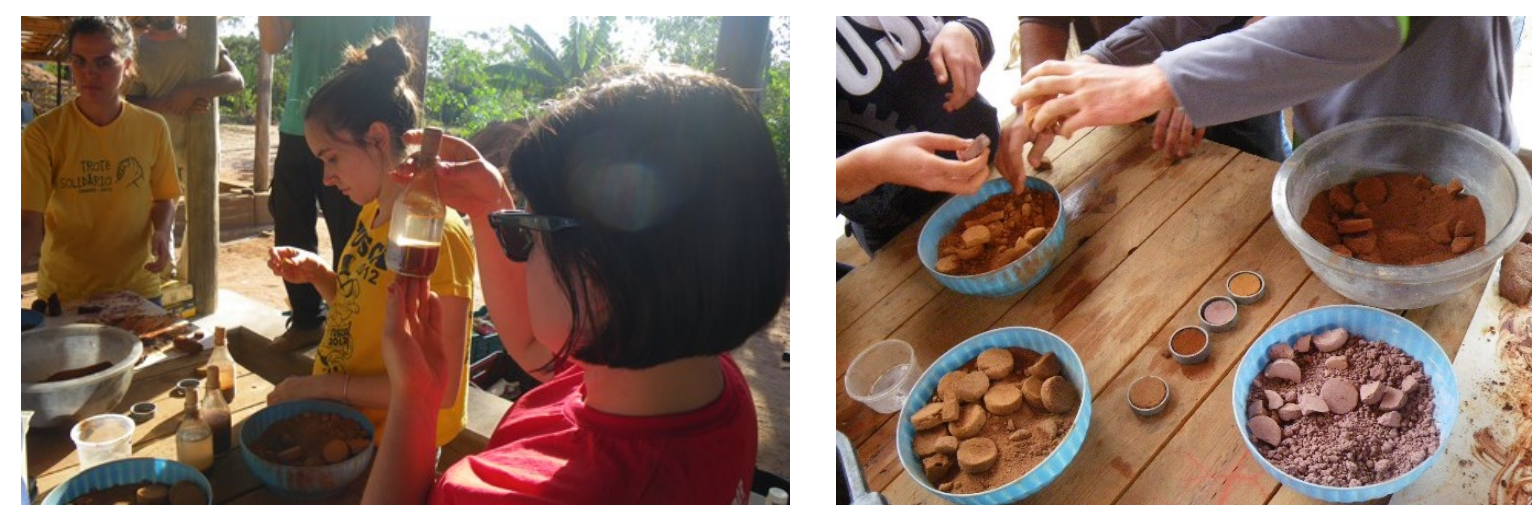

Fotos 263 e 264 - Diferentes testes foram feitos com algumas terras encontradas na região, estabelecendo comparações com a terra utilizada nas taipas. Isso permitiu complementar a compreensão empírica dos participantes com o entendimento mais teórico do material, mostrando claramente outras possibilidades de sua utilização.

Uma vez secas, as bases de taipa envolvendo os pilares do primeiro bloco apresentaram fissuras partindo do centro em direção às faces externas mais próximas. Isso ocorreu, principalmente, devido ao movimento na estrutura de eucalipto. Seu contraventamento necessitava ter sido realizado. Entretanto, as fissuras se estabilizaram e por não ser estrutural não indicavam maiores problemas para a construção.

Para o segundo bloco, contraventamentos provisórios foram fixados nos pilares, e duas alterações foram feitas no processo. A primeira, consistiu em não apiloar a terra preenchida no entorno imediato do pilar, para que esta permitisse um certo movimento dos eucaliptos, sem colocar em risco a integridade das taipas. A segunda mudança, foi o teste de envolver o pilar com uma borracha (câmara de pneu descartado), para verificar se esta amorteceria parte do movimento do pilar. Como resultado, a não compactação do centro dos pilares minimizou o aparecimento das fissuras, e o teste com a borracha que envolvia o pilar, amorteceu completamente a transferência dos movimentos da madeira para a terra, não originando nenhuma fissura. 

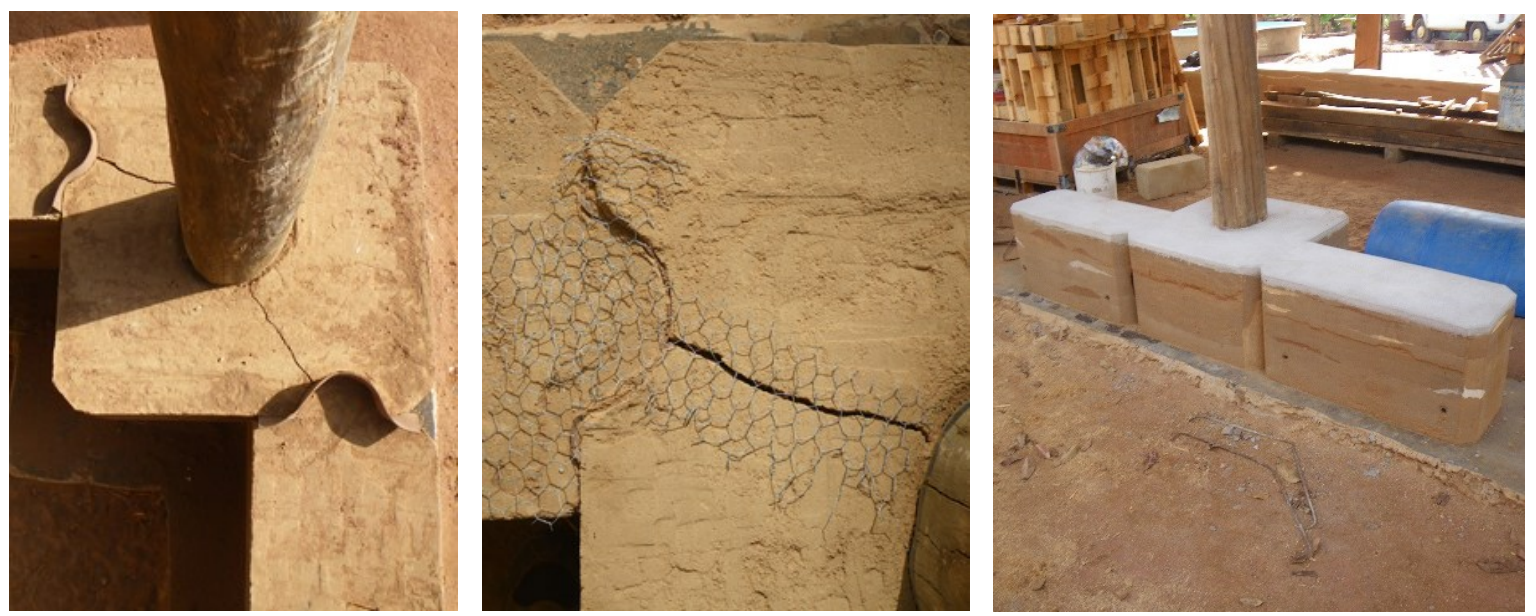

Fotos 265, 266 e 267 - Com o intuito de evitar que as fissuras passassem das bases dos pilares para as bases das paredes, foram dispostas borrachas do tipo EVA nos encaixes "macho-fêmeas". O resultado foi positivo pois nenhuma fissura atravessou para as bases das paredes. Por cima das fissuras existentes, foram colocadas telas de arame que serviram como armação para a fina camada superior de nivelamento, realizada em cimento e areia, ao longo de todo o perímetro das bases de taipa. 0 intuito foi o mesmo: evitar a transferência do movimento através das fissuras.
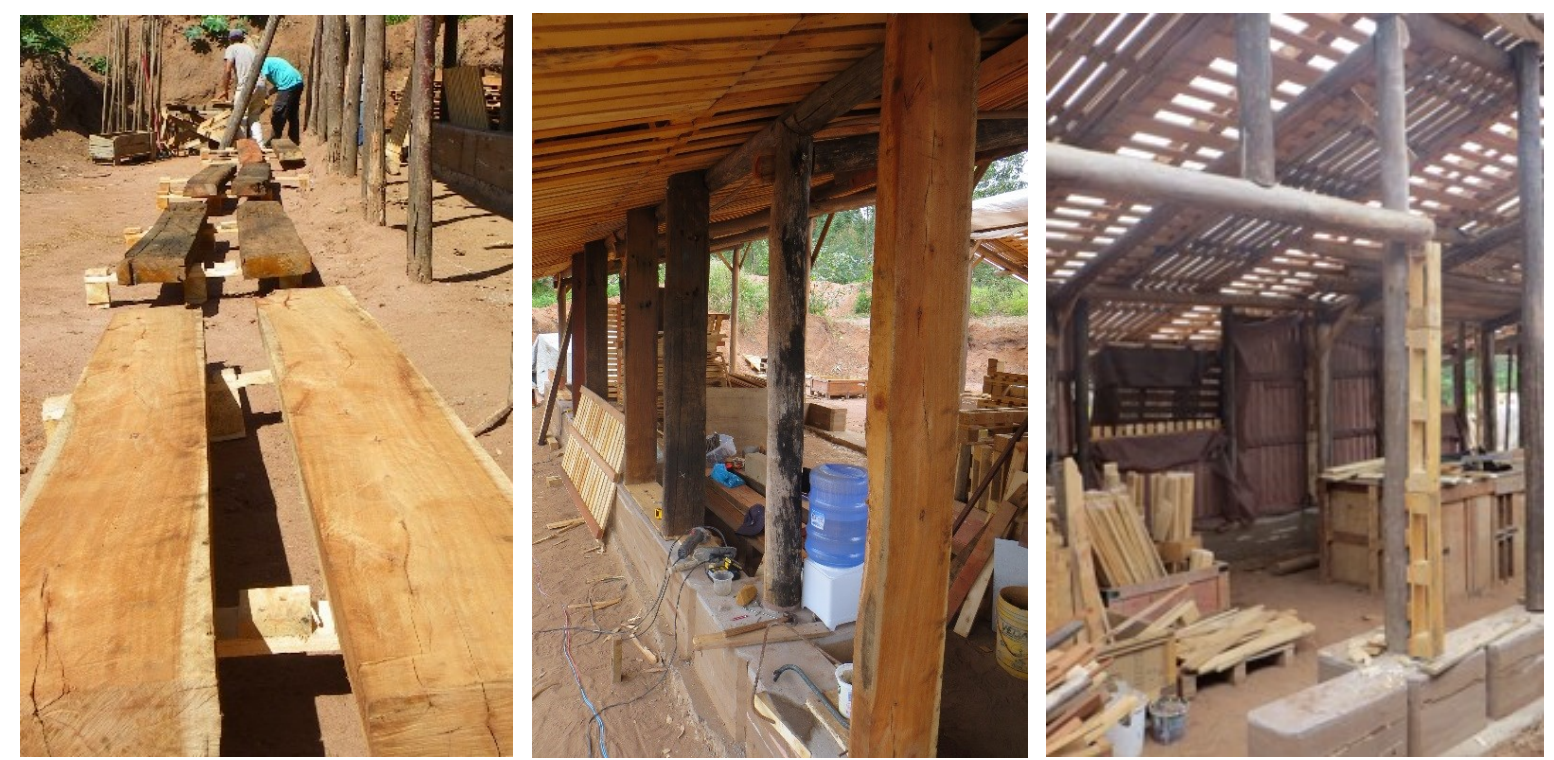

Fotos 268, 269 e 270 - Uma vez finalizadas as taipas de pilão, os trabalhos com terra foram substituídos pelos trabalhos com madeira. A primeira ação foi iniciar a instalação dos batentes das portas e janelas, assim como as estruturas verticais secundárias, necessárias para estruturar os painéis de fachada em paletes. Os batentes foram feitos a partir de dormentes de trilhos férreos, abertos ao meio e fixados junto às taipas de pilão. A estrutura secundária, interna aos painéis de paletes, foi feita com toras de eucaliptos roliços.

Para a realização das fachadas, o interesse desde o início das atividades no lote familiar, convergia para produção de painéis a partir dos paletes disponíveis. Assim, foram criados os diferentes sistemas ao longo do curso optativo. Com o tempo, fomos desenvolvendo reflexões e debates sobre a viabilidade do processo coletivo de pré- 
fabricação dos painéis em paletes, e questionando de maneira mais decisiva os resultados que esperávamos como produto final.

Uma das dificuldades encontradas era a diversidade de paletes doados e a impossibilidade de escolha dos tipos e quantidades que chegavam ao canteiro. Desta maneira, pensar numa modulação anterior à chegada e classificação dos paletes não era a melhor estratégia. $O$ projeto inicial da casa Suindara contava com os três tipos de painéis desenvolvidos durante o curso optativo. Entretanto, em função da variedade de paletes disponíveis, não foi possível reunir a quantidade necessária de peças similares para a produção dos painéis. Assim, os sistemas de painéis foram sendo modificados.

Uma proposta levantada foi fixar os paletes inteiros, lado a lado ao longo das bases de taipa, estruturando vigas horizontais intermediárias de eucalipto, que serviriam como ponto de fixação para os paletes. Mais uma vez a diversidade dos paletes dificultava a tarefa, pois teríamos que fixá-los um de cada vez, resolvendo individualmente a ligação com os paletes vizinhos, estendendo a duração do trabalho.

Este foi um desafio técnico interessante. O sistema construtivo, assim como para os painéis de cobertura, estava mais uma vez sendo criado, experimentado e construído no lote, com os recursos e conjunturas locais. Pensávamos no sistema, em seus materiais, nos equipamentos e ferramentas para sua construção, nas mesas de produção, no perfil dos participantes produtores e aprendizes, no tempo necessário, nos recursos devidos, entre outras questões.

Adotamos por fim, a técnica que pareceu ser a mais adequada para a situação daquele momento. Foi decidido desmontar os paletes, separar suas ripas e refazer os painéis de maneira pré-fabricada e sob medida. Estes, seriam feitos a partir do mesmo princípio técnico, variando somente os tamanhos de suas alturas e larguras. Tais painéis seriam compostos por camadas sucessivas dispostas e fixadas a partir de sua camada exterior. Assim, foi decidido adaptar a mesa de produção existente, onde seria possível produzir até três painéis de maneira simultânea, em função dos tamanhos.

A primeira camada do painel era composta por ripas pregadas de maneira espaçada aos sarrafos de madeira, transversais às ripas, formando uma espécie de 
"estrado". De seu lado externo, novas ripas eram parafusadas entre os espaços vazios das primeiras ripas, também nos sarrafos, de forma a se sobrepor ligeiramente sobre as primeiras, formando mata-juntas externas. Em seu lado interno, um tecido TNT foi grampeado em toda a superfície do estrado. Esse tecido serve para conter a terra que preenche o interior do painel, evitando que esta saia em caso de reparação das ripas externas, por exemplo.

As espessuras dos painéis, uma vez finalizados, eram dadas pelas peças que estruturam os paletes de madeira, aqui chamadas de "sanduíches", e que viram resíduos quando dos seus desmontes. Os "sanduíches" foram fixados nas faces externas dos pilares de eucaliptos da casa, recebendo então os estrados que compunham a parte também externa dos painéis. Essa espessura era preenchida com terra crua solta, com o intuito de aumentar a inércia térmica das paredes, criando assim uma camada acumuladora de energia e melhorando a qualidade das regulações térmicas e higrométricas da casa.

Nas fachadas dispostas ao sul, os painéis de paletes serão preenchidos por serragem de madeira, material abundante na região, que servirá como isolante térmico. Por não estarem expostas à incidência direta do sol, a escolha foi por isolá-las, retardando as perdas de calor da casa que se dão de maneira acentuada através destas fachadas.

Na medida em que a terra for preenchendo o interior dos painéis, telas vão sendo desenroladas e fixadas na superfície interna dos sanduíches, com o objetivo de conter a terra dentro dos painéis. São duas telas conjugadas, de arame fio 16 (geralmente utilizadas em cercas para animais) e de sombrite (utilizadas para o sombreamento de estufas), que trabalham como uma armação da superfície da parede, criando uma estrutura adequada para a aplicação dos revestimentos internos da casa.

Os revestimentos internos estão previstos para serem feitos em terra com duas camadas. A primeira, a partir de uma mistura de terra argilosa e palha, serve para realizar a aderência do revestimento nos painéis, assim como, nivelar a parede, preparando-a para a segunda camada. Esta, consiste em uma mistura menos argilosa, com uma curva granulométrica mais equilibrada, e com grãos menores de areia, servindo como 


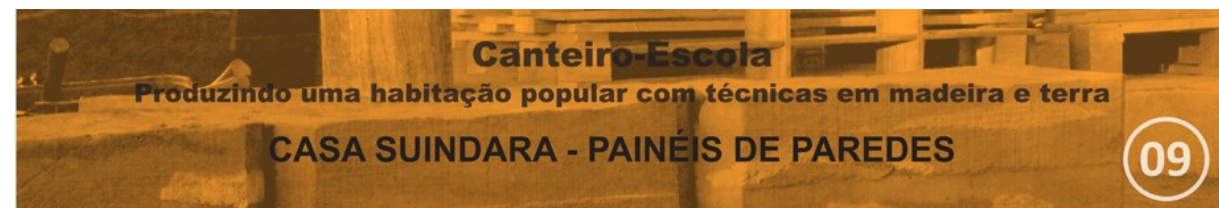

"Q
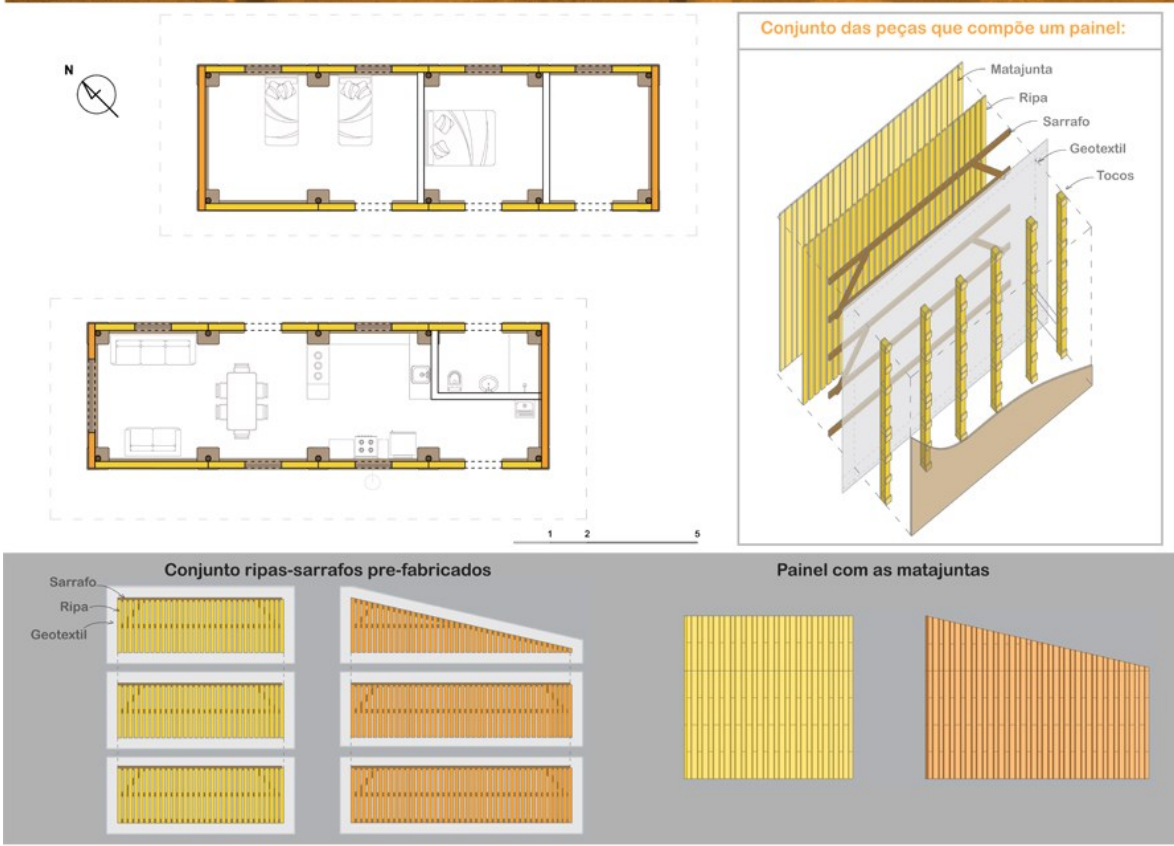

Painel com as matajuntas
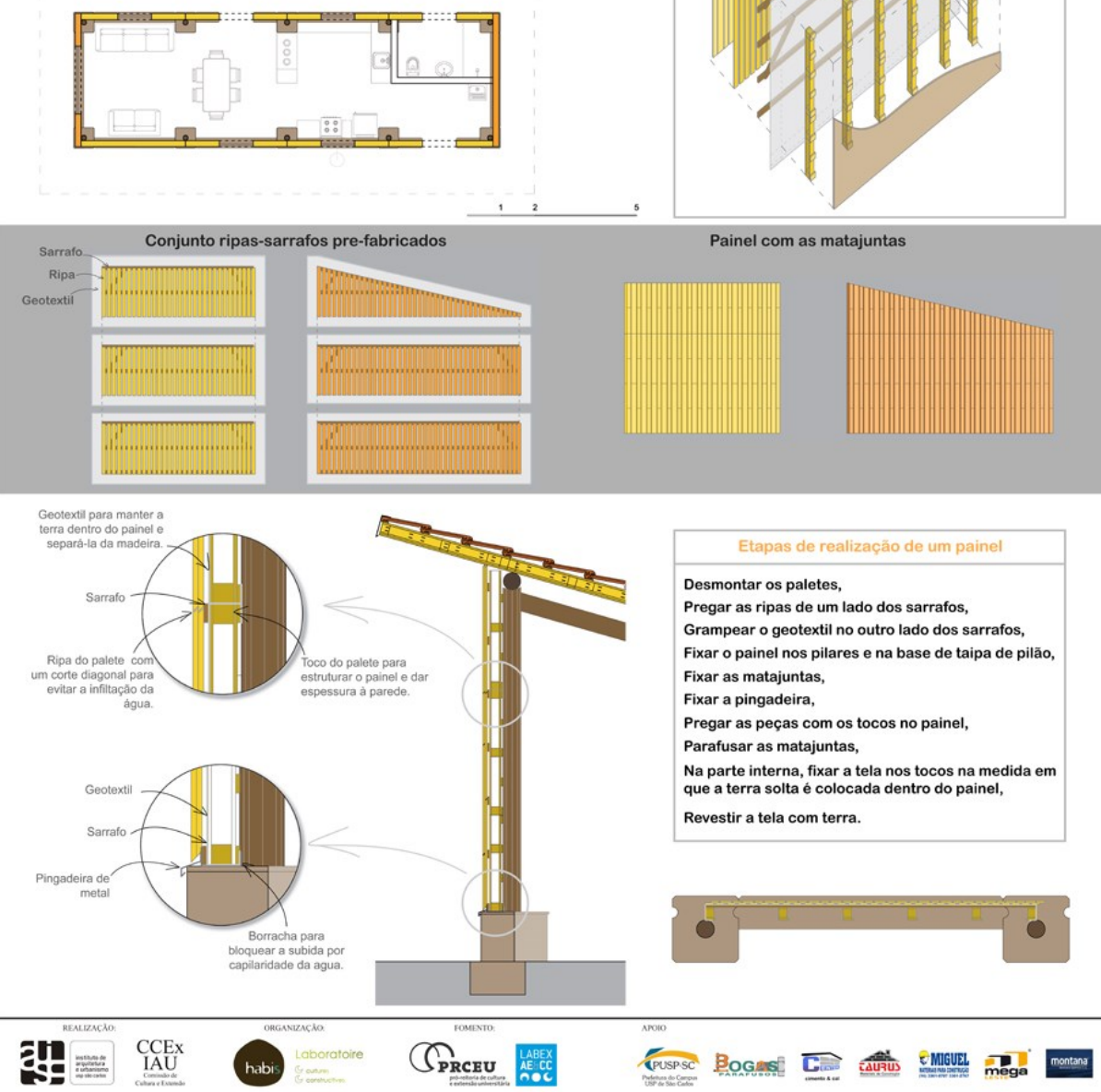

Figura 42 - O suporte pedagógico 09 foi criado como apoio para as explicações e debates referentes ao processo de produção dos painéis de parede em paletes. Estão expostas a composição das diferentes camadas sucessivas constituintes. Cortes e detalhes construtivos ilustram as montagens dos elementos e os materiais utilizados na produção dos painéis. Em média, as paredes acabam com uma espessura final entre 18 e $21 \mathrm{~cm}$. Painel: Anaïs Guéguen Perrin. 

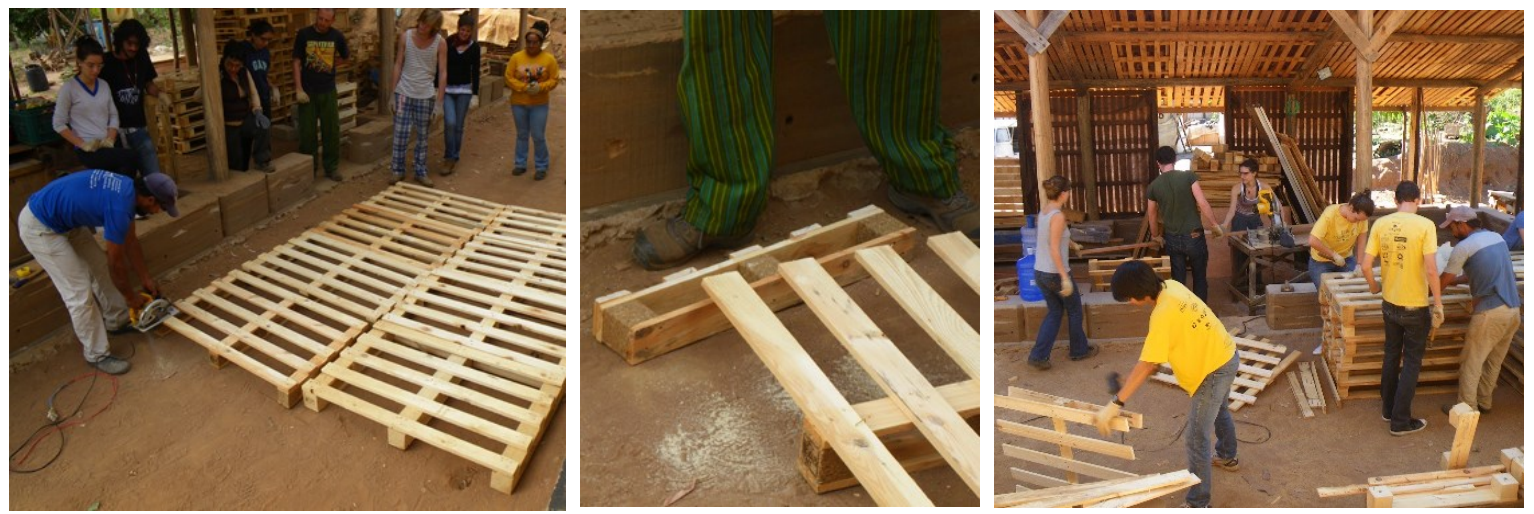

Fotos 271, 272 e 273 - Após as considerações coletivas sobre as dificuldades encontradas, durante a Oficina 2, nas desmontagens dos paletes, resolvemos facilitar o processo cortando os dois "sanduíches" estruturais de suas extremidades. Uma demonstração prática, seguida de algumas explicações técnicas e da organização dos grupos de trabalho, deram início à segunda parte da Oficina 3 , referente à produção e fixação dos painéis de paletes.
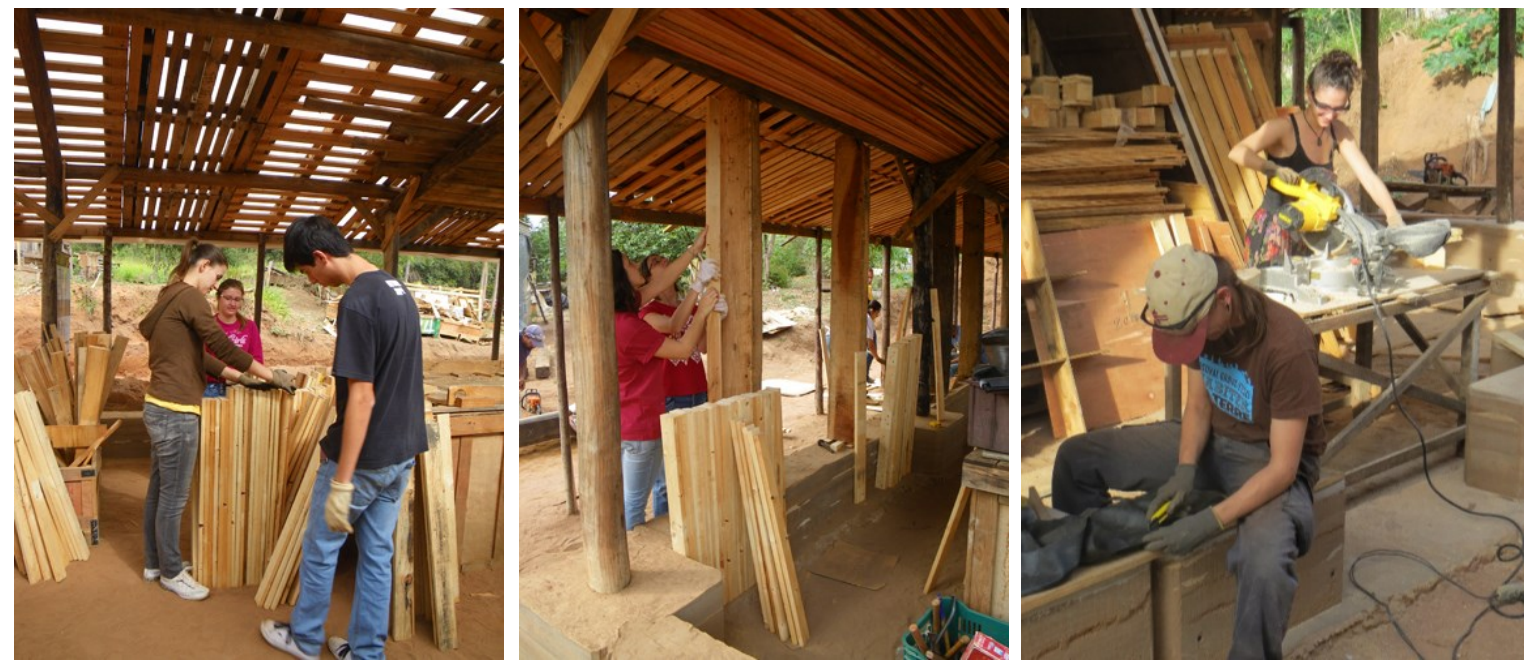

Fotos 274, 275 e 276 - As ripas dos paletes foram separadas e classificadas por tamanho. Os grupos se organizaram a partir dos vãos livres de cada painel e os participantes foram, simultaneamente, medindo seus sarrafos, separando seus jogos de ripas, verificando as dimensões dos painéis e cortando suas peças necessárias.
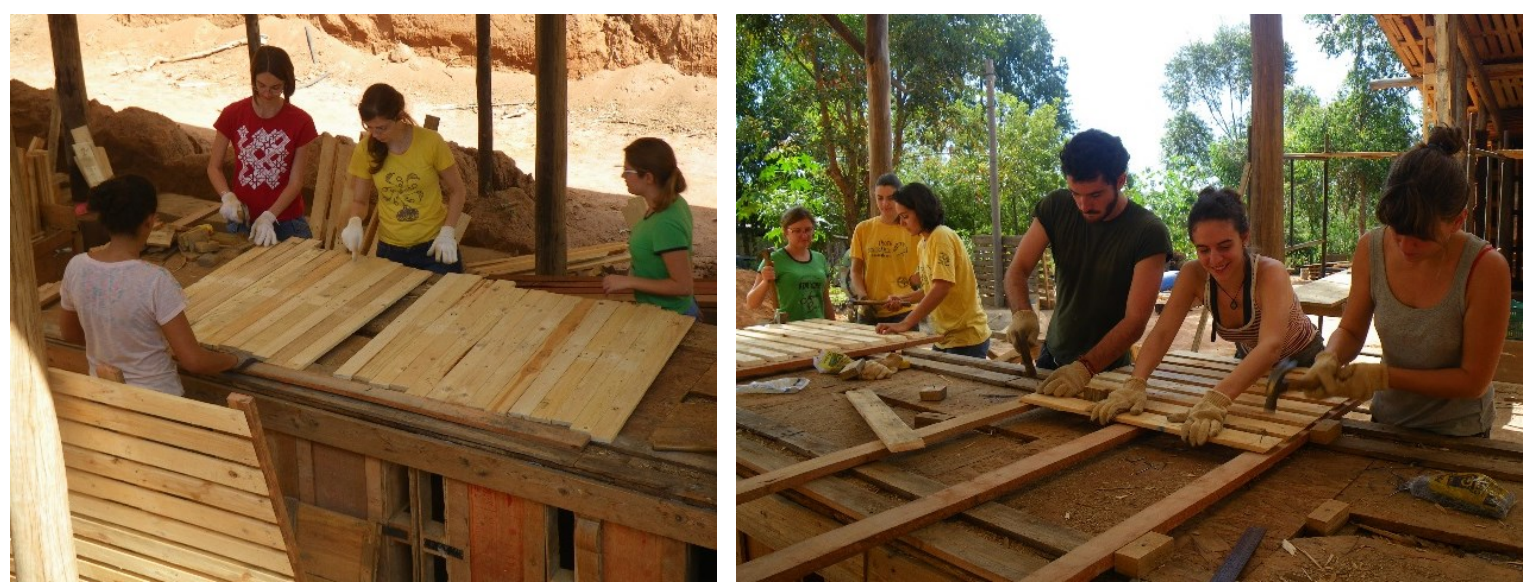

Fotos 277 e 278 - Com as ripas preparadas e dispostas na mesa de produção, os sarrafos foram alinhados e os espaçadores das ripas produzidos. As primeiras partes dos painéis, correspondentes aos estrados de madeira, começaram a ser produzidas pelos diferentes grupos. 

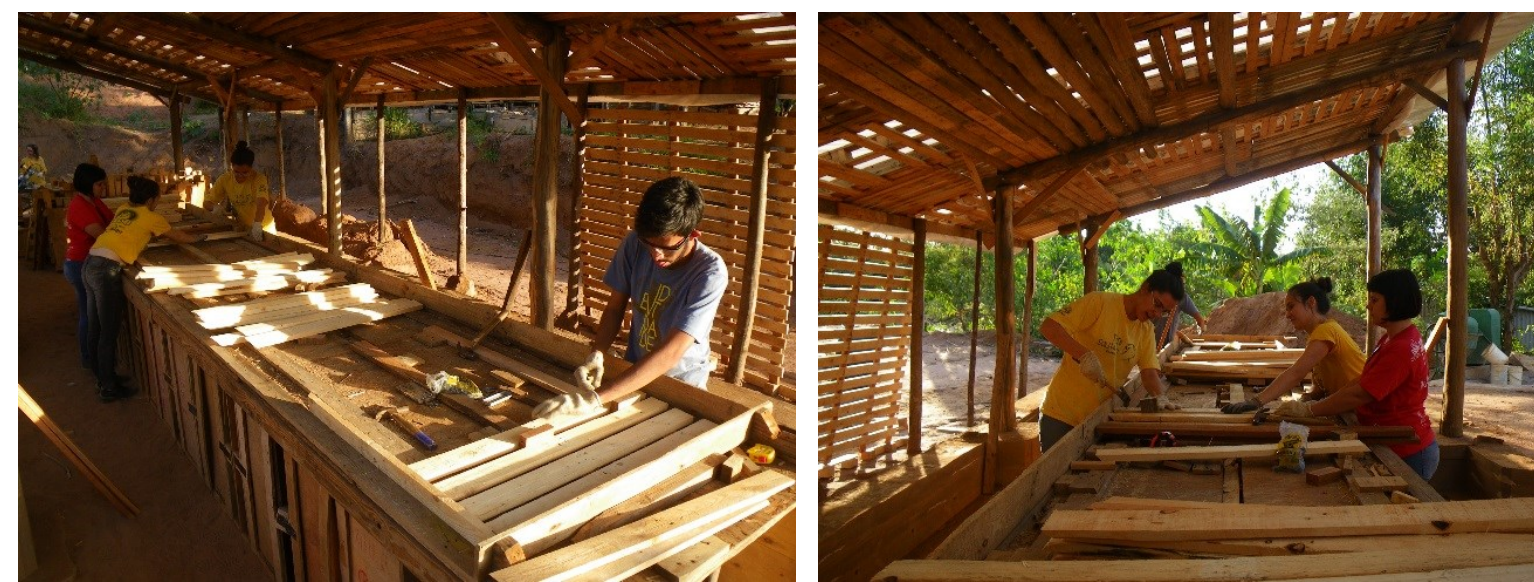

Fotos 279 e 280 - Os painéis das fachadas mais baixas mediam cerca de 2 metros de altura com as larguras variando em função das distâncias entre os pilares, da estrutura secundária e dos batentes das aberturas. Já os painéis das fachadas mais altas, possuíam uma altura com cerca de 3 metros, com larguras também variando em função das distâncias entre os pilares verticais.
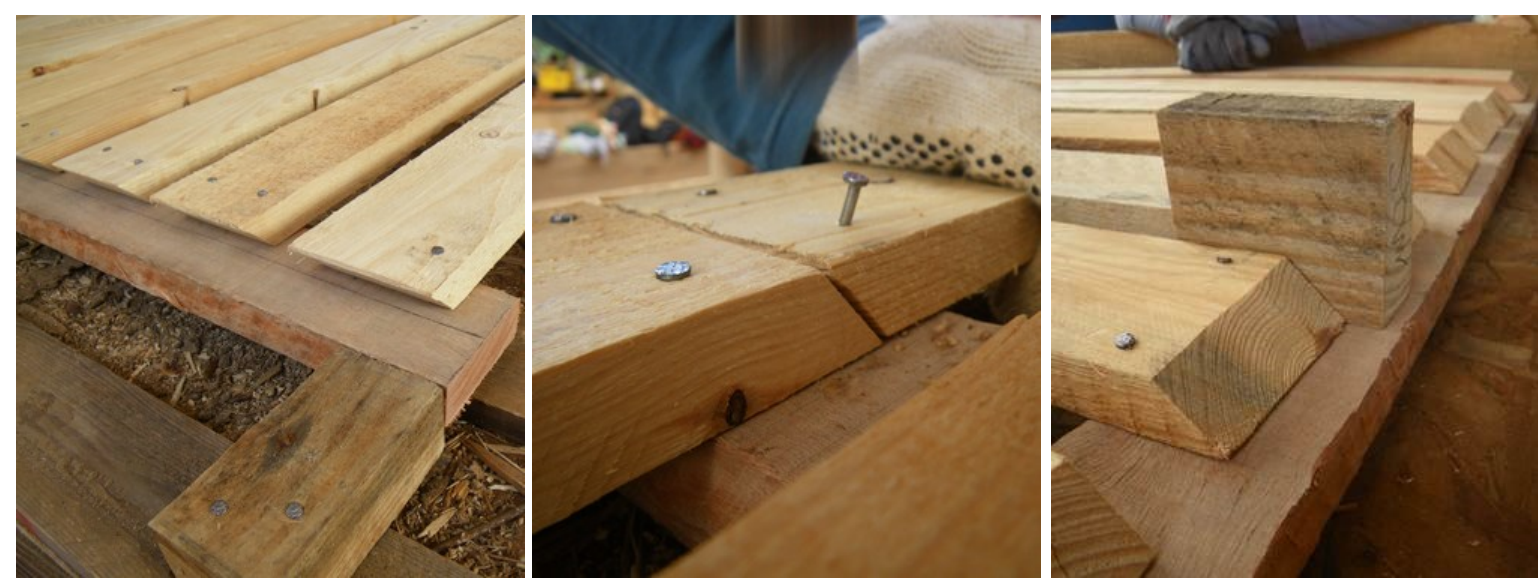

Fotos 281, 282 e 283 - As extremidades das ripas dos painéis foram cortadas em $45^{\circ}$ para uma melhor proteção das chuvas incidentes nas fachadas. Pelo mesmo motivo, as extremidades dos encontros entre duas ripas verticais, estruturadas por sarrafos de madeira, também foram cortadas. Os espaçadores marcavam $3 \mathrm{~cm}$ de separação entre as ripas dos estrados.
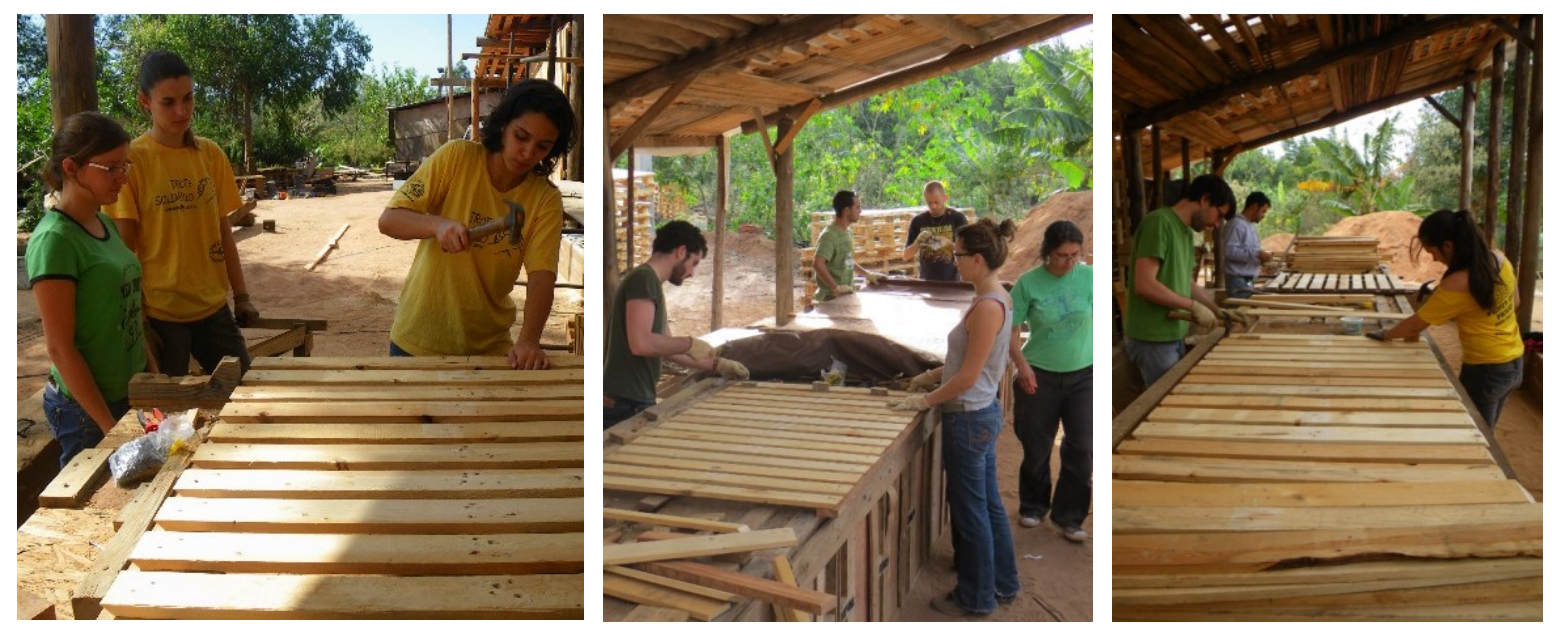

Fotos 284, 285 e 286 - Os participantes foram pouco a pouco desenvolvendo seus gestos no trabalho e aprimorando seus resultados. Os painéis iam sendo finalizados e preparados para a etapa seguinte. Antes dela, eles passaram por um tratamento contra cupins, mediante o uso de um produto industrializado, facilmente encontrado no mercado, recebido como doação. Este produto, foi igualmente aplicado na estrutura de eucalipto da casa, assim como nos painéis de cobertura instalados anteriormente. 

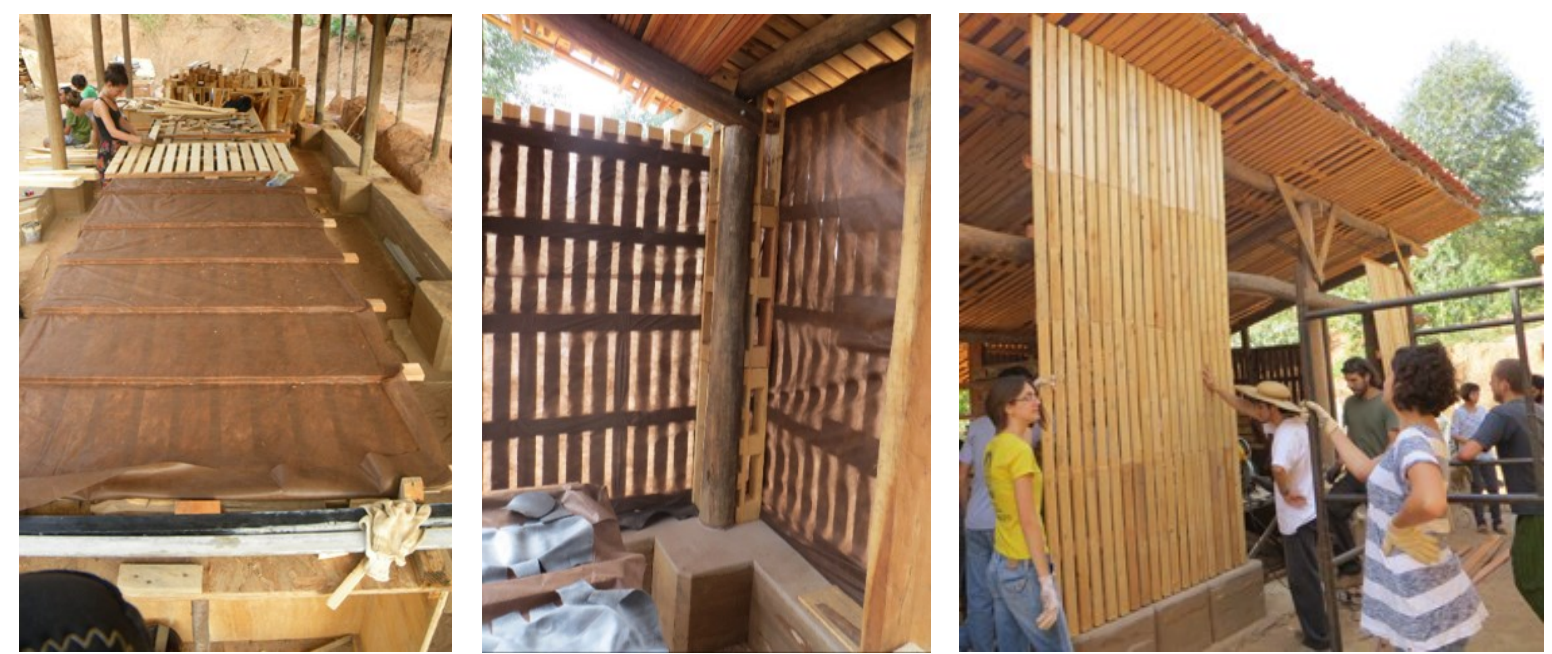

Fotos 287, 288 e 289 - A segunda etapa consistiu na fixação dos tecidos de TNT no lado interno dos painéis. Estes servem como contenção para que a terra, que será disposta no interior do painel, não saia em caso da necessidade de retirada de alguma ripa da fachada. Do mesmo modo, o tecido separa a terra do contato direto com as ripas. Na medida em que iam sendo finalizados, os painéis começavam a ser instalados nos seus devidos lugares.
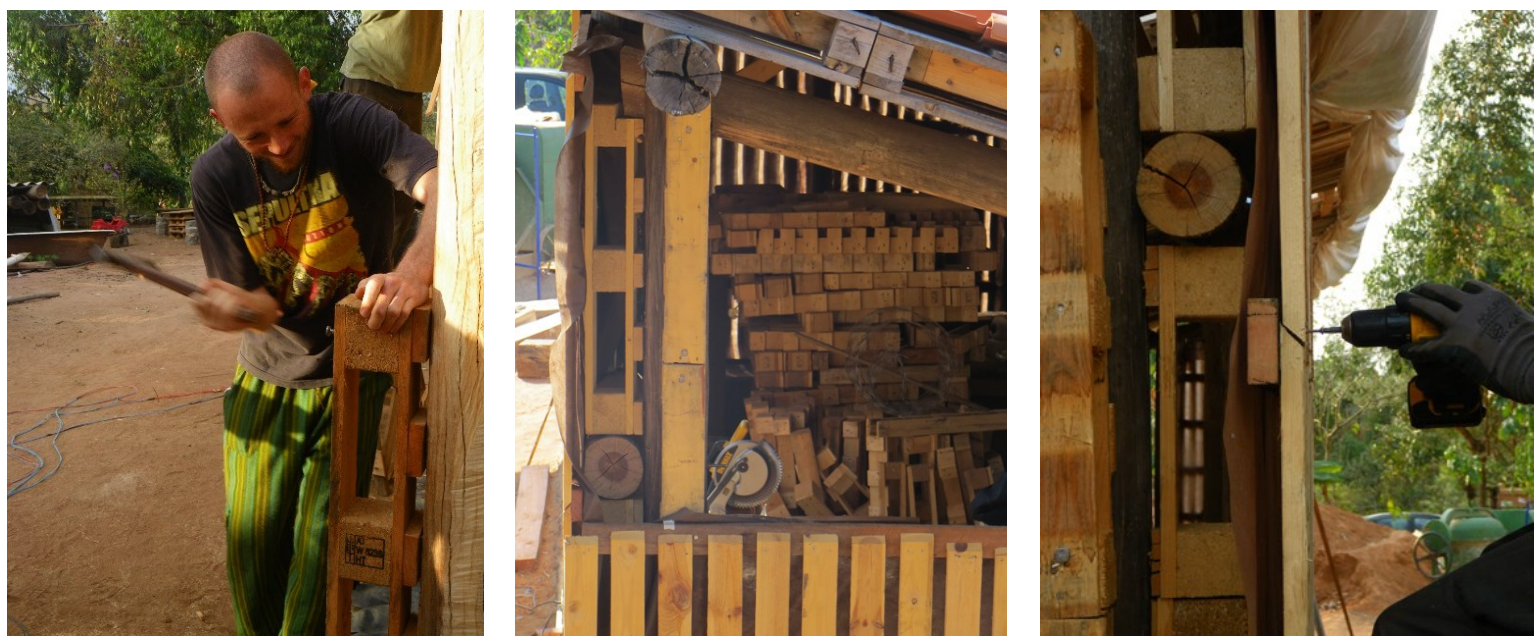

Fotos 290, 291 e 292 - Os sanduíches retirados dos paletes foram aproveitados como espaçadores e fixados nos pilares de eucaliptos da casa, servindo para dar espessura aos painéis de parede. Estes últimos, foram fixados do lado externo dos pilares, protegendo a estrutura da casa das chuvas e intempéries climáticas. Somadas as espessuras dos sarrafos, das duas ripas de mata-juntas e das duas camadas de revestimentos, a parede ficou com uma espessura final variando entre $18 \mathrm{~cm}$ e $21 \mathrm{~cm}$.
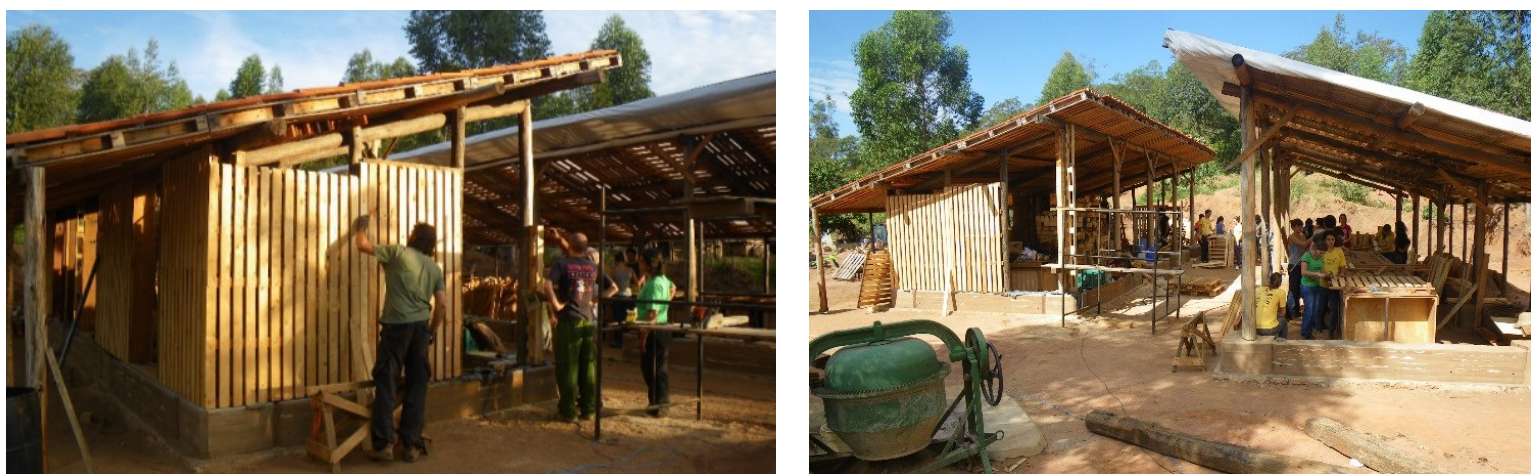

Fotos 293 e 294 - Os painéis foram parafusados nos sanduíches e na estrutura secundária da casa. Os cantos começaram a ser estudados e seu acabamento discutido. Da mesma forma, tínhamos a tarefa de pensar na pingadeira que protegeria o encontro dos painéis com as bases de taipa. 

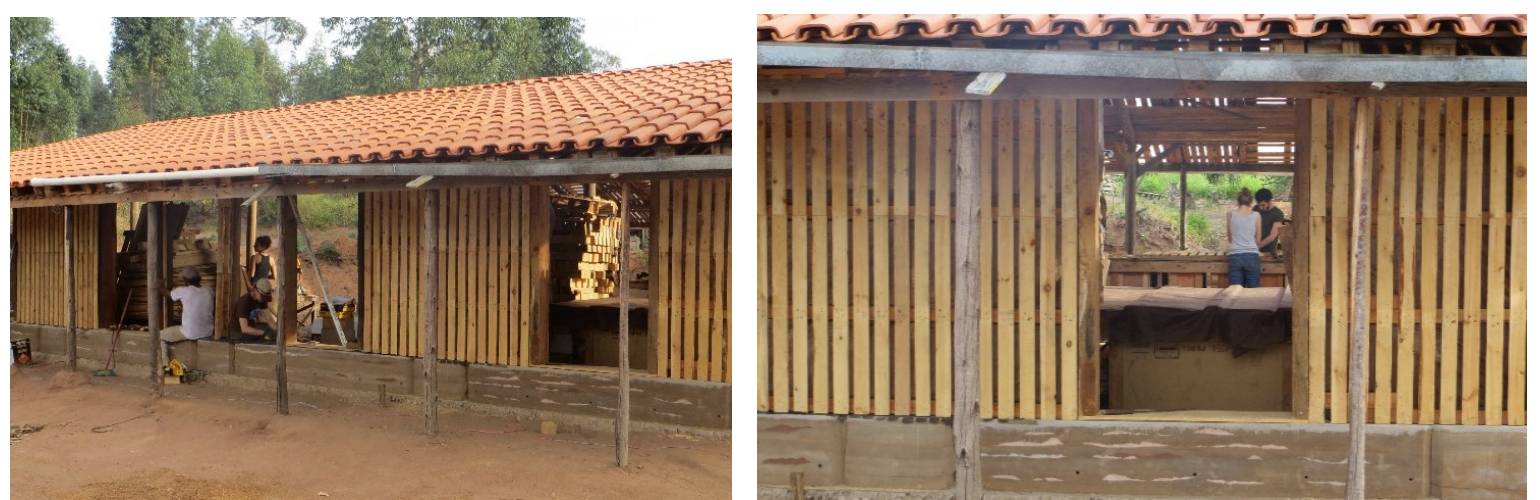

Fotos 295 e 296 - Com a fixação dos painéis, os espaços foram se configurando e a construção foi ganhando sua "cara de casa". A princípio, as janelas dos quartos mantiveram a altura dos painéis, com suas taipas servindo também como assentos.
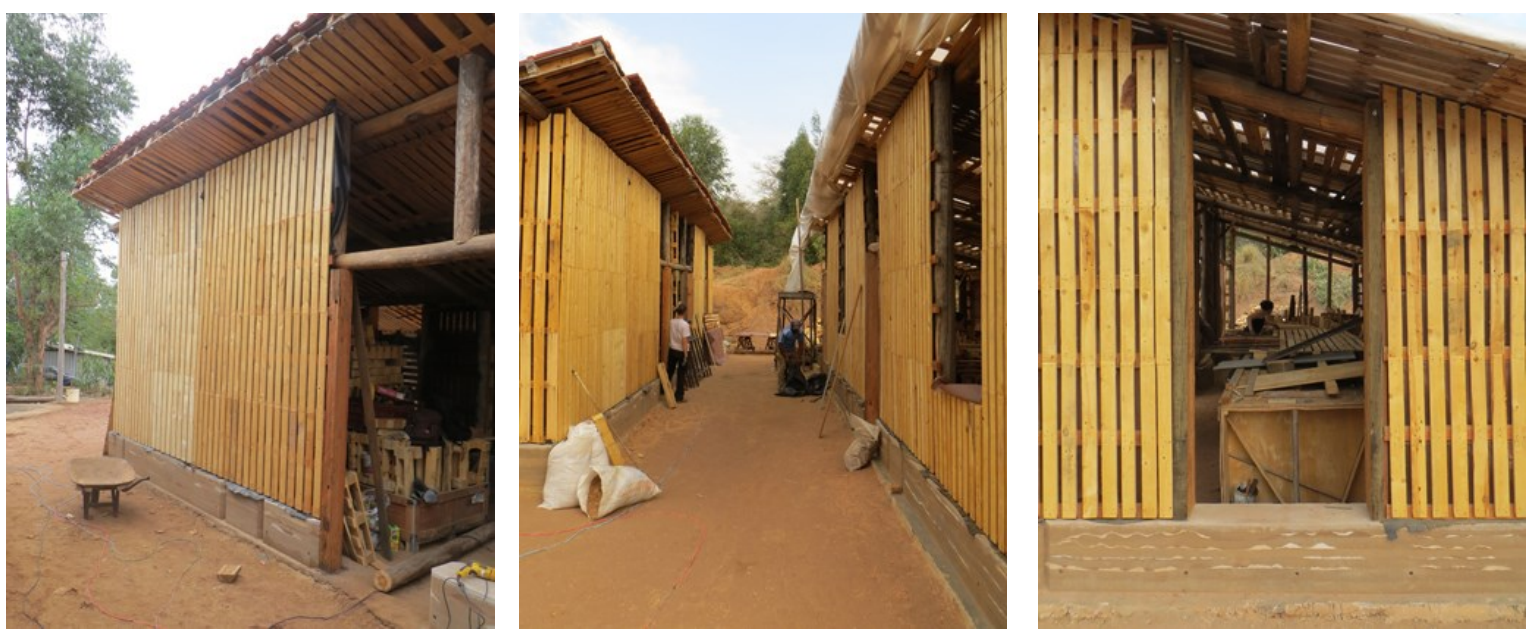

Fotos 297, 298 e 299 - Foi decidido, com a família, de deixar os espaços acima das portas livres para a instalação de futuras janelas. A cobertura central unindo os dois blocos será instalada na mesma altura, abaixo dessas aberturas, de modo que a iluminação e a ventilação sejam cruzadas.
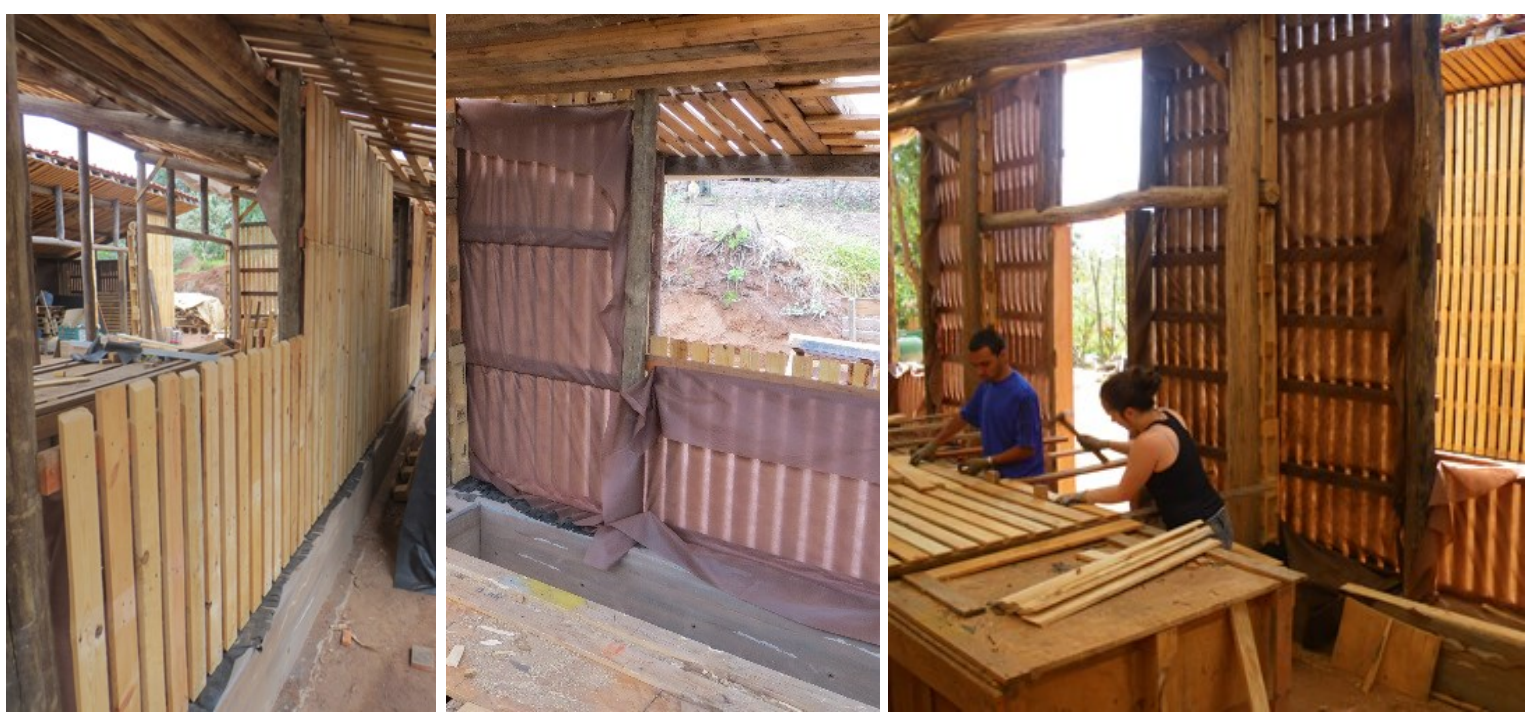

Fotos 300, 301 e 302 - O lado interno da casa fica neste momento aguardando a instalação das matajuntas externas. Somente depois serão feitos seus preenchimentos internos com terra e serragem, além dos acabamentos finais. Os tamanhos das janelas foram rediscutidos e seus painéis produzidos e instalados. 
Ao final do mês de junho, aquém de nossas expectativas, estávamos ainda no processo de produção dos painéis de parede. Os trabalhos se mostraram mais lentos do que prevíamos. Tinham que ser produzidos 36 painéis de paletes para $130,5 \mathrm{~m}^{2}$ de superfície de parede. Sendo $65,5 \mathrm{~m}^{2}$ para o bloco dos quartos (referente a 17 painéis) e $65 \mathrm{~m}^{2}$ para o outro bloco (referente a 19 deles).

Embora tenha sido possível organizar grupos com tarefas diferenciadas, o trabalho marcava seu ritmo próprio, aberto a múltiplos fatores que influenciavam sua evolução, entre eles: a diversidade das condições e características dos paletes disponibilizados, a inconstância na frequência dos participantes; a grande quantidade de painéis de paletes a produzir; o espaçamento entre os dias de atividades; o trabalho artesanal com limitado processo de pré-fabricação; o caráter diferenciado do Canteiro-Escola; o perfil amador dos participantes; o limitado conhecimento das técnicas de trabalho com paletes; entre outras questões.

Vale ressaltar que estes fatores não foram vistos de forma negativa. Pelo contrário, embora limitadores de nosso processo produtivo, foram considerados características inerentes à realidade concreta. Esta, contém as condições dialéticas presentes quando experimentamos um processo de natureza semelhante. A tarefa está em verificar as dificuldades, analisar outras possibilidades e evoluir nas práticas concretas.

Neste contexto, a Instituição de ensino concedeu a prorrogação da Oficina 3 até o final do mês de setembro de 2014, possibilitando assim, três meses a mais de atividades. Como no mês de julho ocorrem as férias acadêmicas, foi experimentado um outro calendário de curso. Ficou decidido pela fixação de cinco dias corridos de atividades no Canteiro-Escola, diferentemente dos finais de semana alternados que estávamos acostumados.

Após uma conversa com a família e o grupo sobre esta possibilidade, foram fixados mais 13 dias de atividades, sendo uma semana intensiva em julho, e quatro finais de semanas alternados durante os meses de agosto e setembro. Este seria o novo limite para terminar, ao menos, a produção e fixação dos painéis de paletes da casa. 

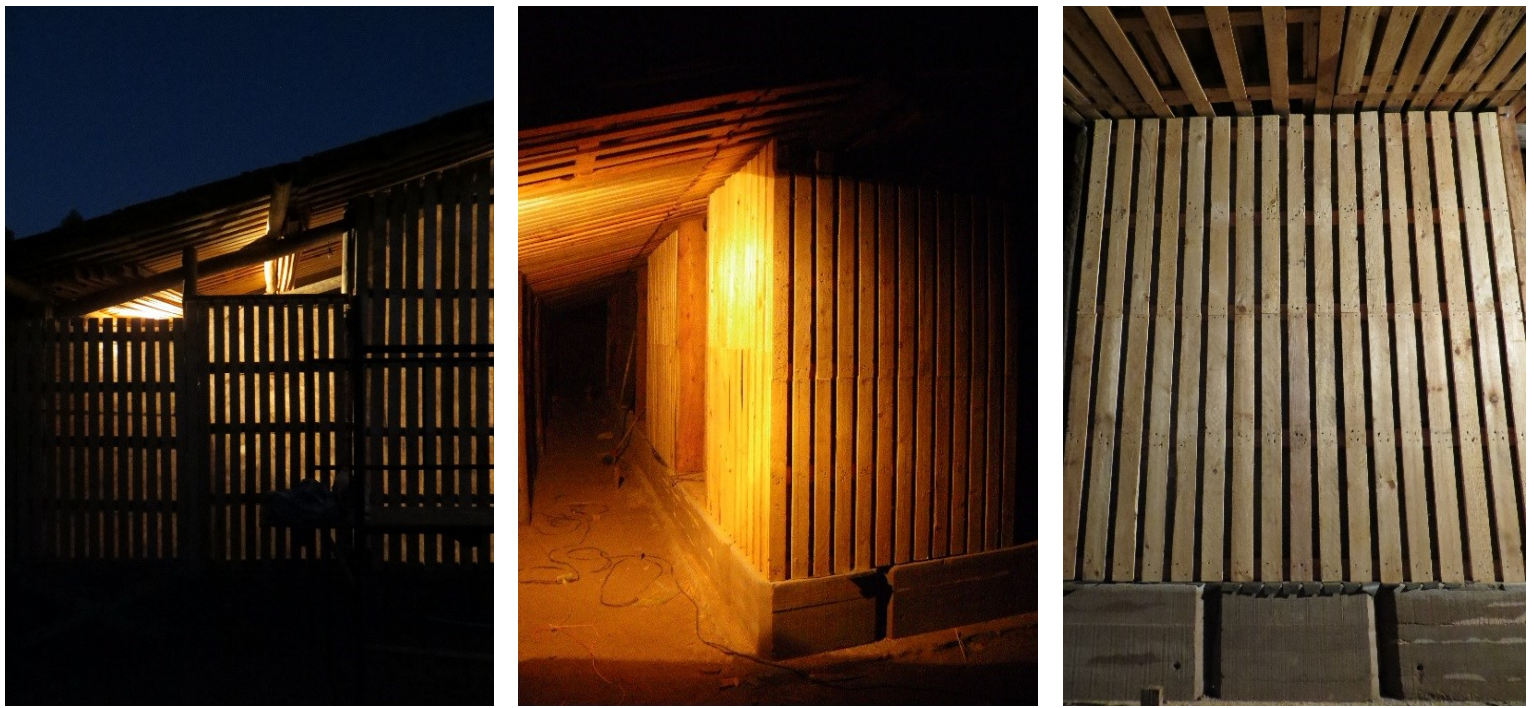

Fotos 303, 304 e 305 - As cores fazem parte da paisagem construída. Suas luzes e sombras marcam as novas formas e revelam as primeiras marcas. Seus cantos, arestas e continuidades vão criando sua própria linguagem arquitetônica, fruto do lugar, de seus recursos e conjunturas.

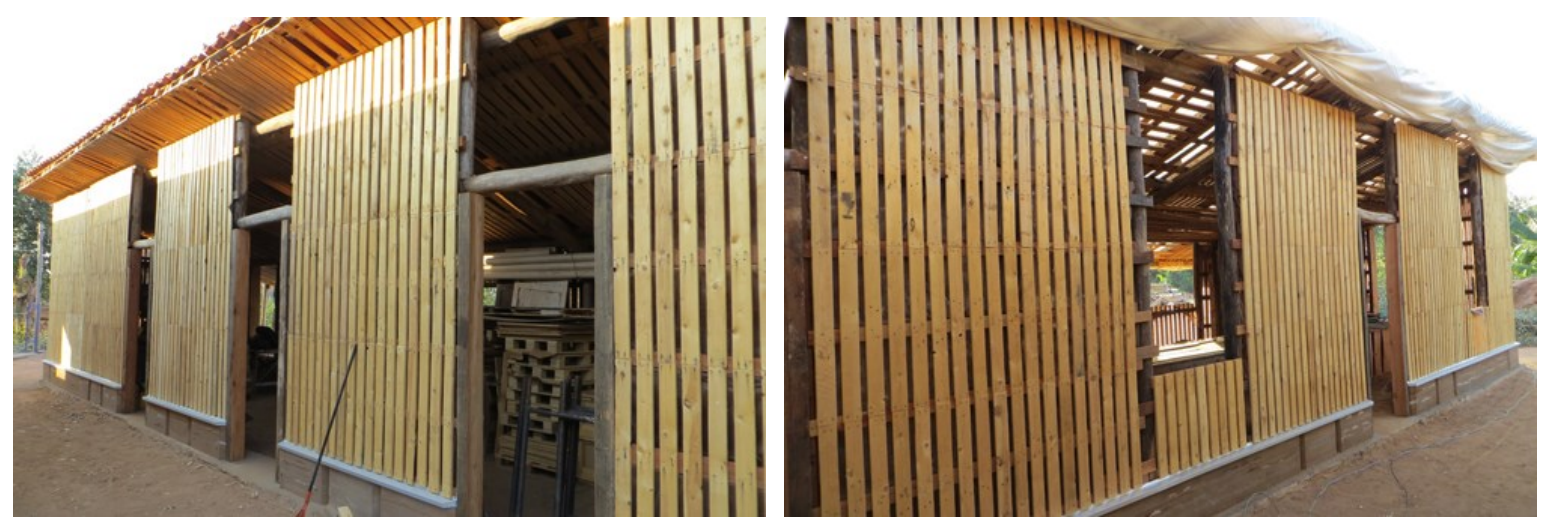

Fotos 306 e 307 - Os dois blocos foram concluídos com a fixação de seus painéis de paletes, deixando as aberturas das esquadrias e portas livres. O projeto para o espaço entre os blocos ainda está aberto para debates. A proposta é cobrir uma parte com telhas transparentes e outra com um teto verde, conforme o projeto inicial. Seus fechamentos externos podem ser feitos com toras de eucaliptos, criando uma espécie de brise-soleil vertical, fronteira entre o interior e o exterior.
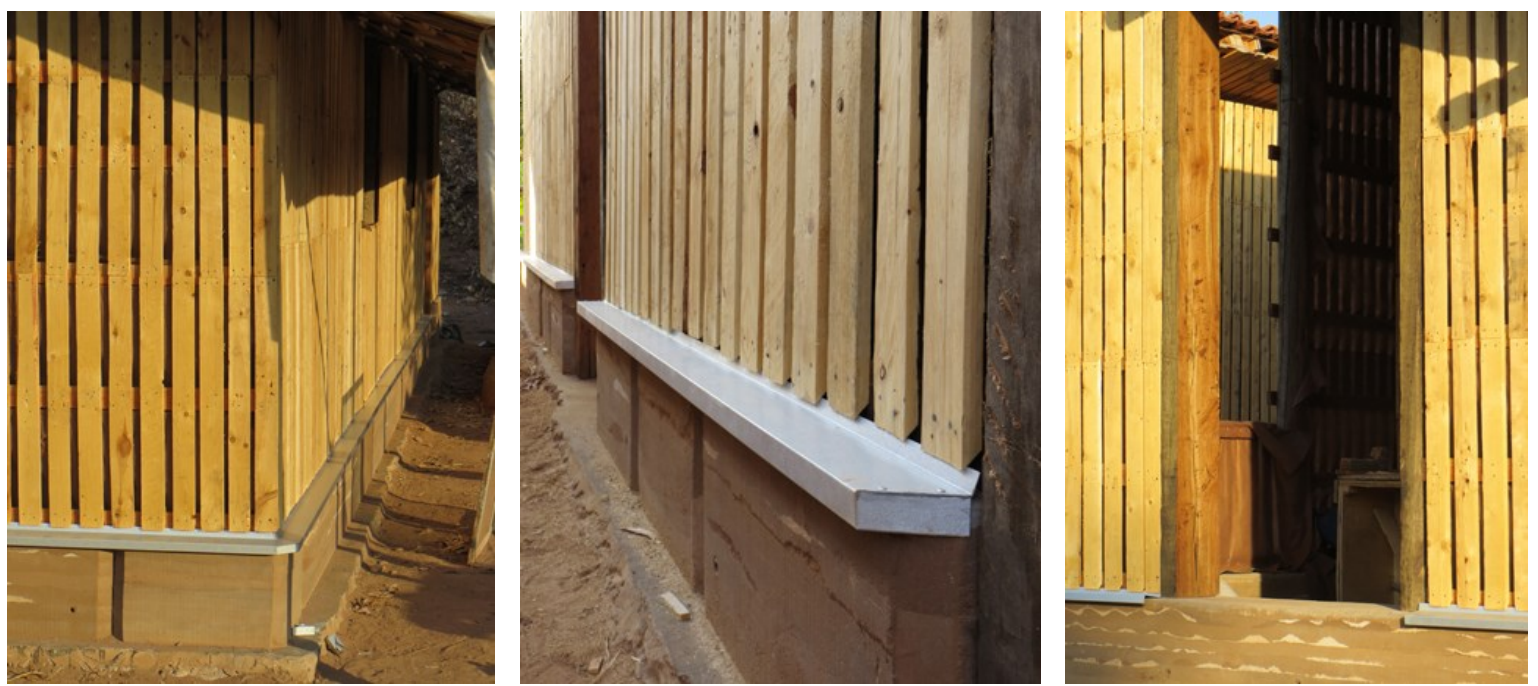

Fotos 308, 309 e 310 - As pingadeiras foram instaladas nas fachadas dos dois blocos da casa, protegendo das chuvas os encontros dos painéis de paletes com as taipas de pilão. Com as pingadeiras colocadas, as mata-juntas poderão ser fixadas aos painéis. 

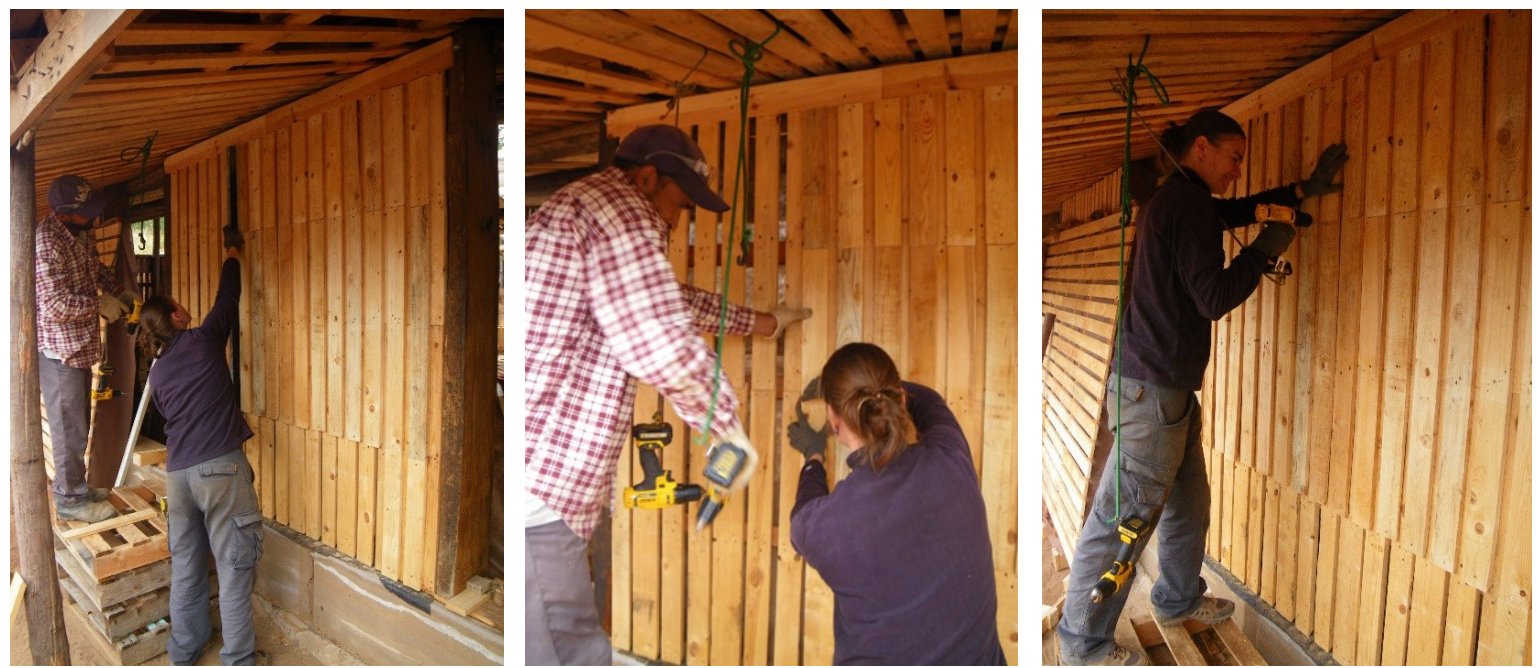

Fotos 311, 312 e 313 - Uma primeira experimentação do trabalho de fixação das mata-juntas foi realizada numa das paredes dos quartos. A intenção foi verificar o acabamento final, os materiais necessários, o tempo gasto e as dificuldades encontradas, de modo a organizar melhor a próxima etapa da obra. Realizando este painel de maneira antecipada, o objetivo também é acompanhar seu comportamento ao longo dos próximos meses, antes da continuação do Canteiro-Escola.
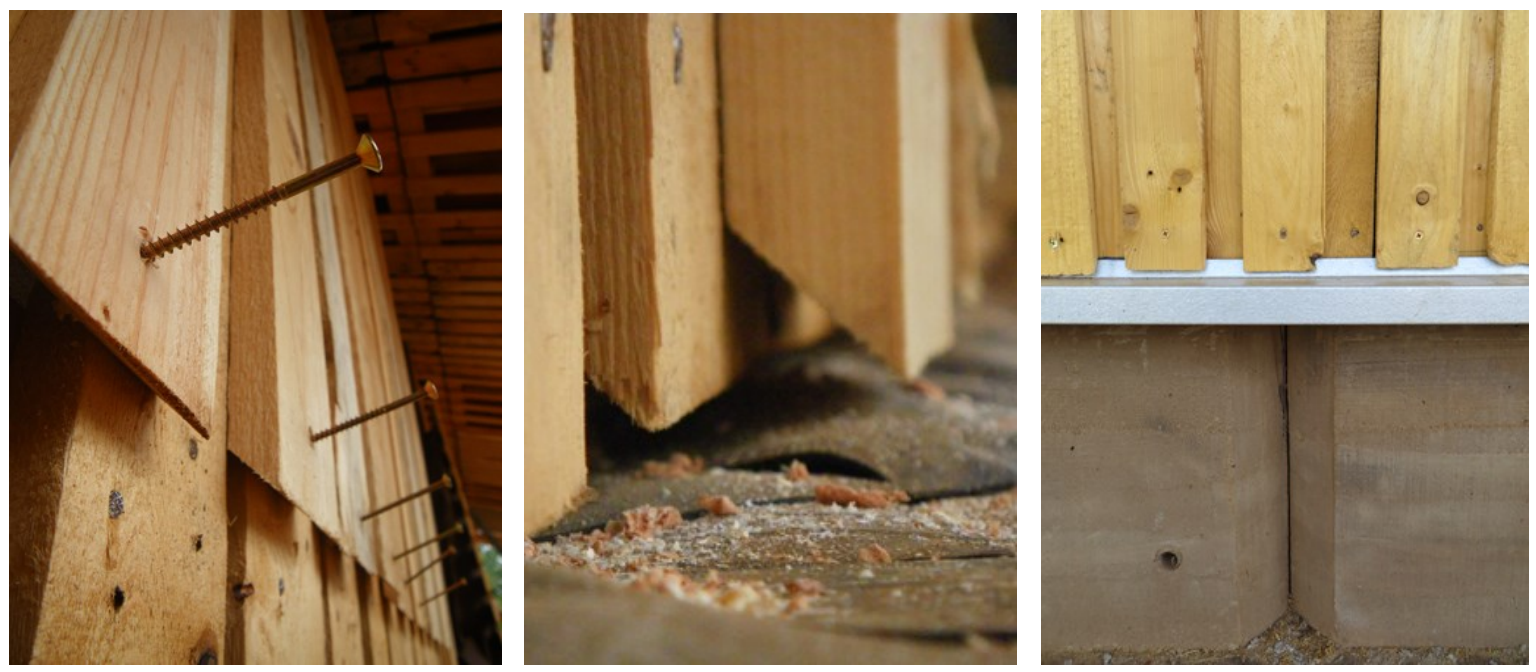

Fotos 314, 315 e 316 - As mata-juntas foram parafusadas aos sarrafos, entre as ripas dos estrados de paletes. $\mathrm{O}$ corte de $45^{\circ}$ protege as madeiras dos painéis e facilita o encaixe das pingadeiras metálicas.
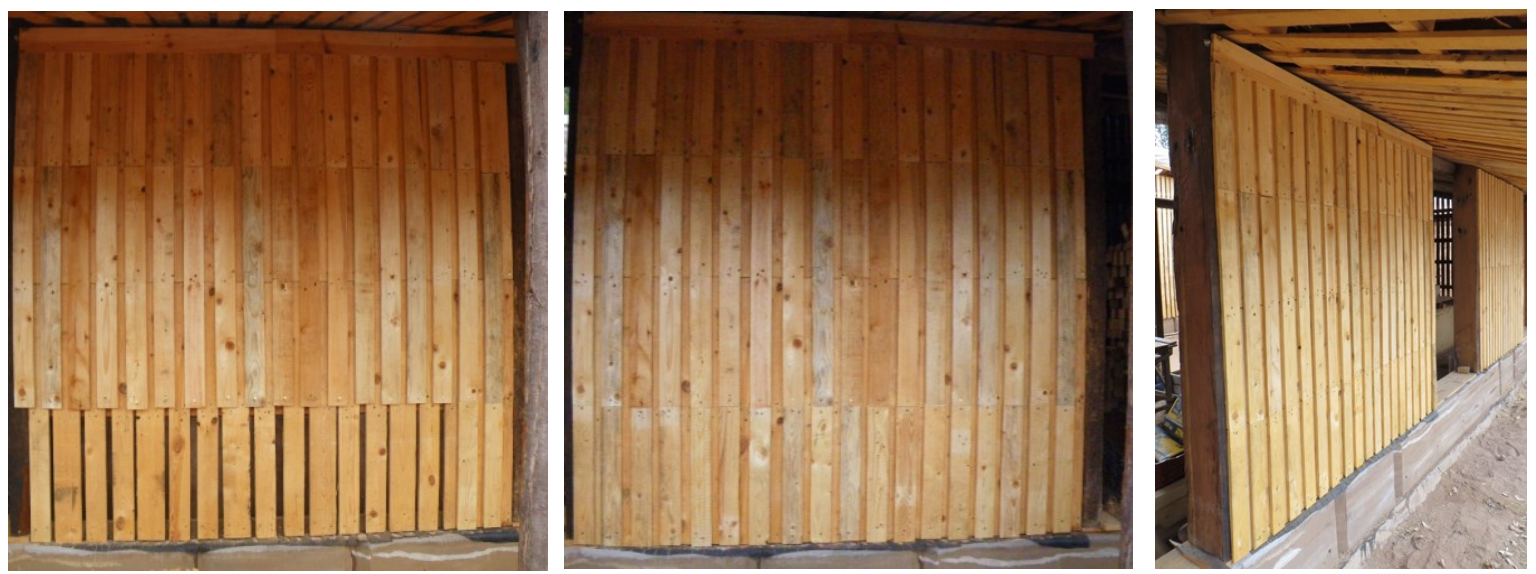

Fotos 317, 318 e 319 - Após a fixação das ripas das mata-juntas nos painéis e finalização externa das fachadas, serão aplicadas duas camadas de stain, produto utilizado para a proteção de madeiras expostas aos raios solares, e para evitar a presença e proliferação de fungos. 

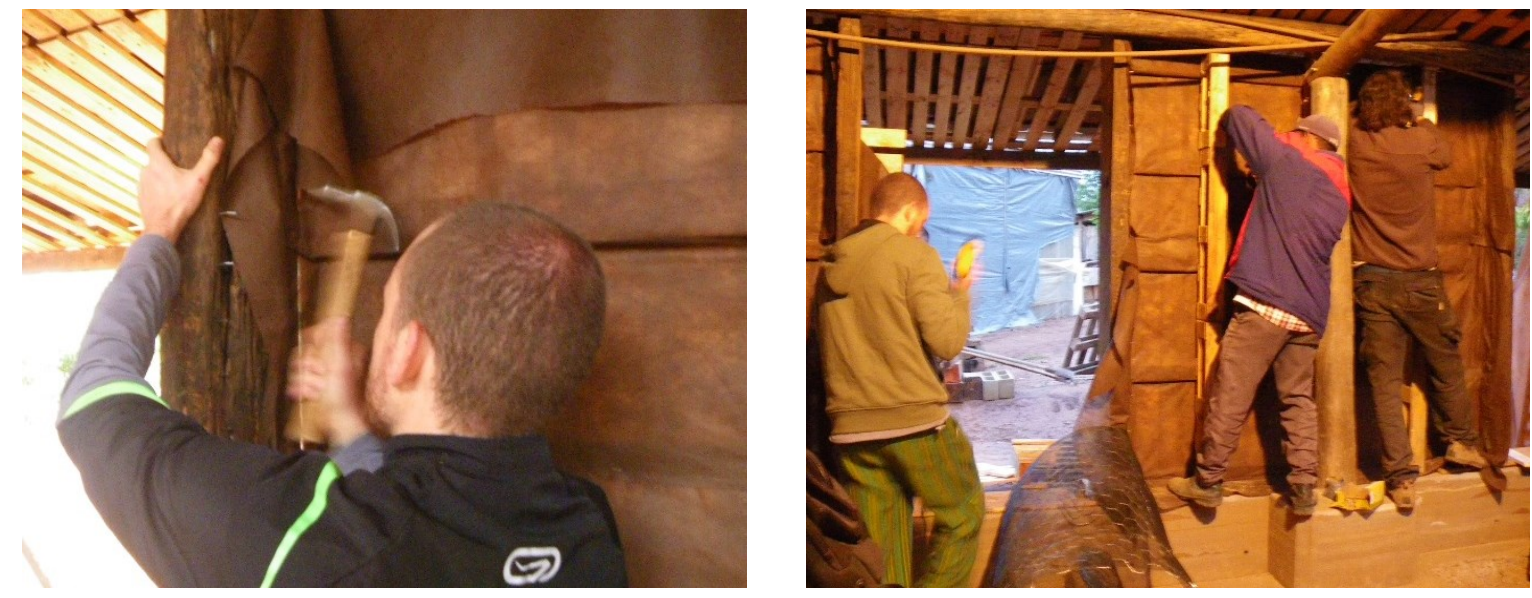

Fotos 320 e 321 - Do seu lado interno, foi dado prosseguimento à realização da parede. A primeira tarefa, consistiu na preparação de pontos de travamento para as telas a serem utilizadas. Os sanduíches foram mais uma vez usados e fixados na parte interior dos painéis de paletes. Eles facilitam o travamento das telas e as mantêm melhor alinhadas em sua superfície.
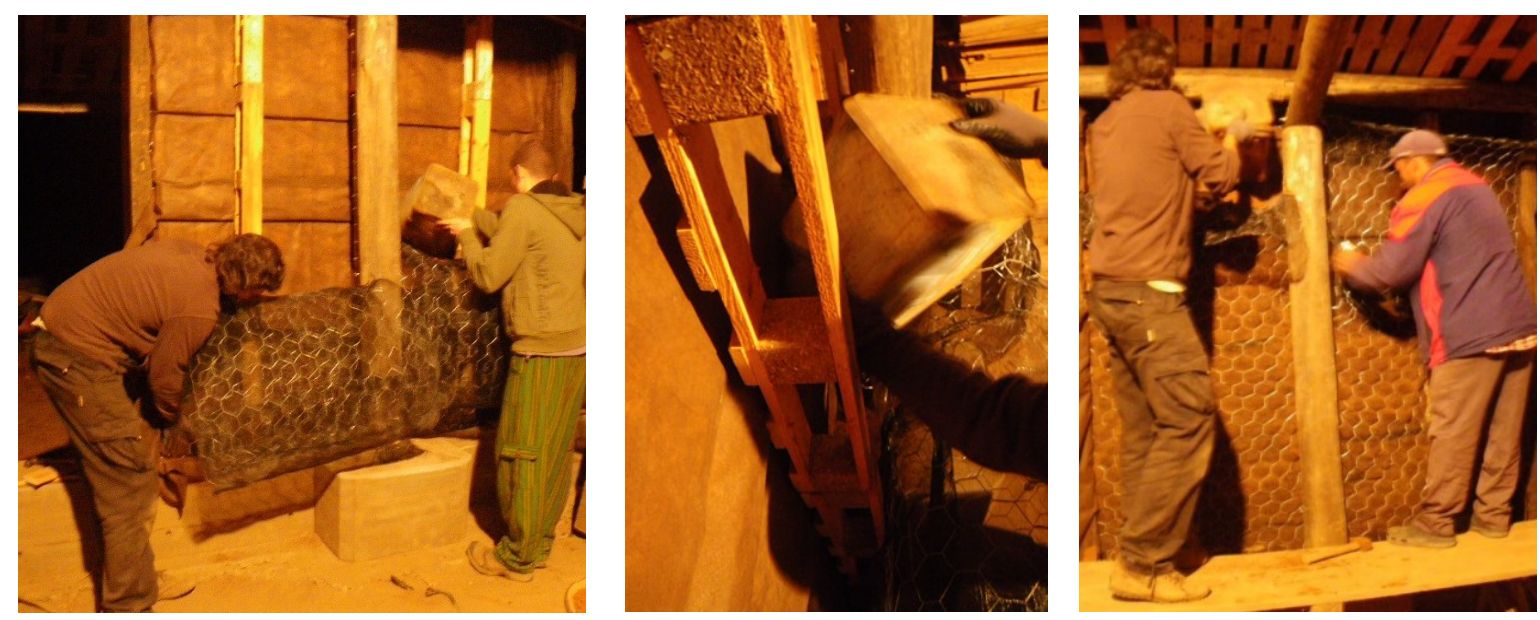

Fotos 322, 323 e 324 - As telas (de arame fio 16 e sombrite) foram cortadas e solidarizadas de modo que pudessem ser manuseadas juntamente. A medida em que a terra ia preenchendo o interior dos painéis, as telas iam sendo desenroladas e travadas como uma espécie de fôrma "perdida", que ia subindo e guardando a massa em seu interior. A terra foi ligeiramente apiloada, de modo a evitar a constituição de espaços vazios no interior da parede.
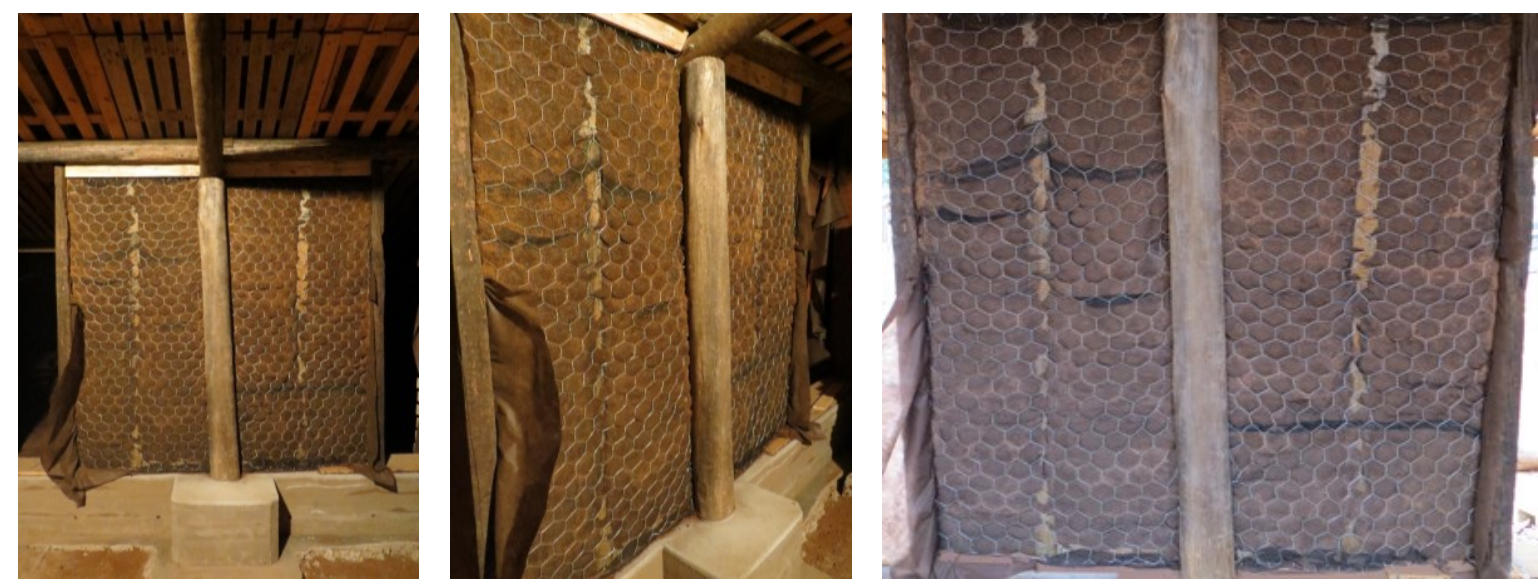

Fotos 325, 326 e 327 - O primeiro painel de parede da casa foi então preenchido. De seu lado externo, o acabamento é em madeira, provenientes dos paletes. De seu lado interno, a espessura em terra contida pelas telas ficou pronta para receber as diferentes camadas de seu revestimento, também em terra. 

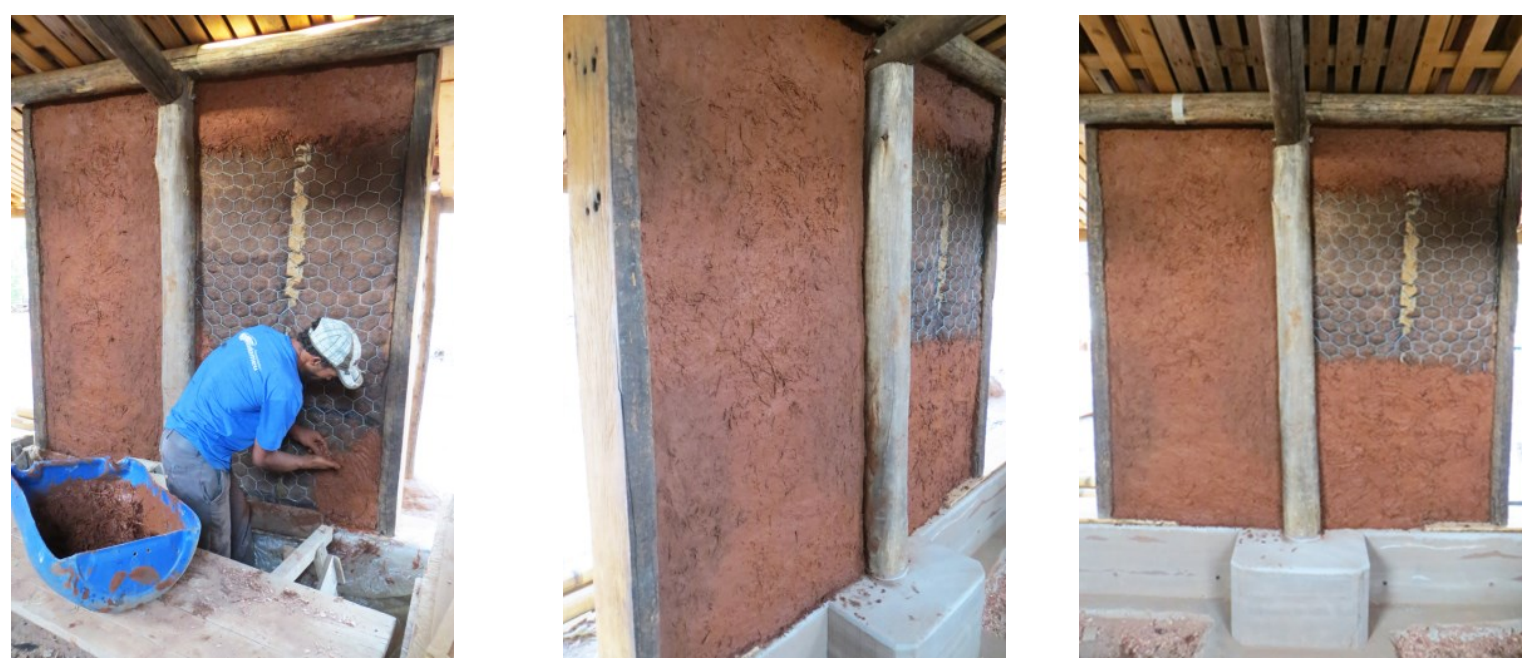

Fotos 328,329 e 330 - A primeira camada do revestimento foi feita a partir de uma mistura de terra argilosa e palha. Esta camada tem a função de realizar a aderência nas telas e preparar a superfície para a segunda camada do revestimento.
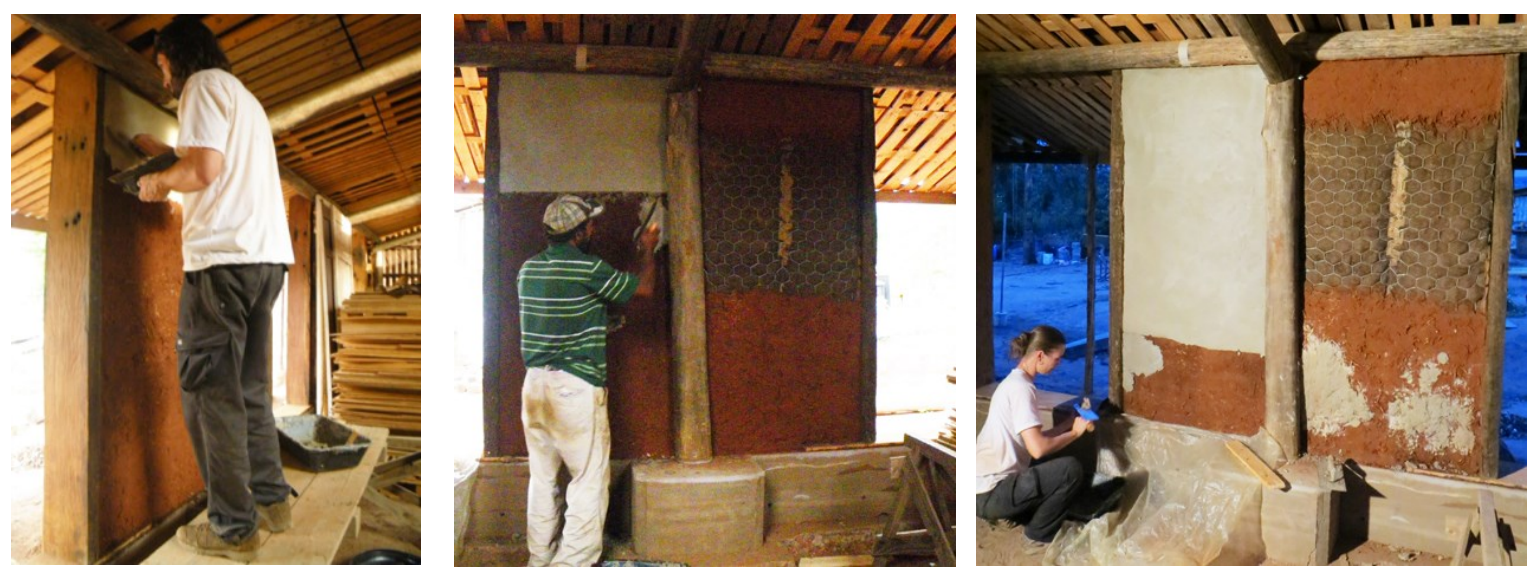

Fotos 331, 332 e 333 - Na segunda camada do revestimento foi utilizada uma terra de cor branca, com a qual foram testadas quatro misturas diferentes em teores de argila, areias médias e finas, e fibras de coco. Outras terras com diferentes cores e características também serão testadas, assim como, texturas e acabamentos variados.
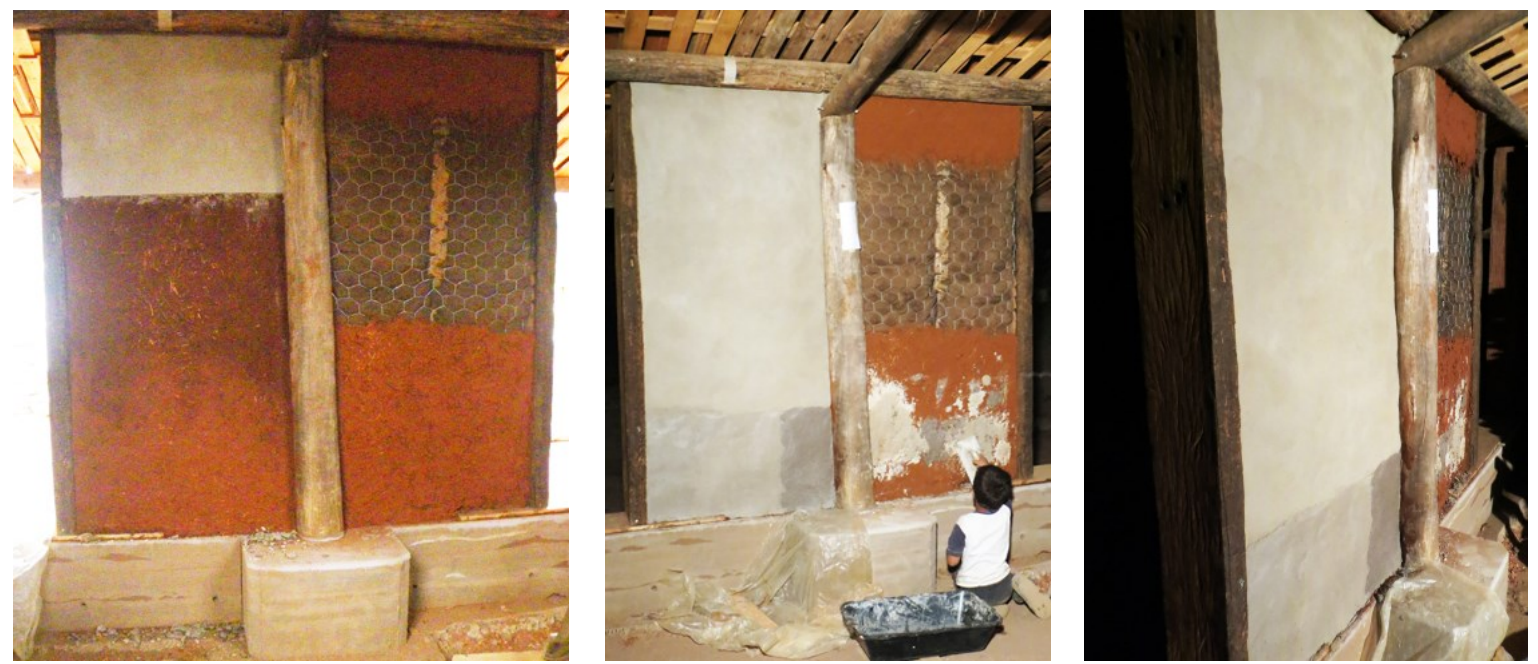

Fotos 334, 335 e 336 - Estes testes servem como amostras de um primeiro conjunto de possibilidades para os acabamentos internos em terra. A intenção é acompanhar a secagem, retração, aderência e resistência mecânica dos testes como forma de indicação dos traços a serem utilizados nas misturas dos revestimentos finais das paredes internas da casa. 

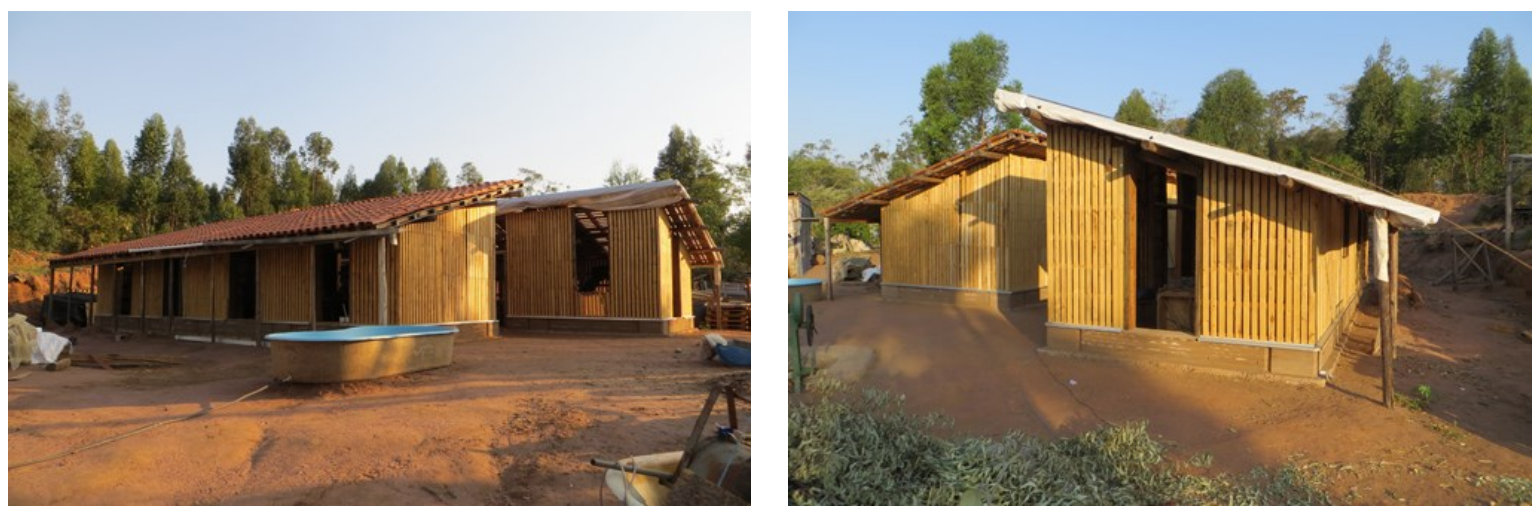

Fotos 337 e 338 - Vistas frontais da casa com os quartos voltados a leste e a sala, em primeiro plano na foto da direita, voltada para o norte.
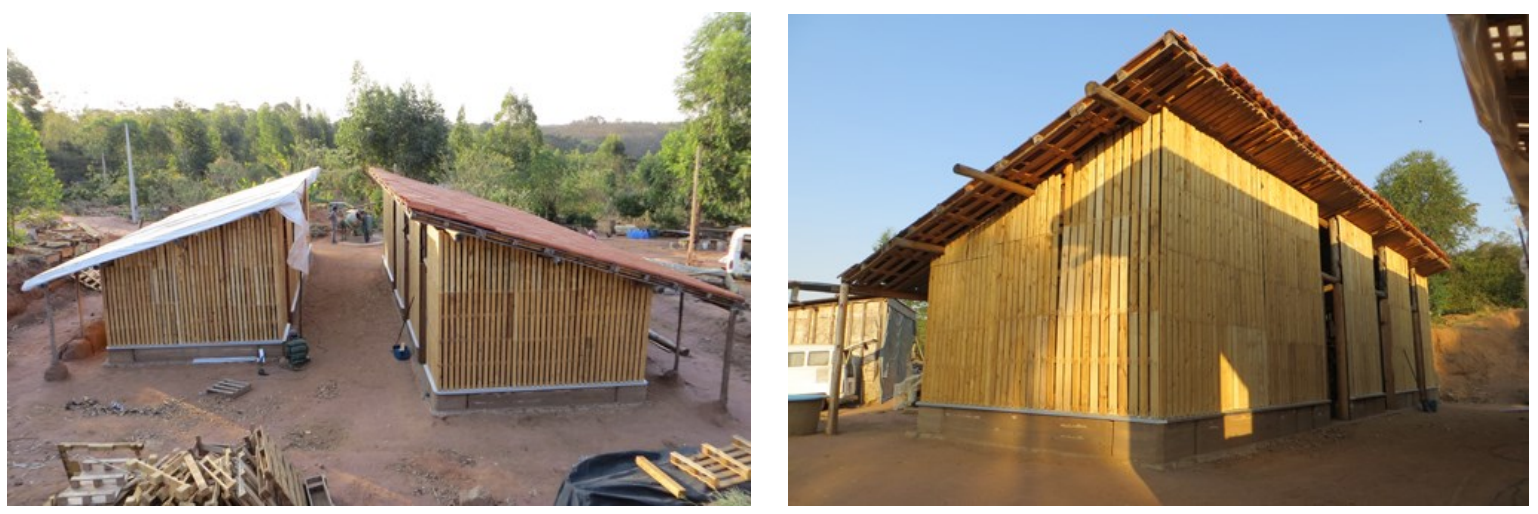

Fotos 339 e 340 - Vista da parte de trás da casa em seu atual estágio de construção. Do lado externo, serão ainda fixadas as matas-juntas entre as ripas de madeira, como acabamento final.

Ao final do mês de setembro foram encerradas as atividades da Oficina 3 do Canteiro-Escola. Ao longo desta Oficina, à medida que as dificuldades apareciam, os diálogos e reflexões foram tecendo uma primeira avaliação do sistema construtivo. As questões ligadas à diversidade dos paletes trabalhados foram as mais comentadas pelo grupo, devido às constantes improvisações e mudanças que fazíamos no processo de produção dos painéis. Evidentemente, isso possibilitava constantes reflexões e debates sobre possíveis alternativas, o que acentuava a dimensão pedagógica do canteiro que se fazia escola, onde as aprendizagens se davam em estado permanente, fossem aquelas relativas às técnicas, aos gestos, aos materiais, ou ao lugar.

O esforço coletivo foi citado como um ponto positivo, no desafio de desenvolver um sistema construtivo adequado aos materiais disponíveis. Cada um participou de diversas etapas, questionando e se apropriando, diferentemente, do processo produtivo. 
Organizaram-se livre e autonomamente, propiciando a produção tecnológica social e local, inserida numa realidade específica.

Foi experimentado um processo de construção sócio técnica onde a tecnologia produzida foi tendo suas características definidas durante o processo produtivo, por meio dos diálogos entre os participantes, onde a opinião da família era decisiva nas escolhas assumidas.

"- Isso tudo teve algum impacto para você fora deste canteiro? Pessoas falam contigo ou você que se liga mais em certas coisas? (A. Guéguen)

- Sim, agora a gente vê outros lugares que estão usando paletes. Acho que isso a gente está vendo cada vez mais. E para mim mesmo a experiência é muito enriquecedora. Para minha formação, enquanto estudante de arquitetura, de estar participando de um canteiro, de uma atividade prática e educativa. A gente sai da sala de aula e vem pra cá para poder trabalhar com a realidade, com a vida das pessoas, com a família." (G. Deleu)

"Acho que foi bem interessante (o Canteiro-Escola) pois a gente está começando a aprender tudo. No projeto, nossos professores começaram a mostrar casas. E muitas coisas que eles estavam mostrando a gente já tinha uma noção bem prática por ter visto aqui no canteiro na estrutura que a gente estava construindo." (G. Duarte)

Ao final de suas atividades, a Oficina 3 contou com 31 dias de Canteiro-Escola onde foram produzidos as bases da casa em taipa de pilão estabilizada com cimento e os painéis das paredes. Foram também realizadas as fixações dos painéis, assim como dos batentes das esquadrias e da estrutura secundária da casa. O custo estimado dos materiais construtivos utilizados nestas atividades foi da ordem de $\mathrm{R} \$ 5.200,00$.

A média de frequência foi de 13 participantes por dia, a mais baixa entre as Oficinas realizadas. Vale ressaltar que durante a prorrogação do curso, poucas pessoas vieram ao canteiro. A média foi de 7 participantes/dia, o que pesou na queda da média final da Oficina. Isso justifica-se pelo fato de que como foi uma prorrogação, as pessoas não haviam previsto em suas agendas previamente, somado ao fato de ter havido greve de funcionários, professores e alunos na Universidade durante este período do curso. 


\begin{tabular}{|c|c|c|c|c|c|c|}
\hline $\begin{array}{c}\text { CANTEIRO- } \\
\text { ESCOLA }\end{array}$ & ETAPAS & DATAS & MATERIAIS E SERVICOS & QUANTIDADES & CUSTOS R\$ & $\begin{array}{l}\text { PESSOAS } \\
\text { (média/dia) }\end{array}$ \\
\hline \multirow{53}{*}{ OFICINA 3} & \multirow{16}{*}{ Taipa de Pilão } & \multirow{16}{*}{$\begin{array}{c}22,23 / 03 / 2014 \text { e } 05,06,17 \\
18,19,20 / 04 / 2014 \text { e } \\
01,02 / 05 / 2014 \\
\text { (10 dias) }\end{array}$} & cimento para base da taipa & 14 sacos & 330 & \multirow{16}{*}{22} \\
\hline & & & Brita para base da taipa & $2 \mathrm{m3}$ & 160 & \\
\hline & & & Areia para base da taipa & $2 \mathrm{m3}$ & 140 & \\
\hline & & & Neutrol & 18 litros & 160 & \\
\hline & & & Terraplanagem & $7 \mathrm{~h}$ & 650 & \\
\hline & & & Tabuas de Madeira & $50(3 \times 0,25)$ & 500 & \\
\hline & & & pregos $15 \times 15$ & $4 \mathrm{~kg}$ & 27,6 & \\
\hline & & & pregos $18 \times 24$ & $6 \mathrm{~kg}$ & 43,4 & \\
\hline & & & cimento para base da parede & 15 sacos & 367,5 & \\
\hline & & & cimento para base da parede & 3 sacos & 73,5 & \\
\hline & & & arruela $3 / 8^{\prime \prime}$ & 220 & 7,84 & \\
\hline & & & porca borboleta3/8" & 120 & 63,43 & \\
\hline & & & cimento para base da parede & 3 sacos & 75 & \\
\hline & & & cimento para base da parede & com os 3 acima & 5,1 & \\
\hline & & & cimento para topo da taipa & 1 saco & 26 & \\
\hline & & & Tubo $1 / 2$ pol. & 4 barras & 40 & \\
\hline & & & & & & \\
\hline & \multirow{36}{*}{ Paineis das paredes } & \multirow{36}{*}{$\begin{array}{c}17,18,31 / 05 / 2014-01,14, \\
15,28,29 / 06 / 2014-21,22, \\
23,24,25 / 07 / 2014-16,17 \\
30,31 / 08 / 2014-13 \\
14 / 09 / 2014 \text { (19dias) }\end{array}$} & Sarrafo & $450 \mathrm{~m}$. & 760 & \multirow{36}{*}{9} \\
\hline & & & pregos $15 \times 21$ - até dia 29/6/14 & $11 \mathrm{~kg}$ & 88,1 & \\
\hline & & & dormentes (batentes) & 11 & 350 & \\
\hline & & & Pentox & 181 & 259 & \\
\hline & & & manta TNT & $48 m$ & 120,9 & \\
\hline & & & prego para telha, etc. & $1 / 2 \mathrm{~kg}$. & 3,6 & \\
\hline & & & parafusos, etc. & 1400 & 177,22 & \\
\hline & & & borracha de pneu & doado & & \\
\hline & & & grampos & $1 \mathrm{cx}$ & 11,9 & \\
\hline & & & folha de EVA & 3 folhas & 7,5 & \\
\hline & & & pregos $18 \times 24$ - até dia 29/6/14 & $6 \mathrm{~kg}$ & 41,4 & \\
\hline & & & pregos26x84 - até dia 29/6/14 & $5 \mathrm{~kg}$ & 49 & \\
\hline & & & prego para telha, etc. & $3 \mathrm{~kg}$ & 21,6 & \\
\hline & & & parafusos $(4,5 \times 60)$ & 50 & 4,74 & \\
\hline & & & parafusos $(5 \times 70)$ & 100 & 14,4 & \\
\hline & & & sombrite monofilamento & $4 \mathrm{~m}$ & 18 & \\
\hline & & & Pregos $15 \times 15$ até dia $10 / 07 / 14$ & $2 \mathrm{~kg}$ & 16 & \\
\hline & & & Pentox incolor - $16 / 07 / 14$ & 18I. $(2 x)$ & 275,04 & \\
\hline & & & Pregos $15 \times 21-(21 / 07 / 14)$ & $5 \mathrm{~kg}$ & 39,5 & \\
\hline & & & Tecido TNT (22/07/14) & $50 \mathrm{~m}$ & 58,8 & \\
\hline & & & Grampo 106/8 (22/07/14) & $1 \mathrm{cx}$ & 10,14 & \\
\hline & & & Pregos 26x84 (22/07/14) & $3 \mathrm{~kg}$ & 34,63 & \\
\hline & & & parafusos (22/07/14) & 100 uni & 14,4 & \\
\hline & & & Tecido TNT $(23 / 07 / 14)$ & $50 \mathrm{~m}$ & 55 & \\
\hline & & & Pregos 26x84 (24/07/14) & $4 \mathrm{~kg}$ & 46,18 & \\
\hline & & & Tela para porco fio 16 & $4 \mathrm{~m} \times 1,5 \mathrm{~m}$ & 39 & \\
\hline & & & Tela para porco fio 16 & $4 \mathrm{~m} \times 1,5 \mathrm{~m}$ & 39 & \\
\hline & & & sombrite monofilamento & $4 \mathrm{~m} \times 1,5 \mathrm{~m}$ & 18 & \\
\hline & & & parafusos $5 \times 70(16 / 08 / 14)$ & 100 uni & 14,4 & \\
\hline & & & Pregos $15 \times 21$ - $(16 / 08 / 14)$ & $2 \mathrm{~kg}$ & 16,73 & \\
\hline & & & Pregos $26 \times 84(16 / 08 / 14)$ & $2 \mathrm{~kg}$ & 23,09 & \\
\hline & & & Pregos $15 \times 21-(17 / 08 / 14)$ & $1 \mathrm{~kg}$ & 7,9 & \\
\hline & & & parafusos $5 \times 70(25 / 08 / 14)$ & 100 uni & 14,4 & \\
\hline & & & Tabeira + pingadeira & $130 \mathrm{~m}$ lin. & 390 & \\
\hline & & & Pregos $26 \times 84(31 / 08 / 14)$ & $1 \mathrm{~kg}$ & 14,09 & \\
\hline & & & Tecido TNT (04/09/14) & $15 \mathrm{~m}$ & 37,5 & \\
\hline TOTAL & & & & & 5760,53 & 13 \\
\hline
\end{tabular}

Figura 43 - Quadro com dados referentes às atividades, custos, tempos e participantes da Oficina 3.

Infelizmente, dentro das condições reais não foi possível terminar a construção da casa Suindara durante as três oficinas do curso de Canteiro-Escola. Conseguimos realizar a maior e mais complexa parte da construção, entretanto sem dar condições suficientes para que a família entre, neste momento, na nova casa. 
Os entendimentos entre o grupo organizador da casa Suindara estão avançados no sentido da continuidade do curso ao longo do ano de 2015, com as atividades referentes à conclusão dos painéis de paredes, englobando os trabalhos de fixação das matas-juntas externas, de seu preenchimento com terra e serragem, bem como as atividades de revestimentos a base de terra no interior da casa.

Nestas circunstâncias, este trabalho concluirá suas análises referentes à realização do curso de cultura e extensão "Canteiro-Escola: Produzindo uma habitação popular com técnicas em madeira e terra", nesta etapa de construção da casa Suindara. Sua continuação fica aberta a outras pesquisas complementares e a outros pesquisadores interessados em prosseguir as análises de suas próximas etapas construtivas, assim como de rever, aprofundar e tecer novas leituras e reflexões sobre os processos pedagógicoconstrutivos experimentados e vividos até o momento. 


\section{Ensaios e compreensões 4}

"Transformar a experiência educativa em puro treinamento técnico é amesquinhar o que há de fundamentalmente humano no exercício educativo: o seu caráter formador." (FREIRE, 2011, p.34)

O canteiro que se fez escola nasceu de um ideal de escola que rediscute o canteiro. Este, torna-se lugar de formação e conscientização, igual a escola, que por sua vez, assume a experimentação prática e coletiva como essência de sua práxis existencial.

Questionando a forma, o conteúdo e o formato dos canteiros de obras convencionais, o Canteiro-Escola busca praticar e desenvolver outros modos de produção, transformando-os em espaços de aprendizagem e experimentação, onde as dimensões do trabalho e da formação ocorrem simultânea e complementarmente.

Desta maneira, são provocadas condições para a constituição de um espaço de trabalho autogerido e de produção de conhecimentos, onde as ferramentas e os diálogos se interagem e proporcionam novas criações em torno das práticas construtivas do habitat. As reflexões críticas dos processos de trabalho alimentam a apreensão e o empoderamento dos sujeitos participantes, acentuados pelo exercício de realização do trabalho coletivo. Isso passa pelos debates acerca dos tipos e usos dos materiais de construção, de seus impactos culturais e ambientais, das relações de produção, de seus mecanismos de organização e gestão, e ainda, pela dimensão sócio-técnica dos processos de desenvolvimento tecnológico, com suas experimentações, sistematizações, aprimoramentos, produção e avaliação.

Por sua natureza, o Canteiro-Escola potencializa a aprendizagem durante a realização prática, indispensável para os que desejam conhecer os princípios gerais e os detalhes construtivos de uma edificação, adentrando no espaço onde o trabalhador transforma os materiais. Por sua dinâmica, ele incita a autonomia na organização e a autogestão no trabalho. A responsabilidade técnica e social orienta as posturas e comportamentos, visto sua condição de existência ser consequência dos conhecimentos, saberes, diálogos e forças coletivas de produção. 
Por seu caráter participativo, o canteiro estimula a curiosidade durante a apreensão e desenvolvimento das atividades. Potencializa os questionamentos das soluções técnicas, provocando a criatividade dos participantes por soluções viáveis e condizentes com a realidade, alimentando práticas de trabalho em grupos, de experimentação livre, de materialização das ideias, e de reflexão crítica dos processos produtivos realizados.

São estas dinâmicas e suas consequências que ampliam a dimensão formadora do trabalho. A materialização do projeto estimula novos olhares que, com outras soluções, traçam as idas e vindas dos processos de desenvolvimento tecnológico. As potencialidades transformadoras são as novas perspectivas reveladas na produção. Elas são fruto da participação coletiva, crítica e criativa dos participantes envolvidos. Às vezes, elas nascem nos gestos, se tornam posturas, começam a questionar, incitam comportamentos, tecem outras reflexões, e assim, pouco a pouco, formam outras compreensões, novas visões, mudam a lógica e, se conseguem realizar-se enquanto práticas transformadoras, acabam por romper com os mecanismos de pensamento e ação vigentes.

A experimentação assume, desta maneira, grande importância no exercício de redescobrir e reinventar os modos de habitar. E, as perspectivas metodológicas de ação e produção crítica do conhecimento vão acompanhando, orientando, modificando e sendo modificadas, pelo próprio realizar do processo formativo.

"Eles poderiam fazer como na construção civil tradicional, trazer o caderno de obras aqui, com todas as 99 folhas, com todos os detalhes, os parafusos e tal, mais não é assim. E me parece que é de propósito. (...) O avanço que teve do desenho, do projeto foi até um certo ponto. (...) É mais ou menos um canteiro livre aqui. Que está livre para propor e ter ideias e ter também uma certa criatividade. No limite é uma produção artística, estamos produzindo arte aqui, está tudo mundo consciente aqui." (C. Barros durante a Oficina 1)

Entretanto, a experiência se propõe a ir além e, a partir da extensão universitária, contribuir com a aproximação da Universidade com a realidade social, através dos questionamentos e ações concretas para o acesso à habitação digna por parte de uma 
das classes sociais mais excluídas de nossa sociedade: à das trabalhadoras e trabalhadores rurais assentados pelas políticas públicas de reforma agrária.

As práticas de extensão acadêmica na perspectiva do trabalho social apresentam um amplo campo de atuação crítica e concreta no desafio por melhorias estruturais e de qualidade de vida das populações excluídas. Nesta perspectiva de ação, as atividades discutidas e realizadas, exercitam suas práxis na constituição de estratégias para a construção de outros sentidos e práticas, nas relações de produção do habitat rural contemporâneo.

A atuação em escala unifamiliar não diminui os resultados alcançados pelo curso em seu processo, nem suas potencialidades futuras. A forma desenhada, foi fruto de um conjunto de fatores incidentes num determinado momento, numa realidade, e que ao modelarem seus contornos, delimitaram sua natureza e grau de atuação, assim como seu horizonte analítico e crítico.

De maneira a prosseguir com as análises a respeito das atividades abordadas ao longo do Momento 4, tratarei algumas questões e resultados obtidos a partir da desconstrução das atividades em dois elementos centrais, transversais à todas as etapas e norteadores de nossas compreensões. Estes elementos referem-se à "formação", em seus aspectos amplos e particulares, e à "produção", no quadro de sua força de trabalho coletiva. Ambos são elementos em constante relação de interdependência entre suas características e condições.

Com o intuito de alimentar as reflexões, disponho de maneira complementar os dados expostos nas Oficinas 1, 2 e 3, quanto aos custos dos materiais, os tempos das etapas e a mão de obra participante, porém agora de forma integral e adicionada de uma comparação estimada com relação à mão de obra e ao tempo de produção em um canteiro habitacional convencional. 


\begin{tabular}{|c|c|c|c|c|c|c|c|c|}
\hline $\begin{array}{l}\text { CANTEIRO- } \\
\text { ESCOLA }\end{array}$ & ETAPAS & DATAS & MATERIAIS E SERVICOS & QUANTIDADES & CUSTOS RS & $\begin{array}{l}\text { PESSOAS } \\
\text { (média/dia) }\end{array}$ & $\begin{array}{l}\text { ESTIMATIVA } \\
\text { PROFISSIONAL } \\
\text { (pessoas) }\end{array}$ & $\begin{array}{c}\text { ESTIMATIVA } \\
\text { PROFISSIONAL (dias) }\end{array}$ \\
\hline \multirow{18}{*}{ OFICINA 1} & \multirow{2}{*}{ Implantação } & \multirow{2}{*}{$24 / 08 / 2013$} & Terraplanagem & $6,5 \mathrm{~h}$ & 600 & \multirow{2}{*}{42} & \multirow{2}{*}{$\begin{array}{c}2 \text { profissionais } \\
\text { (1pedreiro e um } \\
\text { ajudantes) }\end{array}$} & 1dia \\
\hline & & & Eucaliptos & 80 un. & 1200 & & & A tría \\
\hline & & & Cimento (doação) & 10 sacos & 230 & & & \\
\hline & & & Areia & $0,5 \mathrm{~m} 3$ & 40 & & & \\
\hline & Escavação, fundação & & Areia (doação) & $1,5 \mathrm{~m} 3$ & 100 & & & \\
\hline & dos pilares, estruturas & 05, 06, 07 e 08/09/2013 & Brita & $0,5 \mathrm{~m} 3$ & 40 & 22 & (1pedreiro e dois & 7 dias \\
\hline & verticais e & (4dias) & Brita (doação) & $1,5 \mathrm{~m} 3$ & 100 & 22 & & \\
\hline & & & Transporte (Areia/brita) & $3 \mathrm{~m} 3$ & 80 & & & \\
\hline & & & Pregos (doaçăo) & $3 \mathrm{~kg}$. & 30 & & & \\
\hline & & & Oleo queimado & & & & & \\
\hline & & & & & & & & \\
\hline & Escavação das & & Terraplanagem 2 & 2,5 horas & 250 & & & \\
\hline & fundaçôes das & 28 e 29/09/2013 ( 2 dias) & Paletes (doação) & 200 & & 21 & (1pedreiro e dois & 3 dias \\
\hline & paredes & 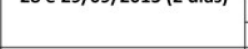 & $\begin{array}{c}\text { Barras roscadas (doação) } \\
\text { Arruelas e borboletas (doação) }\end{array}$ & $\frac{12}{1 \mathrm{cx}}$ & $\begin{array}{l}40 \\
10\end{array}$ & & ajudantes) & \\
\hline & & & 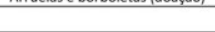 & & & & & \\
\hline & Fundação das paredes & & Cimento & 3 sacos & 67,5 & & 6 profissionais & \\
\hline & e estruturas & $12,13,26,27$ e $28 / 10 / 2013$ & Cimento fundaçăo (doação) & 10 sacos & 230 & 18 & (2pedreiros e 4 & 10 dias \\
\hline & & (5 dias) & Cimento fundaçăo & 28 sacos & 672 & 10 & & \\
\hline & & & Terra & Local & & & & \\
\hline & & & Pregos & $37 \mathrm{~kg}$ & 256,3 & & & \\
\hline & & & Transporte (Telhas e ripas) & 1 dia & 240 & & & \\
\hline & & $02,03,04,15,16$ & Pentox (doaçăo) & $2 \times 18$ litros & 214,2 & & 6 profissionais & \\
\hline OFICINA 2 & Cobertura & $17 / 11 / 2013$ e $30,01 / 12$ e & Paletes (doaçăo) & 200 & & 15 & (2pedreiros e 4 & 12 dias \\
\hline & & 07,08/12 (10 dias) & Barras de ferro $3 / 16$ & 22 & 143 & & ajudantes) & \\
\hline & & & Pentox & 18 litros & 250 & & & \\
\hline & & & Lona $\mathrm{p} /$ estufa branca leitoso & $10 \mathrm{~m} \times 15 \mathrm{~m}$ & 360 & & & \\
\hline & & & cimento para base da taipa & 14 sacos & 330 & & & \\
\hline & & & Brita para base da taipa & $2 \mathrm{~m} 3$ & 160 & & & \\
\hline & & & Areia para base da taipa & $2 \mathrm{~m} 3$ & 140 & & & \\
\hline & & & Neutrol & 18 litros & 160 & & & \\
\hline & & & Terraplanagem & $7 \mathrm{~h}$ & 650 & & & \\
\hline & & & Tabuas de Madeira & $50(3 \times 0,25)$ & 500 & & & \\
\hline & & $22,23 / 03 / 2014$ e $05,06,17$ & pregos $15 \times 15$ & $4 \mathrm{~kg}$ & 27,6 & & & \\
\hline & Taipa de Pilão & $18,19,20 / 04 / 2014$ e & pregos $18 \times 24$ & $6 \mathrm{~kg}$ & 43,4 & 22 & 18 profissionais & 10 dias \\
\hline & & $01,02 / 05 / 2014$ & cimento para base da parede & 15 sacos & 367,5 & 22 & & \\
\hline & & (10 dias) & cimento para base da parede & 3 sacos & 73,5 & & & \\
\hline & & & arruela $3 / 8^{n}$ & 220 & 7,84 & & & \\
\hline & & & porca borboleta $3 / 8^{n}$ & 120 & 63,43 & & & \\
\hline & & & cimento para base da parede & 3 sacos & 75 & & & \\
\hline & & & cimento para base da parede & com os 3 acima & 5,1 & & & \\
\hline & & & cimento para topo da taipa & 1 saco & 26 & & & \\
\hline & & & Tubo $1 / 2$ pol. & 4 barras & 40 & & & \\
\hline & & & Sarrafo & $450 \mathrm{~m}$. & 760 & & & \\
\hline & & & pregos $15 \times 21$ - até dia 29/6/14 & $11 \mathrm{~kg}$ & 88,1 & & & \\
\hline & & & dormentes (batentes) & 11 & 350 & & & \\
\hline & & & Pentox & 181 & 259 & & & \\
\hline & & & manta TNT & $48 \mathrm{~m}$ & 120,9 & & & \\
\hline & & & prego para telha, etc. & $1 / 2 \mathrm{~kg}$ & 3,6 & & & \\
\hline & & & parafusos, etc. & 1400 & 177,22 & & & \\
\hline & & & borracha de pneu & doado & & & & \\
\hline & & & grampos & $1 \mathrm{cx}$. & 11,9 & & & \\
\hline OFICINA 3 & & & folha de EVA & 3 folhas & 7,5 & & & \\
\hline & & & pregos $18 \times 24$ - até dia 29/6/14 & $6 \mathrm{~kg}$ & 41,4 & & & \\
\hline & & & pregos $26 \times 84$ - até dia 29/6/14 & $5 \mathrm{~kg}$ & 49 & & & \\
\hline & & & prego para telha, etc. & $3 \mathrm{~kg}$ & 21,6 & & & \\
\hline & & & parafusos $(4,5 \times 60)$ & 50 & 4,74 & & & \\
\hline & & & parafusos $(5 \times 70)$ & 100 & 14,4 & & & \\
\hline & & $17,18,31 / 05 / 2014-01,14$ & sombrite monofilamento & $4 \mathrm{~m}$ & 18 & & & \\
\hline & & $15,28,29 / 06 / 2014-21,22$ & Pregos $15 \times 15$ até dia $10 / 07 / 14$ & $2 \mathrm{~kg}$ & 16 & & & \\
\hline & Paineis das paredes & $23,24,25 / 07 / 2014-16,17$, & Pentox incolor - $16 / 07 / 14$ & 181. $(2 x)$ & 275,04 & 9 & 9 & 12 \\
\hline & & $30,31 / 08 / 2014-13$ & Pregos $15 \times 21-(21 / 07 / 14)$ & $5 \mathrm{~kg}$ & 39,5 & $y$ & ${ }^{y}$ & 12 \\
\hline & & $14 / 09 / 2014$ (19dias) & Tecido TNT (22/07/14) & $50 \mathrm{~m}$ & 58,8 & & & \\
\hline & & & Grampo 106/8 (22/07/14) & $1 \mathrm{cx}$ & 10,14 & & & \\
\hline & & & Pregos $26 \times 84 \quad(22 / 07 / 14)$ & $3 \mathrm{~kg}$ & 34,63 & & & \\
\hline & & & parafusos $(22 / 07 / 14)$ & 100 uni & 14,4 & & & \\
\hline & & & Tecido TNT $(23 / 07 / 14)$ & $50 \mathrm{~m}$ & 55 & & & \\
\hline & & & Pregos 26x84 (24/07/14) & $4 \mathrm{~kg}$ & 46,18 & & & \\
\hline & & & Tela para porco fio 16 & $4 \mathrm{~m} \times 1,5 \mathrm{~m}$ & 39 & & & \\
\hline & & & Tela para porco fio 16 & $4 \mathrm{~m} \times 1,5 \mathrm{~m}$ & 39 & & & \\
\hline & & & sombrite monofilamento & $4 \mathrm{~m} \times 1,5 \mathrm{~m}$ & 18 & & & \\
\hline & & & parafusos $5 \times 70(16 / 08 / 14)$ & 100 uni & 14,4 & & & \\
\hline & & & Pregos $15 \times 21$ - $(16 / 08 / 14)$ & $2 \mathrm{~kg}$ & 16,73 & & & \\
\hline & & & Pregos $26 \times 84(16 / 08 / 14)$ & $2 \mathrm{~kg}$ & 23,09 & & & \\
\hline & & & Pregos $15 \times 21-(17 / 08 / 14)$ & $1 \mathrm{~kg}$ & 7,9 & & & \\
\hline & & & parafusos $5 \times 70(25 / 08 / 14)$ & 100 uni & 14,4 & & & \\
\hline & & & Tabeira + pingadeira & $130 \mathrm{~m}$ lin. & 390 & & & \\
\hline & & & Pregos $26 \times 84(31 / 08 / 14)$ & $1 \mathrm{~kg}$ & 14,09 & & & \\
\hline & & & Tecido TNT (04/09/14) & $15 \mathrm{~m}$ & 37,5 & & & \\
\hline TOTAL & & 51 dias & & R\$ & 10913,53 & 15 & 9 & 55 \\
\hline
\end{tabular}

Figura 44 - Tabela com os dados do curso de extensão Canteiro-Escola referentes aos materiais, custos, tempo de atividades, mão de obra participante e uma comparação estimada quanto à mão de obra e tempo de serviço para profissionais da construção civil. 


\section{FORMAÇÃO}

As atividades de produção da Casa Suindara foram realizadas em 51 dias formais de idas ao assentamento, estendidas ao longo de um ano de atividades do CanteiroEscola. Ocorreram 159 inscrições somadas as três Oficinas, dentre as quais 91 receberam certificados de participação. Se incluirmos os processos de concepção dos projetos arquitetônicos e as primeiras experimentações com os paletes e a terra, referentes ao curso optativo, foram mais 34 inscritos e 14 idas ao assentamento. Vale registrar que os participantes frequentemente traziam outros colegas e familiares para se juntarem às atividades durante um dia.

Podemos observar ao longo das atividades expostas, a diversidade do público participante. Eram estudantes de arquitetura, engenharia e meio ambiente, e ainda profissionais arquitetos, engenheiros, artistas, publicitários, biólogos, entre outros. Eram brasileiros e também estrangeiros: mexicanos, uruguaios, chilenos, colombianos, cabo verdianos, franceses e alemães. Desta forma, o canteiro configurou-se como um espaço de múltiplas culturas, diferentes idiomas, acúmulos e motivações particulares, vindos da cidade de São Carlos, de sua região mais próxima, ou ainda da capital São Paulo, distante cerca de $300 \mathrm{~km}$. Enfim, um público diversificado, em sua maioria jovens com até 30 anos de idade e em processo de formação acadêmica.

Uma das primeiras questões a considerar refere-se à possibilidade concreta de se conjugar dentro de uma única experiência prática de extensão popular, todas as dimensões da formação acadêmica, assim sendo, o ensino, a pesquisa e a extensão. $E$ realizá-las de maneira aplicada, com estreita conexão entre o mundo acadêmico e a realidade social.

O desafio passa pela visão integrada do processo formador através da experimentação e instrumentalização dos processos dialéticos da teoria e prática, buscando a realização da práxis educativa, com o movimento de reflexão-ação-reflexãoação, num avanço à conscientização dos sujeitos e emancipação do trabalho. Um exercício que demanda, reúne e produz conhecimentos e saberes técnicos e científicos, motivações e curiosidades criativas, improvisos e atitudes proativas, reflexões e práticas dialógicas, entre outros. 
Os debates sobre o processo de formação passam, para além das discussões de seus conteúdos, pela avaliação da própria natureza dos métodos de ensino e aprendizagem. $\mathrm{O}$ aspecto inovador pode não estar em seu ineditismo pedagógico, mas está associado às condições locais de seu desenvolvimento e aplicação. O processo articula a produção localizada de conhecimentos, por exemplo, aqueles relacionados às tecnologias desenvolvidas, com outras relações mais amplas da sociedade, por exemplo, referentes às políticas públicas de produção habitacional nos assentamentos rurais.

Este percurso, passa pela compreensão de como o ambiente social influencia no desenvolvimento tecnológico e como este, por sua vez, também modela o ambiente social. Daí, a importância de iniciar as atividades do curso através das compreensões e reflexões críticas a respeito da realidade na qual estamos inseridos. O que é um assentamento rural? Porque ele existe? Como ele é criado? Porque as famílias estão vivendo nestas condições? Quais relações são estabelecidas com a natureza? E com a cidade? Quais as perspectivas utópicas e as possibilidades concretas?

A formação é pautada pela compreensão da realidade local e têm seus objetivos orientados para a transformação da realidade imediata, criando oportunidades para que os participantes se apropriem dos contextos, tomem partido nas tomadas de decisões e resoluções das dificuldades. Esta conscientização crítica é articulada com a formação técnica e acadêmica, oriundas das atividades práticas do Canteiro-Escola.

A escala do território é tratada em conexão com a organização do lote familiar de produção. Seus elementos e características são estudados dentro do exercício de conceber um projeto arquitetônico localizado e específico para as condições encontradas. A paisagem é debatida, os animais e a vegetação são protagonistas do território, os aspectos energéticos e construtivos são constantemente questionados e pensados.

Este princípio, confronta os estudantes em suas práticas cotidianas de projetar em sala de aula. O concreto, que nos programas de desenho 3D é uma textura, adquire no canteiro seu peso, tempo e energia. As vigas e pilares, linhas retas e constantes na tela, tornam-se reais nas curvas dos eucaliptos e seus variados diâmetros. O trabalho do desenho, individualizado no "personal computer", coletiviza-se nas equipes que se auto organizam durante o trabalho. 
O Canteiro-Escola é, ou deveria ser, um lugar provocador. Como responder à demanda de produzir o habitat a partir dos materiais e condições existentes no lugar? $\mathrm{E}$ ainda com a família? E tendo como um dos professores facilitadores, o morador assentado e pedreiro de ofício?

Esta dinâmica remete ao questionamento da existência de um único "personagem-professor" durante o processo de produção, e propicia situações dialéticas onde o arquiteto vira aprendiz e o pedreiro professor, onde os estudantes se percebem por novos ângulos e os assentados rurais ocupam posições centrais nas escolhas e decisões. Fica evidente a importância da participação permanente dos futuros moradores no desenvolvimento do curso. A leitura da realidade é passada por quem a vive cotidianamente, centrada em suas práticas sociais.

"Eu fui "obrigado" a chegar lá na USP e "bagunçar" todos os projetos. Por defeito em todos. Mas isso para despertar a cabeça da galera, para não ficar só naquilo ali. E dos cinco projetos [produtos do curso optativo], depois de bagunçados, a gente juntou e fez este super projeto, que estamos construindo hoje." (G. Silva)

Os materiais de construção assumem um papel central na realização dos processos de produção tecnológica. São eles que ditam as técnicas trabalhadas e as ferramentas escolhidas. Como necessitam ser transformados, provocam o raciocínio, os diálogos, os testes, os questionamentos, as descobertas desiludidas dos limites de uso, assim como as surpresas potencializadoras dos benefícios aportados.

"Acho que o interessante também é que a gente não tinha aquilo de: o seu grupo vai fazer uma parede, o seu uma porta, e o seu o telhado. Era assim: Vocês têm terra, pregos, martelos e paletes. Então vocês vão pensar em algum sistema para uma casa." (N. Balak durante a Oficina 3)

"Eu com mais de 20 anos de carreira nesta profissão, nunca tinha imaginado que daria para gente fazer uma casa usando terra, madeira, e outras coisas ecológicas. (...) Tem muitas coisas que eu não conhecia nesta área. A parte da terra, é uma coisa bem curiosa. A gente teve que fazer experiências com ela para ver como estabilizar. Mas se fosse a 2 km daqui, talvez a gente não precisasse de cimento pois a terra poderia ser mais argilosa. 
E se ela fossa mais argilosa, talvez o sistema construtivo não fosse com paletes. Aí, seria de adobe ou a taipa de mão." (G.Silva)

A formação implica participação ativa, crítica e experimental na produção efetiva dos conhecimentos e do objeto do curso. O canteiro ganha a forma de uma plataforma de trabalho e formação, mediada por diferentes sujeitos engajados no desafio de se pensar e realizar outros modos de produção do habitat rural.

Dentre os instrumentos de trabalho, o uso dos painéis pedagógicos se revelou substancial como suporte do curso. Eles testemunham o processo, orientam sua continuidade e apoiam a produção. São fundamentais para a memória da construção e para o método pedagógico de trabalho utilizado. São de leitura coletiva, aberto a debates, de fácil compreensão e apropriáveis por todos.

A prática educativa estimula uma perspectiva transformadora na medida em que consegue articular explicação, implicação e aplicação na realidade social. Segundo Paulo Freire (2011), a práxis pedagógica que (re)educa, desconstrói o que a ideologia hegemônica estrategicamente engendra nas mentes das pessoas. É a prática cultural transmitida em seu contexto social que alimenta a reprodução de princípios, gestos e posturas, como por exemplo, atitudes individualistas ou cooperadoras.

Assim, em vez de tentar pré-estabelecer ou controlar as variáveis e as condições do lugar, torna-se necessário descobrir as peculiaridades locais e incorporá-las aos processos tecnológicos. Tornar, tanto as atividades produtivas quanto as formadoras, os pontos de partida dos processos alavancados, e assim, concentrar as análises nas situações em que a atividades ocorrem. $\mathrm{O}$ objeto casa vira ferramenta para constituição deste processo maior, de formação humana, conectada às relações com seu contexto.

"Enquanto a gente estava aqui [no assentamento] construindo a parte do galpão, também estava sendo feito a parte do projeto lá [na USP]. Então, o pessoal vinha aqui e a gente também ia pra USP, para conhecer a respeito de arquitetura, ver como o pessoal trabalha lá dentro, como o pessoal estuda. Isto também foi muito legal." (G. Silva) 
Nesse caso, as aprendizagens que diariamente se constroem dentro dos processos de trabalho e de suas relações de produção, não se fazem por meio de etapas previamente definidas, mas se realizam nas situações relevantes, as vezes imprevisíveis, que emergem do próprio processo. Estas aprendizagens, se expressam "nas" - e são expressões "das" - posturas, interesses e consciências dos participantes. A produção humanizada do canteiro resulta em elemento chave para os processos formadores.

"A universalização não se dá no sistema construtivo e em seus aspectos construtivos. Isso acaba assumindo uma questão secundária do objeto, mas é fundamental enquanto processo. Se não tivesse isso tudo (pesquisas com os materiais madeira, terra, paletes, etc.) a experiência não se efetivaria. Mas a possibilidade de externalização e de universalização das experiências, se dá pela formação." (Prof. J. Marcos em conversa sobre o trabalho)

A dimensão formadora se articula com a dimensão da pesquisa através da escolha metodológica de atuação apoiada substancialmente na pesquisa-ação, onde as análises e atuações se orientam à transformação de uma realidade, consequência da participação direta de todos os interessados e envolvidos no processo. Diagnosticar a realidade, iniciar ações, acompanhar, observar, aprimorar, sistematizar, dialogar, dar sentido e facilitar sua evolução, são condições que a pesquisa-ação alimenta em sua realização.

Já tratamos anteriormente de suas referências conceituais e definições teóricas. Entretanto, penso ser oportuno reafirmar sua proposta como pesquisa engajada com a transformação, participação, e com processos formadores. Sua atuação proporciona práticas dialógicas de compreensão dos "porquês" e amadurecimento dos "como". Ao introduzir a pesquisa no mundo real do assentamento rural, se oferece aos acadêmicos e assentados certos instrumentos para a redução do abismo existente, há muito tempo, entre a pesquisa e a ação, o saber e o fazer, a teoria e a pratica.

"Supera nossas expectativas, porque cada encontro é uma história diferente. Porque no dia de encontro com a galera a gente chega num objetivo. Ai, na próxima vinda a gente já tem que rever as coisas e construir uma outra ideia em cima, usando ferramentas diferentes. Então, nada nesta casa está sendo rotina. Não tem nada que está ali no papel, 
e que a gente tem que fazer, não. A gente está construindo e desconstruindo. Essa é a verdade." (G. Silva)

As atividades amadurecem suas orientações no esforço de responder as questões do mundo real, prático. $\mathrm{E}$ isso lhe dá sentido. A orientação metodológica estimula a valorização da construção cognitiva do processo de experimentação coletiva. De acordo com Khalid Andaloussi (in Thiollent, 2004, p.143), "A participação em uma pesquisa-ação, além de ganhos simbólicos, permite aos atores promover hábitos críticos construtivos, condições necessárias para gerir e produzir conhecimentos mais pertinentes."

Nesta perspectiva, a pesquisa adquire, mais sentido e utilidade quando transforma as problemáticas cotidianas, quando age sobre a prática concreta na procura por alternativas e condições de melhoria do quadro analisado. A oportunidade de trabalhar a orientação de um canteiro de obras, de forma a alargar os espaços de formação, para além das dimensões técnicas e científicas, revela situações onde certos aspectos sociais, emocionais e subjetivos, se misturam tecendo relações de amizade, companheirismo, identidade, entre outros. Essas relações marcam experiências de vida e constroem memórias individuais e coletivas, facilitando a apropriação dos conhecimentos adquiridos.

"Se as atividades pedagógicas devem, numa primeira fase, estimular no grupo de estudantes a capacidade de unificar o ato de conceber-executar, numa segunda etapa é desejável permitir o exercício, agora mais complexo e dialético, da formação da unidade diante da alteridade, isto é, do arquiteto confrontado com seu outro: o operário da construção. Isso significa tomar a lógica da separação em sua determinação histórica e social para ensaiar sua negação determinada em favor de uma possível síntese superadora." (FIORI, 2008, p.29)

Evidentemente, as relações entre os participantes com a família foi, ao longo do curso, sendo fortalecidas e lapidadas. Fomos aprendendo a nos conhecer melhor para trabalhar conjuntamente. As relações sociais foram ganhando intensidade e respeito. Neste ponto, a leitura crítica não pode permitir a compreensão equivocada da prática enquanto ação assistencialista, com atitudes quase heroicas de comportamento social. 
O envolvimento necessário para a construção das relações afetivas e de confiança também constitui uma dimensão da formação humana. Entretanto a figura do herói (possuidor da virtude) deve ser transformada na do educador (facilitador dos processos de formação). A dimensão afetiva deve ser assumida dentro da dimensão política na formação humana, enriquecendo o processo e mantendo sua leitura crítica e atenta da realidade.

"A visão que eu tinha sobre arquiteto, arquitetura.... Eu trabalho nessa área (construção) já tem um certo tempo, e desde o meu começo, o arquiteto não aparecia muito. A verdade é essa. $O$ arquiteto não aparece. A parte de engenharia, tinha um engenheiro que vinha e dava alguma orientação. (...) O arquiteto estava coberto, escondido. Essa é a verdade. Hoje em dia eu vejo a importância que o arquiteto tem em cima dos projetos. Então, eu acho que este contato com a realidade, ali na prática, vai ajudar bastante, vai desenvolver muito esses novos arquitetos que vão chegar no mercado." (G. Silva)

Nos depoimentos relatados pelos participantes, ao longo das atividades descritas neste trabalho, parece tão óbvia a necessidade (em estado quase latente) de se tornar concreta (dentro da grade curricular obrigatória) a vivência intensiva da produção em um canteiro de obras, que sua não existência, revela-se inadequada ao permanente e necessário processo de renovação pedagógica dos futuros profissionais.

\section{PRODUÇÃO}

No que tange a dimensão produtiva das atividades do Canteiro-Escola, a tabela exposta mais acima fornece um conjunto de dados que servem como ponto de partida para algumas análises.

As etapas de produção da Casa Suindara somaram 51 dias de duração com cerca de sete horas de trabalho/dia. A média dos participantes inscritos foi de 15 pessoas por dia, número que somado à estimativa dos membros da equipe coordenadora, incluindo a família, se eleva a 19 pessoas no canteiro. As atividades geraram 357 horas de trabalho, e então 6783 horas/homem de participação na construção da casa. 
No exercício comparativo de estabelecermos algumas relações com a construção de uma habitação dentro de um canteiro de obras convencional, isto é, dentro das relações capitalistas de trabalho e produção, foi realizada uma estimativa de tempo de trabalho e número de profissionais necessários à realização das mesmas tarefas concluídas. Estes valores foram estimados por G. Silva, que por trabalhar em canteiros há quase 20 anos, possui a experiência necessária para tecer estas comparações, considerando as mesmas condições de nosso canteiro. Os números seriam de 09 profissionais para 55 dias de trabalho, o que geraria 385 horas de trabalho, e então 3465 horas/homem de labuta.

Evidentemente, tais comparações seriam parciais se fossem conclusivas a partir de um olhar somente quantitativo. As disparidades reveladas nos números evidenciam uma série de fatores ligados, de maneira profunda, às diferentes naturezas que constituem o valor "tempo", utilizado na produção da casa. O importante a se revelar dos aspectos temporais dos dois tipos de canteiros são seus "porquês" e "como". Por que a produção habitacional dentro de um processo de Canteiro-Escola é mais lenta que a produção habitacional dentro de um canteiro convencional do mercado imobiliário?

Visto que as atividades aconteceram em um lote de vida e produção familiar, suas realizações estavam em conexão direta com o ritmo dos moradores e com os tempos das outras atividades existentes no lote. E ainda com as visitas dos familiares e amigos, as brincadeiras das crianças, os animais que interagiam com os participantes, entre outros.

As Instituições de Ensino também possuem seus tempos próprios: da burocracia, das comissões, das solicitações de cursos, das demandas por fomentos, das aprovações das bolsas de pesquisa, dos calendários acadêmicos, entre outros. Esse tempo é determinante para a construção de um outro, o dos participantes, que entre os cursos acadêmicos obrigatórios vão preenchendo as lacunas a partir de suas prioridades.

Os tempos dos recursos financeiros também são decisivos nos avanços do canteiro. Os recursos advindos pela família, Instituições de Ensino, parcerias com empresas e doações de apoio, possuem seus tempos independentes e pouco articulados entre si. O fato do Canteiro-Escola não dispor de um recurso suficiente para sua plena 
realização, condicionou uma série de escolhas técnicas e organizacionais ao longo do processo, tencionando em algumas situações a organização das atividades.

A pesquisa também possui seu ritmo. A tese está inserida dentro de um programa acadêmico e condicionada a certos compromissos que muitas vezes não possuem seus tempos coincidentes com os outros citados acima.

Todos estes tempos estão ainda articulados a conjunturas mais amplas, que muitas vezes influenciam decisivamente nos andamentos e prioridades. É o caso, por exemplo, do tempo do coletivo de famílias do assentamento. Este se encontrava no momento de acessar aos créditos financeiros para as construções das casas, quando de nossa chegada ao assentamento. E foi esse, o primeiro tempo que relevantemente coincidiu com o tempo do grupo de pesquisa, possibilitando nossas ações. Muitos outros tempos determinam as possibilidades de desenvolvimento do assentamento, como é o caso do tempo da água. Este já dura quatro anos e ainda não foi resolvido. As famílias de agricultores ainda não conseguem produzir para vender e dependem da passagem inconstante do caminhão pipa para o consumo próprio. Paralelamente, buscam soluções alternativas gerando novos custos suplementares e soluções nem sempre duradoras.

O ritmo do Canteiro-Escola foi então delineado por todos estes tempos conjugados em uma constante busca de equilíbrio. Seu formato em Oficinas surgiu da necessidade de estruturar as atividades em um curso longo o suficiente para contemplar as etapas de construção da casa, esticando o calendário ao longo de um ano, com as atividades ocorrendo nos finais de semana alternados.

Interessante notar que esses tempos encontram-se também conjugados com uma outra dimensão importante, que diz respeito aos "engajamentos" dos sujeitos participantes. Estes podem ser oriundos de uma outra articulação de elementos, tais como: os interesses, as disponibilidades, as necessidades, etc.

Os participantes articularam seus interesses com suas disponibilidades, de forma diferenciada da família, que tinha a construção da casa como uma necessidade. Seu engajamento é diferenciado de todos os outros, inclusive dos nossos, ligados à pesquisa, ensino e extensão. 
A longa duração do curso criou múltiplos tipos de participação. Entre eles, o público que foi mais pontual, indo menos vezes ao canteiro, com apropriação do processo diferenciada daqueles que foram de maneira mais regular. $\mathrm{O}$ apoderamento e a participação em processos decisórios também se deram de maneira diferenciada entre o sujeito que entrara no curso durante a Oficina 3 e outro que já participava desde seu início.

Uma forma encontrada para trabalhar com esta realidade, e que ainda precisa ser amadurecida e praticada, foi a valorização do processo de transformação constante do projeto. Mesmo que o sujeito não tivesse participado da concepção da casa durante o curso optativo, os detalhes construtivos e as decisões sobre os painéis de cobertura ou os painéis de parede, por exemplo, foram acertados no momento de sua etapa produtiva, abrindo a possibilidade dos questionamentos, das apropriações, de novas transformações e das decisões coletivas por aqueles que ali estavam trabalhando.

Os engajamentos pessoais também foram sendo descobertos e revelados ao longo do Canteiro-Escola. As figuras que muitas vezes se destacavam no processo, apareciam ou a partir de uma questão técnica, onde iam ganhando espaço pouco a pouco, na medida em que se posicionavam e resolviam situações adversas, ou a partir do acúmulo do processo vivido, se tornando referências para o grupo.

Como percebemos, os tempos do curso foram influenciados por diversos fatores que condicionaram seus ritmos e decisões de planejamento, o que explica em parte, as diferenças encontradas nas estimativas de comparação entre os tempos de produção do Canteiro-Escola e de um canteiro convencional.

Outra dimensão que deve ser compreendida reside nas naturezas constituintes dos dois tipos de canteiros. A produção da casa Suindara possui como característica essencial ser resultado de um trabalho não alienado. Ela não se constitui enquanto mercadoria, não está sendo produzida com valor de troca, mas sim com valor de uso. Sua finalidade social não é especulativa e seu processo produtivo não é orientado por uma perspectiva produtivista. Pelo contrário, a resistência às relações estabelecidas pela ordem capitalista de produção e o ensaio de superação da verticalidade estrutural da 
divisão do trabalho social, norteiam a organização das atividades e o processo de produção da casa.

As experimentações coletivas de produção se tornam espaços onde é possível praticar o exercício da autogestão do trabalho. Os participantes se distribuem em pequenos ou grandes grupos, se organizam em tarefas, discutem, planejam, executam, rediscutem, executam novamente, e assim, vão realizando sua práxis educativa, através do trabalho humanizado e autogerido.

Como ferramenta contra hegemônica, as práticas de autogestão visam, segundo Lia Tiriba Fischer, à constituição de uma cultura do trabalho que se contrapõe à racionalidade da cultura do capital.

"Como prática social e parte integrante de um projeto societário alternativo ao sistema capital, a autogestão materializa-se no exercício de tornar horizontais as relações que diversos produtores associados estabelecem entre si, no campo ou na cidade." (FISCHER, 2012, p.614)

Vale ressaltar que todas as estratégias e esforços de ação e reflexão convergem para a abertura a métodos produtivos que ofereçam perspectivas de desenvolvimento das capacidades e habilidades dos participantes. A prática manual e as reflexões em torno da identificação e solução de questões de relevância imediata, consistem numa ferramenta para o desenvolvimento de inteligências criativas, necessárias para o processo formador.

No canteiro-escola, nota-se a construção dos múltiplos papéis assumidos por cada um dos participantes ao engajarem-se nas responsabilidades colocadas em prática. São ao mesmo tempo aprendizes e facilitadores, pesquisadores e participantes, construtores e planejadores. Assim, batem pregos, descascam eucaliptos, desmontam paletes, organizam-se em grupos, discutem as estratégias de ação, realizam os detalhes construtivos, debatem sobre as dificuldades encontradas, o tempo necessário para a execução das tarefas, os benefícios e os riscos, questionam as técnicas escolhidas, inventam novos sistemas construtivos, indagam sobre as condições de vida na época do acampamento, se alimentam com a comida feita pela família, trocam receitas e riem das 
boas piadas, entre outros. Nesta progressão, vão se reconhecendo protagonistas dos processos de transformação da realidade da família assentada e de sua própria realidade.

Como podemos observar na tabela exposta, foram gastos cerca de $R \$ 11.000,00$ com a aquisição dos materiais de construção e alguns serviços necessários à obra, como por exemplo, a terraplanagem do terreno. $O$ valor inclui as doações realizadas pelos diferentes parceiros estabelecidos ao longo do curso. Somados a este valor, ainda é necessário adicionar todos os custos indiretos, de igual importância para a viabilização das atividades, como a produção dos painéis pedagógicos, o transporte dos participantes, a compra das ferramentas e equipamentos, entre outros, viabilizados pelas duas Instituições de Ensino relacionadas ao curso.

Já foram apresentados anteriormente os acordos instituídos com a família quanto ao aprovisionamento dos materiais e à participação da mão de obra. Esta última, absorveu os custos de transformação dos materiais através dos processos de formação realizados. O desenvolvimento de novos sistemas construtivos e a experimentação livre durante o curso optativo, foram de extrema importância para o amadurecimento da compreensão sobre o que estávamos fazendo ali no assentamento. Este momento (do curso optativo) preparou as bases para a ampliação e posterior transformação no curso do Canteiro-Escola.

As tecnologias produzidas no lote foram surpresas de grandes valias. Apontaram para uma perspectiva criadora e transformadora. Criadora, pois como experimentação livre possibilitou aos participantes imaginarem e desenharem suas tecnologias, refletindo em suas possibilidades, limites e inteligências. De maneira mais explícita, isso foi revelado durante o curso optativo, onde os participantes tornaram-se parte do próprio processo tecnológico. Aprenderam com os erros e incompreensões, buscaram alternativas e opções, retrabalharam, reconstruíram e produziram coletivamente soluções viáveis e criativas de novos sistemas construtivos a partir dos paletes disponíveis.

Transformadoras, pois as tecnologias apresentam condições para implicarem ou contribuírem com novas dinâmicas construtivas. Elas foram produzidas com os materiais disponíveis e encontrados facilmente na região, de modo a demonstrar os potenciais de sua utilização nas construções. As mesas de produção e uma série de ferramentas 
também foram produzidas no momento da necessidade, a partir dos materiais acessíveis. O nível do potencial transformador de tais processos tecnológicos (não somente em seus produtos) será revelado através da sua capacidade, com o decorrer do tempo, de se tornar referência, para outras famílias assentadas, para outros grupos sociais, para outras pesquisas acadêmicas, para outros projetos arquitetônicos, etc.

Estes exercícios de superação das dificuldades a partir da criação de soluções com os recursos locais, enriqueceram os processos de formação individual e coletiva do grupo. Facilitaram a compreensão da produção das tecnologias, não apenas como procedimentos técnicos, mas como processos sociais influenciados pelas dimensões econômicas, políticas e culturais.

"Então foi bem interessante isso, a gente ficava ali pensando, tentando, fazendo e no fim a gente tinha um projeto, e na hora de executar não era bem assim." (N. Balak, durante a Oficina 3)

Os painéis de cobertura e os painéis de parede em paletes consorciados com terra são tecnologias sociais concebidas, discutidas, criadas, desenvolvidas e produzidas no Canteiro-Escola, pelos participantes, junto com a família.

"Ele (G. Silva) acha soluções muito mais simples do que a gente pensou. (...) Muito mais simples e mais fácil. Como ele está na prática do dia a dia pensando em soluções e tal, ele acaba entendendo melhor os processos de produção." (L. Brunaldi, durante a Oficina 3)

Neste momento em que escrevo a tese, o curso Canteiro-Escola encerra as atividades de sua terceira Oficina. A casa Suindara ainda não está terminada. Os diferentes "tempos" descritos anteriormente, elementos da realidade dialética de nossa experimentação formadora, distanciou o processo de construção da casa desta tese de doutorado. Esta, se encontra em vias de conclusão, enquanto a casa, amplia suas perspectivas formadoras e planifica seus desdobramentos.

O processo está em curso, sabemos que ainda ocorrerão modificações no projeto, no calendário, nos detalhes construtivos, no ritmo das atividades, entre outros. E visto seu caráter dialético e provocador, tende ainda a render novas trocas e aprendizados. 
Cada um se descobre e descobre os outros, nossas capacidades e complementaridades se acumulam, se trocam, se inventam. Sonharíamos quase por uma casa nunca acabada, onde pudéssemos estar sempre a experimentar, uma experiência antes de tudo humana.

O habitat é tido não como uma finalidade em si, mas como potencializador de outras relações criadas localmente. A inserção da família no centro do processo de análise das necessidades e tomadas de decisões, estabeleceu um modo de organização produtiva, baseada na participação coletiva e valorização daquele que detinha maior conhecimento técnico aplicado sobre a realização construtiva - o próprio morador.

A casa Suindara consiste numa experimentação coletiva de produção do habitat popular rural. Uma prática formadora que dentro de sua realidade concreta vai sendo transformada e adaptada. Suas condições e formas manifestas foram sendo construídas no arranjo dialético entre as conjunturas dispostas e as possibilidades operadas.

O caráter da experimentação nos é próprio por natureza. Dentro do sistema capitalista de produção, as iniciativas que tendem contra sua hegemonia, ou acordam contentar-se com os limites sufocantes de suas lacunas, reveladas nas tensas relações de trabalho e produção, ou se esforçam incessantemente em rompê-la. O que se percebe historicamente é a capacidade demonstrada pela ordem estabelecida em absorver, assimilar e controlar estas iniciativas. Ainda não foram provocadas todas as condições necessárias à produção dos instrumentos que permitirão a construção do habitat em larga escala, para além do modelo produtivo dado. Assim, o caráter da experimentação se aproxima do caráter educativo, formador e crítico da produção arquitetônica.

Se a replicação for pensada a partir da dimensão de cursos acadêmicos de extensão universitária, os debates e as ações passam pela reavaliação dos programas pedagógicos e de formação contínua nas Instituições de Ensino. Se a replicação for estruturada através da dimensão da produção habitacional em assentamentos rurais, em conjunto com as famílias moradoras, os debates e as ações passam pela formulação e execução de políticas públicas habitacionais, de assistência técnica e de regularização fundiária. 
"Então, só para a gente entender que o que estamos fazendo aqui não é contra a possiblidade do Estado construir, porque isso talvez fosse o caminho legal, mas é que hoje a forma como está desenhada a política pública não permite. (...) Se a gente fosse utilizar o dinheiro da política pública, isso daqui não seria viável. Só para tentar entender porque. Porque do jeito que está desenhado o programa habitacional, eu acho que cerca $65 \%$ dos recursos são para a compra de material. E aí, o que puxa a compra? É o cimento, ferro, areia, etc. Tudo que já está consolidado pelo mercado da construção civil. Então são mercadorias que você vai lá na lojinha, compra e eles entregam aqui. (...) Estamos tocando em materiais que o modelo capitalista ainda não organizou em suas caixinhas técnicas." (C. Barros)

Este "experimentar", embora em estágio embrionário, contêm inspirações e aspirações transformadoras. Ele não rompe com a ordem estabelecida, nem se posiciona como modelo a ser seguido. Contudo, suas atividades alimentam questionamentos, debates, interpretações, inquietudes, e sobretudo, esboçam e tateiam pistas e outras práticas para novos processos de produção do habitat rural.

É portanto na realização do trabalho social, conciliado de sua práxis formadora, que a constituição do Canteiro-Escola humanizado se faz. Espaço onde os desconhecidos tornam-se sujeitos históricos e os conhecimentos ferramentas para a transformação social. 


\section{MOMENTO 5}

\section{SÍNTESE CONCLUSIVA}

"Não podemos deixar de ensaiar. Não podemos deixar de tentar. Não podemos deixar de experimentar, de recriar, renovar, questionar. Sob o risco de realizarmonos na unidade e não na coletividade, essência das culturas." (Paulo Freire, 2002)

"O saber que é poder não conhece barreira alguma, nem na escravidão da criatura, nem na complacência em face dos senhores do mundo." (Adorno, 1985) 


\section{Ressignificações e novas fronteiras}

Os diferentes Momentos deste trabalho abordaram uma série de perspectivas de análises sobre os processos de produção habitacional popular que, ao longo do tempo, transformaram seus significados e suas materializações, a partir de seus modelos e contextos societários. O delineamento analítico adotado articulou um conjunto de reflexões teórico-conceituais com o intuito de contribuir com a produção de conhecimentos, debates, planejamentos e práticas concretas a respeito da produção do habitat popular rural. Este, reinserido em seu contexto social e cultural local, assume na dimensão produtiva seu caráter formativo e conscientizador.

Sobre as arquiteturas vernáculas e culturas construtivas tradicionais, vimos como seus elementos estruturais se articulam e interagem, dinamizando e desenvolvendo uma cadeia produtiva acerca do habitat, inserido em seu território e conectado com seus contextos. Fruto e expressão de quem o produz, ele revela as marcas societárias e a relação de trabalho através de sucessivas gerações, constituindo-se como memória social e coletiva, expressão cultural material e imaterial, síntese dos conhecimentos e saberes técnicos e tecnológicos, que ao transformar a natureza, cria seus territórios, símbolos e modos de habitar.

As diversidades quantitativas e qualitativas das culturas construtivas tradicionais expuseram e demonstraram nos diversos ecossistemas existentes, sob diferentes projetos políticos, crenças religiosas e sistemas culturais, as mais variadas inteligências construtivas oriundas dos processos de adaptação, aprimoramento e desenvolvimento dos grupos sociais e suas relações com o meio ambiente. Acúmulos históricos e aperfeiçoamentos temporais, como respostas às exigências mutáveis dos diferentes períodos históricos, marcaram os processos de memorização e transmissão dos conhecimentos no interior de suas sociedades, codificados em sistemas educacionais e de representação social.

Os choques e conflitos, culturais e tecnológicos, entre as lógicas tradicionais de produção e a ordem contemporânea capitalista, evidenciam as desconstruções e transformações dos modelos e significados das produções dos habitats populares. Tais 
modelos, pouco a pouco influenciados e formatados pelo sistema produtivo hegemônico, orientam-se à acumulação do lucro máximo e à produção incessante, assegurando e controlando o trabalho cada vez mais alienado, e protegendo-se nos dispositivos legais, alinhados aos interesses do livre mercado de capitais.

A técnica planificada, racionalizada, controlada, globalizada e hegemônica, da ordem capitalista de produção, torna-se um instrumento de separação dos sujeitos produtores e seus objetos produzidos, alienados na forma de mercadorias de morar. ${ }^{146}$

Neste modelo produtivo, sufoca-se a liberdade criativa quando do predomínio da quantidade sobre a qualidade, da forma sobre o conteúdo, e dos instrumentos que insuflam a competitividade pelo rendimento em favor dos interesses financeiros. 0 controle das regras e processos, dos produtores e dos meios de produção, assegura a ordem estabelecida e configura novas culturas construtivas pautadas pelos princípios capitalistas de produção. ${ }^{147}$

Analisando as culturas construtivas tradicionais como dinâmicos processos socioculturais localizados, que expressam em suas realizações os conhecimentos, memórias e significados de seus grupos sociais, reforçamos o olhar orientado para os saberes construtivos tradicionais e seus potenciais adaptativos e transformadores. Novas criações, invenções, usos e aprimoramentos encontram inspiração naquilo antes demonstrado e reproduzido, agora resignificado e inserido em novas realidades.

A produção de novas tecnologias possui relações intrínsecas aos ideais, valores, particularidades e bagagens históricas de seu grupo social. Assim como, com as tensões, contradições, ambiguidades e relações de força e poder. O desafio reside na busca por estabelecer diálogos entre os elementos e as variáveis existentes para a produção de

\footnotetext{
${ }^{146}$ Segundo Herbert Marcuse (1996, p.122), "A racionalidade, antes uma força crítica, transforma-se numa força de ajustamento e submissão. A autonomia da razão perde seu significado na mesma medida em que os pensamentos, sentimentos e ações dos homens são moldados pelas exigências técnicas do aparato por eles mesmos criado. A razão encontrou seu túmulo no sistema de controle, produção e consumo padronizados. Neste lugar, ela reina através das leis e mecanismos que garantem a eficácia, a eficiência e a coerência do sistema."

147 Segundo Sérgio Ferro, $(2005$, p.56) "Num tempo em que as coisas definem os possuidores, deixar aparecer que as coisas encobrem relações de exploração e violência é subverter a ordem. Há que apagar o trabalho revelador; mas como para isso é necessário trabalho, nada melhor do que trabalhar com trabalho esvaziado."
} 
novas tecnologias e os elementos e as variáveis necessárias para o desenvolvimento de novas culturas construtivas localizadas.

O canteiro habitacional analisado ao longo do Momento 4 apresentou em suas perspectivas de realização, aproximações entre o processo de produção arquitetônica e de formação técnica e científica, dentro da realidade social de um território rural. Os espaços de debates, aprendizagens e tomadas de decisões ocorreram no próprio canteiro de trabalho, entre a família moradora e os participantes das atividades. Nestas condições, o processo formativo se revelou na forma do trabalho social, que por sua vez, se fundamentou enquanto princípio educativo.

No Canteiro-Escola, foram experimentadas práticas coletivas e participativas de relação e organização do trabalho. O morador, trabalhador da construção civil, assumiu uma posição central nos processos dialógicos de ensino e aprendizagem das práticas construtivas, dos gestos do trabalho e uso dos equipamentos e ferramentas. Na medida em que os futuros arquitetos e profissionais apreendiam e praticavam o ato construtivo, amadureciam suas reflexões questionadoras a respeito das práticas hegemônicas de produção, alimentando, em sua negação, novas perspectivas e outros questionamentos. ${ }^{148}$

Trabalhando nas mais variadas tarefas, os participantes se organizavam autonomamente, respeitando seus tempos e aptidões. Traçavam suas compreensões sobre o conjunto das atividades realizadas e suas relações com o contexto do canteiro e do lote da família, assim como, sobre as escolhas técnicas assumidas e sobre os calendários possíveis de atividades.

No tocante aos materiais de construção, a adoção e utilização daqueles encontrados no local e entorno, potencializou a perspectiva criativa e inovadora do Canteiro-Escola. A transformação de materiais naturais e descartados, e seu uso na construção da nova habitação, propiciou o desenvolvimento de tecnologias sociais locais e sustentáveis, além de permitir o aprofundamento dos debates técnicos, dos

\footnotetext{
${ }^{148}$ Segundo Sérgio Ferro (2005, p.126), “A evolução provável do projetista e do executante separados passa pela sua negação, negação que será gênese de uma nova manifestação do construtor em unidade superior (e não em regressão à figura mítica do artesão, unidade ainda abstrata do fazer e do pensar). Impossível sua apreensão antecipada: só no formar-se proporá o que será."
} 
questionamentos construtivos e das aprendizagens coletivas. Neste processo, foram as propriedades intrínsecas aos materiais as orientadoras dos sistemas construtivos propostos e escolhidos.

As ações mencionadas ganham em potencialidades transformadoras quando inseridas no campo pedagógico, nas dimensões da extensão universitária, gratuita e aberta aos estudantes, profissionais e ao público em geral. Sob a forma de um CanteiroEscola, a produção do habitat não se insere dentro das especulações de mercado. Sua produção não gera lucro nem mais valia, possui valor de uso e não se realiza enquanto mercadoria. Seus processos, nestes termos, abrangem a concepção dos projetos arquitetônicos, a escolha dos materiais e das técnicas construtivas, a organização e as relações de produção, a criação de tecnologias sociais, as práticas construtivas e análises críticas, entre outros. ${ }^{149}$

Os participantes trabalham o conjunto do processo produtivo, participam de todas as etapas construtivas, tecem uma visão global a partir de suas próprias experiências, interagindo autônoma e conscientemente com as equipes de trabalho, e fomentando suas curiosidades criativas na medida em que desvendam e se apropriam das engrenagens dos processos produtivos.

Esta linha reflexiva reforça a importância de alimentar a compreensão crítica da busca pelo "novo", através do "experimentar" que permite o "inventar". Em sua manifestação objetiva e pragmática, o presente ao vislumbrar o futuro carrega o que há de velho. Será na redescoberta dos velhos conteúdos em novas leituras, que o novo será criado. Na compreensão crítica do diferente, do processo dialético de continuar modificando-se, a síntese alimenta o processo evolutivo e fomenta, nos novos processos de produção, sua realização através da verdadeira práxis social, consciente, esclarecida e emancipada.

\footnotetext{
${ }^{149}$ Segundo Khalid Andaloussi (in Thiollent, 2004, p.143), "A produção do saber didático está intimamente vinculada à produção do saber praxiológico. A articulação entre o momento de reflexão e análise e o momento de produção de saber e saber-fazer constitui a base da elaboração teórica e do aperfeiçoamento do saber-prático. A produção do saber praxiológico elabora-se quando os pesquisadores questionam a ampliação do conhecimento relativo à ação, com o intuito de compreender sua lógica e de propor os meios de desenvolver a prática."
} 
Nesta dimensão da produção arquitetônica torna-se imprescindível pensar a questão das arquiteturas vernáculas, a partir de uma perspectiva de classe, com referência às relações e redes de força e poder. Os sentidos, significados, objetivos e a forma como as arquiteturas são produzidas, estabelecem-se dentro dessas disputas. Por integrar os poderes econômicos e políticos, a cultura dominante tende a impor e assegurar sua hegemonia às demais expressões culturais, transformando-as ou assimilando-as às suas vontades.

O exercício não é pensar e definir o que são arquiteturas vernáculas contemporâneas. O interesse reside em refletir sobre seus fenômenos de produção a partir das múltiplas relações entre os elementos chaves de seu desenvolvimento e as dinâmicas evolutivas societárias, tendo em vista uma crítica consciente e uma prática concreta. O compromisso se constrói na dimensão limite entre o possível e o desejável, em um campo dinâmico e dialético.

No caso da experiência da Casa Suindara, as atividades apresentaram condições e resultados correspondentes a sua situação específica e localizada. É na relação entre as situações particulares e as atividades concretas que torna-se possível e coerente a generalização teórica tecida. No âmbito dos assentamentos rurais de reforma agrária no Brasil, sua construção - processo social e coletivo - ganha força quando articulada à perspectiva de constituição de um território do assentamento. Este, resultado de conflitos e conquistas, se constrói através das constantes tensões entre os diferentes projetos políticos para o mundo rural brasileiro.

A organização espacial é condição fundamental para a consolidação do território do assentamento rural, estabelecendo as formas e as maneiras como os assentados constroem suas estratégias de produção e reprodução das relações sociais, familiares e comunitárias. Estas, adaptadas e dependentes de suas relações com a natureza local têm, em sua forma específica de lidar com ela, sua organização produtiva e social. O consumo de água, a produção de resíduos, a distribuição dos lotes, as áreas de reserva e preservação ambiental, as áreas de uso coletivo e suas funções, o escoamento da produção, a mobilidade, entre outras questões, são projetos sociais, culturais, políticos, 
econômicos e ambientais que vem marcando, na medida do possível, os debates em torno da consolidação e desenvolvimento dos assentamentos rurais.

Estes territórios vão se constituindo e apresentando novas dinâmicas qualitativas articuladas aos novos significados que o mundo rural adquire a respeito de suas relações com a natureza e com o meio urbano. Os processos de transformação passam por uma renovação a respeito dos valores da vida rural.

Essa reinterpretação universaliza o rural, agora também globalizado e urbanizado, tecnificado, civilizado, industrializado e capitalizado. Possui sua imagem transformada e conformada pela revalorização da natureza. Os fenômenos de migração da classe média para o campo, a busca por alimentos saudáveis, a necessidade de preservação do patrimônio natural, o controle aos impactos e abusos ambientais, o fortalecimento das agriculturas familiares, os resgates de tradições culturais, entre outras ações, vão descontruindo as antigas imagens e símbolos do rural oposto e tensionado ao urbano, minimizando suas dicotomias e articulando seus territórios. ${ }^{150}$

O resultado não significa o desaparecimento do rural, mas sua inevitável transformação dentro das dinâmicas das sociedades. As potencialidades residem nos pactos urbano-rurais tecidos e na constituição de novas relações estabelecidas pelas identidades, heterogêneas e dinâmicas, que os territórios rurais passam a compreender em seus significados.

O cenário econômico das famílias assentadas indica a exclusão social que estas estão sujeitas e requer políticas públicas que atendam às reivindicações coletivas (moradia, infraestrutura, produção, comercialização, cooperativismo, etc.) e que sejam abertas às alternativas adequadas em busca da permanência e do aumento da qualidade de vida das famílias rurais. No que concerne a dimensão habitacional, é necessária a implementação de políticas públicas que considerem no acesso a moradia de qualidade, as múltiplas dimensões da sustentabilidade (política, econômica, social, cultural e

\footnotetext{
${ }^{150}$ Segundo Roberto Moreira (2007, p.319), "No contexto do pensamento ecológico contemporâneo o rural experimenta uma ressignificação sociopolítica. Nesse quadro, as representaçães sobre o rural deixariam de ser elaboradas a partir de categorias opositivas em relação ao urbano para se firmarem em valores de cunho ambiental e cultural, de cunho universal."
} 
ambiental), enfatizando a participação das famílias na tomada de decisões, nas gestões dos processos e nas etapas de produção das habitações.

A reinserção, com novos significados, dos contextos locais, culturais e naturais, no processo de produção habitacional, questiona os modelos gerais estabelecidos para instaurar novas linguagens, práticas, relações e resultados. Como o habitat pode reconectar-se com as culturas locais e contribuir com novas práticas territoriais? Algumas pistas residem nas dimensões sufocadas pela racionalidade produtiva do sistema capitalista de produção, a saber: humanas, culturais, simbólicas e ecológicas. A produção habitacional é considerada assim como fato cultural, com responsabilidade social e ambiental, processo da ação transformadora, criativa e consciente do trabalho, exercida por indivíduos culturais associados, e reveladora de linguagens que marcam o tempo.

Percebendo a centralidade do trabalho como práxis dialética entre a ação e o pensamento, a teoria e a atividade prática, sua realização permite a experimentação e a (re)criação, nas dimensões culturais e artísticas, de linguagens e símbolos como elementos chaves dos processos produtivos. As potencialidades residem na capacidade de organização e gestão coletiva de seus processos, e no grau de formação e conscientização estabelecido.

Segundo Hermán E. Thomas, o desenvolvimento de tecnologias sociais costuma caracterizar-se por intensiva aplicação de operações de "ressignificação" de tecnologia, ou seja, operações de "reutilização" criativa de tecnologias previamente disponíveis. Essas operações não são meras alterações "mecânicas", mas uma "re-atribuição" de sentido e de seu meio de aplicação. ${ }^{151}$

"A inclusão das culturas locais, é absolutamente relevante na dinâmica de construção do funcionamento das tecnologias sociais. Isto não implica restringir as possibilidades de desenvolvimento tecnológico aos padrões da cultura do grupo beneficiário, mas registrar o potencial aproveitamento

\footnotetext{
151 Segundo THOMAS (2009), "Ressignificar tecnologias é refuncionalizar conhecimentos, artefatos $e$ sistemas. O conhecimento requerido é, em muitos casos, da mesma índole que o que exige, por exemplo, a fabricação da maquinaria original, e é similar em suas condições e características com a atividade de projeto básico. As operações de ressignificação de tecnologia situam-se na interface entre as ações sociais de desenvolvimento tecnológico e as trajetórias tecnológicas de dinâmica sócio técnica."
} 
dos conhecimentos locais (codificados e tácitos), em combinação com outros conhecimentos (codificados e tácitos), gerando ainda terceiros conhecimentos." (THOMAS, 2009)

Nesta perspectiva, a ressignificação tecnológica fundamentada no trabalho cooperado fomenta a prática da autogestão coletiva, favorecendo a descentralização das decisões, as formas autônomas de trabalho e o empoderamento dos trabalhadores em suas atividades produtivas. A criação e recriação da realidade busca conferir humanidade aos materiais e às coisas através das representações e simbologias que são produzidas sobre o mundo.

A metamorfose do trabalho, segundo André Gorz (2010, p.51), o transformará em uma colaboração social racional de indivíduos, em substituição à divisão capitalista do trabalho, submetendo o processo social de produção ao controle dos produtores associados. Segundo ele, "a poïésis coletiva não é mais trabalho de indivíduos serializados e especializados mas atividade autônoma de indivíduos colaborando conscientemente $e$ metodicamente."

Nesta práxis do trabalho emancipatório, o processo educativo e formador é condição essencial do esforço conscientizador, não mais centrado no sujeito individual, mas ancorado na pluralidade do coletivo e dos projetos comuns. A possibilidade de se entender o processo formador como trabalho social opõe-se à visão fragmentada do trabalhador em relação ao processo produtivo capitalista, determinada pela divisão social do trabalho. A superação da alienação gerada pela não posse do produto do trabalho por seus produtores, engendra um processo de apropriação dos trabalhadores quanto à compreensão crítica de sua práxis concreta, fortalecendo a relação entre a teoria e a prática social em prol do desenvolvimento coletivo.

$\mathrm{Na}$ medida em que o trabalho é apreendido como dimensão educativa, modificam-se as relações do homem com a natureza, e assim seus processos produtivos, sentidos, significados, métodos e intensões. A integração trabalho-formação, conjugadas em sua práxis transformadora, articula-se aos processos dinâmicos societários de produção de novas arquiteturas vernáculas, repensadas, renovadas e transformadas continuamente, dialeticamente. 
Esse processo necessita realizar-se objetivamente através de elementos concretos tecidos pela construção social de sua compreensão crítica. A experimentação e a criação assumem grande importância no exercício prático do desenvolvimento das capacidades de adaptação e inovação face ao atual contexto societário, alimentando o amadurecimento de um novo projeto de arquitetura re-localizada, que tende a redescobrir-se, reinventando seus modos de habitar.

Sobre a capacidade de superação de sistemas estabelecidos, o próprio processo histórico-social já mostrou suas possibilidades. A matriz dos questionamentos reside na operacionalização dos processos produtivos das arquiteturas vernáculas no momento contemporâneo, com suas condições, relações e perspectivas. Neste sentido torna-se importante compreender a "re-localização" do habitat não como uma forma de embuti-lo em uma situação geográfica onde seus contextos representam restrições a serem minimizadas pelo projeto. Sua inserção territorial representa, ao contrário, a integração do contexto específico em adequação e ressonância com as culturas e as identidades, a morfologia e as paisagens, estabelecendo um pacto pelo território, entre cultura e natureza.

O esforço também se orienta na direção de uma melhor compreensão das marcas deixadas pelas sociedades anteriores, expressas em suas formas de produzir e viver seus habitats. Reciclando e reinterpretando certas tradições construtivas, simbólicas ou práticas, novas respostas arquitetônicas são fabricadas e aportadas, criando outras linguagens e resolvendo questões específicas. ${ }^{152}$

Nas contradições entre capital e trabalho, local e global, cultura e natureza, autonomia e dependência, único e múltiplo, tradicional e moderno, o reconhecimento do patrimônio converge às energias inovadoras, valorizadoras dos recursos humanos, naturais e identitários. Esse processo, que Jean-Paul Loubes (2010) intitula como "consciência de lugar" designa, segundo ele, o reconhecimento pela comunidade

\footnotetext{
${ }^{152}$ Segundo o professor Hubert Guillaud (CRAterre), em seus cursos sobre as culturas construtivas (2008), "A capacidade de recriar a partir de um fundo patrimonial de culturas construtivas que seria reinterpretado, privilegiando a contextualização (física e cultural) da resposta ao habitat, parece ser uma via de abertura na qual se engajar. Seria então necessário estar em capacidade de identificar as verdadeiras inteligências destas culturas construtivas, especialmente suas capacidades de lidar de forma econômica (otimização de despesas e consumações de diversas naturezas) com os recursos naturais como com suas restrições, e com a economia das sociedades."
} 
estabelecida, do valor patrimonial territorial nos processos de emancipação humana e de autodeterminação do território e de sua natureza.

Os elementos estruturantes dos fenômenos de produção das arquiteturas vernáculas contemporâneas necessitam ensaiar desconstruções e reorganizações na ordem estabelecida. Às suas práticas construtivas cabem a incumbência de criar condições de fortalecimento das identidades particulares com uma nova apropriação do saber-fazer tradicional em sua adaptação ao momento contemporâneo, através especialmente, de experiências pedagógico-conscientizadoras e político-emancipatórias.

Estas perspectivas, fundamentadas nos conteúdos tratados ao longo dos diferentes Momentos deste trabalho, contribuem para o esclarecimento das condições que envolvem nossos questionamentos de pesquisa. As produções locais de expressão e desenvolvimento de novas arquiteturas vernáculas são pautadas pelos esforços de restabelecimento das relações essenciais com os territórios, inseridas, evidentemente, numa orientação de superação do trabalho alienado e heteronomamente controlado.

Os processos experimentais, criativos, participativos e coletivos, buscam romper com a ordem estabelecida, reaproximando o trabalho de seus princípios educativos e culturais. Tornam-se dimensões condicionantes para outras práticas de produção do habitat, inseridas em seu tempo, espaço e significado histórico. Somente por meio do mais ativo e constante envolvimento da educação no processo de trabalho, estarão sendo potencializadas as condições essenciais de desenvolvimento recíproco e consciente entre indivíduo, sociedade e natureza. ${ }^{153}$

No desafio por restabelecer as conexões fundamentais com os territórios, a condição consciente dos produtores livres e associados, indica possibilidades abertas para a apropriação plena dos processos produtivos. A organização coletiva e solidária do trabalho social, fortalecida em suas potencialidades transformadoras, experimenta a relação trabalho/formação através do desenvolvimento de tecnologias sociais locais e

153 Segundo István Meszaros (2008, p.104), “(...) a liberação criativa e a participação produtiva só são concebiveis pelo entendimento apropriado da natureza das tarefas envolvidas, incluindo sua raison d'être histórica, e ao mesmo tempo pela percepção da necessidade de aceitar de forma consciente a grande responsabilidade inseparável de um modo plenamente participativo de regular sua ordem social em uma base sustentável." 
sustentáveis. O rigor investido nas análises da realidade social onde se desenvolve a práxis construtiva, incita a apontar para um processo produtivo onde, para além de seu produto (casa), possam ser articuladas dinâmicas de sociabilidades identitárias, com valores rurais e urbanos (territoriais) e com espaços de disputas e assimetrias culturais e políticas.

No intuito de compreender o caráter e o conteúdo ontológico do lugar/território, novas arquiteturas vernáculas, inseridas em processos contemporâneos de produção, constituem-se como expressões de processos socioculturais influenciados pelas dinâmicas, constantes e necessárias, de adaptação e aprimoramento aos contextos temporais e espaciais, dialéticos e históricos.

"Um renascimento se impõe então, mediante a novos atos fecundadores, capazes de produzir novamente o território, ou melhor, novas relações férteis entre os estabelecimentos humanos e o meio natural. São nesses atos recriadores de territórios que reside o germe de um desenvolvimento realmente sustentável." (MAGNAGHI, 2003, p.07)

Precisamos reinventar os meios de representar nossas arquiteturas vernáculas nas materializações de nossas culturas populares. E, provocá-las objetivamente. Veremos aí o ato de criação reapoderando-se nas mãos do popular consciente. 


\section{BIBLIOGRAFIA CITADA}

ABRAMOVAY, Ricardo, 1992. Paradigmas do capitalismo agrário em questão. São Paulo; Rio de Janeiro; Campinas [Brasil]: Editora Hucitec ; ANPOCS ; Editora da Unicamp.

ADORNO, Theodor W., HORKHEIMER, Max, 1985. Dialética do esclarecimento: fragmentos filosóficos. Rio de Janeiro: J. Zahar.

ANDALOUSSI, Khalid El, 2000. Recherches-actions : sciences, développement, démocratie. Paris : Publisud.

ANDALOUSSI, Khalid El, 2004. Pesquisas-ações: Ciência, Desenvolvimento, Democracia. São Carlos: EdUFSCAR.

ARANTES, Pedro Fiori, 2008a. "O lugar da arquitetura num planeta de favelas ». In: Dafne editora. mars 2008. $\mathrm{n}^{\circ} 11$.

ARANTES, Pedro Fiori, 2008b. "Qual futuro para o Canteiro Experimental? ». In: Canteiro experimental: 10 anos na FAU USP. São Paulo: FAUUSP.

ARCHITECTURE \& CULTURES CONSTRUCTIVES, 1995. Pôle d'enseignement de la construction. L'évidence d'un grand projet. Protocole de présentation du projet des "Grands Ateliers". Paris.

AXELOS, Kōstas, 1961. Marx, penseur de la technique; de l'aliénation de l'homme à la conquête du monde. Paris : Éditions de Minuit.

BARROS, Francisco, 2008. "Canteiro Experimental da FAU e o Canteiro - Cooperativa de Construção ". In: Canteiro experimental : 10 anos na FAU USP. São Paulo: FAUUSP.

BECKER, Howard S., 2007. Segredos e truques da pesquisa. Rio de Janeiro (RJ): ZAHAR.

BENDAKIR, Mahmoud, 2008. Architectures de terre en Syrie : une tradition de onze millénaires. Grenoble : Éd. CRATerre-ENSAG, 2008.

BERGAMASCO, Sônia Maria, NORDER, Luiz Antônio Cabello, 1996. O que são assentamentos rurais. São Paulo: Editora Brasiliense.

BOGO, Ademar, 1999. Lições da luta pela terra. Salvador: Memorial das Letras.

BRANFORD, Sue, ROCHA, Jan, 2003. Rompendo a cerca: a história do MST. São Paulo: Casa Amarela.

BRASIL, 1966. Estatuto da terra. Brasília: Serviço de Documentação do M.T.P.S.

BRAVERMAN, Harry, 1981. Trabalho e capital monopolista: a degradação do trabalho no século XX. Rio de Janeiro (RJ): Zahar.

BRECHT, Bertolt, 1967. Teatro dialético. Rio de Janeiro: Civilização brasileira. 
CARDOSO, Ciro Flamarion Santana, 1980. Agricultura, escravidão e capitalismo. Petrópolis: Editora Vozes.

CASTELLS, Manuel, 1972. La question urbaine. Paris : F. Maspero.

CRATERRE, [s.d.]. Architecture et Paysage Betammaribe. [s.I.] : Ambassade de France au Bénin.

CRATERRE ET CULTURES CONSTRUCTIVES, Laboratoires, 2011. Contribution de l'Unité de Recherche AE\&CC - Architecture, Environnement \& Cultures Constructives à I'Evaluation de l'E.D. $n^{\circ} 454$ (SHPT) par le HCERES. Grenoble : Ecole Nationale Supérieure d'Architecture de Grenoble (ENSAG).

DAGNINO, Renato, (org.), 2010. Tecnologia social: ferramenta para construir outra sociedade. $2^{\circ}$. Campinas/SP: Komedi.

DAGNINO, Renato et al., 2012. Tecnologia social: ferramenta para construir outra sociedade [en ligne]. [s.I.]: University National of Campinas (Unicamp), São Paulo, BR, 2012. Disponible sur: < http://hdl.handle.net/10625/47974 > (consulté le 11 mai 2014).

DAVIS, Mike, 2006. Planeta favela. São Paulo: Boitempo.

DELGADO, Guilherme Costa, 1985. Capital financeiro e agricultura no Brasil, 1965-1985. São Paulo, SP, Brasil; Campinas, SP: Ícone Editora ; Editora da UNICAMP.

DICKSON, David, 1978. Tecnología alternativa y políticas del cambio tecnológico. Madrid: H. Blume.

ÉQUIPE CULTURES CONSTRUCTIVES, 2005. Rapport d'Activité Scientifique, évaluation du programme pluriannuel 2002-2005. Grenoble : ENSAG.

FERNANDES, Bernardo Mançano, 2000. A formação do MST no Brasil. Petrópolis: Editora Vozes.

FERNANDES, Bernardo Mançano, 2012a. "Acampamento ». In: CALDART, Roseli Salete (org.), Dicionário da Educação do Campo. São Paulo: Expressão Popular.

FERNANDES, Bernardo Mançano, 2012b. « Movimento dos Trabalhadores Rurais Sem Terra (MST) ». In: CALDART, Roseli Salete (org.), Dicionário da Educação do Campo. São Paulo: Expressão Popular.

FERRO, Sérgio, 2005 ( $3^{\circ}$ Ed.). O canteiro e o desenho. São Paulo (SP): Editor Vicente Wissenbach. Primeira edição: 1982.

FERRO, Sérgio, 2005. Dessin / Chantier. Paris : Edition de la Villette. Sous la responsabilité éditoriale de Vincent Michel.

FERRO, Sérgio, 2002. Arquitetura e luta de classes: uma entrevista com Sérgio Ferro. CRÍTICA MARXISTA 15. 2002. [s.l.]: [s.n.]. 
FERRO, Sérgio, 2006. Arquitetura e trabalho livre. São Paulo, SP: Cosac Naify.

FERRO, Sérgio, 2008. "Experimentação em arquitetura: práxis crítica e reação conservadora ». In: Canteiro experimental: 10 anos na FAU USP. São Paulo: FAUUSP.

FINDELI, Alain, 2012. "Les chercheurs dans nos campagnes: Pour une recherche architecturale par le projet ». In : Espace Rural \& Projet Spatial : Du terrain à la recherche: objets et stratégies. France: Publications de I'Université de SaintEtienne.

FINDELI, Alain, COSTE, Anne, 2007. De la recherche-création à la recherche-projet: un cadre théorique et méthodologique pour la recherche architecturale [en ligne]. 2007. [s.l.] : Lieux communs, $\mathrm{n}^{\circ} 10$. Disponible sur: < http://hal.archivesouvertes.fr/hal-00978330 > (consulté le 29 septembre 2014).

FISCHER, Lia Tiriba, 2012. " Produção associada e autogestão ». In: CALDART, Roseli Salete (org.), Dicionário da Educação do Campo. São Paulo: Ed. Expressão Popular.

FOLZ, Rosana, 2012. Análise das estratégias, possibilidades e obstáculos para produção coletiva da habitação e infraestruturas para saneamento ambiental mais sustentáveis em assentamentos rurais, Assentamento Rural Sepé Tiaraju - Serra Azul - SP. Relatório final de Pós-doutorado. São Carlos: Universidade de São Paulo, IAU/USP.

FRANCISCO, Scott, 2007. "The Way We Do Things Around Here: Specification Versus Craft Culture in the History of Building ". In: American Behavioral Scientist. mars 2007. Vol. 50, p. 970-988.

FRANCO, Maria Amélia S., 2005. "Pedagogia da Pesquisa-Ação ». In: Educação e Pesquisa. set./dez. Vol. 31, n³, p. p. 483-502.

FREIRE, Paulo, 1970. Pedagogia do oprimido. Rio de Janeiro: Paz e Terra, 1970.

FREIRE, Paulo, 1997. Pedagogia da autonomia: saberes necessários à prática educativa. São Paulo: Paz e Terra.

FREIRE, Paulo, FAUNDEZ, Antônio, 1985. Por uma pedagogia da pergunta. Rio de JaneiroRJ: Paz e Terra.

FREY, Pierre, 2010. Pour une nouvelle architecture vernaculaire. [Arles] : Actes sud.

FRIGOTTO, Gaudêncio, CIAVATTA, Maria, RAMOS, Marise, 2005. "O Trabalho como princípio educativo na educação integral dos trabalhadores ». In: Educação Integral e Sistema de reconhecimento e certificação educacional e profissional. São Paulo: Escola Sindical São Paulo - CUT. p. 19-62.

FUNDAÇÃO JOÃO PINHEIRO, CENTRO DE ESTATÍSTICA E INFORMAÇÕES, BRAZIL, et al., 2013. Déficit habitacional no Brasil: municípios selecionados e microrregiões 
geográficas. Belo Horizonte: Fundação João Pinheiro, Governo de Minas Gerais.

GORZ, André, 1988. Métamorphoses du travail quête du sens, critique de la raison économique [en ligne]. Paris: Galilée, 1988. Disponible sur: http://catalog.hathitrust.org/api/volumes/oclc/20724755.html (consulté le 11 mai 2014).

GRAMSCI, Antônio, 2000. Cadernos do cárcere. Rio de Janeiro (RJ): Civilização Brasileira, 2000.

GUÉGUEN PERRIN, Anaïs, LOPES FERREIRA, Thiago, 2010. Chantier formation et amélioration de l'habitat dans les camps de réfugiés sahraouis. Mémoire du Diplôme de Spécialisation et d'Approfondissement - Architecture de Terre. Grenoble : Ecole Nationale Supérieure d'Architecture de Grenoble (ENSAG).

GUIDONI, Enrico, 1995. Architecture primitive. Paris : Gallimard-Electa.

GUILLOT, Xavier, 2012. Espace rural \& projet spatial. objets et stratégies vol 3. SaintEtienne : Publications de l'université de Saint-Etienne.

GUILLOT, Xavier, BUTTION, Pierre, CHOMIENNE, François, 2010. "De I'architecture au territoire: une expérience d'enseignement pluridisciplinaire au parc naturel régional des volcans d'Auvergne ". In : Espace Rural \& Projet Spatial : Réflexions introductives / stratégies pédagogiques. France: Publications de I'Université de Saint-Etienne.

GUILLOT, Xavier, CHÉNOT, Martin, ECOLE NATIONALE SUPÉRIEURE D'ARCHITECTURE (SAINT-ETIENNE) (dir.), 2010. Espace rural \& projet spatial : réflexions introductives, stratégies pédagogiques. Saint-étienne : Publications de l'Université de Saint-étienne.

GUIMARAES, Alberto Passos, 1963. Quatro séculos de latifúndio. São Paulo: Fulgor.

HABERMAS, Jurgen, 1968. Técnica e ciência como ideologia. Lisboa: Edições 70.

HABIS, Grupo de pesquisa, 2013. Projeto Escola de Construção - IAUUSP: formação profissional, produtos e processos inovadores. 2013. [s.I.] : [s.n.].

HEGEL, Georg Wilhelm Friedrich, 2008. A arquitetura. São Paulo: EDUSP.

HEILBRONER, Robert L., 1988. A natureza e a lógica do capitalismo. São Paulo (SP): Ática.

HEREDIA, Beatriz Maria Alásia de, 1979. A morada da vida: trabalho familiar de pequenos produtores do Nordeste do Brasil. Rio de Janeiro: Paz e Terra.

HERRERA, Amilcar O., 2010. "La generación de tecnologías en las zonas rurales ». In: DAGNINO, Renato (org.), Tecnologia social: ferramenta para construir outra sociedade. $2^{\circ}$. Campinas: Komedi.

HIJIOKA, Akemi, 2013. Canteiro Escola: Taipa Japonesa. Relatório Final de bolsa de 
pesquisa, Pró-Reitoria de Cultura e Extensão Universitária. São Carlos: Instituto de Arquitetura e Urbanismo - IAU, Universidade de São Paulo.

HILLER, Bill, 1971. Au-delà du fonctionnalisme: réflexions sur l'architecture socialdémocrate en Grande-Bretagne. [s.l.] : Maspero.

INDONESIA, from Jayapura, 2006a. Treehouse of the Korowai tribe in Papua New Guinea. [en ligne]. 22 juillet 2006. [s.l.]:[s.n.]. Disponible sur: http://commons.wikimedia.org/wiki/File:Korowai_Treehouse.jpg?uselang=fr (consulté le 28 mars 2014).

INDONESIA, from Jayapura, 2006b. Treehouse of the Korowai tribe in Papua New Guinea. [en ligne]. 23 juillet 2006. [s.I.]:[s.n.]. Disponible sur: http://commons.wikimedia.org/wiki/File:Korowai_Treehouse_3.jpg (consulté le 28 mars 2014).

INO, Akemi, 2008. Tecnologias em habitação social, pesquisa simultaneamente à intervenção na realidade social (extensão) e formação de pessoas (ensino): Uma reflexão da minha trajetória na Universidade Pública. Memorial de Livre Docência. São Carlos: Instituto de Arquitetura e Urbanismo - IAU, Universidade de São Paulo.

INO, Akemi, SHIMBO, Ioshiaqui (coord.), 2007. O encontro de famílias e assessores: organizando grupos para projetos de habitação rural. 2007. [s.l.]: Caixa Econômica Federal.

JOFFROY, Thierry, DJANGUENANE, Nayondjoua, UNESCO, et al., 2005. Koutammakou : les pays des Batammariba : ceux qui façonnent la terre. Grenoble : CRATerre Editions.

KAPP, Silke, BALTAZAR, ET.AL., Ana Paula, 2012. " Arquitetos nas favelas: três críticas e uma proposta de atuação ". In: IV Congresso Brasileiro e III Congresso IberoAmericano Habitação Social: ciência e tecnologia. Florianópolis: [s.n.], 12 novembro.

KEESING, Felix Maxwell, 1961. Antropologia cultural. Rio de Janeiro: Fundo de Cultura.

KONDER, Leandro, 2007. O que e dialética. São Paulo (SP): Brasiliense.

LAFFON, Martine, LAFFON, Caroline, 2004. Habitat du monde. Paris : Éditions de La Martinière.

LARAIA, Roque de Barros, 1986. Cultura: um conceito antropológico. Rio de Janeiro: J. Zahar Editor.

LEFEBVRE, Henri, 1979. Lógica formal, lógica dialética. Rio de Janeiro (RJ): Civilização Brasileira.

LEITE, Sérgio Pereira, 2012. "Assentamento rural ». In: CALDART, Roseli Salete (org.), Dicionário da Educação do Campo. São Paulo: Expressão Popular.

LEITE, Sérgio Pereira, 2004, INSTITUTO NACIONAL DE COLONIZAÇÃO E REFORMA 
AGRÁRIA, NEAD (ORGANIZATION : BRAZIL). Impactos dos assentamentos: um estudo sobre o meio rural brasileiro. Brasília; São Paulo: Ministério do Desenvolvimento Agrário, INCRA : NEAD ; Editora UNESP.

LEMOS, Carlos Alberto Cerqueira, 1989. História da casa brasileira. São Paulo, SP: Editora Contexto.

LINHARES, Maria Yedda Leite, SILVA, Francisco Carlos Teixeira, 1999. Terra prometida: uma história da questão agrária no Brasil. Rio de Janeiro, RJ, Brasil: Editora Campus, 1999.

LINS, Lucicléa Teixeira, MELO NETO, José Francisco, 2010. « A Contribuição da Educação do Campo Para o Fortalecimento de uma Cultura Autogestionária ». In: III Encontro Nacional de Pesquisa em Educação do Campo. Brasília: [s.n.].

LOUBES, Jean-Paul, 2010. Traité d'architecture sauvage: manifeste pour une architecture située. Paris : Ed. du Sextant.

MAGNAGHI, Alberto, Raiola, Marilène, 2003. Le projet local. Sprimont (Belgique) : Mardaga, 2003. Première édition : 2000.

MANTCHEV, Alain B., 2010. Quel habitat en terre pour demain sur Ilhabela, Brésil ? Un regard sur l'habitat traditionnel caïçara. Culture constructive - Habitat - Paysage. Mémoire du Diplôme de Spécialisation et d'Approfondissement Architecture de terre. France : Ecole Nationale Superieure d'Architecture de Grenoble. septembre.

MARCUSE, Herbert, 1996. "Algumas implicações sociais da tecnologia moderna ». In: Praga revista de estudos marxistas. set/dez.

MARTINS, José de Souza, 1986. Os camponeses e a política no Brasil. Petrópolis: Vozes.

MARTINS, José de Souza, 1975. Capitalismo e tradicionalismo: estudos sobre as contradições da sociedade agrária no Brasil. São Paulo: Livraria Pioneira Editora.

MARX, Karl, 1977. Le capital: critique de l'économie politique. Livre premier, Tome deuxième Livre premier, Tome deuxième. Paris : Editions sociales.

MARX, Karl, 1978. Le capital: critique de l'économie politique. Livre premier, Livre premier. Paris : Ed. Sociales.

MARX, Karl, ENGELS, Friedrich, ROY, Joseph, 1973. Le capital: critique de l'économie politique. Livre premier, Tome troisième Livre premier. Paris : Éditions sociales.

MARX, Karl, 1983. O Capital: Crítica Da Economia Política. São Paulo: Abril Cultural. 
MEDEIROS, Leonilde Sérvolo de, 1989. História dos movimentos sociais no campo. Rio de Janeiro: FASE.

MENEZES, Marluci, 1996. "Patrimônio, Memória Social e Saber ». In: Mediterrâneo, Arquitectura de Terra. Instituto Mediterrâneo. Universidade Nova de Lisboa: [s.n.]. $n^{\circ} 8 / 9$.

MESZAROS, István, Tavares, Isa, 2008. A educação para além do capital. São Paulo: Boitempo.

MOREIRA, Roberto José, 2007. Terra, poder e território. São Paulo: Expressão Popular.

MOURA, Margarida Maria, 1978. Os herdeiros da terra: parentesco e herança numa área rural. São Paulo: HUCITEC.

NARAYAN, Kirin, 1997. " How native is a native anthropologist? ". In: LAMPHERE, Louise, RAGONÉ, Helena, ZAVELLA, Patricia, Situated lives: gender and culture in everyday life. New York: Routledge. p. 23-41.

NETO, José Francisco de Melo, 2001. Extensão universitária: uma análise crítica. João Pessoa: Editora Universitária.

NORBERG-SCHULZ, Christian, 1997. L'art du lieu : architecture et paysage, permanence et mutations. Paris : Le Moniteur.

PELLI, Víctor Saúl, 2007. Habitar, participar, pertenecer: acceder a la vivienda: incluirse en la sociedad. [Buenos Aires]: Nobuko.

PEREIRA, Isabel Brasil, LIMA, Júlio César França, 2009. Dicionário da educação profissional em saúde. Rio de Janeiro, RJ: EPSJV.

PINTO, Álvaro Vieira, 2005. O conceito de tecnologia. Rio de Janeiro: Contraponto.

POTIE, Philippe, 2005. Architecture : territoire et mémoires de l'expérience constructive. France : Ecoles de Hautes Etudes en Sciences Sociales. février 2005.

PRADO JUNIOR, Caio, 1981. A questão agrária no Brasil. São Paulo: Editora Brasiliense.

RAPOPORT, Amos, 2003. Culture, architecture et design. Gollion [Suisse] : Infolio.

RONCONI, Reginaldo Luiz Nunes, 2002. Inserção do canteiro experimental nas faculdades de arquitetura e urbanismo. São Paulo: Faculdade de Arquitetura e Urbanismo, Universidade de São Paulo.

ROSA, Marcelo Carvalho, 2012. "Ocupações de terra ». In: CALDART, Roseli Salete (org.), Dicionário da Educação do Campo. São Paulo: Expressão Popular.

SANTOS, Mílton, 1996. A natureza do espaço: técnica e tempo; razão e emoção. São Paulo: Editora Hucitec. 
SENNETT, Richard, 2009. Ce que sait la main la culture de l'artisanat. Paris : A. Michel.

SILVA, José Gomes da, 1971. A reforma agrária no Brasil; frustração camponesa ou instrumento de desenvolvimento? Rio de Janeiro: Zahar Editores.

SOUZA, Marcelo Lopes de, 1995. "O território: Sobre espaço e poder, autonomia e desenvolvimento ». In: Geografia: conceitos e temas. Rio de Janeiro: Bertrand Brasil.

STEDILE, João Pedro, 2005. A questão agrária no Brasil: O debate tradicional (1500-1960). São Paulo: Ed. Expressão Popular.

STEDILE, João Pedro, 2012. "A Questão agrária ». In: CALDART, Roseli Salete (org.), Dicionário da Educação do Campo. São Paulo: Expressão Popular.

STEDILE, João Pedro, FERNANDES, Bernardo Mançano, 1999. Brava gente: a trajetória do MST e a luta pela terra no Brasil. São Paulo, SP, Brasil: Editora Fundação Perseu Abramo.

THOMAS, Hernán Eduardo, 2009. «Tecnologias para Inclusão Social e Políticas Públicas na América Latina ». In: OTTERLOO, Aldalice [et al.], Tecnologias Sociais: caminhos para a sustentabilidade. Rede de Tecnologias Sociais. Brasília: [s.n.]. p. 25-81.

UNESCO, 2002. Koutammakou - le pays des Batammariba: ceux qui façonnent la terre. 2002. [s.I.] : République du Togo.

UNESCO, UNITÉ ARCHITECTURE POUR L'ÉDUCATION, COMMISSION DE LA RÉPUBLIQUE FRANÇAISE POUR L'ÉDUCATION, la science et la culture, et al., 1993. Architecture \& cultures constructives: éléments pour un pôle d'enseignement de la construction. Villefontaine, France : Edition CRATerre-EAG.

VALADARES, Alexandre Arbex, 2014. O gigante invisível: território e população rural para além das convenções oficiais. Brasília: IPEA. Coll. Texto para discussão, 1942.

VALLE, Ivan M.R. do, 2011. A pré-fabricação de dois sistemas de cobertura com madeira de florestas plantadas. Estudos de casos: os assentamentos rurais Pirituba Il e Sepé Tiaraju. São Carlos: Instituto de Arquitetura e Urbanismo, Universidade de São Paulo. 2011.

WANDERLEY, Maria de Nazareth B., 2001. " A ruralidade no Brasil moderno. Por un pacto social pelo desenvolvimento rural. " In: GIARRACCA, Norma, Una nueva ruralidad en América Latina? [en ligne]. Argentina: CLACSO - Consejo Latinoamericano de Ciencias Sociales, Ciudad Autónoma de Buenos Aires. Disponible sur: < http://bibliotecavirtual.clacso.org.ar/ar/libros/rural/wanderley.pdf >

WANDERLEY, Maria de Nazareth Baudel, " Raízes históricas do campesinato brasileiro. » In: Separata de TEDESCO, J.C. (Ed.). Agricultura familiar: realidades e perspectivas. Passo Fundo: EDIUPF, 1999. Cap.1, p.21-55.

WEBER, Max, 1996. A ética protestante e o espírito do capitalismo. São Paulo: Pioneira. 
WEIMER, Günter, 2005. Arquitetura popular brasileira. São Paulo: Martins Fontes.

YAMOUSSA, Fané, JOFFROY, Thierry, 2010. Villes anciennes de Djenné. Bamako; DNPC; Grenoble; [Villefontaine] : CRATerre éd.

YIN, Robert K., 2005. Estudo de caso: planejamento e métodos. $3^{\circ}$. Porto Alegre: Bookman.

YOSHIOCA, Erica Yukiko, RONCONI, Reginaldo Luiz Nunes, ET. AL., 2008. Canteiro experimental: 10 anos na FAU USP. São Paulo: FAUUSP, 2008.

2012. DATALUTA - Banco de Dados da Luta pela Terra [en ligne]. [s.I.]: Pró-Reitoria de Extensão Universitária, 2012. Disponível em:

http://ojs.unesp.br/index.php/revista_proex/article/view/227 (consultado em 29 setembro 2014).

2014a. Iglu [en ligne]. [s.l.] : [s.n.]. Disponible sur :

http://pt.wikipedia.org/w/index.php?title=lglu\&oldid=38493457

(consulté le 28 mars 2014).

2014b. Korowai [en ligne]. [s.l.] : [s.n.]. Disponible sur :

http://fr.wikipedia.org/w/index.php?title=Korowai\&oldid=97646209

(consulté le 28 mars 2014).

2014c. Lapões [en ligne]. [s.I.] : [s.n.]. Disponible sur :

http://pt.wikipedia.org/w/index.php?title=Lap\%C3\%B5es\&oldid=36433978

(consulté le 28 mars 2014). 